\title{
Lietuvos savivaldybių viešųjų bibliotekų projektinė veikla 1995-2017 metais
}

\author{
Petras Biveinis \\ Lietuvos nacionalinès Martyno Mažvydo bibliotekos \\ Informacijos ir komunikacijos mokslų departamentas \\ Department of Information and Communication Sciences \\ at the Martynas Mažvydas National Library of Lithuania \\ petras.biveinis@lnb.lt
}

Santrauka. Straipsnyje nagrinėjama Lietuvos savivaldybių viešųjų bibliotekų projektinė veikla 1995-2017 m. Jị sudaro dvi dalys. Pirma dalis skirta bibliotekų projektinès veiklos iki 2007 m. apžvalgai: atskleidžiama Atviros Lietuvos fondo parama bibliotekoms, aptariami tarptautinių, nacionalinių ir vietos institucijų paremti projektai, apibūdinamas aljanso „Langas ị ateitị“ vaidmuo steigiant viešuosius interneto prieigos taškus, mokant gyventojus kompiuterinio raštingumo. Antroje dalyje analizuojama bibliotekų projektinė veikla 2007-2017 m., pateikiant 2007, 2013, 2015-2017 metų projektų kiekybinius rodiklius ir atskleidžiant jų dinamiką. Pasitelkiant projektų finansavimo šaltinių, rèmëjų, tematikos, partnerysčių analizę apibūdinama jų skaičiaus ir lyginamojo svorio kaita bendroje projektų struktūroje. Atskleidžiama nacionalinių projektų „Bibliotekos pažangai“ (2008-2012) ir „Bibliotekos pažangai 2“ (2013 m. gruodžio mèn. - 2016 m. lapkričio mėn.) reikšmè bibliotekoms, jų bendruomenèms ir visuomenei.

Reikšminiai žodžiai: projektai, savivaldybių viešųjų bibliotekų projektinė veikla, projektų tematika, projektų rèmėjai, projektų partneriai.

\section{Project Activities of Lithuanian Municipal Public Libraries in 1995-2017}

\begin{abstract}
The article examines the project activities of Lithuanian municipal public libraries in 1995-2017. It consists of two parts. The first part is a review of project activities of libraries until 2007: it identifies the support of the Open Lithuania Foundation (OSFL) to libraries, discusses projects supported by international, national and local institutions, and describes the role of the Alliance Langas $j$ ateiti (Window to the Future) in establishing public Internet access points and teaching the population computer literacy. The second part analyses the project activities of libraries in 2007-2017 by presenting quantitative indicators of projects of 2007,2013, and 2015-2017 and finding out their dynamics. The analysis of project funding sources, sponsors, themes, and partnerships shows the change in their number and relative weight in the overall project structure. The article also determines the significance of the national projects Libraries for Innovation (2008-2012) and Libraries for Innovation 2 (December 2013 - November 2016) for libraries, their communities, and society.
\end{abstract}

Keywords: projects, project activities of municipal public libraries, project topics, project sponsors, project partners. 


\section{İvadas}

Projektinė veikla yra viena pagrindinių priemonių pokyčiams bibliotekoje iggyvendinti, bibliotekų paslaugoms modernizuoti ir gerinti. Bibliotekų projektinè veikla naudinga sudètingesniems uždaviniams spręsti, sudaro sąlygas diegti inovacijas, skatina naujovių paiešką, sklaidą, kūrybiškumą. Projektinè veikla reikšmingai prisideda prie bibliotekos strateginių tikslų igyvendinimo, atskleidžia bibliotekos potencialą.

Savivaldybių viešujų bibliotekų projektinè veikla, atverianti galimybę pasiekti kokybiškai naujus veiklos lygmenis, tapo jų darbo kasdienybe. Projektų igyvendinimas esmingai pagerina bibliotekų darbą: sukuriamos naujos paslaugos, produktai, kuriami bendradarbiavimo tinklai, ịsigyjama techninè ir programinè ịranga. Bibliotekoms, disponuojančioms ribotais finansiniais ištekliais, svarbi ir reikšminga yra Lietuvos, Europos Sajungos ir kitų fondų finansinè parama. Partnerystė su ịvairiomis organizacijomis didina bibliotekų matomumą, gerina jų ịvaizdị. Daugelio projektų rezultatai turi ilgalaikị pobūdị. Projektinè veikla sudaro sąlygas tęsti veiklas ir pasibaigus projekto terminui.

Lietuvos Respublikos kultūros politikos teisès aktai, darantys įtaka biblioteku projektinei veiklai. Projektinès veiklos pobūdị lemia kultūros politika, jos prioritetai. Lietuvos Respublikos (LR) Vyriausybès

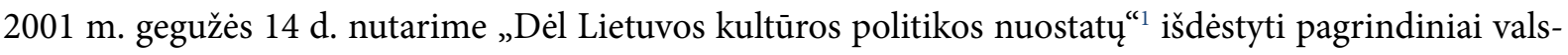
tybės kultūros politikos tikslai: 1) išsaugoti ir puoselèti nacionalinės kultūros tapatumą; 2) skatinti kūrybą ir meno įvairovę; 3) plètoti informacinę visuomenę; 4) skatinti nacionalinès kultūros atvirumą; 5) sudaryti sąlygas visuomenei dalyvauti kultūroje ir ją vartoti. LR Seimo 2010 m. nutarimas „Dèl Lietuvos kultūros politikos kaitos gairių patvirtinimo" ${ }^{\text {"2 }}$ itvirtino kultūros pletotę kaip strateginę valstybès raidos kryptị. Dokumente pabrèžiama, kad „Lietuvos kultūros politikos kaitos tikslas - atnaujinti Lietuvos kultūros politikos modelį, kuris padètų atskleisti, išsaugoti ir plètoti visuomenès kultūrinị tapatumą ir kūrybini potencialą“. Gairèse pažymima, kad būtina spartinti tolygią kultūros sklaidą ir kūrybiškumą regionuose - gerinti kultūros prieinamumą, plèsti modernių kultūros formų îvairovę, sudaryti palankias sąlygas vietos bendruomenių meninei saviraiškai ir kt.

LR Vyriausybė dèmesị ypač skyrè informacinès visuomenès plètrai. $2011 \mathrm{~m}$. kovo $16 \mathrm{~d}$. LR Vyriausybė patvirtino Lietuvos informacinès visuomenès plètros 2011-2019 m. programą ${ }^{3}$. Vienas programos uždavinių - skaitmeninti Lietuvos kultūros paveldo objektus ir jų pagrindu kurti viešai prieinamus skaitmeninius produktus, užtikrinti skaitmeninio turinio išsaugojimą ir sklaidą elektroninėje erdvèje. LR Vyriausybė $2014 \mathrm{~m}$. kovo $12 \mathrm{~d}$. priimtame nutarime „Dèl Informacinès visuomenès plètros 2014-2020 metų programos „Lietuvos Respublikos skaitmeninė darbotvarké" patvirtinimo“ “4 pažymima, kad Lietuvoje vis dar yra gyventojų tikslinių grupių, kurios nesinaudoja šiuolaikiniais skaitmeniniais įrenginiais, internetu arba naudojasi jais mažai. Kadangi technologijos sparčiai tobulèja, skaitmeninio raštingumo igūdžiai turi būti nuolat atnaujinami.

LR Seimo 2012 m. gegužès 15 d. nutarimas „Dèl Valstybès pažangos strategijos „Lietuvos pažan-

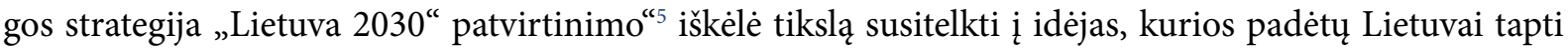

Dèl Lietuvos kultūros politikos nuostatų. Lietuvos Respublikos Vyriausybès nutarimas, $2001 \mathrm{~m}$. gegužès 14 d. Nr. 542 . Prieiga per internetą: https://www.e-tar.lt/portal/lt/legalAct/. Žiūrèta 2019-12-26.

Dèl Lietuvos kultūros politikos kaitos gairiu patvirtinimo. Lietuvos Respublikos Seimo nutarimas, 2010 m. birželio 30 d. Nr. XI-977. Prieiga per internetą: https:/e-seimas.lrs.lt/portal/legalAct/lt/TAD/TAIS.377620. Žiūrèta 2019-12-26.

Dèl Lietuvos informacinés visuomenés pletros 2011-2019 metu programos patvirtinimo ir kai kuriu Lietuvos Respublikos Vyriausybès nutarimu pripažinimo netekusiais galios. Lietuvos Respublikos Vyriausybès nutarimas, $2011 \mathrm{~m}$. kovo $16 \mathrm{~d}$. Nr. 301. Prieiga per internetą: https://www.e-tar.lt/portal/lt/legalAct/TAR.DB3141BCD96B. Žiūrèta 2019-12-26.

Dél informacinés visuomenés plètros 2014-2020 metu programos „Lietuvos Respublikos skaitmeniné darbotvarké " patvirtinimo. Lietuvos Respublikos Vyriausybès nutarimas, 2014 m. kovo 12 d. Nr. 244. Prieiga per internetą: https://e-seimas.lrs.lt/portal/legalAct/lt/ TAD/a66c0760b04011e3bf53dc70cf7669d9. Žiūrèta 2019-12-26.

Dèl valstybès pažangos strategijos „Lietuvos pažangos strategija „Lietuva 2030“ patvirtinimo. Lietuvos Respublikos Seimo nutarimas, 2012 m. gegužès 15 d. Nr. XI-2015. Prieiga per internetą: https://e-seimas.lrs.lt/portal/legalAct/lt/TAD/TAIS.425517. Žiūrèta 2019-12-26. 
modernia, veržlia, atvira pasauliui, puoselejančia nacionalinị tapatumą šalimi. Siekdama ịgyvendinti valstybès pažangos strategiją LR Vyriausybė $2012 \mathrm{~m}$. lapkričio 28 d. prièmé nutarimą „Dèl 2014-2020 metų nacionalinès pažangos programos patvirtinimo “". Programa numato skatinti gyventojus dalyvauti kultūrinèje veikloje, tai yra kurti kultūros paklausą ir patiems tapti kultūros reiškinių kūrẻjais, rasti ir taikyti lanksčius įtraukimo ị kultūrines veiklas būdus; išsaugoti ir aktualizuoti kultūros paveldą, pritaikyti ji visuomenès ugdymo, jos kultūrinès tapatybès stiprinimo, kultūrinio ir pažintinio turizmo poreikiams; plèsti ir atgaivinti Lietuvos gyventojų istorinę ir kultūrinę atmintį; skatinti tautinių mažumų ịtrauktị ir integraciją, užtikrinant etninį tapatumą, dalyvavimą viešajame gyvenime ir tautinių santykių darną. Programoje suformuluoti uždaviniai siejami su gyvenimo kokybės gerinimu.

Reikšmingu dokumentu apibrěžiant pagrindines bibliotekų veiklos kryptis tapo LR kultūros ministro 2016 m. balandžio 29 d. įsakymas „Dèl Bibliotekų plètros strateginių krypčių 2016-2022 metams patvirtinimo"7. Jame pabrěžiama, kad Krypčiu strateginis tikslas - siekti efektyviai išnaudoti bibliotekų, kaip veiksmingos informacinès infrastruktūros, potencialą, užtikrinant visuomenès narių mokymosi visą gyvenimą, socialinės ir ekonominės gerovès plètojimą bei poveikio šalies ir regionų raidai didinimą. Bibliotekų paskirtis - papildyti švietimo sistemos veiklą, ugdyti visuomenès kultūrinị ir informacinį raštingumą - mokymosi visą gyvenimą pagrindą, neatsiejamą nuo inovacijų politikos veiksmingumo. Kryptyse pažymima, kad šiuo metu bibliotekos suvokiamos kaip populiarẻjančios integralios mokymo(si) erdvès, jos galètų tapti visuomenès medijų ir informacinio raštingumo ugdymo koordinatorèmis, integruoti medijų ir informacinio raštingumo ugdymą ị formalujj ir neformalụji švietimą. Bibliotekoms priklauso skaitymo skatinimo proceso organizatoriaus funkcijos skaitymo transformacijos bei skaitymo sąsajų su kitomis medijomis kontekste. Bibliotekoms iškeltas uždavinys plètoti kultūros paveldo, krašto informacijos ir kraštotyros aktualizavimo paslaugas, didinant kultūros turinio skaitmeninimą, prieinamumą ir panaudą mokymo(si) procese. Kryptyse pabrěžiama, kad dèl ribotos kultūros politikos įtakos ir nepakankamos sąsajos su kitais sektoriais nepanaudojamas bibliotekų sistemos potencialas realizuojant valstybès ilgalaikès raidos strategijas ir jas ígyvendinančias švietimo, mokslo ir technologijų, inovacijų, informacinès visuomenès plètros programas.

Kultūros politikos prioritetai, bibliotekų plètros strateginès kryptys buvo pagrindas plètoti bibliotekų projektinę veiklą, apibrèžti jos pagrindines kryptis.

Temos ištirtumas. Metodinès literatūros projektų rengimo ir valdymo tematika yra ištisas masyvas, tačiau jame rastume tik vieną būtent bibliotekininkams skirtą leidini - Audronès Glosienès ir Ramunès Petuchovaitès mokomąją knygą „Projektų valdymo ABC bibliotekininkams“. Joje aptariami esminiai projektinès veiklos aspektai: projektų valdymo samprata ir metodai, fondoieška, paraiškos rengimas ir kt. ${ }^{8}$

Savivaldybių viešujų bibliotekų projektinės veiklos istorija kaip savarankiškas objektas dar netyrinèta; ji aptariama kitų temų kontekste. Paminètinos bibliotekų veiklos apžvalgos ${ }^{9}$. Nors leidiniai pavadinti veiklos apžvalgomis, vienu kitu atveju neatsisakoma analizės. Autoriui šie leidiniai tapo svarbiu informacijos šaltiniu (iki 2010 m.). Projektinès veiklos istorija fragmentiškai apžvelgiama savivaldybių viešųjų

Dèl 2014-2020 metu nacionaliness pažangos programos patvirtinimo. Lietuvos Respublikos Vyriausybès nutarimas, $2012 \mathrm{~m}$. lapkričio 28 d. Nr. 1482. Prieiga per internetą: https://www.e-tar.lt/portal/lt/legalAct/TAR.31A566B1512D. Žiūrèta 2019-12-26.

Dèl biblioteku plètros strateginiu krypčiu 2016-2022 metams patvirtinimo. Lietuvos Respublikos kultūros ministro įsakymas, 2016 m. balandžio 29 d. Nr. IV-344. Prieiga per internetą: https://e-seimas.lrs.lt/portal/legalAct/lt/TAD/9363821010a111e6aa14e8b63147ee94?positionInSearchResults=0\&searchModelUUID=e06d1cda-da64-4c80-953d-e11d484b9ef7. Žiürèta 2019-12-26.

Glosiené, A.; Petuchovaité, R. Projektu valdymo ABC bibliotekininkams: mokomoji knyga. Vilnius: Lietuvos nacionalinè Martyno Mažvydo biblioteka, 2003.

Žr. Savivaldybiu viešosios bibliotekos 1900-2000 metais: veiklos apžvalga / Sud. Dalia Jaskonienè. Vilnius: Lietuvos nacionalinė Martyno Mažvydo biblioteka, 2002; Savivaldybiu viešosios bibliotekos 2001 metais: veiklos apžvalga / Sud. D. Jaskonienė. Vilnius: Lietuvos nacionaline Martyno Mažvydo biblioteka, 2003; Savivaldybiu viešosios bibliotekos 2002 metais: veiklos apžvalga I Sud. D. Jaskonienè. Vilnius: Lietuvos nacionalinė Martyno Mažvydo biblioteka, 2004; Savivaldybiu viešosios bibliotekos 2001-2005 metais: veiklos apžvalga / Sud. D. Jaskonienè. Vilnius: Lietuvos nacionalinè Martyno Mažvydo biblioteka, 2007; Savivaldybiu viě̌osios bibliotekos 2006-2010 metais: veiklos apžvalga / Sud. D. Jaskonienė. Vilnius: Lietuvos nacionalinė Martyno Mažvydo biblioteka, 2012. Prieiga per internetą: https://drive.google.com/file/d/0B_-73IZKEJy5RmI2YldNVml1QUE/view. Žiūrèta 2018-09-11. 
bibliotekų darbuotojų parengtose bibliotekų istorijose ${ }^{10}$, žurnalo „Tarp knygų “ straipsniuose ${ }^{11}$, Kretingos krašto spaudos ir knygos istorijos apžvalgoje ${ }^{12}$, Akmenès r. bibliotekos informaciniuose leidiniuose ${ }^{13}$. Šiuose leidiniuose autoriai paprastai išvardija ir pristato, jų nuomone, svarbiausius projektus; atskleidžia projekto „Bibliotekos pažangai“ reikšmę. Reikšminga vieta skiriama inovatyviems projektams. Jų tyrimui skirtas Violetos Stasėnaitės ir Gabijos Orlakaitės straipsnis „Viešųjų bibliotekų inovatyvių paslaugų taikant projektinę veiklą vertinimas “14, jame nagrinėjama Šiaulių rajono savivaldybės viešosios bibliotekos projektinè veikla 2015-2016 m. Straipsnyje taip pat apžvelgtos teorinès inovatyvumo ir bibliotekų projektinès veiklos sąsajos, pristatyta paslaugų, sukurtų vykdant projektus, kokybė vartotojų požiūriu pagal SERVQUAL paslaugų kokybės metodikoje apibrèžtus vertinimo kriterijus. Savivaldybių viešųjų bibliotekų projektinès veiklos raidai didelę itaką padarè vykdyti projektai „Bibliotekos pažangai“ ir „Bibliotekos pažangai $2 “$. Jų igyvendinimo rezultatai atsispindi sociologiniuose tyrimuose. Projekto „Bibliotekos pažangai“ užsakymu buvo atliekami visuomenès, bibliotekų lankytojų, vadovų ir darbuotojų, ekspertų nuomonių tyrimai. Projekto igyvendinimo rezultatų analizę LNB paskelbė leidiniuose „Bibliotekos pažangai: pokyčiai bibliotekose ir visuomenèje. Poveikio vertinimo tyrimų 2008-2012 m. ataskaita“, „Moderniai visuomenei - naujoviška biblioteka“ ${ }^{15}$. Leidiniuose parodyta projekto igyvendinimo reikšmé bibliotekoms ir visuomenei: igyvendinus projektą, išsiplète bibliotekų misija ir vaidmuo, teikiamų paslaugų repertuaras, sustiprèjo bibliotekų veiklos efektyvumas. Sociologiniai tyrimai buvo atliekami vykdant projektą „Bibliotekos pažangai 2“. Publikacijoje „Projekto „Bibliotekos pažangai 2“ bibliotekų projektų dalyvių tyrimas ${ }^{\text {"16 }}$ labai pozityviai vertinamos visos projekto sukurtos paslaugos ir jų teikiama nauda. Ivvardijami ir kai kurie probleminiai aspektai. Tyrime pabrèžiama, kad viešoji biblioteka privalo išlaikyti literatūrinę-intelektualinę veiklos kryptị ir netapti gyvenvietės pramogų centru, siūlančiu nuo kultūros ir švietimo nutolusias veiklas.

Mokslinių publikacijų apžvalga parodo, kad bibliotekų projektinès veiklos istorija tyrinèta epizodiškai, o projektų „Bibliotekos pažangai“ ir „Bibliotekos pažangai 2“ reikšmè savivaldybių viešosioms bibliotekoms ir visuomenei sulaukè gana nuodugnaus aptarimo.

Žr. Elektrènu savivaldybes viešosios bibliotekos istorija. Vilnius: Lietuvos nacionalinė Martyno Mažvydo biblioteka, 2012; Po knygos ženklu: Pasvalio Mariaus Katiliškio viešosios bibliotekos septynių dešimtmečių kelias, 1937-2007. Panevėžys: Pasvalio Mariaus Katiliškio viešoji biblioteka, 2007; Radviliškio bibliotekos kelias, 1937-2011 / Sud. Daiva Paulauskienè. Radviliškis: Radviliškio rajono savivaldybès viešoji biblioteka, 2011; Rokiškio rajono savivaldybès Juozo Keliuočio viešosios bibliotekos istorija / Sud. Rita Viskaitienè. Vilnius: Margi raštai, 2019; Šiauliu miesto savivaldybès viešosios bibliotekos istorija. Vilnius: Lietuvos nacionalinè Martyno Mažvydo biblioteka, 2015; Vilčiauskienė, V. Joniškio Jono Avyžiaus viešoji biblioteka: 70 veiklos metu, 1937-2007. Šiauliai: Lucilijus, 2007; Zarasu viešosios bibliotekos istorija / Sudarytojai: D. Karlienė, J. Lementauskienė, S. Bikulčiūtė, D. Kiltinavičienè, R. Kuliešienė, D. Davainienė, E. Gaižiuvienė, J. Šepetovskaja, D. Koroliova, D. Macijauskienė, J. Gurskaja, V. Gudaitis. Vilnius: Lietuvos nacionalinè Martyno Mažvydo biblioteka, 2013.

11 Žr. Pikšlingaitė, J. Atviros Lietuvos fondo parama bibliotekoms. Tarp knygų, 1996, rugpjūtis, p. 1-2; Pikšilingaite, J. Laukiame įdomių projektų. Tarp knygų, 1999, gruodis, p. 1-3; Strolienė, N. Naujovès Kretingos M. Valančiaus bibliotekoje. Tarp knygų, 2001, sausis, p. 3-5; Karlienè, D. Aštuoni Zarasų SVB dešimtmečiai. Tarp knygų, 2003, gruodis, p. 5-7; Glosiene, A.; Rutkauskienė, U. Viešos interneto prieigos Lietuvos gyventojams tyrimas. Tarp knygu, 2004, sausis, p. 5-9; Valaitytė, A. Jaunos bibliotekos dešimtmetis. Tarp knygu, 2012, gruodis, p. 1-4.

2 Jonauskaitè, L.; Buikienè L.; Raudytè, N. Spaudos ir knygos kelias Kretingoje. Klaipeda: Klaipėdos universiteto leidykla, 2010.

13 Viešoji biblioteka - informacijos ir kultūros skleidejja, I dalis / Sud. Z. Sinkevičienė. Kaišiadorys: Printèja, 2006.

Viešoji biblioteka - informacijos ir kultūros skleidejja, II dalis / Sud. Z. Sinkevičienė. Kaišiadorys: Printèja, 2010.

Viešoji biblioteka - informacijos ir kultūros skleidejja, III dalis / Sud. Z. Sinkevičienė. Kaišiadorys: Printėja, 2016.

14 Stasėnaitè, V.; Orlakaitė, G. Viešųjų bibliotekų inovatyvių paslaugų taikant projektinę veiklą vertinimas. Informacijos mokslai, 2018, t. 81 , p. $28-46$.

15 Bibliotekos pažangai: pokyčiai bibliotekose ir visuomenejje: poveikio vertinimo tyrimų 2008-2012 m. ataskaita. Vilnius: Lietuvos nacionalinè Martyno Mažvydo biblioteka. Prieiga per internetą: http://www.bibliotekospazangai.lt/media/public/Atsisiuntimui/ TyrimuAtaskaitos/WEB_LT/2011/2011_TyrimuSantrauka.pdf. Žiūrèta 2018-09-12; Moderniai visuomenei - naujoviška biblioteka. Projekto „Bibliotekos pažangai (2008-2012) ịtaka Lietuvos viešųjų bibliotekų raidai. Vilnius: Lietuvos nacionalinė Martyno Mažvydo biblioteka, 2012. Prieiga per internetą: http://www.bibliotekospazangai.lt/media/public/Atsisiuntimui/Moderniai\%20visuomenei-small.pdf. Žiūrèta 2018-09-12.

16 Projekto „Bibliotekos pažangai 2“ bibliotekų projektų dalyviu tyrimas 2016. Vilnius: Lietuvos nacionalinè Martyno Mažvydo biblioteka. Prieiga per internetą: http://3erdve.lt/media/public/Tyrimai_2016/bp2_kokyb_projektu_dalyviai_v2.pdf. Žiūrèta 2015-08-17. 
Tyrimo objektas: savivaldybių viešųjų bibliotekų projektinès veiklos istorija 1995-2017 m.

Tyrimo tikslas: susisteminti ir apibendrinti bibliotekų projektinę veiklą nagrinëjamu laikotarpiu (nuo pirmo projekto $1995 \mathrm{~m}$.); nuodugniau išanalizuoti 2007-2017 m. laikotarpi.

Tyrimo uždaviniai: 1) apžvelgti projektinès veiklos raidą 1995-2006 m., 2) išnagrinèti bibliotekų projektinę veiklą 2007-2017 m.: a) apibūdinti 2007, 2013, 2015-2017 metais projektus ir jų rèmèjus, tematiką, partnerius, pateikti jų lyginamąją analizę; b) atskleisti 2007, 2013, 2015-2017 metais vykdytų projektų geografini (pagal apskritis, rajonus) pasiskirstymą; c) teminiu ir istoriniu aspektais aptarti 2007-2017 m. vykdytus projektus ir parodyti jų naudą projektų dalyviams, vaidmeni gerinant bibliotekų darbą ${ }^{17}$. Šis darbas yra pirmas bandymas ištirti savivaldybių viešųjų bibliotekų projektinę veiklą 1995-2017 m. Autorius atsiriboja nuo daugelio projektų vadybos aspektų (planavimo, organizavimo, kontrolès ir kt.), nenagrinèja projektų finansavimo dydžių (tai galètų būti atskirų studijų objektai).

Metodologija. Rengiant darbą naudoti bendrieji mokslo metodai: statistikos, sisteminis, aprašomasis analitinis, apibendrinimo. Taikytas istorizmo metodas sudaro galimybę atskleisti bibliotekų projektinès veiklos kaitą.

Šaltiniai. Rengiant darbą naudoti šaltiniai: bibliotekų tinklalapiai ${ }^{18}$, bibliotekų 2007, 2013, 2015-2017 metų ataskaitos, žurnalo „Tarp knygų“ kronikos (1996-2017 m.), Atviros Lietuvos fondo (ALF) ataskaitos $^{19}$, LNB portalo $w w w .3 e r d v e . l t$ informacija.

Empiriniam tyrimui atlikti taikoma kiekybinè ir kokybinè dokumentų turinio analizè. Finansiniai rèmejjai skirstomi ị tarptautinius, nacionalinius, vietos. Rėmejjų skaičiai nurodomi pagal dokumentų duomenis. Faktiškai jų buvo daugiau: dokumentuose nurodomi pagrindiniai rèmėjai, kai kada - papildomi, tačiau autoriui tai buvo vienintelis būdas pateikti jų apibūdinimą, atskleisti dinamiką.

Fiksuojamos kiekybinès teminių projektų charakteristikos. Klasifikavimo pagrindas - projektų turinys. Projektai sisteminami pagal autoriaus išskirtą pagrindinę tematiką: infrastruktūros, bibliotekos darbuotojų kvalifikacijos kèlimo, literatūros ir skaitymo skatinimo, edukacijos, kultūrinès meninès veiklos skatinimo, kompiuterinio, skaitmeninio, informacinio raštingumo ugdymo, kraštotyros ir kultūros paveldo aktualizavimo, etninès kultūros, istorijos, socialiniai. Siekiama apibrèžti projektų tikslus, uždavinius, veiklas, rezultatus. Tenka pastebėti, kad skirstymas gana sąlygiškas. Sudètinga atskirti bendro pobūdžio edukacijos projektus nuo kūrybinès meninès veiklos projektų, kraštotyros ir kultūros paveldo aktualizavimo projektus nuo etninès kultūros ir istorijos projektų. Skirstydamas tokio pobūdžio projektus autorius atsižvelge i tai, kokia idejja, tema vyrauja, kam teiktas prioritetas. Socialiniai projektai glaudžiai susiję su edukacijos, biblioterapijos ir kitais projektais. Apskritai bibliotekos kultūrinè funkcija prilygsta socializacijos funkcijai. Autorius socialiniams projektams priskyrè tuos projektus, kuriuose tiesiogiai apibrèžtos socialinès problemos: akcentuojami socializacijos uždaviniai, sociokultūrinè pagalba menkai integruotoms ị visuomenę, patiriančioms didelę socialinę atskirti gyventojų grupėms, keliami nedarbo mažinimo, nusikalstamumo, žalingų ịpročių prevencijos ir kiti panašaus pobūdžio uždaviniai ${ }^{20}$. Analizuodamas šaltinius autorius nagrinėja tipinius projektus. Antra vertus, daugiau dèmesio skiriama kūrybiškiems, inovatyviems projektams apibūdinti. Tai padeda aiškiau suvokti pokyčius bibliotekų veikloje.

Darbo struktūra. Darbo uždaviniai lèmé jo struktūrą. Darbą sudaro įvadas, dvi dalys, išvados ir rekomendacijos, reziumè, literatūros ir šaltinių sąrašas, priedai. Pirmoje dalyje aptariama bibliotekų projektinè veikla iki 2007 m. Parodoma ALF parama bibliotekoms ir jo reikšmé, aljanso „Langas ị ateitị“

2007, 2013, 2015-2017 metams autorius siekè pasitelkti visus prieinamus šaltinius. Be to, jie pasirinkti neatsitiktinai: 2007 m. projektų analizè teikia galimybę ịvertinti projektinès veiklos situaciją projekto „Bibliotekos pažangai“ igyvendinimo išvakarẻse, 2013 m. - iš esmès jam baigiantis, 2015-2017-ieji - paskutiniai tyrimo metai. Didžiulis duomenų masyvas lèmé, kad kitiems metams nagrinèti pasitelkta mažiau informacijos šaltinių (daugiausia - bibliotekų tinklalapiai).

Bibliotekų tinklalapiai žiūrèti $2018 \mathrm{~m}$. rugpjūčio-gruodžio mèn.

ALF tinklalapyje yra 1999, 2000-2001 m. ataskaitos.

Vengiant nuorodų gausos, apsiribota nuorodomis $\mathfrak{x}$ spausdintus šaltinius, nuorodos ị bibliotekų ir kitų institucijų tinklalapius pateikiamos rečiau, atsisakyta nuorodų ị bibliotekų ataskaitas. 
vaidmuo steigiant viešuosius interneto prieigos taškus. Apžvelgiami tarptautinių, nacionalinių ir vietos institucijų paremti projektai. Antroje dalyje nagrinejjama bibliotekų projektinè veikla 2007-2017 m. Ją sudaro du skyriai. Pirmame skyriuje pateikiami 2007, 2013, 2015-2017 metu projektų kiekybiniai rodikliai, atskleidžiama jų dinamika. Apibūdinami projektų rèmèjai, tematika, partneriai, parodoma jų skaičiaus ir lyginamojo svorio kaita bendroje rèmèjų, projektų struktūroje. Atskleidžiama projektų „Bibliotekos pažangai“ ir „Bibliotekos pažangai 2“ reikšmė bibliotekoms ir visuomenei. Antrame skyriuje aptariami 2007-2017 m. bibliotekų vykdyti projektai: apibūdinamas 2007, 2013, 2015-2017 metų projektų geografinis (pagal apskritis, rajonus) pasiskirstymas, parodoma 2007-2017 m. bibliotekų vykdytų projektų nauda jų dalyviams, vaidmuo gerinant bibliotekų darbą.

Autorius tikisi, kad atliktas tyrimas bus naudingas bibliotekininkams praktikams. Gerosios patirties sklaida padètų tobulinti projektinę veiklą.

\section{Projektinès veiklos raida 1995-2006 m.}

Skyriuje aptariama bibliotekų projektinè veikla iki 2007 m. Atskleidžiama ALF parama bibliotekoms, parodoma jos reikšmè. Apžvelgiami kitų tarptautinių, taip pat nacionalinių ir vietos institucijų paremti projektai. Apibūdinamas aljanso „Langas ị ateiți“" vaidmuo steigiant viešuosius interneto prieigos taškus, ugdant gyventojų kompiuterinị raštingumą.

Po Lietuvos nepriklausomybės atkūrimo $1990 \mathrm{~m}$. kovo 11 d. šalyje vyko radikalūs politiniai, ekonominiai, socialiniai ir kultūriniai pokyčiai. Sunki ekonominè padètis, netobuli įstatymai, nuolatinis lèšu trūkumas ir dalies bibliotekininkų negebèjimas dirbti naujomis sąlygomis lėmé, kad XX a. paskutinio dešimtmečio pirmoje pusẻje šalies bibliotekininkystè išgyveno krizę. Bibliotekų veiklai stabilizuoti svarbią reikšmę turëjo $1995 \mathrm{~m}$. birželio 6 d. LR bibliotekų ịstatymas - jis apibrèžè šalies bibliotekų sistemą, bibliotekų paskirtị, funkcijas, valdymą, finansavimo principus. Bibliotekininkystės srityje vykstantys pokyčiai skatino ieškoti naujų veiklos būdų. Savivaldybių viešosios bibliotekos laipsniškai ịsitraukè ị projektinę veiklą. Kita vertus, dalyvauti projektinejje veikloje itin skatino lèšų stygius. Bibliotekų projektinès veiklos istorija prasideda nuo praejjusio amžiaus paskutinio dešimtmečio antros pusès. Ji glaudžiai susijusi su ALF veikla ir teikiama finansine parama.

ALF pradejo veiklą $1990 \mathrm{~m}$. spalio mèn. kaip nepriklausoma, nevyriausybinè, nesiekianti pelno organizacija, kurios pagrindinis tikslas - remti atviros, demokratinès, pilietinès visuomenès kūrimąsi Lietuvoje. ALF įkūrè JAV finansininkas ir garsus filantropas George’as Sorosas. ALF, Bibliotekų rèmimo programą vykdęs 1993-2002 m., paramą bibliotekoms konkurso tvarka teikè kartu su Budapešto atviros visuomenès instituto (OSI; Open Society Institute) Bibliotekų programa, atsižvelgdamas ị jos prioritetus ir reikalavimus, keliamus ir turiniui, ir biudžetui. Bibliotekų rèmimo programa skatino Lietuvos bibliotekų kaip informacijos, kultūros, švietimo ir mokymo centrų veiklą, jų paslaugų gerinimą. Prioritetas buvo teikiamas viešosioms bibliotekoms. Bibliotekų rẻmimo programa numatè tokias veiklos kryptis: bibliotekų modernizavimas, naujų technologijų diegimas; bibliotekininkų mokymas ir kvalifikacijos kèlimas; naujų nestandartinių bibliotekos paslaugų vartotojams (ar jų grupèms) ir darbo formų diegimas ir gerinimas; bendradarbiavimo su savivaldybėmis, mokyklomis, nevyriausybinemis ir kitomis organizacijomis skatinimas $^{21}$. Vienas pirmųjų ALF finansuotų projektų buvo $1995 \mathrm{~m}$. Kretingos r. savivaldybès viešosios bibliotekos (SVB) projektas „Užsienio kalbų mokymosi skaitykla“, dèl kurio kitais metais buvo įkurta pirmoji šalyje Užsienio kalbų mokymosi skaitykla ${ }^{22} .1996 \mathrm{~m}$. Zarasų r. SVB, Alytaus SVB, Utenos SVB ir galimai dar dvi bibliotekos dalyvavo ir laimejjo ALF konkursą „Biblioteka - kultūros

Atviros Lietuvos fondas. 1999 metų ataskaita, p. 19-20. Prieiga per internetą: http://olf.lt/wp-content/uploads/2017/03/alf_ataskaita_1999.pdf. Žiürèta 2018-08-22.

22 Kretingos $r$. SVB tinklalapis. Prieiga per internetą: http://www.kretvb.lt/lt/veikla/projektine-veikla. Žiūrèta 2018-08-23; Strolienė, N. Naujovès Kretingos m. Valančiaus bibliotekoje. Tarp knygu, 2001, sausis, p. 3. 
centras $^{\text {“23. }}$. Projektas pristatytas Alytaus m. bibliotekos tinklalapyje. Apibūdinant projektą teigiama, kad biblioteka yra ne tik tradicinių paslaugų skaitytojams teikimo vieta, bet ir miesto bendruomenei svarbus kultūros centras, kuriame suteikiama erdvè, sudaromos kitos sąlygos vietos menininkų saviraiškai; pristatoma ir eksponuojama žinomų šalies menininkų (literatų, dailininkų, fotografų, muzikų) kūryba; svarbus vaidmuo tenka miesto kultūros, istorijos fragmentų atodangai, informacijos apie iškiliąsias jos asmenybes sklaidai. ALF parama leido ịsigyti techninių priemonių tolesnei bibliotekos veiklos pletotei ${ }^{24}$.

Turima informacija leidžia išsamiau aptarti Zarasų r. SVB dalyvavimą projektinëje veikloje 19971999 m.. Bibliotekos projektai skirti ịvairioms temoms: vaikų ir paauglių užimtumui, paslaugų šeimoms plètrai, programinès įrangos diegimui. $1997 \mathrm{~m}$. biblioteka dalyvavo ALF konkurse „Muziejų ir bibliotekų švietimo programos“ ir gavo finansavimą projektui „Padèkit vaikams ir seneliams“; $1998 \mathrm{~m}$. skirtos lèšos projektui „Šeima ir biblioteka - visų mūsų ateičiai“. Pažymètina, kad tais metais biblioteka taip pat gavo tuometinès Švietimo ir mokslo ministerijos (ŠMM) paramą. Ministerija paremė projektą „Vaikų ir paauglių, gyvenančių ypač sunkiomis sąlygomis, užimtumo programa Zarasų viešojoje bibliotekoje“. 1999 m. ALF finansavo Zarasų SVB projektą „Zarasų viešoji biblioteka internete“. Tais pačiais metais OSI (Open Society Institute / Atviros visuomenès institutas) parèmé projektą „Zarasų viešosios bibliotekos paslaugos vaikams ir krašto visuomenei“, programą „LIBIS programinès ịrangos diegimas Zarasų viešojoje bibliotekoje ${ }^{\text {“25. }}$.

OSI ir ALF parama bibliotekoms 1999-2001 m. 1999-ųjų pradžioje buvo paskelbta nauja OSI programos iniciatyva „Biblioteka - bendruomenès centras“, skirta dešimčiai Vidurio ir Rytų Europos valstybių. Siekta rasti bibliotekas, kurios galètų būti modeliai ne tik savo, bet ir kitose šalyse. ALF kartu su OSI parèmé 8 bibliotekų projektus, laimejjusius konkursą (Šiaulių m. SVB projektas buvo bendras su Šiaulių apskrities viešoji biblioteka (ŠAVB). 4 savivaldybių viešosios bibliotekos iš Lietuvos (Vilniaus ir Klaipèdos miestų bei Utenos ir Zarasų rajono) buvo atrinktos ir pripažintos modelinèmis ${ }^{26}$. Bibliotekos pristatytos ir gerai ịvertintos $2000 \mathrm{~m}$. spalio mèn. Liublianoje (Slovėnija) vykusiame tarptautiniame seminare „Viešųų bibliotekų iniciatyva“. Tolesnei šių bibliotekų veiklai plèsti iš OSI Bibliotekų programos papildomai skirta lèšų, o jų darbuotojams $2001 \mathrm{~m}$. buvo suteikta galimybè stažuotis JAV ir Vokietijos bibliotekose. Be to, Bibliotekų programa, nors tiesiogiai ir neremė fondų komplektavimo, skatino bibliotekas dalyvauti tarptautiniuose projektuose, per kuriuos lengvatinėmis sąlygomis buvo galima ịsigyti knygų (megaprojektas „Puškino biblioteka“), prenumeruoti elektroninius žurnalus ${ }^{27}$.

1999 m. įvyko ALF konkursas „Muzika ir audioinformacija viešojoje bibliotekoje“. Konkurso tikslas suaktyvinti ar atgaivinti fonotekų ir muzikos skyrių veiklą, formuoti naują požiūrị i garso informaciją bibliotekoje. Konkursą laimėjo 13 savivaldybių viešujų bibliotekų ir Lietuvos bibliotekininkų draugijos (LBD) Visagino skyrius (Alytaus r. SVB laimejjo 2 projektus) ${ }^{28}$.

Konkursus ALF skelbė 2000 ir 2001 metais. 2000-aisiais ALF paskelbė konkursus „Mažų miestelių ir kaimų bibliotekos - vaikams ir jaunimui“ ir „Paslaugų bendruomenei plettra viešosiose, vaikų globos namų bei specialiųjų mokyklų bibliotekose“. Pirmą projektą laimëjo 39 savivaldybių viešųjų bibliotekų filialai (Vilkaviškio rajone bendrą projektą laimėjo Aistiškių, Piliakalnio, Pašeimenių ir Lakštučių filialai),

\footnotetext{
23 Asta Valaityte straipsnyje „Jaunos bibliotekos dešimtmetis“ tvirtina, kad Alytaus m. SVB buvo viena iš penkių Lietuvos bibliotekų, laimejusių ALF finansavimą projektui „Biblioteka - kultūros centras“. Kitos bibliotekos nenurodytos (Tarp knygu, 2002, gruodis, p. 2.). Apie Zarasų r. ir Utenos bibliotekų dalyvavimą projekte informacija pateikta: Greiciūnienė, R. Panevėžio regiono savivaldybių viešosios bibliotekos 1990-2000 metais: In: Savivaldybiu viešosios bibliotekos 1900-2000 metais: veiklos apžvalga, p. 145; Petuchovaitè, R. Viešuju biblioteku paslaugu bendruomenei plètra: sèkmingos praktikos Lietuvoje ir tarptautinių veiksnių studija. Vilnius: Vilniaus universiteto leidykla, 2004, p. 54.

24 Alytaus $m$. SVB tinklalapis. Prieiga per internetą: http://www.alytus.mvb.lt/apie-biblioteka/apie-mus/projektai?showall= \&lang=lt\&start=1. Žiūrèta 2018-08-21.

25 Greiciūnienè, R. Panevė̌io regiono savivaldybių viešosios bibliotekos 1990-2000 metais. Iš Savivaldybiu viešosios bibliotekos 1900-2000 metais: veiklos apžvalga, p. 145.

26 Atviros Lietuvos fondas. 1999 metų ataskaita, p. 18. Prieiga per internetą: http://olf.lt/wp- content/uploads/2017/03/alf_ataskaita_1999.pdf. Žiūrèta 2018-08-22.

27 Ibidem, p. 18-19.

28 Ibidem, p. 19-20.
} 
o Utenos SVB buvo skirta parama projektui „Konkurso įvertinimo baigiamosios konferencijos-seminaro organizavimas“. Antrą projektą laimèjo 34 savivaldybių centrinès bibliotekos ir kai kurie filialai. $2001 \mathrm{~m}$. ALF paskelbè konkursą „Paslaugų bendruomenei plètra Lietuvos viešosiose bibliotekose“. Konkursą laimëjo 42 savivaldybių centrinès bibliotekos ir keli filialai bei bendras ŠAVB ir Šiaulių m. centrinès bibliotekos projektas. Projektų paremta daugiau: ALF parėmè po du Alytaus r., Kauno r., Molètų r., Panevèžio r., Skuodo r., Širvintų r., Švenčionių r., Telšių r., Zarasų r. projektus ${ }^{29}$.

Atkreiptinas dèmesys, kad $2001 \mathrm{~m}$. Utenos SVB vykdė stambų projektą, skirtą kraštotyrai ir kultūros paveldui aktualizuoti. ALF, Kultūros ministerija (KM) ir privatūs asmenys parėmė bibliotekos projektą „Utenos krašto enciklopedija“ (elektroninè versija). Sukurtas elektroninis leidinys - pirmas bibliotekos enciklopedinis leidinys, kuriame yra išsami informacija apie krašto istoriją, gamtą, kaimus ir miestelius, švietimą, kultūrą, pramonę, 600 žymių kraštiečiu ir kt.

Toli gražu ne visos bibliotekos laimėdavo ALF konkursus. Paminètini tokie paraiškų trūkumai: nepakankama motyvacija ir argumentacija, padrika projekto struktūra, bandymas vienu užmoju išspręsti visas arba daugelị bibliotekos problemų, tikslo neapibrèžtumas, projekto uždavinių ir biudžeto neatitiktis ${ }^{30}$.

$2001 \mathrm{~m}$. Bibliotekų rèmimo programa iš esmès buvo baigta, tačiau ALF tebesidomėjo jų veikla. Kaip ir ankstesniais metais, visoms bibliotekoms buvo dovanojamos knygos, kurių leidybą rèmé ALF Leidybos programa. OSI administravo tarptautinius projektus, kuriuose sèkmingai dalyvavo Lietuvos bibliotekos. Dar 1999 m. OSI inicijavo projektą „Elektroninè informacija bibliotekoms“, kuris bibliotekų skaitytojams suteikè galimybę naudotis EBSCO duomenų bazèmis. EBSCO duomenų bazių prenumeratai lèšu taip pat skyrè Kultūros ministerija bei Švietimo ir mokslo ministerija (2002 m. projekto administravimas buvo perduotas sukurtam Lietuvos bibliotekų konsorciumui) ${ }^{31}$.

Kiti tarptautiniai rèmèjai. Bibliotekos rado galimybių pasinaudoti kitų tarptautinių fondų parama. Ypač žymūs Kretingos r. SVB fondoieškos pasiekimai. 1997 m. biblioteka dalyvavo igyvendinant PHARE (Poland and Hungary; aid for economic restructuring / Lenkija ir Vengrija; pagalba ekonomikos restruktūrizavimui) ${ }^{32}$ paremtą projektą „Baltijos šalių bibliotekų plètra“; jo rezultatas - organizuota tarptautinè konferencija. $1998 \mathrm{~m}$. igyvendintas Olandijos vyriausybès fondų paremtas projektas - ikurtas Kretingos moterų mokymo ir informacijos centras. Tikslas - organizuoti švietejjiškus užsiemimus, konsultuoti moteris, kurioms reikalinga socialinè, moralinè, teisinè ar kitokia pagalba ir informacija. $1999 \mathrm{~m}$. igyvendintas Danijos demokratijos fondo paremtas projektas „Viešųjų ir mokyklų bibliotekų modernizavimas informacinëje visuomenèje“; jo rezultatas - 15 Lietuvos bibliotekininkų atliko stažuotę Danijos bibliotekose ir informacijos centruose. 2000 m. Danijos ambasada finansavo projektą „Nepilnų šeimų vaikų integracija ì visuomenini gyvenimą", o Danijos Djurs komuna parėmè bendrą bibliotekos ir Kretingos r. nevyriausybinių organizacijų asociacijos „Apskritas stalas“ projektą „Jaunimo interneto centras" ${ }^{\text {“33 }}$.

Naujo tūkstantmečio pradžioje bibliotekos pradèjo dalyvauti Europos Komisijos delegacijos Lietuvoje (EKDL) remiamuose projektuose. $2000 \mathrm{~m}$. EKDL pradèjo vykdyti projektą „Informacija apie Europos Sajungą Lietuvos bibliotekose“. Jo tikslas - objektyvios informacijos apie ES sklaida. Tais metais 51-oje savivaldybių viešojoje bibliotekoje buvo įrengtos lentynos su leidiniais apie Europos Sajungą ${ }^{34} .2002 \mathrm{~m}$. EKDL parèmė Jonavos r. SVB projektą „Kurkime Europą kartu“, Šiaulių m. SVB projektą „Kelias ị Europą per Šiaulius“, 2003-aisiais - Klaipėdos m. SVB projektą „Europiečiai, arčiau Europos“. Projektai skirti Europos dienai.

Atviros Lietuvos fondas. Metinè ataskaita, 2000/01, p. 19-20. Prieiga per internetą: http://olf.lt/wp-content/uploads/2017/03/alf_ ataskaita_2000_2001.pdf. Žiūrèta 2018-08-22.

30 Pikšilingaite, J. Laukiame įdomių projektų. Tarp knygų, gruodis. 1999, p. 2.

31 Atviros Lietuvos fondas. 2002 m. veiklos ataskaita, p. 72. Prieiga per internetą: http://olf.lt/wp-content/uploads/2017/03/alf_ataskaita_2002.pdf. Žiürèta 2018-08-23.

32 Europos Sajungos ekonominès pagalbos programa. 1989 m. programa apėmé tik Lenkiją ir Vengriją. $2000 \mathrm{~m}$. PHARE programoje dalyvavo jau 17 Europos šaliu, ịskaitant Lietuvą.

Kretingos r. SVB tinklalapis. Prieiga per internetą: http://www.kretvb.lt/lt/veikla/projektine-veikla. Žiūrèta 2018-08-23.

34 Europos Komisija. Atstovybe Lietuvoje. Prieiga per internetą: https://ec.europa.eu/lithuania/services/contact-points_lt. Žiūrèta 2018-08-28. 
Kitas tarptautinis rèmejjas - Šiaurès ministrų tarybos biuras Lietuvoje (ŠMTBL). ŠMTBL nuo 1997 m.

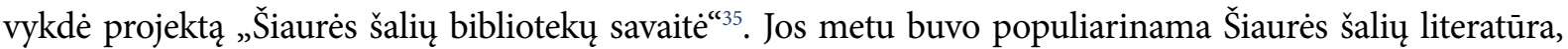
kultūra, istorija, papročiai, tradicijos. Dalyvavimas Šiaurès šalių bibliotekų savaitėje daugeliui bibliotekų tapo tradicija ${ }^{36}$.

Nacionaliniai rèmėjai. Didèjo nacionalinių rèmèjų vaidmuo. Bibliotekos teike projektų paraiškas Kultūros ministerijos $2001 \mathrm{~m}$. konkursui „Visuomenès informacinis aprūpinimas“. $2001 \mathrm{~m}$. Panevèžio r. SVB laimejo KM projektą „Internetas - Biblioteka - Vartotojas“. Buvo gauti penki kompiuteriai ir spausdintuvas. Panašų projektą igyvendino Pasvalio SVB; rezultatas - gauti keturi kompiuteriai, atidarytas informacijos centras - interneto skaitykla. Kultūros ministerija parèmé Zarasų r. SVB projektą „Zarasų viešosios bibliotekos informacijos paslaugų plètra bendruomenei“' Issigyti keturi kompiuteriai, spausdintuvas. Susumuojant bibliotekų dalyvavimo konkurse rezultatus, konstatuojama, kad buvo užtikrinta prieiga prie interneto visose SVB (centrinèse) ir kai kuriuose filialuose ${ }^{37}$.

Kultūros ir sporto rèmimo fondas ${ }^{38}$ (KSRF) parèmè bibliotekų projektus, kurie buvo skirti ịvairioms temoms. 2002 m. KSRF suteike paramą Prienų SVB projektui „Tartum šaltinio versmë“. Organizuoti literatūros renginiai, išleistas pradedančiųjų literatų kūrybos almanachas „Pakèlę sparnus s"39. Vilniaus savivaldybès centrinès bibliotekos (SCB) Naujosios Vilnios filialas vykdè projektą „Debiutas“, kuris suteikè galimybę bibliotekoje debiutuoti jauniems menininkams. Jurbarko r. SVB vykdè projektą, skirtą kraštiečio Stasio Santvaro 100-mečiui (papildomą finansavimą suteikè savivaldybė).

ŠMM ir savivaldybė 2002 m. parėmė Jonavos r. bibliotekos projektą, skirtą socialiai remtinų šeimų vaikų ir paauglių integracijai į visuomenę „Vaikų biblioteka - vaikų ir paauglių iš socialiai remtinų, asocialių ir daugiavaikių šeimų užimtumo centras“.

Didèjo savivaldybių vaidmuo. $2001 \mathrm{~m}$. Šiaulių m. savivaldybè parèmė bibliotekos projektą „Interneto skaitykla Šiaulių miesto viešojoje bibliotekoje“, 2002 m. Klaipèdos m. savivaldybè - projektą „Klaipèdos miesto nekilnojamosios vertybės“, skirtą Klaipèdos 750-mečiui. Tais pačiais metais Zarasų r. savivaldybé finansavo du bibliotekos projektus: „Programa Vasaros skaitymai“ ir „Žinios ir grožis prieš blogï“. Alytaus r. savivaldybe parémé bibliotekos projektą „Naujos knygos - kaimų bibliotekoms“ ir Makniūnų filialo projektą „Makniūnų kaimo biblioteka - vaikų laisvalaikio užimtumo centras“.

Naujo tūkstantmečio pradžioje vis daugiau dèmesio skiriama informacinės visuomenès (IV) plètrai ir infrastruktūrai. Vienas iš svarbiausių IV veiksnių - interneto teikiamų viešujų paslaugų plètotè. $2002 \mathrm{~m}$. Lietuvos verslo įmonès susibūrè ị aljansą „Langas ị ateitị“, kuris pradẻjo vykdyti unikalų Lietuvoje verslo paramos informacinès visuomenès plètrai projektą. Aljansas pradejjo steigti viešuosius interneto centrus (VIC). 2002 m. Lietuvoje ịkurti 75 viešieji interneto centrai. 2003 m. ị centrų kūrimą ịsitraukè LR vidaus reikalų ministerija (VRM). Bendromis pastangomis tais metais įsteigta dar 100 VIC. Aljansas „Langas $\mathfrak{i}$ ateitį" rengè gyventojų mokymus naudotis internetu. $2003 \mathrm{~m}$. kursus baigè 20000 Lietuvos gyventojų. Viešieji interneto centrai buvo steigiami ne tik bibliotekose, tačiau jų kūrimo patirtis parodè, pasak A. Glosienès ir Ugnès Rutkauskienès, kad tinkamiausia viešam internetui institucija yra viešoji biblioteka. Autorés nurodè bibliotekos pranašumus: kvalifikuotas personalas, informacijos šaltinių atrankos ir klasifikavimo gebejjimai, platus paslaugu spektras ir kt. ${ }^{40}$ Iš 175 VIC 50 proc. įkurti viešosiose bibliotekose $\mathrm{e}^{41}$.

Šiaurès šaliu literatūros savaitè. Istorija. Prieiga per internetą: https://www.nordisklitteratur.org/lt/apie-projekt\%C4\%85/istorija/. Žiūrèta 2018-08-28.

36 Šiaurès šalių literatūros portalas pateikia tekstų ištraukas trijụ grupių skaitytojams: vaikams, paaugliams ir suaugusiesiems. Tereikia užsiregistruoti, parsisiųsti tekstus, Šiaurès šalių bibliotekos savaitės plakatą, reklamuoti skaitymus.

37 Žr. Jaskoniené, D. Šalies savivaldybių viešųjų bibliotekų 2001-2005 metų veiklos apžvalga. In: Savivaldybiu viešosios bibliotekos 2001-2005 metais: veiklos apžvalga, p. 24.

LR kultūros ir sporto remimo fondo įstatymas priimtas $1998 \mathrm{~m}$. spalio $8 \mathrm{~d}$.

Pakèlę sparnus: Prienų krašto jaunujju kūrybos almanachas. Marijampolè: UAB „TeleSATpressa“, 2002.

Glosienė, A.; Rutkauskienė, U. Viešos interneto prieigos Lietuvos gyventojams tyrimas. Tarp knygų, 2004, sausis, p. 9.

Jaskoniené, D. Šalies savivaldybių viešųjų bibliotekų 2001-2005 metų veiklos apžvalga, p. 9. 
Aljanso veiklą steigiant interneto centrus pratęsé VRM igyvendinamas PHARE socialinės-ekonominès sanglaudos programos finansuotas 2005-2006 m. projektas „Viešųjų interneto prieigos taškų steigimas kaimiškose vietovėse". Viešųjų interneto prieigos taškų (VIPT) tinklas buvo plečiamas į nuošalias kaimo vietoves. Pavyzdžiui, 2005 m. VIPT buvo ịsteigti Kauno r. Piliuonos, Kačerginès, Sitkūnų, Batniavos, Liučiūnų, Lapių, Linksmakalnio, Vandžiogalos, Čekiškès bibliotekose. Pagal ši projektą Lietuvoje įsteigta 300 interneto prieigos taškų. Nuo $2006 \mathrm{~m}$. spalio mèn. aljansas „Langas ị ateitị" kartu su partneriais Kauno technologijos universitetu ir UAB „S4ID“ administravo VRM vykdomą dar 400 viešųjų interneto prieigos taškų steigimo projektą „Viešujų interneto prieigos taškų tinklo plètra“; jo rezultatas - sukurtas bendras Lietuvos interneto taškų tinklas. Aljansas „Langas ị ateitį“ gavo paramą iš ES fondų gyventojų kompiuteriniam raštingumui ugdyti. Igyvendinant projektą „Lietuvos e. piliečio kompiuterinio raštingumo pradmenys“ (2006-2008 m.) 50400 šalies gyventojų buvo suteikta kompiuterinio raštingumo žinių ${ }^{42}$.

Bibliotekos dalyvavo investiciniuose projektuose. Pagal „Bibliotekų renovacijos ir modernizavimo 2003-2013 metų programą" buvo renovuojami ir statomi nauji bibliotekų pastatai: $2003 \mathrm{~m}$. finansuoti 6 projektai, 2004 m. $-17,2005$ m. $-16^{43}$.

Lygiagrečiai buvo vykdomi kiti projektai, kuriuos rèmè tarptautinès, nacionalinès ir vietos institucijos. Apžvelgsime Kupiškio r. SVB ir Šakių r. SVB projektus, kuriuos finansavo tarptautiniai rèmejai. 2003 m. Europos Komisijos delegacija Lietuvoje parėmé Kupiškio r. bibliotekos projektą „Informacija apie Europos Sąungą Kupiškio bendruomenei“. Organizuoti renginiai: seminaras „Lietuva ir Europos Sąjunga“; susitikimas su Lietuvos Respublikos Seimo nariu Egidijumi Vareikiu; seminaras „Biblioteka informacinejje visuomeneje“; L. Stuokos-Gucevičiaus gimnazijos parlamento nariams (15 žmonių) surengta išvyka ị institucijas, dirbančias Lietuvos integracijos ị ES srityje (Lietuvos Respublikos Seimas, Europos komitetas prie Lietuvos Respublikos Vyriausybès, EKDL Informacijos centras ${ }^{44}$.

2006 m. Šakių r. SVB vykdè projektą „Suvalkijos krašto ir Lenkijos kultūriniai muzikiniai ryšiai“, finansuotą PHARE Bendradarbiavimo abipus sienos Baltijos jūros regione programos. Projekto tikslas atgaivinti, skatinti ir palaikyti kultūrinius muzikinius ryšius tarp Suvalkijos krašto ir Lenkijos. Projekto partneriai: Lenkijos Geldapès miesto kultūros namai, Šakių rajono savivaldybès administracija. Biblioteka įsigijo projektui vykdyti reikalingą ịrangą: kompiuterị, programinę įrangą, pianiną, skaitmeninị projektorių. Organizuotas festivalis, surengta konferencija ir kt. Konferencijoje skaityti pranešimai išleisti atskira knyga „Ilguvos dvaro takais" ${ }^{45}$.

Vykdyti Kultūros ministerijos, Kultūros ir sporto rèmimo fondo finansuoti projektai. 2006 m. KSRF finansavo Joniškio r. bibliotekos projektą „ „amžinti kūrèją meno kalba“, skirtą Jono Avyžiaus 85-osioms gimimo metinėms ir viešosios bibliotekos 70-mečiui, KM - Skaistgirio filialo projektą „Skaistgirio miestelio aplinkos tvarkymo tradicijų puoselèjimas, etninès kultūros paveldo išsaugojimas". Tais metais Kultūros ministerija parèmé Kupiškio r. bibliotekos projektą „Poezijos pavasaris Kupiškyje“. Projektui iggyvendinti pritrūkus lèšų, papildomas finansavimas gautas iš Kupiškio rajono savivaldybės, Všt Rašytojų klubo ir laikraščio „Kupiškẻnų mintys" ${ }^{“ 46}$.

Igyvendinami vietos rèmëjų finansuoti projektai. $2004 \mathrm{~m}$. Klaipėdos apskrities viršininko administracija parèmé Klaipedos $m$. SVB projektą „Nuo draudžiamo žodžio iki išlaisvintos minties“, pagal kurị buvo numatyta edukacinių renginių programa, skirta lietuviškos spaudos lotyniškais rašmenimis atgavimo 100-mečiui. Paminètina reikšminga Joniškio r. savivaldybės parama. Joniškio r. savivaldybė $2004 \mathrm{~m}$. parèmè 14 centrinès bibliotekos ir filialų projektų, $2005 \mathrm{~m}$. - 12, $2006 \mathrm{~m} .-9^{47}$.

Langas i ateiți. Veikla ir laimèjimai. Prieiga per internetą: https://www.langasiateiti.lt/index.php/lt/apie/istorija. Žiūrèta 2018-08-25. Jaskoniené, D. Šalies savivaldybių viešųjų bibliotekų 2001-2005 metų veiklos apžvalga, p. 24.

Lietuvai îstojus ị Europos Sajungą panašaus pobūdžio projektus èmè remti Europos Komisijos atstovybė Lietuvoje (EKAL).

Ilguvos dvaro takais... Ś Śienżkami iłgowskiego dworu... Kauna: Arx Baltica, 2006.

Greiciūnienè, R. et al. Panevėžio apskrities savivaldybių viešosios bibliotekos 2006-2010 metais. In: Savivaldybių viešosios bibliotekos 2006-2010 metais: veiklos apžvalga, p. 203. Prieiga per internetą: https://drive.google.com/file/d/0B- 73IZKEJy5RmI2YldNVm11QUE/view. Žiürèta 2018-09-11.

47 Joniškio r. SVB tinklalapis. Projektai. Prieiga per internetą: https://www.joniskis.rvb.lt/projektai/. Žiūrèta 2018-09-5. 


\section{X X}

Bibliotekų projektinės veiklos plètotei XX a. pabaigoje - XXI a. pradžioje didžiausią įtaką padarè ALF parama.

Bibliotekos pasinaudojo PHARE, EKDL ir kitų tarptautinių institucijų fondų parama. Pagrindiniais nacionaliniais rèmejjais tapo KM, KSRF. Didejjo savivaldybių vaidmuo finansuojant projektus. Projektus rèmè apskrities viršininko administracija.

Bibliotekų veiklai buvo reikšmingi aljanso „Langas ị ateitị“, VRM ịgyvendinti projektai, skirti interneto teikiamų viešųjų paslaugų plètotei, aljanso „Langas ị ateitį“ organizuoti gyventojų kompiuterinio raštingumo mokymai.

ALF ir kitų rèmëjų dèka buvo pradèta modernizuoti bibliotekas, buvo keliama bibliotekininkų kvalifikacija, diegiamos naujos paslaugos vartotojams (ar jų grupėms). Igyvendinti kultūrinio, švietėjiško, socialinio pobūdžio projektai. Bibliotekų igyta dalyvavimo projektuose patirtis tapo pagrindu plètoti projektinę veiklą.

\section{Projektinè veikla 2007-2017 m.}

Antroje darbo dalyje nagrinèjama bibliotekų projektinè veikla 2007-2017 m. Išsamiai aptariami 2007, 2013, 2015-2017 metų projektai, jų rèmėjai, projektų tematika, partneriai, pateikiama jų lyginamoji analizè. Apibūdinamas 2007, 2013, 2015-2017 metų projektų geografinis (pagal apskritis, rajonus) pasiskirstymas, aptariami 2007-2017 m. vykdyti projektai, atskleidžiama jų nauda projektų dalyviams, parodomas projektų vaidmuo gerinant bibliotekų darbą.

2.1. Projektai, rèmèjai, projektu tematika, partneriai (2007, 2013, 2015-2017 metu projektu lyginamoji analize)

Skyriuje pateikiami 2007, 2013, 2015-2017 metų projektų kiekybiniai rodikliai, parodoma jų dinamika. Apibūdinama projektų rẻmèjų, tematikos, partnerių skaičiaus ir lyginamojo svorio kaita bendroje rèmëjų, projektų struktūroje. Atskleidžiama projektų, skirtų vaikams ir jaunimui, skaičiaus bei lyginamojo svorio dinamika. Parodoma projektų „Bibliotekos pažangai“ ir „Bibliotekos pažangai 2“ reikšmė bibliotekoms ir visuomenei.

\subsubsection{Projektai ir jų réméjai}

2007, 2013, 2015-2017 metais vykdytų projektų skaičių ir jo kaitą iliustruoja 1 paveikslas.

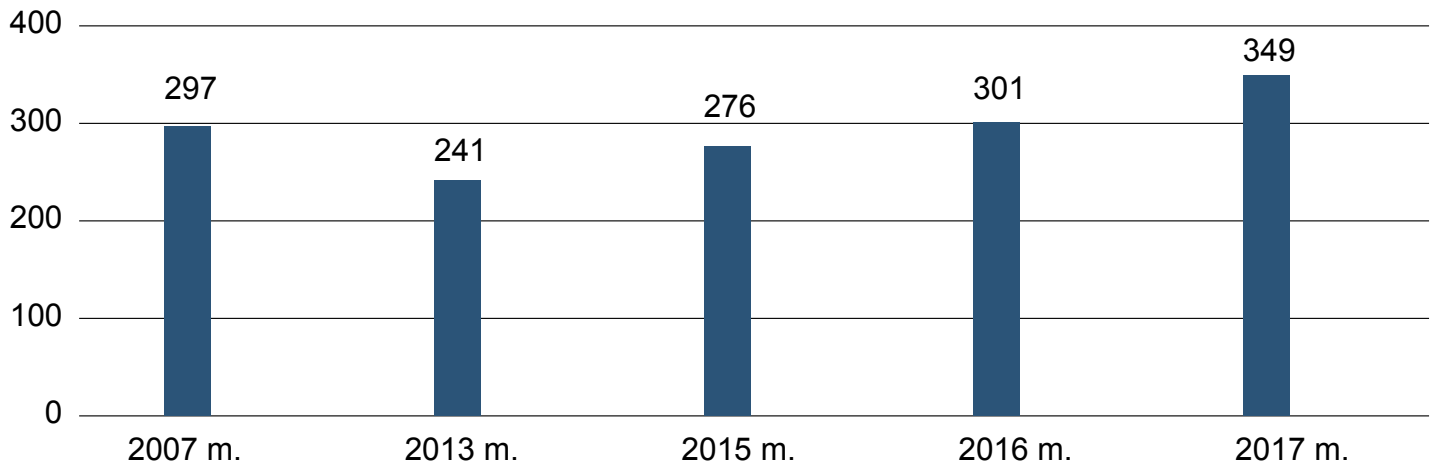

1 pav. 2007, 2013, 2015-2017 metų projektų skaičius

Šaltinis: Paveikslai ir lentelès sudaryti remiantis bibliotekų ataskaitų ir tinklalapių informacija (2015 ir 2016 metų duomenų analizei papildomai panaudota LNB portalo $w w w$.3erdve.lt informacija). 
2007 m. vykdyti 297 projektai. Projektų skaičius sumažejo 2013 m., 2015-2017 m. - didejjo. Projektų skaičiaus sumažejimą $2013 \mathrm{~m}$. galima paaiškinti tuo, kad tų metų pavasarị dar buvo vykdomas nacionalinis projektas „Bibliotekos pažangai“ (BP, pradètas vykdyti $2008 \mathrm{~m}$.), tais metais reikèjo įdiegti jo rezultatus. 2017 m. projektų skaičius, palyginti su 2007 m., padidejo 52 vienetais (17,5 proc.). Iš viso vykdyti 1464 projektai.

Projektų rẻmèjų skaičių ir jo kaitą 2007, 2013, 2015-2017 metais parodo 2 paveikslas.

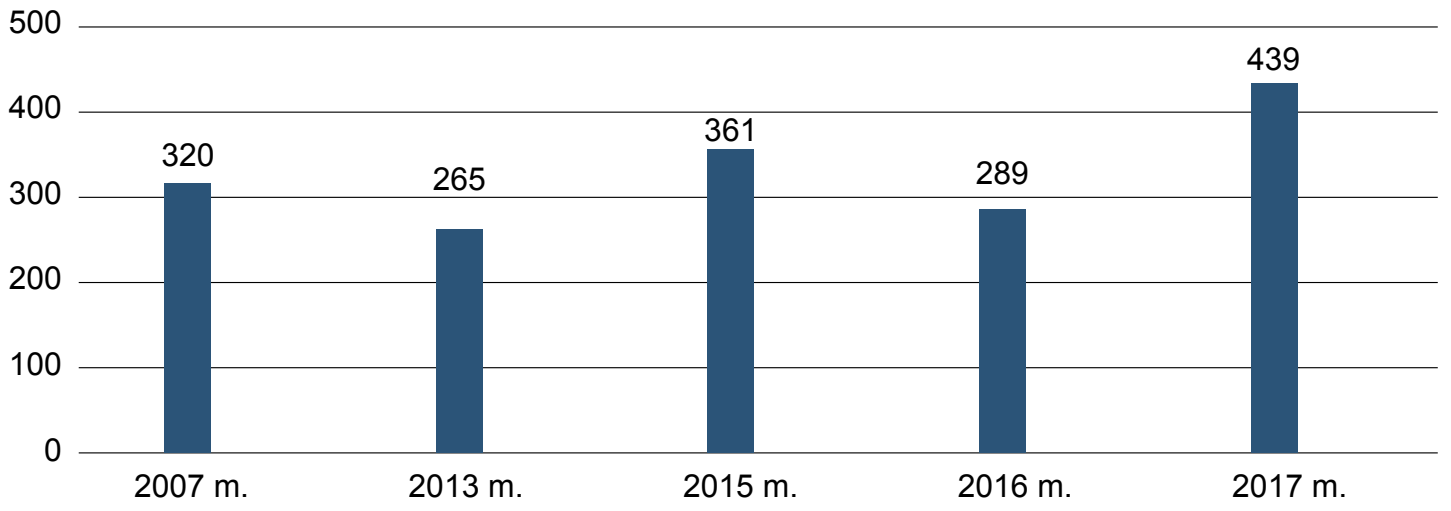

2 pav. Projektų rėmëjų skaičius 2007, 2013, 2015-2017 metais

Autoriaus skaičiavimais (priminsime, kad rėmëjų skaičius nurodomas remiantis bibliotekų dokumentais), mažiausias rèmëjų skaičius buvo 2013-aisiais (tais metais buvo mažiausiai vykdyta projektų), didžiausias - 2017 m. Palyginti su 2007-aisiais, jų padaugèjo 119 vienetų (37,2 proc.).

Informacija apie tarptautinių, nacionalinių, vietos rėmejjų skaičiaus, lyginamojo svorio (procentais) ${ }^{48}$ kaitą bendroje rèmèjų struktūroje pateikiama 1 lentelèje.

1 lentele. Tarptautinių, nacionalinių, vietos rèmëjų skaičius, lyginamojo svorio (procentais) kaita bendroje rèmëjų struktūroje 2007, 2013, 2015-2017 metais

\begin{tabular}{|l|c|c|c|c|c|c|}
\multicolumn{1}{|c|}{ Rèmëjų tipas } & $\mathbf{2 0 0 7} \mathbf{~ m .}$ & $\mathbf{2 0 1 3} \mathbf{~ m .}$ & $\mathbf{2 0 1 5} \mathbf{~ m .}$ & $\mathbf{2 0 1 6} \mathbf{~ m .}$ & $\mathbf{2 0 1 7} \mathbf{~ m .}$ & Vidutiniškai \\
\hline Tarptautiniai rèmëjai & $9(2,8 \%)$ & $42(15,8 \%)$ & $73(20,4 \%)$ & $38(13,4 \%)$ & $48(10,9 \%)$ & $210(12,7 \%)$ \\
\hline Nacionaliniai rèmèjai & $117(36,6 \%)$ & $103(38,9 \%)$ & $140(38,8 \%)$ & $103(35,7 \%)$ & $141(32,1 \%)$ & $604(36,4 \%)$ \\
\hline Vietos rèmèjai & $168(52,5 \%)$ & $103(38,9 \%)$ & $136(37,5 \%)$ & $143(49,2 \%)$ & $243(55,4 \%)$ & $793(46,7 \%)$ \\
\hline Nenurodyta & $26(8,1 \%)$ & $17(6,4 \%)$ & $12(3,3 \%)$ & $5(1,7 \%)$ & $7(1,6 \%)$ & $67(4,2 \%)$ \\
\hline Iš viso & $320(100 \%)$ & $265(100 \%)$ & $361(100 \%)$ & $289(100 \%)$ & $439(100 \%)$ & $1674(100 \%)$ \\
\hline
\end{tabular}

$2007 \mathrm{~m}$. projektus parèmé 9 tarptautinès institucijos, 117 nacionalinių rẻmëjų, 168 vietos rèmëjai (nenurodyti 26 rèmejjai). Projektus finansavo tarptautiniai rèmejjai: Europos Komisijos atstovybe Lietuvoje (EKAL), Europos regioninès plètros fondas, Europos socialinis fondas, Jaunimo tarptautinio bendradarbiavimo agentūra (programa „Veiklus jaunimas" ${ }^{(49}$ ). Pagrindiniai nacionaliniai rèmëjai buvo Kultūros ministerija ir Kultūros ir sporto rèmimo fondas. Paminètini taip pat Švietimo ir mokslo ministerija, Spaudos, radijo ir televizijos rèmimo fondas, Lietuvos tūkstantmečio minëjimo direkcija prie LR Prezi-

\footnotetext{
48 Operuojant rẻmėjų (vèliau - projektų) skaičiais būtina atsižvelgti ị jų lyginamąji svorị (procentais) bendroje rẻmejjų (vèliau - projektų) struktūroje. Lyginamasis svoris parodo rẻmẻjų, projektų tipų tarpusavio santykị. Tekste terminai „lyginamasis svoris“, „procentinè dalis“, „procentinè išraiška“" vartojami sinonimiškai.

49 Programa suteikè jauniems žmonèms neformaliojo ugdymo(si) galimybes ir finansines subsidijas jų inicijuotiems bei ịgyvendinamiems projektams, skatino Europos šalių jaunimo bendradarbiavimą. Programa buvo igyvendinama 2007-2013 m. 2014-2020 m. formaliojo švietimo, neformaliojo ugdymo ir sporto veiklos finansuojamos pagal ES programą „Erasmus+“.
} 
dento kanceliarijos, Žemès ūkio ministerija. Pagrindinès vietos rèmëjos - savivaldybès. Kelis projektus parėmè apskrities viršininko administracija.

Nuo 2008 iki 2013 m. kovo mẻn. šalyje buvo vykdomas didžiausias viešųjų bibliotekų plètros projektas „Bibliotekos pažangai“. Jis vykdytas pagal 2007 m. lapkričio 15 d. pasirašytą susitarimą tarp Billo ir Melindos Gatesų fondo, Kultūros ministerijos ir Lietuvos nacionalinès Martyno Mažvydo bibliotekos. Projekto vykdytoja - Lietuvos nacionalinè Martyno Mažvydo biblioteka.

Nors dèl aljanso „Langas $\mathfrak{i}$ ateitị“ veiklos VIPT bibliotekose gana sparčiai augo, išliko gana didelè bibliotekų elektroninè atskirtis. $2007 \mathrm{~m}$. viešą interneto prieigą gyventojams teikè 76 proc. miestuose veikiančių savivaldybių viešujų bibliotekų ir 28 proc. kaimo filialų. Bibliotekos darbuotojų IT naudojimo igūdžių lygis buvo gana žemas ir nepakankamas ketinant aptarnauti, mokyti interneto vartotojus ${ }^{50}$. Projektu BP siekta, kad Lietuvos gyventojai daug geriau naudotųsi IT galimybėmis naudingai informacijai gauti ir bendrauti. Vykdant projektą, esmiškai buvo pagerinta bibliotekų infrastruktūra (kompiuterizavimas, viešoji interneto prieiga). Visose perspektyviose viešosiose bibliotekose buvo įrengiama viešoji interneto prieiga, o ją turinčiose - išplečiama ir modernizuojama.

Projekte dalyvavo 1276 savivaldybių viešosios bibliotekos ir jų filialai. Bibliotekos gavo techninę ịrangą, joms buvo įrengiamas plačiajuostis interneto ryšys. Visos bibliotekos buvo įtrauktos ị specialistų ir lankytojų mokymo, e. paslaugų vartojimo skatinimo ir konsultavimo veiklas. Buvo kkurti ir sèkmingai veike 11 mokymo centrų bibliotekininkams ir gyventojams; įrengta (modernizuota) viešoji interneto prieiga 891-oje viešojoje miesto ir kaimo bibliotekoje; 72-ose bibliotekose įdiegta speciali programinè iranga akliesiems ir silpnaregiams, bibliotekininkai išmokyti ja naudotis ir konsultuoti lankytojus; parengta ir visose bibliotekose išplatinta medžiaga bibliotekininkams ir gyventojams mokyti (spausdinti leidiniai, mokymo medžiaga internete, mokomosios vaizdinès priemonės).

Projekto rezultatų reikšmé bibliotekoms ir visuomenei:

- beveik visoje šalies teritorijoje (mieste ir kaime) išspręsta fizinès prieigos prie kompiuterio ir interneto problema. Neturintys namuose kompiuterio ir interneto žmonès 5-7 km atstumu gavo galimybę pasinaudoti nemokama viešąja interneto prieiga (VIP) artimiausioje viešojoje bibliotekoje; nemokamą interneto prieigą teikiančių šalies bibliotekų skaičius išaugo beveik dvigubai ir pasiekė 97 procentus. Ivveikta kaimo bibliotekų technologinè atskirtis - VIP paslaugas teikiančių kaimo bibliotekų skaičius padvigubëjo ir beveik susilygino su tokių bibliotekų dalimi miestuose. Bibliotekos pritrauke dvigubai daugiau naujų VIP vartotojų;

- viešosiose bibliotekose sukurtas tinklas specialistų, mokančių ir konsultuojančių gyventojus kasdien ir padedančių tiek mieste, tiek kaime igyti skaitmeninių igūdžių ar juos pagerinti. İ šią kasdienę ir nenutrūkstamą veiklą įsitraukè apie 2000 kompetentingų bibliotekininkų;

- išsiplète bibliotekos misija ir vaidmuo, sustiprëjo bibliotekų veiklos efektyvumas, išsiplète teikiamų paslaugų repertuaras, išaugo bibliotekų prestižas. 2008 metais biblioteka buvo daugiausia siejama su skaitymo skatinimu, o 2012-aisiais ji jau buvo laikoma kompleksinių paslaugų teikejja, informacijos, kultūros, švietimo ir bendruomenès traukos centru, nuolat diegiančiu naujoves ir skatinančiu gyventojus jomis aktyviai naudotis. Bibliotekų veikloje įvykę svarbūs pokyčiai ne tik sustiprino jų vaidmenị visuomenèje, bet ir turèjo įtakos bendrai šalies socialinei pažangai ${ }^{51}$.

Nacionalinio projekto igyvendinimas sudare geresnes prielaidas bibliotekų projektinei veiklai tobulinti.

Moderniai visuomenei - naujoviška biblioteka. Projekto „Bibliotekos pažangai (2008-2012) įtaka Lietuvos viešųų bibliotekų raidai, p. 14. Prieiga per internetą: http://www.bibliotekospazangai.lt/media/public/Atsisiuntimui/Moderniai\%20visuomenei-small.pdf. Žiūreta 2018-09-12.

51 Žr. Bibliotekos pažangai. Prieiga per internetą: https://www.lnb.lt/apie-biblioteka/programos-ir-projektai/edukaciniai-projektai/ bibliotekos-pazangai. Žiūrèta 2018-09-12; Moderniai visuomenei - naujoviška biblioteka. Projekto „Bibliotekos pažangai (20082012) ịtaka Lietuvos viešųjų bibliotekų raidai, p. 5, 14. Prieiga per internetą: http://www.bibliotekospazangai.lt/media/public/Atsisiuntimui/Moderniai\%20visuomenei-small.pdf. Žiūrèta 2018-09-12. 
2013 m. projektus parèmè 42 tarptautinès institucijos, 103 nacionalinės ir 103 vietos institucijos (nenurodyta 17 rèmëjų). Pagrindinis tarptautinis rèmèjas - EKAL. Paminètini taip pat ES struktūriniai fondai (bibliotekų dokumentuose ne visada konkretizuoti), Europos žemès ūkio fondas kaimo plètrai (LEADER ${ }^{52}$ programa), EIFL (Electronic Information for Libraries; Elektroninė informacija bibliotekoms ${ }^{53}$ ), Švietimo mainų paramos fondas ${ }^{54}$ („Leonardo da Vinci“ ${ }^{{ }^{55}}$, „Griundtvig“" ${ }^{“ 6}$ programos), ES programa „Veiklus jaunimas“. Nacionaliniai ir vietos rèmejjai mažai pakito. Tai Kultūros ministerija, Kultūros rèmimo fondas $(\mathrm{KRF})^{57}$, Spaudos, radijo ir televizijos rèmimo fondas, savivaldybès ir kt.

LNB prisiemė ịsipareigojimus užtikrinti projekto „Bibliotekos pažangai“ veiklų tęstinumą, sutelkè jègas naujam projektui „Bibliotekos pažangai 2“. 2013 m. lapkričio mènesị kartu su Billo ir Melindos Gatesų fondu (BMGF) LNB pasirašè bendradarbiavimo sutartį dèl projekto „Bibliotekos pažangai 2“ (BP 2) igyvendinimo Lietuvoje, kurị iš dalies finansavo ir LR kultūros ministerija (KM). Projekto igyvendinimo terminas: 2013 m. gruodis - $2016 \mathrm{~m}$. lapkritis. Projekto tikslas - sustiprinti bibliotekų galimybes tenkinti besivystančios visuomenès poreikius ir itvirtinti bibliotekas kaip tvarias bendruomenès institucijas, galinčias pagerinti žmonių gyvenimo kokybę. Siekta išplèsti viešųjų bibliotekų bendradarbiavimą su verslo atstovais, vietos valdžios institucijomis bei nevyriausybinemis organizacijomis, taip stiprinant biblioteku pajègumus. 57 viešosios bibliotekos pateikè bendruomenių poreikius atitinkančias projektų paraiškas. Projektus laimèjo 41 savivaldybių viešoji biblioteka (ir 4 apskričių bibliotekos) ${ }^{58}$. Laimèti projektai buvo vykdomi 2015-2016 m.

2015 m. projektus finansavo 361 rémejjas: 73 tarptautiniai, 140 nacionaliniai, 136 vietos rèmèjai (nenurodyta 12 rėmejjų). Projektas BP 2 finansuotas iš dviejų šaltinių: tarptautinis rèmèjas - BMGF, nacionalinè rèmëja - Kultūros ministerija. Išaugo tarptautinių rèmèjų (41 projektas paremtas BMGF), nacionalinių ir vietos rèmèjų skaičiai. Pagrindine nacionaline rèmèja tapo Lietuvos kultūros taryba $(\mathrm{LKT})^{59}$.

2016 m. 289 rèmèjai finansavo 301 projektą. Mažesnis rèmèjų skaičius paaiškinamas tuo, kad 2016-aisiais vykdyta nemažai projektų, kurie finansuoti $2015 \mathrm{~m}$. (daugiausia BMGF fondo ir KM). Projektus parèmè 39 tarptautinès, 103 nacionalinès, 143 vietos institucijos (nenurodyti penki rèmëjai). Kaip ir ankstesniais metais, projektus finansavo tarptautiniai rèmejai: EKAL, ES struktūriniai fondai (ne visada konkretizuoti), Europos regioninès plètros fondas. Nauji rèmejai - Europos ekonominès erdvès programa „Europos kultūros paveldo kultūros ir menų ịvairovès skatinimas“ ${ }^{{ }^{60}}$, ES fondų investicijų veiksmų

Prancūziško termino Liaison Entre Actions de Développement de l'Économie Rurale (liet. kaimo ekonomikos plètros darbų sąsajos) pirmos raidès. Pagrindinis LEADER programos tikslas kaimo plètros srityje - skatinti tolygią regionų plètrą, gerinti gyvenimo kokybę kaime, spręsti socialines, ekonomines ir aplinkos problemas pasitelkus vietos gyventojus, kaimo nevyriausybines organizacijas, vietos verslininkus, vietos valdžios institucijas ir kitus kaimo plètros dalyvius.

53 Tarptautinè ne pelno organizacija, siekianti suteikti prieigą prie skaitmeninès informacijos besivystančiose ir pereinamosios ekonomikos šalyse Afrikoje, Azijoje ir Europoje veikiančiose bibliotekose.

54 Nuo 2007 m. sèkmingai veikianti Lietuvos nacionalinė agentūra, kuriai pavesta administruoti „Erasmus+“ ”rogramą „Mokymasis visą gyvenimą" ir kitas Europos Komisijos ir LR Vyriausybẻs finansuojamas iniciatyvas švietimo ir profesinio mokymo srityje.

Profesinio mokymo programa.

Suaugusiųjų švietimo programa (pavadinta danų švietėjo vardu).

İkurtas $2007 \mathrm{~m}$. liepos $4 \mathrm{~d}$. ̣̂statymu, ịsigaliojusiu $2008 \mathrm{~m}$. sausio $1 \mathrm{~d}$.

Bibliotekos pažangai 2. Prieiga per internetą: https://www.google.lt/search?q=Bibliotekos+pa\%C5\%BEangai+2\%E2\%80\%9C.\&rlz=1C1GCEA_enLT771LT772\&oq=Bibliotekos+pa\%C5\%BEangai+2\%E2\%80\%9C.\&aqs=chrome..69i57j0j69i64.1426j0j8\&sourceid=chrome\&ie=UTF-8. Žiūrèta 2018 m. spalio 19 d.

59 LR Lietuvos kultūros tarybos ịstatymas priimtas $2012 \mathrm{~m}$. rugsẻjo $18 \mathrm{~d}$. LR kultūros ministrui nustačius valstybès rèmimo prioritetus (kultūros edukacija, kultūra regionuose, kultūros produktų ir paslaugų kūrimas, tarptautiniai ir mobilumo projektai, kultūros tapatumas, kultūros srities bendrieji tyrimai), Lietuvos kultūros taryba nuo 2014 m. priima paraiškas ir skiria finansavimą pagal tam tikrą prioritetą atitinkančias finansavimo programas.

${ }_{60}$ Europos ekonominès erdvès (EEE) programa - tai Norvegijos, Islandijos ir Lichtenšteino parama Rytų, Vidurio ir Pietų Europos šalims, kuria siekiama mažinti socialinius ir ekonominius skirtumus, stiprinti bendradarbiavimą tarp valstybių donorių ir paramos gavejų. 
programa „Neformaliojo vaikų švietimo paslaugų plètra“ (administravo Lietuvos mokinių neformaliojo švietimo centras), „Nordplus Adult“ programa ${ }^{61}$.

2017-aisiais rèmëjų skaičius buvo didžiausias, palyginti su 2007, 2013, 2015 ir 2016 metais. Projektus parèmè 48 tarptautinių institucijų, 141 nacionalinès, 243 vietos institucijų fondai (nenurodyti 7 rèmèjai). Reikšmingai dominavo vietos rèmëjai. Be savivaldybių, kiek didesnis buvo uždarųjų akcinių bendrovių (UAB) vaidmuo.

Tarptautinių rèmèjų lyginamasis svoris $2007 \mathrm{~m}$. sudarè 2,8 proc. 2013, 2015 metais tarptautinių rèmèjų procentinè dalis bendroje rèmëjų struktūroje gerokai padidèjo, $2015 \mathrm{~m}$. sudare daugiau kaip 20 proc. 2016-2017 m. tarptautinių rèmèjų procentinè dalis sumažèjo (didẻjant bendram tarptautinių rèmèjų skaičiui). $2017 \mathrm{~m}$. tarptautiniai rèmėjai sudare 10,9 proc. Vidutiniškai tarptautiniai rèmėjai sudare 12,7 proc. 2017 m. procentinè dalis, palyginti su vidurkiu, sumažèjo 1,8 proc.

Nacionalinių rėmėjų lyginamasis svoris 2007 m. sudarė 36,6 proc., 2013 ir 2015 metais truputị padidèjo (arti 40 proc.). 2016-2017 m. nacionalinių rèmèjų procentinè dalis sumažejo (didèjant bendram nacionalinių rèmèjų skaičiui), $2017 \mathrm{~m}$. ji sudare 32,1 proc. Vidutiniškai nacionaliniai rèmėjai viršijo trečdalị visų rèmëjų, sudarẻ daugiau kaip 36 proc. $2017 \mathrm{~m}$. procentinė dalis, palyginti su vidurkiu, sumažèjo 4,3 proc.

Vietos rèmejai $2007 \mathrm{~m}$. bendroje rèmèjų struktūroje sudarẻ daugiau kaip 50 proc. Jų procentinè dalis sumažèjo 2013 ir 2015 metais, 2016-2017 m. didèjo. Didžiausias vietos rèmèjų lyginamasis svoris buvo 2017 m., sudare 55,4 proc. Vietos rèmèjams vidutiniškai tenka 46,7 proc. 2017 m. procentinè dalis, palyginti su vidurkiu, išaugo 8,7 proc.

Pažymėtina, kad ne visi bibliotekų projektai laimėdavo konkursus. Pavyzdžiui, $2007 \mathrm{~m}$. Tauragès $\mathrm{r}$. SVB pateike 11 projektų paraiškų Kultūros ministerijos konkursui „Skaitymo skatinimas“, finansuoti 4 projektai. Kultūros ministerija nefinansavo 2 Jurbarko r. SVB konkursui „Skaitymo skatinimas“ pateiktų paraiškų. Trakų r. biblioteka pateike įvairioms institucijoms 28 projektų paraiškas. Finansavimą gavo 3 projektai: 2 buvo finansuoti Kultūros ministerijos ir 1 Švietimo ir mokslo ministerijos. Savivaldybe nefinansavo né vieno projekto.

Projektinè veikla plètojosi smarkios konkurencijos sąlygomis. Lietuvos kultūros tarybos duomenimis, $2016 \mathrm{~m}$. jai buvo pateiktos 6148 projektų paraiškos, finansavimas skirtas 2038 projektams, t. y. trečdaliui iniciatyvų ${ }^{62}$. Informacija apie savivaldybių viešųjų bibliotekų projektų atmetimo priežastis yra skurdi. Šiek tiek informacijos apie atmestus projektus 2015 m. pateikia Kupiškio r. biblioteka. Tais metais Lietuvos kultūros tarybai teikta paraiška projektui „Keliaujame su knyga“. Projektas ịvertintas 54 balais (praeinamasis balas - 55). Projektas „Kultūros renginių ciklas Sugrįžimai“ ịvertintas 50 balų (praeinamasis balas - 57). Biblioteka projektui „Bibliotekos pažangai 2“ teike paraišką „Bibliotekos sveikesniam gyvenimui“. Tai buvo sveikos gyvensenos populiarinimo projektas, kuriame numatyta sukurti informacinius blokus bibliotekos interneto svetainèje, kad vyresnio amžiaus žmonèms būtų patogu ieškoti informacijos apie sveikatą. Planuota aprūpinti medicinos diagnostikos įranga visus 16 viešosios bibliotekos padalinių, organizuoti sveikatingumo mokymus - teorinius bei praktinius. Projektui nebuvo pritarta. Galime daryti prielaidą, kad projektui nepritarta todèl, jog jo numatytos veiklos panèšèjo i medicinos įstaigos veiklas.

Projektų skaičius didëjo mažèjant bibliotekų bei lankytojų skaičiams. 2007 m. šalyje veikè 1 tūkst. 375 bibliotekos, 2016 m. - 1 tūkst. 257, 2017 m. - 1 tūkst. 247. Bibliotekų filialų tinklas traukiasi. Lankytojų skaičiaus mažèjimas nèra didelis. 2014-2016 m. duomenimis, apsilankymų SVB skaičius sumažèjo 2,8 proc.

„Nordplus Adult“ - Šiaurès ministrų tarybos suaugusiųjų švietimo programa.

62 Lietuvos kultūros taryba. 2016 m. veiklos ataskaita. Prieiga per internetą: https://www.ltkt.lt/apie-ltkt/2016-m-ataskaita. Žiūrèta 2019-01-03. 
$2017 \mathrm{~m}$. apsilankymų buvo 1,56 proc. mažiau nei $2016 \mathrm{~m} .{ }^{63}$ Itakos tam turëjo demografinis veiksnys - mažèjo nuolatinių gyventojų skaičius. Nepaisant minètų aplinkybių, bibliotekų projektinè veikla plètėsi.

\subsubsection{Projektu tematika ir ju partneriai}

Projektų pagal tematiką 2007, 2013, 2015-2017 metais skaičių ir lyginamajị svorị (procentais) bendroje projektų struktūroje iliustruoja 2 lentelè.

2 lentelè. Projektų tematikos skaičiaus ir lyginamojo svorio (procentais) pasiskirstymas bendroje projektų struktūroje 2007, 2013, 2015-2017 metais

\begin{tabular}{|c|c|c|c|c|c|c|c|}
\hline \multicolumn{2}{|r|}{ Projektų tematika } & $2007 \mathrm{~m}$. & $2013 \mathrm{~m}$. & $2015 \mathrm{~m}$. & $2016 \mathrm{~m}$. & $2017 \mathrm{~m}$. & Vidutiniškai \\
\hline 1 & Infrastruktūra & $\begin{array}{c}4 \\
(1,4 \%)\end{array}$ & $\begin{array}{c}10 \\
(4,1 \%)\end{array}$ & $\begin{array}{c}1 \\
(0,4 \%)\end{array}$ & $\begin{array}{c}2 \\
(0,7 \%)\end{array}$ & $\begin{array}{c}3 \\
(0,8 \%)\end{array}$ & $\begin{array}{c}20 \\
(1,5 \%)\end{array}$ \\
\hline 2 & Kvalifikacijos kèlimas & $\begin{array}{c}9 \\
(3,0 \%)\end{array}$ & $\begin{array}{c}5 \\
(2,1 \%)\end{array}$ & $\begin{array}{c}4 \\
(1,4 \%)\end{array}$ & $\begin{array}{c}5 \\
(1,7 \%)\end{array}$ & $\begin{array}{c}6 \\
(1,7 \%)\end{array}$ & $\begin{array}{c}29 \\
(2,0 \%)\end{array}$ \\
\hline 3 & $\begin{array}{l}\text { Literatūra, skaitymo } \\
\text { skatinimas }\end{array}$ & $\begin{array}{c}129 \\
(43,4 \%)\end{array}$ & $\begin{array}{c}51 \\
(21,2 \%)\end{array}$ & $\begin{array}{c}69 \\
(24,9 \%)\end{array}$ & $\begin{array}{c}87 \\
(28,8 \%)\end{array}$ & $\begin{array}{c}91 \\
(26,1 \%)\end{array}$ & $\begin{array}{c}427 \\
(28,9 \%)\end{array}$ \\
\hline 4 & $\begin{array}{l}\text { Edukacija (išskyrus } 4-8 \\
\text { tematikos projektus) }\end{array}$ & $\begin{array}{c}46 \\
(15,5 \%)\end{array}$ & $\begin{array}{c}57 \\
(23,7 \%)\end{array}$ & $\begin{array}{c}87 \\
(31,4 \%)\end{array}$ & $\begin{array}{c}91 \\
(30,1 \%)\end{array}$ & $\begin{array}{c}114 \\
(32,7 \%)\end{array}$ & $\begin{array}{c}395 \\
(26,7 \%)\end{array}$ \\
\hline 5 & $\begin{array}{l}\text { Kūrybinès meninès } \\
\text { veiklos skatinimas }\end{array}$ & $\begin{array}{c}18 \\
(6,1 \%)\end{array}$ & $\begin{array}{c}20 \\
(8,3 \%)\end{array}$ & $\begin{array}{c}27 \\
(9,8 \%)\end{array}$ & $\begin{array}{c}35 \\
(11,6 \%)\end{array}$ & $\begin{array}{c}42 \\
(12,0 \%)\end{array}$ & $\begin{array}{c}142 \\
(9,6 \%)\end{array}$ \\
\hline 6 & $\begin{array}{l}\text { Kompiuterinio, skait- } \\
\text { meninio, informacinio } \\
\text { raštingumo ugdymas }\end{array}$ & $\begin{array}{c}3 \\
(1,0 \%)\end{array}$ & $\begin{array}{c}10 \\
(4,1 \%)\end{array}$ & $\begin{array}{c}11 \\
(4,0 \%)\end{array}$ & $\begin{array}{c}10 \\
(3,6 \%)\end{array}$ & $\begin{array}{c}8 \\
(2,3 \%)\end{array}$ & $\begin{array}{c}42 \\
(3,0 \%)\end{array}$ \\
\hline 7 & $\begin{array}{l}\text { Kraštotyra, kultūros } \\
\text { paveldo aktualizavimas } \\
\text { (ǐsskyrus } 7-8 \\
\text { tematikos projektus) }\end{array}$ & $\begin{array}{c}23 \\
(7,7 \%)\end{array}$ & $\begin{array}{c}26 \\
(10,8 \%)\end{array}$ & $\begin{array}{c}17 \\
(6,1 \%)\end{array}$ & $\begin{array}{c}20 \\
(6,6 \%)\end{array}$ & $\begin{array}{c}32 \\
(9,2 \%)\end{array}$ & $\begin{array}{c}118 \\
(8,1 \%)\end{array}$ \\
\hline 8 & Etninė kultūra & $\begin{array}{c}33 \\
(11,1 \%)\end{array}$ & $\begin{array}{c}37 \\
(15,4 \%)\end{array}$ & $\begin{array}{c}24 \\
(8,7 \%)\end{array}$ & $\begin{array}{c}14 \\
(4,6 \%)\end{array}$ & $\begin{array}{c}24 \\
(6,9 \%)\end{array}$ & $\begin{array}{c}132 \\
(9,3 \%)\end{array}$ \\
\hline 9 & Istorija & $\begin{array}{c}26 \\
(8,8 \%)\end{array}$ & $\begin{array}{c}20 \\
(8,3 \%)\end{array}$ & $\begin{array}{c}24 \\
(8,7 \%)\end{array}$ & $\begin{array}{c}22 \\
(7,3 \%)\end{array}$ & $\begin{array}{c}19 \\
(5,4 \%)\end{array}$ & $\begin{array}{c}111 \\
(7,7 \%)\end{array}$ \\
\hline 10 & Socialiniai & $\begin{array}{c}6 \\
(2,0 \%)\end{array}$ & $\begin{array}{c}5 \\
(2,1 \%)\end{array}$ & $\begin{array}{c}12 \\
(4,3 \%)\end{array}$ & $\begin{array}{c}15 \\
(5,0 \%)\end{array}$ & $\begin{array}{c}10 \\
(2,9 \%)\end{array}$ & $\begin{array}{c}48 \\
(3,2 \%)\end{array}$ \\
\hline & Iš viso & $\begin{array}{c}297 \\
(100 \%)\end{array}$ & $\begin{array}{c}241 \\
(100 \%)\end{array}$ & $\begin{array}{c}76 \\
(100 \%)\end{array}$ & $\begin{array}{c}301 \\
(100 \%)\end{array}$ & $\begin{array}{c}349 \\
(100 \%)\end{array}$ & $\begin{array}{c}146 \\
4(100 \%)\end{array}$ \\
\hline
\end{tabular}

Infrastruktūros klausimai (objektai, IT diegimas ir kt.) buvo sprendžiami nacionaliniu mastu, tad atskirų projektų, kuriuos vykde bibliotekos, skaičiai nèra dideli (infrastruktūros projektų daugiausia buvo igyvendinta 2013 m.). Projektų procentinè dalis ir jos kitimas nèra dideli. Kiek didesnis lyginamasis svoris buvo 2013 m. (4,1 proc.). Vidutiniškai jis sudarè 1,5 proc.

Bibliotekos darbuotojų kvalifikacijos kèlimo projektų skaičiai yra kuklūs, kiek daugiau jų buvo ịgyvendinta $2007 \mathrm{~m}$. Projektų procentinè dalis ir jos kitimas nèra dideli. Bendroje projektų struktūroje $2007 \mathrm{~m}$. ji sudarè 3,0 proc., kitais metais sumažèjo. Vidutiniškai ji sudarè 2,0 proc.

Lietuvos biblioteku 2006-2010 m. statistika. Vilnius: Lietuvos nacionalinė Martyno Mažvydo biblioteka, 2011, p. 63; Lietuvos biblioteku 2016 m. statistika, Vilnius: Lietuvos nacionalinė Martyno Mažvydo biblioteka, p. 41, 49. Prieiga per internetą: https://drive. google.com/file/d/0B_-73IZKEJy5RIFEYUN1OHAwTGs/view. Žiūreta 2018-05-16; Lietuvos biblioteku 2017 m. statistika, Vilnius: Lietuvos nacionalinė Martyno Mažvydo biblioteka, p. 49. Prieiga per internetą: https://drive.google.com/file/d/1iHtFq2eSrOBuHbYt5ZaQC7ci0aL6Z73Q/view. Žiūrèta 2019-02-01. 
Literatūros, skaitymo skatinimo projektų daugiausia buvo vykdyta 2007-aisiais. Tais metais bibliotekų projektinę veiklą smarkiai suaktyvino LR Vyriausybès $2006 \mathrm{~m}$. lapkričio $30 \mathrm{~d}$. nutarimas „Dèl skaitymo skatinimo programos patvirtinimo“. Projektų gerokai sumažèjo 2013-aisiais, 2015-2017 m. padaugejo. Projektų lyginamasis svoris bendroje projektų struktūroje $2007 \mathrm{~m}$. sudare 43,4 proc. Projektų procentinè dalis smarkiai sumažèjo 2013 m., nuo $2013 \mathrm{~m}$. - didejjo, $2017 \mathrm{~m}$. sumažèjo ir sudarè 26,1 proc. Vidutiniškai ji sudarẻ beveik 29 proc. 2017 m. procentinè dalis, palyginti su vidurkiu, sumažejo 2,8 proc.

Bendro pobūdžio edukacijos projektų nuosekliai daugèjo, 2017-aisiais jie viršijo $2007 \mathrm{~m}$. lygi beveik 2,5 karto. Projektų lyginamasis svoris augo (2016 m. truputị sumažèjo). Visų projektų struktūroje 2017 m. jis viršijo 30 proc. Vidutiniškai projektai sudarė beveik 27 proc. 2017 m. procentinè dalis, palyginti su vidurkiu, išaugo 6 proc.

Kūrybinès meninès veiklos skatinimo projektų nuosekliai daugèjo, 2017 m. jie viršijo 2007-ụjų lygi daugiau kaip 2,3 karto. Projektų procentinè dalis nuosekliai didèjo, $2017 \mathrm{~m}$. sudarė 12 proc. Vidutiniškai ji sudarè 9,6 proc. $2017 \mathrm{~m}$. procentinè dalis, palyginti su vidurkiu, išaugo 2,4 proc.

Kompiuterinio, skaitmeninio, informacinio raštingumo ugdymo projektų skaičiai nèra dideli: kiek daugiau jų buvo igyvendinta 2013, 2015-2016 metais, mažiausiai - 2007 m. Projektų procentinè dalis svyravo (nuo 1,0 proc. iki 4,1 proc.). Vidutiniškai jų lyginamasis svoris sudare 3 proc. $2017 \mathrm{~m}$. procentinè dalis, palyginti su vidurkiu, sumažejo 0,7 proc.

Kraštotyros, kultūros paveldo aktualizavimo projektų skaičius, jų lyginamasis svoris svyravo. Procentinè dalis $2007 \mathrm{~m}$. bendroje projektų struktūroje sudarè 7,7 proc., $2017 \mathrm{~m}$. - 9,2 proc. Vidutiniškai ji sudare 8,1 proc. $2017 \mathrm{~m}$. procentinè dalis, palyginti su vidurkiu, išaugo 1,1 proc.

Etninès kultūros projektų daugiausia buvo igyvendinta 2007 ir 2013 metais, kitais metais jų vykdyta mažiau. Projektų lyginamais svoris svyravo. $2007 \mathrm{~m}$. jis sudare 11,1 proc., 2017-aisiais $-6,9$ proc. Vidutinis dydis - 9,3 proc. $2017 \mathrm{~m}$. procentinè dalis, palyginti su vidurkiu, sumažèjo 2,4 proc.

Istorinès tematikos projektų daugiausia buvo vykdyta 2007 ir 2015 metais, kitais metais - kiek mažiau. Projektų procentinè dalis mažèjo. Bendroje projektų struktūroje $2007 \mathrm{~m}$. ji sudarè 8,8 proc., 2017 m. - 5,4 proc. Vidutiniškai ji sudare 7,7 proc. 2017 m. procentinè dalis, palyginti su vidurkiu, sumažejo 2,3 proc.

Socialinių projektų skaičiai nèra dideli, daugiausia jų vykdyta $2016 \mathrm{~m}$. Projektų procentinè dalis nèra didelè. Bendroje projektų struktūroje ji sudare nuo 2,0 proc. (2007 m.) iki 5,0 proc. (2016 m.). Vidutiniškai ji sudarè 3,2 proc. $2017 \mathrm{~m}$. procentinè dalis, palyginti su vidurkiu, šiek tiek sumažèjo.

Projektų, skirtų vaikams ir jaunimui, skaičių ir dinamiką 2007, 2013, 2015-2017 metais iliustruoja 3 paveikslas.

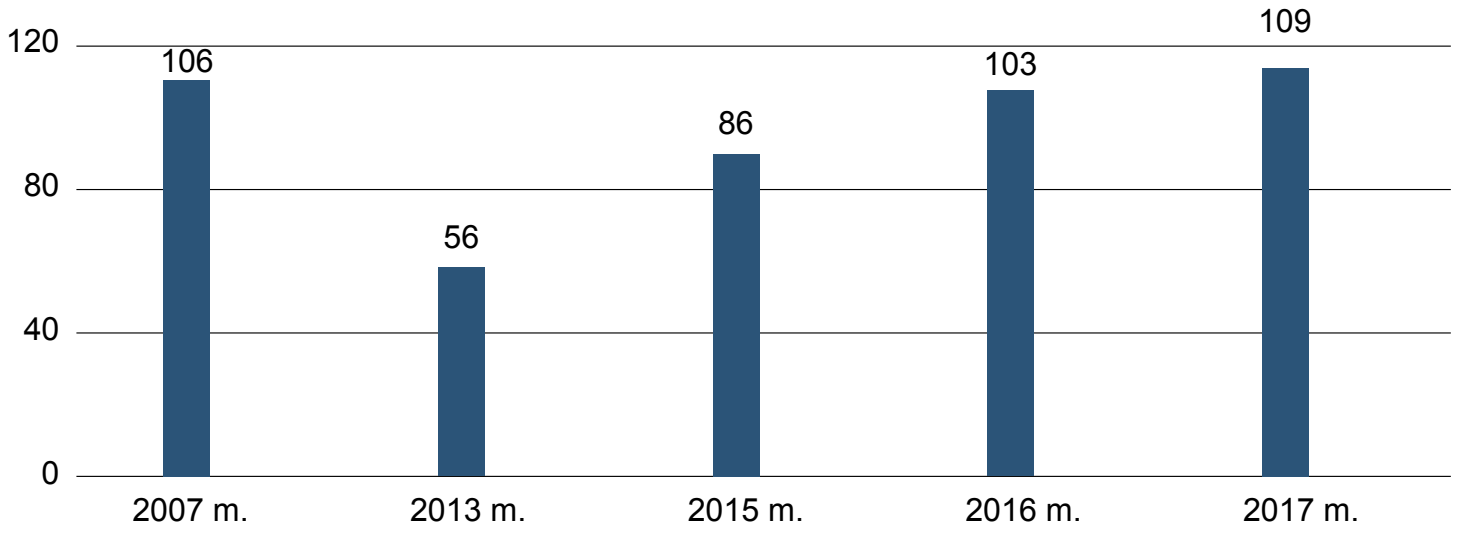

3 pav. Projektų, skirtų vaikams ir jaunimui, skaičius 2007, 2013, 2015-2017 metais 
Vaikams ir jaunimui $2007 \mathrm{~m}$. skirti 106 projektai, tai sudare 35,7 proc. visų projektų skaičiaus. $2013 \mathrm{~m}$. vaikams ir jaunimui skirtų projektų, palyginti su 2007 m., sumažèjo beveik du kartus. Manytume, kad bendras projektų skaičiaus sumažejimas paveikè projektų, skirtų vaikams ir jaunimui, skaičių. 56 projektai sudarè 23,2 proc. 2015 m. 86 projektai sudare 31,2 proc. (rodiklis smarkiai pagerèjo). Šiek tiek padaugèjo projektų 2016 metais: 103 projektai sudare 34,2 proc. $2017 \mathrm{~m} .109$ projektai sudare 31,2 proc. (nedidelis procentinès dalies sumažejimas, palyginti su $2016 \mathrm{~m}$.). Iš viso vykdyta 460 projektų.

Projektų, skirtų vaikams ir jaunimui, skaičių ir lyginamajji svorị (procentais) bendroje projektų struktūroje 2007, 2013, 2015-2017 metais parodo 3 lentelè.

Projektų, skirtų vaikams ir jaunimui, kiekị ir dinamiką 2007, 2013, 2015-2017 metais iliustruoja 3 paveikslas.

3 lentelè. Projektų, skirtų vaikams ir jaunimui, skaičius ir lyginamasis svoris (procentais) bendroje projektų struktūroje 2007, 2013, 2015-2017 metais (laužtiniuose skliaustuose nurodytas bendras projektų skaičius)

\begin{tabular}{|c|c|c|c|c|c|c|c|}
\hline & Projektų tematika & $2007 \mathrm{~m}$. & $2013 \mathrm{~m}$. & $2015 \mathrm{~m}$. & $2016 \mathrm{~m}$. & $2017 \mathrm{~m}$. & Vidutiniškai \\
\hline 1 & Literatūra, skaitymo skatinimas & $\begin{array}{l}67[129] \\
(51,9 \%)\end{array}$ & $\begin{array}{l}14[51] \\
(27,5 \%)\end{array}$ & $\begin{array}{l}25[69] \\
(36,2 \%)\end{array}$ & $\begin{array}{r}37[87] \\
(42,5 \%)\end{array}$ & $\begin{array}{l}29[91] \\
(31,9 \%)\end{array}$ & $\begin{array}{l}172[427] \\
(38,0 \%)\end{array}$ \\
\hline 2 & $\begin{array}{l}\text { Edukacija (išskyrus 3-7 temati- } \\
\text { kos projektus) }\end{array}$ & $\begin{array}{c}13[46] \\
(28,3 \%)\end{array}$ & $\begin{array}{c}10[57] \\
(17,5 \%)\end{array}$ & $\begin{array}{l}20[87] \\
(23,0 \%)\end{array}$ & $\begin{array}{l}27[91] \\
(29,7 \%)\end{array}$ & $\begin{array}{l}22[114] \\
(19,3 \%)\end{array}$ & $\begin{array}{l}92[395] \\
(23,6 \%)\end{array}$ \\
\hline 3 & $\begin{array}{l}\text { Kūrybinès meninès veiklos } \\
\text { skatinimas }\end{array}$ & $\begin{array}{l}16[18] \\
(88,9 \%)\end{array}$ & $\begin{array}{l}18[20] \\
(90,0 \%)\end{array}$ & $\begin{array}{l}21[27] \\
(77,8 \%)\end{array}$ & $\begin{array}{c}24[35] \\
(68,5 \%)\end{array}$ & $\begin{array}{c}32[42] \\
(76,2 \%)\end{array}$ & $\begin{array}{c}111[142] \\
(80,3 \%)\end{array}$ \\
\hline 4 & $\begin{array}{l}\text { Kompiuterinio, skaitmeninio, in- } \\
\text { formacinio raštingumo ugdymas }\end{array}$ & [3] & $\begin{array}{c}3[10] \\
(30,0 \%)\end{array}$ & $\begin{array}{c}2[11] \\
(18,2 \%)\end{array}$ & $\begin{array}{c}1[10] \\
(10,0 \%)\end{array}$ & $\begin{array}{c}3[8] \\
(37,5 \%)\end{array}$ & $\begin{array}{c}9[42] \\
(19,1 \%)\end{array}$ \\
\hline 5 & $\begin{array}{l}\text { Kraštotyra, kultūros paveldo } \\
\text { aktualizavimas (išskyrus 6-7 } \\
\text { tematikos projektus) }\end{array}$ & [23] & $\begin{array}{c}2[26] \\
(7,7 \%)\end{array}$ & $\begin{array}{c}2[17] \\
(11,8 \%)\end{array}$ & [20] & $\begin{array}{c}7[32] \\
(21,9 \%)\end{array}$ & $\begin{array}{c}11[118] \\
(8,3 \%)\end{array}$ \\
\hline 6 & Etninè kultūra & $\begin{array}{c}5[33] \\
(15,2 \%)\end{array}$ & $\begin{array}{c}3[37] \\
(8,1 \%)\end{array}$ & $\begin{array}{c}4[24] \\
(16,7 \%)\end{array}$ & $\begin{array}{c}4[14] \\
(28,6 \%)\end{array}$ & $\begin{array}{c}7[24] \\
(29,2 \%)\end{array}$ & $\begin{array}{l}23[132] \\
(19,6 \%)\end{array}$ \\
\hline 7 & Istorija & [26] & $\begin{array}{c}3[20] \\
(15,0 \%)\end{array}$ & $\begin{array}{c}1[24] \\
(4,2 \%)\end{array}$ & $\begin{array}{c}2[22] \\
(9,1 \%)\end{array}$ & $\begin{array}{c}4[19] \\
(21,1 \%)\end{array}$ & $\begin{array}{c}10[111] \\
(9,9 \%)\end{array}$ \\
\hline 8 & Socialiniai & $\begin{array}{c}5[6] \\
(83,3 \%)\end{array}$ & $\begin{array}{c}3[5] \\
(60,0 \%)\end{array}$ & $\begin{array}{c}10[12] \\
(83,3 \%)\end{array}$ & $\begin{array}{c}8[15] \\
(53,3 \%)\end{array}$ & $\begin{array}{c}5[10] \\
(50,0 \%)\end{array}$ & $\begin{array}{l}31[48] \\
(66,0 \%)\end{array}$ \\
\hline
\end{tabular}

2007 m. iš 129 literatūros ir skaitymo skatinimo projektų vaikams ir jaunimui tenka 67 projektai. 2013 m. projektų smarkiai sumažèjo, kitais metais - laipsniškai didèjo, nors toli gražu nepasiekè $2007 \mathrm{~m}$. lygio. Projektų lyginamasis svoris bendroje projektų struktūroje didžiausias buvo 2007 m. - 51,9 proc. Projektų procentinè dalis smarkiai sumažèjo 2013-aisiais (27,5 proc.), kitais metais buvo didesnè. $2017 \mathrm{~m}$. ji sudarè beveik 32 proc. Vidutiniškai procentinè dalis sudare 38 proc. $2017 \mathrm{~m}$. procentinè dalis, palyginti su vidurkiu, sumažèjo 6,1 proc.

Bendro pobūdžio edukacijos projektų skaičiai ir jų procentinè dalis svyravo. $2007 \mathrm{~m}$. ji sudarè kiek daugiau kaip 28 proc., 2017 m. - kiek daugiau kaip 19 proc. Vidutiniškai ji sudare 23,6 proc. 2017 m. procentinè dalis, palyginti su vidurkiu, sumažejo 4,3 proc.

Vaikams ir jaunimui daugiausia skirta kūrybinès meninès veiklos skatinimo projektų: $2007 \mathrm{~m}$. iš 18 projektų vaikams ir jaunimui skirta 16, $2013 \mathrm{~m}$. iš 20 projektų vaikams ir jaunimui skirta 18, $2017 \mathrm{~m}$. iš 42 projektų vaikams ir jaunimui skirti 32 projektai. Projektų didžiausia procentinè išraiška buvo 2007 ir 2013 metais ( 2007 m. - beveik 89 proc.), kitais metais truputi sumažèjo. 2017-aisiais ji sudare kiek daugiau kaip 76 proc. Projektų lyginamasis svoris vidutiniškai sudare daugiau kaip 80 proc. 2017 m. procentinè dalis, palyginti su vidurkiu, sumažejo 4,1 proc. 
Kitos tematikos projektų vykdyta nedaug. Kompiuterinio, skaitmeninio, informacinio raštingumo ugdymo projektų procentinė dalis svyravo, didžiausia procentinè išraiška buvo $2017 \mathrm{~m}$. (37,5 proc.). Vidutiniškai ji priartejjo prie penktadalio visų projektų. $2017 \mathrm{~m}$. procentinè dalis, palyginti su vidurkiu, išaugo 18,4 proc.

Kraštotyros ir kultūros paveldo aktualizavimo, etninès kultūros, istorijos projektų skaičiai bei lyginamasis svoris svyravo. Kiek didesnè yra etninès kultūros procentinè dalis (2017 m. sudarè kiek daugiau kaip 29 proc., vidutinis dydis - arti 20 proc.). Minètos tematikos projektai paprastai skirti visiems bibliotekų lankytojams.

Socialiniai projektai daugiausia skirti vaikams ir jaunimui (2007 ir 2015 metais jų procentinè dalis sudarẻ daugiau kaip 83 proc.). Projektų lyginamasis svoris $2017 \mathrm{~m}$. sudare 50 proc., vidutinis dydis 66 proc. $2017 \mathrm{~m}$. procentinè dalis, palyginti su vidurkiu, sumažejo 16 proc.

2007, 2013, 2015-2017 metų projektų, vykdytų kartu su partneriais, skaičių parodo 4 paveikslas.

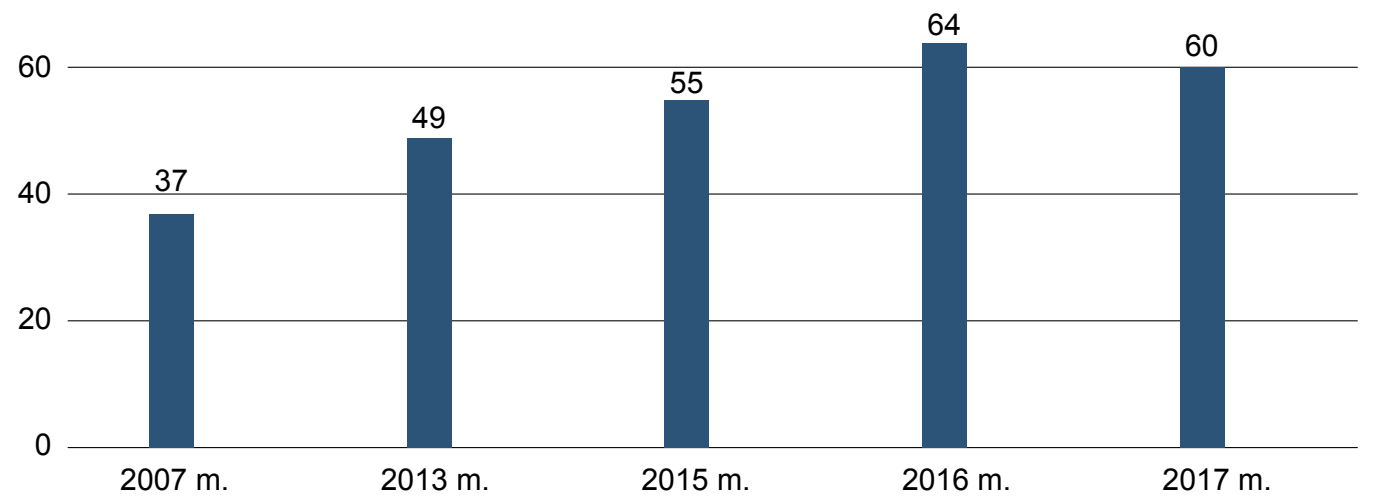

4 pav. Projektų, vykdytų kartu su partneriais, skaičius 2007, 2013, 2015-2017 metais

2007, 2013, 2015, 2016 metais projektų, vykdytų kartu su partneriais, skaičius didejjo. 2016 m. tokių projektų buvo įvykdyta 64.2017 m. projektų, vykdytų kartu su partneriais, šiek tiek sumažejo. Projektai, vykdyti kartu su partneriais, visų projektų struktūroje sudarè:

2007 m. - 12,5 proc., 2013 m. - 20,3 proc., 2015 m. - 19,9 proc., 2016 m. - 21,2 proc., 2017 m. 17,2 proc. 2017 m. projektų, vykdytų kartu su partneriais, palyginti su 2016 metais, sumažèjo 4,0 proc. Kartu su partneriais vykdyti 265 projektai, jų vidurkis sudare 18,2 proc.

Projektų, vykdytų kartu su partneriais, pasiskirstymo pagal tematiką skaičių ir lyginamąji svorị bendroje projektų struktūroje 2007, 2013, 2015-2017 metais parodo 4 lentelè.

4 lentele. Projektų, vykdytų kartu su partneriais, pasiskirstymo pagal tematiką skaičius ir lyginamasis svoris (procentais) bendroje projektų struktūroje 2007, 2013, 2015-2017 metais (laužtiniuose skliaustuose nurodomas bendras projektų skaičius)

\begin{tabular}{|l|l|c|c|c|c|c|c|}
\hline & Projektų tematika & $\mathbf{2 0 0 7} \mathbf{~ m}$ & $\mathbf{2 0 1 3} \mathbf{~ m}$ & $\mathbf{2 0 1 5} \mathbf{~ m .}$ & $\mathbf{2 0 1 6} \mathbf{~ m .}$ & $\mathbf{2 0 1 7} \mathbf{~ m .}$ & Vidutiniškai \\
\hline 1 & Infrastruktūra & $1[4]$ & $4[10]$ & $1[1]$ & $1[2]$ & $3[3]$ & $10[20]$ \\
& & $(25 \%)$ & $(40 \%)$ & $(100 \%)$ & $(50 \%)$ & $(100 \%)$ & $(63,0 \%)$ \\
\hline 2 & Kvalifikacijos kèlimas & $2[9]$ & $1[5]$ & $2[4]$ & $2[5]$ & $2[6]$ & $9[29]$ \\
& & $(22,2 \%)$ & $(20 \%)$ & $(50,0 \%)$ & $(40,0 \%)$ & $(33,3 \%)$ & $(33,1 \%)$ \\
\hline \multirow{2}{*}{3} & Literatūra, skaitymo & $12[129]$ & $7[51]$ & $8[69]$ & $13[87]$ & $11[91]$ & $51[427]$ \\
& skatinimas & $(9,3 \%)$ & $(13,7 \%)$ & $(11,6 \%)$ & $(14,9 \%)$ & $(12,1 \%)$ & $(12,3 \%)$ \\
\hline \multirow{2}{*}{4} & Edukacija (išskyrus 4-8 & $5[46]$ & $5[57]$ & $10[87]$ & $15[91]$ & $19[114]$ & $54[395]$ \\
& tematikos projektus) & $(10,9 \%)$ & $(8,8 \%)$ & $(11,5 \%)$ & $(16,5 \%)$ & $(16,7 \%)$ & $(12,9 \%)$ \\
\hline
\end{tabular}




\begin{tabular}{|c|c|c|c|c|c|c|c|}
\hline & Projektų tematika & $2007 \mathrm{~m}$ & $2013 \mathrm{~m}$. & $2015 \mathrm{~m}$. & $2016 \mathrm{~m}$. & $2017 \mathrm{~m}$. & Vidutiniškai \\
\hline 5 & $\begin{array}{l}\text { Kūrybinès meninès } \\
\text { veiklos skatinimas }\end{array}$ & $\begin{array}{c}1[18] \\
(5,6 \%)\end{array}$ & $\begin{array}{c}1[20] \\
(5,0 \%)\end{array}$ & $\begin{array}{c}5[27] \\
(18,5 \%)\end{array}$ & $\begin{array}{c}7[35] \\
(20,0 \%)\end{array}$ & $\begin{array}{c}5[42] \\
(11,9 \%)\end{array}$ & $\begin{array}{l}19[142] \\
(12,2 \%)\end{array}$ \\
\hline 6 & $\begin{array}{l}\text { Kompiuterinio, skait- } \\
\text { meninio, informacinio } \\
\text { raštingumo ugdymas }\end{array}$ & & $\begin{array}{c}3[10] \\
(30,0 \%)\end{array}$ & $\begin{array}{c}3[11] \\
(27,3 \%)\end{array}$ & $\begin{array}{c}5[10] \\
(50,0 \%)\end{array}$ & $\begin{array}{c}3[8] \\
(37,5 \%)\end{array}$ & $\begin{array}{c}14[39] \\
(29,0 \%)\end{array}$ \\
\hline 7 & $\begin{array}{l}\text { Kraštotyra, kultūros } \\
\text { paveldo aktualizavimas } \\
\text { (išskyrus 7-8 tematikos } \\
\text { projektus) }\end{array}$ & $\begin{array}{c}4[23] \\
(17,4 \%)\end{array}$ & $\begin{array}{c}17[26] \\
(65,4 \%)\end{array}$ & $\begin{array}{c}10[17] \\
(58,8 \%)\end{array}$ & $\begin{array}{c}8[20] \\
(40,0 \%)\end{array}$ & $\begin{array}{c}10[32] \\
(31,3 \%)\end{array}$ & $\begin{array}{l}49[118] \\
(42,6 \%)\end{array}$ \\
\hline 8 & Etninė kultūra & $\begin{array}{c}8[33] \\
(24,2 \%)\end{array}$ & $\begin{array}{c}5[37] \\
(13,5 \%)\end{array}$ & $\begin{array}{c}3[24] \\
(12,5 \%)\end{array}$ & $\begin{array}{c}2[14] \\
(14,3 \%)\end{array}$ & $\begin{array}{c}3[24] \\
(12,5 \%)\end{array}$ & $\begin{array}{l}21[135] \\
(15,4 \%)\end{array}$ \\
\hline 9 & Istorija & $\begin{array}{c}3[26] \\
(11,5 \%)\end{array}$ & $\begin{array}{c}4[20] \\
(20,0 \%)\end{array}$ & $\begin{array}{c}6[24] \\
(25,0 \%)\end{array}$ & $\begin{array}{c}5[22] \\
(22,7 \%)\end{array}$ & $\begin{array}{c}3[19] \\
(15,8 \%)\end{array}$ & $\begin{array}{l}21[111] \\
(19,0 \%)\end{array}$ \\
\hline 10 & Socialiniai & $\begin{array}{c}1[6] \\
(16,7 \%)\end{array}$ & $\begin{array}{c}2[5] \\
(40,0 \%)\end{array}$ & $\begin{array}{c}7[12] \\
(58,3 \%)\end{array}$ & $\begin{array}{c}6[15] \\
(40,0 \%)\end{array}$ & $\begin{array}{c}1[10] \\
(10,0 \%)\end{array}$ & $\begin{array}{c}17[48] \\
(33,0 \%)\end{array}$ \\
\hline & Iš viso vidutiniškai & $\begin{array}{l}37[297] \\
(12,5 \%)\end{array}$ & $\begin{array}{l}49[241] \\
(20,3 \%)\end{array}$ & $\begin{array}{l}55[276] \\
(19,9 \%)\end{array}$ & $\begin{array}{l}64[301] \\
(21,3 \%)\end{array}$ & $\begin{array}{l}60[349] \\
(17,2 \%)\end{array}$ & $\begin{array}{c}265[1464] \\
(18,2 \%)\end{array}$ \\
\hline
\end{tabular}

Projektų, vykdytų su partneriais, procentinè dalis bendroje projektų struktūroje $2013 \mathrm{~m}$. padidèjo, palyginti su 2007-aisiais, kitais metais svyravo. Vidutiniškai ji sudare 18,2 proc. Drauge su partneriais daugiausia ịgyvendinta infrastruktūros projektų (vidutiniškai - 63 proc.). Antra vieta tenka kraštotyros ir kultūros paveldo aktualizavimo projektams. Rezultatyviai partnerių pagalba pasinaudota 2013 ir 2015 metais. Vidurkis sudare 42,6 proc. Kiek daugiau kaip trečdalis projektų tenka kvalifikacijos kèlimo projektams, 2015 ir 2016 metais jie sudarè 50 ir 40 proc. Trečdalis projektų, vykdytų kartu su partneriais, tenka socialiniams projektams, ypač geri $2015 \mathrm{~m}$. rodikliai. Beveik trečdalis projektų tenka kompiuterinio, skaitmeninio, informacinio raštingumo ugdymo projektams (vidurkis - 29 proc.). Kitos tematikos projektų, igyvendintų kartu su partneriais, procentinè dalis yra kukli. Istorijos projektams vidutiniškai tenka 19 proc., etninès kultūros projektams - 15,4 proc., edukacijos - 12,9 proc., literatūros, skaitymo skatinimo projektams - 12,3 proc., kūrybinès meninès veiklos skatinimo projektams - 12,2 proc.

Krenta ị akis projektų, vykdytų kartu su partneriais, sumažejimas 2017 m. Palyginti su 2016-aisiais, sumažèjo procentinè dalis kvalifikacijos kèlimo, literatūros, literatūros ir skaitymo skatinimo, kūrybinès meninès veiklos skatinimo, kompiuterinio, skaitmeninio, informacinio raštingumo ugdymo, kraštotyros, kultūros paveldo aktualizavimo, etninès kultūros, istorijos, socialinių projektų (išimtis - edukacijos ir infrastruktūros projektai).

\section{$\mathrm{X} \times \mathrm{X}$}

Esmines bibliotekų projektinės veiklos tobulinimo prielaidas sudare projekto BP igyvendinimas. Projektinę veiklą skatino vykdomas projektas BP 2.

Projektų skaičius sumažèjo 2013 m., palyginti su 2007-aisiais, kitais metais nuosekliai didèjo. Rèmèjų skaičius sumažèjo 2013 m., 2015-aisiais išaugo, 2016 m. vèl sumažèjo. Daugiausia rèmèjų buvo 2017 m. Rèmëjų skaičius augo sparčiau negu projektų skaičius. Tai liudijo apie projektinès veiklos stiprejjimą.

2017 m. tarptautinių rèmèjų skaičius, palyginti su 2007-aisiais, padidëjo daugiau kaip penkis kartus, išaugo jų lyginamasis svoris bendroje rèmëjų struktūroje, tačiau nepasiekè vidurkio. Nacionalinių rèmëjų skaičius 2017 m., palyginti su 2007-aisiais, padidejo penktadaliu, tačiau jų procentinè dalis šiek 
tiek sumažèjo, nepasiekè vidurkio. 2017 m. gerokai padidèjo vietos rèmèjų skaičius, palyginti su $2007 \mathrm{~m}$. Nors jų procentinè dalis išaugo nežymiai, ji viršijo vidurkị.

Infrastruktūrai, bibliotekos darbuotojų kvalifikacijai kelti skirti pavieniai projektai, jų skaičiai ir lyginamasis svoris bei kaita bendroje projektų struktūroje yra nedideli.

Daugiausia buvo igyvendinta literatūros ir skaitymo skatinimo bei edukacijos projektų. Literatūros, skaitymo skatinimo projektų skaičiai ir lyginamasis svoris bendroje projektų struktūroje didžiausi buvo 2007 m. 2017 m., palyginti su 2007-aisiais, projektų sumažèjo beveik trečdaliu, lyginamasis svoris taip pat sumažèjo, buvo žemesnis už vidurkị.

Edukacijos, kūrybinès meninès veiklos skatinimo projektų nuosekliai daugèjo, didèjo ir viršijo vidurkị jų procentinès dalys. Kompiuterinio, skaitmeninio, informacinio raštingumo ugdymo projektų vykdyta nedaug, jų lyginamasis svoris bei kaita bendroje projektų struktūroje nedideli.

Kraštotyros, kultūros paveldo aktualizavimo, etninès kultūros, istorinės tematikos projektų skaičiai ir lyginamasis svoris svyravo. Artimų tematika kraštotyros ir kultūros paveldo aktualizavimo, etninès kultūros, istorijos projektų bendras lyginamasis svoris $2007 \mathrm{~m}$. sudare daugiau kaip ketvirtadali visų projektų, 2017 m., palyginti su 2007-aisiais, sumažèjo, sudarẻ kiek daugiau kaip penktadalị visų projektų.

Projektų, tiesiogiai orientuotų ị socialinių problemų sprendimą, buvo vykdoma nedaug. Jų skaičiai ir procentinè dalis svyravo, $2017 \mathrm{~m}$., palyginti su 2007-aisiais, procentinè dalis truputi padidèjo, tačiau nepasieke vidurkio.

Projektų, skirtų vaikams ir jaunimui, lyginamasis svoris bendroje projektų struktūroje sudarè apie trečdalị visų projektų. Pirmenybė priklausè kūrybinès meninès veiklos skatinimo projektams. Antra vieta teko socialiniams projektams, trečia - literatūros ir skaitymo skatinimo projektams. Literatūros ir skaitymo skatinimo, kūrybinès meninès veiklos skatinimo, socialinių projektų procentinè dalis $2017 \mathrm{~m}$., palyginti su 2007-aisiais, sumažèjo, tačiau išlaikè gana aukštą lygị. Edukacijos projektų skaičiai ir lyginamasis svoris smarkiai svyravo. Kompiuterinio, skaitmeninio, informacinio raštingumo, kraštotyros ir kultūros paveldo aktualizavimo, etninès kultūros, istorijos projektų buvo vykdyta nedaug. Kompiuterinio, skaitmeninio, informacinio raštingumo, kraštotyros ir kultūros paveldo aktualizavimo, istorijos projektų skaičiai ir lyginamasis svoris smarkiai svyravo. Nuo $2013 \mathrm{~m}$. augo etninès kultūros projektų procentinè dalis.

Projektų, vykdytų kartu su partneriais, daugèjo, 2017 m. šiek tiek sumažèjo. Jų procentinė dalis svyravo, jos vidurkis nesiekè penktadalio visų projektų. Gerų rezultatų pasiekta tik kai kuriuose projektuose: infrastruktūros, kraštotyros ir kultūros paveldo aktualizavimo ir kt.

\subsection{7-2017 m. biblioteku vykdyti projektai bei ju vaidmuo gerinant biblioteku darba}

Skyriuje apibūdinami 2007-2017 m. bibliotekų vykdyti infrastruktūros, bibliotekų darbuotojų kvalifikacijos kèlimo, literatūros ir skaitymo skatinimo, edukacijos, kūrybinès meninès veiklos skatinimo, kompiuterinio, skaitmeninio, informacinio raštingumo ugdymo, kraštotyros ir kultūros paveldo aktualizavimo, etninès kultūros, istorijos, socialiniai projektai. Pateikiami statistiniai duomenys, kurie parodo bibliotekų projektinès veiklos mastą, jų geografinị pasiskirstymą. Siekiama apibrèžti projektų tikslus, veiklas, rezultatus, parodyti projektų naudą jų dalyviams bei vaidmenį gerinant bibliotekų darbą. Daugiau dèmesio skiriama 2007, 2013, 2015-2017 metų projektams.

\subsubsection{Infrastruktūros ir bibliotekų darbuotojų kvalifikacijos kèlimo projektai}

5 lentelèje pateikiama informacija apie bibliotekų vykdytus infrastruktūros projektus 2007, 2013, 2015-2017 metais (apskritys nurodomos pagal bibliotekų veiklos regionus). 
5 lentele. Bibliotekų infrastruktūros projektų vykdymas 2007, 2013, 2015-2017 metais (skliaustuose - bibliotekų skaičius apskrityse, vykdytų projektų skaičius, rèmėjų tipas: $\mathrm{Tr}$ - tarptautinis rèmėjas, $\mathrm{Nr}$ - nacionalinis rèmèjas, $\mathrm{Vr}$ - vietos rèmèjas ${ }^{64}$

\begin{tabular}{|c|c|c|c|c|c|c|c|}
\hline & \multirow{2}{*}{\begin{tabular}{l}
\multicolumn{1}{c}{$\begin{array}{c}\text { Kauno } \\
\text { apskr. (8), } \\
\text { Marijampolès } \\
\text { apskr. (5) }\end{array}$} \\
Marijampolès \\
SVB (2, Tr - 1, \\
$\mathrm{Nr}-1)$
\end{tabular}} & \multirow{2}{*}{$\begin{array}{l}\text { Klaipèdos } \\
\text { apskr. (7), } \\
\text { Tauragès } \\
\text { apskr. (4) } \\
\text { Jurbarko r. } \\
\text { SVB (1, } \\
\mathrm{Nr}-1)\end{array}$} & \multirow{2}{*}{$\begin{array}{c}\text { Panevèžio } \\
\text { apskr. (6), } \\
\text { Utenos } \\
\text { apskr. (6) } \\
\text { Utenos SVB (1, } \\
\text { nenurodyta - 1) }\end{array}$} & \multirow[t]{2}{*}{$\begin{array}{c}\text { Šiaulių } \\
\text { apskr. (7), } \\
\text { Telšių apskr. (4) }\end{array}$} & \multirow[t]{2}{*}{$\begin{array}{l}\text { Vilniaus } \\
\text { apskr. (8), } \\
\text { Alytaus } \\
\text { apskr. (5) }\end{array}$} & \multirow{2}{*}{ 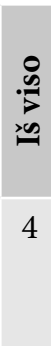 } \\
\hline 1 & $2007 \mathrm{~m}$ & & & & & & \\
\hline 2 & $2013 \mathrm{~m}$ & $\begin{array}{l}\text { Kalvarijos SVB } \\
(1, \operatorname{Tr}-1, \mathrm{Nr}-1) \text {, } \\
\text { Marijampolès } \\
(1, \operatorname{Tr}-1) \text {, } \\
\text { Šakių r. SVB }(1, \\
\text { Nr }-1, \mathrm{Vr}-3)\end{array}$ & & $\begin{array}{l}\text { Biržų r. SVB } \\
(1, \operatorname{Tr}-1), \\
\text { Kupiškio r. SVB } \\
(1, \operatorname{Tr}-1), \\
\text { Pasvalio SVB } \\
(1, \operatorname{Tr}-1)\end{array}$ & $\begin{array}{l}\text { Pakruojo r. SVB } \\
(1, \operatorname{Tr}-1)\end{array}$ & $\begin{array}{l}\text { Vilniaus } \mathrm{m} . \\
\text { SCB }(1, \operatorname{Tr}-1) \text {, } \\
\text { Varėnos r. SVB } \\
(2, \operatorname{Tr}-2)\end{array}$ & 10 \\
\hline 3 & $2015 \mathrm{~m}$ & & & & $\begin{array}{l}\text { Mažeikių r. SVB } \\
(1, \operatorname{Tr}-1, \mathrm{Nr}-1)\end{array}$ & & 1 \\
\hline 4 & $2016 \mathrm{~m}$ & & & & $\begin{array}{l}\text { Šiaulių r. SVB (1, } \\
\text { Nr - 1, Vr - 1), } \\
\text { Mažeikių r. } \\
\text { SVB (1, Tr - 1, } \\
\text { Nr - 1), }\end{array}$ & & 2 \\
\hline 5 & $2017 \mathrm{~m}$ & & & $\begin{array}{l}\text { Utenos SVB } \\
(2, \operatorname{Tr}-2, \mathrm{Nr}-1), \\
\text { Zarasų }(1, \operatorname{Tr}-1)\end{array}$ & & & 3 \\
\hline \multicolumn{2}{|c|}{$\begin{array}{l}\text { Projektų } \\
\text { skaičius, } \\
\text { tarptautinių, } \\
\text { nacionalinių, } \\
\text { vietos rèmejuc } \\
\text { parama } \\
\text { vykdant } \\
\text { projektus }\end{array}$} & \multicolumn{5}{|c|}{ 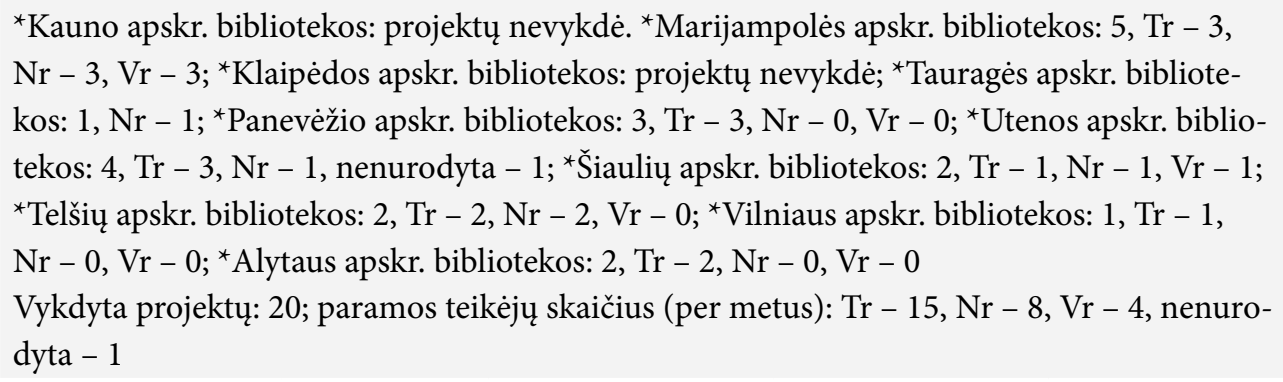 } & 20 \\
\hline
\end{tabular}

Infrastruktūros diegimas, jos atnaujinimas priklauso bendriems valstybinio masto investiciniams projektams, tačiau bibliotekos sugeba nebūti nuošalyje. Infrastruktūros projektams itin svarbi tarptautinių fondų parama (didžiausias finansavimas). Bibliotekos siekė užsitikrinti jų finansavimą atnaujinant infrastruktūrą, gerinant bibliotekų informacinę, edukacinę, kultūrinę aplinką bei paslaugų teikimą. Iš viso vykdyta 20 projektų. Vyravo tarptautinių rèmejjų parama (53,6 proc.). Kauno apskr. ir Klaipejdos apskr. bibliotekos infrastruktūros projektų nevykdè.

Marijampolès SVB 2007 m. igyvendino stambų tarptautinị projektą „,Multicentrų ikkūrimas Olštyne ir Marijampoleje“. Rèmèjas - Europos regioninès plètros fondas. Bibliotekoje atlikti „MultiCentro“ patalpų remonto ir pritaikymo darbai, įrengtos 24 edukacinès darbo vietos, sukurta centro interneto svetainè.

Atkreipiame demesį, kad šioje ir kitose tokio pobūdžio lentelèse pateikiamas projektų vykdymas nurodytais metais (parodomas bibliotekų darbas); pačių projektų ir jų rèmejų buvo mažiau, nes kai kurie projektai buvo vykdomi dvejus ir daugiau metų. Daugelis tarptautinių, kai kurie nacionaliniai rẻmèjai pasikartoja (lèšos buvo panaudojamos per visą projekto vykdymo terminą). 
Vykdant edukacinès programos „MultiCentras“ importo iš Izraelio procedūras, 3 „MultiCentro“ darbuotojai dalyvavo edukacinès programos gamintojų „Degem Systems Ltd“ surengta mokymuose Izraelyje. Bibliotekoje atidarytas pirmas Lietuvoje „MultiCentras“. Jị kuriant buvo naudingas Kultūros ministerijos paremtas projektas „Marijampolès ir Vroclavo viešujų bibliotekų bendradarbiavimas diegiant naujas technologijas bibliotekose“. Buvo ịgyvendintas pagrindinis projekto uždavinys - surengta pažintinè profesinè kelionè ị Vroclavo miesto viešąją biblioteką, i joje jau veikiantị „MultiCentrą“.

Kiek daugiau infrastruktūros projektų, paremtų ES struktūrinių fondų ir tarptautinès organizacijos, vykdyta 2010-2014 m. Paminètini Jonavos r., Pasvalio, Biržų r., Pakruojo r., Marijampolès, Kalvarijos, Kupiškio r., Vilniaus m., Varẻnos r. bibliotekų projektai. 2010 m. Jonavos r. biblioteka laimejjo ES finansinę paramą projektui „Interaktyvių elektroninių paslaugų, skirtų leidiniams ir publikacijoms užsakyti ir gauti viešosiose bibliotekose, plètra“. Bibliotekoje buvo įdiegta nauja savitarnos (knygų grąžinimo) įranga.

Inovatyvios veiklos - teikti paslaugas ūkininkams ir verslininkams - èmèsi Pasvalio biblioteka. Biblioteka 2011-2012 m. vykdè projektą „Libr-A: ị pagalbą Pasvalio ūkininkams“, finansuotą tarptautinio EIFL fondo. Projektas buvo skirtas Pasvalio krašto žemdirbiams. Igyvendinant projektą talkino daug partnerių: Pasvalio r. savivaldybè, Lietuvos ūkininkų sąjungos Pasvalio skyrius, Pasvalio bitininkų draugija „Bičiulis“, Lietuvos agrarinių ir miškų mokslų centro Žemdirbystės instituto Joniškèlio bandymų stotis, Pasvalio rajono laikraštis „Darbas“. Išplèstos bibliotekos mobiliosios ir kompiuterinès leidybos paslaugos žemdirbiams, sukurtas informacinis interneto portalas. Portalas pateikia susistemintą informaciją žemdirbiams, suteikia galimybę nemokamai reklamuoti ūkininkų produkciją, bendrauti tarpusavyje. Interneto svetainès populiarumas pranoko lūkesčius: nuo jos sukūrimo iki $2012 \mathrm{~m}$. birželio sulaukta apie 16 tūkst. lankytojų ${ }^{65}$. Svetainejje informacija skelbiama pasvaliečių pastangomis.

Pasvalio, Biržų r., Pakruojo r. bibliotekos kartu su Bauskès bei Rundalès rajonų (Latvija) bibliotekomis dalyvavo vykdant tarptautini programos „Latvija-Lietuva abipus sienos 2007-2013 m.“ projektą „Tarpvalstybinio verslui palankių bibliotekų tinklo kūrimas“. Projektas finansuotas Europos regioninès plètros fondo lěšomis. Projekto trukmè: $2012 \mathrm{~m}$. gegužè - $2014 \mathrm{~m}$. lapkritis. Buvo siekiama skatinti konkurencingą Latvijos ir Lietuvos pasienio regiono verslumą, kurti verslui palankią aplinką. Pasvalyje atnaujintas viešosios bibliotekos pastatas, jame ikurtas Verslo informacijos centras. Sukurta interneto svetainè verslui.pasvalys.lt, skirta verslo informacijai rajone skelbti. Joje informacija pateikiama lietuvių ir anglų kalbomis. Verslo informacijos centras teikia šias paslaugas: supažindina su leidiniais verslui, informuoja apie savivaldybės, privačių asmenų, verslininkų parduodamą, išnuomojamą, privatizuojamą ar be šeimininkų likusị nekilnojamąjį turtą (registruoti vartotojai patys gali skelbti informaciją). Centras turi katalogą „Pasvalio rajono verslo įmonès“, interaktyvų investicinị gidą-žemèlapị „Verslo aplinka Pasvalio rajone" (nurodyti objektai Pasvalio rajone, $\mathfrak{i}$ kuriuos galima investuoti). Biržuose buvo parengtas techninis projektas naujo Biržų r. savivaldybès viešosios bibliotekos pastato statybai. Viešojoje bibliotekoje įsteigtas informacinis pagalbos verslui centras, sukurtas interneto tinklalapis birzaiverslui.lt, atnaujinta kompiuterinè įranga bei knygų, skirtų verslininkams, fondas. Pakruojyje projekto lèšomis iš dalies suremontuotos bibliotekos vaikų literatūros sektoriaus patalpos.

Marijampolès bibliotekos projektas buvo skirtas paslaugų teikimo šeimoms infrastruktūrai gerinti. Biblioteka èmèsi igyvendinti projektą „Bendradarbiavimas kuriant biblioteką šeimai“, kurị finansavo Europos Sąunga (2007-2013 m. Lietuvos, Lenkijos ir Rusijos bendradarbiavimo per sieną programa). Projektas igyvendintas 2012-2014 m. kartu su Černiachovsko municipaline biudžetine įstaiga „Centralizuota bibliotekų sistema“ (Rusija). Projektą iggyvendinančios bibliotekos siekė gerinti edukacinių, informacinių ir kultūrinių paslaugų šeimoms teikimo aplinką, prisidedant prie pasienio regionų socialinès

Žr. Bedulytė, R.; Dunauskaitė, A. Pasvalio Mariaus Katiliškio viešosios bibliotekos paslaugos verslininkams. Tarp knygu, 2013, birželis, p. 15-17. 
ir ekonominès plettros. Vykdant projektą modernizuota Draugystès biblioteka (filialas). Kalvarijos biblioteka 2012-2014 m. vykdè projektą „Kalvarijos savivaldybės viešosios bibliotekos Akmenynų, Brukų, Liubavo, Jungėnų, Sangrūdos filialų patalpų pritaikymas visuomenès poreikiams" (finansuotas Europos žemès ūkio fondo kaimo plètrai ir valstybès lèšomis). Buvo modernizuotos filialų patalpos. Kupiškio r. biblioteka vykdė projektą „Moderni biblioteka - bendruomenès informacijos ir saviraiškos centras“, kuris finansuotas Europos žemès ūkio fondo kaimo plètrai lèšomis. Renovuotos Kupiškio r. SVB Šepetos k. filialo patalpos. Vilniaus m. biblioteka pasinaudojo ES parama ${ }^{66}$ vykdant projektą „Interaktyvių elektroninių paslaugų, skirtų leidiniams ir publikacijoms užsakyti bei gauti viešosiose bibliotekose, plètra“. Specifinius projektus ėmèsi igyvendinti Varènos r. biblioteka. ES suteikẻ finansinę paramą Varénos r. bibliotekos projektams „Anzelmo Matučio drevès atnaujinimas“ ir „Anzelmo Matučio drevès aplinkos sutvarkymas ${ }^{\text {“67 }}$. Biblioteka èmèsi darbo kurti poilsiui patrauklią infrastruktūrą.

Kitais metais projektų, kuriuos rèmé tarptautinès institucijos, smarkiai sumažèjo. 2015-2016 m. infrastruktūros projektą, finansuotą BMGF ir Kultūros ministerijos [BP 2], vykdè Mažeikių r. SVB. Biblioteka iggyvendino projektą „Pažangių technologijų ir laisvalaikio centras“. Projekto partneriai: Mažeikių rajono nevyriausybinių organizacijų asociacija, Mažeikių rajono savivaldybès švietimo skyrius, Mažeikių moterų LIONS ${ }^{68}$ klubas ir savivaldybės visuomenės sveikatos biuras. Projekto rezultatas: centrinejje bibliotekoje ir šešiuose filialuose (Palnosų, Renavo, Sedos, Šerkšnènų, Ukrinų, Viekšnių) sukurta techninẻ bazė nevyriausybinių organizacijų veikloms organizuoti, ugdymo įstaigų darbuotojų ir mokinių savišvietai ir saviraiškai. Šiek tiek daugiau projektų vykdyta $2017 \mathrm{~m}$. Europos regioninès plètros fondas finansavo bendrą Utenos, Zarasų r., Daugpilio ir Preilių (Latvija) bibliotekų projektą „Švietimui ir gerovei skirtų šeimos skaitmeninių veiklų centrų sukūrimas Rytų Aukštaitijoje ir Pietų Latgaloje“. Keturiose Latvijos ir Lietuvos pasienio regiono bibliotekose pradèti kurti šeimos skaitmeninių veiklų centrai (terminas: 2017 m. kovo 1 d. - 2019 m. vasario 28 d.). Kuriami centrai papilde bibliotekų edukacines veiklas, tapo naujausių technologijų pažinimo vieta. Centruose buvo diegiamos virtualios realybès, robotikos, 3D ir kitos naujausios technologijos, rengiami instruktoriai. Europos regioninès plètros fondas taip pat parèmé Utenos bibliotekos projektą „Utenos A. ir M. Miškinių viešosios bibliotekos modernizavimas" (papildomai finansuotas valstybès biudžeto lèšomis). Vykdant projektą pagerinta bibliotekos infrastruktūra ${ }^{69}$.

Nacionalinių ir vietos rèmèjų vaidmuo nedidelis - jie parèmė tik kelis projektus. Žemès ūkio ministerija parėmé Jurbarko r. Skirsnemunès filialo projektą (2007 m., filiale pakeisti langai). Kultūros ministerija, savivaldybė, Kriūkų seniūnija, Miškų savininkų kooperatyvas „Zanavykų šilas“ parèmė Šakių r. bibliotekos projektą „Skulptūrų parkas - vaikų literatūros klasiko Vytauto Tamulaičio 100-mečiui“ (2013 m.). Kriūkų skulptūrų parką „Vabalų kalnelis“ papuošè rašytojo sukurti personažai. Lietuvos kultūros taryba ir savivaldybė parėmé Šiaulių r. bibliotekos projektą „Pamatykim kiekvieną nepastebėtą kaimo biblioteką..." (2016 m.). Jo rezultatas: teritoriniams padaliniams (25 bibliotekos) ịrengti modernūs, šviečiantys lauko reklamos stendai.

Pavieniai projektai numatė bibliotekų darbuotojų kvalifikacijos tobulinimą. 6 lenteleje pateikiama informacija apie bibliotekų darbuotojų kvalifikacijos kèlimo projektų vykdymą 2007, 2013, 2015-2017 metais.

Kai kuriais atvejais ES finansiné parama bibliotekų dokumentuose nekonkretizuota.

A. Matučio drevè yra kultūrinès ir turistinès traukos centras, bibliotekos lankytojai lankosi bibliotekos organizuotuose ir vykstančiuose drevès erdvèje renginiuose.

68 Angliškų žodžių Liberty (liet. laisvè), Intelligence (liet. intelektas), Our Nations Safety (liet. mūsu tautu saugumas) pirmų raidžiu santrumpa. Lietuvoje veikia LIONS klubai, kurie priklauso Tarptautinei LIONS klubų asociacijai (LIONS Clubs International). Mažeikių moterų LIONS klubas aktyviai dalyvauja bendruomenès veikloje, organizuoja labdaros bei švietejiškus projektus.

${ }^{69}$ Isigyti ir sumontuoti nauji baldai. 
6 lentelè. Bibliotekų darbuotojų kvalifikacijos kèlimo projektų vykdymas 2007, 2013, 2015-2017 metais (skliaustuose - bibliotekų skaičius apskrityse, vykdytų projektų skaičius, rèmėjų tipas: $\mathrm{Tr}$ - tarptautinis rẻmèjas, $\mathrm{Nr}$ - nacionalinis rèmèjas, $\mathrm{Vr}$ - vietos rèmèjas)

\begin{tabular}{|c|c|c|c|c|c|c|c|}
\hline & \multirow{2}{*}{$\begin{array}{c}\text { Kauno } \\
\text { apskr. (8), } \\
\text { Marijampolès } \\
\text { apskr. (5) } \\
\text { Kalvarijos SVB } \\
(1, \mathrm{Nr}-1)\end{array}$} & \multirow[t]{2}{*}{$\begin{array}{c}\text { Klaipėdos } \\
\text { apskr. (7), } \\
\text { Tauragès apskr. } \\
\text { (4) }\end{array}$} & \multirow{2}{*}{$\begin{array}{c}\begin{array}{c}\text { Panevėžio } \\
\text { apskr. (6), } \\
\text { Utenos } \\
\text { apskr. (6) }\end{array} \\
\text { Pasvalio SVB (1, } \\
\text { Vr - 1), Utenos } \\
\text { SVB (2, nenuro- } \\
\text { dyta - 2) }\end{array}$} & \multirow{2}{*}{$\begin{array}{l}\begin{array}{c}\text { Šiaulių } \\
\text { apskr. (7), } \\
\text { Telšių } \\
\text { apskr. (4) }\end{array} \\
\text { Šiaulių m. SVB } \\
(1, \mathrm{Nr}-1), \mathrm{Ma}- \\
\text { žeikių r. SVB (1, } \\
\mathrm{Vr}-1) \text {, Plun- } \\
\text { gès r. SVB } \\
(2, \mathrm{Tr}-1, \\
\mathrm{Nr}-1)\end{array}$} & \multirow{2}{*}{$\begin{array}{c}\text { Vilniaus } \\
\text { apskr. (8), } \\
\text { Alytaus } \\
\text { apskr. (5) } \\
\text { Vilniaus m. SCB } \\
(1, \text { nenurody- } \\
\text { ta - 1) }\end{array}$} & \multirow{2}{*}{ 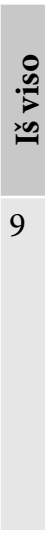 } \\
\hline 1 & $2007 \mathrm{~m}$ & & & & & & \\
\hline 2 & $2013 \mathrm{~m}$ & & $\begin{array}{l}\text { Klaipèdos r. } \\
\text { SVB }(1, \mathrm{Vr}-1) \text {, } \\
\text { Šilutès r. SVB (1, } \\
\mathrm{Nr}-1)\end{array}$ & & $\begin{array}{l}\text { Šiaulių m. SVB } \\
(1, \operatorname{Tr}-1), \text { Ma- } \\
\text { žeikių r. SVB (1, } \\
\text { Vr - 1) }\end{array}$ & $\begin{array}{l}\text { Švenčionių r. } \\
\operatorname{SVB}(1, \mathrm{Nr}-1)\end{array}$ & 5 \\
\hline 3 & $2015 \mathrm{~m}$ & & $\begin{array}{l}\text { Klaipèdos m. } \\
\text { SVB }(1, \operatorname{Tr}-1, \\
\text { Nr }-1, \operatorname{Vr}-1), \\
\text { Klaipèdos } r . \\
\text { SVB }(1, \mathrm{Vr}-1)\end{array}$ & $\begin{array}{l}\text { Ignalinos } \mathrm{r} \text {. } \\
\text { SVB }(1, \mathrm{Tr}-1) \text {, } \\
\text { Utenos SVB } \\
(1, \mathrm{Nr}-1)\end{array}$ & & & 4 \\
\hline 4 & $2016 \mathrm{~m}$ & & $\begin{array}{l}\text { Klaipėdos m. } \\
\text { SVB }(1, \mathrm{Tr}-1 \text {, } \\
\mathrm{Nr}-1, \mathrm{Vr}-1)\end{array}$ & $\begin{array}{l}\text { Ignalinos r. } \\
\text { SVB }(1, \mathrm{Tr}-1) \text {, } \\
\text { Utenos SVB } \\
(1, \mathrm{Nr}-1) \text {, } \\
\text { Zarasų r. SVB } \\
(1, \mathrm{Nr}-1)\end{array}$ & & $\begin{array}{l}\text { Širvintų r. SVB } \\
(1, \mathrm{Nr}-1)\end{array}$ & 5 \\
\hline 5 & $2017 \mathrm{~m}$ & & $\begin{array}{l}\text { Klaipèdos r. } \\
\operatorname{SVB}(1, \mathrm{Vr}-1)\end{array}$ & $\begin{array}{l}1 \text { Utenos SVB } \\
(1, \mathrm{Nr}-2)\end{array}$ & $\begin{array}{l}\text { Radviliškio r. } \\
\operatorname{SVB}(1, \mathrm{Vr}- \\
\text { 2), Šiaulių r. } \\
\operatorname{SVB}(1, \mathrm{Nr}-1 \text {, } \\
\text { Vr - 1) }\end{array}$ & $\begin{array}{l}\text { Širvintų r. SVB } \\
(1, \mathrm{Nr}-1), \\
\text { Švenčionių r. } \\
\text { SVB }(1, \mathrm{Tr}-1)\end{array}$ & 6 \\
\hline \multicolumn{2}{|c|}{$\begin{array}{l}\text { Projektų } \\
\text { skaičius, } \\
\text { tarptautinių, } \\
\text { nacionalinių, } \\
\text { vietos rè- } \\
\text { mejjų } \\
\text { parama } \\
\text { vykdant } \\
\text { projektus }\end{array}$} & \multicolumn{5}{|c|}{ 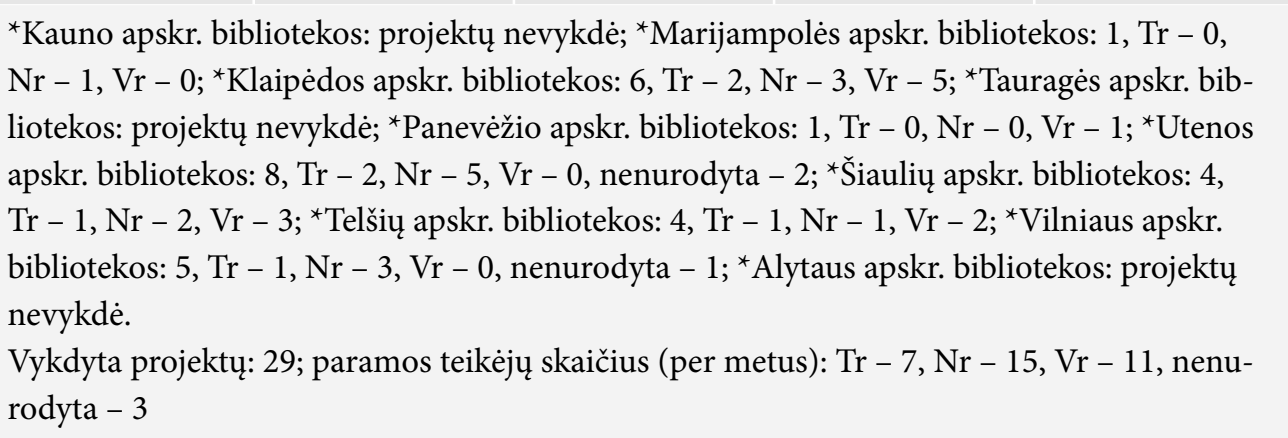 } & 29 \\
\hline
\end{tabular}

Iš viso vykdyti 29 projektai. Vyravo nacionalinių rèmèjų parama. Tarptautinių rèmėjų parama sudarè arti 20 proc. Kauno apskr., Tauragès apskr., Alytaus apskr. bibliotekos projektų nevykdè.

Bibliotekos darbuotoju kvalifikacijai kelti reikšminga tarptautiniu fondu parama. 2006-2007 m. Plungès r. SVB vykdè Europos regioninès plètros fondo finansuojamą projektą „Kaimynai Europoje - 
Latvijos ir Lietuvos bibliotekų kontaktai“. Projekto partnerè - Saldaus biblioteka (Latvija). Vykdant projektą surengtos 2 mokomosios išvykos Plungès ir Saldaus bibliotekininkams. Siekta suteikti galimybę bibliotekos specialistams ịgyti naujų žinių ir patirties, padèti suvokti europietiškąją bibliotekos sampratą, pagerinti bibliotekų darbo kokybę, inicijuoti naujas veikas. Buvo surengti du seminarai. Plungès $r$. biblioteka surengè tarptautinị seminarą „Europietiškosios ir baltiškosios kultūros samprata: menas, literatūra, pasaulěžiūra“. Saldaus miesto bibliotekoje įvyko seminaras „Latvijos bibliotekos šiandien“. Šiaulių m. SVB dalyvavo vykdant didelį tarptautinị projektą „Kaip muziejai, galerijos, bibliotekos ir archyvai gali prisidèti prie mokymosi visą gyvenimą“ (2011-2013 m.), kurị parėmè Švietimo mainų paramos fondas („Leonardo da Vinci“ programa). Tarptautiniame projekte dalyvavo organizacijos ir įstaigos iš įvairių ES šalių siekiant išsiaiškinti, kokị vaidmenį jos atlieka remiant visą gyvenimą trunkantị mokymąsi, kokiu mastu planuoja ị mokymosi visą gyvenimą veiklas įtraukti socialiai pažeidžiamas grupes: senjorus, neigaliuosius, bedarbius, nepasiturinčias šeimas. Šiaulių m. biblioteka, bendradarbiaudama su Šiaulių teritorine darbo birža, Šiaulių Parkinsono draugija, Šiaulių neįgaliųjų draugija, bibliotekininkams organizavo seminarą, kuriame buvo aptarta, kaip įtraukti socialiai neaktyvius žmones ị bibliotekoje vykstančias veiklas.

2008-2013 m. bibliotekos darbuotojų kvalifikacija IT srityje gerokai padidejjo dalyvaujant projekto „Bibliotekos pažangai“ veiklose. Vykdant projektą organizuotuose mokymuose mokèsi apie 2700 bibliotekų darbuotojų. Dauguma jų dalyvavo ne vienuose mokymuose: per 200 bibliotekų darbuotojų išklausè 5 ar daugiau, o 29 iš jų - net 7 arba dar daugiau mokymo programų. Iš viso kursuose dalyvavo apie 7500 dalyvių ${ }^{70}$.

2014 m. tapo bibliotekų darbuotojų kvalifikacijos kèlimo naujo etapo pradžia. Pirmaisiais projekto „Bibliotekos pažangai 2“ igyvendinimo metais LNB organizavo mokymus bibliotekų darbuotojų kvalifikacijai tobulinti. Mokymai apėmè tokias temas: projektų rengimą ir jų igyvendinimą, projektų valdymą, vartotojų analizę, inovacijų kūrimą, atstovavimą, viešinimą, poveikio vertinimą ir lyderystę. Atlikta bibliotekininkų apklausa parodè, kad absoliuti dauguma apklausos dalyvių (96 proc.) praktiškai panaudojo projekto „Bibliotekos pažangai 2“ mokymuose igytas žinias"

2015-2017 m. projektai, kuriuos finansavo tarptautiniai rèmëjai su kitų tipų rèmejjais, buvo skirti naujoms mokymų temoms. Siekta igyti naujų kompetencijų vykdant 2015 m. BMGF, KM [BP 2] bei savivaldybès paremtą Klaipèdos m. bibliotekos projektą „Šeimos istorija - išsaugok atmintį“ (2015-2016 m.), kurio partneriai: Klaipėdos apskrities archyvas, Klaipėdos m. pedagogų švietimo ir kultūros centras, Lietuvos genealogijos ir heraldikos draugija. Darbuotojai mokèsi maketuoti ir kurti grafinį dizainą, taip pat kurti leidinius „Microsoft Office“ aplinkoje („Publisher“) ir dirbti kompiuterine grafikos programa GIMP; pagal Lietuvos genealogijos ir heraldikos draugijos parengtą programą darbuotojai dalyvavo mokymuose "Genealogija - fiziniai ir interneto šaltiniai“ ir "Genealoginių medžių, lentelių, herbų sudarymas, braižymas“. Europos ekonominès erdvès programa „Europos kultūros paveldo kultūros ir menų ịvairovės skatinimas“ parèmé Ignalinos r. bibliotekos projektą „Kultūrinis bendradarbiavimas tarp Ignalinos rajono savivaldybès viešosios bibliotekos (Lietuva) ir Estfoldo apskrities bibliotekos (Norvegija), siekiant skaitmeninti kraštotyrą“ (2015-2016 m.). Švenčionių r. biblioteka vykdė projektą „Tarpkultūrinis migrantų švietimas - personalo kompetencijų tobulinimas“ (2017-2018 m.), paremtą „Erasmus+“ programos „Mobility“ lěšomis (partnerè - Vilniaus apskrities viešoji biblioteka (VAVB). Siekta igyti žinių migrantų integravimo srityje, sužinoti, kaip skandinavų ir kitos užsienio šalių bibliotekos ir organizacijos dirba su pabègèliais ${ }^{72}$.

Bibliotekos pažangai. Prieiga per internetą: https://www.lnb.lt/apie-biblioteka/programos-ir-projektai/edukaciniai-projektai/bibliotekos-pazangai. Žiūrèta 2018-09-12.

Bibliotekos pažangai 2. Prieiga per internetą: https://www.google.lt/search?q=Bibliotekos+pa\%C5\%BEangai+2\%E2\%80\%9C.\&rlz= 1C1GCEA_enLT771LT772\&oq=Bibliotekos+pa\%C5\%BEangai+2\%E2\%80\%9C.\&aqs=chrome..69i57j0j69i64.1426j0j8\&sourceid=chrome\&ie=UTF-8. Žiūrèta 2018-10-19.

72 Panašaus pobūdžio projektai labiau būtų reikalingi didmiesčių bibliotekoms. 
Ivairios tematikos projektus finansavo nacionaliniai rèmejjai (kai kada - drauge su vietos rèmejjais). 2007 m. projektai skirti bendrajai kompetencijai ugdyti. Plungès r. biblioteka vykdė projektą „Kultūros tekstai ir kontekstai: Skandinavijos ieškojimai“ (paremė KSRF, SV). Bibliotekos darbuotojai lankèsi Boksholmo (Švedija) regiono bibliotekose, suaugusiųjų švietimo įstaigose, nevyriausybinèse organizacijose, domëjosi bendruomenine veikla, susitiko su kolegomis bibliotekininkais, kultūros žmonèmis, valdžios atstovais. Kalvarijos SVB vykdẻ Kultūros ministerijos paremtą projektą „Švietejjiškos veiklos galimybès bibliotekoje“. Šia tema buvo organizuotas seminaras. Darbuotojų profesiniam tobulëjimui pasitelktas Kultūros ministerijos paremtas Šiaulių m. SVB projektas „Tarptautinis seminaras Latvijoje (Ventspilis)“, Vilniaus m. SCB projektas „Knygos tiesia tiltus (Книги строят мосты)““(rèmëjas nenuro-

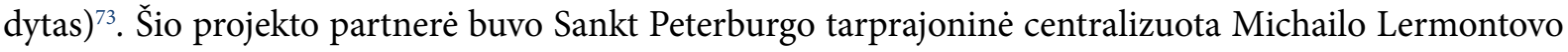
viešųjų bibliotekų sistema (Rusija).

Projektai skirti inovacijoms, vaikų skaitymo problemoms, elektroninių paslaugų teikimui. $2009 \mathrm{~m}$. Lietuvos bibliotekininkų draugijos Šiaulių skyrius laimėjo projektą „Kultūrinis bendradarbiavimas: inovacijų paieška bibliotekose" (rèmèjos - KM, SV). Buvo organizuota Šiaulių m. SVB, miesto bendrojo lavinimo mokyklų, kolegijų, Šiaulių universiteto, Šiaulių m. profesinio rengimo centro bibliotekų bei Trakų r. SVB darbuotojų grupès stažuotė Talino ir Helsinkio bibliotekose. Surengtas seminaras „Kultūros ịstaigos ir kultūros darbuotojo įvaizdžio kūrimas nūdienos visuomenèje“. Tais pačiais metais Kelmès r. bibliotekai vykdant projektą „Tegyvuoja knyga!: Konferencijos skaitytojams ir skaitymo vadovams“ (rèméja - KM) surengtos dvi konferencijos, skirtos vaikų skaitymo problemoms aptarti. 2013 metais Kultūros ministerija parèmé Šilutès r. SVB projektą „Elektroninių paslaugų vadybininkai - kompetentingi bibliotekininkai“. Igyvendinant projektą viešosios bibliotekos ir filialų darbuotojai mokèsi pagal programas: „Efektyvus Office 2010 naudojimas“, „Google Drive funkcijų naudojimas“, „Inkscape - vektorinès grafikos programa“, „Gimp - taškinès grafikos programa“, „Elektroninès skaityklès“. Kultūros rèmimo fondas finansavo Švenčionių r. SVB bibliotekos projektą „E. paslaugos - saugu, patogu, patikima“. El. paslaugu mokymai vyko viešosios bibliotekos, miestų ir kaimo filialų darbuotojams.

Igyvendinant projektus perimama geroji Lietuvos ir užsienio bibliotekų patirtis. Čia pažymètinas Savivaldybių viešųjų bibliotekų asociacijos (SVBA) vaidmuo. $2014 \mathrm{~m}$. asociacija vykdè LKT paremtą projektą „Viešųjų bibliotekų patirties mainų akademija: gebejimų stiprinimas Lietuvoje ir užsienio šalyse“. Buvo siekiama sudaryti sąlygas bibliotekų darbuotojams tobulinti igūdžius ir gebejjimus inovacijų diegimo srityje, skatinti gerosios patirties sklaidą Lietuvoje ir užsienio šalyse. Organizuotas seminaras „Gerosios patirties sklaida: formos, metodai ir būdai“, patirties sklaidos konferencija „Inovacijos bibliotekose: iššūkiai ir naujos galimybès“, pažintinè patirties stažuotė „Inovacijos bibliotekose: Lietuvos, Prancūzijos ir Vokietijos bibliotekų patirtis". Stažuotė vyko Berlyno, Nicos, Marselio, Liono, Avinjono bibliotekose.

Projektai, skirti biblioteku darbuotoju skaitmeninems kompetencijoms tobulinti. Kultūros ministerija finansavo Klaipėdos m. bibliotekos projektą „Skaitmeninès kompetencijos išmaniam bibliotekininkui“, kurio dèka vyko mokymai Klaipėdos m., Klaipėdos r. ir Kretingos r. bibliotekų specialistams bei gyventojų mokymai ir konsultavimas temomis „Prezi pateiktys“, „Populiarioji debesų kompiuterija“, „Internetinis marketingas“. Utenos biblioteka kartu su grupe partnerių vykdè LKT paremtą projektą „Šiuolaikinių technologijų taikymas ir kūrybiška partnerystė populiarinant kultūros paslaugas jaunimui“, kuris buvo skirtas Utenos regiono kultūros darbuotojų kvalifikacijai. Surengti moduliniai mokymai Utenos regiono savivaldybių kultūros darbuotojams, suteikta žinių ir praktinių igūdžių, reikalingų kūrybiškiau ir išradingiau populiarinti kultūros paslaugas jaunimui. Perimta geroji užsienio kolegų patirtis: surengta regiono kultūros ịstaigų darbuotojų studijinè išvyka ị Lenkijos kultūros ịstaigas - Varšuvos Koperniko mokslo centrą ir Olštyno miesto viešąą biblioteką, kuri 2013 m. laimėjo EIFL fondo apdovanojimą už sukurtą technologijų laboratoriją jaunimui.

\footnotetext{
Šių projektų renginių temos bibliotekos dokumentuose nenurodytos.
} 
Aktualejo 2015-2017 m. projektų tematika. LKT paremė Utenos SVB vykdytą projektą „Atminties institucija - inovatyvi ugdymo erdve jaunimui“ (2015-2016 m.). Projekto partneriai: Vilniaus universiteto (VU) Komunikacijos fakultetas, Všt „Creativitas“ir kt. Projekto tikslas - suaktyvinti jaunimo kultūrini ugdymą, kūrybiškumo ir saviraiškos skatinimą Utenos regiono bibliotekose suteikiant jų darbuotojams kompetencijų tikslingai naudoti veiklų sužaidybinimo ${ }^{74}$ praktiką. Vykdant projekto veiklas surengta studijinè išvyka ị Lenkijos, Serbijos, Bosnijos ir Hercegovinos bibliotekas, kurios sékmingai taikè sužaidybinimo praktiką. Zarasų r. biblioteka 2016 metais igyvendino projektą „Pilietiškumo skatinimo programa Partnerystèje - jèga“" (rèmèja - LKT). Siekiant skatinti bibliotekų ir vietos bendruomenių bendradarbiavimą centrinejje bibliotekoje organizuotas seminaras bibliotekininkams ir vietos bendruomenių pirmininkams „Bibliotekų ir bendruomenių bendradarbiavimas ir partnerysté“, Turmanto $\mathrm{m}$. bendruomenéje - diskusija „Kaip tai veikia?“.

2016-2017 m. vykdyti keli projektai, skirti medijoms pažinti. 2016 m. Lietuvos kultūros taryba parèmé Širvintų RVB projektą „Medijos keičia mūsų pasaulį“. Bibliotekos darbuotojams surengti mokymai "Asmens duomenų apsaugos įstatymas“, „Nematomi pavojai internete: asmens duomenų apsauga elektroninëje erdveje“ ir kt. 2017 m. LKT parèmè bibliotekos projektą „Medijos keičia mūsų pasauli - suprask jas“ (kiek kitu pavadinimu buvo tęsiamos $2016 \mathrm{~m}$. projekto veiklos). Surengti seminarai: „Kaip pateikti informaciją spaudai ir interneto svetainei“, „Socialiniai tinklai: tuštybė ar vertybės?“, „Žiniasklaidos monitoringas. Žiniasklaidos turinio analizë“ ir kt. Šiaulių r. biblioteka igyvendino projektą „Išdrịskime pasitikti kintantị pasauli““ (rèmëjos - LKT, SV). Bibliotekos darbuotojai dalyvavo Šiaulių valstybinèje kolegijoje surengtoje dr. Vinco Grigo ir dr. Andriaus Šumino paskaitoje-seminare „Medijos ir informacija - kaip jas šiuolaikiniam žmogui suvaldyti“. 2017 m. Utenos biblioteka vykdé projektą „Šiuolaikinių technologijų taikymas ir kūrybiška partnerystė populiarinant kultūros paslaugas jaunimui: interneto svetainès ir socialiniai tinklai“" (rèmèjos - LKT, KM, partnerè - UAB „IT akademija“). Siekta išplèsti bibliotekininkų žinias apie interneto svetainių pritaikymą jaunimo poreikiams, supažindinti su optimizuoto interneto galimybėmis, paskatinti kūrybiškumą ir praktinėse veiklose pritaikyti regiono bibliotekų svetaines išradingai komunikacijai su jaunimo auditorija.

Vietos rẻmėjų finansuoti projektai daugiausia skirti seminarams organizuoti, o jų tematika labai ịvairi. 2007 m. Pasvalio SVB projektą „Archyvai, bibliotekos, muziejai: bendradarbiavimo galimybès“ parèmè Panevėžio apskrities viršininko administracija. Organizuotas seminaras skirtas Panevėžio apskrities bibliotekų, muziejų, kitų kultūros ir švietimo įstaigų darbuotojams. Mažeikių r. SVB vykdè savivaldybės paremtą projektą „Kultūrinès kompetencijos ugdymas“. Pranešimą skaitė LNB Bibliotekų vadybos skyriaus vyriausioji metodininkè Dalia Jaskonienė. Pridursime, kad Utenos SVB vykdė projektus „Dviejų seminarų organizavimas“, „Utenos rajono bibliotekų darbuotojų dalyvavimas seminare Torunès (Lenkija) universiteto bibliotekoje “75.

Mažeikių r. savivaldybės viešoji biblioteka $2010 \mathrm{~m}$. igyvendino projektą „Modernios bibliotekinès technologijos ir vartotojų aptarnavimas“ (rèmèja - SV). Klaipèdos r. bibliotekos $2012 \mathrm{~m}$. projektas „Papročių ir apeigų teatralumas" buvo skirtas rajono bibliotekininkų ir kultūros centrų darbuotojams (rèmejja - SV). Biblioteka organizavo seminarą „Papročių ir apeigų teatralumas: pažinimas ir sklaida“. Kvalifikacijai kelti etninès kultūros srityje taip pat buvo naudingas $2013 \mathrm{~m}$. savivaldybės paremtas Klaipėdos r. bibliotekos organizuotas seminaras kultūros ir švietimo darbuotojams „Tarmès šioj ir anoj gadynejj“. Savivaldybė parèmé Mažeikių r. bibliotekininkų draugijos projektą „Didèjantys vartotojų poreikiai - nauji iššūkiai tobulejjimui“" (2013 m.). Vykdant projektą buvo organizuota išvyka ị ŠAVB, kurios metu bibliotekininkai susipažino su skyrių veikla, dalyvavo kvalifikacijos kèlimo seminare, kuriame perskaityti ŠAVB darbuotojų pranešimai: „E-knyga: už ir prieš. Pasaulio ir Lietuvos patirtis ir perspektyvos“, „Nauji vaikų bibliotekininko vaidmenys skaitymo baruose“ ir kt.

Sužaidybinimas - tai žaidimų logikos, elementų ar technikos perkèlimas ị tiesiogiai su žaidimais nesusijusias situacijas, siekiant pagerinti darbo, mokymosi ar kitokios veiklos rezultatus.

Seminarų temos ir rèmejjai bibliotekos dokumentuose nenurodyti. 
Klaipėdos m. savivaldybė finansavo bibliotekos projektą „Biblioteka - partnerystė, draugystė, žinios“ (2015 m.). Surengta kvalifikacinè išvyka ị Mardu miesto bibliotekas (Estija). 2017 m. švietimo programą „Viešieji ryšiai“ vykdè Radviliškio r. biblioteka (rèmèja - SV, panaudotos ir bibliotekos lèšos). Darbuotojai gilino žinias apie profesinị etiketą, bibliotekos išskirtinumo kūrimą ir žinomumo visuomenèje didinimą panaudojant viešųjų ryšių metodus ir organizacijos įvaizdžio kūrimo praktikumus.

Bibliotekos darbuotojai kèlè kvalifikaciją dalyvaudami kitų institucijų projektuose. Vilniaus m. SCB darbuotojai $2007 \mathrm{~m}$. dalyvavo vykdant savivaldybės projektą „Vilniaus miesto kultūros įstaigų darbuotojų kvalifikacijos kèlimas", kurị finansavo Europos socialinis fondas. Igyvendinant projektą vyko mokomieji seminarai, konferencijos, praktinių užsièmimų stovyklos, kuriose kultūros specialistai pagilino modernios kultūros vadybos, ekonomikos, strateginio planavimo ir kitas specialiąsias žinias. Lazdijų r. bibliotekų darbuotojai kèlè kvalifikaciją vykdant savivaldybės projektą „Lazdijų rajono savivaldybės ir jos įstaigų darbuotojų kvalifikacijos ir žinių lygio kèlimas ${ }^{\text {“776 }}$. Jonavos r. SVB darbuotojai dalyvavo Kauno technologijos universiteto vykdytame projekte „Kompiuterinis raštingumas bendruomenèms - geresnès kokybès garantas" (2011 m.). Utenos bibliotekos darbuotojai dalyvavo kultūros specialistų kvalifikacijos tobulinimo projekte „Utenos regiono (apskrities) kultūros darbuotojų kvalifikacijos jaunimo kultūrinei ir socialinei ittraukčiai didinti stiprinimas“ (2012 m.). Bibliotekininkams igyti darbui su jaunimu reikalingų žinių bei igūdžių padejjo projekte numatyta studijuojamoji išvyka ị Talino ir jo regiono kultūros, socialinius ir neformaliojo švietimo multicentrus siekiant perimti jų gerąją patirtị.

\subsubsection{Literatūros, skaitymo skatinimo projektai}

Literatūros populiarinimas, skaitymo skatinimas - tiesioginè bibliotekų funkcija. 7 ir 8 lentelèse pateikiama informacija apie literatūros, skaitymo skatinimo projektų vykdymą 2007, 2013, 2015-2017 metais Kauno apskr. ir Vilniaus apskr. bibliotekose atkreipiant dèmesị i bibliotekas, vykdžiusias du ir daugiau projektų ir jų nevykdžiusias. Manytume, dviejų apskričiu bibliotekų projektinè veikla daug parodo situaciją visose bibliotekose.

7 lentelè. Kauno apskrities bibliotekų (8) literatūros, skaitymo skatinimo projektų vykdymas 2007, 2013, 2015-2017 metais (skliaustuose - bibliotekų skaičius apskrityje, vykdytų projektų skaičius, rèmëjų tipas: $\mathrm{Tr}$ - tarptautinis rèmejjas, $\mathrm{Nr}$ - nacionalinis rèmèjas, $\mathrm{Vr}$ - vietos rèmèjas)

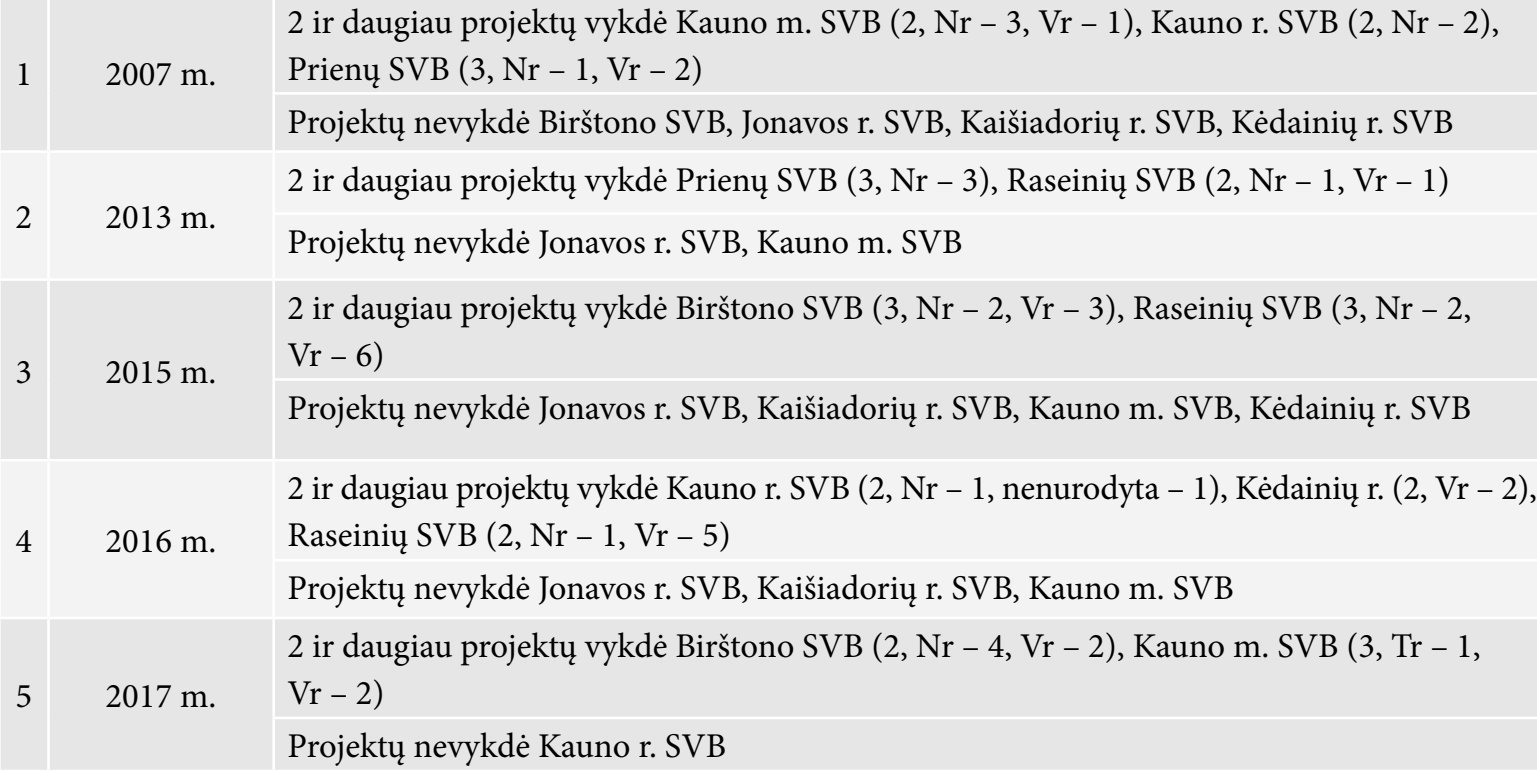

Informacijos apie projekto turinị bibliotekos dokumentuose nepateikta. 
Projektų skaičius, tarptautinių, nacionalinių, $\quad$ Vykdyta projektų: 29; paramos teikèjų skaičius (per metus): $\mathrm{Tr}-1, \mathrm{Nr}-20, \mathrm{Vr}-24$, nenuvietos rèmèjų rodyta -1

parama vykdant

projektus

2 ir daugiau projektų skirtingais metais vykdè 6 bibliotekos: Kauno m. SVB, Kauno r. SVB, Prienų SVB, Raseinių SVB, Birštono SVB, Kėdainių r. SVB. Vykdant literatūros ir skaitymo skatinimo projektus pagrindinè buvo vietos ir nacionalinių rèmejjų parama. Projektinèje veikloje itin reiškèsi sporadiškumas: vienais metais biblioteka vykdè 2 ir daugiau projektų, kitais - nevykdè.

8 lentelè. Vilniaus apskrities bibliotekų (8) literatūros, skaitymo skatinimo projektų vykdymas 2007, 2013, 2015-2017 metais

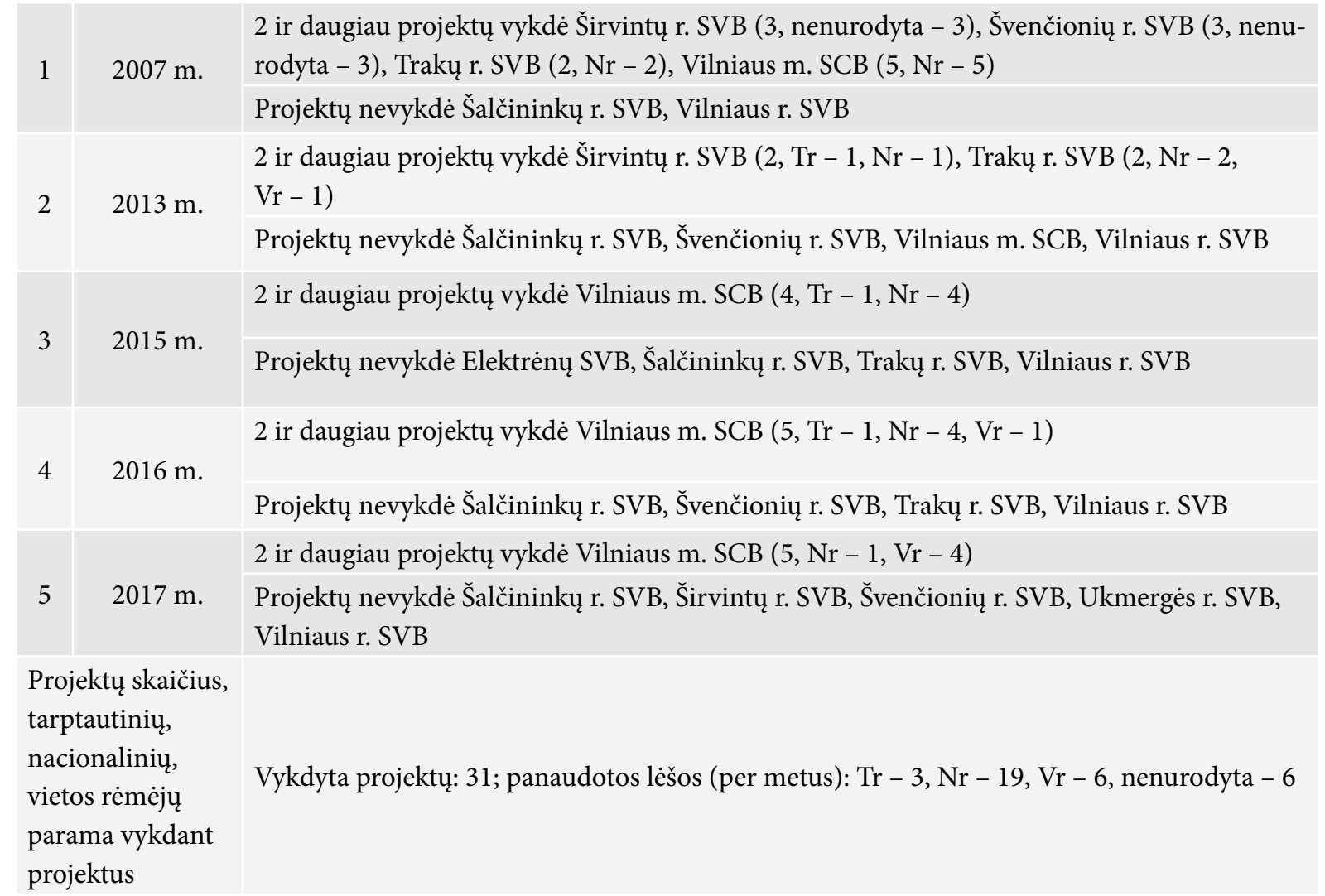

2 ir daugiau projektų skirtingais metais vykdė 4 bibliotekos: Širvintų r. SVB, Švenčionių r. SVB, Trakų r. SVB, Vilniaus m. SCB. Pažymėtinas Vilniaus m. SCB dėmesys literatūros ir skaitymo skatinimo projektams (2007, 2015-2017 metais vykdyta net 19 projektų). Vyravo nacionalinių rėméjų parama. Vykdant literatūros ir skaitymo skatinimo projektus stipriai reiškèsi sporadiškumas: vienais metais biblioteka vykdè 2 ir daugiau projektų, kitais - nevykdè. Projektų nevykdè Šalčininkų r. SVB ir Vilniaus r. SVB (abi bibliotekos apskritai nevykdè savarankiškų projektų).

Kitose apskrityse gerų rezultatų pasiekė Šilutès r. SVB, Klaipėdos r. SVB, Kretingos r. SVB, Klaipėdos m. SVB (Klaipėdos apskr.), Tauragès r. SVB (Tauragès apskr.), Pasvalio SVB, Rokiškio r. SVB, Panevėžio m. SVB (Panevėžio apskr.), Molètų r. SVB, Zarasų r. SVB (Utenos apskr.), Akmenès r. SVB, Kelmès r. SVB (Šiaulių apskr.), Telšių r. SVB (Telšių apskr.), Alytaus SVB (Alytaus apskr.). Kalvarijos 
SVB (Marijampolès apskr.), Šilalès r. SVB (Tauragès apskr.), Rietavo SVB (Telšiu apskr.) 2007, 2013, 2015-2017 metais literatūros ir skaitymo skatinimo projektų nevykdè.

Organizuodamos literatūros sklaidos renginius, konkursus, įamžindamos rašytojų atminimą, skatindamos skaitymą bibliotekos gebejjo pasinaudoti tarptautinių rèmëjų parama. Tauragès r. ir Pagėgių bibliotekos dalyvavo Europos regioninès plètros fondo paremtame projekte „Internetinis literatūros festivalis Euroskaitymai 2007“. Projekto partneriai: Kaliningrado srities universalioji mokslinè biblioteka (Rusijos Federacija), Olštyno vaivadijos viešoji biblioteka (Lenkija) ${ }^{77}$. Projekto tikslas - ilgalaikio bendradarbiavimo tarp Lenkijos, Lietuvos ir Rusijos Federacijos Kaliningrado srities bibliotekų stiprinimas panaudojant šiuolaikines informacines technologijas vartotojų, ypač jaunimo nuo 16 iki 25 metų, skaitymui skatinti. Vykdant projektą bibliotekos organizavo nuotolinị konkursą renkant geriausią rašinị (esė) apie nacionalinio ar užsienio autoriaus kūrybą. Projektas tęsèsi ir $2008 \mathrm{~m}$. sausio - vasario mẻn. Iš viso konkurse dalyvavo daugiau nei 1000 žmonių. Širvintų r. SVB pasinaudojo ES parama rašytojų atminimui ịamžinti. Biblioteka gavo Europos žemès ūkio fondo kaimo plètrai finansinę paramą 2012-2013 m. projektui „Apie žodị - išlekiantị ir sugrịžtantị“. Jo ịgyvendinimo rezultatas: Bagaslaviškio filiale ịkurtas Kazimiero Skebèros literatūrinis muziejus, parengtos atminimo lentos rašytojams Juozui Kruminui, Ignui Šeiniui, memuaristui Kazimierui Skeberai, rašytojui Viktorui Brazauskui, rašytojui, kunigui Nikodemui Švogžliui, taip pat - Nepriklausomybės Akto signatarui, kunigui Alfonsui Petruliui. 2012-2013 m. Zarasų r. biblioteka vykdè Europos regioninès plètros fondo paremtą projektą „Skaitymo skatinimas panaudojant informacines technologijas ir kūrybinę veiklą (Zarasai-Daugpilis)“ (sutrumpintas projekto pavadinimas „Skaitymas - IT - Küryba“). Bibliotekos partneris: Latgalès centrinè biblioteka (Daugpilio m., Latvija). Projekto tikslas - populiarinti skaitymą panaudojant informacines technologijas ir kūrybinę veiklą; plètoti tarpkultūrinius ryšius ir bendradarbiavimą abipus sienų.

Atkreiptinas dèmesys ị Akmenès r. bibliotekos iniciatyvą. Biblioteka vykdè BMGF ir KM [BP 2] finansuotą projektą „Internetinès literatūrinès svetainès sukūrimas viešojoje bibliotekoje“ (partnerè - Lietuvos nepriklausomųjų rašytojų sąjunga). Projekto tikslas - reprezentuoti iš Akmenès krašto kilusius žymius kultūros žmones, skleisti informaciją apie krašto literatus, jų leidžiamas knygas, biografijas. Projekto ịgyvendinimas sudare galimybę kuriantiems Akmenès karšto gyventojams dalytis savo kūryba ir ją populiarinti ir savo krašte, ir už jo ribų.

Šilutès r. biblioteka vykdè tarptautinius projektus. $2012 \mathrm{~m}$. bibliotekos projektą „Trys keliaujančios knygų mugès: lietuviško žodžio akiračiai“ parėmè Kultūros ministerija, Lietuvos bibliotekininkų draugija, asociacija „Šilutès raštijos ir knygių draugija“ bei verslininkai. Bibliotekininkai aplanke Ararato sritinę biblioteką Armėnijoje, Karaliaučių, jo bibliotekas ir Tolminkiemi. Armėnijoje organizuoti edukaciniai renginiai tradicinių bei modernių bibliotekinių paslaugų teikimo ir bibliotekos ịvaizdžio formavimo temomis. Karaliaučiuje organizuoti Maironio kūrybos skaitymai, surengta šilutiškių ir kaliningradiečių bibliotekininkų jungtinè paroda, skirta Maironiui. Tolminkiemyje pristatyta virtuali paroda „Kristijonas Donelaitis: laikmečio ir dabarties liudytojai“. Po metų biblioteka vykdè projektą „Trys keliaujančios knygų mugès: lietuviško žodžio atodangos“, kurio rėmejja buvo jau tik KM. Ekspedicijos Karaliaučiuje metu šilutiškiai ir kaliningradiečiai bibliotekininkai kartu su Salos etnokultūros ir informacijos centro Rusnès moterų vokalinio ansamblio dalyviais ir Kaliningrado lietuvių L. Rèzos draugijos jaunimu lankè su lietuvišku raštu, knyga ir jos veikejjais susijusias senojo Karaliaučiaus vietas. Kaliningrado miesto municipaliteto centralizuotos bibliotekų sistemos 4-ajame filiale vyko skaitymai, skirti K. Donelaičiui, parodos „Mažosios Lietuvos knygininkų Karaliaučiuje ir Klaipėdos krašte istorinès sąsajos“ virtualus pristatymas, ekspozicijos „Donelaitika šiuolaikinëje literatūroje ir mene“ pristatymas ir kt. Be to, ịvairūs renginiai organizuoti aplankius Punską bei Kazachstano Akajinsko rajono Smirnovo biblioteką.

Sumanymas organizuoti festivalị priklausė Olštyno vaivadijos bibliotekai. 
2012 m. Šilutès r. biblioteka drauge su asociacija „Šilutės raštijos ir knygių draugija“ vykdè tęstinị projektą „Literatūrinis ruduo Prisijaukinkim žodį, paukštį, debesįi...'. Organizuodama literatūrinị konkursą biblioteka siekè užsitikrinti kuo didesnį rėmejjų ir partnerių skaičių. Projektą finansavo KM, SV, AB DNB bankas, UAB „Šilutès būstas“, SVB. Projektui talkino partneriai Bauskès centrinè biblioteka, Latvijos rašytojų sajunga, Kaliningrado Gaidaro sritinė vaikų biblioteka, Brašovo George’o Baritiu apskrities viešoji biblioteka (Rumunija). Literatūrinio rudens konkursui „Prisijaukinkim žodị, paukštị, debesį...“ pristatytos 56 autorių 75 knygos.

Šilutès r. biblioteka projektus skyrè literatūros paveldui. Biblioteka 2007 m. laimèjo Kultūros ministerijos projektą „Knygos ir rašto paveldo aktualizavimas ir sklaida“. Projektu siekta Šilutès bendruomenès nariams padèti geriau pažinti Mažosios Lietuvos senosios raštijos ir kultūros paveldą fiksuojant elektroninèse laikmenose viešojoje bibliotekoje sukauptą medžiagą apie šio krašto knygos ir rašto veikejjus. Vykdant Kultūros ir sporto rèmimo fondo finansuotą projektą „Hermannas Sudermannas savo knygose ir biblioteka" organizuoti literatūriniai renginiai, skirti vokiečių rašytojo ir dramaturgo 150-osioms gimimo metinèms ${ }^{78}$, atidaryta paroda „Hermanas Zudermanas savo ir mūsų knygose“ bei pristatytas prof. Domo Kauno sudarytas iki Antrojo pasaulinio karo pabaigos H. Sudermanno išleistų knygų parodos katalogas. Kultūros ministerijos paremtas projektas „Lietuviškas žodis ir raštas Karaliaučiaus krašte“ buvo skirtas Karaliaučiaus krašto literatūriniam paveldui bei dabartinei lietuvių nacionalinei literatūrai populiarinti. Projektas buvo vykdomas drauge su asociacija Šilutès raštijos ir knygių draugija.

Projektai, skirti literatūriniam palikimui. 2007 m. projektai skirti Jurgio Kunčino, Stasio Santvaro, Jono Avyžiaus, Žemaitès, Roberto Keturakio, Juozo Keliuočio, Kazio Bradūno literatūriniam palikimui. Alytaus SVB projektą „Literatūriniai metai po Jurgio Kunčino ženklu“ parèmė Kultūros ministerija, Alytaus apskrities viršininko administracija, savivaldybė. Vyko rašytojui skirti renginiai. Parengta kompaktinès plokštelès „Gyvas rašytojo J. Kunčino pèdsakas“ antroji dalis „Gyvenimo stebètojo užrašai“, kurioje sudètos rašytojo publikacijos, spausdintos periodikoje ${ }^{79}$. Išleistas pirmųjų ir antrųjų respublikinių trumposios prozos skaitymų, skirtų J. Kunčino atminimui, almanachas „Imbiero vakarai“, kurị sudare bibliotekos direktorè Giedrè Bulgakoviene $\dot{e}^{80}$. Metų pabaigoje surengta literatūrinè konferencija „Novelès anatomija“. Kultūros ministerija ir savivaldybès parėmé Jurbarko r. SVB projektą „Sugrị̌žtantis Stasys Santvaras“, Joniškio r. SVB projektą „Rašytojo aura knygos ir žinių šventovẻje“, skirtą J. Avyžiaus 85-osioms gimimo metinėms ir viešosios bibliotekos 70-mečiui, Kultūros ministerija finansavo Kauno r. SVB projektą „Biobibliografinè rodyklė. Rašytojas Robertas Keturakis“, Kelmès r. SVB projektą „Antrieji Žemaitès skaitymai“. Kultūros ir sporto rèmimo fondas parèmé Rokiškio r. SVB ir Juozo ir Alfonso Keliuočių palikimo studijų centro projektą, skirtą J. Keliuočio 105-osioms metinèms. Vilkaviškio r. savivaldybė finansavo bibliotekos projektą, skirtą kraštiečio poeto K. Bradūno 90-mečio jubiliejui.

Tad bibliotekos puoselejo susiformavusią projektinès veiklos tradiciją - pagerbti iškilius literatus, populiarinti jų kūrybą. Prienų SVB pagerbė Just. Marcinkevičiaus atminimą jam mirus $2011 \mathrm{~m}$. vasario $16 \mathrm{~d}$. Tais metais biblioteka ịgyvendino projektą „Laiko ir vietos prasmés ieškojimas“ (rẻmejjas nenurodytas). Jị vykdant surengtas poezijos ir muzikos vakaras „Valanda su Justino Marcinkevičiaus poezija“, taip pat du jubiliejiniai vakarai, skirti rašytojos, poetės, dramaturgès Jurgos Ivanauskaitės 50 -osioms ir Česlovo Milošo 100-osioms gimimo metinėms; pristatyta Just. Marcinkevičiaus knyga „Dienoraščiai ir datos“, V. Sventicko knyga „Apie Justiną Marcinkevičių“. 2012 m. biblioteka vykdè projektą „Prie tėviškès vartų", skirtą kraštiečiui poetui (rèmèjas - KRF, parneriai - Prienų kultūros ir laisvalaikio centrs, Prienų rajono savivaldybės bendruomenių asociacija, Prienų ir Birštono krašto kūrèjų asociacija „Gabija“). Buvo irengtas ir atidarytas poeto memorialinis kambarys, ivvko susitikimas su prof. Viktorija Daujotyte-Pa-

Hermannas Sudermannas gimè 1857 m. Šilutès r. Macikų k.

Gyvenimo stebètojo užrašai: 2 dalis, CD-ROM. Alytus: Alytaus Jurgio Kunčino viešoji biblioteka, 2007; 1 dalis išleista $2006 \mathrm{~m}$.

Imbiero vakarai: almanachas, 2004/06. Vilnius: Eugrimas, 2007. 
keriene ir jos knygos „Justino Marcinkevičiaus žemė: žmogaus šiapus“ pristatymas. Joniškio r. SVB tęse Jono Avyžiaus kūrybos populiarinimą. 2010 ir 2012 metų bibliotekos projektus parèmé KRF. Kelmès r. biblioteka toliau populiarino Žemaitès kūrybą. Tradicija tapo Žemaitės skaitymų organizavimas. $2012 \mathrm{~m}$. biblioteka vykdè projektą „Ketvirtieji Žemaitès skaitymai“ (rèmëjas - KRF).

Alytaus biblioteka vykdè projektus „Imbiero vakarai - 08“, „Imbiero vakarai - 2010“, „Imbiero vakarai - 2012“. Tai respublikiniai trumposios prozos skaitymai, skirti Jurgio Kunčino atminimui ${ }^{81} .2008$ m. projektą parèmé Kultūros ministerija ir savivaldybè. Organizuotas renginių ciklas. 2010 ir 2012 metų projektus finansavo KRF ir SV. 2011 m. biblioteka taip pat vykde projektą „Imbiero vakarai. Post Scriptum“ (rèmèjai - KRF, SV). Alytuje ir Lazdijuose surengti literatūriniai-muzikiniai vakarai. Išleistas trumpają prozą populiarinantis literatūrinis almanachas „Imbiero vakarai 2008-2010“82. Igyvendinant projektą užmegztas tradicinių literatūros festivalių rengejjų bendradarbiavimas - surengta konferencija "Literatūriniai festivaliai Lietuvoje. Organizavimo patirtys ir problemos“. Akmenès r. biblioteka $2012 \mathrm{~m}$. vykdè projektą „Literatūrinès kelionès bibliotekose. Lazdynų Pelèda. Ar pražuvo kaip sapnas?“. Projektą parėmè KRF, SV, SVB, Akmenès krašto muziejus. Viešojoje bibliotekoje ir jos filialuose vyko literatūriniai skaitymai, Lazdynų Pelèdos kūrybos apžvalgos, surengtos literatūros ir spaudinių parodos, geriausio scenarijaus pagal Lazdynų Pelèdos kūrinius, geriausios kūrinio iliustracijos, geriausios kūrybos ir gyvenimo apžvalgos konkursai. Rašytojoms pagerbti skirta konferencija surengta Papileje ${ }^{83}$.

LR Seimas 2011 m. paskelbè Česlovo Milošo metais. Rokiškio r. SVB ir Juozo ir Alfonso Keliuočiu palikimo studijų centras iggyvendino projektą „Konferencija: Česlovo Milošo skaitymai“ (rèmèjai - KRF, SV). Buvo siekiama nuodugniai aptarti Nobelio premijos laureato gyvenimą ir kūrybą, apžvelgti jo sąsajas su Lietuva, Kėdainių kraštu. Pranešimus skaitė VU Polonistikos centro dėstytoja Danuta Balašaitienè, rašytoja Birutė Jonuškaitė, Kẻdainių krašto muziejaus direktorius Rimantas Žirgulys ir kiti.

LR Seimas 2012 m. paskelbè Maironio metais. Maironio kūryba bibliotekose sulaukè deramo dèmesio. Lietuvių literatūros klasikui skirtus projektus daugiausia parėmè Kultūros rẻmimo fondas. Paminètini projektai: Joniškio r. SVB igyvendino projektą-renginių ciklą „Maironio poezija visoms kartoms“ (rèmejjas - KRF); Mažeikių r. SVB - projektą-renginių ciklą „Ar mokame mylèti kaip Maironis Tẻvynę, Dievą, žmogų?“ (rèmèjas - KRF); Panevė̌io r. SVB - projektą „Literatūrinès kelionès su Maironiu“ (rèmëja - KM); Prienų SVB - projektą „Nuo Dubysos slènių iki Birutės kalno. Maironio gyvenimo ir kūrybos keliais“ (rèmèjas - KRF); Šilalès r. SVB - projektą „Kas tas paslaptis suprastų“ (rèmèjas - KRF); Šiaulių m. SVB - projektą „Kuriame įkvèpti Maironio...“ (rèmejjai - KRF, SV); Utenos SVB - projektą „Literatūros ir meno renginių programa Rekomenduojama kultūros dozé menant Maironį" (rèmèjas - KRF).

Artẻjant Kristijono Donelaičio 300-osioms gimimo metinėms (LR Seimo nutarimu 2014-ieji paskelbti Kristijono Donelaičio metais, 300-osios jo gimimo metinès įtrauktos ị UNESCO sukakčių sąrašą) bibliotekos vykdè jo kūrybai skirtus projektus. Šilutès r. biblioteka vykdė projektą „Kristijonas Donelaitis: knygos metų laikai“, kurị parėmė KRF ir SV. Biblioteka surengè tarptautinę konferenciją „Kristijonas Donelaitis ir laikas“. Šilutės r. biblioteka taip pat skyre projektą K. Donelaičio ir Mažosios Lietuvos literatūriniam paveldui.

Kiti bibliotekų projektai, skirti K. Donelaičio kūrybai: Prienų SVB vykdė projektą „Poetas prasideda žemèj“ (Just. Marcinkevičius). Kristijono Donelaičio gyvenimo ir kūrybos keliais“ (rèmèjas - KRF); Kaišiadorių r. SVB - projektą „Nuo Kristijono Donelaičio iki XXI amžiaus rašytojų“ (rèmėjas - KRF); Elektrėnų SVB - projektą „Literatūrinių renginių ciklas Donelaitis - lietuviškos raštijos pradininkas“ (rèmejjas - KRF); Trakų r. SVB - projektą „Donelaitis praeityje ir dabartyje“ (rèmëjai - KRF ir SV); Tauragès r. SVB - projektą „Donelaičio metus pasitinkant“ (rèmejja - SV).

Imbiero vakarai vyksta kas antri metai.

Imbiero vakarai, 2008-2010: almanachas / sud. G. Bulgakovienè. Vilnius: Eugrimas, 2011.

Žr. Sinkevičienė, Z. Lazdynų Pelèda. Ar pražuvo kaip sapnas? (Akmenè). Tarp knygų, 2013, sausis, p. 28. 
K. Donelaičio kūryba buvo populiarinama ir 2014-aisiais. Tų metų projektai skirti vaikams ir jaunimui. LKT finansavo Panevėžio m. bibliotekos projektą „Knyga - raktas ị pažinimą. Mūsų metai“. Siekta puoselèti K. Donelaičio atminimą, skatinti vaikus domètis tautos kultūriniu ir literatūriniu paveldu.

Pagerbtas Marius Katiliškis: 2014 m. Pasvalio biblioteka įgyvendino projektą „Mariaus Katiliškio šimtmetis kartų atmintyje“ (rèmèja - LKT), skirtą 100-osioms rašytojo gimimo metinèms paminèti. Pasak projekto sumanytojų, rašytojo jubiliejus ịpareigoja ịveikti užmaršties slenksčius, iš naujo atrasti jo asmenybę, gyvenimą, kūrybą, ̨̧amžinti šiandienos atmintyje.

Lietuvos kultūros taryba ir Kultūros ministerija parèmè projektus, skirtus neseniai anapilin išějusiems iškiliems rašytojams. Prienų SVB nuosekliai populiarino Just. Marcinkevičiaus kūrybą. 2015 m. bibliotekos iniciatyva Prienų r. savivaldybės taryba paskelbė Justino Marcinkevičiaus metais savivaldybèje. Tais metais biblioteka igyvendino LKT laimètą projektą „Justino Marcinkevičiaus jubiliejinių metų renginiai jo vardo bibliotekoje“. Jị vykdant parengta kilnojamoji paroda „Justinas Marcinkevičius. Nuo ištakų iki šiandienos“, organizuota konferencija „Laiko negali pasirinkti“. Kultūros ministerija finansavo Skuodo r. bibliotekos projektą „Tradiciškiausio lietuvių kaimiškosios prozos kūrẻjo Romualdo Granausko pèdsakų ịamžinimas Skuodo žemèje“. Biblioteka ịvairiose organizacijose surengè R. Granausko kūrybos skaitymus. Atminimo lentomis paženklintos vietos, kuriose rašytojas gyveno, mokèsi, dirbo. Raseinių biblioteka su grupe partnerių (Lietuvos literatūros ir tautosakos institutas, Lietuvos dailès muziejus ir kt.) vykdè projektą „Marcelijus Martinaitis: pilietis ir kūrèjas epochų sankirtoje“ (2015-2016 m., prie LKT paramos prisidejo UAB „Raseinių žuvininkystë“, UAB „Danspin“ ir kt.). Surengta respublikinè konferencija, skaityti pranešimai paskelbti bibliotekos išleistame leidinyje „Marcelijus Martinaitis: pilietis ir kūrejjas epochų sankirtoje ${ }^{\text {"84 }}$. Savivaldybė parėmé Klaipèdos r. bibliotekos 2016 m. projektą „Petras Dirgèla mūsų atmintyje: asmenybè, kūrejjas, pilietis“. Petro Dirgèlos (1947-2015) mirties metines bibliotekoje pagerbè jo kūrybos gerbejjai, buvę mokytojai ir klasès draugai.

2015-2017 m. buvo toliau vykdomi projektai, skirti literatūriniam palikimui. Igyvendinant Panevèžio r. SVB projektą „Literatūrinès edukacinès kelionès su Šiaurès Lietuvos kūrejjais“ (rèmèja - LKT) buvo siekiama populiarinti Juozo Tumo-Vaižganto kūrybą, J. Tumo-Vaižganto ir knygnešių bei Puziniškio (G. Petkevičaitės-Bitės) muziejų veiklą̨ ${ }^{85}$ Biržų r. SVB vykde projektą „Gimtojoj mano Šiaurès Lietuvoj“ (rèmèja LKT, partnere - „Balticum TV“ Biržų atstovybè). Aplankytos ir nufilmuotos Biržų krašte esančios rašytojų tėviškès, sukurtas filmas apie Biržų krašto kūrejus (Julių Janonį, Almą Karosaitę, Balį Sruogą, Kazị Binkị ir kitus). Biržų r. bibliotekos projektas „Teigiantis gyvenimą“ buvo skirtas Balio Sruogos 120-osioms gimimo metinèms (rèmèja - LKT). Surengta konferencija „Teigiantis gyvenimą. Baliui Sruogai - 120“.

Projektuose izžvelgtini nauji darbo metodai, taikomos moderniosios technologijos. Zarasų r. SVB igyvendino projektą „Pasaulis pagal poetus romantikus (Antanas Vienažindys, Faustas Kirša, Paulius Širvys ir Petras Gaulè)“(rèmejja - LKT). Sukurta 11 virtualių panoraminių ekskursijų po poetų romantiku gimtąsias vietas panaudojant bibliotekos kraštotyros fondo rašytinius ir kitus šaltinius. Klaipèdos m. biblioteka vykdė KM paremtą projektą „Teatralizuoti Ievos Simonaitytės kūrybos vakarai O buvo taip...“. Projektas skirtas rašytojos 120-osioms gimimo metinèms. Girulių bibliotekoje atkurta I. Simonaitytès kūriniuose aprašoma autentiška Klaipėdos krašto aplinka, organizuoti I. Simonaitytės kūrinių skaitymai ir diskusijos, jaunimo esė konkursas ir kt. Lankytojus sužavèjo I. Simonaitytės metams skirtas renginys „Kalėdinis Ievos Simonaitytės knygų aromatas“, organizuotas kartu su kvapų Všt „KapKap“. Vilniaus SCB vykdè projektą „360““ (rèmèja - LKT). Pagal lietuvių autorių kūrinius sukurta virtualiosios realybės akinių instaliacija.

Projektai reprezentavo šiuolaikinę literatūrą. $2007 \mathrm{~m}$. Kultūros ministerija parèmè Zarasų r. SVB projektą „Literatūrinè programa Nešami mūzos sparnų“. Igyvendinta literatūros renginių programa „Poezijos

Marcelijus Martinaitis: pilietis ir kūrejjas epochų sankirtoje: konferencijos medžiaga. Kaunas: Naujasis lankas, 2016.

5 Panevėžio r. SVB administruoja J. Tumo-Vaižganto ir knygnešių muziejų, Puziniškio muziejų (Gabrielès Petkevičaitės-Bitės gimtinè), Mato Grigonio memorialinę ekspoziciją. 
pavasarèlis“ ir „Prozos ruduo VB ir Salako bibliotekose“. Susitikta su rašytojais, bardais, aktoriais. $2011 \mathrm{~m}$. Kultūros rẻmimo fondas finansavo Biržų r., Lazdijų r. bibliotekų projektus, kurie suteikè galimybę bibliotekų lankytojams susitikti su rašytojais, aktoriais. Biržų r. SVB tais pačiais metais vykdè projektą „Kaimyniški pašnekesiai Biržų pilyje“. Organizuotas literatūrinių susitikimų ciklas: svečiavosi poetas Mykolas Karčiauskas, rašytojas Sigitas Parulskis, Kauno valstybinio dramos teatro aktorius Henrikas Savickis. Lazdijų r. SVB vykdė projektą „Nespalvota istorija rudens prozos šurmulyje“. Surengtas susitikimas su rašytoju, aktoriumi, režisieriumi Vytautu V. Landsbergiu, susitikimas su prozininku, kritiku Liudviku Gadeikiu, prozininku Danieliumi Mušinsku. Ivyko rajono bendruomenės ir rajono literatų klubo „Jotvingis" narių susitikimai Kapčiamiesčio, Seirijų ir Lazdijų bibliotekose. Bibliotekos jaunimo centre surengta lietuvių rašytojų mažoji knygų mugè.

Išskirtinis dèmesys projektuose skirtas poezijai. Kultūros ir sporto rèmimo fondas $2007 \mathrm{~m}$. parèmé Biržų r. SVB ir Telšių r. SVB filialo projektus. Biržų r. biblioteka vykde projektą „Tarptautinis poezijos pavasaris 2007 Biržuose“. Originalų tęstinị projektą „Poezija sodų žydejjime“ vykdè Telšių r. Kaunatavos k. biblioteka. Surengta jau tradicija tapusi šventè. Poezijos skaitymai vyko gamtoje, pasinaudojus šalia bibliotekos esančiu daugiau kaip 100 ha vaismedžių sodu. Poeziją skaitė poetai Alma Karosaitè, Vytautas Rubavičius, Aidas Marčènas, svečias iš Moldavijos Leo Butnarus. Projektus finansavo savivaldybès: Rokiškio r. SVB igyvendino projektą „Poezijos pavasaris 2007 Rokiškyje“, Anykščių r. SVB - projektą „Poezijos pavasaris - 2007“, Akmenès r. SVB - „Tradicinė Poezijos rudens šventè viešojoje bibliotekoje“.

Igyvendinant projektus buvo numatytos kompleksinès priemonès. Atkreiptinas dėmesys $\mathfrak{i}$ Pasvalio bibliotekos projektinę veiklą. $2012 \mathrm{~m}$. biblioteka vykdè projektą „Festivalis Literatūros šèlsmas Vytauto Didžiojo aikštėje“ (rèmëjas - KRF). Pagrindiniai projekto tikslai - per pasirinktus ịvairių kartų ryškiausius kūrẻjus, ịvairiomis jų kūrybos pristatymo formomis (kūrybos skaitymai, pokalbiai, diskusijos, literatūrinès improvizacijos su teatralizuotais muzikiniais intarpais, parodos) atskleisti lietuvių literatūros istorinę raidą, plèsti bendrą kultūrinę savivoką, remiantis literatūra skatinti jaunąją kartą permąstyti XXI a. humaniškumo principus, palyginti juos su nuostatomis, vyravusiomis XX a., analizuoti tautiškumo idèją. Ambicingą projektą biblioteka vykdè $2014 \mathrm{~m}$. LKT finansavo projektą „Literatūros dienos ir naktys 2014: skaitymų mozaika“. Patraukia dèmesį projekto tikslo, uždavinių, priemonių apibūdinimas. Tikslas - skatinti skaitymą ir kūrybą kaip alternatyvią laisvalaikio praleidimo ir asmenybės kritinio mąstymo, kūrybiškumo, savęs pažinimo, kalbos ir žodyno lavinimo, socialinių ir moralinių nuostatų, emocijų, kitų su skaitymu susijusių îgūdžių ugdymo formą. Siekta gerinti skaitymo ir bibliotekos, kaip kultūrinès institucijos, prestižą, sudarant sąlygas skaitymo skatinimo veikloje bei renginiuose dalyvauti ịvairaus amžiaus, išsilavinimo, socialinès padèties bendruomenès nariams, taip mažinant socialinę atskirtị tarp miesto ir rajono gyventojų. Organizuoti literatūros skaitymai, knygų pristatymai, parodos, edukaciniai ir meno renginiai, susitikimai su rašytojais, menininkais. Pasitelktos vietos bendruomenès, seniūnijos, Pasvalio ir kitų rajonų literatų klubai, ugdymo, socialinès paramos įstaigos, kitos kultūros įstaigos, vietos verslininkai ir ùkininkai. Skaitymo skatinimo renginiuose buvo panaudotos šiuolaikinès modernios informacinès technologijos ${ }^{86}$.

Pažymėtina, kad vykdant projektus siekta atskleisti literatūros ir kitų meno formų dermę. Klaipèdos m. biblioteka 2009 m. vykde projektą „Literatūros skaitymai ir dainavimai“. Igyvendinant Prienų SVB 2012 m. projektą "Literatūros ir muzikos vakarų ciklas Išleidę mintị žodžio ieškoti“ surengti literatūros ir muzikos vakarai (abu projektus paremė KRF). Utenos biblioteka tais pačiais metais vykde projektą „Skaityti - save ir pasauli pažinti“ (rèmèjas - KM). Organizuoti literatūriniai-muzikiniai renginiai, monospekliai, dainuojamosios poezijos vakarai, teatralizuoti kūrinių skaitymai. Lietuvos kultūros taryba ir Kultūros ministerija parèmé Pasvalio bibliotekos projektą „Literatūros dienos ir naktys 2017: skaitymo prieskoniai“. Projektas numatė renginių ciklą, siejanti knygą ir kitų rūšių meną. Pasak projekto

Pasvalio SVB tinklalapis. Prieiga per internetą: http://www.psvb.lt/lt/projektai/igyvendinti/1277-testinis-projektas-literaturos-dienos-ir-naktys-2014-skaitymu-mozaika. Žiūrèta 2018-10-02. 
sumanytojų, muzika, teatras, vizualieji menai, dailè (prieskoniai) suteikia skaitymui naujo turinio, ịvairovès, atradimų bei skatina kūrybiškumą.

Projektais siekta aktyvinti visuomenès susidomejimą vietos literatais. Tokio pobūdžio projektus paprastai rèmè savivaldybès. Alytaus miesto savivaldybė $2014 \mathrm{~m}$. parèmè bibliotekos projektą „Alytietiškos istorijos. (Ne)šventųjų gyvenimai“, skirtą alytiškio kūrẻjo Kosto Poškaus literatūrinei ir meninei kūrybai išsaugoti ir populiarinti miesto bei šalies mastu. Savivaldybės ir literatų klubo „Lèvens balsai“ narių lèšomis ịgyvendintas Kupiškio r. bibliotekos projektas „Prošvaitės“. Išleista literatų klubo narių kūrybos rinktine $\dot{e}^{87}$. Krašto literatus ir jų kūrybą pristate Rokiškio r. bibliotekos projektas „Rokiškio krašto literatų kūrybos almanacho „Vaivorykštë“ leidyba“ (2016 m., rèmëja - SV). Projektas skirtas Rokiškio r. literatų klubo „Vaivorykštè" 30 -osioms ịkūrimo metinèms ir almanacho leidybai. Leidinys pasirodè tais pačiais metais ${ }^{88}$.

Atskira grupe sudaro projektai, tiesiogiai susije su skaitymo skatinimu. Didelè jų dalis skirta vaikams ir jaunimui. Krinta ị akis Panevėžio m. bibliotekos dèmesys skaitymui skatinti, $\mathfrak{i}$ tai ịsitraukè visos miesto bibliotekos. Nuo 2008 m. biblioteka vykdè tęstinị projektą „,Skaitymo skatinimas ir kultūros sklaida miesto bibliotekose“, kurị nuolat (tinklalapis fiksuoja galutinius metus - $2017 \mathrm{~m}$.) rèmé savivaldybè. Projekto tikslai - skatinti gyventojų norą skaityti, stiprinti skaitymo svarbos suvokimą, skatinti žinių troškimą, kūrybiškumą ir kritinị mąstymą.

Kelios bibliotekos vykdè projektus, skirtus šeimos vaidmeniui skatinant vaikų skaitymą. Kauno m. savivaldybė $2014 \mathrm{~m}$. parèmé bibliotekos projektą „Mano skaitanti šeima“. Organizuoti îvairūs renginiai, tarp jų: atidaryta vaikų ir tėvelių kūrybinių darbelių paroda „Mano skaitanti šeima“, surengtos komiksų kūrybinès dirbtuvès „Susikurk savo knygą“, teatralizuotas knygų paradas, knygų miestelis. Klaipėdos m. SVB drauge su Klaipèdos m. pedagogų švietimo ir kultūros centru 2016 m. vykdè projektą „Mano šeima skaitè, skaito ir skaitys" (rémejjos - LKT, KM). Projekto tikslas - patraukliais renginiais, skirtais šeimos nariams, ugdyti vaikų skaitymo ịgūdžius, didinti jų skaitymo motyvaciją. Lietuvos kultūros taryba parèmé Šiaulių m. bibliotekos ir Panevėžio m. filialo projektus. Šiaulių m. SVB vykdè projektą „Didelis mažųų skaitytojų pasaulis“. Buvo siekiama atkurti klubo „Skaitanti mama“veiklas ${ }^{89}$ ir skatinti jaunas šeimas neatitrūkti nuo skaitymo, kultūrinès, meninès ir visuomeninès veiklos. Panevėžio m. „Židinio“ filialas igyvendino projektą „Biblioteka - tavo šeimos narys“. Pasak projekto sumanytojų, jo tikslas - paskatinti šeimas aktyviau įsitraukti į skaitymo procesą, parodant skaitymą kaip vieną iš svarbiausių veiksnių, padedančių išauginti raštingą ir išsilavinusią jaunąją kartą.

Projektai, skirti biblioterapijai. 2015 m. biblioterapijai projektą „Inovatyvių terapijų taikymas ir sklaida bibliotekoje“ skyrè Birštono biblioteka, ji parèmè Lietuvos kultūros taryba, Kultūros ministerija ir savivaldybè. Surengta konferencija „Biblioterapija. Knyga gali prakalbinti ir gydyti $2^{\text {“90 }}$. Projektas igyvendintas bendradarbiaujant su Humanistinès egzistencinès psichologijos institutu, Všt „Tulpès“ sanatorija. Elektrènų SVB 2016 m. laimëjo Lietuvos kultūros tarybai teiktą projektą „Knyga - sielos namų vaistinë“. Bendruomenè supažindinta su biblioterapija ir jos galimybėmis. Viešojoje bibliotekoje ir 11 jos filialų eksponuota biblioterapiné literatūra, organizuotas renginių-praktinių užsièmimų ciklas „Biblioterapijos galimybès psichosocialiniams pokyčiams“ ir kt. 2017 m. biblioterapijos projektus vykdẻ Birštono, Marijampolès bibliotekos. Lietuvos kultūros taryba, Kultūros ministerija ir savivaldybẻ finansavo Birštono bibliotekos projektą „Universali biblioterapijos kalba“. Marijampolès biblioteka igyvendino savivaldybès finansuotą projektą „Knyga gali prakalbinti ir gydyti“. Projekto partneriai: Marijampolés savivaldybès visuomenès sveikatos biuras, Marijampolès savivaldybės neịgaliųjų draugija, Marijampolès „Sniego gniūžtès ${ }^{\text {" } 91}$ skyrius. Projektas skirtas paaugliams, jaunimui, senjorams, neigaliesiems.

\footnotetext{
Prošvaitès: Kupiškio rajono literatų klubo „Lèvens balsai“ "kūrybos almanachas. Panevėžys: Panevėžio sp., 2015.

Rokiškio krašto literatų kürybos almanachas „Vaivorykštė“. Utena: Utenos Indra, 2016.

Klubas ịsteigtas $2010 \mathrm{~m}$. rugsëjo mèn.

Pirma konferencija ịvyko $2013 \mathrm{~m}$. lapkričio $8 \mathrm{~d}$.

Programos „Sniego gniūžte்“ tikslas - parodyti jaunimui, kaip linksmintis be alkoholio, tabako ir kitų kvaišalų. Organizacijos „Sniego gniūžte“" programą kuria ir iggyvendina paaugliai savanoriai.
} 
Skaitymo projektai diferencijuojami pagal jų tikslines grupes. Marijampolès SVB $2016 \mathrm{~m}$. drauge su partneriais (Lietuvos krikščioniškojo jaunimo blaivybès sąungos „Žingsnis“ Marijampolès skyriumi, Marijampolès dramos teatro jaunimo studija „Nauja karta“, Marijampolès kolegija) vykdė LKT paremtą projektą „Skaitymo virusas Marijampoleje“. Buvo siekiama populiarinti ir skatinti ịvairaus amžiaus ir socialinių grupių gyventojų skaitymą, padidinti skaitomumo ir bibliotekos lankomumo rodiklius plètojant bendruomeniškumą ir socialinę sanglaudą. 2017 m. tarptautinès institucijos paramą laimèjo Kauno m. SVB. Biblioteka vykde tarptautini senjorų skaitymo skatinimo projektą „Jauskis geriau su knyga: skaitymas geresnei savijautai vyresniame amžiuje“, finansuotą „Nordplus Adult“ programos. Partneriai: Vilniaus m. SCB, Utenos SVB, Lidčiopingo m. biblioteka (Švedija), Ventspilio m. biblioteka (Latvija), Pernu m. biblioteka (Estija). Siekta padidinti visų projekte dalyvaujančių bibliotekų potencialą kuriant naujus senjorų tikslinio skaitymo ir biblioterapijos modelius, kurie juos įtrauktų i prasmingas rekreacinio skaitymo, mokymosi veiklas.

Projektai, skirti vaiku ir jaunimo skaitymui skatinti. Bibliotekų rūpestis - skatinti vaikų ir jaunimo skaitymą. 2007 m. skaitymui populiarinti, skaitymo igūdžiams ugdyti skirti Panevėžio m., Pasvalio, Visagino ir daugelio kitų bibliotekų projektai. Jie įvairūs tematika, skaitymo skatinimo renginių formomis. Panevėžio m. biblioteka vykdè tęstinị projektą „Vaikų knygos šventë“ (rèmëjos - KM, SV). Knygos šventès organizuotos vaikams ir jų tèveliams, jų programose - susitikimai su vaikų rašytojais, knygų pristatymai, leidyklų naujienų pristatymai, aktyviausių skaitytojų bei ịvairių kūrybinių konkursų laureatų apdovanojimai. Kultūros ministerija finansavo Pasvalio ir Visagino bibliotekų projektus. Pasvalio biblioteka vykdè projektą „Nekasdieniai pasimatymai“. Igyvendinant projektą organizuotas renginių ciklas jaunimui: susitikimai-diskusijos su rašytojais Egle Černiauskaite, Aiste Vilkaite, Pavelu Borkovskiu bei leidyklų „Alma littera“ ir „Versus aureus“ darbuotojais. Visagino biblioteka igyvendino projektą „Skaitymas veža!“. Vykdant projektą buvo sprendžiami uždaviniai: populiarinti skaitymą, ugdyti vaikų ir jaunimo skaitymo ịūdžius, stiprinti bibliotekos ir pedagogų bendradarbiavimą skaitymo skatinimo klausimais. Kiti Kultūros ministerijos paremti projektai:

Alytaus SVB vykdè projektą „Knygele, vesk mane į savo šalį“,

Šakių r. SVB - projektą "Skaitau - augu - tobuleju“,

Šiaulių r. SVB - projektą „Pasibelsk ị knygos širdị“,

Tauragès r. SVB Dacijonų f. - projektą „Skaitymas - tai kelias ị pažinimą“,

Vilniaus m. SCB Tomo Zano f. - projektą „Vaiko draugystė su knyga“,

Vilniaus m. SCB Kalvarijų f. - projektą „Skatinam skaitymą - per garsą ir vaizdą prie žodžio“,

Vilniaus m. SCB Antakalnio f. - projektą „Kiekvieną knygą reikia moketi skaityti“.

Projektus taip pat finansavo Kultūros ir sporto rèmimo fondas, pavyzdžiui, fondas parėmé Šiaulių m. SVB projektą „Su knyga ị pasaulį“.

Vaikų ir jaunimo skaitymo skatinimo projektus rèmè savivaldybės: Šakių r. SVB vykdè savivaldybès finansuotą projektą „Vaikų skaitymo kultūros ugdymas“, Prienų SVB - projektą „Literatūrinis ugdymas viešojoje bibliotekoje“, Alytaus r. SVB - projektą „Skaitau - kuriu - mąstau“.

Dėmesio ypač sulauke pasakos populiarinimas. Kultūros ministerija parėmė Kupiškio r. SVB projektą „Atversk pasakos lapus ir raidelès pabus“. Itvyko susitikimas su dailininke, vaikiškų knygelių autore Sigute Ach, surengtas pamokèlių ciklas „Kelionė po didžiųjų pasaulio pasakininkų knygas“, viktorinos, teminès spaudinių ir vaikų piešinių parodos. Populiarinamos švedų rašytojos Astridos Lindgren pasakos. Kultūros ministerija parèmė Ukmergès r. SVB, Vilniaus m. SCB „Saulutė“ filialo, savivaldybès finansavo Kretingos r. SVB Vydmantų filialo, Klaipèdos r. SVB Dauparų filialo projektus, skirtus A. Lindgren kūrybai.

Paminètini Panevěžio m., Kelmès r., Kupiškio r., Radviliškio r., Alytaus bibliotekų projektai, numatę ìvairias vaikų ir jaunimo skaitymo skatinimo formas. Panevėžio $\mathrm{m}$. SVB nuosekliai rūpinosi vaikų skaitymu. 2008 m. „Židinio“ filialas vykdè projektą „Imink žodžio paslaptị“ (rėmëja - KM). Siekta skatinti pradinių klasių mokinių kūrybinį ir kritinį mąstymą, kalbos tobulinimą. Išleistas vaikų kūrybos laikraštukas 
„Minčių laivas“. 2010 m. miesto biblioteka vykdè du projektus. Projektu „Šiuolaikiniai rašytojai vaikams“ siekta skatinti mokinių motyvaciją skaityti, didinti skaitymo prestižą organizuojant knygų skaitymą Panevèžio miesto mokyklose. İ projektą įsitraukè 14 miesto mokyklų, organizuoti 4 kūrybiniai konkursai. Tais pačiais metais buvo vykdomas projektas „Mamos ir tèčio vaikystès knyga“. I projektą įsitraukè 16 miesto mokyklų, organizuoti 4 kūrybiniai konkursai. $2012 \mathrm{~m}$. „Židinio“ biblioteka vykdè projektą „Su „Šlepete“ per debesis“. İvyko 13 renginių: 3 išvykos, 1 kūrybinis užsièmimas, 2 filmų peržiūros, 7 šventès. Bibliotekoje veikiantis „Šlepetės“ klubas ${ }^{92}$ pasipildè naujais nariais (šių projektų rèmèjas - KRF). Be to, buvo vykdomi tęstiniai projektai „Vaikų knygos švente““ (rèmėjos - KM, SV) „Vaikų vasaros užimtumas“ (rèmëja - SV). Kelmès r. biblioteka 2008 metais igyvendino projektą „Pažintis su lietuvių autorių kūryba vaikams“, 2009-2012 m. kasmet vykdè projektus „Lietuvių autoriai vaikams“ (rèmèjas - KRF). Vyko susitikimai su vaikų rašytojais ir jų herojais, buvo pristatomos knygos vaikams.

Kupiškio r. biblioteka 2008 m. vykdè projektą „Raganų išmintis - knygose“ (rèmèja - KM). Buvo sukomplektuotos dvi knygų skrynelès „Raganos rekomenduoja“, jų teatralizuoti pristatymai vyko 12 kaimo bibliotekų ir mokyklų. Organizuoti moksleivių kūrybiniai konkursai ir parodos. $2012 \mathrm{~m}$. biblioteka vykdè projektą „Atverk nepakartojamą knygų pasaulị“ (rèmėjai - KRF, SV, Kupiškio „Rotary“ klubas). Projektas turejjo tikslą kelti skaitymo prestižą panaudojant animacijos galimybes. Projekto léšomis Noriūnų, Subačiaus, Skapiškio, Rudilių, Antašavos padaliniuose ir Alizavos pagrindinèje mokykloje buvo ¡kurti skaitymo ir filmų peržiūrų kampeliai ${ }^{93}$. Radviliškio r. biblioteka 2008 m. vykdè projektą „Atidarius pasakų skrynią“ (rėmejja - KM). Buvo organizuotas pasakorių konkursas. Konkurse dalyvavo beveik 60 ivvairių švietimo įstaigų ugdytinių ${ }^{94}$. Alytaus biblioteka $2010 \mathrm{~m}$. vykdė projektą „Kas pasakè, kad skaityti - nuobodu ir... nemadinga?!!“ (rèmëjai - KRF, SV), 2011 m. - projektą „Pažink lietuvišką pasaką - tai linksma!“ (rèmejja - SV). Vykdant projektus surengtos teatralizuotos literatūrinès popietès, vaikų darbų parodos-konkursai, organizuoti susitikimai su vaikų literatūros kūrejju Vytautu Račicku.

Jaunimui ir vaikams sudaromos sąlygos kūrybinei saviraiškai. Atkreiptinas dèmesys ị Telšių r. SVB ir Prienų SVB iniciatyvas. Vykdant tuometinès Švietimo ir mokslo ministerijos $2007 \mathrm{~m}$. paremtą projektą „Lietuvių literatūra - jaunimui vertybë“ biblioteka organizavo jaunimo literatūrinių kūrinių konkursą „Septintoji kalva“. Literatūrinių kūrinių konkurse dalyvavo jaunimas iš Plungès, Rietavo, Mažeikų ir Telšių miestų. Konkursas tapo tradicija ${ }^{95}$. Prienų biblioteka vykdè tęstini projektą „Prienų krašto vyturiai“. Kartu su projekto partneriais Prienų „Žiburio“ gimnazija, Prienų „Ažžuolo“ pagrindine mokykla, Prienų rajono savivaldybès administracijos Švietimo skyriumi, Prienų rajono švietimo centru rengti mokinių kūrybos konkursai „Prienų krašto vyturiai“, „Kuriame pasaką“, „Tikrai yra kalba, kur žodis pasitinka ir palydi“ (Justinas Marcinkevičius). Geriausi konkurso darbai patenka ị bibliotekos leidžiamą mokinių kūrybos almanachą „Prienų kašto vyturiai“. Kiekvienais metais jaunųjų kūrybos almanachą palydėdavo literatūros kritikų ar rašytojų recenzija su geranoriškais ir dalykiškais patarimais. 2009 metais surengtas konkursas „Prienų krašto vyturiai 2009“. Jame dalyvavo per 120 rajono moksleivių. Prizininkų ir laureatų kūriniai įtraukti ị aštuntąjị Prienų krašto moksleivių kūrybos almanachą. Išleista 400 egzempliorių „Prienų krašto vyturių ${ }^{\text {“96. }}$. Knygos recenziją parašè vaikų literatūros kritikas, žurnalo „Rubinaitis“ redaktorius doc. dr. Kęstutis Urba. Projektą parėmė KRF ir Kauno apskrities viršininko administracija.

Plètèsi temų ir darbo metodų spektras. Klaipèdos m. biblioteka 2014 m. vykdè projektą , Moksliukai madingi: mokslinès literatūros bumas" (rèmèja - LKT). Projekto tikslas - patraukliais renginiais aktyvinti mokslo populiarinimo literatūros skaitymą, pasitelkiant ne tik knygas, bet ir naująsias technologijas,

Klubas pradèjo veiklą $2006 \mathrm{~m}$. Veikia Buratino pasakų kambaryje.

Išsirinkę labiausiai patikusią knygą ar geriausią knygos ekranizaciją ir apsisprendę, ar labiau patiko knyga, ar kino filmas, vaikai kartu su mokytojomis, bibliotekininkèmis, kultūros darbuotojomis surengè literatūrinį teismą.

Žr. Pakštiené, N. Jaunujų pasakorių konkursas (Radviliškis). Tarp knygų, 2008, gruodis, p. 31.

5 Bibliotekos tinklalapyje paskelbti nuostatai „Jaunimo literatūrinių kūrinių konkursas Septintoji kalva 2018 m.“ Žiūrèta 2018-11-18.

Prienų krašto vyturiai, kn. 8. Alytus: Alytaus sp., 2009. 
ir kelti skaitymo prestižą. Vykdant projektą buvo sudarytos galimybės pabendrauti su mokslininkais bei iš arti apžiūrèti robotus ir palydovą. Lapkričio 24 d. ịvyko susitikimas „Imam kosmosą?" su pirmojo lietuviško palydovo „Lituanica SAT-1“ kūrèju Laurynu Mačiuliu. Savivaldybė parèmė Alytaus bibliotekos projektą „Aš jau perskaičiau. O tu?“ Vykdant projektą organizuoti mokymai, kurių dalyviai gilinosi ị literatūros skaitymo potyrius ir mokėsi kompiuterinès grafikos meno pagrindų. Panaudojant kompiuterinę grafiką vaikai įamžino perskaitytos knygos i̇spūdžius. Iš padarytų darbų buvo suformuota keliaujanti paroda.

BMGF ir KM [BP 2] skyré finansavimą Šiaulių m. bibliotekos projektui „Komiksų erdvè bibliotekoje“. Irengta komiksų centro erdvė Šiaulių m. SVB „Saulès“ filiale bei 3 mobilios komiksų skaityklos bibliotekos „Šaltinèlio“, Lieporių ir Rèkyvos filialuose. Bibliotekos populiarino komiksų žanrą kaip priemonę, padedančią nagrinèti visuomenès problemas, kokybiškai leisti laisvalaikị. Pradètos organizuoti teminès komiksų kūrimo edukacines veiklos. Anykščių r. biblioteka 2017 m. vykdė projektą „Knygos anatomija: knygos vaikams" (rèmèja - LKT). Panaudojant inovatyvias, šiuolaikinėmis technologijomis grịstas priemones skleista informacija apie knygą, jos vertę, surengta knygos anatomijos plakatų paroda. Savivaldybẻ parèmé Elektrẻnų bibliotekos projektą „Skaitymas su šunimi“.

Bibliotekos vykdè biblioterapijos projektus, skirtus vaikams ir jaunimui; Naujosios Vilnios bibliote$\mathrm{ka}$ - biblioterapijos projektus, skirtus romų tautybės vaikams ir jaunimui. $2014 \mathrm{~m}$. ji vykdè projektą „Biblioterapija kaip skaitymo skatinimo priemonè romų tautybės vaikams ir jaunimui“'. Skaitymo skatinimo užsièmimuose buvo nagrinèjamos grožinès literatūros kūrinių, aktualių tikslinei grupei, ištraukos. Kitais metais biblioteka vykde projektą „Skaitymo skatinimo teatralizuotos biblioterapijos programa romų vaikams ir jaunimui“ (abiejų projektų rèmèja - LKT). Panaudojant edukacinę teatralizuotos formos biblioterapijos programą siekta ugdyti Romų visuomenès centro Vilniuje lankytojų - vaikų ir jaunimo skaitymo igūdžius, pozityvias vertybines gyvenimo nuostatas. Taip pat paminètinas Kauno r. bibliotekos projektas „Biblioterapija: atrask save“ $(2015 \mathrm{~m}$., rèmejjai - LKT, KM). Projekte dalyvavo vaikai ir paaugliai iš Garliavos, Domeikavos, Babtų, Vilkijos. Psichologė Gražina Sapiegienė konsultavo Garliavos vaikų dienos centro vaikus. Vaikai dalyvavo tapybos ant vandens pamokose, kurias vedè Všt „Meno terapijos ir socializacijos instituto VYTA“ („Veidas Yra Tavo Atspindys“) atstovas Donatas Končius. Knygų skaitymo patirtimi dalijosi rašytoja Lina Žutautė, leidèja Jurga Baltrukonytė, buriuotojas, „Tūkstantmečio odisèjos“ dalyvis Paulius Kovas, verslininkas Mindaugas Paleckaitis ${ }^{97}$.

Krinta ị akis, kad daug dèmesio šiai problemai skiriama Vilniaus m. SCB ir jos Naujosios Vilnios filiale. Vilniaus m. SVB èmèsi ṫgyvendinti BGMF ir KM [BP 2] paremtą projektą „Mes Knygų s@loje“. Projektas turejjo daug partnerių: Mykolo Romerio universitetas, Vilniaus miesto Antakalnio vaikų socialinès globos namai, Vaikų ir jaunimo dienos centras „Mūsų nameliai“ ir kt. Pagrindinis projekto tikslas - per interneto erdveje sukurtą biblioterapinį žaidimą, bendraujant nuotoliniu būdu, spręsti socialinès rizikos vaikų ir jaunimo psichosocialines problemas, stiprinti jų psichinę sveikatą. $2017 \mathrm{~m}$. Vilniaus m. SCB Naujosios Vilnios, Antakalnio ir Karoliniškių filialų projektas „Atvirumo s@la bibliotekoje“ (rèmëja - KM) pratęsė projekto „Mes Knygų s@loje“ veiklas, pritaikè e. biblioterapinị žaidimą socialineje rizikoje esantiems vaikams ir suaugusiems jų šeimų nariams. Naujosios Vilnios biblioteka vykdè projektą „Atvirumo s@la vaikui ir šeimai“, kurị parėmè savivaldybė. Sèkmingai ìvykdžius projektus „Mes Knygų s@loje“ „Atvirumo s@la bibliotekoje“ biblioteka nutarè išplèsti jų veiklas. Projektas - inovatyvi, neturinti analogų Lietuvoje, virtuali psichikos sveikatos stiprinimo paslauga - interneto erdvèje sukurta pokalbių svetainè su žaidimo elementais taikant biblioterapijos metodą sudaro galimybę spręsti socialiai pažeidžiamų vaikų ir paauglių, vaikų ir jaunimo dienos centro „Mūsų nameliai“ lankytojų bei kitų Naujosios Vilnios švietimo ir ugdymo institucijų auklètinių ir jų tėvų ar globejjų psichosocialines problemas.

Žr. Pakalnytė, N. Biblioterapija Garliavos bibliotekoje (Kaunas). Tarp knygų, 2016, kovas, p. 34. 
Projektus vaikams ir jaunimui, turinčiam specialiųjų poreikių, $2017 \mathrm{~m}$. vykdė Klaipėdos m. SVB, Vilniaus $\mathrm{m}$. SCB ir jos Naujosios Vilnios biblioteka. Klaipèdos m. biblioteka vykdè projektą „Sulèkime skaityti ì gūžtas“ (rèmėjos - LKT, KM, SV, leidyklos UAB „Presa“, UAB „Nieko rimto“, UAB „Lutute“). Drauge su partneriais (Klaipėdos m. pedagogų švietimo ir kultūros centras ir kt.) siekta patraukliais renginiais, žaidimais ir edukacija ugdyti girdinčiųjų, silpnai girdinčiųjų ir kurčiųjų vaikų skaitymo ịgūdžius, didinti skaitymo motyvaciją ir tarpusavio bendravimą ${ }^{98}$. Vilniaus $\mathrm{m}$. SCB igyvendino savivaldybės finansuotą projektą „Literatūros lobių s@loje“. Projektas skirtas vaikams ir jaunuoliams, esantiems socialinèje atskirtyje, turintiems emocinių ir mokymosi sunkumų. Vilniaus m. SCB Naujosios Vilnios filialas vykdè projektą „Pažinimo legenda: programa romų vaikams ir jaunimui“ (rèmejja - SV). Pasak projekto sumanytojų, organizuoti ịvairių šalių legendų skaitymai labai artimi romų bendruomenei, kurioje daug metų iš lūpų i lūpas buvo perduodama tik žodinè informacija. Igyvendinant projektą romų vaikai ir jaunimas susipažino su skirtingų tautų kultūromis, papročiais ir gyvenimo būdu.

\subsubsection{Edukacijos projektai}

Kita svarbi bibliotekų veiklos sritis - edukacijos projektų vykdymas. 9 ir 10 lentelèse pateikiami duomenys apie Šiaulių apskr. ir Telšių apskr. bibliotekų 2007, 2013, 2015-2017 metais vykdytus 2 ir daugiau projektų 99 .

9 lentelè. Šiaulių apskr. bibliotekų (7) edukacijos projektų vykdymas 2007, 2013, 2015-2017 metais (skliaustuose - bibliotekų skaičius apskrityje, vykdytų projektų skaičius, rèmėjų tipas: $\operatorname{Tr}$ - tarptautinis rèmèjas, $\mathrm{Nr}$ - nacionalinis rèmejjas, $\mathrm{Vr}$ - vietos rèmëjas)

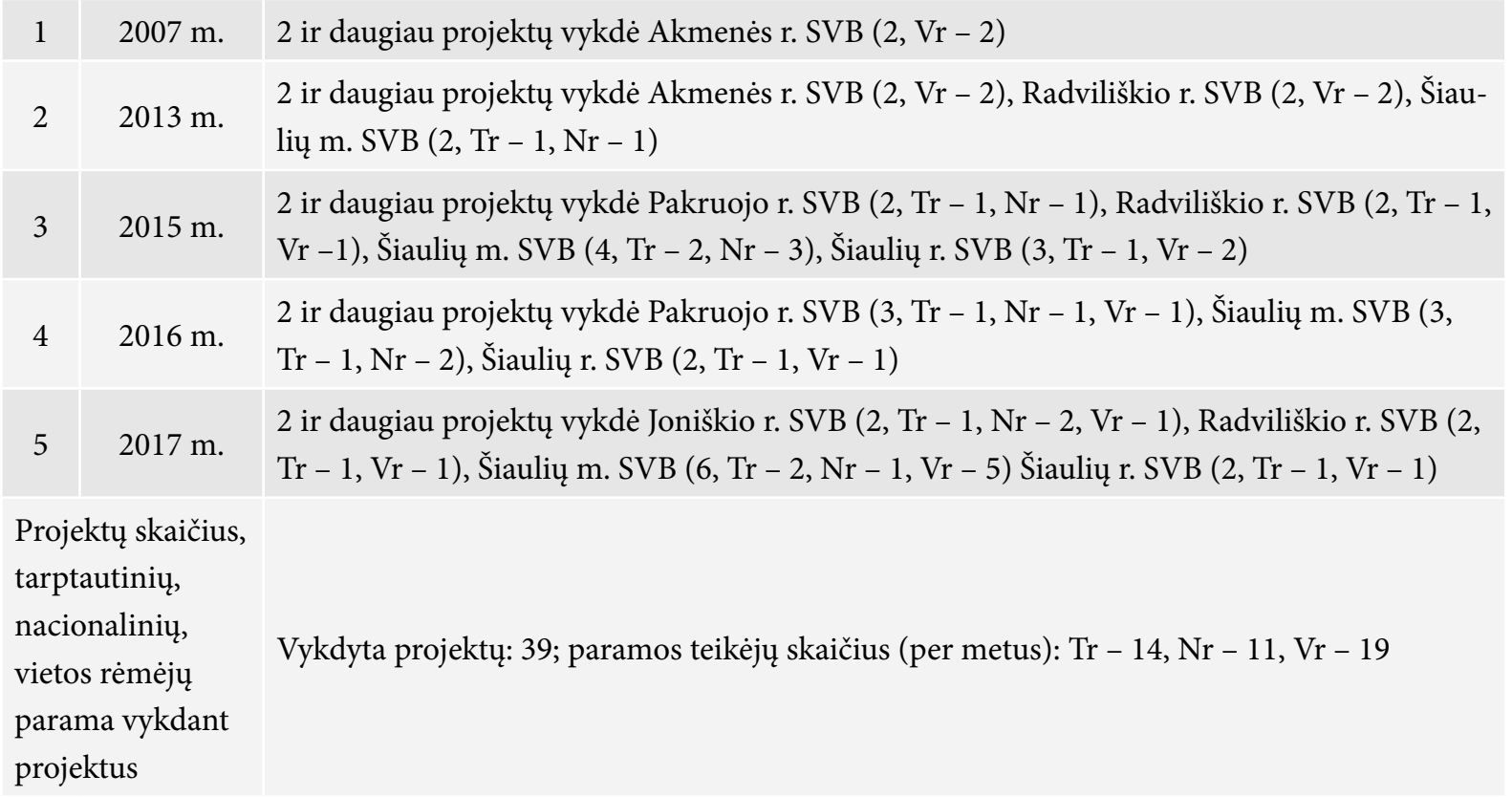

2 ir daugiau projektų skirtingais metais vykdè 6 bibliotekos. Pažymètinas Šiaulių m. SVB dèmesys edukacijos projektams: 2013, 2015-2017 metais vykdyta net 15 projektų. Nors vyravo vietos rèméjų parama, nemažai projektų finansavo ir tarptautiniai rèmejjai.

Vaikai buvo buriami į mažus knygų skaitymo klubus („gūžtas“).

99 Kitaip nei 7 ir 8 lentelèse, nenurodomos bibliotekos, kurios nevykdè projektų (lentelèse pateikiami tik bendro pobūdžio edukacijos projektai, kituose poskyriuose edukacijos projektai bus diferencijuojami pagal tematiką, aiškès jų visuminis vaizdas). 
10 lentele. Telšių apskr. bibliotekų (4) edukacijos projektų vykdymas 2007, 2013, 2015-2017 metais

\begin{tabular}{|c|c|c|}
\hline 1 & $2007 \mathrm{~m}$. & $\begin{array}{l}2 \text { ir daugiau projektų vykdè Mažeikių r. SVB }(2, \mathrm{Nr}-1, \mathrm{Vr}-2) \text {, Telšių r. SVB }(2, \mathrm{Nr}-1 \text {, } \\
\mathrm{Vr}-2)\end{array}$ \\
\hline 2 & $2013 \mathrm{~m}$ & 2 ir daugiau projektų vykdė Plungès $\mathrm{r}$ SVB $(2, \mathrm{Tr}-1, \mathrm{Vr}-1)$ \\
\hline 3 & $2015 \mathrm{~m}$. & $\begin{array}{l}2 \text { ir daugiau projektų vykdè Mažeikių r. SVB }(3, \operatorname{Tr}-1, \mathrm{Nr}-1, \mathrm{Vr}-1) \text {, Plungès } \mathrm{r} \text {. SVB (3, } \\
\operatorname{Tr}-1, \mathrm{Vr}-2) \text {, Telšių r. SVB }(3, \mathrm{Tr}-1, \mathrm{Nr}-1, \mathrm{Vr}-2)\end{array}$ \\
\hline 4 & $2016 \mathrm{~m}$. & 2 ir daugiau projektų vykdè Telšių r. SVB $(2, \mathrm{Tr}-1, \mathrm{Nr}-1, \mathrm{Vr}-2)$ \\
\hline 5 & $2017 \mathrm{~m}$. & $\begin{array}{l}2 \text { ir daugiau projektų vykdè Mažeikių r. SVB }(2, \mathrm{Nr}-1, \mathrm{Vr}-1) \text {, Plungès r. SVB (5, } \mathrm{Tr}-1 \text {, } \\
\mathrm{Nr}-2, \mathrm{Vr}-3)\end{array}$ \\
\hline \multicolumn{2}{|c|}{$\begin{array}{l}\text { Projektų skaičius, } \\
\text { tarptautinių, } \\
\text { nacionalinių, } \\
\text { vietos rèmejuc } \\
\text { parama vykdant } \\
\text { projektus }\end{array}$} & Vykdyta projektų: 24; paramos teikèjų skaičius (per metus): $\mathrm{Tr}-6, \mathrm{Nr}-8, \mathrm{Vr}-16$ \\
\hline
\end{tabular}

2 ir daugiau projektų skirtingais metais vykdè 3 bibliotekos. Pažymètini Plungès r. SVB pasiekimai: 2013, 2015-2017 metais vykdyta 10 projektų. Vyravo vietos rèmejjų parama.

Kitose apskrityse gerų rezultatų vykdant bendro pobūdžio edukacijos projektus pasiekè Kauno $\mathrm{r}$. SVB, Kauno m. SVB (Kauno apskr.), Šilutės r. SVB, Klaipėdos m. SVB (Klaipėdos apskr.), Pasvalio SVB, Panevėžio r. SVB, Rokiškio r. SVB, Kupiškio r. SVB (Panevėžio apskr.), Elektrènų SVB, Trakų r. SVB, Vilniaus m. SCB (Vilniaus apskr.), Alytaus SVB, Lazdijų r. SVB (Alytaus apskr.).

Vykdant edukacijos projektus buvo siekiama parodyti bibliotekos vaidmenį ir reikšmę visuomenès ir individo gyvenime. Pasvalio bibliotekos $2007 \mathrm{~m}$. projektas „Knyga, biblioteka, žmogus istorijoje ir šiandienoje“ (rèmëjas - KSRF) numatė renginių ciklą. Siekta remiantis šalies ir pasaulio šalių patirtimi per knygos, bibliotekos ir žmogaus sąsajas apžvelgti kultūros procesą praeityje ir dabar, apibrěžti bibliotekos vietą šalies kultūros istorijos kontekste. Tẻveliams projektą skyrẻ Šiaulių m. biblioteka. Kultūros ministerija paremė bibliotekos projektą „Biblioteka ir vaiko ugdymas“. Šiai temai taip pat skirti savivaldybių finansuoti projektai: Akmenès r. SVB projektas „Bibliotekos - informacijos ir kultūros skleidejjos“, Alytaus r. SVB Makniūnų filialo projektas „Biblioteka - informacijos ir saviraiškos centras“ ir kai kurie kiti.

Kitoms kultūroms pažinti buvo naudingas Panevėžio r. SVB drauge su Panevėžio apskrities nevyriausybinių organizacijų informacijos centru $2007 \mathrm{~m}$. vykdytas projektas „Palikime savo pédsakus“ (rèmèja - ES programa „Veiklus jaunimas“). Jị realizuojant ị rajono bibliotekų veiklą ịsitraukè pirmi savanoriai: Maurizióas Melito’as iš Italijos, Annika Schaefer iš Vokietijos ir Gokhanas Gulbas iš Turkijos. Rajono bendruomenei jie pristatė savo šalis, kultūrą, surengè teatralizuotus vaidinimus.

Sparčiai daugejo projektų, skirtų informacijai apie ES skleisti. Jie skirti Europos dienai, finansuoti EKAL. 2011-ieji Europos Parlamento iniciatyva paskelbti Europos savanoriškos veiklos metais, todèl šventiniuose renginiuose būta daug savanorystès akcentų. Pasvalio biblioteka tais metais vykdè projektą „Aš galiu. Tu gali. Mes galime“. Improvizuotame savanorystès informacijos centre pasvaliečiai galejjo susipažinti su išsamia informacija apie savanorystę, susirasti organizacijų, plètojančių savanorišką veiklą ir kt. Europos Komisija 2013-uosius paskelbẻ Europos piliečiu metais. Projektų tematikos centre - ES piliečių teisių ir laisvių teikiamos galimybès. Kalvarijos biblioteka ịgyvendino projektą „Tavo teisès. Būk informuotas“. „Facebooko“ profilyje buvo surengtas konkursas „Būk informuotas: pilietinès ir politinès teisès“, taip pat vyko konferencija „Būk informuotas: ekonominès ir socialinès teisès“, orientacinis žaidimas jaunimui „Judèjimo laisvë“, renginys vaikams „Būk informuotas: kultūrinès teisès“, baigiamasis Europos dienos renginys. 
Projektas „Bibliotekos pažangai 2“ atvėre galimybes vykdyti edukacijos projektus, sudarančius galimybę keisti bibliotekini aptarnavimą siejant ji su moderniomis technologijomis. Klaipèdos r. SVB biblioteka vykdè projektą „Bibliotekos be sienų“. İsigyta kilnojamosios studijos įranga ir technika, reikalinga renginiams transliuoti į filialus. Igyvendinę projektą, rajono gyventojai igijo galimybę bibliotekos filialuose tiesiogiai stebėti centrinėje bibliotekoje vyksiančius renginius, interaktyviai dalyvauti užduodant klausimus ir pan. Lazdijų r. SVB kartu su Kauno technologijos universitetu vykde projektą „Intelektinè ir pramoginè biblioteka“. Projekto tikslas - išplèsti ir ị aukštesnị kokybès lygị pakelti Druskininkų, Lazdijų, Alytaus savivaldybių teritorijose viešųjų bibliotekų vykdomą gyventojų technologinio ir skaitmeninio raštingumo mokymą bei sukurti naujas veiklas. Lazdijų viešojoje bibliotekoje ir Seirijų, Kapčiamiesčio, Šeštokų, Šventežerio, Krosnos, Veisiejų padaliniuose, Druskininkų ir Alytaus bibliotekose organizuoti praktiniai nuotoliniai programavimo mokymai, vyko susitikimai su rašytojais, literatais ir kt. Telšiu r. SVB vykdè projektą „Moki žodị - randi kelią: mokymosi visą gyvenimą nauda praktiškai, užsienio kalbų mokymasis“. Projekto tikslas - skatinti gebejjimus bendrauti užsienio kalba panaudojant moderniausias kalboms mokyti skirtas technologijas. Projektas sudarè galimybes įsigyti kalbų mokymosi programinę įrangą ir įsteigti naują paslaugą viešojoje bibliotekoje, t. y. gyventojus kviesti mokytis kalbų (anglų, vokiečių, rusų, prancūzų, švedų, ispanų) savarankiškai.

2017 m. Šiaulių m., Rokiškio r. bibliotekos vykdė ES fondų paremtus projektus. Projektai skirti inovatyvioms paslaugoms kurti. Europos regioninès plètros fondas (drauge su savivaldybe) parèmé Šiaulių m. bibliotekos projektą „Inovatyvių bibliotekos sprendimų skirtingoms kartoms plètra pasienio regione“ (2017-2019 m.). Partnerès: Jelgavos m. biblioteka, Liepojos centrinė mokslinè biblioteka (Latvija). Siekta gerinti bibliotekų efektyvumą ir darbuotojų gebėjimus kokybiškai aptarnauti skirtingų kartų lankytojus atsižvelgiant $\mathfrak{i}$ individualius jų poreikius, paskatinti vyresnio amžiaus žmonių integraciją i visuomenę ir, pasitelkiant interaktyvias priemones ir edukacinius žaidimus, užtikrinti tikslingą ir produktyvų vaikų ir jaunimo susidomejjimą asmeniniu tobulèjimu. $2017 \mathrm{~m}$. bibliotekoje ịkurtas Užsienio kalbų mokymosi centras (su galimybe savarankiškai mokytis 7 kalbų) ir interaktyvi šeimų erdvė. Vykdant projektą skatintas naujas požiūris ị skirtingų kartų bibliotekos lankytojus ir jų tarpusavio ryšius: parengtos skirtingoms kartoms telkti programos „Mokytis vieniems iš kitų“ ir „Šeimos bendrauja ir mokosi“. Europos regioninès plètros fondas taip pat finansavo Rokiškio r. bibliotekos projektą „Verslo paramos sistemos kūrimas ir prieinamumas Žiemgaloje, Kuržemëje ir Šiaurès Lietuvoje“ (2017-2019 m.). Projekto partneriai: Všt̨ Žiemgalès planavimo regionas, Všt Kuržemès planavimo regionas, Latvijos kaimo verslo konsultavimo ir mokymų centras, Aizkrauklès savivaldybė (Latvija), Šiaulių verslo inkubatorius, Panevėžio verslo konsultacinis centras. Projekto idèja - verslumo skatinimas, paslaugų verslui plètros didinimas ir verslo paramos organizacijų bendradarbiavimo plètra. Vykdydama projektą $2017 \mathrm{~m}$. biblioteka ịkūrè bibliotekos, nevyriausybinių organizacijų ir smulkiojo verslo atstovų klasterị „Versli biblioteka“, Vaikų ir jaunimo skyriaus patalpose pradejo veikti moderni verslo klasè.

Projektai, skirti biblioteku lankytojų kompetencijoms ugdyti ìvairiose kultūros srityse. Pasvalio bibliotekos $2007 \mathrm{~m}$. vykdyto projekto „Studija Kultūros užuoveja“ turinị sudarè literatūros ir meno studijos (rèmejja - KM). Jų esmé - įvairiomis tarpusavyje suderintomis formomis (seminarai, diskusijos, rašytojų kūrybos skaitymai) gerinti žmonių kultūrines kompetencijas. I tautinių mažumų edukaciją atkreipe dėmesị Vilniaus m. SCB Naujosios Vilnios filialas, vykdęs pilietinio ugdymo projektą-programą „Būk savas matomas pilietis“ (rèmëja - SV). Siekta ugdyti pagarbą įvairių tautų kultūroms, tradicijoms, papročiams. Tautinių bendrijų kultūrai pažinti skirtas Vilniaus m. SCB Tomo Zano filialo $2012 \mathrm{~m}$. vykdytas projektas „Bendraukime, pažinkime ir keiskimès“ (rèmèja - SV). Projekto partneriai: Všt Tautinių bendrijų namai, vaikų ir jaunimo klubas „Kregždutë“. Itvyko šie renginiai: bibliotekoje - Vilniaus Pranciškaus Skorynos vidurinès mokyklos moksleivių tapybos ir keramikos darbų parodos atidarymas, susitikimas su Lietuvoje gyvenančiais gruzinais, Tautinių bendrijų namuose - renginys „Kuo mes panašūs ir kuo skiriamès?" 
Kurti naujas edukacines paslaugas ir produktus skatino Lietuvos kultūros tarybos finansuoti projektai. LKT 2015 m. parèmė tris Šiaulių m. bibliotekos ir jos filialo projektus. Biblioteka vykdè projektą "Atradus biblioteką - gyventi patogiau“. Panaudojant šiuolaikines interaktyvias galimybes sukurtas inovatyvus produktas - interaktyvus pažintinis virtualus bibliotekos turas www.smsvb.lt/virtualus-3d-turas, kuris suteikia galimybę atskleisti bibliotekos ir jos filialų funkcionavimo principus, naudojamas technologijas, lankytojų informavimą ir kitas teikiamas bibliotekos paslaugas. Virtualus bibliotekos turas sukurtas bendradarbiaujant su Všt „3D Vilnius“. Kitas bibliotekos vykdytas projektas „Privatus ir viešas asmuo. Jų ribos ir galimybès medijose“. Projekto dalyviai supažindinti su pavojais, susijusiais su asmens duomenų platinimu, ugdyti jų gebejjimai apsaugoti savo privatumą viešojoje erdvejje. Šiaulių m. SVB Lieporių filialas igyvendino projektą „Visuomeninè mokykla bibliotekoje“. Igyvendinant projektą buvo mokomasi esperanto kalbos gramatikos, skaitomas projekto metu prenumeruojamas žurnalas „Monato ${ }^{\prime 100}$. Besimokantieji dalyvavo Lietuvos katalikų esperantininkų suvažiavime Žagareje. LKT taip pat finansavo Klaipėdos m. SVB Girulių ir Pempininkų filialų projektą. Filialai vykdė projektą „Biblioteka, burianti šeimą“. Projekto tikslas - prisidèti prie šeimų susvetimèjimo problemos sprendimo ị renginius kviečiant visą šeimą. Igyvendinant projektą vyko lietuviškų biografinių knygų pristatymai. Buvo mokoma šeimos istorijai kurti ir išsaugoti naudingų dalykų: skaitmeninti šeimos archyvinius dokumentus, sudaryti genealoginius medžius ir kt. Pempininkų filiale visai šeimai organizuoti stalo žaidimai, šeimos buvo pakviestos í psichologès Andromedos Kurbatovienès paskaitą apie bendravimą šeimoje, Dalios Klumbienès paskaitą „Kaip auklèti vaikus iki 10 metų“. Girulių filiale igyvendinta programa „Pẻdink i Girulius" (spektaklis, koncertas šeimoms ir kt.).

Edukaciniai projektai skirti ịvairioms gyventojų grupėms. Užtikrinti senjorams galimybes šviestis, mokytis ir bendrauti sieke Šiaulių m. SVB, 2013 m. vykdžiusi KM finansuotą projektą „Senjorų klubas bibliotekoje - mokymosi visą gyvenimą erdvë“. Centrinejje bibliotekoje ir „Saulès“ filiale buvo ịkurti senjorų užimtumo klubai, kuriuose pradètos teikti biblioterapijos, menų terapijos, stalo žaidimų, susitikimų su rašytojais, kompiuterinio raštingumo mokymų paslaugos senjorams. Klaipėdos m. SVB 2016 m. projektas „Kultūros edukacija pajūryje vaikams ir suaugusiems“ (rèmèjos - LKT, KM, SV) turëjo tikslą sudaryti sąlygas Klaipedos pajūrio gyvenviečių skirtingo amžiaus gyventojams ir pajūryje poilsiaujantiems svečiams dalyvauti kultūrinėje-edukacinèje veikloje. Šilutès r. SVB, Šiaulių m. SVB, Vilniaus m. SCB projektus 2016 m. parèmé LKT. Šilutės r. SVB vykdytas projektas „Prabylančios mūzos \& inovatyvūs žiniadieniai“ buvo skirtas vyresnio amžiaus bei socialinės atskirties žmonėms ir turëjo tikslą sujungti profesionaliosios kūrybos sklaidą rajone su bibliotekos teikiamomis inovatyviomis paslaugomis. Šiaulių m. biblioteka toliau orientavosi ị senjorų poreikius: skatinti pagyvenusių žmonių dalyvavimą kultūrinèje veikloje turejo tikslą bibliotekos projektas „Aktyvus ir kultūringas senjoras bibliotekoje“. Vilniaus m. SCB Naujosios Vilnios filialas vykde projektą „Mokèti kalbą - pažinti Lietuvą“. Igyvendinta suaugusiujju kitataučių valstybinès kalbos mokymosi programa.

Vykdant projektus skatinami bibliotekos ir bendruomenès ryšiai. Lietuvos kultūros taryba parèmè Mažeikių r. bibliotekos projektą „B. A. B. 2017“ (Biblioteka arčiau bendruomenès - bendruomenè arčiau bibliotekos). Projekto tikslas - skatinti skirtingų institucijų bendradarbiavimą priartinant prie bibliotekos vykdomos visuomenès švietimo ir kultūrinès veiklos atskiras bendruomenių grupes. Lietuvos kultūros taryba ir Kultūros ministerija finansavo Pasvalio bibliotekos projektą „Biblioteka ir bendruomenè: istorijų tiltai“. Organizuoti renginiai sudarẻ galimybes bendruomenès nariams gilinti žinias apie kultūros procesą, valstybės ir krašto istoriją, motyvuoti juos kūrybinei saviraiškai. Lietuvos kultūros taryba ir savivaldybė parėmé Šiaulių m. bibliotekos projektą „24/3: spalvotos laisvės dienos“. Igyvendinant projektą 24 dienas nuo Vasario 16-osios iki Kovo 11-osios buvo siekiama skatinti šiauliečius dalyvauti kultūriniame gyvenime, bendradarbiauti kartas, ugdyti patriotiškumą.

100 „Monato“ (liet. mènuo) - mėnesinis žurnalas, leidžiamas esperanto kalba. 
Naujos tematikos projektus vykdė Šilutės r. ir Zarasų r. bibliotekos. Šilutès r. biblioteka projektą skyrė Vydūnui. Kultūros ministerija ir savivaldybè finansavo bibliotekos projektą „Tarptautinis ekslibrisų konkursas „Ex Libris. Vilhelmui Storostai Vydūnui - 150“. Projekto partneriai: Lietuvos dailininkų sąjunga, Lietuvos ekslibrisininkų klubas, Vydūno draugija ir kt. Siekta naujai ịvertinti ir interpretuoti Lietuvos kultūrai bei istorijai nusipelniusio rašytojo, filosofo Vilhelmo Storostos (Vydūno) gyvenimą ir kūrybinị palikimą, aktualizuoti ir ịprasminti jo filosofines bei humanistines mintis profesionalioje kultūroje surengiant tarptautinį ekslibrisų konkursą. Originalų Zarasų r. bibliotekos projektą „Istoriniai literatūriniai personažai Zarasų viešosios bibliotekos languose“ (2017-2018 m.) finansavo Lietuvos kultūros taryba ir Kultūros ministerija. Projektas skirtas Lietuvos valstybès atkūrimo šimtmečiui. Šventinių renginių ciklas numate performansą ${ }^{101}$ : priešais biblioteką buvo sukurta „gyvoji“ Lietuva: aukurų ugnis, žmonès ir simboliai, Lietuvos vèliavos spalvų rankų miškas ir paukščiai.

Atskira grupe sudare projektai, skirti meno edukacijai. 2007 m. Kultūros ministerija finansavo Marijampolès bibliotekos projektą „Muziką reikia atrasti“ (pradètas vykdyti 2006 m.). Alytaus biblioteka 2009 m. vykdè projektą „Miniformų pasjansas J. Kunčino bibliotekoje“ (rèmëjai - KM, KRF). Vykdant projektą surengta trijų dienų ekslibrisų miniartelè, du konkursai, dailès miniatiūrų paroda, pranešimai trumpųjų literatūros žanrų bei mažujų vizualaus meno formų temomis, literatūrinių ir muzikinių miniatiūrų vakaras, vizualiųjų menų vakaras, performansas.

Meno edukacijos projektus parèmė savivaldybės: $2007 \mathrm{~m}$. Plungès $\mathrm{r}$. biblioteka vykdè projektą „Poezijos, muzikos ir kino vakarai Plungeje“" Šilutės r. SVB Juknaičių ir Pašyšių filialai - projektą „Menas ir mes“, Kretingos r. SVB Salantų filialas - projektą „Romansų ir dainuojamosios poezijos renginys Nuskaidrinantys bütị palaiminga šviesa“. $2008 \mathrm{~m}$. Alytaus biblioteka drauge su bibliotekoje veikiančiu salonu „Baltos varnos“ vykde projektą „Tarp dangaus ir širdies: vaizduojamojo meno, poezijos ir muzikos derme““.

Pagerbtas mūsų genialus tèvynainis. 2011 m. Druskininkų biblioteka kartu su Poezijos ir menų mègèjų asociacija „Branduma“ minint M. K. Čiurlionio 100-ąsias mirties metines vykdė projektą „Kaip nuostabu būti reikalingam žmonèms ir jausti šviesą savo delnuose" (rèmèja - SV). Biblioteka organizavo renginių ciklą „Vainikas M. K. Čiurlioniui“. Buvo pristatyta spaudinių paroda „Čiurlionis ir Druskininkai“.

Projektai, skirti fotomenui, skulptūrai, architektūrai. Kultūros rèmimo fondas $2013 \mathrm{~m}$. finansavo Kupiškio r. bibliotekos projektą „Kupiškio krašto fotometraštininko Juozo Kraujūno fotografijų fondo formavimas ir sklaida“. Jis skirtas fotomenininko perduotam bibliotekai fotografiju archyvo fondui tvarkyti, sisteminti ir skleisti. Parengtos parodos, kurios eksponuotos centrineje bibliotekoje, Rudilių, Subačiaus bibliotekose, Kauno „Saulès“ gimnazijoje, Noriūnų bendruomenès patalpose, Kupiškio rajono savivaldybëje. Surengtas jaunųjų fotomenininkų konkursas „Mano žvilgsnis ị Kupiškį “102. 2015 m. Kupiškio r. biblioteka vykdė projektą „Skulptoriaus Juozo Kèdainio kūryba šiandienos žvilgsniu“ (rèmëja - LKT). Jo tikslas - J. Kèdainio kūrybinio palikimo aktualizavimas ir sklaida paminint skulptoriaus 100-ąsias gimimo metines, didinant profesionalaus meno ir kultūros prieinamumą įvairioms amžiaus ir socialinèms gyventojų grupėms. Savivaldybė parėmė Joniškio r. bibliotekos projektą „Moderniosios architektūros apraiškos Joniškyje 1918-1940 m." (2013 m.). Projektas ịgyvendintas drauge su Joniškio A. Raudonikio meno mokyklos Dailès skyriaus moksleiviais. Surengta konferencija, eksponuotos parodos.

Dėmesio sulaukè menų terapija. 2013 m. savivaldybė parèmė Birštono bibliotekos projektą „Menų terapija Birštono savivaldybės gyventojams“ (partnerè - Všı sanatorija „Tulpë“). Biblioteka organizavo seminarą „Meno terapija“, šokio terapijos seminarą „Streso mažinimas šokio terapijos pagalba“. Surengta konferencija. Pranešimus skaitė gydytoja psichiatrè, poezijos terapeutė Jūratė Sučylaitė, Klaipėdos

101 Apšviestuose bibliotekos languose pasirodè istorinès asmenybès: Antanas Smetona (aktorius Ugnius Meškas), Aleksandras Stulginskis (aktorius Justinas Talutis), Kazys Grinius (aktorius Alanas Šablinskas), Vincas Kudirka (aktorius Dovydas Kavaliauskas) ir kiti. Iš bibliotekos balkono Lietuvos nepriklausomybès aktą skaitė aktorius Gediminas Storpirštis, jis vaidino lietuvių visuomenès veikèją, Nepriklausomybès Akto signatarą Joną Basanavičių.

102 Plačiau žr. Pipyniené, J. Kraštiečiui skirtas projektas (Kupiškis). Tarp knygu, 2013, spalis, p. 35-36. 
universiteto Komunikacijos katedros doc. dr. Daiva Janavičienè ir kiti pranešẻjai. Praktinius užsiėmimus vedè lietuviškosios psichoterapijos kūrèjas, nusipelnęs gydytojas Aleksandras Alekseičikas ir J. Sučylaitè.

Daugiau dèmesio sulaukè kino menas. Pasvalio biblioteka $2011 \mathrm{~m}$. vykdė projektą „Knygos kino dienos Pasvalio krašte“ (rèmëjas - KRF). Buvo pristatyti filmai, sukurti pagal lietuvių autorių knygas. Kauno r. biblioteka 2014-2015 m. vykdè projektą „Lietuvių kino vakarai netradicinèje erdvejje“ (rèmëja LKT). Lietuviško dokumentinio kino pristatymai vyko centrinèje bibliotekoje ir Kačerginèje, Liučiūnuose, Babtuose. LKT parèmé Utenos bibliotekų projektą „Pažintis su lietuvišku kinu bibliotekoje“ (2015 m., rèmejja - LKT). Projekto tikslas buvo sudominti lankytojus lietuvišku vaidybiniu ir dokumentiniu kinu, supažindinti su kino kūrèjais, jų darbais, kino meno aktualijomis.

BMGF, KM [BP 2] ir SV parèmé Trakų r. bibliotekos projektą „Migruojantis kinas“. Kartu su projekto partneriais (Trakų kultūros rūmai, Trakų istorijos muziejus ir kt.) organizuoti teminiai filmų pristatymai, filmų peržiūros, susitikimai su kino kūrẻjais. Edukaciniai kino vakarai ir užsiėmimai vyko netradicinėse (dažniausiai lauko, rajono miestelių ir kaimų) erdvèse. Pažintis su kino menu buvo tęsiama $2017 \mathrm{~m}$. Lietuvos kultūros taryba parėmė Biržų r., Pasvalio bibliotekų projektus. Biržų r. biblioteka iggyvendino projektą „Sniego ilgesys“, skirtą kraštiečio pasaulinio garso avangardo kino kūrèjo Jono Meko 95-osioms metinèms ${ }^{103}$. J. Meko gyvenimą ir kūrybą pristatė profesionalūs menininkai, Biržų krašto kultūrininkai. Pasvalio biblioteka vykde projektą „Kino dienos Pasvalio krašte 2017: lietuviško kino atradimai“. Pasvalio krašto gyventojams buvo suteikta galimybe pamatyti vaidybinius ir dokumentinius lietuviškus kino filmus, apdovanotus kasmetiniu Lietuvos kino ir televizijos kino prizu „Sidabrinė gervë“, bei susitikti su jų kūrèjais.

Grupe projektų skirta sveikai gyvensenai ugdyti. Tokio pobūdžio projektus 2007 m. vykdè Mažeikių r. SVB filialas, Panevėžio r. SVB, Rokiškio r. SVB, Akmenės r. SVB. Apžvelgsime Mažeikių r. SVB Ventos filialo projektą „Dvasinè sveikata - fizinès sveikatos pagrindas“, kurị parèmé KSRF ir SV. Projekto tikslas teikti šviečiamąją informaciją apie fizinès ir dvasinès sveikatos stiprinimo priemones, skatinti žmones gyventi sveikai, didinti sveikos gyvensenos motyvacijos efektyvumą, populiarinti knygų skaitymą kaip vieną iš dvasinio tobulèjimo būdų. Parengti teminiai aplankai „Sveika siela - sveikas kūnas“, „Sportas ir sveikata“, „Netradicinè medicina“ ir kt. Organizuota popietė „Gyvenkime sveikai“, joje paskaitą skaitė Lietuvos sveikuolių sąjungos generalinis sekretorius Eligijus Valskis. Radviliškio r. biblioteka gebëjo rasti tarptautinị rèmèją. Švedijos Buroso miesto labdaros ir paramos organizaciją "Stiftelsen Vitryssland“ 2012 m. parèmè bibliotekos sveikos gyvensenos projektą „Nuo čiobrelio lig avietès“.

Bibliotekų demesys gyventojų sveikatingumo ugdymui sustiprejo LR Seimui 2013-uosius paskelbus Sveikatingumo metais. Ypač tai pasakytina apie Panevėžio m. ir Panevėžio r. bibliotekų vykdytus projektus. Savivaldybė paremė Panevėžio m. bibliotekos projektus „3 žingsniai sveikatos link“, „Pakeliui $\mathfrak{i}$ vaistinę - užsuk ị biblioteką". Vaikų sveikatingumu rūpinosi Panevėžio r. bibliotekos. Savivaldybè parèmė Panevėžio r. centrinès bibliotekos projektą „Kuriu ir sveikai gyvenu“, Raguvos filialo projektą „Vaikų sveikata - tai fizinè, dvasine, socialinè gerovéc.

Iš projektų, skirtų gyventojų sveikatingumui palaikyti 2015 m., krinta ị akis BMGF ir KM [BP 2] laimètas Šakių r. bibliotekos projektas „Šiuolaikinès technologijos - bendruomenès sveikatai“. Panaudojant idiegtas šiuolaikines informacines technologijas, taikant „Biofeedback“ (BFB - biologinio grįžtamojo ryšio) metodą ${ }^{104}$ siekta prisidèti prie projekto dalyvių dvasinès ir psichinès gerovès, jų pažintinių gebèjimų ugdymo ir treniravimo. Paminètinas $2016 \mathrm{~m}$. savivaldybès paremtas Marijampolès bibliotekos projektas „Menas gyventi - menas būti sveikam“. Vykdant projektą siekta taikyti psichinès sveikatos stiprinimo prevencijos priemones. Surengtas edukacinis užsièmimas „Mandala ${ }^{105}$ - tai kelionè į save“.

Jonas Mekas gimė 1922 m. Semeniškių k., dab. Biržų rajone.

104 Biofeedback (angl. k. - biologinis grižtamasis ryšys) - metodas, kai žmogus išmoksta kontroliuoti tas savo organizmo fiziologines reakcijas, kurios paprastai laikomos nevalingomis arba sunkiai valdomomis (pavyzdžiui, širdies ritmas, raumenų ịtampa, galvos smegenų aktyvumas).

105 Mandala (sanskrito k. - ratas) yra apskritimo arba kvadrato formos geometrinè kompozicija, simboliškai vaizduojanti tam tikrą dvasinę, kosminę arba psichologinę tvarką. Mandala yra pagalbinè priemonė meditacijos praktikoje. 
Isidemėtinas Kauno r. SVB bibliotekos dalyvavimas $2017 \mathrm{~m}$. Elektronikos platintojų asociacijos projekte. Bendradarbiaujant su LNB rajono bibliotekoje vykdytas asociacijos organizuotas projektas „Atsakingas skaitytojas“. Biblioteka kvietė bibliotekos lankytojus dalyvauti elektronikos atliekų rinkimo akcijoje ir nebenaudojamus elektronikos prietaisus (virdulius, telefonus, barzdaskutes, baterijas) atnešti i biblioteką. Per 3 mėnesius viešosios bibliotekos lankytojai atsikratė $800 \mathrm{~kg}$ elektronikos atliekų. Rajono bibliotekos lankytojai buvo aktyviausi ir surinko didžiausią elektronikos atliekų kiekị iš visų šalies bibliotekų, dalyvaujančiu projekte ${ }^{106}$.

Vaikams ir jaunimui skirti edukacijos projektai paženklinti temu įvairove. 2007 m. savivaldybės finansavo Kèdainių r. bibliotekos projektą „Prisijaukinkime muziką“, Alytaus r. SVB Vankiškių filialo projektą „Menas - tai veržimasis i gèrị“, Panevėžio r. bibliotekos projektą "Jaunieji mokslininkai“ ir Linkaučių filialo projektą „Menas būti savimi“. Projektai skirti renginiams organizuoti.

Originalios darbo su vaikais formos buvo numatytos Klaipėdos $\mathrm{m}$. bibliotekos projekte, skirtame kalbos kultūrai. Savivaldybė parėmé projektą „Išsišluokime kalbos „šiukšles“. Siekta atkreipti vaikų dèmesị i gimtosios kalbos išsaugojimo būtinybę, puoselèti kalbą, aktyvinti knygų skaitymą. Igyvendinant akciją „Balandis - švarios kalbos mėnuo“ bibliotekos padaliniuose ir 17-oje miesto švietimo ir ugdymo istaigų i specialias urnas buvo renkamos kalbos „šiukšlès“, organizuojamos viktorinos pagal surinktus nevartotinus kalbos pavyzdžius ${ }^{107}$. Išleistas lietuvių kalbos šiukšlių žodynèlis, kuriame vaikai surinko apie 240 nevartotinų žodžių ir posakių bei jų lietuviškų atitikmenų. Elektroninè žodynèlio versija paskelbta internete.

Atkreiptas dèmesys ị ekologinį ugdymą. Tauragès r. biblioteka $2007 \mathrm{~m}$. vykdė EKAL paremtą projektą „Drauge“ (partneris - Tauragès apskr. „Europe Direct“ informacinis centras). Per teatralizuotas edukacines pamokèles vaikams lèlių teatro „Batuotas katinas" ${ }^{\text {“108 }}$ lèlès pasakojo apie gamtos saugojimą, klimato kaitą, raudonają knygą. Veikè knygų ekologine tema „Saugokime gamtą“ paroda. Projektas pristatytas Tauragès rajone vasarą vykusios respublikinès skautų stovyklos dalyviams, Pagramančio pagrindinès mokyklos vaikams, Tauragès miesto mokyklų pradinukams. 2013 m. savivaldybė finansavo Panevėžio r. SVB Piniavos filialo projektą „Tausokime ir puoselèkime mus supančią aplinką“ bei Paliūniškio filialo projektą „Aš ir mane supantis pasaulis“. Pirmas projektas numate aplinkinių vietovių aplinkos tvarkymą, vykdant antrą projektą siekta vaikams suteikti žinių apie aplinkos tausojimą ir sveikatos saugojimą.

Vykdant projektą BP 2 padaugejjo jaunimui skirtų edukacijos projektų, paremtų modernių technologijų taikymu. Igyvendinant projektus ugdytos kompetencijos IT, inžinerijos, elektronikos, robotikos srityje, teiktos įvairios kitos mokymo, laisvalaikio, užimtumo paslaugos. Atkreiptinas demesys ị itin turiningus Šilutės r., Kauno m., Kauno r., Šiaulių r. bibliotekų projektus, kuriuos parėmė BMGF ir KM [BP 2]. Šilutès r. SVB vykdè projektą „Bendruomenès „HUB’as“ bibliotekoje „Atrask savo saviraiškos kodą“. Organizuoti ịvairūs saviraiškos užsièmimai (saviraiškos kodai): 1) kūrybiškumo (mokyta dirbti ịvairiomis dailès technikomis ir priemonèmis, vaidinti su personažais-lèlèmis, žaisti, draugauti, bendrauti), 2) elektronikos (supažindinama su elektronikos pagrindais, mokoma jas pritaikyti praktiškai), 3) žinių (kompiuterinio raštingumo mokymai pradedantiesiems ir pažengusiems, užsienio kalbų mokymai, žinių lygos, turnyrai, viktorinos), 4) modeliavimo (3D skeneriu ir spausdintuvu), 5) multimedijos (interaktyvios integruotos pamokos panaudojant interaktyvųji ekraną su integruotų pamokų paketu). Kauno m. biblioteka vykdè projektą „Atrask save 3D mieste“, skirtą Kauno ir Klaipédos moksleiviams. Vykdant projektą Kauno ir Klaipėdos bibliotekose ịkurtos laboratorijos, kuriose 14-19 metų jaunuoliai kūrè miesto 3D maketą, mokèsi inovacijų vadybos pagrindų, aplankẻ verslo, informacinių ir komunikacinių technologijų ịmones. Projektas pelnè tarptautini pripažinimą, taip pat tarptautinès organizacijos

106 Plačiau žr. Vasauskaité, R. Projekto „Atsakingas skaitytojas“ nugalètojai (Kaunas). Tarp knygư, 2017, spalis, p. 37.

107 Per baigiamąją šventę, skirtą Spaudos atgavimo, kalbos ir knygos dienai, kalbos „šiukšlès“ buvo viešai sudegintos Danès upès krantineje.

108 Bibliotekos lèlių teatras ịkurtas $1991 \mathrm{~m}$. 
EIFL apdovanojimą už modernias paslaugas, gerinančias gyvenimo kokybę $e^{109}$. Kauno r. biblioteka su grupe partnerių igyvendino projektą „Moksleivių bendrųjų kompetencijų ugdymas Kauno rajono bibliotekose ir mokyklose panaudojant informacines technologijas“. Pagrindinis projekto tikslas - ugdyti Kauno rajono moksleivių kūrybines, iniciatyvumo ir technologines kompetencijas, taikant IT priemones bei sudarant sąlygas kokybiškam integruotam formaliam ir neformaliam ugdymui. Vykdant projektą buvo tobulinami moksleiviu gebejimai papildomo ugdymo srityse (robotika, informatika, matematika, fizika). Ugdant meninius gebejjimus naudotos vaizdo technologijų programos (integruojama ị mokyklinius dailès, dizaino ir muzikos dalykus) ir planšetiniai kompiuteriai (kuriant animacijas, videofilmus, supažindinant su tinklaraščių kūrimu ir kompiuterine leidyba, muzikos kūrimo principais). Šiaulių r. biblioteka vykdė projektą „Verslo ir amatų akademija“. Projekto tikslas - sudaryti sąlygas jaunimui, norinčiam pradèti savo verslą. Šešiuose bibliotekos filialuose įrengtos modernios erdvès - mažieji biurai mokytis ir verslumui skatinti. Jose organizuoti teoriniai ir praktiniai seminarai. Projektas turëjo daug partnerių - tai Šiaulių rajono savivaldybès Etninès kultūros ir tradicinių amatų centras, Šiaulių rajono Kuršėnų kūrybos namai, Šiaulių teritorinės darbo biržos Jaunimo darbo centras ir kt.

BMGF ir KM [BP 2] taip pat finansavo:

Alytaus bibliotekos - projektą „Išmanioji biblioteka jaunimui“,

Birštono SVB - projektą „Interaktyvi biblioteka - erdve kūrybai ir atradimams“,

Kaišiadorių r. SVB - projektą „Robotikos mokykla bibliotekoje“,

Kretingos r. SVB - projektą „Edukacinis kūrybinių medijų centras bibliotekoje“.

LKT parėmė Ignalinos r. SVB projektą „Inovatyvių technologijų ir kūrybiškumo taikymas populiarinant bibliotekos paslaugas jaunimui“. Moksleiviai ir mokytojai supažindinti su „Geocaching “110 žaidimu.

İsidèmètinas Klaipėdos $\mathrm{m}$. bibliotekos $2015 \mathrm{~m}$. projektas, smarkiai atliepiantis nūdienos realijas. LKT ir KM finansavo bibliotekos projektą „Kibernetiniai karai“. Projekto tikslas - patraukliomis jaunimui veiklomis ugdyti gebejjimus kritiškai vertinti bei analizuoti žiniasklaidos informaciją, siekti atpažinti tikrą žiniasklaidos pranešimų esmę, taip motyvuojant jaunimą aktyviau dalyvauti pilietiniame gyvenime. Vyko susitikimai ir paskaitos apie informacinius karus. Paskaitas aktualiomis temomis skaite politologas dr. Laurynas Kasčiūnas (informaciniai ir kibernetiniai karai, Rusijos vykdomas informacinis karas prieš Ukrainą, propagandinè informacija, su kuria susiduria lietuviai), Kauno technologijos universiteto doc. dr. Saulius Japertas (interneto saugumas, naudojamos techninès priemonés informacijai skleisti, ją pakeisti).

Kupiškio r., Klaipėdos m., Elektrėnų bibliotekos 2016 m. projektus skyrė naujoms edukacinėms paslaugoms kurti. ES investicijų veiksmų programos „Neformaliojo vaikų švietimo paslaugų plètra“ lěšomis finansuotos Kupiškio r. bibliotekos programos „Šeštadieninė mokyklèlè 7-9 metų amžiaus vaikams“ ir „Eko dirbtuvèlès“ (projektus administravo Lietuvos mokinių neformaliojo švietimo centras). Pirmos programos tikslas - per menines veiklas atskleisti vaiko gebėjimus, skatinti vaikų užimtumą, mažinti socialinę atskirtį, padèti lengviau adaptuotis mokykloje. Šeštadieniais buvo organizuojami edukaciniai užsiemimai įvairiomis temomis: kompiuterinio raštingumo, rankdarbių, dailès ir kt. „Eko dirbtuvèlès" vyko Skapiškio padalinyje. Jų tikslas - skatinti jaunimo ir vaikų atsakingą požiūrị i gamtos išteklių saugojimą, ugdyti ekologinị sąmoningumą ir draugišką aplinkai elgesị. Kultūros ministerija parèmė Klaipėdos m. SVB projektą „Kitokia realybė bibliotekoje“. Kaip projekto partneriai dalyvavo keturios SVB: Neringos, Kretingos r., Palangos, Klaipėdos r. Siekta papildyti bibliotekoje ịkurtą edukacinę naujų galimybių erdvę novatoriškais, kūrybiškumą ugdančiais ir motyvaciją didinančiais technologiniais sprendimais, ugdyti

109 Plačiau žr. Gavėnė, R. Projektas „Atrask save 3D mieste“ pelnè tarptautinį apdovanojimą (Kaunas). Tarp knygų, 2016, liepa-rugpjūtis, p. 36-37.

110 Geocaching - angliškas žaidimo pavadinimas, kilęs iš tarptautinio žodžio geo (žymi sąsają su Žeme, geografija) ir angliško žodžio cache - slèptuvé. Žaidimas susijęs su geografija ir judejjimu Žemès paviršiumi - pésčiomis, dviračiu, automobiliu, ir slèptuvių ieškojimu. 
profesinę motyvaciją. Jaunimas buvo mokomas dirbti su papildytosios realybès kūrimo programomis, dalyvavo dronų (skraidyklių) praktiniuose mokymuose ir kt. Igytas žinias jaunimas pritaikè Klaipèdos m. bibliotekos interneto svetainei „Klaipèdos miesto nekilnojamosios kultūros vertybès“ papildyti ir naudojimui patobulinti. Elektrènų biblioteka vykdè projektą „Tëvynès meilès ir grožio keliu“ (rèmèja - SV). Siekta padeti vaikams geriau pažinti gimtąją šali, gimtąji miestą ir savo šaknis, ugdyti tautinị ir pilietinị sąmoningumą, mokyti tolerancijos kitos tautybės, kito tikejjimo, kitos rasès žmonėms.

Pažymetinos Lazdijų r., Rokiškio r., Naujosios Vilnios bibliotekų 2017 m. iniciatyvos. Lietuvos ir Lenkijos jaunimo mainų fondas parèmé Lazdijų r. bibliotekos projektą „Kūrybinès verslo industrijos jauniems“. Projekto tikslas - skatinti Lietuvos ir Lenkijos jaunimo tarpkultūrinị bendravimą. Surengta stovykla, kurioje jaunuoliai dalyvavo protų mūšiuose, pokalbiuose istorijos, politikos ir verslo temomis, susitiko su ịvairiose srityse dirbančiais Lazdijų krašto verslininkais, susipažino su Lenkijos ir Lietuvos politika verslumo skatinimo sferoje. Rokiškio r. biblioteka projektą skyrè Lietuvių kalbos kultūros metams (LR Seimas 2017-uosius paskelbè Lietuvių kalbos kultūros metais). Lietuvos kultūros taryba ir savivaldybė finansavo bibliotekos projektą „Lietuvos kodas - lietuvių kalba“. Vykdant projektą siekta atskleisti lietuvių kalbos, kaip tautos kultūrinès tapatybès, reikšmingumą. Pristatyti lietuvių kalbos puoselètojai, kalbininkai. Savivaldybė parėmė Naujosios Vilnios bibliotekos projektą „Kūrybinis anglų kalbos mokymasis“. Vaikų ir jaunimo dienos centro „Mūsų nameliai“ lankytojams surengti interaktyvūs meniniai ir terapiniai žaidimai, skatinantys mokytis anglų kalbos.

\subsubsection{Kürybinès meninès veiklos skatinimo projektai}

Dabarties laikotarpiu ypatingą reikšmę turi gyventojų kūrybiškumo skatinimas. 11 lentelèje pateikiama informacija apie kūrybinès meninès veiklos skatinimo 2007, 2013, 2015-2017 metais vykdytus projektus.

11 lentele. Kūrybinès meninès veiklos skatinimo projektų vykdymas 2007, 2013, 2015-2017 metais (skliaustuose - bibliotekų skaičius apskrityse, vykdytų projektų skaičius, rèmëjų tipas: $\mathrm{Tr}$ - tarptautinis rèmëjas, $\mathrm{Nr}$ - nacionalinis rèmèjas, $\mathrm{Vr}$ - vietos rèmèjas)

\begin{tabular}{|c|c|c|c|c|c|c|c|}
\hline & Metai & $\begin{array}{c}\text { Kauno } \\
\text { apskr. (8), } \\
\text { Marijampo- } \\
\text { lès apskr. (5) }\end{array}$ & $\begin{array}{l}\text { Klaipėdos } \\
\text { apskr. (7), } \\
\text { Tauragès } \\
\text { apskr. (4) }\end{array}$ & $\begin{array}{l}\text { Panevèžio } \\
\text { apskr. (6), } \\
\text { Utenos } \\
\text { apskr. (6) }\end{array}$ & $\begin{array}{c}\text { Šiaulių } \\
\text { apskr. (7), } \\
\text { Telšių } \\
\text { apskr. (4) }\end{array}$ & $\begin{array}{l}\text { Vilniaus } \\
\text { apskr. (8), } \\
\text { Alytaus } \\
\text { apskr. (5) }\end{array}$ & 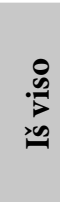 \\
\hline 1 & $2007 \mathrm{~m}$ & $\begin{array}{l}\text { Jonavos r. } \\
\text { SVB (1, } \\
\mathrm{Nr}-1)\end{array}$ & $\begin{array}{l}\text { Klaipèdos r. } \\
\text { SVB }(1, \mathrm{Vr}-1) \text {, } \\
\text { Kretingos r. } \\
\text { SVB }(2, \mathrm{Vr}-2) \text {, } \\
\text { Šilutès } \mathrm{r} . \mathrm{SVB} \\
(1, \mathrm{Nr}-1)\end{array}$ & $\begin{array}{l}\text { Panevėžio m. } \\
\text { SVB }(4, \mathrm{Vr}-4), \\
\text { Rokiškio r. SVB } \\
(1, \mathrm{Vr}-1), \\
\text { Anykščių r. } \\
\text { SVB }(1, \mathrm{Vr}-1)\end{array}$ & $\begin{array}{l}\text { Joniškio r. SVB } \\
(1, \mathrm{Nr}-1), \mathrm{Pa}- \\
\text { kruojo r. SVB (1, } \\
\mathrm{Nr}-1) \text {, } \\
\text { Plungès r. SVB } \\
(1, \mathrm{Nr}-1)\end{array}$ & $\begin{array}{l}\text { Traku r. SVB } \\
(1, \mathrm{Nr}-1), \text { Vil- } \\
\text { niaus m. SCB } \\
(2, \mathrm{Vr}-2) \text {, } \\
\text { Alytaus r. SVB } \\
(1, \mathrm{Vr}-1)\end{array}$ & 18 \\
\hline 2 & $2013 \mathrm{~m}$ & & $\begin{array}{l}\text { Kretingos r. } \\
\text { SVB }(2, \mathrm{Vr}-2) \text {, } \\
\text { Tauragès r. SVB } \\
(1, \mathrm{Vr}-1)\end{array}$ & $\begin{array}{l}\text { Kupiškio r. } \\
\text { SVB }(4, \mathrm{Nr}-2 \text {, } \\
\text { Vr - 4), Pane- } \\
\text { vėžio m. SVB } \\
(3, \mathrm{Nr}-3), \\
\text { Panevezžio r. } \\
\text { SVB (2, Vr - 2), } \\
\text { Rokiškio r. SVB } \\
(2, \mathrm{Vr}-2),\end{array}$ & $\begin{array}{l}\text { Radviliškio r. } \\
\operatorname{SVB}(1, \operatorname{Tr}-1)\end{array}$ & $\begin{array}{l}\text { Trakų r. SVB } \\
(1, \mathrm{Nr}-1), \text { Vil- } \\
\text { niaus m. SCB } \\
(1, \text { nenurody- } \\
\text { ta }-1)\end{array}$ & 20 \\
\hline
\end{tabular}




\begin{tabular}{|c|c|c|c|c|c|c|c|}
\hline & Metai & $\begin{array}{c}\text { Kauno } \\
\text { apskr. (8), } \\
\text { Marijampo- } \\
\text { lès apskr. (5) }\end{array}$ & $\begin{array}{l}\text { Klaipėdos } \\
\text { apskr. (7), } \\
\text { Tauragės } \\
\text { apskr. (4) }\end{array}$ & $\begin{array}{l}\text { Panevėžio } \\
\text { apskr. (6), } \\
\text { Utenos } \\
\text { apskr. (6) }\end{array}$ & $\begin{array}{c}\text { Šiaulių } \\
\text { apskr. (7), } \\
\text { Telšių } \\
\text { apskr. (4) }\end{array}$ & $\begin{array}{c}\text { Vilniaus } \\
\text { apskr. (8), } \\
\text { Alytaus } \\
\text { apskr. (5) }\end{array}$ & $\begin{array}{l}0 \\
\stackrel{\infty}{>} \\
: \infty \\
: \infty\end{array}$ \\
\hline & & & & $\begin{array}{l}\text { Anykščių r. } \\
\text { SVB (1, } \\
\text { nenurody- } \\
\text { ta -1), Igna- } \\
\text { linos r. SVB } \\
(1, \mathrm{Nr}-1) \text {, } \\
\text { Zarasų r. SVB } \\
(1, \mathrm{Nr}-1)\end{array}$ & & & \\
\hline 3 & $2015 \mathrm{~m}$ & $\begin{array}{l}\text { Kaišiado- } \\
\text { rių r. SVB } \\
(1, \mathrm{Tr}-1, \\
\mathrm{Nr}-1), \\
\text { Vilkaviškio r. } \\
\text { SVB }(1, \text { nenu- } \\
\text { rodyta - } 1)\end{array}$ & $\begin{array}{l}\text { Klaipėdos m. } \\
\text { SVB }(1, \mathrm{Nr}-2) \text {, } \\
\text { Klaipėdos r. } \\
\text { SVB }(3, \mathrm{Tr}-1 \text {, } \\
\mathrm{Nr}-1, \mathrm{Vr}-2) \text {, } \\
\text { Kretingos r. } \\
\text { SVB (1, Vr - 1), } \\
\text { Skuodo r. SVB } \\
(1, \mathrm{Vr}-1), \text { Ši- } \\
\text { lutès r. SVB (2, } \\
\text { Tr - 1, Nr - 2, } \\
\text { Vr - 1), } \\
\text { Pagègių SVB } \\
(1, \text { nenurody- } \\
\text { ta - 1); Taura- } \\
\text { gės r. SVB } \\
(2, \text { Tr - 2, } \\
\text { Nr - 1) }\end{array}$ & $\begin{array}{l}\text { Kupiš- } \\
\text { kio r. SVB } \\
(1, \mathrm{Nr}-1), \\
\text { Panevėžio m. } \\
\text { SVB (1, Tr - 1, } \\
\text { Nr - 1), Pane- } \\
\text { věžio r. SVB (2, } \\
\text { Nr - 2), } \\
\text { Anykščių r. } \\
\text { SVB (2, Tr - 1, } \\
\text { Nr - 1, Vr - 1), } \\
\text { Ignalinos r. } \\
\text { SVB (1, Nr - 1) }\end{array}$ & $\begin{array}{l}\text { Kelmès r. SVB } \\
(1, \mathrm{Tr}-1, \\
\mathrm{Nr}-1, \mathrm{Vr}-1), \\
\text { Radviliškio r. } \\
\text { SVB (2, Vr }-3), \\
\text { Mažeikių r. SVB } \\
(1, \mathrm{Vr}-1)\end{array}$ & $\begin{array}{l}\text { Elektrènų } \\
\text { SVB }(2, \mathrm{Tr}-1, \\
\mathrm{Nr}-1, \mathrm{Vr}-1), \\
\text { Lazdijų r. SVB } \\
(1, \mathrm{Tr}-1, \\
\mathrm{Nr}-1)\end{array}$ & 27 \\
\hline 4 & $2016 \mathrm{~m}$ & $\begin{array}{l}\text { Kaišiado- } \\
\text { rių r. SVB } \\
(1, \mathrm{Tr}-1 \text {, } \\
\mathrm{Nr}-1), \mathrm{Kau}- \\
\text { no } \mathrm{m} . \mathrm{SVB} \\
(1, \mathrm{Nr}-1) \text {, } \\
\text { Vilkaviškio r. } \\
\text { SVB }(1, \text { nenu- } \\
\text { rodyta - } 1)\end{array}$ & 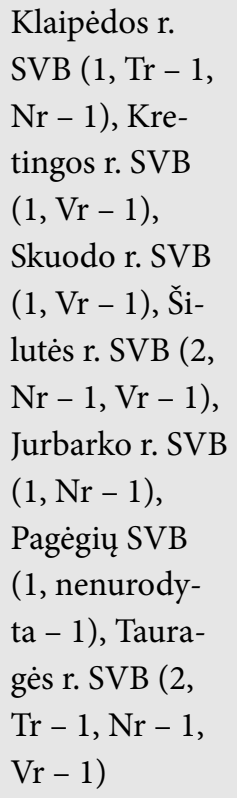 & $\begin{array}{l}\text { Kupiškio r. } \\
\text { SVB (2, Tr - 1, } \\
\text { Nr - 1), } \\
\text { Panevěžio m. } \\
\text { SVB (1, Tr - 1, } \\
\text { Nr - 1), Pane- } \\
\text { vėžio r. SVB } \\
(2, \mathrm{Vr}-2), \\
\text { Pasvalio SVB } \\
(1, \mathrm{Nr}-1), \\
\text { Rokiškio r. SVB } \\
(1, \mathrm{Vr}-1), \\
\text { Anykščių r. } \\
\text { SVB (1, Tr - 1, } \\
\text { Nr - 1) }\end{array}$ & $\begin{array}{l}\text { Kelmès r. SVB } \\
(3, \mathrm{Tr}-1, \\
\text { Nr - 2, Vr - 2), } \\
\text { Radviliškio r. } \\
\text { SVB (1, Vr - 1), } \\
\text { Mažeikių r. SVB } \\
\text { (2, Vr - 2), Plun- } \\
\text { gès r. SVB (1, } \\
\text { Vr - 1), Telšių r. } \\
\text { SVB (2, Vr - 2) }\end{array}$ & $\begin{array}{l}\text { Elektrè- } \\
\text { nų SVB }(1, \\
\text { Tr - 1, Vr - 1), } \\
\text { Vilniaus m. } \\
\text { SCB }(3, \mathrm{Nr}-2 \text {, } \\
\text { Vr - 1), } \\
\text { Alytaus r. SVB } \\
(1, \mathrm{Vr}-1), \\
\text { Varènos r. SVB } \\
(1, \mathrm{Vr}-1)\end{array}$ & 35 \\
\hline
\end{tabular}




\begin{tabular}{|c|c|c|c|c|c|c|c|}
\hline & Metai & $\begin{array}{c}\text { Kauno } \\
\text { apskr. (8), } \\
\text { Marijampo- } \\
\text { lès apskr. (5) }\end{array}$ & $\begin{array}{l}\text { Klaipėdos } \\
\text { apskr. (7), } \\
\text { Tauragės } \\
\text { apskr. (4) }\end{array}$ & $\begin{array}{l}\text { Panevėžio } \\
\text { apskr. (6), } \\
\text { Utenos } \\
\text { apskr. (6) }\end{array}$ & $\begin{array}{c}\text { Šiaulių } \\
\text { apskr. (7), } \\
\text { Telšių } \\
\text { apskr. (4) }\end{array}$ & $\begin{array}{l}\text { Vilniaus } \\
\text { apskr. (8), } \\
\text { Alytaus } \\
\text { apskr. (5) }\end{array}$ & \\
\hline 5 & $2017 \mathrm{~m}$ & $\begin{array}{l}\text { Birštono SVB } \\
(1, \mathrm{Nr}-2, \\
\text { Vr - 1), Kau- } \\
\text { no m. SVB (3, } \\
\mathrm{Nr}-2, \mathrm{Vr} \text { - } \\
\text { 2), Kauno r. } \\
\text { SVB (2, } \\
\mathrm{Nr}-2), \\
\text { Kazlų Rūdos } \\
\text { SVB (1, nenu- } \\
\text { rodyta - 1); } \\
\text { Vilkaviškio r. } \\
\text { SVB (1, nenu- } \\
\text { rodyta - 1) }\end{array}$ & $\begin{array}{l}\text { Klaipėdos m. } \\
\text { SVB }(1, \mathrm{Vr}-1) \text {, } \\
\text { Klaipėdos r. } \\
\text { SVB }(3, \mathrm{Vr}-3) \text {, } \\
\text { Kretingos r. } \\
\text { SVB }(3, \mathrm{Vr}-3) \text {, } \\
\text { Skuodo r. SVB } \\
(1, \mathrm{Nr}-1), \text { Si- } \\
\text { lutės r. SVB (2, } \\
\text { Nr - 2, Vr - 2) }\end{array}$ & $\begin{array}{l}\text { Panevéžio r. } \\
\text { SVB }(2, \mathrm{Vr}-2) \text {, } \\
\text { Ignalinos } \mathrm{r} \text {. } \\
\text { SVB } \\
(1, \mathrm{Nr}-1)\end{array}$ & $\begin{array}{l}\text { Kelmès r. SVB } \\
(1, \mathrm{Nr}-1, \\
\text { Vr - 1), Radvi- } \\
\text { liškio r. SVB (3, } \\
\mathrm{Tr}-1, \mathrm{Vr}-2) \text {, } \\
\text { Šiaulių m. SVB } \\
(1, \mathrm{Nr}-1 \text {, } \\
\text { Vr - 1), Šiaulių r. } \\
\text { SVB (3, Nr - 2, } \\
\text { Vr - 2), } \\
\text { Mažeikių r. SVB } \\
(2, \mathrm{Vr}-2), \text { Plun- } \\
\text { gès r. SVB (3, } \\
\text { Vr - 3), Telšių r. } \\
\text { SVB (1, Vr - 1) }\end{array}$ & $\begin{array}{l}\text { Elektrènų SVB } \\
(2, \mathrm{Vr}-2) ; \\
\text { Švenčio- } \\
\text { nių r. SVB (1, } \\
\mathrm{Nr}-1) \text {, } \\
\text { Alytaus SVB } \\
(1, \mathrm{Vr}-1) \text {, } \\
\text { Lazdijų r. SVB } \\
(1, \mathrm{Vr}-1) \text {, } \\
\text { Varènos r. SVB } \\
(2, \mathrm{Nr}-1, \\
\text { Vr - 1) }\end{array}$ & 42 \\
\hline
\end{tabular}

Projektų skai- $\quad{ }^{\star}$ Kauno apskr. bibliotekos: $10, \mathrm{Tr}-2, \mathrm{Nr}-10, \mathrm{Vr}-3$; ${ }^{\star}$ Marijampolès apskr. bibliote-

čius, tarptautinių, nacionalinių, vietos rèmèjų parama vykdant projektus kos: 4, $\mathrm{Tr}-0, \mathrm{Nr}-0, \mathrm{Vr}-0$, nenurodyta -4 ; ${ }^{\star} \mathrm{Klaipejdos} \mathrm{apskr.} \mathrm{bibliotekos:} 29, \mathrm{Tr}-3$, $\mathrm{Nr}-11, \mathrm{Vr}-22$; ${ }^{\star}$ Tauragès apskr. bibliotekos: $8, \mathrm{Tr}-3, \mathrm{Nr}-3, \mathrm{Vr}-2$, nenurodyta -2 ; ${ }^{\star}$ Panevėžio apskr. bibliotekos: $29, \mathrm{Tr}-3, \mathrm{Nr}-12, \mathrm{Vr}-18$; ${ }^{\star}$ Utenos apskr. bibliotekos: 9, $\mathrm{Tr}-2, \mathrm{Nr}-6, \mathrm{Vr}-2$, nenurodyta -1 ; *Šiaulių apskr. bibliotekos: $18, \mathrm{Tr}-4, \mathrm{Nr}-9$, $\mathrm{Vr}-13$; ${ }^{\star}$ Telšiu apskr. bibliotekos: $13, \mathrm{Tr}-0, \mathrm{Nr}-1, \mathrm{Vr}-12$; $^{\star}$ Vilniaus apskr. bibliotekos: $14, \mathrm{Tr}-2, \mathrm{Nr}-6, \mathrm{Vr}-7$, nenurodyta -1 ; ${ }^{\star}$ Alytaus apskr. bibliotekos: $8, \mathrm{Tr}-1$, $\mathrm{Nr}-2, \mathrm{Vr}-6$

Vykdyta projektų: 142; paramos teikèjų skaičius (per metus): $\mathrm{Tr}-20, \mathrm{Nr}-60, \mathrm{Vr}-85$, nenurodyta -8

Vykdyti 142 projektai. Pažymėtini Panevėžio m. SVB, Kupiškio r. SVB (Panevėžio apskr.), Klaipèdos r. SVB, Kretingos r. SVB (Klaipedos apskr.), Anykščiu r. SVB (Utenos apskr.) pasiekimai vykdant kūrybinès meninès veiklos skatinimo projektus. Vyravo vietos ir nacionalinių rèmëjų parama.

18 bibliotekų (30 proc.) 2007, 2013, 2015-2017 metais nevykdè kūrybinès meninès veiklos skatinimo projektų. Kauno apskrityje projektų nevykdè Kèdainių r. SVB, Prienų SVB, Raseinių SVB, Marijampolès apskrityje - Marijampolès SVB, Kalvarijos SVB, Šakių r. SVB, Klaipèdos apskrityje - Neringos SVB, Palangos m. SVB, Tauragès apskrityje - Šilalès r. SVB. Panevėžio apskrityje projektų nevykdè Biržų r. SVB, Utenos apskrityje - Molètų r. SVB, Utenos SVB, Visagino SVB, Alytaus apskrityje - Druskininkų SVB. Vilniaus apskrityje projektų nevykdè 4 bibliotekos: Šalčininkų r. SVB, Širvintų r. SVB, Ukmergès r. SVB, Vilniaus r. SVB.

Kürybinès meninès veiklos skatinimo projektai daugiausia buvo skirti vaikams ir jaunimui. Projektais siekta skatinti vaikų ir jaunimo kūrybinę saviraišką. Kultūros ministerija 2007 m. parèmė Jonavos r. SVB projektą „Jaunụjų menininkų sklaida Jonavoje“. Buvo organizuota moksleivių Gretos Markevičiūtès ir Jurgos Ribačiauskaitès kūrybos leidinio „Kai gerai būti nebegali“ pristatymas, surengtas literatūros ir muzikos vakaras „Mes ateinam“. Surengti parodų pristatymai, tarp jų - Jonavos Jeronimo Ralio vidurinès mokyklos dailès studijos mokinių kūrybos parodos. Vaikų ir jaunimo meniniam ugdymui bei jų saviraiškai skirtas Kultūros ministerijos paremtas Joniškio r. SVB projektas „Jaunųjų menininkų galerija bibliotekos erdveje“ ir kiti bibliotekų projektai. 
Vykdant projektus buvo siekiama ugdyti vaikų ir jaunimo kūrybinius meninius gebëjimus. Igyvendinant Kupiškio r. bibliotekos $2011 \mathrm{~m}$. projektą „Lèlių teatras - jaukus vaikystės pasaulis“ (rèmèja KM) vaikai ir paaugliai gamino lèles, kūré scenarijus, vaidino, dalyvavo teatrų festivalyje „Vaikai ir lèlès“. Renginiuose dalyvavo 10 institucijų: Kupiškio r. centrinè biblioteka ir 5 jos padaliniai, Vaikų ir jaunimo ugdymo centras „Varpelis“, Kupiškio vaikų dienos centras, Paketurių Šv. Kazimiero vaikų globos namai, Alizavos pagrindinè mokykla. Panašų projektą 2012 m. vykde Šiaulių m. biblioteka („Skaitantys vaikai kuria lèlių teatrą“, rèmėja - KM). Utenos bibliotekos projektą „Utenos krašto padavimai animacijoje“ parèmė KM. Projekto tikslas - per animacinio filmo kūrimą paskatinti vaikų kūrybiškumą, jų domèjimąsi krašto istorija. Buvo paskelbtas piešinių konkursas 7-12 metų vaikams „Utenos krašto padavimų knygą atvèrus..." Mokytojų ir bibliotekininkių komisija išrinko geriausius darbus, kurių autoriai buvo pakviesti ł kūrybines dirbtuves. Kūrybinius užsièmimus vedè profesionalūs animatoriai Jūratė Leikaitè-Aškinienė ir Valentas Aškinis. Vaikai susipažino su animacijos istorija ir technika, drauge su animatoriais sukūre animacinį filmą „Kunigaikštis Utenis“, jis buvo įrašytas ị DVD.

Tad vaikų ir jaunimo kūrybinių meninių gebėjimų ugdymas apėmè įvairias sritis. Pavyzdys galètụ būti Lietuvos kultūros tarybos finansuotas Šiaulių r. SVB filialo projektas. Ginkūnų mst. biblioteka igyvendino projektą „Kelionė skaitymo, pažinimo ir kūrybos keliais“ (2014 m.). Projekte buvo numatyti mokymai savarankiškai pasirinkti knygą, rašyti perskaitytų knygų anotacijas. Siekiant plètoti vaikų vaizduotę ir kūrybingumą organizuoti tokie užsièmimai: knygų personažų kūrimas iš džiovintų žolynų, bibliografinių žymelių pynimas iš siūlų, dirbinių iš molio lipdymas. Mažieji skaitytojai buvo pakviesti i susitikimą su dailininke, vaikiškų knygų iliustratore, rašytoja Lina Žutaute. Aktyviausiems projekto dalyviams organizuota ekskursija ị Naisius (aplankyti Zigmo Gèlès literatūros, Baltų dievų, Inkilų muziejai, Žemaitukų žirgynas ir „Naisių vasaros“ teatras).

Projektus, skirtus vaikų ir jaunimo kūrybinei meninei veiklai, paremè tarptautinės institucijos. Pažymėtina, kad Radviliškio r. ir Tauragès r. bibliotekos sulaukė JAV lietuvių paramos. $2013 \mathrm{~m}$. Radviliškio r. biblioteka vykdè projektą „Vaikų vasaros stovykla Būsim, dalyvausim, daug ką sužinosim“, $2015 \mathrm{~m}$. Tauragès r. bibliotekos vykdè projektą „Vaikai-biblioteka-lèlių teatras“. Juos finansavo JAV lietuvių bendruomenès krašto valdyba. Lazdijų r. SVB 2015 m. vykdè projektą „Istorijos menas“ (rèmejjai Lietuvos ir Lenkijos jaunimo mainų fondas ir savivaldybè). Buvo organizuotos Lietuvos ir Lenkijos jaunimo kūrybinès meninès dirbtuves ir dailès pleneras, sukurta projekto „Facebooko“ grupé, kurioje jaunuoliai igijo galimybę dalytis informacija apie vykstančias veiklas abiejose šalyse. Projekto dalyviai rengè pristatymus apie LDK istoriją.

BMGF ir KM [BP 2] parėmè Panevėžio m., Elektrènų, Kelmès r., Tauragès r. SVB bibliotekų projektus. Panevėžio m. biblioteka vykdè projektą „3D: Domèkis. Dalyvauk. Dalinkis“. Pasiūlytos naujos kokybiško laisvalaikio praleidimo vaikams ir jaunimui formos: 3D modeliavimas, stopkadro filmukų kūrimas, skaitmeninè fotografija, Jaunojo informatiko mokyklèlè. Elektrènų SVB vykdè projektą „Saviraiškos erdvès paaugliams ir jaunimui ịkūrimas“. Buvo siekiama skatinti kūrybiškumą, ugdyti kompetencijas IT srityje organizuojant Autocad mokymus ir kūrybinius užsièmimus 3D kūrybinių dirbtuvių laboratorijoje, intelektualius interaktyvius stalo žaidimus, protų mūšius ir kt. Kelmės r. SVB vykdè projektą „Inovatyvi bibliotekos erdve - jaunimo saviraiškai“. Buvo sukurta 14-24 metu jaunuoliams skirta, naujausiomis technologijomis aprūpinta, asmenybei tobulèti prasmingai leidžiant laisvalaikị pritaikyta erdvè. Tauragès r. SVB vykdė projektą „Jaunụjų inžinierių laboratorija (2015-2016 m.)“. Irrengus laboratoriją su ịvairiomis techninèmis bei elektronikos priemonèmis buvo sudarytos sąlygos prasmingam jaunimo užimtumui, verslumo skatinimui, kūrybiškumui.

Panašaus pobūdžio projektus rẻmė Lietuvos kultūros taryba ir savivaldybės. $2016 \mathrm{~m}$. LKT finansavo Vilniaus m. SCB projektą „Mano kambarèly keturios kèdutès“. Projektas skirtas vaikams ir paaugliams susikurti personalinę „erdvę“ bibliotekoje, tokią, kokią ją ịsivaizduoja, naudojant ịvairias meno priemones. LKT ir SV parėmé Kelmès r. bibliotekos projektą „Jaunimo inovatyvios erdvės paslaugų plètra“. 
Savivaldybės parėmė Kretingos r. bibliotekos projektą „Atvira jaunimo erdvė Savas kampas bibliotekoje“, Mažeikių r. bibliotekininkų draugijos projektą „Jaunimo erdvè - laisvalaikiui ir iniciatyvoms“, Alytaus r. SVB Ūdrijos filialo projektą „Atrask erdves saviraiškai ir kūrybai“.

Projektai skirti atskiroms kūrybinio meninio ugdymo sritims. Lietuvos kultūros taryba $2016 \mathrm{~m}$. parèmė Kupiškio r. SVB projektą „Fotografijos mokymai-paroda Neatrastas Kupiškis“. Savivaldybės finansavo Tauragès r. SVB projektą „Lèlių paradas“, Šilutès r. SVB projektą „Jaunimo divizionas - ateik, mąstyk, šturmuok“. Vykdant pastarąji projektą bibliotekoje sukurtas galvosūkių kambarys. Meninès kūrybos skatinimo kontekste pažymètinas Druskininkų bibliotekos dalyvavimas kitų institucijų projekte. 2015 m. biblioteka įsitraukè ị Všț „Žaliasis taškas“ ir Všt „RV Agentūra“ vykdomą projektą „Kita forma bibliotekose“. Jị iggyvendinant vyko užsièmimai, kaip pasitelkus kūrybiškumą ir savo aplinkoje rastas atliekas sukurti naujus, funkcionalius, buityje ar interjere pritaikomus daiktus. Vaikai buvo mokami iš atliekų pasigaminti vèl naudojamus daiktus: muzikos instrumentus, aksesuarus, kanceliarinius reikmenis. Mokytojai supažindinti su galimybe ekodizainą pritaikyti švietimo įstaigose.

Plètèsi projektuose numatytų darbo formų ir metodų spektras. Aptarsime 2017 m. Kauno r., Birštono, Kelmės r. bibliotekų projektus. Kauno r. biblioteka laimëjo LKT projektą „Knygos menas bibliotekoje“. Projektas pakvietė vaikus ị ịvairias edukacijas: mirioramų - ritininių knygų dirbtuves, tapybos ant vandens edukacijas, tapybos ant akmenèlių; Olego Karavajevo dailès studijos ${ }^{111}$ edukacijas Garliavoje. LKT, KM ir SV parėmė Birštono bibliotekos projektą „Biblioteka - kūrybinių atradimų namai“. Bendradarbiaujant su kūrybinių industrijų atstovais, Birštono gimnazija ir Nemajūnų dienos centru organizuotos veiklos: viktorinos, 3D spausdinimo dirbtuvès, robotikos technologijų laboratorija, smèlio terapija ir kt. Kelmès r. biblioteka vykdè projektą „Inovatyvios bibliotekos paslaugos vaikams“ (rèmëjos - LKT, SV). Skatinant kūrybiškumą panaudotos naujosios technologijos ir inovatyvios priemonès: 3D modeliavimas, žaidimų pultas su judesio kamera, interaktyvios grindys, kūrybinis braižymas, magnetinių kubelių konstravimas ir kt.

Pažymètini Kauno m. ir Šiaulių m. bibliotekų vykdyti originalūs projektai. Lietuvos kultūros taryba ir Kultūros ministerija parèmė Kauno m. bibliotekos projektą „Jaunimo teatro akademija“. Vykdant projektą talkino partneriai: Kauno miesto kamerinis teatras, Všl Kauno medijų centras ir kt. Projekto dalyviai ugdè teatrinès raiškos ịgūdžius ịsitraukdami ị kūrybines užduotis, improvizacijas, vaidmenų žaidimus, psichoterapines praktikas, judesio ir viešojo kalbẻjimo technikas. Užsièmimus vedè žinomi teatro pasaulio atstovai: šokio teatro „Aura“ vadove Birute Letukaite, režisieriai Gytis Padegimas ir Gildas Aleksa, aktorius Vytautas Gasiliūnas, teatro ir kino kritikas Vaidas Jauniškis, dramaturgas Mindaugas Nastaravičius, Oratorių mokyklos vadovè Vilma Kubilienè ir kiti. Projekto vykdymo pabaigoje vaikai parengè spektakli „Skrudžo ${ }^{112}$ Kalèdos“, kurị rodè kalèdiniu laikotarpiu. Sukurta projekto svetainè www.teatroakademija.lt. Šiaulių m. SVB vykdè projektą „Rèkyvos lobių paieška“ (rèmèjos - LKT, SV). Siekta paskatinti netradicines veiklas. Sukurtas naujas interaktyvus žaidimas - lobių paieškos. Jos vyko bibliotekoje: 1-5 klasių moksleiviai su mokytojais keliavo ieškoti Rèkyvos „lobių“ (konkretus miesto objektas, jo istorija).

Kūrybinė vaikų veikla buvo skatinama per vasaros atostogas. Projektus finansavo savivaldybès. $2007 \mathrm{~m}$. Panevėžio m. centrinè biblioteka ir jos filialai, Vilniaus m. SCB filialai projektus skyrè vaikų užimtumui vasarą - edukacinèms kūrybinèms stovykloms organizuoti. Panevėžio m. VB vaikų literatūros skyriuje „Žalioji pelèda“, „Židinio“, Smèlynès, vaikų bibliotekoje „Žiburèlis“ veikè vaikų vasaros stovyklos. Vaikai dalyvavo literatūrinèse viktorinose, susitikimuose, bibliografinèse pamokèlèse, mokèsi ìvairių piešimo „gudrybių“, rengè parodas, dalyvavo kūrybiniuose poezijos konkursuose, vyko ị pažintines ekskursijas Panevėžio mieste. Su bibliotekininkių pagalba vaikai leido stovyklų laikraščius. Panašaus

111 Dailès studija pradejjo veiklą $2001 \mathrm{~m}$.

112 Skrudžas - komiksų ir animacinių filmų herojus. 
pobūdžio projektus Vilniuje vykdè Naujosios Vilnios biblioteka (2007 m., projektas „Vaikų vasaros dienos stovykla Robinzonu Sala“), Tomo Zano biblioteka (2007 m., projektas „Vaikų vasaros poilsio programa Fantazija“), Panevėžio rajone - Ėriškių k. biblioteka (2013 m., projektas „Vaikų vasaros stovyklèlè Kodè ị biblioteką, o ne ị gatvę?"), Velžio mst. biblioteka (2013 m., projektas „Vaikų kūrybiškumo skatinimas. Kūrybingas laisvalaikis vasaros dienos stovyklos metu").

Pažymėtina, kad tokio pobūdžio novatoriškus projektus parèmé Lietuvos kultūros taryba. Šilutès r. biblioteka vykdè tęstinị projektą „Jaunieji genijai - menininkai“ (2015 m., 2017 m.). 2015 m. organizuotoje stovyklose dalyvavo atostogaujantys jaunieji šilutiškiai. Tradiciškai stovyklose mokyta teatro žmonėms reikalingų igūdžių - režisuoti spektaklius, kurti scenarijus, pritaikyti muzikinius kūrinius ir kt. Organizuotose kūrybinèse dirbtuvèse aktoriai kūrè kartu su vaikais ${ }^{113}$. Kauno m. biblioteka vykdè projektą "Greimo žurnalistikos akademija“ (2016 m.). Organizuota jaunimo kūrybinio rašymo vasaros stovykla Petrašiūnų ir Panemunès struktūriniuose padaliniuose. Stovyklos tikslas - suteikti moksleiviams teorinių ir praktinių žurnalistinio darbo igūdžių. Paskaitas ir kūrybines dirbtuves organizavo žurnalistai, literatūros kritikai, rašytojai, dainininkai, viešųjų ryšių specialistai. Geriausi moksleivių tekstai publikuoti portale www.kaunozinios.lt.

Suaugusiems gyventojams projektu skirta mažiau. $2007 \mathrm{~m}$. buvo vykdomi tik du jiems skirti projektai. Plungès r. SVB Narvaišių k. filialas vykdè projektą „Nuo gelstančių lapų iki sniego gniūžtès“ (rèmèja $\mathrm{KM}$ ), pagrindiniu jo renginiu tapo floristikos seminaras. Klaipėdos r. SVB Judrènų filialas iggyvendino projektą „Meno mylètojų kūrybos pleneras“ (rèmëja - SV).

Ryškëjo orientacija ị kūrybinių dirbtuvių organizavimą. Kūrybinės dirbtuvės sujungè įvairias temas. Kupiškio r. SVB projektas „Kūrybinès dirbtuvès - dar vienas žingsnis knygos link“ (2012-2013 m., rèmejjai - KRF, SV, UAB „Patogu pirkti“) buvo skirtas norintiems išbandyti save meninèje veikloje. $2012 \mathrm{~m}$. bibliotekoje veikè penkios kūrybinès dirbtuvès: „Velykinių puokščių kompozicijos“, „Kūrybiniai darbai savęs pažinimui“, „Vilnos vèlimo menas“, „Knygos kelias“, „Popieriniai stebuklai“. 2013 m. projekto dalyviai kūrybinèse dirbtuvèse kūrẻ floristines kompozicijas, piešè ant stiklo ir vandens, kūrè iliustracijas knygoms, išbandè vilnos vèlimo techniką. Klaipedos r. SVB drauge su Klaipèdos apskrities viešąja biblioteka (KlAVB) vykdè KM paremtą projektą „Keliaujantis menas“ (2012 m.). Kūrybinès dirbtuvès surengtos Priekulès m. filiale (kūrybinio rašymo) ir Vèžaičiu mst. filiale (akvarelès liejimo).

Projektai skirti kūrybiškumui skatinti ịvairiose meno srityse. $2015 \mathrm{~m}$. Skuodo r. biblioteka iggyvendino projektą-edukacinių renginių ciklą „Menas žmogaus gerovei“. Igyvendinant projektą surengti piešimo ant stiklo, dekupažo ${ }^{114}$, vèlimo iš vilnos, floristikos mokymai. Baigiamasis projekto renginys - sukurtų darbų paroda. Klaipèdos r. SVB vykdè projektą „Nuo tradicijos iki meno“. Pristatytas karpinių menas. Bibliotekos darbuotoja Zita Kontrimienè eksponavo ir pristatė savo karpinių parodą bei surengè karpinių karpymo valandèles filialuose. Abu projektus parèmé savivaldybès.

Kretingos r. SVB biblioteka kūrybinę meninę veiklą susiejo su meno terapija. $2016 \mathrm{~m}$. biblioteka vykdè projektą „Meno terapija ir edukacija moterims“ (rèmëjai - LKT ir SV). Projekto partneriais buvo Kretingos moterų informacijos ir mokymų centras, Kretingos rajono pedagogų švietimo centras, Kretingos meno klubas PINX. Projektas turèjo tikslą Kretingos m. moterims sudaryti sąlygas ugdyti savo kūrybinị potencialą, tobulèti meno srityje, meną pateikiant ne vien kaip malonų laisvalaikio užsièmimą, bet kaip efektyvią terapiją dvasinèms ir fizinèms problemoms spręsti, priemonę lavėti, laisvèti. Užsièmimuose siekta jungti dailès terapiją ir edukaciją, muzikos terapiją, biblioterapiją bei rankdarbių edukaciją. Meninei kūrybai viešinti skirtas Vilniaus m. SCB Lazdynų filialo projektas „Kuriantys lazdyniečiai“ (2016 m., rèmëja - LKT). Lankytojai turèjo galimybę susipažinti su Veronikos Tauragienès ir Živilès Vasiliauskienès tapybos darbais. Plungès r. SVB vykdè projektą „Lauko fotografijos paroda „Fotoalèja - 2016“

113 Plačiau žr. Gerulienè, V. Žymūs lèlininkai stovyklavo su vaikais (Šilutè). Tarp knygų, 2015, spalis, p. 36.

114 Dekupažas (pranc. k. decouper - iškirpti, išpjauti) - daiktų dekoravimo įvairiais piešinèliais technika. 
(rèmèja - SV). Dalyvavo Plungès ir Rietavo krašto fotoklubas „Žybt“, Tauragės fotoklubas „Fotojūra“. Sukurta ir eksponuota daugiau kaip 100 darbų.

İvairūs kūrybiniai užsièmimai 2017 m. buvo numatyti pagal Skuodo r., Ignalinos r., Elektrėnų, Šiaulių r. Kuršènų ir kitų bibliotekų projektus. Lietuvos kultūros taryba ir Kultūros ministerija parèmė Skuodo r. SVB bibliotekos projektą. Biblioteka kartu su partneriais (Gèsalų, Vižančių kaimų bendruomenės, Skuodo kaimo verslų, amatų ir paslaugų mokykla, Skuodo dekanato šeimos centras) vykdè projektą „Atrask neatrastus savo gebejimus bibliotekoje“. Projekto tikslas - skatinti šeimų užimtumą. Siekta padèti rasti naujų laisvalaikio leidimo būdų, netgi iggti naujų igūdžių bei panaudoti juos šeimos finansiniam gèriui kurti. Šeimoms buvo pasiūlyti edukaciniai kūrybiniai užsièmimai: sausasis ir šlapiasis vèlimas iš vilnos, dekupažas, dirbiniai iš odos, floristika, sutažas ${ }^{115}$, tapyba ant šilko, mezgimas ir nėrimas su karoliukais ir kauline adata, audimas, dekoratyviniai dirbiniai iš cemento. Lietuvos kultūros taryba finansavo Ignalinos r. bibliotekos projektą „Kūrybos ABC“. Igyvendinant projektą lankytojai supažindinti su meno terapijos poveikiu sveikatai; praktiniai užsiemmimai skirti ornamentui, kaleidoskopui gaminti, mandaloms, fraktalams ${ }^{116}$ piešti. Fraktalams piešti skirtas Elektrènų bibliotekos projektas „Fraktalų terapija netradicinè sielų gydykla“, kurị parėmè savivaldybė. Šiaulių r. Kuršėnų biblioteka vykdè projektą „Fotomeno erdvės Kuršènų bibliotekoje" (rèmèjos - LKT ir SV). Buvo organizuoti fotomeno kursai, kurių dalyviai, padedant lektoriams, bendradarbiaujant su Šiaulių „Aušros“ muziejaus padaliniu - Fotografijos muziejumi, mokèsi fotografijos meno.

\subsection{Kompiuterinio, skaitmeninio, informacinio raštingumo ugdymo projektai}

Duomenys apie gyventojų kompiuterinio, skaitmeninio, informacinio raštingumo ugdymo projektų vykdymą 2007, 2013, 2015-2017 metais pateikiami 12 lentelèje. Nors tokio pobūdžio projektai svarbūs, jų skaičiai gana kuklūs.

12 lentele. Kompiuterinio, skaitmeninio, informacinio raštingumo ugdymo projektų vykdymas 2007, 2013, 2015-2017 metais (skliaustuose - bibliotekų skaičius apskrityse, vykdytų projektų skaičius, rèmejjų tipas: $\mathrm{Tr}$ - tarptautinis rèmèjas, $\mathrm{Nr}$ - nacionalinis rèmëjas, $\mathrm{Vr}$ - vietos rèmëjas)

\begin{tabular}{|c|c|c|c|c|c|c|c|}
\hline & Metai & $\begin{array}{c}\text { Kauno } \\
\text { apskr. (8), } \\
\text { Marijampolès } \\
\text { apskr. (5) }\end{array}$ & $\begin{array}{l}\text { Klaipėdos } \\
\text { apskr. (7), } \\
\text { Tauragès } \\
\text { apskr. (4) }\end{array}$ & $\begin{array}{c}\text { Panevėžio } \\
\text { apskr. (6), } \\
\text { Utenos apskr. } \\
\text { (6) }\end{array}$ & $\begin{array}{c}\text { Šiaulių } \\
\text { apskr. (7), } \\
\text { Telšių } \\
\text { apskr. (4) }\end{array}$ & $\begin{array}{c}\text { Vilniaus } \\
\text { apskr. (8), } \\
\text { Alytaus apskr. } \\
\text { (5) }\end{array}$ & $\underset{\substack{\infty \\
\infty}}{\infty}$ \\
\hline 1 & $2007 \mathrm{~m}$ & $\begin{array}{l}\text { Prienų SVB } \\
(1, \mathrm{Vr}-1)\end{array}$ & $\begin{array}{l}\text { Klaipèdos r. } \\
\operatorname{SVB}(1, \operatorname{Tr}-1)\end{array}$ & & $\begin{array}{l}\text { Radviliškio r. } \\
\text { SVB }(1, \mathrm{Nr}-1 \text {, } \\
\operatorname{Vr}-1)\end{array}$ & & 3 \\
\hline 2 & $2013 \mathrm{~m}$ & & $\begin{array}{l}\text { Klaipèdos m. } \\
\operatorname{SVB}(1, \mathrm{Nr}-1)\end{array}$ & $\begin{array}{l}\text { Panevėžio m. } \\
\text { SVB }(1, \mathrm{Nr}-1), \\
\text { Pasvalio SVB (1, } \\
\text { Nr - 1), Utenos } \\
\text { SVB }(1, \mathrm{Nr}-1), \\
\text { Zarasų r. SVB (1, } \\
\text { Tr - 1) }\end{array}$ & $\begin{array}{l}\text { Šiaulių m. SVB } \\
(1, \mathrm{Nr}-1) \text {; } \\
\text { Šiaulių r. SVB } \\
(1, \mathrm{Nr}-1)\end{array}$ & $\begin{array}{l}\text { Trakų r. SVB } \\
(1, \mathrm{Nr}-1, \\
\text { Vr - 1), } \\
\text { Ukmergès r. } \\
\text { SVB }(1, \\
\mathrm{Nr}-1), \\
\text { Lazdijų r. SVB } \\
(1, \mathrm{Nr}-1)\end{array}$ & 10 \\
\hline
\end{tabular}

Sutažas (pranc. k. soutache - galionas, apsiuvas, apvadas) reiškia siaurą, skersai sukryžiuotų šilkinių siūlų apdailos virvelę, apvadą, naudojamą siuvinių apdailai.

11 Fraktalas (lotyn. k. fractus - suskaldytas) - sudètinis geometrinis darinys, kurio atskiri fragmentai yra panašūs arba identiški visumai arba kitiems fragmentams. Pagrindinė fraktalų bendra savybė yra panašumas ị save, t. y. išdidinta maža geometrinės struktūros dalis atrodo identiška didesnei daliai. Fraktalų piešimas - žmogaus psichinès būsenos diagnozavimo priemonė. 


\begin{tabular}{|c|c|c|c|c|c|c|c|}
\hline \multicolumn{2}{|r|}{ Metai } & $\begin{array}{c}\text { Kauno } \\
\text { apskr. (8), } \\
\text { Marijampolès } \\
\text { apskr. (5) }\end{array}$ & $\begin{array}{l}\text { Klaipėdos } \\
\text { apskr. (7), } \\
\text { Tauragès } \\
\text { apskr. (4) }\end{array}$ & $\begin{array}{c}\text { Panevėžio } \\
\text { apskr. (6), } \\
\text { Utenos apskr. } \\
\text { (6) }\end{array}$ & $\begin{array}{c}\text { Šiaulių } \\
\text { apskr. (7), } \\
\text { Telšių } \\
\text { apskr. (4) }\end{array}$ & $\begin{array}{c}\text { Vilniaus } \\
\text { apskr. (8), } \\
\text { Alytaus apskr. } \\
\text { (5) }\end{array}$ & $\begin{array}{l}8 \\
\sum_{\infty}^{\infty} \\
i \infty\end{array}$ \\
\hline 3 & $2015 \mathrm{~m}$ & $\begin{array}{l}\text { Kèdainių r. SVB } \\
(1, \text { nenurody- } \\
\text { ta }-1) \text {, Prienų } \\
\text { SVB (2, Tr - 1, } \\
\text { Nr - 2), Raseinių } \\
\text { SVB (1, Tr - } 1 \text {, } \\
\text { Nr - 1), } \\
\text { Marijampolès } \\
\text { SVB (1, Tr - } 1, \\
\text { Nr - 1) }\end{array}$ & & $\begin{array}{l}\text { Ignalinos } r \text {. } \\
\text { SVB }(2, \mathrm{Tr}-1 \text {, } \\
\mathrm{Nr}-2)\end{array}$ & $\begin{array}{l}\text { Mažeikių r. } \\
\text { SVB (1, } \\
\text { Nr - 1), Plun- } \\
\text { gès r. SVB (1, } \\
\text { Vr - 1) }\end{array}$ & $\begin{array}{l}\text { Ukmergès } r \text {. } \\
\text { SVB }(1, \operatorname{Tr}-1 \text {, } \\
\text { Nr }-1, \operatorname{Vr}-1) \text {, } \\
\text { Švenčionių r. } \\
\text { SVB }(1, \operatorname{Vr}-1)\end{array}$ & 11 \\
\hline 4 & $2016 \mathrm{~m}$ & $\begin{array}{l}\text { Prienų SVB } \\
(1, \operatorname{Tr}-1, \mathrm{Nr}-1), \\
\text { Raseinių SVB } \\
(1, \mathrm{Tr}-1, \mathrm{Nr}-1), \\
\text { Marijampolès } \\
\text { SVB (2, Tr - 1, } \\
\mathrm{Nr}-2)\end{array}$ & $\begin{array}{l}\text { Kretingos r. } \\
\operatorname{SVB}(1, \mathrm{Vr}-1)\end{array}$ & $\begin{array}{l}\text { Biržų r. SVB (1, } \\
\text { Nr - 1), Igna- } \\
\text { linos r. SVB (1, } \\
\text { Tr - 1, Nr - 1), } \\
\text { Utenos SVB (1, } \\
\text { Nr - 1) }\end{array}$ & $\begin{array}{l}\text { Šiaulių m. SVB } \\
(1, \mathrm{Nr}-1)\end{array}$ & $\begin{array}{l}\text { Ukmergès r. } \\
\text { SVB }(1, \operatorname{Tr}-1 \text {, } \\
\mathrm{Nr}-1, \mathrm{Vr}-1)\end{array}$ & 10 \\
\hline 5 & $2017 \mathrm{~m}$ & $\begin{array}{l}\text { Kauno m. SVB }(1, \\
\mathrm{Nr}-2, \mathrm{Vr}-1), \\
\text { Kauno r. SVB }(1, \\
\mathrm{Nr}-1)\end{array}$ & $\begin{array}{l}\text { Klaipèdos m. } \\
\text { SVB }(2, \mathrm{Nr}-4 \text {, } \\
\text { Vr }-2), \text { Kre- } \\
\text { tingos r. SVB } \\
(1, \mathrm{Vr}-1)\end{array}$ & $\begin{array}{l}\text { Panevėžio m. } \\
\operatorname{SVB}(1, \mathrm{Vr}-1) \\
\text { Pasvalio SVB }(1, \\
\mathrm{Nr}-2)\end{array}$ & & $\begin{array}{l}\text { Lazdijų r. SVB } \\
(1, \mathrm{Nr}-1, \\
\mathrm{Vr}-1)\end{array}$ & 8 \\
\hline \multicolumn{2}{|c|}{$\begin{array}{l}\text { Projektų } \\
\text { skaičius, } \\
\text { tarptautinių, } \\
\text { nacionalinių, } \\
\text { vietos rèmėjų } \\
\text { parama vyk- } \\
\text { dant projektus }\end{array}$} & \multicolumn{5}{|c|}{ 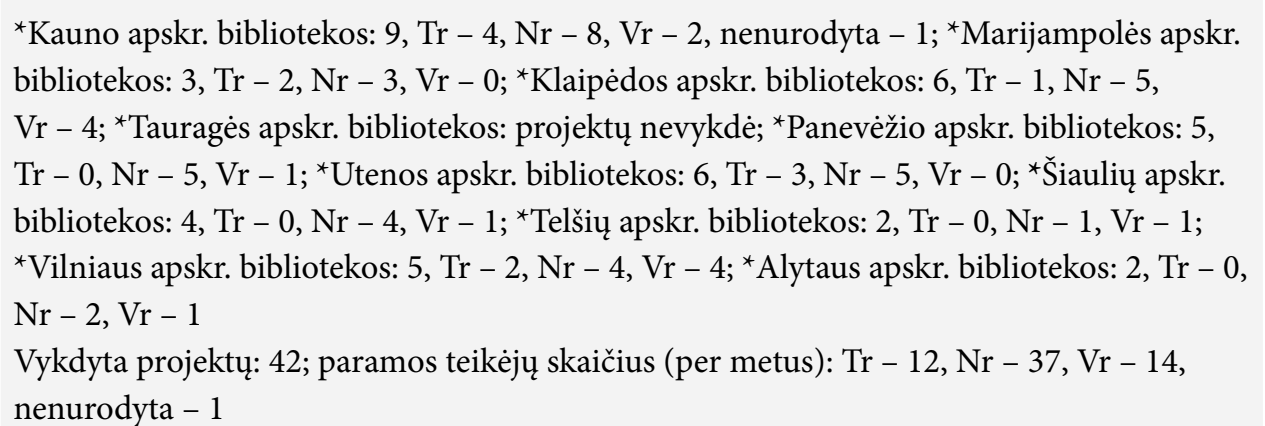 } & 42 \\
\hline
\end{tabular}

Vykdyti 42 projektai. Prienų SVB, Raseinių SVB (Kauno apskr.), Marijampolès SVB (Marijampolès apskr.), Klaipėdos m. SVB, Kretingos r. SVB (Klaipėdos apskr.), Panevežio m. SVB, Panevėžio r. SVB (Panevėžio apskr.), Ignalinos r. SVB (Utenos apskr.), Šiaulių m. SVB (Šiaulių apskr.), Ukmergès r. SVB (Vilniaus apskr.), Lazdijų r. SVB (Alytaus apskr.) skirtingais metais vykdè po 2-4 projektus. 37 bibliotekos (61,7 proc.) projektų nevykdè. Dominavo nacionalinių rèmèjų parama.

Gyventojų kompiuteriniam raštingumui ugdyti buvo naudingi aljanso „Langas i ateitį“ organizuoti mokymai. 2007 m. bibliotekoms priskirtini tik trys projektai, skirti gyventojų kompiuteriniam, skaitmeniniam raštingumui ugdyti. Klaipèdos $\mathrm{r}$. SVB vykdè Europos socialinio fondo finansuojamą projektą „Klaipėdos rajono seniūnijų dirbančiųjų gyventojų kompiuterinio raštingumo skatinimas“ (pradètas vykdyti 2006 m.), Radviliškio r. SVB - Kultūros ministerijos ir savivaldybės paremtą projektą „Skaitytojui naujausios informacinès technologijos“, Prienų SVB - savivaldybès paremta projektą „Skaitmeninès eros sankryžoje“. 
Gyventojų kompiuterinio raštingumo ugdymas efektyviai buvo sprendžiamas bibliotekoms dalyvaujant projekte „Bibliotekos pažangai“. 2008-2012 m. bibliotekininkai kompiuterinio raštingumo žinių suteikè daugiau nei 60 tūkst. šalies gyventojų ${ }^{117} .2013$ m. mokymai, vykdant projektą „Bibliotekos pažangai“, buvo tęsiami. Atkreiptinas dèmesys ị Prienų centrinès bibliotekos ir jos filialų patirtị. Buvo vykdoma 3 modulių gyventojų mokymo programa. Grupès buvo sudaromos pagal pageidaujančių mokytis poreikius, žinias ir gebejjimus bei atsižvelgiant į bibliotekos turimas kompiuterines darbo vietas ir naudojant projekto metu gautą ịrangą. Gyventojų skaitmeninio raštingumo mokymų programą sudare 3 moduliai: 1 modulis „nE-Drąsiems“ - pradedantiems, neturintiems skaitmeninio raštingumo žinių ir gebẻjimų; 2 modulis „nE-Pasitikintiems“ - pažengusiems, turintiems šiek tiek žinių ir ịūdžių; 3 modulis „nE-Pritaikantiems“ - gyventojams, pageidaujantiems plèsti interneto naudojimo ịgūdžius, išmokti naudotis elektroninemis valdžios ir verslo paslaugomis, t. y. kompiuterị ir internetą pritaikyti kasdieniams gyvenimo poreikiams tenkinti ir gerinti savo gyvenimo kokybę (bankas, deklaravimas, sveikatos paslaugos, darbo paieška, poilsis ir kt.).

Nuo 2013 m. gyventojų kompiuterinio, skaitmeninio, informacinio raštingumo ugdymo projektų padaugejo: po 10-11 projektų vykdyta 2013, 2015-2016 metais, $2017 \mathrm{~m}$. - 8. Zarasų r. biblioteka gavo ES paramą. Europos žemès ūkio fondas kaimo plètrai finansavo bibliotekos projektą „Mobilus mokymo centras kaimo bendruomenių švietimui (2012-2014 m.)“. Projekto tikslas: paskatinti kaimo bendruomenes naujoms iniciatyvoms, mokant vyresnio amžiaus žmones naudotis interneto teikiamomis galimybėmis, jaunimui suteikiant žinių ir gebẻjimų naudotis naujomis interneto technologijomis - žiniatinkliu 2.0. Irrengus mobilųj mokymo centrą vyresnio amžiaus žmonėms organizuoti kompiuterinio raštingumo mokymai „Kompiuterio pradžiamokslis“, „Sveikata - brangiausias turtas“, „Mokomès filmuoti“, „Bendravimas Skype“, „E. valdžios paslaugos“. Jaunuoliai mokèsi naudotis vaizdo kamera, kūrè filmukus apie kaimo bendruomenès gyvenimą ir, naudodamiesi žiniatinklio 2.0 technologijomis, skelbė juos internete.

Turiningas programas numate Utenos ir Pasvalio bibliotekų projektai, kuriuos parėmè Kultūros ministerija. Utenos bibliotekos projektą „Efektyvus technologijų naudojimas: neatrastos galimybès mokymuisi, laisvalaikiui ir kūrybai“ igyvendinti padejjo partneriai: VU Komunikacijos fakultetas, VGTU leidyklos „Technika“ Elektroninès leidybos skyrius, Všt „Skaitmeninių bendruomenių link“, Všt Informacijos technologijų mokymo centras. Mokymai vyko Utenos r., Anykščių r., Ignalinos r., Molètų r., Visagino ir Zarasų r. bibliotekose. Sudarytos galimybės susipažinti su elektroninėmis knygomis, jų formatais, nesudètingomis skaitmeninio turinio kūrimo programomis, planšetiniu kompiuteriu, slaptažodžių saugumu, socialinių tinklų nauda bei jų grèsmėmis ir kt. Pasvalio bibliotekos vykdyto projekto „Pasvalio Mariaus Katiliškio viešoji biblioteka - skaitmeninės kompetencijos ugdymo centras" tikslas - tapti pirmu skaitmeninès kompetencijos ugdymo bei skaitmeninių technologijų centru Pasvalio krašte. Igyvendinant projektą parengtos skaitmeniniams ịgūdžiams tobulinti skirtos edukacinès programos, pritaikytos skirtingoms vartotojų grupèms, organizuoti mokymai pagal sukurtas mokymo programas; sukurta virtuali erdvè vaikams ir jaunimui - interneto svetainè, kuri pildoma pačiu vartotojų sukurtu skaitmeniniu turiniu; sukurtas ugdymo įstaigų bendradarbiavimo tinklas skaitmeninio raštingumo mokymams; surengta konferencija „Šiandienos galimybès ir ateities tendencijos ugdant skaitmeninę kompetenciją bibliotekose“.

Kultūros ministerija ir savivaldybė parėmè Lazdijų r. bibliotekos projektą „Informacinis raštingumas bibliotekose Mums rūpi!“ Parengtos dvi metodinès priemonès „Informacinis raštingumas iki 18 m.“ ir „Informacinis raštingumas suaugusiems“, pagal kurias organizuoti mokymai. Šiaulių m., Panevėžio m., Šiaulių r. bibliotekų projektus parėmė Kultūros ministerija. Pažymėtina, kad vykdant Šiaulių m. ir

Moderniai visuomenei - naujoviška biblioteka. Projekto „Bibliotekos pažangai“ (2008-2012) įtaka Lietuvos viešųjų bibliotekų raidai, p. 6. Prieiga per internetą: http://www.bibliotekospazangai.lt/media/public/Atsisiuntimui/Moderniai\%20visuomenei-small. pdf. Žiūrèta 2018-09-12. 
Panevėžio m. bibliotekų projektus atsigręžta ị socialiai pažeidžiamų žmonių grupes. Šiaulių m. SVB vykdè projektą „Kompiuterinis ir informacinis raštingumas: mokymosi visą gyvenimą galimybès“. Daugiausia dèmesio atkreipta ị negalią turinčius žmones, bedarbius, senjorus. I socialiai pažeidžiamas žmonių grupes buvo orientuotas Panevėžio m. bibliotekos projektas „E-žinios kiekvienam“. Organizuoti kompleksiniai informacinio raštingumo kursai, neịgaliuosius apmokant namuose ar neiggaliụjų draugijos patalpose. Šiaulių r. centrinè biblioteka ir Gilaičių filialas vykde projektą „Informacinès technologijos tiltas tarp kartų“. Gilaičių, Sauginių ir aplinkinių kaimų vyresniosios kartos žmonèms ir jaunimui organizuoti kompiuterinio raštingumo mokymai. Mokymo programos medžiaga išleista atskiru leidiniu „Informacinès technologijos - tiltas tarp kartų“.

Plètėi gyventojų skaitmeninio raštingumo ugdymo projektų tematika. Turiningą skaitmeninio raštingumo ugdymo projektą $2014 \mathrm{~m}$. vykdè Lazdijų r. biblioteka. Kultūros ministerija parèmé bibliotekos projektą „Mus jungia biblioteka“. Igyvendinant projektą parengta mokymų programa ir organizuoti mokymai gyventojams, kurių metu Lazdijų r., Varènos r. ir Druskininkų bibliotekų lankytojai buvo supažindinti su elektroniniais žemèlapiais, Lietuvos erdvinès informacijos portalo www.geoportal.lt ir Registru centro REGIA teikiamomis elektroninėmis paslaugomis. Vykdydama projektą biblioteka surengè Lazdijų, Druskininkų ir Varénos ugdymo, švietimo įstaigoms ir regiono bibliotekų atstovams konferenciją "Medijų ir informacinis raštingumas: pažintis su naujienomis ir reklama" ${ }^{118}$. Atkreiptinas dèmesys ị Vilniaus $\mathrm{m}$. SCB ir asociacijos „Langas $\mathfrak{i}$ ateitị“ dalyvavimą tarptautiniame projekte „E. skautai - moderatorių iggalinimas skirtingų kartų dialogui“. Projektas finansuotas pagal „Leonardo da Vinci“ programą. Jo idèja - paskatinti jaunimo ir senjorų socialinę ir skaitmeninę ịtrauktị, mezgant skirtingų kartų dialogą bei tarpusavio supratimą. Kitaip tariant, buvo kuriamas mokymosi ratas, kuriame jaunuoliai mokè senjorus naudotis informacinėmis technologijomis, o senjorai dalijosi patirtimi, krašto istorijos žiniomis ir pan. Projektas buvo iggvendinamas Vilniaus centrinèje bibliotekoje Žirmūnuose, taip pat Antakalnio ir Pilaitès filialuose.

Tad gyventojai buvo supažindinami su naujomis elektroninėmis paslaugomis, mokomi naudotis ju teikiamomis galimybėmis. Apžvelgsime Ukmergès r., Raseinių, Ignalinos r., Prienų r. bibliotekų $2015 \mathrm{~m}$. vykdytus projektus. BMGF, KM [BP 2] ir SV parèmé Ukmergès r. SVB projektą „E-paslaugų fakultetas „Žinios naudingos tada, kai jos gali palengvinti gyvenimą“. Viešojoje bibliotekoje organizuoti kompiuterinio raštingumo ir elektroninių paslaugų kursai senjorams. BMGF, KM [BP 2] parèmé Raseinių, Ignalinos r., Prienų r. bibliotekų projektus. Raseinių biblioteką vykdè projektą „Pažangèjanti biblioteka kiekvienam“. Projekto tikslas - ugdyti gyventojų skaitmenines kompetencijas, ịtraukiant vietos bendruomenių narius ị skaitmeninio turinio kūrimą. Gyventojai supažindinti su skaitmeninio turinio kūrimo programų "Corel Draw“, „Adobe Photoshop“ ir „Adobe Premiere Pro“ pagrindais. Ignalinos r. biblioteka vykde projektą „Vidutinio, vyresnio ir pagyvenusio amžiaus žmonių informacinių, socialinių ir sveikatingumo igūdžių ugdymas naudojant naujausias kompiuterines technologijas Ignalinos rajono ir Visagino miesto bibliotekose“. Jo tikslas - sudaryti geresnes sąlygas gyventojams susipažinti ir naudotis elektroninèmis paslaugomis bei specialiomis kompiuterinemis programomis. Igyvendinant Prienų bibliotekos projektą "Inovatyvi komunikacija - naujos galimybės vartotojams (2015-2016 m.) " siekta suteikti rajono gyventojams kuo daugiau informacijos apie atvirosios prieigos informacinius išteklius. Vietos bendruomenès nariai per mokymus, edukacijas ir konsultacijas susipažino su elektroninèmis verslo, valstybinių institucijų viešosiomis ir administravimo paslaugomis; išmoko naudotis planšetinių kompiuterių teikiamomis galimybėmis. Paskatinti naudoti šiuolaikines inovatyvias technologijas siekta ir LKT paremtu bibliotekos projektu „Inovatyvi elektroninių paslaugų sklaida Prienų rajone“.

Informacijos, medijų raštingumas kartu su informacinių ir kompiuterinių technologijų raštingumu ir skaitmeniniu raštingumu vienas kitą papildo. UNESCO siūlo sujungti abu raštingumus ị vieną - medijų ir informacinị raštingumą. Žr. Grigas, V.; Šuminas, A.; Gudinavičius, A.; Grigaliūnas, M. Šiuolaikinès medijos ir informacija: požeminiai garažai Google karalystẻje. Vilnius: Akademinè leidyba, 2016. 
Kompiuterinio, skaitmeninio, informacinio raštingumo ugdymo projektus rẻmė LKT, ŠMM. Biržų r. biblioteka ịgyvendino projektą „E. paslaugos arčiau namų“ (2016 m., rejmèja - LKT). Surengti mokymai kaimo bendruomenėse. Mokymų grupės išklausė kursą pagal temas: internetas (informacijos paieška, išsaugojimas, www adresų kolekcijos); CV kūrimas; darbo paieška; elektroninès paslaugos (bibliotekų e. paslaugos, e. bankininkystė, e. valdžia ir kt.); el. paštas; socialiniai tinklai (Gmail, Facebook, Youtube); saugumas internete. ŠMM parèmė Marijampolès bibliotekos projektą „Neformaliojo suaugusiųjų švietimo ir tęstinio mokymosi programa IT akademija“. Partnerè - Marijampolès teritorinè darbo birža. Projekto tikslas - organizuojant kompiuterinio ir informacinio raštingumo, informacijos valdymo ir darbo su informacinèmis technologijomis mokymus ugdyti visuomenei ir darbo rinkai aktualias suaugusiųjų kompetencijas. Mokymų programą sudarè 9 moduliai: „Kompiuterinio raštingumo pradmenys“” „Dokumentų rengimas“, „Skaitmeninis raštingumas išsamiai“ ir kt., kuriuos programos dalyviai galëjo pasirinkti pagal poreikị ir pradinių žinių lygmenị.

Daugiau dèmesio skirta vyresniojo ir senyvo amžiaus vartotojams. Utenos biblioteka igyvendino projektą „Skaitmeninès atminties pamokos senjorams“ (2016 m., rẻmejja - ŠMM). Tai buvo mokymo programa Utenos TAU klausytojams. Ją sudare 9 teminiai moduliai. Mokymų temos: „Tekstinès ir vaizdinès informacijos skaitmeninimas“, „Interneto taikymas šeimos genealogijos ir lokaliosios bendruomenès istorijos tyrimuose“, „Informacijos publikavimas internete“, „Ką paliksime anūkams?“ ir kt. Lietuvos kultūros taryba, Kultūros ministerija, UAB „Mūsų laikas“ parémé Klaipėdos m. SVB projektą „Nugalèk elektroninių paslaugų baimę“ (2017 m.). Projektas turejjo daug partnerių: Všț „Trečiasis amžius", Klaipėdos pagyvenusių žmonių asociacija ir kt. Siekta skatinti vyresniojo amžiaus žmones aktyviau naudotis elektroninèmis paslaugomis, padèti nugalèti baimes, siekiant sumažinti informacinę ir skaitmeninę atskirtị, ir užtikrinti viešujų paslaugų prieinamumą bei mokymosi visą gyvenimą galimybę.

Šiek tiek padaugejo projektų, skirtų medijų ir informaciniam raštingumui ugdyti. Lietuvos kultūros taryba ir savivaldybė parèmė Lazdijų r. bibliotekos drauge su partneriais (Všt̨ Lazdijų švietimo centras, Lazdijų rajono Neigaliụjų draugija, Alytaus TAU Seirijų f.) projektą „Medijų ir informacinis raštingumas: galimybės ir iššǔkiai“ (2017 m.). Projekto tikslas - ugdyti visuomenès bendravimo ir naujo turinio kūrimo medijose igūdžius efektyviai naudojantis vaizdais, garsais ir tekstais. Surengti praktiniai mokymai, sukurtas virtualus turas po Lazdijų, Veisiejų, Seirijų bibliotekas. Vykdomus projektus siekta pritaikyti skirtingoms vartotojų grupèms. Šiaulių m. biblioteka $2016 \mathrm{~m}$. vykdè projektą „Medijų ir informacinio raštingumo mokymai Šiaulių miesto bendruomenėms“ (rèmejja - LKT, partnere - UAB „Media Traffic“). Jo tikslas - ugdyti jaunimo, taip pat organizacijų, dirbančių su neigaliais asmenimis, atstovų galimybes atsakingai naudotis, kritiškai vertinti ir analizuoti medijuotą informacinị turinị. Kauno m. biblioteka vykde projektą „Medijų ir informacinio raštingumo akademija“ (2017 m., rèmèjos - LKT, KM, SV). Projektas turèjo tikslą suteikti vyresniojo amžiaus žmonėms medijų ir informacinio raštingumo žinių bei praktinių jų panaudojimo i̇gūdžių. Kursų dalyviai mokèsi praktiškai naudotis ịvairiomis viešųjų institucijų internetu teikiamomis paslaugomis, kūrẻ savo profilio ar reikiamo produkto pristatymą socialiniuose tinkluose, gilinosi $\mathfrak{x}$ virtualaus pasaulio teikiamas galimybes. Siekiant užtikrinti mokymo programos tęstinumą ir ugdyti bibliotekininkų informacinio raštingumo ịgūdžius, buvo surengti $20 \mathrm{ak}$. val. mokymai 25 bibliotekos darbuotojams ${ }^{119}$. Panašių tikslu siekè LKT ir KM finansuotas Pasvalio bibliotekos projektas „Informacijos pasaulyje: suprask, vertink, naudok“ (2017-2018 m.).

Vaikų ir jaunimo kompiuterinio, skaitmeninio, informacinio raštingumo ugdymo uždaviniai buvo sprendžiami kai kurių edukacinių, kūrybinès meninès veiklos skatinimo projektų kontekste, taip pat vykdant atskirus projektus. Projektus, skirtus tam tikrų kategorijų vaikų ir jaunimo skaitmeniniam

119 Žr. Straupyte, M. Medijų ir informacinio raštingumo akademija (Kaunas). Tarp knygu, 2017, lapkritis, p. 39. 
raštingumui ugdyti, 2013 m. vykde Klaipėdos m., Trakų r. ir Ukmergès r. bibliotekos. Klaipėdos m. bibliotekos su partneriais (Klaipėdos pedagogų švietimo ir kultūros centras, Kretingos rajono pedagogų švietimo centras) vykdytas projektas „Kai „Google“ nepadeda, padès Biblioteka!“ (rèmëja - KM) buvo skirtas pedagogams ir vyresniųjų klasių gimnazijų moksleiviams. Informacinio raštingumo mokymais siekta supažindinti su kokybiškais interneto šaltiniais mokslui ir studijoms, skleisti ir populiarinti bibliotekų elektronines paslaugas, bibliotekose prenumeruojamas duomenų bazes, ugdyti gebëjimus bei skatinti naudotis bibliotekos sukurtais skaitmeninès informacijos šaltiniais. Trakų r. biblioteka vykdè projektą „Esu jaunas, energingas, naujovių ieškantis žmogus“ (rèmëjos - KM ir SV), kurio tikslas - skatinti siekiančių žinių, tačiau neturinčių finansinių galimybiu jaunuolių motyvaciją naudotis naujomis informacinèmis technologijomis ir bibliotekos paslaugomis, susipažinti ir išbandyti naujausius mobiliuosius i̇renginius (planšetinius kompiuterius), programinę įrangą ir kitas modernias technologijas. Ukmergès r. biblioteka vykdė KM paremtą projektą „@š mokausi su draugais“. Projektas skirtas „Ryto“ specialiosios mokyklos mokiniams (intelekto sutrikimų turintiems vaikams). Buvo siekiama suteikti vaikams ir jaunimui galimybę igyti kompiuterinio raštingumo pagrindus ir tobulinti jau turimus informacinio raštingumo igūdžius.

Aptarsime 2015-2017 m. projektus. Marijampolès biblioteka su partneriais (V̌̌t „Marijampolès telekinas“, kūrybos namai „Exter“) vykdè BMGF ir KM [BP 2] projektą „IT kartos iniciatyvos bibliotekoje“. Pagrindinis projekto tikslas - skatinti jaunimo saviraišką ir bendruomeniškumą, gerinant galimybes kūrybiškai naudoti informacines technologijas. [̨kurtose Audiovizualinių menų dirbtuvès buvo ugdomos jaunimo audiovizualinių menų skaitmeninio turinio kūrimo kompetencijos. Kauno r. biblioteka $2017 \mathrm{~m}$. iggyvendino Lietuvos kultūros tarybos finansuotą projektą „Inovacijų keliu: atrask, išbandyk ir tobulèk“. Igyvendinant projektą centrinejje bibliotekoje ir šešiuose jos padaliniuose (Domeikavos, Ežerèlio, Lapių, Piliuonos, Ringaudų ir Zapyškio) vaikams ir paaugliams vyko „Lego robotikos“, „Minecraft“ ir „Actionbound“ edukaciniai renginiai. Projekto dalyviai kūrè įvairias konstrukcijas trimateje žaidimo erdvèje, konstravo robotus „Lego Mindstroms EV3“ ir „m-Bot“, mokesi juos programuoti. Surengtas moksleivių kūrybinių darbų konkursas „Išmanusis miestas“. Per konkursą jaunieji dalyviai projektavo išmanųj ̨ miestą. Konkurso nugalètojus rinko vertinimo komisija ${ }^{120}$. Klaipèdos m. biblioteka vykdè projektą „Medijos - kas, kodèl ir kaip?“ (rèmëjos - LKT, KM, UAB „Mūsų laikas“; partneris - Klaipédos miesto pedagogų švietimo ir kultūros centras). Jo tikslas - ugdyti jaunimo gebejjimus prasmingai, efektyviai, kūrybiškai naudotis ir kurti kokybišką tekstinị, vizualinị ir audiovizualinị turinị medijose.

Savivaldybės parėmé Švenčionių r. SVB filialo ir Kretingos r. bibliotekų projektus. $2015 \mathrm{~m}$. Švenčionių r. SVB Švenčionèlių filialas vykdè projektą „Kompiuterio labirintai ${ }^{{ }^{\prime 121}}$. Kretingos r. biblioteka 2017 metais vykdè projektą „Naujausios technologijos Z kartai“"122. Vaikai, pakviesti susipažinti su programavimo pagrindais, garso efektų panaudojimu animacijoje bei interaktyvumo galimybėmis, kūrè animacinius filmukus „Autodesk Maya“ 3D kompiuterinès grafikos modeliavimo programa.

\subsubsection{Kraštotyros ir kultūros paveldo aktualizavimo, etninès kultūros, istorijos projektai}

Kraštotyros ir kultūros paveldo aktualizavimo, etninès kultūros, istorijos projektai glaudžiai tarpusavyje susiję. 13, 14, 15 lentelèse pateikiami duomenys apie projektų vykdymą Panevėžio apskr. ir Klaipèdos apskr. bibliotekose, kurios pasiekė gerų rezultatų šioje srityje ir Utenos apskr. bibliotekų, pasiekusių vidutiniškus rezultatus.

\footnotetext{
20 Pirmą vietą užèmè moksleiviai Jokūbas Žmuida ir Justas Jonkus, suprojektavę išskirtinị, itin originalų Garliavos miestelį. Žr. Vasauskaitė, R. Projektavome išmanujji miestą (Kaunas). Tarp knygų, 2017, lapkritis, p. 39-40.

121 Apie projekto turinį bibliotekos dokumentai informacijos nepateikia.

122 Mokslininkų nuomone, Z kartai priklauso vaikai, gimę po $1995 \mathrm{~m}$.
} 
13 lentelè. Panevėžio apskr. bibliotekų (6) kraštotyros ir kultūros paveldo aktualizavimo, etninės kultūros, istorijos projektų vykdymas 2007, 2013, 2015-2017 metais (skliaustuose - bibliotekų skaičius apskrityje, vykdytų projektų skaičius, rėmėjų tipas: $\mathrm{Tr}$ - tarptautinis rėmëjas, $\mathrm{Nr}$ - nacionalinis rėmëjas, $\mathrm{Vr}$ - vietos rèmëjas)

\begin{tabular}{|c|c|c|}
\hline \multirow[t]{2}{*}{1} & \multirow[t]{2}{*}{2007 m. } & $\begin{array}{l}\text { Projektus vykdė Kupiškio r. SVB }(1, \mathrm{Nr}-1) \text {, Pasvalio SVB }(1, \mathrm{Nr}-1, \mathrm{Vr}-3) \text {, Rokiškio r. } \\
\operatorname{SVB}(8, \mathrm{Nr}-4, \mathrm{Vr}-6 \text {, nenurodyta - 1) }\end{array}$ \\
\hline & & Projektų nevykdė Biržų r. SVB, Panevėžio m. SVB, Panevėžio r. SVB \\
\hline \multirow[t]{2}{*}{2} & \multirow[t]{2}{*}{$2013 \mathrm{~m}$} & $\begin{array}{l}\text { Projektus vykdė Biržų r. SVB (1, nenurodyta - 1), Kupiškio r. SVB }(2, \mathrm{Nr}-2, \mathrm{Vr}-1) \text {, Pas- } \\
\text { valio SVB }(7, \mathrm{Nr}-4, \mathrm{Vr}-4 \text {, nenurodyta - 1), Rokiškio r. SVB }(6, \mathrm{Nr}-4, \mathrm{Vr}-6)\end{array}$ \\
\hline & & Projektų nevykdė Panevėžio m. SVB, Panevėžio r. SVB \\
\hline \multirow[t]{2}{*}{3} & \multirow[t]{2}{*}{$2015 \mathrm{~m}$} & $\begin{array}{l}\text { Projektus vykdė Panevėžio m. SVB }(2, \mathrm{Nr}-2) \text {, Panevėžio r. SVB }(1, \mathrm{Tr}-1, \mathrm{Nr}-1) \text {, Pasva- } \\
\text { lio SVB }(3, \mathrm{Nr}-2, \mathrm{Vr}-4 \text {, nenurodyta - 1) Rokiškio r. SVB }(3, \mathrm{Nr}-2, \mathrm{Vr}-3)\end{array}$ \\
\hline & & Projektų nevykdė Biržų r. SVB, Kupiškio r. SVB \\
\hline \multirow[t]{2}{*}{4} & \multirow[t]{2}{*}{2016 m. } & $\begin{array}{l}\text { Projektus vykdė Biržų r. SVB (1, Nr - 1), Kupiškio r. SVB (1, Nr - 1), Panevèžio r. SVB (5, } \\
\operatorname{Tr}-5, \mathrm{Nr}-1, \mathrm{Vr}-5) \text {, Pasvalio SVB }(2, \mathrm{Nr}-2, \mathrm{Vr}-3) \text {, Rokiškio r. SVB }(3, \mathrm{Nr}-2, \mathrm{Vr}-3)\end{array}$ \\
\hline & & Projektų nevykdè Panevėžio m. SVB \\
\hline \multirow[t]{2}{*}{5} & \multirow[t]{2}{*}{2017 m. } & $\begin{array}{l}\text { Projektus vykde Kupiškio r. SVB }(4, \mathrm{Tr}-1, \mathrm{Nr}-2, \mathrm{Vr}-6) \text {, Panevėžio r. SVB }(5, \mathrm{Nr}-2 \text {, } \\
\text { Vr - 4), Pasvalio SVB }(1, \mathrm{Nr}-1, \mathrm{Vr}-3) \text {, Rokiškio r. SVB }(4, \mathrm{Nr}-3, \mathrm{Vr}-4)\end{array}$ \\
\hline & & Projektų nevykdė Biržų r. SVB, Panevėžio m. SVB \\
\hline \multicolumn{2}{|c|}{$\begin{array}{l}\text { Projektų skaičius, } \\
\text { tarptautinių, } \\
\text { nacionalinių, } \\
\text { vietos rėmėjų } \\
\text { parama vykdant } \\
\text { projektus }\end{array}$} & $\begin{array}{l}\text { Vykdyta projektų 61; paramos teikèjų skaičius (per metus): } \mathrm{Tr}-7, \mathrm{Nr}-38, \mathrm{Vr}-55 \text {, nenu- } \\
\text { rodyta }-4\end{array}$ \\
\hline \multicolumn{3}{|c|}{$\begin{array}{l}\text { Vykdytas } 61 \text { projektas. } 4 \text { bibliotekų projektinè veikla buvo } \\
\text { de } 24 \text { projektus, Pasvalio SVB - 14, Panevèžio r. SVB - } 11 \text { (2 } \\
\text { 2013, 2016-2017 m.). Atkreiptinas dèmesys, kad Biržų r. SV } \\
\text { lenteleje nenurodytas metais. Vyravo vietos rèmèjų parama. }\end{array}$} \\
\hline \multicolumn{3}{|c|}{$\begin{array}{l}14 \text { lentele. Klaipèdos apskr. (7) bibliotekų kraštotyros ir kultūros paveldo aktualizavimo, etninès kultūros, } \\
\text { istorijos projektų vykdymas 2007, 2013, 2015-2017 metais }\end{array}$} \\
\hline \multirow[t]{2}{*}{1} & \multirow[t]{2}{*}{$2007 \mathrm{~m}$} & $\begin{array}{l}\text { Projektus vykde Klaipėdos m. SVB }(1, \mathrm{Nr}-1) \text {, Klaipėdos r. SVB }(6, \mathrm{Nr}-2, \mathrm{Vr}-4), \mathrm{Kretin}- \\
\text { gos r. SVB }(15, \mathrm{Vr}-16) \text {, Palangos SVB }(1, \text { nenurodyta - 1), Šilutès r. SVB }(8, \mathrm{Nr}-2, \mathrm{Vr}-7)\end{array}$ \\
\hline & & Projektų nevykdė Neringos SVB, Skuodo r. SVB \\
\hline \multirow[t]{2}{*}{2} & \multirow[t]{2}{*}{$2013 \mathrm{~m}$} & $\begin{array}{l}\text { Projektus vykdė Klaipėdos m. SVB }(1, \mathrm{Nr}-1) \text {, Klaipèdos r. SVB }(3, \mathrm{Vr}-3) \text {, Kretingos r. } \\
\text { SVB }(11, \mathrm{Nr}-1, \mathrm{Vr}-10) \text {, Skuodo r. SVB }(1, \mathrm{Nr}-1) \text {, Šilutès r. SVB }(2, \mathrm{Nr}-1, \mathrm{Vr}-1)\end{array}$ \\
\hline & & Projektų nevykdė Neringos SVB, Palangos SVB \\
\hline \multirow[t]{2}{*}{3} & \multirow[t]{2}{*}{$2015 \mathrm{~m}$} & $\begin{array}{l}\text { Projektus vykdė Klaipèdos r. SVB (1, Vr - 1), Kretingos r. SVB (10, Nr }-1, \mathrm{Vr}-10), \mathrm{Pa}- \\
\text { langos SVB }(1, \mathrm{Tr}-1, \mathrm{Nr}-1) \text {, Skuodo r. SVB }(4, \mathrm{Tr}-1, \mathrm{Nr}-4) \text {, Šilutès r. SVB }(3, \mathrm{Vr}-2 \text {, } \\
\text { nenurodyta - 1) }\end{array}$ \\
\hline & & $\mathrm{m}$ SVB \\
\hline
\end{tabular}


Projektus vykdė Klaipėdos m. SVB (3, Nr - 5), Kretingos r. SVB (6, Vr - 6), Palangos SVB

42016 m. (1, Tr $-1, \mathrm{Nr}-1)$, Skuodo r. SVB (3, Tr - 1, Nr - 3), Šilutės r. SVB (2, Nr - 2, Vr - 3)

Projektų nevykdè Klaipėdos r. SVB, Neringos SVB

Projektus vykdè Klaipėdos m. SVB (1, Nr - 1), Klaipėdos r. SVB (5, Vr - 6), Kretingos r.

$2017 \mathrm{~m}$.

$\operatorname{SVB}(7, \mathrm{Vr}-7)$, Skuodo r. SVB (3, Nr - 2, Vr - 2), Šilutès r. SVB $(1, \mathrm{Nr}-2, \mathrm{Vr}-1)$

Projektų nevykdè Neringos SVB, Palangos SVB

Projektų skaičius, tarptautinių, nacionalinių, vietos rèmèjų Vykdyta projektų: 100; paramos teikejjų skaičius (per metus): $\mathrm{Tr}-4, \mathrm{Nr}-31, \mathrm{Vr}-79$, nenuparama vykdant projektus

Vykdyta lygiai 100 projektų. Puikių rezultatų pasiekė Kretingos r. SVB, Šilutès r. SVB, Klaipėdos r. SVB, Skuodo r. SVB. Kretingos r. SVB vykdė 49 projektus, t. y. beveik pusę visų projektų (projektai paprastai smulkios tematikos, 2 projektus finansavo nacionaliniai rèmejjai, 1 - Klaipėdos apskrities viršininko administracija ir 49 - savivaldybès). Šilutès r. SVB vykdè 16, Klaipèdos r. SVB - 15 projektų (nevykdè 2016 m.), Skuodo r. SVB - 11 projektų (nevykdè 2007 m.). Vyravo vietos rèmëjų parama.

15 lentelè. Utenos apskr. bibliotekų (6) kraštotyros ir kultūros paveldo aktualizavimo, etninès kultūros, istorijos projektų vykdymas 2007, 2013, 2015-2017 metais

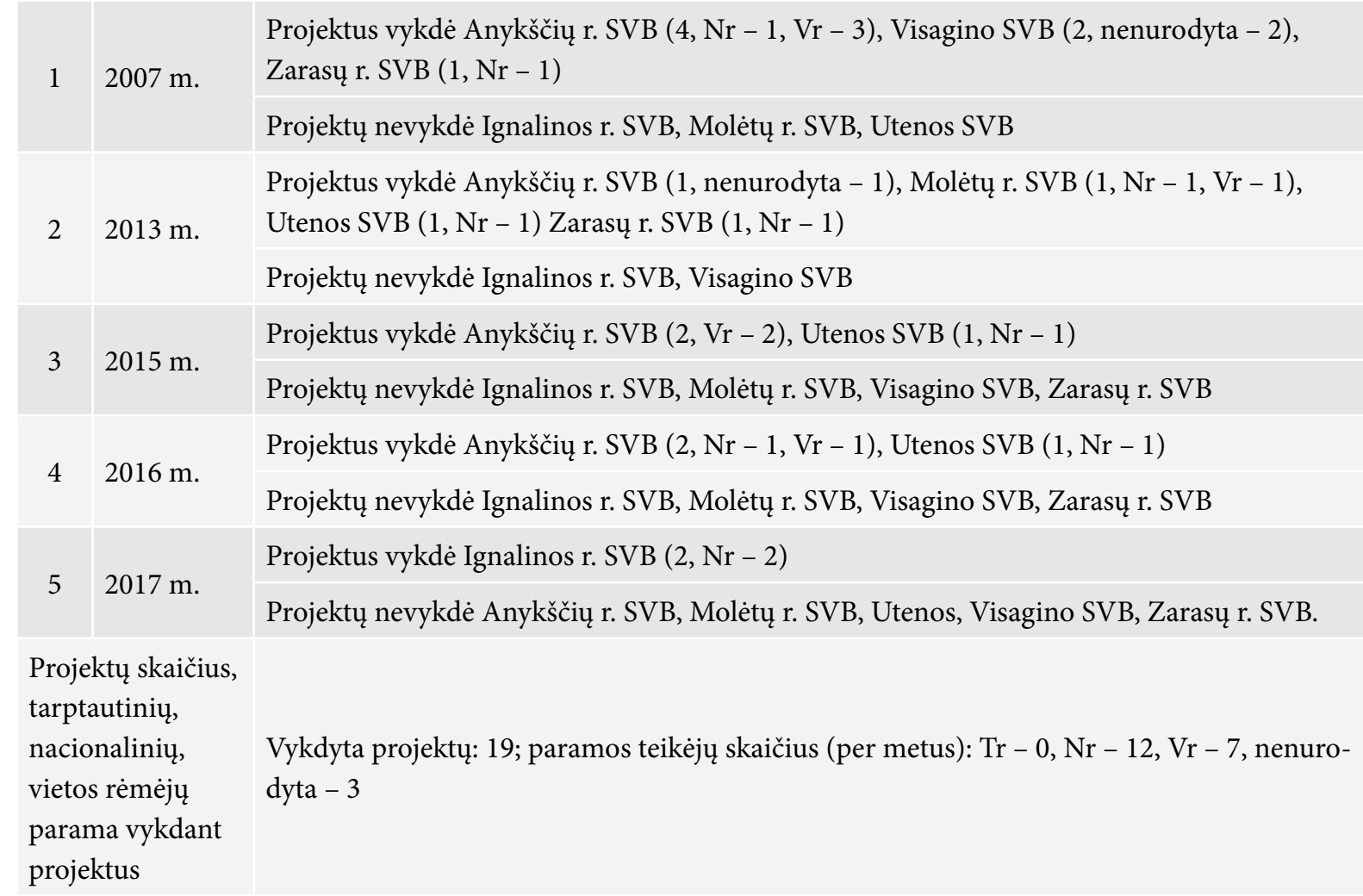

Vykdyta 19 projektų. Daugiausia projektų vykde Anykščių r. SVB (9 projektai). Kitų bibliotekų projektinès veiklos apimtis mažesnè: Utenos SVB vykdė 3, Zarasų r. SVB, Ignalinos r. SVB, Visagino SVB po 2 projektus. Dominavo nacionalinių rèmèjų parama. 
Tarp kitose apskrityse veikiančių bibliotekų gerų projektinès veiklos rezultatų 2007-2017 m. pasiekè Kauno r. SVB (Kauno apskr.), Marijampolès SVB, Kalvarijos SVB (Marijampolès apskr.), Tauragès r. SVB (Tauragės apskr.), Šiaulių r. SVB, Šiaulių m. SVB (Šiaulių apskr.), Plungès r. SVB (Telšiu apskr.), Elektrènų SVB (Vilniaus apskr.), Alytaus r. SVB (Alytaus apskr.). Tačiau ne visos bibliotekos 2007, 2013, 2015-2017 metais vykdè kraštotyros ir kultūros paveldo aktualizavimo, etninès kultūros, istorijos projektus (pavyzdžiui, Kauno apskrityje tokių projektų nevykdè Kėdainių r. SVB, Jonavos r. SVB, Alytaus apskrityje - Alytaus SVB).

Kraštotyros ir kultūros paveldo aktualizavimo projektai. Aktualizuojant kultūros paveldą išskirtinę reikšmę turèjo vykdyti fundamentiniai projektai. Paminètinas Kretingos r. bibliotekos tęstinis projektas „Elektroninio leidinio Kretingos krašto enciklopedija kūrimas“, kurị 2007 m. parèmé savivaldybė. Svetainè sukurta $2010 \mathrm{~m}$. Enciklopedijos turinị sudaro straipsnių rinkinys, iliustruotas nuotraukomis ir (ar) vaizdo medžiaga, kuris pagal tematiką suskirstytas ị 10 pagrindinių kategorijų (temų): gamta, geografija, kultūra, religija, švietimas, sportas, sveikata, visuomenè, verslas ir istorija. Elektroninėje enciklopedijoje pateikiama susisteminta informacija skirta ne tik kretingiškiams, bet ir visos Lietuvos žmonèms, išeiviams, visiems, besidomintiems Kretingos krašto istorija, kultūra, gamta, nusipelniusių žmonių biografijomis ir kt. Vilniaus apskr. bibliotekos nuo $2008 \mathrm{~m}$. partnerio teisèmis dalyvavo tęstiniame VAVB vykdomame projekte „Vilnijos vartai“. „Vilnijos vartų“ projekto tikslas - atskleisti visuomenei vienoje vietoje sutelktą, susistemintą, atrinktą, išliekamąją vertę turinčią ir bibliografiniais sąrašais paremtą informaciją apie Vilniaus apskritị, jos materialinès ir dvasinès kultūros paveldą, savitas tradicijas. Nuo $2008 \mathrm{~m}$. Pasvalio biblioteka vykdo projektą „Pasvalio krašto skaitmeninè biblioteka: kultūros paveldas virtualioje erdvejje“. Pradèta kurti lokali skaitmeninto kultūros paveldo saugykla „Pasvalia“ - tai Pasvalio krašto kultūros švietimo institucijose, privačiuose archyvuose sukaupto kultūros paveldo, Lietuvos ir užsienio atminties institucijose saugomo Pasvalio krašto paveldo atvėrimas kraštui, Lietuvai, pasauliui. Abu projektus parèmè Kultūros ministerija.

$2015 \mathrm{~m}$. didelius projektus, skirtus vietos kultūros paveldui aktualizuoti, vykdè Plungès r. biblioteka, o Alytaus r. biblioteka dalyvavo VAVB projekte. Juos paremė BMGF ir KM [BP 2]. Plungès r. SVB kartu su grupe partnerių (Žemaičių dailès muziejus ir kt.) vykdè projektą „Plungès išmanusis parkas“. Sukurtas Plungès išmaniojo parko interneto puslapis plugesparkas.lt ${ }^{123}$. Socialiniame tinkle „Instagram“ sukurta viešosios bibliotekos paskyra „Plunge_Clock_Tower_Library“, kurioje bendrinamos nuotraukos su grotažymėmis \#plunge, \#plungelibrary, \#park, \#biblioteka, \#library, \#lithuania, \#clocktower. Idomu: mažojoje lauko bibliotekèlèje, pastatytoje šalia laikrodinès, paslèptas lobis, $\mathfrak{i}$ kurị ịdèti bibliotekos atributai. Lobis užregistruotas pasaulinèje „Geocaching" lobių paieškos sistemoje. Alytaus r. SVB partnerio teisėmis pradejo dalyvauti VAVB vykdomame tęstiniame projekte „\#MŪSŲ KRAŠTAS: Alytaus ir Vilniaus bendruomenių tapatumo ugdymas bibliotekose“. Pasak sumanytojų, projekto tikslas - Alytaus ir Vilniaus apskričių bibliotekose sukauptą kraštotyros informaciją padaryti lengviau prieinamą ir patrauklią, kad bendruomenès ja galètų naudotis laisvalaikiui ir poilsiui savarankiškai planuoti, kraštui pažinti, studijoms. Igyvendinant projektą sukurta interneto svetainė „Dainavos kraštas“.

2017 m. LKT parėmè Marijampolès, Kauno r., Elektrėnų bibliotekų projektus. Marijampolès biblioteka vykdè projektą „Suvalkijos elektroninè biblioteka“. Projekto partneriai: Marijampolès apskrities archyvas, Lietuvos prezidento K. Griniaus memorialinis muziejus, Marijampolès Rimanto Stankevičiaus pagrindinè mokykla ir kt. Pagrindinis projekto tikslas - užtikrinti kultūros vertybių išlikimą, apsaugą ir sklaidą, sukuriant prieinamą visuomenei elektroninę biblioteką. Skaitmeninta senoji spauda, senosios fotografijos, miesto planavimo projektai ir brèžiniai, grožinè literatūra, susijusi su Sūduvos regiono kultūra, tradicijomis ir žmonèmis. Kauno r. biblioteka igyvendino projektą „Išmanusis kultūros kelias

${ }^{123}$ Tarptautineje turizmo, kelionių ir aktyvaus laisvalaikio parodoje „Adventur“ (2017 m. sausio 20-22 d.) „Plungès išmanusis parkas“ buvo pripažintas sèkmingiausiu Lietuvos turizmo projektu $2016 \mathrm{~m}$. 
Kauno rajone“. Išmanusis kultūros kelias - tai interaktyvi, šiuolaikinių technologijų sprendimais pagrịsta mokymosi ir kultūros pažinimo priemonè, skirta Lietuvos ir užsienio vartotojui susipažinti su Kauno rajone esančiais reikšmingais ir unikaliais kultūros paveldo objektais bei žymiais rajono žmonèmis. Objektai išdèstyti interaktyviame žemèlapyje (sodybos, namai, dvarai, paminklai, kryžiai, atminimo ženklai lietuviško žodžio kūrẻjams ir skleidejjams ir kt.). Elektrènų biblioteka vykdè projektą „Kultūros paveldo išsaugojimas, mokymai ir sklaida pasitelkiant inovatyvias technologijas“. Projekto tikslas - sukurti naują, inovatyviomis technologijomis paremtą bibliotekos paslaugą - interaktyvų pažintinį žemèlapị bei edukacinę programą, supažindinančią su Elektrènų savivaldybès kultūros paveldo objektais. Žemèlapis ir edukacine programa paskelbti bibliotekos portale $w w w$.paveldas.elektrenai.mvb.lt.

Atkreiptinas dėmesys, kad projektai suteikè bibliotekoms galimybę leisti žurnalus. Radviliškio r. SVB vykdè tęstinį projektą „Radviliškio krašto kultūros ir istorijos žurnalo Radviliškio kraštas leidyba“. Žurnalo leidybą paremė KSRF. Žurnalas „Radviliškio kraštas“124 skelbia publikacijas kultūros ir istorijos, kraštotyros temomis. Pasvalio biblioteka vykdè tęstini projektą „Šiaurès verdenès“ (rèmëjas - Spaudos, radijo ir televizijos rèmimo fondas). Pagrindinè projekto idejja - pažinti ir išsaugoti savo krašto, tarmès, savų šaknų, šeimos ir bendruomenès vertybes, ịtraukti jaunimą ir užsienyje gyvenančius kraštiečius ị šią veiklą. Tai igyvendinama drauge su visuomenine redakcija leidžiant istorijos ir kultūros žurnalą „Šiaurietiški atsivèrimai" ${ }^{125}$. Rokiškio r. biblioteka ir Juozo ir Alfonso Keliuočių palikimo studijų centras vykdè tęstinị projektą „Rokiškio krašto žurnalas Prie Nemunèlio“126 (rèmèja - SV). Žurnalas skelbia publikacijas apie krašto istoriją, kultūrą, tradicijas ir papročius, bendruomenių kultūrinị gyvenimą, J. ir A. Keliuočiu kūrybinị palikimą.

Kraštotyros informaciją ir krašto kultūros paveldą 2007 m. aktualino Šilutès r. SVB, Elektrènų, Visagino SVB, Rokiškio r. SVB, Kauno m. SVB „Aušros“ filialo vykdomi projektai. Jų tematika ịvairi. Šilutès r. SVB vykdė KM paremtą projektą „Pamario krašto kultūros paveldo aktualizavimas ir sklaida socialinèje aplinkoje“, skirtą regiono kraštotyrininkams, visiems, besidomintiems etnokultūra, krašto knygos ir rašto paveldu, knygininkų veikla. Nauja informacija papildyta interneto svetainè www.silutesknygininkai.lt. Parengti šeši bibliografiniai sąrašai Mažosios Lietuvos tematika Lietuvos istorijos laikraščio „Voruta“ interneto svetainei „Mažoji Lietuva“ ir „Literatūrinis maršrutas po Šilutės rajoną“ Šilutès turizmo ir verslo informacijos centro leidiniui „Šilutės rajono kultūros paveldo maršrutai“. Elektrẻnų SVB ịgyvendino Lietuvos tūkstantmečio minèjimo direkcijos prie LR Prezidento kanceliarijos finansuotą projektą „Renginių ciklas Elektrènų krašto kultūros paveldo istorija ir dabartis“. Visagino m. biblioteka vykdè jaunimo pilietinio ir tautinio ugdymo projektą „Lietuvos šiaures rytų Aukštaitija - kur mūsų proseneliai gyveno“ ir nekilnojamojo kultūros paveldo pažinimo bei sklaidos projektą „Lietuvos šiaurès rytų Aukštaitijos kultūros paveldo paminklai“ (rèmèjai nenurodyti). Projektai tarpusavyje susiję. Pirmas projektas suteikè galimybę moksleiviams keliauti po savo kraštą, tyrinèti architektūros ir istorijos objektus, juos piešti, fotografuoti, filmuoti. Igyvendinant antrą projektą bibliotekos meno skaitykloje-galerijoje buvo parengta senujų krašto statinių (malūnų, bažnyčių, vienuolynų ir kt.) piešinių ir nuotraukų paroda, pristatytas pažintinis lankstinukas „Lietuvos šiaurès rytų Aukštaitijos kultūros paveldo paminklai 2007 m.", parodytas sukurtas filmas apie kultūros paveldo objektus. Rokiškio r. biblioteka vykdè projektą „Rankraštynas - vertingiausia kultūrinio paveldo dalis“ (rèmèjas nenurodytas). Biblioteka organizavo rankraščiu ekspoziciją, kurioje pateikè per 260 saugojimo vienetų. Kauno m. bibliotekos „Aušros“ filialas drauge su bendruomenès centru „Žaliakalnio aušra“ vykdè tęstinị projektą „Žaliakalnio bendruomenès atmintis“" (rèmèja - SV). Jis turèjo tikslą sutelkti vienoje vietoje, skaitmeninti ir išsaugoti unikalų Žaliakalnio bendruomenès kultūros paveldą, organizuoti jo sklaidą; ịtraukti Žaliakalnio bendruomenę ị kultūros paveldo išsaugojimo veiklas, ugdyti bendruomeniškumą. 2007 metai buvo skirti romanistikos profesoriaus Vlado Dubo 120-osioms gimimo metinèms, jo moksliniam palikimui.

\footnotetext{
124 Žurnalas leidžiamas nuo $2004 \mathrm{~m}$.

125 Laikraštis „Šiaurietiški atsivèrimai“ leidžiamas nuo 1999 m, žurnalas išleistas 2002 m., nuolat leidžiamas nuo 2005 m.

126 Žurnalas leidžiamas nuo 2006 m. 2012 m. analogiškas projektas vadinosi „Romuvos keliais“.
} 
Projektai, skirti kraštotyros informacijai ir kultūros paveldui aktualizuoti, sèkmingai buvo vykdomi ir vèlesniais metais. 2011-2012 m. Kalvarijos bibliotekos igyvendintas projektas „Kalvarijos krašto kultūros bei istorijos puoselèjimas ir sklaida“" (rèmèjas - Europos žemès ūkio fondas kaimo plètrai) sujungè tokias temas: etninès kultūros sklaida Sūduvos regione, Kalvarijos praeitis, Kalvarijos krašto dvarvietės kaip nauji turistų traukos objektai. Šioms temoms nagrinèti buvo skirta konferencija. İsidèmètinas faktas bibliotekos filialas gavo tarptautinès institucijos paramą. Panevėžio r. SVB Velžio filialas $2012 \mathrm{~m}$. vykdè projektą „Oho, koks mano kaimas!“, kurị finansavo ES programa „Veiklus jaunimas“. Jaunimo iniciatyvinės grupès „Skeneriai“ dalyviai skenavo Velžio miestelio vaizdus, užrašinėjo ir skenavo pasakojimus, istorijas, legendas. Suskaitmeninto kultūros paveldo reikšmę bibliotekos lankytojams siekè atskleisti Klaipėdos m. SVB 2011 m. vykdytas projektas „Tavo kultūros metaduomenys“ (rèmëja - KM).

Reikšmingus darbus $2013 \mathrm{~m}$. atliko Pasvalio biblioteka. Biblioteka gavo „Europeanos“ generalinès direktorès Jill Cousins pasiūlymą ịsilieti ị šio projekto viešųjų bibliotekų tinklą. Pasiūlymas buvo priimtas. 2013 m. buvo vykdomas Pasvalio SVB projektas „Europeana 1989: Pasvalio Mariaus Katiliškio viešosios bibliotekos patirtis“ (rẻmèjas nenurodytas). Projekto partneriai: Kauno apskrities viešoji biblioteka (KAVB), Utenos SVB. Pasvalio bibliotekai teko užduotis dokumentuoti „Europeanoje“ Sajūdžio laikotarpi (bibliotekos rankraštyne saugomas Pasvalio Sąūdžio archyvas). Be to, bibliotekos darbuotojai rinko Baltijos kelio ir kitų Sąūdžio ịvykių liudijimus, kvietè pasvaliečius savarankiškai skelbti Baltijos kelio liudijimus „Europeanoje 1989“. Pasvalio biblioteka tapo „Europeanos“ viešųjų bibliotekų tinklo nare. Bibliotekos fonduose saugomais dokumentais pasidalyta su pasauliu ${ }^{127}$. Kultūros ministerija parèmé Šiaulių m. SVB projektą „Šiaulių krašto pažinimas: interaktyvi skaitmeninio turinio sklaida jaunųjų kraštotyrininkų internetiniame puslapyje“ (partnerès - UAB „Edukacinès sistemos“, Všt „3D Vilnius"). Padedami partnerių jaunieji kraštotyrininkai sukūrẻ ir paskelbė interaktyvų Šiaulių miesto žemèlapi bei tris interaktyvius žaidimus: „Sudèk Šiaulių vaizdelį“, „Šiaulių miesto lobiai“, „Pažink Šiauliu ižžymybes“. Žemèlapis yra puiki edukacinè priemonè, vedlys po Šiaulius ir jų apylinkes, žymius kultūros paveldo objektus. Rokiškio r. biblioteka vykdè tęstini projektą „Sèlių kultūra virtualioje erdvejje" (rèmejjas - Spaudos, radijo ir televizijos rèmimo fondas). Siekta pristatyti sèlių krašto kultūrini paveldą. Vykdant projektą taip pat buvo pateikiama informacija apie regiono kultūrinius renginius, iniciatyvas. Mažosios Lietuvos kultūros paveldui projektą skyrè Tauragès r. SVB. Centrinè biblioteka, Lauksargių filialas, Tauragès kultūros centras ir Lauksargių pagrindinė mokykla vykdė projektą „Mažosios Lietuvos kultūros atspindžiai Tauragès krašte" (rèmèjas nenurodytas). Centrinès bibliotekos darbuotojos ir Lauksargių filialo vedejja rinko ir sistemino informaciją apie mokytoją ir kraštotyrininką Joną Bicką ir Lauksargių krašto praeitị ${ }^{128}$.

Ivairioms temoms ir aktualijoms skirti 2015-2017 m. projektai. BMGF, KM [BP 2] parėmé Panevèžio r. SVB skaitmeninimo projektą „Štai koks mano kaimas“. Igyvendinti projektą padejo partneriai: Panevėžio rajono švietimo centras, Panevèžio rajono bendruomenių sąunga. Projekto sumanytojai pabrèžè, kad jo tikslas yra stiprinti bendruomenių kartų ryšị, kuriant krašto paveldo skaitmeninị turinị pasitelkus naujausias informacines ir ryšių technologijas. Kultūros paveldo departamentas prie KM 2015 m. suteikè paramą Kauno r. bibliotekos nekilnojamojo kultūros paveldo pažinimo, atgaivinimo ir sklaidos projektui „Ateitis paveldint praeitị“. Buvo nustatyta ir nufotografuota apie keturiasdešimt apleistų, nunykusių dvarų sodybų ar jų išlikusių fragmentų; užrašyti vietos gyventojų, kraštotyrininkų pasakojimai, atsiminimai apie dvaruose vykusị politinị, ūkinị, kultūrinị gyvenimą, ten gyvenusius žmones. Parengta mobili paroda lankytojams atskleidė dvarų statinių architektūrinę, istorinę vertę. Pasak bibliotekos darbuotojos Virginijos Tamašauskienès, ji ugdè supratimą, jog dvarų praeitis yra ịdomi ir spalvinga, dabartis - slogi, o ateitis priklauso nuo mūsų pagarbos kultūros paveldui ir pastangų jị išsaugoti ${ }^{129}$. Šiaulių r. SVB vykde projektą

Plačiau žr. Kazilionyte, V. Projektas „Europeana 1989“: Pasvalys atkuria Baltijos kelią. Tarp knygų, 2013, rugsèjis, p. 30-31.

${ }_{128}$ Lauksargių seniūnija - vienintelè Tauragès rajone, kurios teritorija priskiriama Mažajai Lietuvai (Klaipèdos kraštui).

129 Tamašauskiené, V. Rajono dvarai kilnojamojoje parodoje (Kaunas). Tarp knygu, 2016, sausis, p. 36. 
„Kuršėnų biblioteka - lituanistikos atminties ir sklaidos vieta“ (rèmėja - LKT). Projektas skirtas Kuršènų Vytauto Vitkausko bibliotekos 90-mečiui ir kalbininko V. Vitkausko 80-mečiui paminèti. Radviliškio r. SVB drauge su Radviliškio turizmo centru iggyvendino projektą „Radviliškis. Lankytinų objektų žemèlapis ir maršrutai“ (rèmëja - SV).

Kupiškio r. bibliotekos projektas „Bibliotekos - bendruomenėms“ (2016 m., rèmèja - LKT) buvo skirtas Kupiškio krašto kultūros paveldo, kraštotyros informacijos ir etnokultūros sklaidai bei bibliotekų ir bendruomenių kultūriniam bendradarbiavimui stiprinti. Skapiškyje vykusiame XX tarptautiniame teatrų festivalyje "Pienių vynas“ pristatyta projekto edukacinè programa „Mus sujungé juostų pynë“, skirta Skapiškyje praejusio amžiaus trečiame dešimtmetyje veikusioms Vandos Silvestravičiūtès tautinių juostų dirbtuvèms atminti. Paminètina Skuodo r. bibliotekos iniciatyva. $2017 \mathrm{~m}$. biblioteka vykdè LKT ir KM paremtą projektą „Tarptautine kultūrinių mainų savaite „Baltų genčiu - latgalių, kuršių ir žemaičių kraštų panašumai bei skirtumai“. Projekto partnerès: Rèzeknès miesto biblioteka, Priekulès krašto savivaldybė (Latvija), Skuodo žemaičių draugija. Siekta stiprinti kultūrinị bendradarbiavimą tarp Latgalos, Kuržemès ir Žemaitijos kultūros darbuotojų, suteikti galimybę kultūrininkams igyti naujų žinių apie vienas kito gimtuosius kraštus, su gautomis žiniomis supažindinti visuomenę, tarptautiniu mastu viešinti minètų kraštų ịvaizdị. Skuodo meno mokykloje surengta mokslinẻ konferencija. Viešnių iš Latvijos pranešimai buvo verčiami į žemaičių kalbą ${ }^{130}$.

LR Seimas 2017 m. paskelbè Piliakalniu metais. Bibliotekų projektai, skirti šiems metams, sudaro atskirą grupę. Lietuvos kultūros paveldo departamentas prie KM finansavo Kauno r. bibliotekos projektą „Kauno rajono kraštovaizdžio populiarinimo iniciatyvos ir sklaida“. Projekto tikslas - suaktyvinti visuomenès domejimąsi savo krašto vertybėmis ir kultūriniu kraštovaizdžiu, aktualizuojant Kauno rajone esančių piliakalnių istorijos pažinimą ir jų lankymą, juos fotografuojant ir prisidedant prie parodos „Piliakalniai - mūsų krašto identiteto dalis“ sukūrimo. Ignalinos r. biblioteka vykdè projektą „Piliakalnių istorija žadina vaizduotę", kurị finansavo LKT ir KM. Projekto partneriai: Aukštaitijos nacionalinio parko ir Labanoro regioninio parko direkcija, Všt „Mūsų Ignalina“, UAB „Nauja vaga“, Švenčionių rajono Kaltanenų ugdymo ir turizmo centras ir kt. Aplankyti Aukštaitijos nacionalinio ir Labanoro regioninio parkų bei Švenčionių krašto piliakalniai, surengti edukaciniai užsiemimai. Žurnalas „Tarp knygų“ informuoja, jog projekto renginiuose dalyvavo daugiau kaip 1000 lankytojų ${ }^{131}$. Savivaldybė finansavo Mažeikių r. SVB filialų projektus: Tirkšlių ir Šerkšnėnų filialų - „Ką byloja Daubarių piliakalnis“; Ukrinų, Pikelių ir Židikų filialų - „Piliakalniai - turtingas praeities pažinimo šaltinis“; Viekšnių filialo - „Gyvolių piliakalnio atsiradimo istorija“.

Igyvendinant projektus plečiamos ir modernizuojamos bibliotekų paslaugos. $2016 \mathrm{~m}$. LKT parèmė Pasvalio SVB projektą „Pasvalios modernizavimas ir plètra“. Jo tikslas - didinti Pasvalio krašto kultūros paveldo prieinamumą bei patrauklumą, modernizuojant portalą ir plečiant elektronines paslaugas. Taikant inovatyvius metodus ir technologijas sukurtas portalo grafinis dizainas, atnaujinti navigacijos irankiai ir kt. Vilniaus m. SCB drauge su UAB „Gluk media“, Lietuvos edukologijos universitetu, Kultūros paveldo centru èmèsi iggyvendinti projektą „Vilnius GO“ (2016-2018 m., rèmëja - LKT). 2016 m., igyvendinant pirmą projekto etapą, sukurta mobilioji programèlè supažindina su daugiau nei 100 kultūrinių, istorinių ir gamtinių Vilniaus miesto objektų. LKT ir KM parèmė Klaipèdos m. bibliotekos projektą „Kalbantys pastatai“ (2016 m.). Projekto tikslas - skleisti ir populiarinti informaciją apie suskaitmenintas Klaipėdos m. nekilnojamąsias kultūros vertybes bei jose gyvenusių (gyvenančių) kultūros šviesuolių atminimą. Kultūros vertybès viešinamos bibliotekos svetainėje „Klaipėdos miesto nekilnojamosios kultūros vertybès“. Svetaine pritaikyta QR technologijoms. Surengtas orientacinis žaidimas „Klaipėdos paveldo labirintai“, dalyvavo 22 komandos.

130 Žr. Strakšytė, B. Baltų vienybès dieną kartu minėjo latgaliai, kuršiai ir žemaičiai (Skuodas). Tarp knygu, 2017, spalis, p. 39.

131 Andrijauskiené, L. Istoriniais piliakalnių takais (Ignalina). Tarp knygu, 2017, spalis, p. 36. 
Pažymėtina, kad savivaldybių viešosios bibliotekos dalyvavo apskričių bibliotekų vykdytuose projektuose, skirtuose kultūros paveldui aktualizuoti. 2015 m. Kauno apskr. bibliotekos dalyvavo KAVB projekte „Išnykę, bet nepamiršti“. Buvo sukurtas elektroninis leidinys „Išnykę ir pasikeitę: pastatų istorijos“. Jame pateikta medžiaga ir nuotraukos apie buvusius ar išlikusius, bet pasikeitusius žymius pastatus. Šiaulių r. biblioteka dalyvavo ŠAVB projekte „Kraštotyros ekspedicija Ko liūdi kryžiai pakelèj“. Per ekspediciją užfiksuota daugiau nei 300 mažosios sakralinès architektūros objektų, atlikti matavimai, užrašyti pasakojimai apie kryžių ir koplytstulpių statymo iniciatorius ir autorius. Per ekspediciją surinkta faktografinè medžiaga apie Šiaulių rajone esančius kryžius suskaitmeninta ir paskelbta duomenų bazeje www.epaveldas.lt.

Atskira projektų grupè skirta kraštiečiams. Šilutès r. bibliotekai realizuojant Kultūros ministerijos ir savivaldybès 2007 m. paremtą projektą „Kraštiečių sueiga Pirmąkart susitikę šviesos parnešti, gera padaryti" buvo organizuota jau trečia kraštiečių sueiga. I ją sukviesti Lietuvoje ir užsienyje gyvenantys žymūs kraštiečiai, nusipelnę mokslo, meno ar kitose visuomeninio gyvenimo srityse. Per sueigą buvo rengiamos kraštiečių menininkų darbų parodos, koncertinès programos, kraštiečių kūrybos skaitymai ir kt. Panašių tikslų siekė Zarasų r. bibliotekos projektas „Pažink kraštiečius virtualioje erdvėje“ (rèmëja - KM), Kupiškio r. bibliotekos projektas „Sugrịžimai i téviškę“ ir Telšių r. bibliotekos projektas „Kraštiečių šventė Žemaičiu žemèj užaugę dideli“ (rèmèja - SV). Kraštiečiams ypač dèmesinga Biržų r. biblioteka. Jos projektus finansavo KRF. 2009 m. biblioteka vykdè projektus „Kai širdimi su tèviške suaugi“ (skirtas kraštiečio poeto Pauliaus Drevinio 90-osioms gimimo metinèms paminèti gimtuosiuose Gulbinuose) ir „Sugrịžimai i gimtinę“. I gimtinę sugrịžti buvo pakviesti poetas Jonas Strielkūnas, filosofè Jūratė Baranova, poetė Aušra Kaziliūnaitė, vienas žymiausių krepšinio trenerių Vladas Garastas, astronomas, muziejininkas Gunaras Kakaras, literatūrologas Virginijus Gasiliūnas. 2010 m. biblioteka vykdè projektą „Laukiami gimtinèje“, $2011 \mathrm{~m}$. - projektą "Gimtinès pakviesti“.

Iš 2016 m. projektų, skirtų kraštiečiams, paminètini turiningi Klaipèdos m. ir Telšių r. projektai. Klaipėdos m. biblioteka vykdè projektą „Gyvoji kraštotyra“ (rėmejos - LKT, KM). Jo tikslas - elektroninèje erdvèje išsaugoti klaipèdiečių autentiškus prisiminimus: su Klaipėda susijusią rašytinę, žodinę ir vaizdinę informaciją. Sukurta virtuali „Gyvosios kraštotyros“ erdvè. Telšiu r. bibliotekos projektas „Nuo rankraštinès knygos iki skaitmeninio pasakojimo („+ Gidas kraštiečiu galerijai kurti)“ (rèmejja - SV) skirtas žymių, nusipelniusių Telšiu kraštui asmenybių ir jų gerųjų darbų atminimui puoselèti virtualioje erdvejje. İdomiausia galerijos dalis - skaitmeniniai pasakojimai apie kraštiečius (trumpi filmukai apie žymų asmenį).

Igyvendinant projektus išleisti kraštotyrinio pobūdžio leidiniai. Kultūros ministerija 2007 m. parèmé Lazdijų r. SVB projektą, skirtą knygos „Burokaraistis“ 2 dalies leidybai. Kraštotyrinès tematikos leidinys pasirodè tais pačiais metais ${ }^{132}$. Ukmergès r. SVB Lyduokių filialas igyvendino projektą „Bibliografijos rodyklè Kraštotyrininkè Albina Katinaité-Navickiené“ (rèmèjas nenurodytas). Leidinys pasirodè tais pačiais metais ${ }^{133}$.

Pažymėtina Anykščių r. SVB projektinė veikla leidžiant kraštotyros leidinius. 2012 m. Anykščių r. biblioteka vykdè projektą „Leidinio Anykščiu krašto tyrèjo parankinè knyga leidyba“ (rèmëjas - KRF). Kraštietis prof. Osvaldas Janonis parengè tris knygas. 2012 m. išleistos dvi pirmosios knygos „Anykščiu kraštas Rusijos imperijos sudètyje (1795-1914 m.) ir Pirmojo pasaulinio karo metais (1914-1918 m. “134 $^{\text {“134 }}$ ir „Vardų rodykle “135. Trečioji knyga „Anykščių kraštas tarpukariu ir okupacijų metais“ išèjo 2014 m. ${ }^{136}$

132 Valeškevičiūtè-Zakarauskienè, O. Burokaraistis: istorija, buitis, papročiai, liaudies medicina, prietarai, tautosaka. Vilnius: Jandrija, 2007; 1 dalis išejo 2003 metais.

133 Kraštotyrininkè Albina Katinaitè-Navickienè: bibliografijos rodyklè / sud. J. Baškauskienè. Ukmergè: Valdo leidykla, 2007.

134 Anykščiu krašto tyrëjo parankinè knyga: kn. 1. Anykščiu kraštas Rusijos imperijos sudètyje (1795-1914 m.) ir Pirmojo pasaulinio karo metais (1914-1918 m.) / sud. O. Janonis. Anykščiai: Petro ofsetas, 2012.

135 Anykščiu krašto tyréjo parankine knyga: kn. 2. vardų rodyklè. Anykščiai: Petro ofsetas, 2012.

${ }_{136}$ Anykščių krašto tyrëjo parankinè knyga: kn. 3. Anykščiu kraštas tarpukariu ir okupacijų metais / parengè O. Janonis. Anykščiai: Petro ofsetas, 2014. 
Knygų paskirtis - palengvinti archyvinių dokumentų ir faktografinės medžiagos paiešką Anykščių rajono kraštotyrininkams ir kitiems Anykščių krašto praeities tyrëjams. Knygos reikšmingos ne tik Anykščiu krašto, bet ir visos Lietuvos istorijai, kultūrai. 2016 m. Anykščių r. biblioteka realizavo projektą „Anykščių kraštotyrininkų biobibliografinis žodynas“ (rèmejja - SV). Tais metais išleista leidinio pirmoji dalis - „Anykščių kraštotyrininkai. Biografijo ${ }^{\text {“ }}{ }^{137}$. Knygos sudarytojai: Krašto dokumentų ir kraštotyros skyriaus vedèja Audronė Berezauskienè ir kraštietis O. Janonis. Rengiant knygą talkino kraštietis Romualdas Vytautas Rimša ir kiti. Pridursime, kad kiek anksčiau igyvendinus Tauragès r. bibliotekos projektą „Tauragès krašto šviesuoliai“ (rèmèjas - KRF) išleista kraštotyrininkès Almos Mizgirienès to paties pavadinimo knyga ${ }^{138}$.

Rašytinio paveldo turtus èmėsi viešinti Šilutès r. SVB. 2013 m. savivaldybè parèmė bibliotekos projektą „Biblioteka - kultūros paveldo buveiné“. Jo rezultatas - išleista knyga „Biblioteka - kultūros paveldo buveinè: iš Knygos muziejaus rinkinių “139. Tai pirmasis iliustruotas Knygos muziejaus rinkinius pristatantis leidinys. Joniškio r. biblioteka vykde LKT ir KM 2017 m. finansuotą projektą „Joniškio krašto dvarai. Didžioji ir Mažoji Daunoravos, Bertaučiai, Satkūnai“, o savivaldybė parėmé projektą „Knygos Joniškio krašto dvarai. Didžioji ir Mažoji Daunorava, Bertaučiai, Satkūnai leidyba“. Jų igyvendinimo rezultatas - išleistas solidus dvikalbis Ernesto Vasiliausko leidinys „Joniškio krašto dvarai. Didžioji ir Mažoji Daunoravos, Bertaučiai, Satkūnai / Güter in der Gegend von Joniškis. Gross und Klein Donnerhof, Bärtautzen, Satkuhnen ${ }^{\text {“140 }}$.

Projektai, skirti vaikams ir jaunimui. Kalbant apie kultūros paveldo aktualizavimą vaikams ir jaunimui pirmiausia paminètini Klaipèdos $\mathrm{m}$. bibliotekos projektai. Kultūros paveldo departamentas prie KM 2014 m. finansavo Klaipėdos m. bibliotekos projektą „Klaipėdos nekilnojamasis kultūros paveldas: realus ir virtualus“. Projekto tikslas - puoselèti ir populiarinti nekilnojamąji kultūros paveldą, parodyti jo reikšmę pasitelkiant kompiuterines technologijas bei edukacines veiklas. Biblioteka organizavo edukacinius užsièmimus 5-12 klasių moksleiviams „Neatrastas Klaipėdos nekilnojamasis kultūros paveldas“ ir pakvietė dalyvauti trumpametražių videofilmukų konkurse: reikëjo įamžinti Klaipėdos nekilnojamojo kultūros paveldo objektus ir (arba) įdomiai pristatyti „Klaipėdos miesto nekilnojamųjų kultūros vertybių" svetainę. Sukurti filmukai buvo paviešinti bibliotekos paskyroje www.youtube.com/user/kmsvbiblioteka. Lietuvos kultūros taryba parèmè bibliotekos projektą „Viskas apie jūrą - nuo vètrungès iki stintos uodegos“. Igyvendinant projektą organizuotuose edukaciniuose užsiemmimuose moksleiviai susipažino su Lietuvos pamario ir pajūrio vizitine kortele - vètrunge, vyko mažujų vètrungių gamyba, buvo surengta jų paroda. Moksleiviai supažindinti su vienu svarbiausių uosto infrastruktūros įrenginių - švyturiu, taip pat su Mažosios Lietuvos ir Klaipedos pajūrio apylinkių kulinariniu paveldu. Žinias apie kultūros paveldą moksleiviai pagilino Lietuvos jūrų muziejuje. Klaipèdos universiteto folkloro laboratorijoje vyko pažintis su kuršininkų šnekta, folkloru, drabužiais, instrumentais. 2017 m. Kultūros paveldo departamentas prie KM finansavo Klaipėdos m. bibliotekos projektą „Dingęs paveldas“. Projekto partneriai: Všt Klaipėdos turizmo ir kultūros informacijos centras, Klaipèdos pedagogų švietimo ir kultūros centras, Klaipèdos m. savivaldybès administracijos Urbanistinès pletros departamento paveldosaugos skyrius. Siekta supažindinti jaunimą su miesto istorija, ugdyti jo paveldosauginį sąmoningumą, pagilinti jo žinias apie nekilnojamąji kultūros paveldą.

Anykščiu kraštotyrininkai: biografijos / sud. A. Berezauskienè, O. Janonis. Vilnius: Petro ofsetas, 2016.

138 Mizgirienè, A. Taurages krašto šviesuoliai / sud. B. Lukoševičienè. Kaišiadorys: Printeja, 2012.

139 Biblioteka - kultūros paveldo buveinè: iš Knygos muziejaus rinkinių: skiriama Mažosios Lietuvos poeto ir kultūros veikëjo Fridricho Bajoraičio 130-osioms gimimo metinèms / Šilutès rajono savivaldybès Fridricho Bajoraičio viešoji biblioteka; sudarytojai: L. Dumšienè, D. Užpelkienè, V. Veiverienė]. Klaipèda: S. Jokužio leidykla-spaustuvè, 2013.

140 Vasiliauskas, E. Joniškio krašto dvarai. Didžioji ir Mažoji Daunoravos, Bertaučiai, Satkūnai / Güter in der Gegend von Joniškis: Gross und Klein Donnerhof, Bärtautzen, Satkuhnen / Manors of the Joniškis Region: Daunorava, Daunorava Minor, Bertaučiai and Satkūnai. Klaipéda: Klaipėdos universiteto leidykla, 2017. Pagrindinis Daunoravos dvaras ne kartą keite savininkus, nuo XVII a. valdytas Kuršo ir Žiemgalos kunigaikštystès ịtakingų vokiečių šeimų (baronų von Tranckwitzų, von Plettenbergų, von der Brüggenų ir kitų). 
Vaikams ir jaunimui projektus skyre Šiaulių r., Kauno m., Kupiškio r., Naujosios Vilnios bibliotekos. Kultūros ministerija ir savivaldybè 2016 m. finansavo Šiaulių r. bibliotekos projektą „Susipažinkim su Šiaulių rajonu kitaip“. Tai buvo pirmas bandymas Šiaulių rajone ị virtualią erdvę perkelti 12 vietovių sukaupto turizmo ir kraštotyros (gamtos, kultūros, istorijos paminklų) lobyną panaudojant kompiuterini žaidimą Actionbound. Kauno m. biblioteka $2017 \mathrm{~m}$. vykdè projektą „Piliakalnių takais“. Projektą parèmé LKT, KM, SV, Všt „Turizmo akademija“ (partneriai - Lietuvos archeologijos draugija, Vytauto Didžiojo karo muziejus, Kauno miesto muziejus). 10-ties mokyklų moksleiviams buvo suteikta pagrindinių žinių apie piliakalnius. Savivaldybės paremė Kupiškio r., Naujosios Vilnios bibliotekų projektus. Kupiškio r. biblioteka vykdė projektą „Vasaros ekspedicija“. Projektas skirtas vaikų pažinčiai su rajono kultūros, istorijos ir gamtos paminklais. Naujosios Vilnios biblioteka vykdè projektą „Vasaros stovykla Mano atrastas Vilnius“. Vasaros stovykloje taikytos ịvairaus pobūdžio meninès priemonès, naudojant naujųjų technologijų galimybes (išmaniosios kultūrinio ir geografinio pobūdžio programèlès) miesto kultūriniams objektams pažinti. Aplankyti Vilniaus miesto istorinio, kultūrinio ir gamtinio paveldo paminklai.

Etninès kultūros projektai. Etnokultūros sklaida buvo rūpinamasi bibliotekų regiono mastu. KM parèmè KlAVB $2006 \mathrm{~m}$. pradètą igyvendinti projektą „Klaipèdos regiono etnokultūros lobiai. Internetinis portalas“. $2007 \mathrm{~m}$. projektas buvo tęsiamas. Jo tikslas - skleisti ir populiarinti etnokultūrą ir kraštotyros informaciją virtualioje erdvėje. Sprendžiant iš bibliotekų ataskaitų, tais metais vykdant projektą dalyvavo Klaipėdos r., Tauragès r., Kretingos r., Pagègių, Šilalès r. bibliotekos.

Bendro pobūdžio etnokultūros projektus 2007 m. vykdė Alytaus r., Akmenès r., Lazdijų r. bibliotekos. KM finansavo Alytaus r. SVB projektą „Alytaus rajono savivaldybės viešosios bibliotekos kraštotyros duomenų bazės Alytaus krašto etnokultūra sukūrimas elektroninėje laikmenoje“, Alytaus apskrities viršininko administracija - projektą „Etninès kultūros pėdomis“. Vykdydama pastarajji projektą biblioteka surengè konferenciją, organizavo renginius. Akmenès r. SVB projektas „Etnokultūra ir jos sklaida“ (rèmejja - SV) numatė VB ir jos filialuose organizuoti Užgavėnių, Velykų, Jurginių, Joninių, Vasaros šventes ir kitus renginius. Lazdijų r. savivaldybė parėmè bibliotekos projektą „Lazdijų krašto etninès kultūros paveldo fiksavimas ir perteikimas visuomenei“. Buvo parengta kilnojamoji fotografijų paroda „Vaizdais prabilusi praeitis“.

Skuodo r., Klaipėdos m., Kretingos r. bibliotekų projektai skirti atskiroms etnokultūros sritims. Skuodo r. centrinè biblioteka, dalyvaujant Daukšių, Ylakių, Mosėdžio filialams, vykdė projektą „Žemaičių tarmès autentiškumo puoselejimas ir sklaida" (rèmèja - KM). VB buvo organizuotas tradicinis konkursas „Skaitymai žemaitiškai“, skirtas Simono Daukanto 215-osioms gimimo metinėms. Bibliotekos surengtame konkurse dalyvavo 20 žemaitiškai kuriančių literatų iš visos respublikos ir netgi iš Latvijos. Filialuose vyko literatūriniai vakarai, populiarinantys žemaičių tarmę. Kultūros ir sporto rẻmimo fondas parėmè Klaipėdos m. bibliotekos projektą „Klaipėdos krašto tautodailè ir dailieji amatai“. Sudarytas krašto tautodailę kūrusių ir tebekuriančių menininkų registras, kurio pagrindu parengta skaitmeninė duomenų bazė „Klaipèdos krašto tautodaile““.

Projektinę veiklą vykdė bibliotekų filialai. Pažymètini Kretingos r. SVB filialų vykdyti projektai, kuriuos parèmé savivaldybè:

Baublių f. iggvendino projektą „Darbais ịprasminti baubliškių gyvenimai: senieji amatai, kasdienė buitis ir darbymečio talkos",

Grūšlaukès f. - „Grūšlaukès krašto drožybos tradicijos ir paveldas“,

Erlènų f. - kraštotyros darbą „Erlènų ir aplinkinių kaimų etnokultūros lobynas“, etnokultūrinę popietę „Duona, kvepianti ajerais“ (2 projektai),

Juodupėnų f. - „Mažoji kaimo architektūra“,

Rūdaičių f. - renginị „Žemaičių poezijos ruduo“ ir kraštotyros darbą „Taip kalbèjo mūsų senoliai“ (1 projektas),

Salantų f. - kraštotyros darbą „Salantų tautodailininkai“. 
Kretingos r. SVB filialai daug dèmesio etnokultūrai skyrè ir vèlesniais metais. Vien $2008 \mathrm{~m}$. savivaldybė parėmé projektus „Šeimos, bažnytinès ir kalendorinès šventės senajame Baublių kaime“ (vykdè Baublių f.), „Drožèjų tradicijos ir paveldas“ (vykdė Grūšlaukès f.), renginių ciklą „Etnokultūros ir literatūros sąsajos“ (vykdẻ Jokūbavo f.), renginių ciklą "Medžiai lietuvių literatūroje ir tautosakoje“ (vykdè Juodupènų f.), „Kūlupènų ir aplinkinių kaimų mažoji architektūra“ (vykdė Kūlupènų f.).

Savivaldybės taip pat parėmė kitų Klaipėdos bibliotekų regiono bibliotekų projektus. Klaipėdos r.

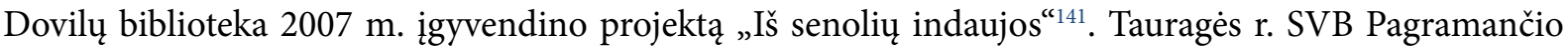
biblioteka drauge su kaimo bendruomene vykde projektą „Taip uliojo mūs senoliai“. Etnokultūra taip pat buvo populiarinama igyvendinant kraštotyros projektus.

Kalvarijos bibliotekos veikla daugiaplanè: projektas „Etninès kultūros sklaida Kalvarijos krašto bibliotekose“ (2008 m., rẻmëja - KM), projektas „Senųjų tradicijų vėrinys“ (2009 m., rėmëja - apskrities viršininko administracija), projektas „Etninès kultūros populiarinimas organizuojant renginius ir parodas" (2011 m., rèmèja - SV) numatė ịvairių etnokultūrai skirtų renginių organizavimą puoselëjant ir populiarinant etninę kultūrą ir tradicijas Kalvarijos krašte.

Žemaitijos regione esančios bibliotekos populiarino žemaičių tarmę, krašto amatininkus ir jų darbus, tautosaką. Skuodo r. biblioteka $2011 \mathrm{~m}$. iggyvendino projektą „Skaitome ir kuriame žemaitiškai“ (rèmèja - SV). Organizuotas konkursas „Skaitymai žemaitiškai“, ị kurị susirinko gausus žemaitiškai kuriančių literatų būrys. Iš viso konkurse dalyvavo 27 kūrëjai ${ }^{142}$. Tauragès r. SVB Pagramančio filialas vykdè projektą „Nagingi pagramantiškiai“ (rèmèja - SV). Sukurtas ir visuomenei pristatytas to paties pavadinimo filmas, kuriame įamžinti Pagramančio krašto amatininkai ir jų darbai.

Lazdijų r. SVB vykdè tęstini projektą „Dievdirbiai iš arti“ (rèmëja - SV). Rezultatas: 2012 m. prie Dumblio k. bibliotekos pastatyta knygnešio skulptūra. Molètų r. SVB projektas „Smulkiosios tautosakos ekspedicija. Už centą ir blusą iš Molètų nuvarytų i Vilnių "buvo skirtas krašto smulkiajai tautosakai (2012 m., rèmejjos - KM, SV). Projekto vykdytojai organizavo ekspedicijas po Dubingių, Giedraičių, Alantos apylinkes. Ekspedicijos rezultatas - bibliotekos kraštotyros fondas pasipildè pasakojimais, padavimais, lietuvių liaudies dainomis, mįslemis ir patarlemis.

2013-uosius LR Seimas paskelbė Tarmiu metais. Tad etninès kultūros projektai tais metais daugiausia skirti tarmėms. Projektinè veikla populiarinant tarmes, patarmes, šnektas igavo didelị mastą. Projektai buvo skirti mokslinėms konferencijoms organizuoti. İsidėmètinas Skuodo r. bibliotekos projektas „Žemaičiu būdo ir išminties skleidejjui Simonui Daukantui - 220“, kurị parèmé Kultūros ministerija. Vykdydama projektą biblioteka organizavo tarptautinę konferenciją „Su žodžiais, šiandien mūs kalboj tebkalbamais", kurioje dalyvavo kašubų (Lenkija, Puckas) ir latgalių (Latvija, Rèzeknè) delegacijos. Pranešimais siekta supažindinti konferencijos dalyvius su tarmiškos kalbos ir papročių išsaugojimu ir puoselèjimu bei jos teisine padètimi Lietuvoje, Latvijoje ir Lenkijoje. Apie kašubų kalbą pranešimus skaitè Lenkijos Pucko pavieto tarybos nare Ewa Kownacka ir kiti Lenkijos delegacijos dalyviai. Rèzeknès viešosios centrinès bibliotekos direktorès pavaduotojos Marijos Šerniovos pranešime gvildentas Latvijos Latgalos etnokultūrinio regiono savitumas, o bibliotekos direktorẻ Marija Sproge skaitė pranešimą „Latgalių tarmès vartojimas ir sklaidos galimybès Latvijos Respublikoje“. Buvo eksponuojamos kašubų, latgalių ir žemaičių tarmėmis išleistos knygos. Tarptautinè konferencija buvo unikali - pirmąkart ị konferenciją Lietuvoje sukviesti draugèn žemaičiai, latgaliai, kašubai diskutuoti apie savo tarmès, papročių, etninio paveldo saugojimą, puoselèjimą ir sklaidą. Kazlų Rūdos SVB vykdè projektą „Tarmès - brangūs akmenèliai lietuvių kalbos lobyne“ (rèmèjas - KRF). Pagal projektą buvo numatyta organizuoti konferenciją „Tarmès - svarbi kultūros paveldo dalis“. Joje mokslinius pranešimus skaitė žymūs lietuvių kalbos tyrinètojai, puoselètojai ir kalbininkai. Iš Kazlų Rūdos kilusio kalbininko Aldono Pupkio pranešime nagrinèta

Bibliotekininkè iš seniūnijos gyventojų surinko 46 išlikusius senovinius ịrankius maistui gaminti ir stalui serviruoti. Jie buvo nufotografuoti, aprašyti.

${ }_{142}$ Plačiau žr. Strakšytė, B. Žemaitiškumo puoselèjimas (Skuodas). Tarp knygu, 2012, vasaris, p. 35. 
svarbi kalbos paveldo dalis - vardynas. KRF taip pat finansavo Zarasų r. SVB projektą, skirtą konferencijai „Tarmių gyvastis ir ịtaka šiaurrytinei aukštaičių šnektai: tarmių analizė, dabartinè situacija - ịtaka ir šnektos metamorfozès" organizuoti. Konferencijoje nagrinètos šiaurrytinès Aukštaitijos patarmès, kelti klausimai apie tarmių vietą XXI a., analizuoti tautosakos tekstai, aptartos rankraštinio paveldo, kaip tarmių šaltinio, surinkimo ir išsaugojimo problemos.

Projektuose buvo numatyta organizuoti renginius. Vykdydamos projektus turiningus renginius organizavo Rokiškio r. ir Radviliškio r. bibliotekos. Rokiškio r. SVB vykde Kultūros ministerijos ir savivaldybės paremtą projektą „Literatūrinè-kūrybinè-edukacinė programa: „Sava tarmi rakuoju, dainuoju, kuriu“. Jị realizuojant vyko tarminiai meninio skaitymo ir literatūrinès kūrybos konkursai, edukaciniai užsièmimai ir mokymai, tarmių rinkimo mažosios ekspedicijos, literatūriniai tarminiai susitikimai-skaitymai. Pažymètinos bibliotekos iniciatyvos siekti renginių masiškumo. Kovo-gegužès mèn. buvo paskelbti rajoninio tarminio meninio skaitymo konkurso „Sava tarmi rakuoju“ nuostatai, konkursas ịvyko gegužès 7 d. - Spaudos atgavimo, kalbos ir knygos dieną. Dalyvavo skaitovai - Obelių, Juodupès, Panemunio, Kriaunų kraštų kūrẻjai, literatai, Kamajų Antano Strazdo, Rokiškio Juozo Tumo-Vaižganto gimnazijų, Rokiškio Rudolfo Lymano muzikos mokyklos moksleiviai ir kt. Renginiai igavo vis naujas, kokybiškesnes formas. Liepos-spalio mèn. buvo paskelbtas tarmiškos kūrybos konkursas „Sava tarmi kuriu“, o lapkričio 21 d. - tarmiškos kūrybos šventė „Sava tarmi rakuoju, dainuoju, kuriu: bagotas esu“. Radviliškio r. SVB kartu su rajono švietimo, kultūros ir sporto skyriumi, Šeduvos kultūros namais vykdant projektą „Tarmių atstovai! Vienykimės Šeduvoj!“ (rẻmëjas - KRF) surengė Radviliškio rajono tarmių festivalị. Festivalio dalyvių komandos pristatė savo kraštą ir tradicijas, skambejjo tarmiška šnekta, tarmiškos dainos, buvo pristatyti regionų rakandai, kulinarinio paveldo pavyzdžiai.

Tarmes populiarino daugelis bibliotekų. KRF finansavo Kupiškio r. SVB projektą „Kupiškèniški vaizdèliai“. Projektu siekta populiarinti kupiškẻnų tarmę ir prie jos išsaugojimo prisidèti panaudojant literatūrinę ir meninę kūrybą. Biržų r. SVB, vykdydama projektą „Tarmèse - tikroji kalbos gyvastis“ (rèmèjas nenurodytas), siekè sudominti rajono bendruomenę tarmèmis, daugiau dėmesio skiriant aukštaičių tarmei. To siekta ir Molètų r. SVB igyvendintu projektu „Tarmé - gyvoji kalbos versmë“ (rèmèjos - KM, SV). Igyvendinant KRF paremtą Utenos SVB projektą „Gyvojo žodžio sukviesti“ buvo organizuotas renginių ciklas, skirtas aukštaičių tarmei ir uteniškių šnektai. Alytaus ir Lazdijų rajonų savivaldybių bibliotekos vykdė KRF paremtus projektus, skirtus dzūkų tarmei. Alytaus r. biblioteka vykdè projektą „Cieskim kelalị dzūkų žodeliu“, Lazdijų r. biblioteka - projektą „Renginių ciklas: „Dzūkiškai šneku - apsisomyc negaliu“. Abiejų projektų tikslai panašūs - puoselèti ir populiarinti dzūkų tarmę, krašto papročius. Tarmes populiarino Joniškio r. (rèmèjas - KRF), Mažeikių r. (rèmëjai - KRF, SV), Pasvalio (rèmèja - KM) ir dar kelių bibliotekų vykdyti projektai. Paminètinas ir $2014 \mathrm{~m}$. savivaldybès paremtas Lazdijų r. bibliotekos projektas. Biblioteka igyvendino projektą „Šeštieji tarmių atlaidai Demeniškiuose“. Projekto tikslai - telkti intelektualus, rašytojus, menininkus, vietos bendruomenes Dzūkijos krašte ir skleisti tarmių bei šnektų autentiškumą; populiarinti etninę kultūrą, kulinarinị paveldą, atgaivinti ir saugoti senolių papročius bei tradicijas ${ }^{143}$.

2013 m. projektai taip pat skirti liaudies amatams. Du projektus finansavo Europos žemès ūkio fondas kaimo plètrai. Elektrènų SVB Gilučių filialas vykdè projektą „Liaudies amatų kūrybinès dirbtuvès“. Buvo mokoma audimo, keramikos meno paslapčių. Lazdijų r. SVB Veisiejų bei Seirijų filialai ir Barčių kaimo bendruomené vykdẻ bendrą projektą „Senujjų amatų puoselëjimas Veisiejų ir Seirijų bibliotekų kiemeliuose bei amatų demonstravimas Lazdijų rajono bendruomenėse“. Savivaldybė finansavo Kretingos r. SVB filialų projektus: Juodupėnų filialas vykdė projektą „Juodupènų ir aplinkinių kaimų amatai ir menas“, Kartenos filialas - „Kuriantys Kartenos krašto žmonès“, Grūšlaukès filialas - tęstinị projektą „Darbščių rankų ir žodžio meistrai“, Laukžemès filialas - tęstinį projektą „Darbščių rankų meistrai“.

43 „Tarmių atlaidai“ buvo surengti rašytojo Romo Sadausko sodyboje Demeniškiuose. 
2015-uosius LR Seimas paskelbė Etnografiniu regionu metais. Daug projektų, skirtų šiai temai, ̣gyvendino Vilkaviškio $r$. ir Skuodo r. bibliotekos. Juos paremė BMGF ir KM [BP 2]. Vilkaviškio r. biblioteka vykdè projektą „Vilkaviškio krašto e. etnografijos akademija“ (partneriai - Vilkaviškio turizmo ir verslo informacijos centras, Vilkaviškio rajono švietimo pagalbos tarnyba). Biblioteka užsibrèžè tikslą susisteminti informaciją apie Vilkaviškio kraštą, padaryti ją prieinamą virtualioje erdveje. Pasak projekto sumanytojų, pagrindinis jo tikslas - užtikrinti vienodą prieigą prie kokybiškos, aktualios, išliekamąją vertę turinčios etnografinès informacijos išteklių Vilkaviškio krašte, suteikiant erdvę edukacinei veiklai, amatų verslo kūrimuisi, turizmo plètrai rajone. Sukurta interneto svetainè tuo pačiu pavadinimu. Skuodo r. SVB vykdè projektą „Žemaičių kalba - 24/7“. Projektas skirtas žemaičių kalbai (tarmei) puoselèti ir žemaitiškos literatūros sklaidai. Pagrindinis projekto tikslas - bendradarbiaujant su Žemaitijos etnografiniame regione veikiančiomis viešosiomis bibliotekomis, kultūros ir švietimo įstaigomis ir nevyriausybinèmis organizacijomis bei panaudojant viešųjų bibliotekų pajègumus informacijos rinkimo ir kaupimo srityje sukurti vartotojams patrauklų informacinị portalą, leisiantị ne tik susipažinti su žemaičių kalbos raidos istorija, gramatika, žemaitiškai rašančiais autoriais ir jų kūriniais, bet ir suteikiantị galimybę mokytis žemaičių kalbos nuotoliniuose kursuose arba žaidžiant edukacinius žaidimus. Sukurtas informacinis portalas www.zemaiciukalba.lt, du edukaciniai žaidimai, skirti mokytis žemaičių kalbos, parengta žemaičių kalbos mokymo programa, pradètos montuoti pirmosios nuotolinės žemaičių kalbos pamokos. Portale paskelbta informacija apie žemaitiškai rašančius autorius, pateikti jų kūriniai.

İvairaus pobūdžio renginius numatė Joniškio r., Pasvalio SVB filialo, Šilutės r., Kėdainių r. SVB filialo bibliotekų projektai. Joniškio r. biblioteka vykdè projektą „Pasisemkim savasties iš tautos lobyno“ (rèmejjos - LKT, SV). Surengta etnografinè ekspedicija Skaistgirio apylinkèse - bibliotekininkai kartu su bendruomenès nariais Skaistgirio apylinkèse aplankè ir fiksavo kapinėse, kaimuose, pakelèse, sodybose esančius mažosios architektūros objektus: kryžius, rūpintojèlius, koplytstulpius, stogastulpius. Filmuotos medžiagos pagrindu sukurtas filmas „Amžini tik laike. Skaistgirio apylinkių mažosios architektūros paveldo takais“. Surengtos konferencijos „Kraštotyros ekspedicijos Skaistgiryje pėdsakais“, „Etninė kultūra ir tautinis paveldas laiko tèkmëje“. Pasvalio SVB Jurgènų filialas vykdè projektą „Kaimas gyvas, kol gyvos tradicijos“ (remejjas nenurodytas). Pavadinimas ịprasmina ši projektą - krašto tradicijos yra kiekvienos vietos bendruomenès susitelkimo pagrindas.

Projektus finansavo savivaldybės. Šilutės r. biblioteka vykdė projektą „Prieteliau, atverk skarbinyčią ${ }^{144}$ savą... “ Buvo surengtos Lietuvos etnografinių regionų „,subègtuvès-varžytuvès“, kurias biblioteka organizavo drauge su Šilutès raštijos ir knygių draugija, LBD Šilutės skyriumi, Gargždų kultūros centru ir Šilutès turizmo ir paslaugų verslo mokykla. Varžytuvių dalyviai kovėsi „Buities ir aplinkos“, „Tarmės“, „Etnografinio žaidimo“, „Kulinarinio paveldo“ rungtyse dèl nominacijų „Puikiausios gaspadinès ir gaspadoriai“, „Etnostiliaus deimančiuks“, „Geriausi savo tarmès šnekoriai“. Kèdainių r. SVB Pajieslio filialas vykdè projektą „Senieji kaimai pasakoja“. Organizuotose ekspedicijose užrašyti pagyvenusių žmonių pasakojimai, užfiksuoti senosios kaimo architektūros elementai, kulinarinio paveldo pavyzdžiai. Parengta paroda „Autentiški Deveikiškių kaimo senujų sodybų akcentai“, edukacinė programa „Senoji kaimo architektūra ir kulinarinis paveldas Pajieslio krašte“.

Apžvelgsime 2016 m. Utenos, Kalvarijos, Plungès r., Šiaulių r. bibliotekų projektus. Lietuvos kultūros taryba finansavo Utenos SVB projektą „Kultūra kitaip: malonūs atradimai savame krašte“. Biblioteka etnokultūros paveldą pritaikẻ kultūrinio turizmo tikslams - buvo sukurtas interaktyvus maršrutas Utenos krašto etninei kultūrai pažinti. Kitų bibliotekų projektus parèmè savivaldybès. Kalvarijos SVB biblioteka vykdè projektą „Etninè kultūra - tiltas tarp bendruomenès narių ir bibliotekos“. Projektas numatè renginių organizavimą skatinant gyventojus domètis savo krašto istorija, tradicijomis, papročiais, juos gaivinti ir puoselèti. Surengta konferencija „Kraštotyra ir etninè kultūra bibliotekose“, vyko

144 Skarbinyčia - dèžè pinigams, taupyklè. 
edukaciniai užsièmimai. Plungès r. SVB vykdè projektą „Skaitīmā žemaitěškā“. Skaitymų konkurse dalyvavo beveik pusšimtis skaitovų - vaikų bei suaugusiųjų. Etnokultūros sklaidai pasitarnavo Šiaulių r. SVB projektas „Žvilgsnis į senelių žaislų dèže. Projekto dalyviai užrašinėjo vyresnių žmonių pasakojimus apie savo vaikystės žaislus, jų gaminimo būdus, tai fiksavo garso ir vaizdo laikmenose.

Skuodo r. biblioteka nenuilstamai populiarino krašto etninę kultūrą. 2017 m. ji vykdè LKT ir KM paremtą projektą „Mūsų stiprybè - kalboje ir kultūroje“. Pagrindinis projekto tikslas - atskleisti ir pristatyti Skuodo krašto etninès kultūros savitumą ir išskirtinumą kitiems Lietuvos etnografiniams regionams ${ }^{145}$. Skuodo etninès kultūros puoselètojai, tarp kurių buvo ir bibliotekos darbuotojų, aplankẻ Trakų r. SVB, Zarasų r. SVB, Žemaičių kultūros draugijos Vilniaus skyrių (Vilniaus mokytojų namai) ir pristate ịvairių žanrų etnokultūrinę programą. Renginiuose pristatytas Skuodo r. bibliotekos išleistas leidinys „Mūsų stiprybè - kalboje ir kultūroje ${ }^{\text {“146 }}$, kurio leidyba buvo ịtraukta ị projekto programą.

Susipažinta su Ukrainos etnokultūra. Skuodo r. ir Klaipèdos r. savivaldybės finansavo Klaipėdos r. bibliotekos projektą „Etno book (Lietuva - Ukraina)“. Ukrainiečiai pristate liaudiškus instrumentus bandūras. Igyvendinant projektą vyko daug renginių: susitikimų, kelionių, vakarų, koncertų ir kt.

LR Seimas 2017-uosius paskelbė Tautinio kostiumo metais. Siekdama populiarinti tautinị kostiumą Klaipèdos r. SVB vykdè savivaldybès paremtą projektą „Babūnēles jopēle “147. Projekto tikslas - sutelkti bendruomenę (vaikus, tèvelius ir senelius, ugdymo įstaigas) ị bendrą kūrybinị ir edukacinị procesą populiarinant tautinị drabuži kaip etninio tapatumo formą. Projekto dalyviai rungtyniavo, kas geriau pažins tautinių drabužių elementus (sermėgą, vyžas, delmoną ${ }^{148}$ ir kt.), atspès, kokio regiono tautiniais drabužiais buvo pasipuošusi LR prezidentè.

Kita bibliotekų projektinio darbo kryptis - leidybinè veikla. $2007 \mathrm{~m}$. Kretingos r. biblioteka iggvendino savivaldybès paremtą projektą „Knyga Juozo Lukausko lobiai“. Išèjo to paties pavadinimo Algirdo Kuklio knyga ${ }^{149}$, skirta žymiam Vakarų Lietuvos tautodailininkų dinastijos atstovui.

Reikšmingus darbus populiarinant etnokultūrą leidiniuose atliko Kalvarijos biblioteka. Vykdant 2010-2011 m. projektą „Kalvarijos krašto kultūros bei istorijos puoselëjimas ir sklaida“ (rèmèjas - Europos žemès ūkio fondas kaimo plètrai) išleistos knygos „Kalvarijos krašto senieji amatai ir amatininkai, „Kaimų istorijos: Žalioji, Sabaliavas, Durbè, Garnabūdis, Naujas kaimas, Vilkavizna, Komenka, Santa-

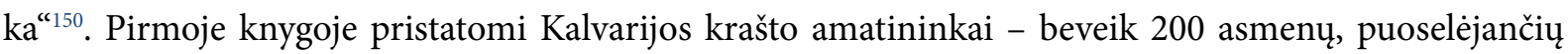
pačius ịvairiausius senuosius krašto amatus: siuvimą, audimą, mezgimą, margučių marginimą, žaislų gamybą, batų siuvimą, ratų gaminimą, kalvystę, rimoriaus amatą. Antroje knygoje ịamžintos išnykusių kaimų istorijos, juose gyvenusių žmonių, kurių daugumos jau nebèra, likimai. Knygoje sudèta tai, kas liko iš 8 kaimų ir 65 sodybų iki mūsų dienų. Igyvendinant 2012 m. projektą „Etninè kultūra: prisiminkim, saugokim, puoselèkim“ (rèmëjas - Europos žemès ūkio fondas kaimo plètrai) išleistos knygos „Kalvarijos

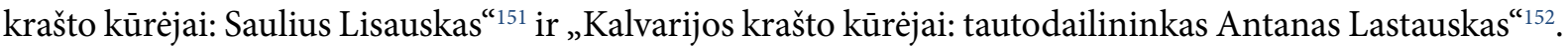
Abi knygos skirtos krašto tautodailininkams. Leidybos projektą paremė savivaldybė. Igyvendindama 2011 m. projektą „Etninè kultūra - leidiniuose“ biblioteka išleido leidinius: „Kalvarijos krašto padavimai ir pasakojimai“ ${ }^{153}$ ir Algimanto Babecko knygą „Išnykę (ne)pamiršti dvarai: Aleksandravas, Makauskai,

Plačiau žr. Daukantienè, G. Skuodo žemaičių stiprybè - kalboje ir kultūroje (Skuodas). Tarp knygų, 2017, lapkritis, p. 42-43.

${ }_{146}$ Mūsų stiprybè - kalboje ir kultūroje: projektas / sud. G. Daukantienè. Skuodas: Skuodo rajono savivaldybès R. Granausko viešoji biblioteka, 2017.

147 Jopēlè - žemaičių tarme suknelè.

${ }_{148}$ Delmonas (arba dalmonas) - lietuvių moterų puošni kišenè, austine juostele (rištuvu) rišta prie juosmens; būdinga tik Mažajai Lietuvai.

149 Kuklys, A. Juozo Lukausko lobiai. Klaipeda: Libra Memelensis, 2007.

${ }_{150}$ Kaimu istorijos: Žalioji, Sabaliavas, Durbè, Garnabūdis, Naujas kaimas, Vilkavizna, Komenka, Santaka / sud. V. K. Svitojus. Marijampolè: Piko valanda, 2011.

151 Kalvarijos krašto kürèjai: Saulius Lisauskas / sud. A. Jankeliūnienė, L. Karpavičienè, S. Palionienè. Marijampolè: Piko valanda, 2012.

152 Kalvarijos krašto kūrejjai: tautodailininkas Antanas Lastauskas / sud. A. Jankeliūnienè et al. Marijampolè: Piko valanda, 2012.

153 Kalvarijos krašto padavimai ir pasakojimai / sud. A. Jankeliūnienè, L. Karpavičiené, S. Palionienè. Marijampolè: Piko valanda, 2011. 


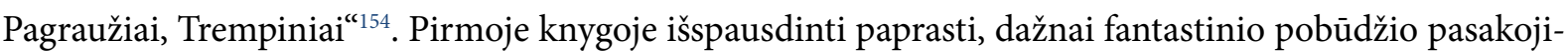
mai, padavimai apie įvairių, Kalvarijos krašto žmonèms brangių vietų ir jų vardų atsiradimą, apie upes, ežerus, akmenis, antgamtiškus, nekasdieniškus reiškinius, istorinius įvykius. A. Babecko knygoje apžvelgiama dvarų istorija nuo seniausių laikų iki mūsų dienų ${ }^{155}$.

Išskirtinio dèmesio sulaukẻ kulinarinis paveldas. „Skaityk, atmink, pasmuokavuok“ - taip vadinosi Kultūros rèmimo fondo ir savivaldybès paremtas Šilalès r. SVB 2013 m. projektas. Surinkti ir užrašyti Šilalès krašto kulinarinio paveldo patiekalų receptai išleisti atskira knyga „Pasmokavuok, kap skane ${ }^{“ 156}$. Šilalès krašto kulinarinio paveldo knyga „Pasmuokavuok, kap skane“ apkeliavo dali Lietuvos bibliotekų, buvo pristatyta Vilniaus knygų mugeje.

2015 m. Skuodo r. biblioteka vykdė projektą „Kultūrų spiečius“ (rèmèja - LKT). Pagrindinis projekto tikslas buvo supažindinti Lietuvos etnografinius regionus su Skuodo krašto kalbos, kultūros, tradicijų savitumu ir išskirtinumu. Vykdant projektą išleistas leidinys „Esam ir būsim žemaičiai“157. Leidinyje išspausdinta informacija apie Skuodo krašte žemaitiškumą puoselèjančias įstaigas ir organizacijas, jų veiklą, taip pat pateikiama informacija apie tarmiškai rašančių autorių kūrybą.

Projektai, skirti vaikams ir jaunimui. Kultūros ministerija 2007 m. finansavo Mažeikių r. SVB projektą „Žemaitija - vaikų akimis“, dvi Rokiškio r. SVB etnokultūrines programas vaikams ir jaunimui, Anykščių r. savivaldybè - Anykščių r. SVB Rubikių filialo projektą „Išgirsk ir pamatyk, ką tau sako mūsų senolių praeitis..." Marijampolès SVB Sasnavos filialas drauge su vidurine mokykla igyvendino projektą „Spalvos metų rate“ (rèmëjas nenurodytas).

Pažymėtina Panevėžio r. bibliotekų projektinè veikla. Europos Sąungos ir savivaldybės finansinès paramos 2016 m. sulaukè Panevėžio r. Naujarodžių k. ir Raguvos k. bibliotekos. Naujarodžių biblioteka vykdè neformalaus vaikų švietimo programą „Modernus etnokultūrinis teatras“. Ją sudarè teoriniai bei praktiniai užsièmimai, kurių tikslas - geriau suvokti tautos kūrybos savitumą, pagrindinius vaizdinius, simboliką. Raguvos biblioteka igyvendino dvi programas: „Mes esam ETNO“ ir „Pažinkime senolių praeiț, pažinkime savo kaimą“. Programų tikslas - supažindinti jaunimą su tautos etninès kultūros puoselejimu, tradicijomis.

Kiek daugiau projektų, skirtų vaikams ir jaunimui, tgyvendinta $2017 \mathrm{~m}$. Lietuvos mokinių neformaliojo švietimo centras parèmé Kupiškio r. bibliotekos programą „Etno turistai“. Panaudodami informacines technologijas, bendraudami su žmonèmis, moksleiviai sudarinejjo turistinius, pažintinius etnografinius maršrutus po Kupiškio miestą ir rajoną. Kitus projektus finansavo savivaldybès. Mažeikių r. Auksodès k. ir Laižuvos mst. filialai igyvendino bendrą projektą „Pažink tautinio kostiumo grožị. Daugiausia dèmesio skirta žemaičių tautiniam kostiumui. Elektrẻnų SVB vykdè projektą „Žvilgsnis ị Lietuvos praeitị“. Vaikai buvo mokomi senųjų amatų (lipdyti iš molio), supažindinti su senaisiais muzikos instrumentais bei lietuvių liaudies melodijomis. Skuodo r. SVB Šliktinès filialas vykdė projektą „Senųjų tradicijų pèdsakais“. Vaikams ir jaunimui buvo organizuoti edukaciniai užsièmimai: „Prakalbinkim molį“, „Mediniai stebuklai drožiniuose“, „Viskas iš vytelių“, „Auskit, riškit, mano rankos“, „Riešinès - šilta ir gražu“. Panevėžio r. SVB Velžio filialas igyvendino vaikų vasaros poilsio projektą „Senovinių lietuviškų žaidimų dirbtuvès“.

Istorijos projektai. Istorinès tematikos projektai skirti gyvenviečių, krašto istorijai, jų kultūros paveldui, bibliotekų istorijai, žymių žmonių atminimui ịamžinti, reikšmingoms datoms šalies istorijoje ịprasminti. Apžvelgsime projektus, skirtus krašto, gyvenviečių istorijai. Tokio pobūdžio igyvendintų projektų skaičius yra solidus. $2007 \mathrm{~m}$. turiningą projektą vykdè Tauragès r. SVB. Lietuvos tūkstantmečio minejjimo

Babeckas, A. Išnykę (ne)pamiršti dvarai: Aleksandravas, Makauskai, Pagraužiai, Trempiniai. Marijampolè: Piko valanda, 2011.

Dvarų kultūra etninei kultūrai neatstovauja (galimas tik abiejų kultūros klodų sąlytis).

Pasmokavuok, kap skane: Šilalès krašto kulinarinis paveldas. Kaunas: Naujasis lankstas, 2013.

${ }^{157}$ Esam ir būsim žemaičiai = Esam èr būsem žemaitēs: projektas-renginių ciklas „Kultūrų spiečius“. Skuodas: Skuodo savivaldybès viešoji biblioteka, 2015. 
direkcija prie LR Prezidento kanceliarijos paremė Tauragès r. bibliotekos projektą „Tauragé: 500 metu rašytiniuose šaltiniuose", skirtą Tauragès miesto ịkūrimo jubiliejui. Projektu siekta atkreipti visuomenès dèmesị $\mathfrak{i}$ bibliotekose sukauptą rašytinị ir skaitmeninị kultūros paveldą, supažindinti krašto bendruomenę ir miesto svečius su Tauragès viešojoje bibliotekoje saugoma medžiaga apie Tauragès istoriją ir šiandieną. Parengtos trijų kilnojamųjų parodų, apžvelgiančių svarbiausius miesto istorijos etapus, supažindinančių su krašto kultūros ir istorijos paveldu, žymiais krašto žmonėmis, grupès. Suskaitmeninta didžioji dalis parodose eksponuotos medžiagos, išleista kompaktine plokštelè „Tauragès istorija periodineje spaudoje: bibliografija ir tekstai“ ir informacinis leidinukas „Ǐ̌kilieji Tauragès krašto žmonès“. Klaipèdos krašto istorijai projektą skyre Šilutės r. Kintų biblioteka. Biblioteka igyvendino projektą „Vertinkime tai, ką turime“ (rèmèja - SV), kurio metu Kintų bendruomenei pristatyta paroda „Šeimos albumų istorijos. Klaipedos krašto pokario laikotarpis 1944-1960 m. “158 Paskaitą „Klaipėdos krašto istorija po Antrojo pasaulinio karo" skaite Klaipėdos universiteto Baltijos regiono istorijos ir archeologijos instituto direktore dr. Silva Pocytè. Savivaldybių remiami gyvenviečių istorijai skirtus projektus vykdė Šilutès r. SVB Usėnų, Kintų, Inkaklių filialai, Kretingos r. SVB Kurmaičių filialas, Klaipėdos r. SVB Veiviržènų, Daukšaičių, Pèžaičių ir Šalpènų filialai (bendras filialų projektas).

Krašto, gyvenviečių istorijai projektai buvo skiriami vèlesniais metais. Projektų rẻmèjos - Lietuvos kultūros taryba, savivaldybės. Varėnos r. SVB 2012 m. igyvendindama projektą „Varėnai - 150“ (rèmèja SV) organizavo konferenciją „150 Varénos istorijos minučių“, skaityti 13 pranešimų atskleidè Varènos istoriją nuo pat jos įkūrimo. 2013 m. Lietuvos kultūros taryba parèmé Panevėžio r. SVB projektą „Vakarojimai dvarelyje: dvarų istorijos“. Buvo pristatyta šiaurès dvarų kultūra, jų istorija. Šiaulių m. biblioteka vykdè savivaldybės paremtą projektą „Septynios spindinčios Šiaulių dienos“. Jis numatè renginių ciklą, skirtą 777-ajam miesto gimtadieniui. Bibliotekos tikslai išties buvo ambicingi: „Minint Šiaulių miesto 777-ajji gimtadienį, naudojant inovatyvius, patrauklius laisvalaikio praleidimo, lavinimo metodus bei formas, stiprinti miesto istorinị, kultūrinị ir meninị identitetą, atitinkantị ịvairaus amžiaus Šiaulių miesto gyventojų poreikius, ugdyti kūrybiškai laisvus, iniciatyvius ịvairios kartos šiauliečius, žinančius gimtojo miesto ir savo krašto istoriją ${ }^{159}$. Bibliotekos organizuotuose renginiuose dalyvavo apie 1000 įvairaus amžiaus šiauliečių. Jaunajai kartai buvo suteikta galimybė sukurti plakatą, skirtą miesto gimtadieniui, piešti savo svajonių miestą. Joniškio r. biblioteka vykde projektą „Miesto istorijos ženklai“ (2015 m., rèmejja - SV). Jị ịgyvendinant surengta konferencija „Joniškio tapatumo ženklai urbanistikoje ir architektūroje“, fotografijų konkursas „Miestovaizdžio poezija“, varžybos moksleiviams ir jaunimui „Kaip keitėsi Joniškis, arba atrask lobị".

Miesto istorijai, jo kultūros paveldui skaitmeninti 2015 m. skirtas stambus tęstinis Marijampolès SVB projektas „Marijampolès miesto gatvių kaita: iliustruotas interaktyvus žinynas“, kurị parėmè LKT. Projekto tikslas - integruoti kultūros paveldo objektus ị skaitmeninio turinio žinyną. Žinynas buvo kuriamas bendradarbiaujant su Marijampolès istorikais, kraštotyrininkais, fotografais, kolekcininkais, Marijampolès apskrities archyvu ir kitomis institucijomis. 2015 m. aprašyti 123 objektai: muziejai, paminklai, dvarai, kapinès, parkai ir kt. Šiaulių r. SVB vykdè projektą „Verbūnai. Čia mano šaknys, čia aš gyvenu" (rèmèja - LKT). Buvo siekiama, kad gyventojai (daugiausia jaunimas) giliau pažintų Verbūnų istoriją, gyvenvietės ir jos apylinkių materialųji ir nematerialụji paveldą ${ }^{160} .2017 \mathrm{~m}$. turiningą projektą, skirtą krašto istorijai, vykdè Kupiškio r. biblioteka. Bibliotekos projektą „Prabylanti krašto istorija: interaktyvus žemèlapis“ parèmė LKT. Buvo kuriamas žemèlapis, kurio pagrindas - autentiški pasakojimai apie istorinius objektus ar įvykius, žymius žmones, kaimus. Organizuoti mokymai „Filmavimas, vaizdo ir garso i̇rašų montavimas“, kuriuos vedè Kupiškio televizijos ir informacijos centro direktorius. Vasarą suburta

Parodą parengè Klaipedos universiteto Baltijos regiono istorijos ir archeologijos instituto darbuotojai.

159 Šiauliu m. SVB tinklalapis. Prieiga per internetą: http://biblioteka.smsvb.lt/lt/virtualios-parodos/irasai/3215-2013-metu-projektai. Žiūrèta 2018-09-21.

160 Projektas kiek kitu pavadinimu „Verbūnai - čia mūsų etninè savastis, čia aš gyvenu...“ buvo tęsiamas $2016 \mathrm{~m}$. 
vaikų ir jaunimo kraštotyros stovykla, jos metu keliauta po istorines rajono vietas, nufilmuoti pasakojimai apie Palèvenès bažnyčią ir vienuolyną, Komarų dvarą, Skapiškio varpinę, Blaivybès paminklą ir kt. Bibliotekai daug padejjo kraštiečiai, kurie dalijosi sukauptomis žiniomis ir fotografijomis apie savo kraštą, žmones. Vilniaus universiteto profesorė Genovaitė Dručkutè pasakojo studijų metų prisiminimus apie semiotiką Algirdą Julių Greimą.

Geresnes sąlygas pažinti gimtojo miesto, krašto istoriją sudaro diegiamos modernios technologijos. 2016-aisiais tokias galimybes atvère Šiaulių m., Šilutės r., Biržų r., Kauno m. bibliotekų projektinè veikla. Lietuvos kultūros taryba finansavo Šiaulių m., Šilutès r., Biržų r. bibliotekų projektus. Šiaulių m. biblioteka kartu su partnere Všt „3D Vilnius“ igyvendino projektą „Interaktyvus Šiaulių žemèlapis: pažink Šiaulius per virtualią viktoriną - labirintą“. Projektas skirtas Šiaulių miesto 780-ajam jubiliejui. Interaktyvus žemèlapis apėmé istorijos, architektūros, kultūros, meno sritis, sudarè galimybes organizuoti viktorinas ir žaidimus, spręsti įvairias užduotis. Šilutès r. SVB projekto „Knygnešių kelias interaktyvioje erdvèje“ rezultatas - interaktyvus „pasivaikščiojimas“ knygnešių keliais bei Žemaičių Naumiesčio ir Švèkšnos apylinkių knygnešių duomenų bazių sukūrimas. Biržų r. SVB drauge su Všs „3D Vilnius“ ir Biržų krašto muziejumi „Sèla“ igyvendino projektą „Virtuali ekskursija - Biržų pilis prieš šimtmečius ir šiandien“. Virtuali ekskursija suteikè galimybę susipažinti su Biržų tvirtove, Biržų krašto muziejumi „Sèla“, biblioteka. Kultūros ministerija ir savivaldybė parėmé Kauno m. bibliotekos drauge su partneriais (KTU Vaižganto progimnazija, Kauno jaunųjų turistų centras ir kt.) projektą „Mano gatvės istorija 360 laipsnių kampu“. Parengtame virtualiame ture sumontuotos 97 panoraminès nuotraukos, pristatyta 20 objektų.

Modernių technologijų degimas suteikia galimybę puoselèti bei perduoti jaunimui vyresniosios kartos istorinę atmintị. Tokio pobūdžio projektus ịgyvendino Klaipèdos m. SVB, Utenos SVB. Klaipédos $\mathrm{m}$. biblioteka drauge su Girulių bendruomene vykdè Socialinès apsaugos ir darbo ministerijos paremtą projektą „Girulių bendruomenès atminties stiprinimas“. Igyvendintas edukacinių užsièmimų genealogijos tema ciklas („Genealoginès informacijos paieška ir medžių braižymas“ ir kt.). Švietimo ir mokslo ministerija parèmė Utenos bibliotekos kartu su Utenos trečiojo amžiaus universitetu (TAU) ir UAB „IT akademija“ vykdytą projektą „Skaitmeninès atminties pamokos senjorams“. Vienas iš projekto tikslų - vykdyti vyresnès kartos atminties sklaidą skaitmeninėmis priemonėmis (tinklaraščiai, asmeniniai archyvai ir kt.).

Isidèmètinas veiksmingo dalyvavimo kitos institucijos projekte atvejis. Raseinių centrinès bibliotekos ir filialų darbuotojai $2016 \mathrm{~m}$. dalyvavo Dubysos regioninio parko direkcijos organizuoto projekto „Raseinių krašto dvarai“ veiklose: vyko ị pažintines ekspedicijas po Lietuvos dvarus. Surinkta medžiaga apie Lotyniškès, Tendžiogalos, Biliūnų, Skaraitiškès, Katauskių, Burbiškių, Gruzdiškès, Gylių dvarus.

Projektai, skirti iškiliu žmoniu, žymiu kraštiečiu atminimui įamžinti. Paminètini Kretingos r. bibliotekų projektai, kuriuos parèmè savivaldybè. Kretingos r. SVB Baublių filialo $2007 \mathrm{~m}$. projektas buvo skirtas skulptoriaus Rimanto Dauginčio tragiškam likimui ąamžinti ${ }^{161} .2011 \mathrm{~m}$. Kretingos r. SVB vykdè projektą „Nuo piemenuko iki ganytojo", skirtą vyskupo, rašytojo Motiejaus Valančiaus 210-osioms gimimo metinèms. Buvo parengta ir igyvendinta literatūrinè-muzikinè programa.

Plačiau apžvelgsime originalų Kupiškio r. SVB 2017 m. projektą „Kupiškènai - Lietuvos istorijoje“. Projektas skirtas Lietuvos valstybès atkūrimo šimtmečiui, kupiškènų pilietiškumui, istorinei savimonei ir savojo krašto pažinimui ugdyti. Projektą parėmé LKT, SV, SVB, privatūs asmenys ir kt. Bendradarbiaujant su istorikais, muziejininkais sudarytas šimto asmenybių, kurios dirbo, kūrẻ 1918-2017 m., sąrašas (iš jų tik 22 buvo gyvi), parengtos biografijos, surinktos nuotraukos. Vyko Šimtmečio kupiškènu

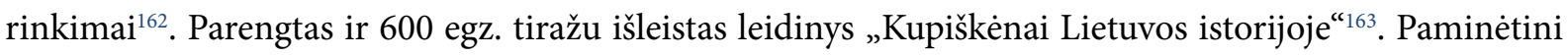

\footnotetext{
161 Protestuodamas prieš sovietinio režimo politiką Lietuvoje, $1990 \mathrm{~m}$. gegužès 9 d. R. Daugintis susidegino prie SSRS-Vengrijos sienos. Mirè gegužès $19 \mathrm{~d}$. Budapešto (Vengrija) ligoninejje.

162 Daugiausia balsų surinko ir Šimtmečio kupiškènu tapo olimpinis ir pasaulio čempionas Virgilijus Alekna.

163 Kupiškenai Lietuvos istorijoje / sud. L. Matiukaitė. Panevežys: Amalkera, 2017.
} 
taip pat Šakių r. SVB, Šiaulių r. SVB filialo projektai. LKT parèmé Šakių r. bibliotekos projektą „Kultūriniai valstybingumo maršrutai Suvalkijoje“. Vykdant projektą organizuoti 3 žygiai į Šakių rajone esančias Lietuvos Nepriklausomybès Akto signatarų Justino Staugaičio, Jono Vailokaičio ir Saliamono Banaičio tėviškes bei parengtas vaizdo reportažas. Šiaulių r. SVB Ginkūnų filialas vykdè projektą „Ginkūnų žemès šviesuolių Janulaičių gyvenimo ir darbų keliais“ (rèmèjos - LKT, SV). Projektas numatè Ginkūnų bibliotekoje sukaupti ir susisteminti medžiagą, skirtą iš Ginkūnų kilusių šviesuolių Janulaičių šeimos paveldui iamžinti ir skleisti, ịrengiant jiems skirtą ekspoziciją ir virtualią parodą.

Grupe projektų buvo skirta bibliotekų istorijai. Kultūros ir sporto rẻmimo fondas $2007 \mathrm{~m}$. parèmé Anykščių r. SVB projektą „100 bibliotekos Anykščiuose gyvavimo metų“, pagal kurị buvo numatyta kultūrinių renginių programa. Išèjo prisiminimų knyga „Anykščių biblioteka istorijos vingiuose: 1937-2007“164. Rokiškio r. SVB Pandèlio m. filialas ịgyvendino savivaldybès paremtą projektą „Pandèlio krašto istorija“; rezultatas - išleistas leidinys „Lietuviškos knygos kelias Pandèlio apylinkèse: 70-osioms Pandèlio bibliotekos ịkūrimo metinèms s"165. Šiaulių m. savivaldybé finansavo bibliotekos projektą „Šiaulių miesto savivaldybės viešosios bibliotekos istorija gyva elektroninejje laikmenoje“. Igyvendinus projektą sukurtas elektroninis katalogas. Savivaldybės parėmė Prienų bibliotekos ir Kelmès r. SVB Kražių filialo projektus, skirtus bibliotekų istorijai. Šakių r. savivaldybė finansavo bibliotekos projektą „Pradžia amžino...", kuris buvo skirtas Šakių viešosios bibliotekos 70-mečiui ir pirmosios lietuviškos knygos 460ties metų sukakčiai.

2012 m. Plungès r. biblioteka vykdè projektą, skirtą leidinio „Plungès Palazzo Vecchio: nuo grafụ Zubovų pilaitės iki Plungès viešosios bibliotekos (1846-2012)“ leidybai (rèmèjai - KRF, Plungès pilietiškumo ir bendruomeniškumo ugdymo draugija, UAB „Plungès Jonis“, plungiškis verslininkas Petras Beinoras). Leidinys išèjo tais pačiais metais ${ }^{166}$. Savivaldybès remiami Kretingos r. SVB filialai $2013 \mathrm{~m}$. igyvendino projektus „Rūdaičių bibliotekai - 60“, „Jubiliejaus paminejjimo renginys 55-eri metai kartu su skaitytojais" (Jokūbavo filialas). Baublių, Kalniškių, Šukès filialai taip pat vykdè projektus, kurie numate jubiliejinius renginius. Panašūs projektai buvo vykdomi Bibliotekų metais (2016). Projektus vykdė Juodupėnų, Kartenos, Kurmaičių, Raguviškių, Senosios Ipilties filialai. Projektais atkreiptas dèmesys i nedidelių bibliotekų (filialų) reikšmę krašto gyvenime.

Istorinès tematikos projektai skirti dedikaciniams metams. LR Seimo sprendimu 2013-ieji buvo paskelbti 1863-iujų metu sukilimo, Stepono Dariaus ir Stasio Girèno skrydžio per Atlantą, Klaipédos krašto atgavimo metais. Pasvalio, Šiaulių m., Raseinių bibliotekos projektus skyrè 1863-iųjų sukilimui. Kultūros rèmimo fondas finansavo Pasvalio SVB projektą „1863-1864 metų sukilimas: už Jūsų ir mūsų laisvę (1863 m. sukilimo 150-osioms metinėms)“. Jí igyvendinus sukurtas skaitmeninis sukilimo žemèlapis ir paviešintas e. bibliotekoje „Pasvalia“. Žemèlapyje atkurtas sukilimo įvykių krašte kelias. Žemèlapis svarbus pažintinę, kultūrinę vertę turintis vedlys po Pasvalio krašto sukilimo atminties vietas, skirtas ne tik vietinei visuomenei, mokytojams ir mokiniams, bet ir Pasvalyje besilankantiems turistams, sukilimu besidomintiems žmonèms. Kultūros ministerija paremė Šiaulių m. bibliotekos projektą „1863 metų sukilimo istorinè ir kultūrinè reikšmė: praeitis ir rytojus“. Vykdant projektą organizuota konferencija, skirta mokiniams. Pranešimus skaite kraštotyrininkai, Šiaulių universiteto studentai, Šiaulių „Aušros“ muziejaus darbuotojai, Šiaulių gimnazijų ir progimnazijų mokiniai, bibliotekininkai. KRF parèmė Raseinių bibliotekos projektą „1863 sukilimas Raseinių apskrityje. Biografijų žodynas“. Išleista tuo paties pavadinimo Jono Brigio knyga ${ }^{167}$.

164 Anykščiu biblioteka istorijos vingiuose: 1937-2007 / sud. A. Berezauskienė. Anykščiai: Anykščių rajono savivaldybės viešoji biblioteka, 2007.

165 Lietuviškos knygos kelias Pandèlio apylinkèse: 70-osioms Pandèlio bibliotekos įkūrimo metinèms / sud. R. Baškienè. Rokiškis: I. Skripkos individuali įmonè, 2007.

166 Plungés Palazzo Vecchio: nuo grafų Zubovu pilaites iki Plungés viešosios bibliotekos (1846-2012) / sud. O. Juozapaitienè, V. Skieriene, V. Liutikaitė, Z. Paulauskaitè. Klaipèda: Plungès r. SVB, 2012. Antrasis pataisytas leidinys išèjo $2015 \mathrm{~m}$.

167 Brigys J. 1863 sukilimas Raseiniu apskrityje: biografijų žodynas. Vilnius: Petro ofsetas, 2013. 
Klaipėdos krašto atgavimo metinėms skirtą projektą laimėjo Klaipėdos m. biblioteka. Kultūros ministerija finansavo projektą „Minime Lietuvos Respublikos ir Klaipèdos krašto susijungimo 90-metį“. Girulių filiale vyko atviras forumas „Klaipedos krašto prijungimo prie Lietuvos 90-metis“. Idomus atvejis: Girulių f. kieme surengta 1923 m. Klaipèdos sukilimo inscenizacija. Stepono Dariaus ir Stasio Girèno skrydžio per Atlantą 80-mečiui skirtus projektus laimėjo Švenčionių r. ir Trakų r. bibliotekos. KRF parèmé Švenčionių r. bibliotekos projektą „Žuvę, bet nepralaimèję“, KM - Trakų r. bibliotekos projektą „Kelionè ị aviacijos pasaulị̆.

LR Seimas, atsižvelgdamas ị tai, kad 2015 m. sukako 250 metų, kai gimė iškilus valstybès ir visuomenès veikëjas, diplomatas, kompozitorius Mykolas Kleopas Oginskis, ir ị tai, kad šią sukaktị UNESCO ịtraukẻ ị minimų datų sąrašą, paskelbẻ 2015-uosius Mykolo Kleopo Oginskio metais. M. K. Oginskiui projektus skyrė Plungès r. ir Trakų r. bibliotekos. LKT parėmė Plungės r. SVB projektą „Kunigaikštis M. K. Oginskis ir jo epocha“. Projektas, skirtas M. K. Oginskio indèliui $\mathfrak{i}$ Lietuvos politinị ir kultūrinị gyvenimą, turëjo dvi partneres: LNB ir VUB. Bendromis pastangomis Plungès bendruomenei surengta konferencija. Pranešimus skaitė prof. Leonidas Donskis („M. K. Oginskio Europa: XIX a. Europos idèjų žemèlapis“), dr. Ramuné Šmigelskytė-Stukienė („Tarp Varšuvos, Hagos ir Konstantinopolio: diplomatiniai M. K. Oginskio keliai“) ir kiti. Bibliotekoje pristatyta originalių dokumentų ir knygų paroda „Žinomas ir nepažintas Mykolas Kleopas Oginskis. Dokumentai iš Vilniaus universiteto bibliotekos“. LKT ir savivaldybė finansavo Trakų r. bibliotekos kartu su partneriais (Trakų meno mokykla, Trakų kultūros rūmai) igyvendintą projektą „Istorinè-muzikinè dekada Sugrižžimas į Tëvynę“. Surengtas istorinis-muzikinis renginys „Tèvynei skiriu turtus ir gyvenimą“. Pristatyta programa „Mykolo Kleopo Oginskio polonezų kelias"; apie M. K. Oginskio rašytinị palikimą pasakojo jo knygų vertėjas ị lietuvių kalbą, kraštietis Virginijus Baranauskas. Parengta kilnojamoji paroda „Mykolas Kleopas Oginskis“, organizuoti kiti renginiai.

Iprasminamos svarbiausios šalies istorijos datos. $2014 \mathrm{~m}$. Panevèžio r. SVB vykdant LKT paremtą projektą „Literatūrinès edukacinès kelionès Kai knygas draude்" sukurta edukaciné programa pristatyta krašto visuomenei. Knygnešiu istorijai skirtas Tauragès r. SVB projektas „3 dienų žygis - stovykla Knygnešiu keliais“ (2015 m., rèmèjos - LKT ir SV). Atsigręžta ị pirmajji lietuvių kultūros istorijos veikalą. LKT paremė Skuodo r. SVB projektą „Simono Daukanto Büdas senovés lietuviu, kalnènu ir žemaičiu pirmoji lietuvių kultūros istorija: aktualizavimas ir populiarinimas" (2015-2016 m.). Vykdant projektą buvo siekiama populiarinti kraštiečio parašytą pirmąją lietuvių kultūros istoriją pristatant naujausius mokslinių tyrinèjimų rezultatus bei supažindinant visuomenę su mažiau žinomais faktais. Organizuota konferencija „Simonas Daukantas ir pirmoji lietuvių kultūros istorija“, parengta mobili paroda „Simonas Daukantas ir Būdas senovés lietuviu kalnènų ir žemaičių: archyviniai dokumentai liudija“.

Projektai, skirti tragiškiems mūsų šalies istorijos ịvykiams. $2011 \mathrm{~m}$. Šilalès r. biblioteka vykdè projektą „Holokausto istorija ir jos ypatumai Lietuvoje bei Šilalès rajone“ (rèmejja - SV). Bibliotekos lankytojams ir svečiams buvo pristatyta unikali autentiškų Vilniaus geto afišų kolekcija iš Vilniaus Gaono žydų muziejaus rinkinių. Parodoje atskiras kampelis skirtas Šilalès krašto žydų atminimui. Po parodos atidarymo surengta konferencija „Holokausto istorija ir jos ypatumai Lietuvoje bei Šilalès rajone“. Žydų istorijai bei Holokaustui 2013 m. projektą skyrè Plungès r. biblioteka. Biblioteka vykdè Kultūros paveldo departamento prie KM paremtą projektą „Paskutinis pasivaikščiojimas po žydiškąją Plungę“. Surengtas žydų atminties vakaras. Jo metu atidaryta senųjų ir šiuolaikinių fotografijų paroda „Plungės žydai: paprasto gyvenimo štetle akimirkos“ ir pristatyta prieš karą Plungèje gyvenusios rašytojos Mašos Rolnikaitès knyga „Kam žmogui veidrodis?“

Sulaukè dèmesio partizanų kovų atminties įamžinimas. Lietuvos kultūros taryba $2015 \mathrm{~m}$. parèmè Šakių r. SVB projektą „Laisvès kovų atmintis“. Parengta kilnojamoji paroda „Tauro apygardos Žalgirio rintinès laisvès kovų takais“. Paroda eksponuota rajono savivaldybejje, viešojoje bibliotekoje, „Žiburio“, Kudirkos Naumiesčio gimnazijose, Kriūkų pagrindinejje mokykloje, Gelgaudiškio dvare. Parengtas ir 
išleistas informacinis leidinys „Tauro apygardos Žalgirio rinktinei 70“168. Radviliškio r. SVB 2017 m. vykdè projektą „Minaičiai - Lietuvos laisvès kovų istorinè sostine““ (rèmëjos - LKT ir SV). Bibliotekos darbuotojai prisidèjo prie Lietuvos laisvès kovos sąjūdžio tarybos $1949 \mathrm{~m}$. vasario $16 \mathrm{~d}$. deklaracijos pasirašymo inscenizacijos Minaičiuose. Biblioteka surengè parodą „Minaičiai - Lietuvos laisvès kovų istorinè sostinë“. Savivaldybè parèmé Kretingos r. bibliotekos projektą „Lietuvos valstybingumo gynëjų - partizanų - veiklos ženklai Kretingos rajone“. Surinkta medžiaga apie rajono partizanų veiklos, žūties, laidojimo vietas, jų atminimui ịamžinti pastatytus paminklus, atminimo lentas, kryžius, paminklines kompozicijas, pastatus, kuriuose buvo tardomi, kankinami ir žudomi rezistencijos dalyviai. Objektai aprašyti ir naujais straipsniais papildyta elektronine „Kretingos krašto enciklopedija“.

Kultūrinio turizmo poreikiams pasitarnavo Rokiškio r. SVB drauge su Juozo ir Alfonso Keliuočių palikimo studijų centru pradètas igyvendinti projektas „Grafų Komarovskių gimtinès ${ }^{169}$ istorinè ir kultūrinè sklaida“ (2015-2016 m.), kurị parèmè savivaldybè.

Krašto istorijai bei kraštiečių biografijoms, jų indèliui ị krašto kultūrą skirti leidybos projektai. Kraštiečiams projektus skyrė Tauragès r. SVB filialas, Kalvarijos SVB, Vilkaviškio r. SVB filialas, Zarasų r. SVB. Tauragès r. SVB Pagramančio filialas $2007 \mathrm{~m}$. vykdè savivaldybès paremtą projektą „Dainininko, operos solisto J. Mažeikos 100-metis gimtinèje“. Buvo išleistas leidinys „Operos solistas Juozas Mažeika, 1907-1976: atsiminimai“ ${ }^{1170}$. Kalvarijos SVB ir Kalvarijos literatų klubas „Rasa“ vykdè savivaldybès finansuotą tęstinị projektą „Kalvarijos krašto šviesuoliai“. $2007 \mathrm{~m}$. išèjo knygos tokiu pat pavadinimu 2 dalis ${ }^{171}$. Vilkaviškio r. SVB Virbalio m. filialas drauge su bendruomene vykdė projektą, skirtą kraštiečio Juozo Zabielavičiaus atsiminimų knygos leidybai (rèmejjas nenurodytas); rezultatas - Juozo Zabielavičiaus knygos „Virbalis mano atsiminimuose“ 1 dalies pasirodymas ${ }^{172} .2$ dalis pasirodè $2013 \mathrm{~m} .{ }^{173} 2011 \mathrm{~m}$. Zarasų r. SVB igyvendino projektą „Knygos apie Zarasų krašto šviesuolį Domininką Bukontą išleidimas“ (rèmèjas - KRF). Knyga pasirodè tais pačiais metais ${ }^{174}$.

Lazdijų r., Tauragès r., Šilalès r., Pasvalio SVB filialo, Trakų r., Raseinių, Varènos r. bibliotekų projektai numatė leidinių apie gimtąji kraštą išleidimą. Lazdijų r. biblioteka tęsė dar $2004 \mathrm{~m}$. pradètą vykdyti projektą „Monografijos Meteliai leidyba“ (2007 m. ji parèmė KM ir SV). Monografija pasirodè $2008 \mathrm{~m} .{ }^{175}$ Tauragès r. SVB drauge su kaimo bendruomene $2013 \mathrm{~m}$. vykdè projektą „Lomių kaimo bendruomenès paveldo tąsa ir sklaida" (rèmèja - vietinès veiklos grupe (VVG). Jo rezultatas - išleista enciklopedinio pobūdžio knyga „Lomiai amžių sandūroje: žmonès, ịvykiai, statiniai““176. Kultūros rèmimo fondas tais pačiais metais parèmè knygos apie Šilalès rajono bažnyčias išleidimą. Leidinio „Šilalès krašto bažnyčios: istorija ir architektūra" rengimas užtruko, knyga pasirodè $2016 \mathrm{~m} .{ }^{177}$ Pasvalio SVB Jurgènų filialo projektas „Pažink ir garsink savo kaimą“ numate knygos „Jurgènų kraštas: istorija, etnokultūra ir dabartis“ išleidimą (rèmèja - SV). Solidi knyga išleista 2014 metais, autorius - prof. Jonas Aničas ${ }^{178}$. Trakų r. SVB 2015 m. vykdè projektą „Tiltų krašto kaimai šimtmečiu kaitoje“ (rèmèjai - LKT, SV). Išèjo Tiltų bibliotekos vedejjos Elenos Žilinskienès knyga „Tiltų krašto kaimai šimtmečių kaitoje“179.

Tauro apygardos Žalgirio rinktinei 70 / sud. K. Vaičiūnas. Kaišiadorys: Printėja, 2015.

169 Komorovskiai XVIII-XX a. pirmoje puseje valdẻ Kavoliškị (gyvenviete Rokiškio rajone). Iš šios giminès kilęs Lenkijos prezidentas Bronislavas Komorovskis (Bronisław Komorowski). Kavoliškyje yra išlikęs jo senelio Zygmunto Leopoldo Komorovskio (mirè 1920 m.) kapas.

170 Operos solistas Juozas Mažeika: 1907-1976: atsiminimai. Tauragè: Tauragès viešoji biblioteka, 2007.

171 Kalvarijos krašto šviesuoliai, 2 d. / sud. S. Palionienè, N. Skrobliené, L. Karpavičienè. Marijampolè: Piko valanda, 2007. 1 knygos dalis pasirodè $2006 \mathrm{~m}$.

172 Zabielavičius. J. Virbalis mano atsiminimuose, 1 d. Vilnius: Baltijos kopija, 2007.

173 Zabielavičius. J. Virbalis mano atsiminimuose, 2 d. / sud. D. Stankūnienè. Vilnius: Baltijos kopija, 2013.

174 Domininkas Bukontas (1873-1919): leidinių ir straipsnių rinkinys. Vilnius: Petro ofsetas, 2011.

175 Meteliai [Lazdiju rajonas]: monografija / redakcinè kolegija: Irena Seliukaitè ir kit. Marijampolè: Piko valanda, 2008.

176 Lomiai amžiu sandūroje: žmonès, įvykiai, statiniai / sud. E. Bazinienè, L. Užkurienè. Kaišiadorys: Printẻja, 2013.

177 Šilalès krašto bažnyčios: istorija ir architektūra / parengè Loreta Šimutytė-Balčiūnienė. Klaipèda: Druka, 2016.

178 Aničas, J. Jurgènu kraštas: istorija, etnokultūra ir dabartis. Kaunas: Žiemgalos leidykla, 2014.

179 Žilinskienè, E. Tiltų krašto kaimai šimtmečiu kaitoje. Trakai: Standartų spaustuvè, 2015. 
2017 m. Raseinių SVB igyvendino projektą „Jono Brigio knygos Pasistačius bendra darbo tikslą. 1918-1940 m. Raseiniu krašte veikusiu draugiju, politiniu, visuomeniniu, ekonominiu organizaciju sąvadas leidyba“. Knyga, skirta valstybès atkūrimo šimtmečiui, pasirodè tais pačiais metais ${ }^{180}$. Varènos $r$. SVB vykdè projektą „Leidinio Varènos krašto dienoraščiai leidyba“"181. Projektus parèmé savivaldybès.

Kalbant apie projektus, skirtus vaikams ir jaunimui, atkreiptinas dėmesys ị Šiaulių m. ir Šiaulių r. bibliotekų projektinę veiklą. Šiaulių m. biblioteka $2011 \mathrm{~m}$. vykde projektą „Mano Šiauliai - mano pasaulis“" (rèmejja - SV), skirtą Šiaulių miesto 775-ajam gimtadienio jubiliejui. Buvo siekiama, kad vaikai edukacijose geriau pažintų miesto istoriją, mokytųsi ją kūrybiškai atskleisti piešiniuose. Šiaulių m. SVB „Šaltinèlio“ filialas $2015 \mathrm{~m}$. vykdè projektą „Tradicijos ir modernumas: interaktyviai kuriame istoriją Šiauliams 2“ (rèmejjos - LKT, SV ${ }^{182}$ ). Rengiantis Šiaulių 780-ajam gimtadieniui, miesto ir rajono mokiniai buvo pakviesti kurti pasakas, sakmes, legendas apie žinomus ir lankomus objektus. Atrinkta dvylika geriausių, kūrybiškiausių istorijų, kurios pateko ị 2016-ųjų metų sieninị kalendorių - vaikų kurtų sakmių ir kitokių pasakojimų rinktinę „Vaikų istorijos Šiauliams" ${ }^{\text {"183 }}$. Kitas svarbus projekto akcentas - panaudojant šešèlių teatro kūrimo metodiką skatinti jaunosios kartos šiauliečius domètis gimtuoju miestu. Pagal sukurtas sakmes, pasakas ir legendas apie Šiaulių miestą jaunieji šiauliečiai buvo pakviesti kurti šešèlių teatro spektaklius. Nufilmuoti šešèlių teatro spektakliai ịrašyti ị kompaktinį diską „Kuriu istoriją Šiauliams 2“.

2016 m. savivaldybės finansavo Šiaulių m. ir Šiaulių r. Kuršènų bibliotekos projektus. Šiaulių m. biblioteka bendradarbiaujant su UAB „Media Traffic“ igyvendino projektą „Šiaulių krašto istorija atgimsta animacijoje“. Jo tikslas - paskatinti moksleivius geriau pažinti savo gimtojo miesto istoriją pakviečiant kurti animacinius filmukus pagal Šiaulių miesto 780-ajam gimtadieniui sukurtas sakmes. Kuršènų biblioteka vykde projektą „Nežiopsok, kas dar liko, užfiksuok“. Siekta suaktyvinti jaunimo domèjimąsi Kuršènų istorija, jo urbanistiniu paveldu. Jaunimas kartu su projekto vadove rinko medžiagą apie miesto XX a. 6-10 dešimtmečiuose veikusias pramonès ir kitokio pobūdžio įmones. Sukaupta medžiaga ịrašyta i elektronines laikmenas.

Paminètinas originalus Šilutès r. SVB projektas, skirtas knygos istorijai. Lietuvos kultūros taryba, Kultūros ministerija ir savivaldybe $2017 \mathrm{~m}$. finansavo bibliotekos projektą „Knygos istorija: nuo rašto ištakų iki ekslibriso" (partneriai: Šilutès Hugo Šojaus muziejus, Pagėgių savivaldybės Martyno Jankaus muziejus, Šilutès raštijos ir knygių draugija). Projektas skirtas kultūros edukacijos stovyklai. Edukacija vykdyta nuo įvado ị rašto ir knygos gimimą (praktiniai rašymo ant vaškinių, molinių, grifelinių lentelių ir kitokie užsièmimai Šilutės Hugo Šojaus muziejuje) pereinant prie pažinties su Mažosios Lietuvos knygos ypatumais, knygininkais, knygnešystės reiškinio unikalumo ịtvirtinimu viešosios bibliotekos Knygos muziejuje bei Pagègių savivaldybės Martyno Jankaus muziejuje. Baigiamasis renginys - asmeninio ekslibriso kūrimas.

\subsubsection{Socialiniai projektai}

Kaip pažymèta ịvade, autorius socialiniams projektams priskyrè projektus, kuriuose tiesiogiai apibrežtos socialinès problemos. Bibliotekos vykdè projektus, skirtus socializacijai, įvairių gyventojų grupių socialinei atskirčiai mažinti, jaunimo socialinèms problemoms spręsti. Projektai numate įvairias sociokultūrinès pagalbos priemones gyventojams. Gyventojų socializacijai, socialinėms-psichologinėms problemoms spręsti buvo reikšmingi ir jau aptarti kultūros edukacijos, biblioterapijos, meno terapijos projektai. Duomenys apie 2007, 2013, 2015-2017 m. vykdytus socialinius projektus (jų nèra daug) pateikiami 16 lentelèje.

\footnotetext{
180 Brigys, J. Pasistačius bendrą darbo tikslą:1918-1940 m. Raseinių krašte veikusių draugijų, politinių, visuomeninių, ekonominių organizacijų sąvadas. Kaišiadorys: Printeja, 2017.

181 Knyga Varénos krašto dienoraščiai: gamtos ritmu / sud. J. Žitkauskas. Vilnius: Petro ofsetas, 2019.

182 Sprendžiant iš šaltinių, ì ši projektą buvo taip pat buvo integruotas savivaldybès paremtas projektas „Tradicijos ir modernumas: interaktyviai kuriame istoriją Šiauliams“.

183 Vaikų istorijos Šiauliams / sud. D. Maskuliūnienè, R. Božienè. Radviliškis: Litera, 2016.
} 
16 lentele. Socialinių projektų vykdymas 2007, 2013, 2015-2017 m. (skliaustuose - bibliotekų skaičius apskrityse, vykdytų projektų skaičius, rèmėjų tipas: $\mathrm{Tr}$ - tarptautinis rèmėjas, $\mathrm{Nr}$ - nacionalinis rèmëjas, $\mathrm{Vr}$ - vietos rèmèjas)

\begin{tabular}{|c|c|c|c|c|c|c|c|}
\hline & & $\begin{array}{c}\text { Kauno } \\
\text { apskr. (8), Ma- } \\
\text { rijampolès } \\
\text { apskr. (5) }\end{array}$ & $\begin{array}{l}\text { Klaipèdos } \\
\text { apskr. (7), } \\
\text { Tauragès } \\
\text { apskr. (4) }\end{array}$ & $\begin{array}{l}\text { Panevėžio } \\
\text { apskr. (6), } \\
\text { Utenos } \\
\text { apskr. (6) }\end{array}$ & $\begin{array}{c}\text { Šiaulių } \\
\text { apskr. (7), } \\
\text { Telšių } \\
\text { apskr. (4) }\end{array}$ & $\begin{array}{l}\text { Vilniaus } \\
\text { apskr. (8) } \\
\text { Alytaus } \\
\text { apskr. (5) }\end{array}$ & $\underset{\substack{\infty \\
: \infty}}{\infty}$ \\
\hline 1 & $2007 \mathrm{~m}$ & $\begin{array}{l}\text { Kèdainių r. } \\
\text { SVB }(1, \mathrm{Vr}-1) \text {, } \\
\text { Prienų SVB (1, } \\
\text { Vr - 1), Mari- } \\
\text { jampolès SVB } \\
(1, \mathrm{Vr}-1)\end{array}$ & & $\begin{array}{l}\text { Visagino SVB } \\
\text { (nenurody- } \\
\text { ta }-1 \text { ) }\end{array}$ & $\begin{array}{l}\text { Radviliškio } \mathrm{r} . \\
\operatorname{SVB}(2, \mathrm{Vr}-2)\end{array}$ & & 6 \\
\hline 2 & $2013 \mathrm{~m}$ & & & $\begin{array}{l}\text { Kupiškio r. SVB } \\
(1, \mathrm{Nr}-1), \mathrm{Pa}- \\
\text { nevėžio r. SVB } \\
(1, \mathrm{Vr}-1) \\
\text { Utenos SVB (2, } \\
\operatorname{Tr}-2)\end{array}$ & & $\begin{array}{l}\text { Varènos r. SVB } \\
(1, \operatorname{Tr}-1)\end{array}$ & 5 \\
\hline 3 & $2015 \mathrm{~m}$ & $\begin{array}{l}\text { Kauno m. SVB } \\
(1, \text { nenurody- } \\
\text { ta }-1)\end{array}$ & $\begin{array}{l}\text { Šilalès } r . \text { SVB } \\
(1, \operatorname{Tr}-1 \\
\mathrm{Nr}-1)\end{array}$ & $\begin{array}{l}\text { Panevėžio r. } \\
\text { SVB }(2, \mathrm{Vr}-2), \\
\text { Pasvalio SVB } \\
(1, \operatorname{Tr}-1, \mathrm{Vr}-1), \\
\text { Utenos SVB } \\
(1, \operatorname{Tr}-1, \mathrm{Nr}-1)\end{array}$ & $\begin{array}{l}\text { Pakruo- } \\
\text { jo r. SVB } \\
(1, \mathrm{Tr}-1, \\
\mathrm{Nr}-1), \text { Šiau- } \\
\text { lių m. SVB (2, } \\
\mathrm{Nr}-1, \text { nenu- } \\
\text { rodyta - 1) }\end{array}$ & $\begin{array}{l}\text { Elektrènų SVB } \\
(1, \mathrm{Vr}-1) \text {, } \\
\text { Vilniaus } \mathrm{m} . \\
\text { SCB }(1, \mathrm{Nr}-1) \text {, } \\
\text { Švenčionių r. } \\
\text { SVB }(1, \mathrm{Tr}-1 \text {, } \\
\mathrm{Nr}-1)\end{array}$ & 12 \\
\hline 4 & $2016 \mathrm{~m}$ & $\begin{array}{l}\text { Marijampolès } \\
\operatorname{SVB}(1, \mathrm{Vr}-1)\end{array}$ & $\begin{array}{l}\text { Šilutès r. SVB } \\
(1, \mathrm{Nr}-1), \\
\text { Šilalès r. SVB } \\
(1, \mathrm{Tr}-1, \\
\mathrm{Nr}-1)\end{array}$ & $\begin{array}{l}\text { Pasvalio SVB } \\
(1, \operatorname{Tr}-1, \\
\text { Vr }-1), \text { Rokiš- } \\
\text { kio r. SVB (1, } \\
\text { Vr }-1), \text { Utenos } \\
\text { SVB }(1, \operatorname{Tr}-1, \\
\text { Nr }-1)\end{array}$ & $\begin{array}{l}\text { Pakruo- } \\
\text { jo r. SVB } \\
(1, \mathrm{Tr}-1, \\
\mathrm{Nr}-1), \text { Šiau- } \\
\text { lių m. SVB } \\
(1, \mathrm{Nr}-1), \\
\text { Šiaulių r. SVB } \\
(1, \mathrm{Nr}-1, \\
\mathrm{Vr}-1)\end{array}$ & $\begin{array}{l}\text { Elektrènų SVB } \\
(1, \mathrm{Vr}-1), \\
\text { Švenčionių r. } \\
\text { SVB (1, Tr - } 1 \text {, } \\
\mathrm{Nr}-1), \mathrm{Vil}- \\
\text { niaus m. SCB } \\
(3, \mathrm{Nr}-3) \text {, } \\
\text { Alytaus r. SVB } \\
(1, \mathrm{Vr}-1)\end{array}$ & 15 \\
\hline 5 & $2017 \mathrm{~m}$ & & $\begin{array}{l}\text { Šilutès r. SVB } \\
(1, \mathrm{Nr}-1)\end{array}$ & $\begin{array}{l}\text { Panevéžio r. } \\
\text { SVB }(2, \mathrm{Nr}-1, \\
\text { Vr }-1), \text { Rokiš- } \\
\text { kio r. SVB (1, } \\
\text { Vr }-1)\end{array}$ & $\begin{array}{l}\text { Akmenès r. } \\
\text { SVB (1, } \\
\text { Vr - 1), Plun- } \\
\text { gès r. SVB (1, } \\
\text { Nr - 1) }\end{array}$ & $\begin{array}{l}\text { Širvintų r. SVB } \\
(1, \text { nenurody- } \\
\text { ta }-1), \text { Vil- } \\
\text { niaus m. SVB (3, } \\
\text { Nr - } 2, \mathrm{Vr}-1)\end{array}$ & 10 \\
\hline $\begin{array}{l}\text { Pro } \\
\text { tarp } \\
\text { nac } \\
\text { viet } \\
\text { par } \\
\text { pro }\end{array}$ & $\begin{array}{l}\text { ktų skaičius, } \\
\text { autinių, } \\
\text { nalinių, } \\
\text { s rèmëjų } \\
\text { na vykdant } \\
\text { ktus }\end{array}$ & $\begin{array}{l}{ }^{\star} \text { Kauno apskr. bi } \\
\text { bibliotekos: } 2, \mathrm{Tr} \\
\mathrm{Vr}-0 ;{ }^{\star} \text { Tauragė } \\
\text { kos: } 10, \mathrm{Tr}-2, \mathrm{~N} \\
\text { rodyta }-1 \text {; }{ }^{\star S} \text { Siau } \\
\text { apskr. biblioteko } \\
\mathrm{Nr}-8, \mathrm{Vr}-2, \mathrm{n} \\
\text { Vykdyta projekt } \\
\text { nenurodyta }-4\end{array}$ & $\begin{array}{l}\text { iotekos: } 3, \mathrm{Tr}-0 \\
-0, \mathrm{Nr}-0, \mathrm{Vr}- \\
\text { apskr. bibliotekc } \\
-2, \mathrm{Vr}-8 ;{ }^{*} \mathrm{Ut} \\
\text { ue apskr. bibliote } \\
1, \mathrm{Tr}-0, \mathrm{Nr}-1 \\
\text { hurodyta }-1 ;{ }^{*} \\
\text { 48; paramos te }\end{array}$ & $\begin{array}{l}\mathrm{Nr}-0, \mathrm{Vr}-2, \text { nen } \\
\text {; }{ }^{\star} \mathrm{Klaipejdos} \mathrm{apskr} \\
: 2, \mathrm{Tr}-2, \mathrm{Nr}-2 \text {, } \\
\text { os apskr. bibliotek } \\
\text { os: } 9, \mathrm{Tr}-2, \mathrm{Nr}-5 \\
\mathrm{Vr}-0 ;{ }^{\star} \text { Vilniaus a } \\
\text { ytaus apskr. bibliot } \\
\text { rejju skaičius (per }\end{array}$ & $\begin{array}{l}\text { urodyta }-1 ;{ }^{\star} \text { Mar } \\
\text { br }-0 ;{ }^{\star} \text { Panevèži } \\
\text { ros: } 5, \operatorname{Tr}-4, \mathrm{Nr} \\
\text { 5, Vr }-4 \text {, nenuro } \\
\text { pskr. bibliotekos } \\
\text { tekos: } 2, \operatorname{Tr}-1, \mathrm{~N} \\
\text { metus): } \operatorname{Tr}-13,1\end{array}$ & $\begin{array}{l}\text { rijampolès apskr. } \\
\mathrm{r}-0, \mathrm{Nr}-2 \text {, } \\
\text { io apskr. bibliote- } \\
-2, \mathrm{Vr}-0 \text {, nenu- } \\
\text { dyta }-1 \text {; }{ }^{\star} \text { Telšių } \\
\mathrm{12}, \mathrm{Tr}-2 \\
\mathrm{Vr}-0, \mathrm{Vr}-1 \\
\mathrm{Nr}-22, \mathrm{Vr}-19\end{array}$ & 48 \\
\hline
\end{tabular}


Vykdyti 48 projektai. Rezultatyviai socialinius projektus vykdė Šilutès r. SVB (Klaipėdos apskr.), Panevėžio r. SVB (Panevėžio apskr.), Utenos SVB (Utenos apskr.), Šiaulių m. SVB (Šiaulių apskr.), Vilniaus $\mathrm{m}$. SVB (Vilniaus apskr.). Vyravo nacionalinių ir vietos rèmëjų parama. Tarptautinių rèmèjų parama daugiausia pasinaudojo Utenos SVB biblioteka.

Socialiniuose projektuose, kurie daugiausia skirti vaikams ir jaunimui (2007-2015 m. projektai daugiausia skirti vaikams ir jaunimui, suaugusiesiems projektų padaugèjo 2016 ir 2017 m.), keliami socializacijos uždaviniai. Radviliškio r. centrinė biblioteka ir Radviliškio r. SVB Šeduvos filialas vykdè projektus „Vaikų socializacijos programa“ (2007 m., 2 projektai), Ignalinos r. SVB - socializacijos projektą „Kūrybos versmë“ (2008 m.). Projektų rèmėjos buvo savivaldybès. 2009 m. Naujosios Vilnios biblioteka vykdè socializacijos programą „Gyvenimo ịgūdžių ugdymas“, kurią parèmé Švietimo ir mokslo ministerija.

Projektai, skirti vaikų ir paauglių socialinei atskirčiai mažinti. Kupiškio r. SVB projektas „Lèlių teatras - jaukus vaikystès pasaulis“ buvo skirtas vaikų ir paauglių iš probleminių, socialiai remtinų šeimų socialinei atskirčiai mažinti (2011 m., rèmëjai - Atviros visuomenès instituto Pagalbos fondas $\left.{ }^{184}, \mathrm{KM}\right)$. Sprendžiant vaikų ir paauglių socialinès atskirties mažinimo problemą išskirtinis vaidmuo priklauso 2013 m. pradètam vykdyti Utenos SVB tęstiniam projektui „Žaisdami mokomès“, kurị parèmė EIFL fondas. Jo tikslas - parodyti bibliotekų, kaip neformaliojo švietimo įstaigų, svarbą formaliojo švietimo sistemoje vykdant vaikų ir paauglių nenoro mokytis bei mokyklos nelankymo prevencijos ir popamokinio užimtumo programas. Siekta bendradarbiaujant mokykloms bei bibliotekoms įtraukti problemiškus vaikus ir paauglius ị veiklas, skatinančias mokytis, siekti pripažinimo mokykloje ir ją lankyti. Igyvendinant projektą sukurtas socialinis edukacinis žaidimas „Iššǔkis“ ir mokytis motyvuojanti metodika, kuri taikyta 13 Utenos rajono mokyklų ir 25 bibliotekose. Tinklalapis „Naujasis knygnešys“ informuoja, kad 2013-2014 m., bendradarbiaujant su Ugdymo plètotès centru, žaidimas „Iššǔkis“ pritaikytas platesnei auditorijai išplečiant jo turinị bei technologinès sistemos galimybes ir įdiegtas dar 9-iose Lietuvos savivaldybėse. Jis veikia Alytaus miesto ir rajono, Ignalinos, Lazdijų, Molètų, Utenos, Zarasų rajonų, Klaipèdos bei Šiaulių miestų ir Birštono savivaldybių bibliotekose ir mokyklose ${ }^{185}$.

BMGF ir KM [BP 2] finansavo Švenčionių r., Pasvalio, Pakruojo r., Šilalès r., Utenos bibliotekų projektus, skirtus jaunimo socialinėms problemoms spręsti. Švenčionių r. SVB vykdè projektą „Informacinių technologijų centro Failiukas ịkūrimas ir veikla bibliotekose", kuriuo siekta užimti vaikus iš socialiai remtinų šeimų ir vaikų globos namų. Centrinèje bibliotekoje, Pabradès, Švenčionèlių bibliotekose sukurta nauja paslauga - vaikų užimtumas techniniuose būreliuose. Pasvalio biblioteka su grupe partnerių (Panevėžio teritorinès darbo biržos Pasvalio skyrius ir kt.) vykdė projektą „Modernių jaunimo erdvių Mono arba Stereo tinklo kūrimas“. Projektas skirtas Pasvalio rajono jaunimo socialinėms problemoms spręsti: menkai jaunimo motyvacijai, pilietiniam pasyvumui, menkam dalyvavimui bendruomenès gyvenime, verslumo stokai, socialinių igūdžių praradimui, žalingų ỉpročių prevencijai, nepakankamam laisvalaikio užimtumui. Siekiant realizuoti šiuos uždavinius ịkurta jaunimo kūrybinè erdvè centrinèje bibliotekoje ir šešiuose filialuose. Pakruojo r. SVB ịgyvendino projektą „IRT kilnojamojo centro įkūrimas Pakruojo Juozo Paukštelio viešojoje bibliotekoje“ (partneriai - Žeimelio gimnazija, Pakruojo r. savivaldybès visuomenès sveikatos biuras). Siekta atitraukti nuo žalingų ịpročių, nusikalstamo elgesio ir patyčių rajono vaikus ir jaunimą suteikiant jiems galimybę turiningai leisti laisvalaikị ${ }^{186}$. Šilalès r. SVB projektas „Interaktyvi edukacinè-terapinè erdvè jaunimui“ (partneriai - mokyklos, AB „TEO LT“) turejjo tikslą ikurti bibliotekoje terapinę erdvę jaunimui, siekiant užtikrinti kokybišką laisvalaikĭ, kelti jaunų žmonių motyvaciją bei prisidèti prie savižudybių prevencijos. Tai buvo pirmoji ir vienintelè tokio pobūdžio erdvè jaunimui rajone.

\footnotetext{
184 Atviros visuomenès institutas filantropo G. Soroso iniciatyva $2009 \mathrm{~m}$. įsteigè Pagalbos fondą, kuriuo buvo siekiama padèti labiausiai pažeidžiamoms visuomenių grupèms įveikti globalios krizès padarinius.

185 Socialinis edukacinis kompiuterinis žaidimas „Iššūkis“. Prieiga per internetą: http://www.naujasis-knygnesys.lt/dalyviai/socialinis-edukacinis-kompiuterinis-zaidimas-quot-issukis-quot/15. Žiūrèta 2018-09-28.

186 Vykdant projektą dèmesys ypač skirtas „pavežamiems“ vaikams, kurie po pamokų priversti iki 3 valandų laukti mokyklinio autobuso, kol bus parvežti namo.
} 
Pažymėtina Utenos bibliotekos iniciatyva - buvo atkreiptas dèmesys ị sutrikusios raidos vaikus. Biblioteka laimèjo projektą „Sutrikusios raidos vaikų bendrụjų gebejjimų ir socialinių igūdžių ugdymas bibliotekose panaudojant tikslinius žaidimus bei kompiuterines ir aplinkos technologijas". Projektas vykdytas kartu su Vilniaus universiteto Matematikos ir informatikos institutu, Šiaulių universitetu, technologiju bei kūrybinių industrijų įmonèmis (Všt „Hiteco“, UAB „Gluk Media“). Vaikų literatūros skyriuje įkurtas mobilus tikslinių žaidimų centras, kuriame vaikai galëjo žaisti ne tik kompiuteriu, bet ir naudodami atpažinimo technologijas, pasitelkdami robotiką (robotai su specialiai sutrikusios raidos vaikams pritaikytomis užduotimis). VB ir kaimo bibliotekų kompiuteriuose įdiegtas lietuvių kalbos ir socialinių igūdžių lavinimo žaidimas „Pagalbininkas“. 11 centrinès ir kaimo bibliotekų darbuotojų, baigę atitinkamus mokymus, tapo tikslinių žaidimų instruktoriais ir pradejjo dirbti su sutrikusios raidos vaikais, juos instruktuoti ir konsultuoti.

Lietuvos kultūros taryba ir savivaldybė parėmé Šiaulių r. SVB projektą „Biblioteka - kūrybiškumui ir edukacijai" (2016 m.). Jo tikslas - sudaryti sąlygas socialinę atskirtị patiriantiems Šiaulių rajono vaikams ir jaunimui integruotis ị visuomenę, ugdyti jų savivertę ir kūrybiškumą. LKT finansavo Naujosios Vilnios bibliotekos projektą „Kultūrų dialogas vienija: programa romų vaikams ir jaunimui“ (2016 m.). Socializacijos, socialinès atskirties mažinimo programa skirta Kirtimų taboro romų vaikams ir jaunimui. Socialinès apsaugos ir darbo ministerija parèmé Naujosios Vilnios bibliotekos projektą „Psichosocialinès paslaugos vaikų ir jaunimo dienos centro „Mūsų nameliai“ lankytojams ir jų šeimoms“ (2016-2017 m.). Projektas numatė kompleksinių socialinių-psichologinių ir sociokultūrinių paslaugų teikimą dienos centro lankytojams ir jų šeimoms. Socialinès apsaugos ir darbo ministerija taip pat skyrè lèšų Panevėžio r. SVB Gustonių bibliotekos projektui „Popietès Gustonių bibliotekoje - UDC, vykdant vaikų dienos centro veiklas" (2017-2018 m.). Projektas suteikè galimybę Gustonių kaimo vaikams po pamokų igyti socialinių igūdžių. Vaikai mokèsi elgesio prie stalo etiketo, gilino žinias apie sveiką gyvenseną, asmens higieną.

Mèginama padèti jaunimui spręsti nedarbo problemą. Varènos r. SVB drauge su VVG vykdẻ projektą „Varẻnos krašto jaunimo iniciatyvų skatinimas“ (2013-2014 m.), kurị parèmé Europos žemès ūkio fondas kaimo plètrai. Siekta išsiaiškinti rajono jaunimo poreikius, apibrěžti veiklas, motyvuojančias jaunimą dirbti ir gyventi kaime. Apklausos, kurią atliko biblioteka, rezultatai parodè, kad jaunimas turi veiklos idẻjų, tačiau joms iggyvendinti trūksta lèšų, žinių, vietos bendruomenès paramos jaunimo idejjoms. Igyvendintos veiklos: sukurta interneto svetainè jaunimas.varena.lt, apmokyta 80 rajono jaunuolių verslo idèjų generavimo, projektų rengimo temomis, organizuota gerosios patirties išvyka ị kitų rajonų organizacijas, surengti mokymai „Jaunimo organizacijos kūrimas“ ir baigiamoji konferencija, kurioje pristatytos jaunimo projektų finansavimo galimybès. Pradèta bendradarbiauti su Lietuvos darbo birža, kuri 2013 m. spalio pabaigoje pradejjo igyvendinti Europos socialinio fondo finansuojamą projektą „Pasitikèk savimi“. Projekto tikslas - kartu su nevyriausybinèmis organizacijomis skatinti jaunimo integraciją i darbo rinką ar švietimo sistemą teikiant socialinès reabilitacijos ir parengimo užimtumui darbo rinkoje paslaugas. I projekto vykdymą $2014 \mathrm{~m}$. įsitraukè Vilniaus m. centriné biblioteka, Antakalnio, Naujosios Vilnios, Pilaités filialai. Projekto tikslinè grupé - 16-25 metụ jaunuoliai, kurie nedirbo, nesimoke ir nedalyvavo aktyviose darbo rinkos politikos priemonèse. Organizuotuose mokymo kursuose pristatyta „YouRock“ platforma, kuria siekiama didinti jaunimo i̇darbinimo galimybes. Bibliotekos darbuotojos taip pat pristatė jaunuoliams elektroninès valdžios vartus: dalyviai buvo supažindinti su kandidatavimo ị valstybės tarnybą procedūra. $2015 \mathrm{~m}$. ị projekto vykdymą įsitraukẻ Šiaulių m., Zarasų r., Panevėžio r., Jonavos r., Telšių r. SVB ir kitos bibliotekos.

Projektus, skirtus vaikų ir jaunimo užimtumui bei socialinei atskirčiai mažinti, rèmé savivaldybès. 2016 m. Alytaus r. biblioteka vykde projektą „Aš toks pat kaip tu“. Projektas skirtas socialinès rizikos šeimų vaikams, jų savivertei ugdyti. Elektrènų biblioteka vykdė projektą "Jaunimo užimtumo skatinimas“. Siekta ịtraukti i̇ projektą ne tik gabų, bet ir niekur nedirbantị ir nesimokantị jaunimą, sudaryti sąlygas prasmingam jaunimo laisvalaikiui ir užimtumui organizuojant edukacinius užsièmimus. Rokiškio r. 
biblioteka vykdè projektą „Padèk sau - niekas kitas to nepadarys“. Buvo teikiama socialinè ir psichologiné pagalba jaunimui parenkant specialią literatūrą, kviečiant ịvairių sričių specialistus. Specifinị projektą vykdė Kuršènų biblioteka. Ji realizavo projektą „122 žingsniai bendravimo ir tobulejimo link“. Projekto tikslas - mažinti Kuršènų jaunimo socialinę atskirtị, ugdyti jų kūrybiškumo ịgūdžius, pritaikant inovatyvias akvariumo ịrengimo ir jo priežiūros veiklas. Organizuotos teorinės paskaitos, diskusijos, viktorinos, edukaciniai užsièmimai apie povandeninio kraštovaizdžio kūrimą. İkurta terapinè relaksacinè erdvè su žuvų ir augalų akvariumu. Siekta mažinti socialinę atskirtị per vasaros atostogas. $2017 \mathrm{~m}$. Naujosios Vilnios biblioteka vykdè projektą „Vasaros stovykla Būk sveikas ir laimingas“. Vaikų vasaros programa skirta vaikams ir paaugliams iš socialinès rizikos šeimų. Stovykloje kas savaitę organizuotos skirtingo pobūdžio veiklos. Pavyzdžiui, „Kūrybiškumo“ savaitė skirta kūrybiniams užsiėmimams, kuriuose stovyklos dalyviai lavino meninius gebėjimus, padedami savanorio psichologo ugdè socialines kompetencijas.

Savivaldybės rèmė projektus, skirtus narkomanijos, žalingų ịpročių, nusikalstamumo prevencijai. 2007 m. Kèdainių r. bibliotekos projektas „Gyvenkime prasmingai“ ir Prienų bibliotekos programa „Savojo kelio beieškant“ skirti narkomanijos prevencijai. Lazdijų r. biblioteka vykdè vaikų ir paauglių nusikalstamumo prevencijos projektą „Sąskaita gèrio link“ (2011 m.). Panevė̌zio r. Velžio mst. biblioteka igyvendino projektą „Atsisakyti sunku, tačiau verta“ (2013 m.), kurio tikslas - jaunimo žalingų ịpročiu prevencija. Akmenès r. SVB centriné biblioteka ir Sablauskių k. filialas $2017 \mathrm{~m}$. realizavo bendrą projektą „Teisingo požiūrio ị sveiką gyvenseną formavimas, žalingų ịpročių prevencija“. Panevėžio r. biblioteka vykdè projektą „Svaigintis - žalinga ir nemadinga“. Projektas skirtas ne tik alkoholio, tabako ir kitų psichoaktyvių medžiagų vartojimo prevencijai, bet ir vaikų bei paauglių užimtumui didinti.

Projektai skirti ir suaugusiems gyventojams. $2007 \mathrm{~m}$. Marijampolès SVB projektą skyrė neigaliujų socialinei integracijai. Biblioteka kartu su Lietuvos neịgaliųjų draugijos Marijampolès skyriaus nariais igyvendino projektą „Neịgaliųų socialinès integracijos programa“ (rèmëja - SV). Biblioteka surengè šventę neiggaliesiems „Ateik, užteks ir tavo sielai vietos, širdies tiek daug - jau neišsemti jos“. 2012 metais Marijampolès SVB, vykdydama projektą „Negalia - ne kliūtis bendrauti ir bendradarbiauti“ (rèmèja $\mathrm{KM}$ ), neịgaliesiems organizavo kultūrinių ir kūrybinių renginių ciklus. Mažinti neịgaliụjų ir pagyvenusių žmonių socialinę atskirtị siekè Panevěžio r. biblioteka. $2012 \mathrm{~m}$. ji ịgyvendino du panašius projektus: „Šviesos link“ (rèmejja - KM) ir „Gyvenimo šviesa“ (rèmëja - SV). Realizuodamos pirmą projektą, rajono bibliotekos organizavo neigaliụjų kūrybines akcijas (dailiųjų amatų, saviveiklinio meno, literatų kūrybos pristatymai), surengė susitikimus su profesionaliais kūrẻjais, lektoriais. Vykdydami antrą projektą, bibliotekų darbuotojai įtraukè ị veiklas ịvairių meninių sugebejjimų turinčius neiggalius ir pagyvenusius socialinès atskirties asmenis. Atskleisti siuvinejjimo, origamio ${ }^{187}$, audimo, mezgimo, pynimo iš vytelių, vèlimo iš vilnos, skiautinių meno ${ }^{188}$, kalvystès, drožybos, kryždirbystės, tapybos, literatų, dainavimo, vaidybos talentai. Senyvo amžiaus bei sutrikusio intelekto žmonių integracijai ị visuomenę, ivvairių kartų sanglaudai stiprinti buvo naudingas Pasvalio bibliotekos su daugeliu partnerių vykdytas projektas „Senolių pasakos, žaislai ir žaidimai dabartyje“ (rèmèja - KM). Organizuotas atokiuose kaimuose gyvenančių senyvo amžiaus žmonių lankymas, pasakų knygų ir žaislų rinkimas, žaislų gamyba ir kt. Pasvalio specialiojoje mokykloje atidaryta paroda „Mūsų vaikystès knygos ir žaislai“, surengti Pasvalio rajono sutrikusio intelekto žmonių užimtumo centro „Viltis“ lankytojų spektakliai.

Skatinti neiggalių žmonių ir kitų socialiai pažeidžiamų gyventojų grupių socialinę integraciją bibliotekų vykdomais projektais siekta ir vèlesniais metais. Šiaulių m. bibliotekos projekto realizavimas suteike pagalbą neigaliųjų vaikų tėvams. 2015 m. LKT paremė Lietuvos bibliotekininkų draugijos Šiaulių m. skyriaus projektą „Informacinių paslaugų plètra neịgaliųjų vaikų tėvams“. Tẻvams parengta informacinio

Origamis (jap. k. ori - „lankstyti“ + kami - „popierius“) - japoniškas popieriaus lankstymo menas. Origamiais vadinami ir patys lankstiniai.

188 Skiautinys - iš medžiagos gabalelių sukurtas rankdarbis, paremtas siuvimu, daigstymu iš audinių skiaučių. Skiautinių technika geometrinių formų menas. 
pobūdžio medžiaga. Ji tapo pagalbine priemone ne tik negalią turinčių vaikų tėvams, bet ir bibliotekų darbuotojams, dirbantiems su šia socialinès atskirties žmonių grupe. Kauno m. bibliotekos „Aušros“ padalinys kartu su partneriais (labdaros fondas „Aušta“, silpnaregių bendrija „Akių šviesa“, Žaliakalnio seniūnija ir kt.) vykdè projektą „Žaliakalniečiai - aktyvi, kūrybinga, brandi bendruomenë“ (rèmèjas nenurodytas). Organizuotas sociokultūrinès pagalbos teikimas Žaliakalnio bendruomenėje gyvenančioms socialinę atskirtị patiriančioms šeimoms ir vienišiems seneliams.

Šilutès r. biblioteka 2016 m. vykdè projektą „Inovatyvūs pramogadieniai kartu su biblioteka“, kurị finansavo Lietuvos kultūros taryba. Projektas vykdytas su 5 partneriais: Lietuvos pensininkų sąjungos „Bočiai“ Šilutès r. skyriumi, klubu „Moterų seklyčia“, Macikų socialinės globos namais, Šilutès socialinių paslaugų centru, Šilutès sielos negalią turinčių žmonių klubu „Sielos paguoda“. Siekta telkti vyresniojo amžiaus ir socialinès atskirties žmones, integruoti juos ị bendruomenès gyvenimą siūlant inovatyvias paslaugas, sudarančias sąlygas palankiam ir aktyviam mokymuisi bei pažinimui, turiningam laisvalaikiui (pavyzdžiui, tarp bibliotekos paslaugų - interaktyvios boulingo varžytuvės). Šiaulių m. biblioteka vykdė projektą „Tylos kalba: integruota kūrybinè edukacija klausos negalią turintiems“, kurị parèmė Kultūros ministerija. Siekta sudaryti sąlygas ugdyti saviraišką ir skaitmenines kompetencijas, mažinti socialinę atskirtị, atverti naujas kūrybos galimybes miesto klausos negalią turinčiųjų bendruomenei. Organizuoti edukaciniai užsièmimai, parengtas el. leidinys „Fotografijos pradžiamokslis klausos negalią turintiems“. Ypatingą bibliotekos rūpinimąsi klausos negalią turinčiais žmonėmis parodo iškalbingas faktas: šešios darbuotojos lankė gestų kalbos vertejų kursus. Skatinti socialiai pažeidžiamų grupių užimtumą, aktyvinti jų dalyvavimą bendruomenès gyvenime mažinant kultūrinę bei socialinę atskirtị siekẻ Marijampolès bibliotekos projektas „Sielos terapija“ (rèmèja - SV).

Daugèjo projektų partnerių, plètėsi tikslinès grupès. Šilutės r. biblioteka 2017 m. vykdè projektą „Trys žingsniai socializacijos link“ (rèmëja - LKT). Projektas skirtas socialinę atskirti patiriantiems moksleiviams, jaunimui, senjorams. Socializacijos uždaviniai buvo sprendžiami trimis etapais (pirmas etapas rengtos paskaitos senjorams apie sveiką gyvenseną, konfliktų valdymą, jie buvo mokomi skaitmeninio raštingumo ir kt.). Tarp projekto partnerių - asociacija Kintų jaunimo klubas, Šilutès rajono policijos komisariatas, „Diemedžio“ ugdymo centras (Švèkšna). Širvintų r. SVB vykde projektą „Gydanti knygos galia“" (rèmëjas nenurodytas). Vykdant projektą siekta mažinti senyvų ir neịgalių žmonių socialinę ir kultūrinę atskirtị, padèti spręsti jų dvasines problemas. Projekto tikslinè grupė: Širvintų parapijos globos namų, Socialinių paslaugų centro globotiniai, Neigaliųjų draugijos, Lietuvos aklųjų ir silpnaregių sąungos Širvintų rajono filialo, Širvintų žmonių bendrijos „Lemties bičiuliai“ nariai.

Naujus akcentus įžiūrime Plungès r. bibliotekos, Naujosios Vilnios, Radviliškio r. bibliotekų vykdytuose projektuose. Lietuvos kultūros taryba finansavo Plungès r. bibliotekos projektą „TA vieta - jaučiu, liečiu, girdžiu esu - „žalieji pasimatymai“. Projektas siūle ekskursijas po parką klausos, regèjimo ir judèjimo negalią turintiems žmonèms. Kūrybinèse gamtos dirbtuvèlèse neiggalieji, vadovaujami profesionalų, mokèsi kurti meno kūrinius iš augalų, rinkti vaistinguosius augalus ir kt. Naujosios Vilnios biblioteka vykdè projektą „Nestovèk vietoje - menas padès“ (rèmèja - LKT). Projekto tikslinè grupé - Naujosios Vilnios bendruomenès ne lietuvių tautybès nariai, turintys silpnus socialinius, mokymosi ir kalbinius igūdžius. Parengta socialinès integracijos ir neformalaus ugdymo meninè programa, organizuoti edukacinio pobūdžio užsièmimai. Realizuojant programą formuoti kalbiniai igūdžiai. Vykdant Rokiškio r. bibliotekos projektą „Neužsimerkime, kai skriaudžiami vaikai“ (rèmëja - SV) buvo siekiama spręsti visą socialinių ir psichologinių problemų kompleksą. Projektas skirtas užtikrinti pagalbos prieinamumui asmenims, turintiems emocinių, elgesio ir asmenybės sunkumų, išgyvenantiems krizes, patyrusiems smurtą, susidūrusiems su artimo žmogaus savižudybe. Siekta mokyti laiku ir teisingai ịvertinti gresiančio pavojaus ženklus, ugdyti teigiamas gyvenimo nuostatas, gilinti rajono bendruomenès žinias, kaip spręsti tarpusavio santykius nenaudojant smurto ir prievartos; padèti tèvams, globejams rasti informaciją, kaip vaikams apsisaugoti nuo patyčių, smurto, skriaudos. 
Pabejgèlių integracijai projektą skyrė Vilniaus m. SCB ir jos filialai. Centrinė biblioteka kartu su Antakalnio, Karoliniškių ir Pilaitès filialais vykdè LKT paremtą projektą „Priimti Negalima Grịžti“ (2016 m.). Projekto tikslas - spręsti pabėgèlių socialinès integracijos problemas organizuojant viešas diskusijas ir užtikrinant patikimos informacijos sklaidą.

\section{$\mathrm{X} \times \mathrm{X}$}

Gerų projektinès veiklos rezultatų pasiekė Kauno r. SVB, Prienų SVB (Kauno apskr.), Marijampolès SVB (Marijampolès apskr.), Šilutės r. SVB, Klaipėdos m. SVB, Klaipėdos r. SVB, Kretingos r. SVB (Klaipėdos apskr.), Tauragės r. SVB (Tauragès apskr.), Rokiškio r. SVB, Pasvalio SVB, Panevėžio m. SVB, Panevėžio r. SVB, Kupiškio r. SVB (Panevėžio apskr.), Utenos SVB (Utenos apskr.), Šiaulių m. SVB (Šiaulių apskr.), Plungès r. SVB (Telšių apskr.), Vilniaus m. SVB, Elektrėnų SVB (Vilniaus apskr.), Alytaus SVB, Alytaus r. SVB, (Alytaus apskr.) bibliotekos.

Tarptautinių fondų parama rezultatyviai gebejjo pasinaudoti Marijampolès SVB, Pasvalio SVB, Utenos SVB, Rokiškio r. SVB, Kupiškio r. SVB, Plungès r. SVB. Bibliotekų pagrindiniais nacionaliniais rèmejjais buvo KSRF, KRF, LKT, KM. Minètų institucijų fondų parama pasinaudojo visos bibliotekos. Bibliotekos gebejo taip pat pasinaudoti ŠMM, Socialinès apsaugos ir darbo ministerijos, Spaudos, radijo ir televizijos rèmimo ir kitais nacionaliniais fondais. Pagrindinès vietos rèmèjos buvo savivaldybės. Ypač rezultatyviai savivaldybių parama pasinaudojo Kretingos r. SVB, Klaipėdos r. SVB, Šilutès r. SVB, Tauragès r. SVB, Panevėžio r. SVB, Anykščių r. SVB, Plungès r. SVB, Telšių r. SVB.

Reikšmingą patirtị vykdant projektus su partneriais sukaupe Marijampolès SVB, Šilutès r. SVB, Pasvalio SVB, Rokiškio r. SVB, Tauragès r. SVB, Vilniaus m. SVB.

Menkai projektinėje veikloje dalyvavo Kėdainių r. SVB, Kaišiadorių r. SVB, Jonavos r. SVB (Kauno apskr.), Kazlų Rūdos SVB (Marijampolès apskr.), Rietavo SVB (Telšių apskr.) ir kai kurios kitos bibliotekos. Šalčininkų r. ir Vilniaus r. bibliotekos (Vilniaus apskr.) nevykdė savarankiškų projektų.

Infrastruktūros, bibliotekos darbuotojų kvalifikacijos kèlimo projektų buvo vykdyta nedaug. Kiek daugiau infrastruktūros projektų igyvendinta 2013 m. (infrastruktūros klausimai iš esmès buvo sprendžiami nacionaliniu mastu). Bibliotekos darbuotojų kvalifikacijos kèlimui IT, projektų rengimo ir valdymo srityje esmiškai buvo naudingas projektų BP ir BP 2 vykdymas.

Bibliotekų projektai siekè formuoti teigiamą požiūrị i̇ knygą, kelti skaitymo prestižą, populiarino literatūrą. Juos vykdant visuomenė supažindinta su literatūros palikimu, naujausia literatūra suaugusiesiems ir vaikams. Pradèta vykdyti projektus, pasitelkiant modernias technologijas, inovatyvias priemones. Vykdyti projektai, skirti skaitymui skatinti šeimoje, tèvų vaidmeniui skatinant vaikų skaitymą. Igyvendinant projektus organizuoti biblioterapijos renginiai. Biblioterapijos reikšmę ypač siekė atskleisti Vilniaus m. SCB ir jos filialas - Naujosios Vilnios biblioteka, Birštono biblioteka. Projektai aktyvino visuomenès domejjimąsi vietos literatais (įsidèmètinas Akmenès $\mathrm{r}$. bibliotekos projektas „Internetinès literatūrinės svetainės sukūrimas viešojoje bibliotekoje“). Siekta sudaryti sąlygas jaunimo ir vaikų kūrybiniai saviraiškai (Telšių r. ir Prienų bibliotekų iniciatyvos).

Projektai liudijo apie augantį bibliotekų dèmesį edukacijai. Jie skirti bibliotekų lankytojų kompetencijoms ugdyti ịvairiose kultūros ir švietimo srityse, taikyti ịvairiems gyventojų sluoksniams. Sparčiai daugèjo projektų, skirtų informacijai apie ES skleisti. Projektai suteikẻ galimybę susipažinti su ịvairiomis meno rūšimis. Daugiau dèmesio sulaukẻ kino menas. Populiarūs buvo projektai, skirti sveikai gyvensenai ugdyti. Igyvendinant projektus buvo kuriamos naujos edukacinės paslaugos. Projektų vykdymas vaikus ir jaunimą priartino prie formaliojo ir neformaliojo švietimo. Keli projektai skirti gyventojų ekologiniam švietimui.

Kūrybinès meninès veiklos skatinimo projektai daugiausia skirti vaikams ir jaunimui. Projektai ugdè vaikų ir jaunimo kūrybinius meninius gebejjimus. Igyvendinant projektus buvo kuriamos jaunimo kūrybinès erdvės, plètėsi naujųjų technologijų ir inovatyvių priemonių taikymas. Projektų suaugusiems 
bibliotekų lankytojams padaugèjo 2016-2017 m. Jų vyraujanti tendencija - kūrybinių dirbtuvių organizavimas.

Gyventojų kompiuterinio, skaitmeninio, informacinio raštingumo ugdymo projektų vykdyta nedaug. Kompiuterinio, skaitmeninio, informacinio raštingumo ugdymo klausimai taip pat buvo sprendžiami vykdant nacionalinị projektą BP, edukacijos projektus, dalyvaujant kitų institucijų projektuose. Keli projektai skirti medijų ir informaciniam raštingumui ugdyti.

Kraštotyros ir kultūros paveldo aktualizavimo, etninès kultūros, istorijos projektų igyvendinimas atskleidè gimtojo krašto, etnografinio regiono savitumus, prisidejo prie vietos identiteto, tradicijų puoselejjimo, kultūros vertybių perdavimo iš kartos ị kartą. Išskirtinę reikšmę turèjo fundamentinių projektų vykdymas. Krašto kultūrai, istorijai populiarinti pagelbejjo leidybos projektai.

Gyventojų socializacijai, socialinei atskirčiai mažinti, socialinėms-psichologinėms problemoms spręsti buvo reikšmingi kultūros edukacijos, biblioterapijos, meno terapijos projektai. Tiesiogiai orientuotų ị socialinių problemų sprendimą projektų vykdyta nedaug. Projektai numate ịvairias sociokultūrinès pagalbos priemones skatinant žmonių su negalia, vaikų iš probleminių, socialiai remtinų šeimų ir kitų socialiai pažeidžiamų gyventojų grupių socialinę integraciją. Gyventojų socialinėms problemoms spręsti buvo naudingas bibliotekų dalyvavimas vykdant kitų institucijų projektus.

\section{Išvados ir rekomendacijos}

Lietuvos viešųjų bibliotekų projektinės veiklos istorija prasideda nuo XX a. paskutinio dešimtmečio antrosios pusès. Didžiulę paramą bibliotekoms suteikè Atviros Lietuvos fondas. Praejusio tūkstantmečio paskutinio dešimtmečio antrojoje pusèje - naujo tūkstantmečio pradžioje bibliotekos gebejjo taip pat pasinaudoti įvairių tarptautinių fondų parama. Didejo nacionalinių ir vietos rèmejų vaidmuo finansuojant projektus. Naujo tūkstantmečio pradžioje bibliotekoms buvo reikšminga aljanso „Langas ị ateitị“, VRM vykdytų projektų parama steigiant viešuosius interneto centrus, viešuosius interneto prieigos taškus kaimo vietovèse. Realizuoti projektai padèjo tolesnès bibliotekų modernizacijos, bibliotekininkų kvalifikacijos kèlimo, naujų paslaugų kūrimo pagrindus.

Bibliotekų dalyvavimas projekte „Bibliotekos pažangai“ sustiprino jų veiklos efektyvumą, sudarè prielaidas tobulinti projektinę veiklą. Igyvendinant projektą „Bibliotekos pažangai 2“ išaugo bibliotekų darbuotojų patirtis projektų rengimo, valdymo srityje.

2007 m. vykdyti 297 projektai. Projektų skaičius sumažèjo 2013 m. (bibliotekoms teko įdiegti projekto BP rezultatus), 2015-2017 m. - nuosekliai didejjo. $2017 \mathrm{~m}$. vykdyti 349 projektai. Per trejus metus projektų padaugèjo daugiau kaip ketvirtadaliu. Projektai - pagrindinè priemonė pokyčiams bibliotekose igyvendinti. Bibliotekų veikloje pokyčių daugès. Bibliotekoms būtina išlaikyti projektų didejjimo tendenciją.

Tarptautinių rèmėjų lyginamasis svoris bendroje rèmëjų struktūroje sparčiai augo 2007, 2013, 2015 m. 2016-2017 m. jis sumažèjo augant bendram tarptautinių rèmëjų skaičiui. Nacionalinių rèmèjų procentinè dalis 2007, 2013 ir 2015 metais buvo gana pastovi, 2016-2017 m. ji sumažèjo augant bendram nacionalinių rẻmėjų skaičiui. Vietos rèmèjų procentinè dalis 2013-aisiais sumažèjo, palyginti su $2007 \mathrm{~m}$., kitais metais - didejjo. Išaugo bibliotekų pastangos užsitikrinti savivaldybių paramą (pagrindinè vietos rèmëja - savivaldybè). Menkai buvo panaudotos privačiojo sektoriaus galimybės. Bibliotekoms rekomenduotina daugiau dẻmesio skirti tarptautinių, nacionalinių, privačiojo sektoriaus rèmèjų paieškai.

Projektų, skirtų vaikams ir jaunimui, 2007, 2015-2017 metais lyginamasis svoris bendroje projektų struktūroje sudarè apie trečdalị visų projektų (2013 m. - arti ketvirtadalio). Vaikams ir jaunimui daugiausia skirta kūrybinès meninès veiklos skatinimo, socialinių, literatūros ir skaitymo skatinimo projektų. Nuo $2013 \mathrm{~m}$. didèjo etninès kultūros projektų procentinè dalis. Iš esmės projektų, skirtų vaikams ir jaunimui, vykdymas vertintinas teigiamai. Igyvendindamos projektus bibliotekos priartina vaikus ir jaunimą prie formaliojo ir neformaliojo švietimo, ugdo jų kūrybiškumą. 
Partnerių pagalba gausiau pasinaudota vykdant nedaug projektų (infrastruktūros, kraštotyros ir kultūros paveldo aktualizavimo ir kt.). Vykdant projektus plètota partnerystė su įvairių tipų mokyklomis, viešosiomis i̊staigomis, neigaliujų institucijomis. Projektai, vykdyti kartu su partneriais, vidutiniškai nesieke penktadalio visų projektų. Rodikliai nepakankami. Retai pasitelkiamos NVO, kaimo bendruomenès. Su partneriais ịgyvendinti projektai teikia naudos didesniam gavejjų skaičiui. Partnerių paieška, bendradarbiavimas su ịvairiomis institucijomis - tai bibliotekų ịvaizdžio gerinimas, poveikio visuomenei stiprinimas. Partnerystė sudaro geresnes sąlygas laimèti projektus, lemia efektyvesni lèšų naudojimą. Partnerystę rekomenduotina plèsti ir stiprinti.

Infrastruktūros projektų buvo vykdyta nedaug, tačiau neginčytina jų nauda rekonstruojant bibliotekų patalpas, modernizuojant bibliotekų erdves, diegiant modernias technologijas. Ypač reikšmingi buvo projektai, kuriems paramą suteikè tarptautiniai fondai. Bibliotekų kvalifikacijos kèlimo projektai apėmé atskiras temas, neigavo sisteminio pobūdžio. Bibliotekos darbuotojų kvalifikacijos kèlimo IT, projektų rengimo ir valdymo srityje svarbų vaidmeni atliko LNB organizuoti mokymai vykdant nacionalinius projektus BP ir BP 2.

Literatūros, skaitymo skatinimo projektų daugiausia ịgyvendinta $2007 \mathrm{~m}$. (bibliotekų projektinę veiklą smarkiai suaktyvino LR Vyriausybės 2006 m. nutarimas „Dèl Skaitymo skatinimo programos patvirtinimo"). Projektų sumažèjo 2013 m., 2015-2017 m. jų skaičius didejjo, lyginamasis svoris bendroje projektų struktūroje iki 2017 m. didèjo, 2017 m. jis sumažèjo didèjant projektų skaičiui, sudarè kiek daugiau kaip ketvirtadalį visų projektų. Literatūros, skaitymo skatinimo problematika taip pat rado vietą kompleksiniuose edukacijos projektuose. Literatūros, skaitymo skatinimo projektų vykdymas vertintinas teigiamai. Bibliotekų projektinè veikla išsaugo ir puoselëja vieną esminių jų darbo krypčių - ugdyti pagarbą literatūrai, skatinti skaitymą. Atkreipiant dèmesị i šiuolaikines skaitymo aktualijas darytinos išvados, kad projektų, skirtų skaitymui skatinti šeimoje, igyvendinta nepakankamai, 2007, 2013, 2015-2017 metais nevykdyta projektų, skirtų skaitymo transformacijoms, literatūros kūrinių skaitmeninimo poveikiui skaitymui, skaitymo popieriuje ir ekrane ypatybėms. Bibliotekoms rekomenduotina daugiau inicijuoti tokio pobūdžio projektus.

Didejo bibliotekų dèmesys edukacijai. Edukacijos projektų skaičius ir lyginamasis svoris bendroje projektų struktūroje nuosekliai augo. Vykdant projektus edukacinė veikla tapo aktyvesnè ir ịvairesnè. Iš esmès vykdyti edukacijos projektai vertintini teigiamai. Turint omenyje ekologines problemas, su kuriomis susiduria šiuolaikinis pasaulis, nepakankamai vykdyta projektų, skirtų gyventojų ekologiniam švietimui. Bibliotekoms rekomenduotina daugiau inicijuoti projektų, skirtų gyventojų ekologiniam švietimui.

Kūrybinès meninès veiklos skatinimo projektų vykdyta nepakankamai. Gyventojų kūrybiškumo skatinimas - mūsų epochos aktualija. Bibliotekų paskirtis - vykdyti projektus, skirtus kūrybiškumui skatinti, prisidèti prie kūrybos visuomenès kūrimo. Realizuojant ši uždavinị būtina rasti daugiau galimybių vykdyti kūrybiškumo skatinimo projektus.

Viena esminių bibliotekų darbo krypčių - ugdyti gyventojų kompiuterinį, skaitmeninị, informacinị raštingumą. Nors skaičiai kuklūs, plètèsi skaitmeninio, informacinio raštingumo projektų tematika, bibliotekos siekè užtikrinti mokymų tęstinumą, tačiau visų bibliotekų kontekste procesas buvo lètas. Medijų ir informacinio raštingumo projektų vykdyta mažai. Gyventojams aktualu kritiškai vertinti medijuotą informacijos turinị. Rekomenduotina sustiprinti medijų ir informacinio raštingumo projektų inicijavimą.

Artimų tematika kraštotyros ir kultūros paveldo aktualizavimo, etninès kultūros, istorijos projektų lyginamasis svoris 2007 m. sudare daugiau kaip ketvirtadalị, 2017 m. - daugiau kaip penktadalị visų projektų struktūroje. Nors projektų procentinè dalis sumažèjo, rodikliai patenkinami. Bibliotekos atsižvelgè i kultūros paveldo vaidmeni šiuolaikinèje visuomenèje ir bendruomenių poreikius. Tenka konstatuoti, kad iš esmès buvo ignoruojamos tautinès mažumos, jų kultūra, istorija. Padètis taisytina.

Projektų, tiesiogiai skirtų socialinėms problemoms spręsti, vykdyta nedaug. Bet ir nedideli skaičiai liudija apie bibliotekų demesį neigalių žmonių, vaikų iš probleminių, socialiai remtinų šeimų ir kitų 
socialiai pažeidžiamų gyventojų grupių socialinei integracijai. Sprendžiant gyventojų socialines problemas pagelbejjo bibliotekų dalyvavimas vykdant kitų institucijų projektus. Tačiau ignoruojama migrantų, pabėgèlių socialinè integracija. Projektų vykdymas liudija apie humanišką bibliotekos prigimtį, tokio pobūdžio projektinè veikla turètų būti nuolat plètojama.

Projektų igyvendinimas lèmè teigiamus pokyčius bibliotekų veikloje. Dèl jų buvo kuriami nauji produktai bei paslaugos. Siekiant vengti projektinès veiklos sporadiškumo, užtikrinti jos efektyvumą, rekomenduotina patikslinti projektų struktūros (dalies ir jos visumos) procentinị santykị. Ieškant tinkamo dalies ir jos visumos modelio būtina atsižvelgti i d dabarties aktualijas, vartotojų poreikius. Projektų poreikiui nustatyti taip pat rekomenduotina atlikti empirinius tyrimus.

Projektinè veikla yra viena pagrindinių priemonių pokyčiams bibliotekoje igyvendinti. Projekto iggyvendinimas suteikia postūmį vykdyti naujas veiklas ir pasibaigus jo terminui. Daugelis pastarųjų metų projektų paremti moderniụjų technologijų sprendimais. Vykdant projektus kuriamas šiuolaikiškos bibliotekos ịvaizdis. Kūrybiški, inovatyvūs projektai - tai galimybè atsakyti ị naujus iššūkius, atsižvelgiant i besivystančių technologijų pokyčius, mūsų visuomenès socialinę, kultūrinę kaitą, besikeičiančius bendruomeniu poreikius.

\section{Literatūra ir šaltiniai}

Alytaus m. SVB tinklalapis. Prieiga per internetą: http://www.alytus.mvb.lt/apie-biblioteka/apie mus/projektai?showall=\&lang=lt\&start=1. Žiūrèta 2018-08-21.

Andrijauskienè, Laima. Istoriniais piliakalniu takais (Ignalina). Tarp knygu, 2017, spalis, p. 35-36.

Aničas, Jonas. Jurgènų kraštas: istorija, etnokultūra ir dabartis. Kaunas: Žiemgalos leidykla, 2014.

Anykščiu biblioteka istorijos vingiuose: 1937-2007 / sudarytoja A. Berezauskienè. Anykščiai: Anykščių rajono savivaldybès viešoji biblioteka, 2007.

Anykščiu krašto tyrëjo parankinè knyga: kn. 1. Anykščiu kraštas Rusijos imperijos sudètyje (1795-1914 m.) ir Pirmojo pasaulinio karo metais (1914-1918 m.) / sudarè O. Janonis. Anykščiai: Petro ofsetas, 2012.

Anykščiu krašto tyrejjo parankinè knyga: kn. 2. Vardų rodyklè / sudarè O. Janonis. Anykščiai: Petro ofsetas, 2012.

Anykščiu krašto tyrëjo parankinè knyga: kn. 3. Anykščiu kraštas tarpukariu ir okupacijų metais / sudarè O. Janonis. Anykščiai: Petro ofsetas, 2014.

Anykščių kraštotyrininkai: biografijos / sudarytojai: A. Berezauskienè, O. Janonis. Vilnius: Petro ofsetas, 2016.

Atviros Lietuvos fondas: 1999 metu ataskaita. Prieiga per internetą: http://olf.lt/wp-content/uploads/2017/03/alf_ ataskaita_1999.pdf. Žiūrèta 2018-08-22.

Atviros Lietuvos fondas: metiné ataskaita, 2000/01. Prieiga per internetą: http://olf.lt/wp-content/uploads/2017/03/ alf_ataskaita_2000_2001.pdf. Žiūrèta 2018-08-22.

Atviros Lietuvos fondas: $2002 \mathrm{~m}$. veiklos ataskaita. Prieiga per internetą: http://olf.lt/wp-content/uploads/2017/03/ alf_ataskaita_2002.pdf. Žiūrèta 2018-08-23.

Babeckas, Algimantas. Išnykę (ne)pamiršti dvarai: Aleksandravas, Makauskai, Pagraužiai, Trempiniai. Marijampolè: Piko valanda, 2011.

Bedulytė, Rita; Dunauskaite, Ama. Pasvalio Mariaus Katiliškio viešosios bibliotekos paslaugos verslininkams. Tarp knygu, 2013, birželis, p. 15-17.

Biblioteka - kultūros paveldo buveinè: iš Knygos muziejaus rinkinių: skiriama Mažosios Lietuvos poeto ir kultūros veikejo Fridricho Bajoraičio 130-osioms gimimo metinèms / Šilutės rajono savivaldybės Fridricho Bajoraičio viešoji biblioteka / sudarytojos: L. Dumšienė, D. Užpelkienè, V. Veiverienė. Klaipėda: S. Jokužio leidykla-spaustuvė, 2013.

Bibliotekos pažangai. Prieiga per internetą: https://www.lnb.lt/apie-biblioteka/programos-ir-projektai/edukaciniai-projektai/bibliotekos-pazangai. Žiūrèta 2018-09-12. 
Bibliotekos pažangai: pokyčiai bibliotekose ir visuomeneje: poveikio vertinimo tyrimų 2008-2012 m. ataskaita. Vilnius: Lietuvos nacionalinè Martyno Mažvydo biblioteka. Prieiga per internetą: http://www.bibliotekospazangai.lt/media/public/Atsisiuntimui/TyrimuAtaskaitos/WEB_LT/2011/2011_TyrimuSantrauka.pdf. Žiūrèta 2018-09-12.

Bibliotekos pažangai 2. Prieiga per internetą: https://www.google.lt/search?q=Bibliotekos+pa\%C5\%BEangai+2\%E2\% 80\%9C.\&rlz=1C1GCEA_enLT771LT772\&oq=Bibliotekos+pa\%C5\%BEangai+2\%E2\%80\%9C.\&aqs=chrome..69i57j0j69i64.1426j0j8\&sourceid=chrome\&ie=UTF-8. Žiūrèta 2018-10-19.

Brigys, Jonas. Pasistačius bendra darbo tikslą: 1918-1940 m. Raseinių krašte veikusių draugiju, politiniu, visuomeniniu, ekonominiu organizacijų sąvadas. Kaišiadorys: Printejja, 2017.

Brigys, Jonas. 1863 sukilimas Raseinių apskrityje: biografijų žodynas. Vilnius: Petro ofsetas, 2013.

Daukantienè, Gražina. Skuodo žemaičių stiprybė - kalboje ir kultūroje (Skuodas). Tarp knygu, 2017, lapkritis, p. $42-43$.

Domininkas Bukontas (1873-1919): leidiniu ir straipsnių rinkinys / sudarytojai: J. Nemanis, D. Kiltinavičienė, V. Mikštienė, D. Pulokaite, D. Karlienè. Vilnius: Petro ofsetas, 2011.

Elektrènu savivaldybès viešosios bibliotekos istorija. Vilnius: Lietuvos nacionalinė Martyno Mažvydo biblioteka, 2012.

Esam ir būsim žemaičiai = Esam èr būsem žemaitēs: projektas-renginių ciklas „Kultūru spiečius“. Skuodas: Skuodo savivaldybès viešoji biblioteka, 2015.

Europos Komisija: AtstovybėLietuvoje. Prieiga per internetą: https://ec.europa.eu/lithuania/services/contact-points_lt. Žiūrèta 2018-08-28.

Gavėnè, Rūta. Projektas „Atrask save 3D mieste“ pelnè tarptautinị apdovanojimą (Kaunas). Tarp knygų, 2016, liepa-rugpjūtis, p. 36-37.

Gerulienè, Vita. Žymūs lèlininkai stovyklavo su vaikais (Šilutè). Tarp knygų, 2015, spalis, p. 36.

Gyvenimo stebètojo užrašai: 2 dalis, CD-ROM. Alytus: Alytaus Jurgio Kunčino viešoji biblioteka, 2007.

Glosienè, Audronė; Petuchovaitè, Ramunè. Projektų valdymo ABC bibliotekininkams: mokomoji knyga. Vilnius: Lietuvos nacionalinè Martyno Mažvydo biblioteka, 2003.

Glosiené, Audrone்; Rutkauskienè, Ugnè. Viešos interneto prieigos Lietuvos gyventojams tyrimas. Tarp knygų, 2004, sausis, p. 5-9.

Greiciūnienè, Ramunè. Panevėžio regiono savivaldybių viešosios bibliotekos 1990-2000 metais. In: Savivaldybių viešosios bibliotekos 1900-2000 metais: veiklos apžvalga. Vilnius: Lietuvos nacionalinė Martyno Mažvydo biblioteka, 2002, p. 137-160.

Greiciūnienè, Ramunè, et al. Panevėžio apskrities savivaldybių viešosios bibliotekos 2006-2010 metais. In: Savivaldybių viešosios bibliotekos 2006-2010 metais: veiklos apžvalga. Vilnius: Lietuvos nacionalinè Martyno Mažvydo biblioteka, 2012, p. 177-215. Prieiga per internetą: https://drive.google.com/file/d/0B_-73IZKEJy5RmI2YldNVml1QUE/view. Žiūrèta 2018-09-11.

Dèl bibliotekų plètros strateginių krypčiu 2016-2022 metams patvirtinimo. Lietuvos Respublikos kultūros ministro įsakymas, $2016 \mathrm{~m}$. balandžio $29 \mathrm{~d}$. Nr. IV-344. Prieiga per internetą: https://e-seimas.lrs.lt/portal/legalAct/ lt/TAD/9363821010a111e6aa14e8b63147ee94? positionInSearchResults=0\&searchModelUUID=e06d1cda-da64-4c80-953d-e11d484b9ef7. Žiūrèta 2019-12-26.

Dèl informacines visuomenès plètros 2014-2020 metu programos „Lietuvos Respublikos skaitmenine darbotvarke““ patvirtinimo. Lietuvos Respublikos Vyriausybès nutarimas, $2014 \mathrm{~m}$. kovo $12 \mathrm{~d}$. Nr. 244. Prieiga per internetą: https://e-seimas.lrs.lt/portal/legalAct/lt/TAD/a66c0760b04011e3bf53dc70cf7669d9. Žiūrèta 2019-12-26.

Dèl Lietuvos informacinés visuomenés plètros 2011-2019 metu programos patvirtinimo ir kai kurių Lietuvos Respublikos Vyriausybès nutarimu pripažinimo netekusiais galios. Lietuvos Respublikos Vyriausybès nutarimas, $2011 \mathrm{~m}$. kovo 16 d. Nr. 301. Prieiga per internetą: https://www.e-tar.lt/portal/lt/legalAct/TAR.DB3141BCD96B. Žiūrèta $2019-12-26$.

Dèl Lietuvos kultūros politikos kaitos gairiu patvirtinimo. Lietuvos Respublikos Seimo nutarimas, 2010 m. birželio 30 d. Nr. XI-977. Prieiga per internetą: https://e-seimas.lrs.lt/portal/legalAct/lt/TAD/TAIS.377620. Žiūrèta 2019-12-26.

Dèl Lietuvos kultūros politikos nuostatų. Lietuvos Respublikos Vyriausybès nutarimas, 2001 m. gegužès 14 d. Nr. 542. Prieiga per internetą: https://www.e-tar.lt/portal/lt/legalAct/. Žiūrèta 2019-12-26. 
Dèl 2014-2020 metų nacionalinès pažangos programos patvirtinimo. Lietuvos Respublikos Vyriausybės nutarimas, 2012 m. lapkričio 28 d. Nr. 1482. Prieiga per internetą: https://www.e-tar.lt/portal/lt/legalAct/ TAR.31A566B1512D. Žiūrèta 2019-12-26.

Dèl valstybès pažangos strategijos „Lietuvos pažangos strategija „Lietuva 2030“ patvirtinimo. Lietuvos Respublikos Seimo nutarimas, 2012 m. gegužès 15 d. Nr. XI-2015. Prieiga per internetą: https://e-seimas.lrs.lt/portal/lega1Act/lt/TAD/TAIS.425517. Žiūrèta 2019-12-26.

Grigas, Vincas; Šuminas, Andrius; Gudinavičius, Arūnas; Grigaliūnas, Modestas. Šiuolaikinès medijos ir informacija: požeminiai garažai Google karalystèje. Vilnius: Akademinè leidyba, 2016.

Ilguvos dvaro takais... = Ścienżkami iłgowskiego dworu... Kaunas: Arx Baltica, 2006.

Imbiero vakarai: almanachas, 2004/06. Vilnius: Eugrimas, 2007.

Imbiero vakarai: 2008-2010 almanachas / sudarytoja G. Bulgakovienė. Vilnius: Eugrimas, 2011.

Jaskonienė, Dalia. Šalies savivaldybių viešųjų bibliotekų 2001-2005 metų veiklos apžvalga. In: Savivaldybių viešosios bibliotekos 2001-2005 metais: veiklos apžvalga. Vilnius: Lietuvos nacionalinė Martyno Mažvydo biblioteka, 2007, p. 5-47.

Jonauskaitè, Laima; Buikienè, Lina; Raudytė, Nijolè. Spaudos ir knygos kelias Kretingoje. Klaipèda: Klaipèdos universiteto leidykla, 2010.

Joniškio r. SVB tinklalapis. Projektai. Prieiga per internetą: https://www.joniskis.rvb.lt/projektai/. Žiūrèta 2018-09-05.

Kaimu istorijos: Žalioji, Sabaliavas, Durbè, Garnabūdis, Naujas kaimas, Vilkavizna, Komenka, Santaka / sudarytojas V. K. Svitojus. Marijampolè: Piko valanda, 2011.

Kalvarijos krašto kūrèjai: Saulius Lisauskas / sudarytojos: A. Jankeliūnienè, L. Karpavičienè, S. Palionienè. Marijampolè: Piko valanda, 2012.

Kalvarijos krašto kūrèjai: tautodailininkas Antanas Lastauskas / sudarytojos: A. Jankeliūnienė et al. Marijampolè: Piko valanda, 2012.

Kalvarijos krašto padavimai ir pasakojimai / sudarytojos: A. Jankeliūnienè, L. Karpavičienè, S. Palionienè. Marijampolè: Piko valanda, 2011.

Kalvarijos krašto šviesuoliai, 2 d. / sudarytojos: S. Palionienè, N. Skroblienè, L. Karpavičienè. Marijampolè: Piko valanda, 2007.

Karlienè, Danutè. Aštuoni Zarasų SVB dešimtmečiai. Tarp knygų, 2003, gruodis, p. 5-7.

Kazilionytė, Vitalija. Projektas „Europeana 1989“: Pasvalys atkuria Baltijos kelią. Tarp knygu, 2013, rugsẻjis, p. 30-31.

Kraštotyrininké Albina Katinaité-Navickiené: bibliografijos rodyklè / sudarè J. Baškauskienė. Ukmergè: Valdo leidykla, 2007.

Kretingos r. SVB tinklalapis. Prieiga per internetą: http://www.kretvb.lt/lt/veikla/projektine-veikla. Žiūrèta 2018-08-23.

Kuklys, Algirdas. Juozo Lukausko lobiai. Klaipėda: Libra Memelensis, 2007.

Kupiškènai Lietuvos istorijoje / sudarè L. Matiukaitè. Panevėžys: Amalkera, 2017.

Langas $\mathfrak{j}$ ateiti. Veikla ir laimëjimai. Prieiga per internetą: https://www.langasiateiti.lt/index.php/lt/apie/istorija. Žiūrèta 2018-09-25.

Lietuviškos knygos kelias Pandèlio apylinkèse: 70-osioms Pandèlio bibliotekos įkūrimo metinèms / sudarytoja R. Baškienè. Rokiškis: I. Skripkos individuali įmonè, 2007.

Lietuvos kultūros taryba. 2016 m. veiklos ataskaita. Prieiga per internetą: https://www.ltkt.lt/apie-ltkt/2016-m-ataskaita. Žiūrèta 2019-01-03.

Lietuvos biblioteku 2006-2010 m. statistika. Vilnius: Lietuvos nacionalinė Martyno Mažvydo biblioteka, 2011.

Lietuvos biblioteku 2016 m. statistika. Vilnius: Lietuvos nacionalinė Martyno Mažvydo biblioteka, 2017. Prieiga per internetą: https://drive.google.com/file/d/0B_-73IZKEJy5RlFEYUN1OHAwTGs/view. Žiūrèta 2018-05-16.

Lietuvos bibliotekų 2017 m. statistika. Vilnius: Lietuvos nacionalinė Martyno Mažvydo biblioteka, 2018. Prieiga per internetą: https://drive.google.com/file/d/1iHtFq2eSrOBuHbYt5ZaQC7ci0aL6Z73Q/view. Žiūrèta 2019-01-01. 
Lomiai amžių sandūroje: žmonès, įvykiai, statiniai / sudarytojos: E. Bazinienè, L. Užkurienè. Kaišiadorys: Printėja, 2013. Marcelijus Martinaitis: pilietis ir kürëjas epochu sankirtoje: konferencijos medžiaga. Kaunas: Naujasis lankas, 2016.

Meteliai [Lazdiju rajonas]: monografija / redakcinė kolegija: Irena Seliukaitė ir kit. Marijampolè: Piko valanda, 2008.

Mizgirienè, Alma. Tauragès krašto šviesuoliai / sudarė B. Lukoševičienè. Kaišiadorys: Printėja, 2012.

Moderniai visuomenei - naujoviška biblioteka. Projekto „Bibliotekos pažangai (2008-2012) įtaka Lietuvos viešųjų bibliotekų raidai. Vilnius: Lietuvos nacionalinè Martyno Mažvydo biblioteka, 2012. Prieiga per internetą: http://www. bibliotekospazangai.lt/media/public/Atsisiuntimui/Moderniai\%20visuomenei-small.pdf. Žiūrèta 2018-09-12.

Mūsu stiprybè - kalboje ir kultūroje: projektas / sudarè G. Daukantienè. Skuodas: Skuodo rajono savivaldybės R. Granausko viešoji biblioteka, 2017.

Operos solistas Juozas Mažeika: 1907-1976: atsiminimai. Tauragè: Tauragès viešoji biblioteka, 2007.

Pakalnyte, Neringa. Biblioterapija Garliavos bibliotekoje (Kaunas). Tarp knygų, 2016, kovas, p. 34.

Pakštienè, Nijolè. Jaunųjų pasakorių konkursas (Radviliškis). Tarp knygų, 2008, gruodis, p. 31.

Pakèlę sparnus: Prienų krašto jaunujų kūrybos almanachas. Marijampolè: UAB „TeleSATpressa“, 2002.

Pasmokavuok, kap skane: Šilalès krašto kulinarinis paveldas. Kaunas: Naujasis lankstas, 2013.

Pasvalio SVB tinklalapis. Prieiga per internetą: http://www.psvb.lt/lt/projektai/igyvendinti/1277-testinis-projektas-literaturos-dienos-ir-naktys-2014-skaitymu-mozaika. Žiūrèta 2018-12-02.

Petuchovaitè, Ramunè. Viešuju biblioteku paslaugu bendruomenei plètra: sékmingos praktikos Lietuvoje ir tarptautiniu veiksniu studija. Vilnius: Vilniaus universiteto leidykla, 2004.

Pikšlingaitè, Julija. Atviros Lietuvos fondo parama bibliotekoms. Tarp knygų, 1996, rugpjūtis, p. 1-2.

Pikšilingaitè, Julija. Laukiame įdomių projektų. Tarp knygu, 1999, gruodis. p. 1-3.

Pipynienė, Jolita. Kraštiečiui skirtas projektas (Kupiškis). Tarp knygu, 2013, spalis, p. 35-36.

Plungès Palazzo Vecchio: nuo grafų Zubovų pilaitès iki Plungès viešosios bibliotekos (1846-2012) / sudarytojos: O. Juozapaitienè, V. Skierienè, V. Liutikaitè, Z. Paulauskaitè. Klaipèda: Plungès r. SVB, 2012.

Po knygos ženklu: Pasvalio Mariaus Katiliškio viešosios bibliotekos septynių dešimtmečių kelias, 1937-2007 / sudarytojos: D. Abazoriuvienè, Z. Baltrušiūnienè. Panevėžys: Pasvalio Mariaus Katiliškio viešoji biblioteka, 2007.

Prienų krašto vyturiai, kn. 8. Alytus: Alytaus sp., 2009.

Projekto „Bibliotekos pažangai 2“ biblioteku projektu dalyviu tyrimas 2016. Vilnius: Lietuvos nacionalinė Martyno Mažvydo biblioteka. Prieiga per internetą: http://3erdve.lt/media/public/Tyrimai_2016/bp2_kokyb_projektu_ dalyviai_v2.pdf. Žiūrèta 2015-08-17.

Prošvaitės: Kupiškio rajono literatų klubo „Lèvens balsai“ kūrybos almanachas. Panevèžys: Panevėžio sp., 2015.

Radviliškio bibliotekos kelias, 1937-2011 / sudarè D. Paulauskienė. Radviliškis: Radviliškio rajono savivaldybès viešoji biblioteka, 2011.

Rokiškio krašto literatų kūrybos almanachas „Vaivorykštė“. Utena: Utenos Indra, 2016.

Rokiškio rajono savivaldybès Juozo Keliuočio viešosios bibliotekos istorija / sudarytoja R. Viskaitienė. Vilnius: Margi raštai, 2019.

Savivaldybiu viešosios bibliotekos 1900-2000 metais: veiklos apžvalga / sudarytoja D. Jaskonienė. Vilnius: Lietuvos nacionalinė Martyno Mažvydo biblioteka, 2002.

Savivaldybiu viešosios bibliotekos 2001 metais: veiklos apžvalga / sudarytoja D. Jaskonienė. Vilnius: Lietuvos nacionalinè Martyno Mažvydo biblioteka, 2003.

Savivaldybiu viešosios bibliotekos 2002 metais: veiklos apžvalga / sudarytoja D. Jaskonienė. Vilnius: Lietuvos nacionalinè Martyno Mažvydo biblioteka, 2004.

Savivaldybiu viešosios bibliotekos 2001-2005 metais: veiklos apžvalga / sudarytoja D. Jaskonienė. Vilnius: Lietuvos nacionalinè Martyno Mažvydo biblioteka, 2007.

Savivaldybiu viešosios bibliotekos 2006-2010 metais: veiklos apžvalga / sudarytoja D. Jaskonienè. Vilnius: Lietuvos nacionalinė Martyno Mažvydo biblioteka, 2012. Prieiga per internetą: https://drive.google.com/file/d/0B_-73IZKEJy5RmI2YldNVml1QUE/view. Žiūrèta 2018-09-11. 
Sinkevičienė, Zita. Lazdynų Pelèda. Ar pražuvo kaip sapnas? (Akmenė). Tarp knygų, 2013, sausis, p. 28.

Socialinis edukacinis kompiuterinis žaidimas „Iššūkis“. Prieiga per internetą: http://www.naujasis-knygnesys.lt/dalyviai/socialinis-edukacinis-kompiuterinis-zaidimas-quot-issukis-quot/15. Žiūrèta 2018-09-28.

Stasėnaitè, Violeta; Orlakaitė, Gabija. Viešųjų bibliotekų inovatyvių paslaugų taikant projektinę veiklą vertinimas. Informacijos mokslai, 2018, t. 81, p. 28-46.

Strakšytė, Birutè. Baltų vienybės dieną kartu minėjo latgaliai, kuršiai ir žemaičiai (Skuodas). Tarp knygų, 2017, lapkritis, p. 37.

Strakšytė, Birutė. Žemaitiškumo puoselëjimas (Skuodas). Tarp knygu, 2012, vasaris, p. 35.

Straupytè, Monika. Medijų ir informacinio raštingumo akademija (Kaunas). Tarp knygų, 2017, lapkritis, p. 39.

Strolienè, Nijolè. Naujovès Kretingos miesto Valančiaus bibliotekoje. Tarp knygų, 2001, sausis, p. 3-5.

Šiaulių miesto savivaldybès viešosios bibliotekos istorija. Vilnius: Lietuvos nacionalinè Martyno Mažvydo biblioteka, 2015.

Šiauliu mieato. SVB tinklalapis. Prieiga per internetą: http://biblioteka.smsvb.lt/lt/virtualios-parodos/irasai/3215-2013-metu-projektai. Žiūrèta 2018-08-21.

Šiaurès šalių literatūros savaitè. Istorija. Prieiga per internetą: https://www.nordisklitteratur.org/lt/apie- projekt\%C4\%85/istorija/. Žiūrèta 2018-09-28.

Šilalès krašto bažnyčios: istorija ir architektūra / parengè Loreta Šimutytė-Balčiūnienė. Klaipėda: Druka, 2016.

Tamašauskienė, Virginija. Rajono dvarai kilnojamojoje parodoje (Kaunas). Tarp knygu, 2016, sausis, p. 36.

Tauro apygardos Žalgirio rinktinei 70 / sudarytojas K. Vaičiūnas. Kaišiadorys: Printẻja, 2015.

Vaiku istorijos Šiauliams / sudarytojos: D. Maskuliūnienè, R. Božienė. Radviliškis: Litera, 2016.

Valaitytė, Asta. Jaunos bibliotekos dešimtmetis. Tarp knygu, 2012, gruodis, p. 1-4.

Valeškevičiūtè-Zakarauskienè, Ona. Burokaraistis: istorija, buitis, papročiai, liaudies medicina, prietarai, tautosaka. Vilnius: Jandrija, 2003.

Varènos krašto dienoraščiai: gamtos ritmu / sudarytojas J. Žitkauskas. Vilnius: Petro ofsetas, 2019.

Vasauskaitė, Regina. Projekto „Atsakingas skaitytojas“ nugalètojai (Kaunas). Tarp knygu, 2017, spalis, p. 37.

Vasauskaitè, Regina. Projektavome išmanųj miestą (Kaunas). Tarp knygų, 2017, lapkritis, p. 39-40.

Vasiliauskas, Ernestas. Joniškio krašto dvarai. Didžioji ir Mažoji Daunoravos, Bertaučiai, Satkūnai / Güter in der Gegend von Joniškis: Gross und Klein Donnerhof, Bärtautzen, Satkuhnen / Manors of the Joniškis Region: Daunorava, Daunorava Minor, Bertaučiai and Satkūnai. Klaipèda: Klaipèdos universiteto leidykla, 2017.

Viešoji biblioteka - informacijos ir kultūros skleidejja. I dalis / sudarytoja Z. Sinkevičienè. Kaišiadorys: Printẻja, 2006. Viešoji biblioteka - informacijos ir kultūros skleideja. II dalis / sudarytoja Z. Sinkevičienè. Kaišiadorys: Printejja, 2010. Viešoji biblioteka - informacijos ir kultūros skleideja. III dalis / sudarytoja Z. Sinkevičienè. Kaišiadorys: Printèja, 2016. Vilčiauskienè, Violeta. Joniškio Jono Avyžiaus viešoji biblioteka: 70 veiklos metų, 1937-2007. Šiauliai: Lucilijus, 2007.

Zarasų viešosios bibliotekos istorija / sudarytojai: D. Karlienė, J. Lementauskienė, S. Bikulčiūtė, D. Kiltinavičienė, R. Kuliešienè, D. Davainienè, E. Gaižiuvienè, J. Šepetovskaja, D. Koroliova, D. Macijauskienè, J. Gurskaja, V. Gudaitis. Vilnius: Lietuvos nacionalinė Martyno Mažvydo biblioteka, 2013.

Zabielavičius. Juozas. Virbalis mano atsiminimuose. I dalis: Virbalio praeitis. Vilnius: Baltijos kopija, 2007.

Zabielavičius. Juozas. Virbalis mano atsiminimuose. II dalis / sudarytoja D. Stankūnienè. Vilnius: Baltijos kopija, 2013. Žilinskienė, Elena. Tiltų krašto kaimai šimtmečiu kaitoje. Trakai: Standartų spaustuvė, 2015.

$$
\text { X X X }
$$

Savivaldybių viešujų bibliotekų 2007, 2013, 2015-2017 metų ataskaitos [žiūrètos 2018 m. rugpjūčio-gruodžio mèn.]. Prieiga per internetą: https://www.lnb.lt/paslaugos/bibliotekoms/lietuvos-biblioteku-statistika/savivaldybiu-viesuju-biblioteku-ataskaitos.

Savivaldybių viešujų bibliotekų tinklalapiai. Žiūrèti 2018 m. rugpjūčio-gruodžio mèn. 
1 priedas. Kauno apskr. savivaldybių viešųjų bibliotekų 2007, 2013, 2015-2017 metų projektai

\begin{tabular}{|c|c|c|c|}
\hline Eil.nr. & Pavadinimas & Biblioteka, partneriai & Rèmèjai \\
\hline 1 & Jaunuju menininku sklaida Jonavoje & Jonavos r. SVB & KM \\
\hline 2 & XII vaiku knygos šventè „Skaitantis miestas" & Kauno m. SVB & KM, KSRF \\
\hline 3 & XIII knygos šventè „Laikas gyvena knygose“ & Kauno m. SVB & KM, KSRF, SV \\
\hline 4 & Skaitykime drauge & Kauno m. SVB & $\mathrm{KM}, \mathrm{SV}$ \\
\hline 5 & $\begin{array}{l}\text { Žaliakalnio bendruomenés atmintis [tęstinis; } \\
\text { vykdomas nuo } 2004 \mathrm{~m} \text {.] }\end{array}$ & $\begin{array}{l}\text { Kauno m. SVB Aušros f.; } \\
\text { partneris - bendruomenès cen- } \\
\text { tras „Žaliakalnio aušra“ }\end{array}$ & [nenurodyta] \\
\hline 6 & Ar galime neskaityti Mes & Kauno r. SVB & KM \\
\hline 7 & $\begin{array}{l}\text { Bibliotekos erdveje tobulindami save tampame } \\
\text { asmenybèmis }\end{array}$ & Kauno r. SVB & KM \\
\hline 8 & $\begin{array}{l}\text { Biobibliografinè rodyklè. Rašytojas Robertas } \\
\text { Keturakis }\end{array}$ & Kauno r. SVB & KM \\
\hline 9 & Dailininkas Viktoras Vizgirda & $\begin{array}{l}\text { Kauno r. SVB; } \\
\text { partnere - NVO Garliaviečių } \\
\text { klubas }\end{array}$ & [nenurodyta] \\
\hline 10 & Prisijaukinkime muzika [skirtas vaikams] & Këdainių r. SVB & SV \\
\hline 11 & $\begin{array}{l}\text { Gyvenkime prasmingai [skirtas vaikų užimtu- } \\
\text { mui ir prevencijai nuo priklausomybių] }\end{array}$ & Kèdainių r. SVB & SV \\
\hline 12 & Iš kartos į karta & Prienų SVB & KM \\
\hline 13 & Popiečiu pašnekesiai [skirtas rusų romansams] & $\begin{array}{l}\text { Prienų SVB; } \\
\text { partneré - Prienų bendruomené }\end{array}$ & KM \\
\hline 14 & Meninio žodžio šviesoje & Prienų SVB & KSRF \\
\hline 15 & $\begin{array}{l}\text { Prienu krašto vyturiai [skirtas mokinių kūrybos } \\
\text { leidiniui parengti] }\end{array}$ & Prienų SVB & SV \\
\hline 16 & Literatūrinis ugdymas viešojoje bibliotekoje & Prienų SVB & SV \\
\hline 17 & Nuo Velykų iki Kaledu & Prienų SVB & SV \\
\hline 18 & 70 metu viešajai bibliotekai & Prienų SVB & SV \\
\hline 19 & $\begin{array}{l}\text { Narkomanijos prevencijos programa „Savojo } \\
\text { kelio beieškant" }\end{array}$ & Prienų SVB & SV \\
\hline 20 & Skaitmeninès eros sankryžoje & Prienų SVB & SV \\
\hline 21 & Vaikystè su knyga & Raseinių SVB & KM \\
\hline \multicolumn{4}{|c|}{2013 metai } \\
\hline 1 & Birštonas ir birštoniečiai Europoje & Birštono SVB & EKAL \\
\hline 2 & $\begin{array}{l}\text { New EVS horizons / Nauji EST horizontai [Eu- } \\
\text { ropos savanorių tarnybos projektas] }\end{array}$ & Birštono SVB & $\begin{array}{l}\text { ES programa „Vei- } \\
\text { klus jaunimas“ }\end{array}$ \\
\hline 3 & $\begin{array}{l}\text { Po žvaigždètu rugpjūčio dangum. Kameriniai } \\
\text { poezijos ir muzikos vakarai Birštone [tęstinis] }\end{array}$ & Birštono SVB & KRF \\
\hline 4 & Gimtosios kalbos grožis ir savastis - tarmès & Birštono SVB & SV \\
\hline 5 & $\begin{array}{l}\text { Menu terapija Birštono savivaldybès } \\
\text { gyventojams }\end{array}$ & $\begin{array}{l}\text { Birštono SVB; } \\
\text { partnerè - Vš̨ sanatorija „Tulpe“ }\end{array}$ & SV \\
\hline 6 & Ars - Europos Sajungos pilietis & Jonavos r. SVB & EKAL \\
\hline
\end{tabular}




\begin{tabular}{|c|c|c|c|}
\hline Eil.nr. & Pavadinimas & Biblioteka, partneriai & Rèmèjai \\
\hline 7 & $\begin{array}{l}\text { Nuo Kristijono Donelaičio iki XXI amžiaus } \\
\text { rašytojų (2013-2014 m.) }\end{array}$ & Kaišiadorių r. SVB & $\mathrm{KRF}$ \\
\hline 8 & Sužinok ir naudokis Europos piliečių teisèmis & Kauno r. SVB & EKAL \\
\hline 9 & $\begin{array}{l}\text { Lietuvos nacionalinès premijos laureatų kūrybos } \\
\text { sklaida Kauno rajono bibliotekose - II [tęstinis] }\end{array}$ & Kauno r. SVB & $\mathrm{KRF}$ \\
\hline 10 & $\begin{array}{l}\text { Kauniškiams rūpi didžiuotis turtinga lietuvių } \\
\text { kalba ir skleisti jos groži }\end{array}$ & Kauno r. SVB & [nenurodyta] \\
\hline 11 & $\begin{array}{l}\text { Sukurk man avelę [skaitymo skatinimo projek- } \\
\text { tas vaikams ir paaugliams] }\end{array}$ & Kauno r. SVB & [nenurodyta] \\
\hline 12 & $\begin{array}{l}\text { Varom į Europa! Ar tu - kartu? Visur gerai - na- } \\
\text { mie geriausia, o aš Europoje kaip namuose }\end{array}$ & Prienų SVB & EKAL \\
\hline 13 & $\begin{array}{l}\text { Renginiu ciklas „Tuo keliu aš pareinu“ [skirtas } \\
\text { poeto Just. Marcinkevičiaus } 83 \text {-iosioms gimi- } \\
\text { mo metinėms] }\end{array}$ & $\begin{array}{l}\text { Prienų SVB; } \\
\text { partneriai: Prienų kultūros ir } \\
\text { laisvalaikio centras, Prienų } \\
\text { krašto muziejus, Prienų rajono } \\
\text { savivaldybės bendruomenių } \\
\text { asociacija, Prienų ir Birštono } \\
\text { krašto kūrèjų asociacija „Gabija“ }\end{array}$ & KRF \\
\hline 14 & $\begin{array}{l}\text { Poetas prasideda žemèj (Just. Marcinkevičius). } \\
\text { Kristijono Donelaičio gyvenimo ir kūrybos } \\
\text { keliais }\end{array}$ & Prienų SVB & $\mathrm{KRF}$ \\
\hline 15 & $\begin{array}{l}\text { Veidai ir vardai [skirtas literatūros sklaidos } \\
\text { renginiams] }\end{array}$ & Prienų SVB & $\mathrm{KRF}$ \\
\hline 16 & $\begin{array}{l}\text { Draugų ratas kiTOKS: pažink - priimk - da- } \\
\text { linkis [skirtas Tarmių metams; tikslinė grupè - } \\
\text { vaikai] }\end{array}$ & Prienų SVB & [nenurodyta] \\
\hline 17 & Skambèk, lietuviškas žodi & Raseinių SVB & KRF \\
\hline 18 & $\begin{array}{l}1863 \text { sukilimas Raseiniu apskrityje. Biografiju } \\
\text { žodynas }\end{array}$ & Raseinių SVB & $\mathrm{KRF}$ \\
\hline 19 & Dailininkas ir vaikiška knyga - 2013 [tęstinis] & Raseinių SVB & KRF \\
\hline 20 & $\begin{array}{l}\text { Trisdešimt Dubysos pavasarių [skirtas rajono } \\
\text { literatų klubo „Dubysa“ veiklos sukakčiai ir jų } \\
\text { kūrybos almanacho leidybai] }\end{array}$ & Raseinių SVB & SV \\
\hline 21 & Skaitau ir sveikstu & Raseinių SVB & SV \\
\hline 22 & Sveikas žmogus - sveika visuomene & Raseinių SVB Vosiliškio f. & SV \\
\hline \multicolumn{4}{|c|}{2015 metai } \\
\hline 1 & Europos dienos minėjimas & Birštono SVB & EKAL \\
\hline 2 & $\begin{array}{l}\text { Inovatyviu terapiju taikymas ir sklaida bibliote- } \\
\text { koje }\end{array}$ & Birštono SVB & LKT, KM, SV \\
\hline 3 & $\begin{array}{l}\text { Po žvaigždètu vasaros dangum. Literatūriniai } \\
\text { vakarai Birštone } 2015 \mathrm{~m} \text {. [tęstinis] }\end{array}$ & Birštono SVB & LKT, KM, SV \\
\hline 4 & $\begin{array}{l}\text { Interaktyvi erdve - erdve kūrybai ir atradimams! } \\
(2015-2016 \text { m.) [skirtas vaikams ir jaunimui] }\end{array}$ & Birštono SVB & $\begin{array}{l}\text { BMGF, KM [BP 2], } \\
\text { SV }\end{array}$ \\
\hline 5 & Kai man liūdna ar smagu - su knyga aš gyvenu & Birštono SVB & SV \\
\hline 6 & $\begin{array}{l}\text { Gimtaji žodị ir kraštą pažinti [skirtas vaikams ir } \\
\text { jaunimui] }\end{array}$ & Birštono SVB & SV \\
\hline
\end{tabular}




\begin{tabular}{|c|c|c|c|}
\hline Eil.nr. & Pavadinimas & Biblioteka, partneriai & Rèmèjai \\
\hline 7 & $\begin{array}{l}\text { Mūsu pasaulis, mūsu orumas, mūsu ateitis } \\
\text { [skirtas Europos dienai] }\end{array}$ & Jonavos r. SVB & EKAL \\
\hline 8 & Mokomès ịdomiau (2015-2016 m.) & Jonavos r. SVB & BMGF, KM [BP 2] \\
\hline 9 & Krašto istorija atgimsta vaiku darbuose & Kaišiadorių r. SVB & LKT \\
\hline 10 & $\begin{array}{l}\text { Robotikos mokykla bibliotekoje } \\
(2015-2016 \mathrm{~m} .)\end{array}$ & Kaišiadorių r. SVB & BMGF, KM [BP 2] \\
\hline 11 & Auganti ir vieninga Europa & Kauno m. SVB & EKAL \\
\hline 12 & Atrask save 3D mieste (2015-2016 m.) & $\begin{array}{l}\text { Kauno m. SVB; } \\
\text { partnerė VšI Robotikos mokykla }\end{array}$ & BMGF, KM [BP 2] \\
\hline 13 & Gamtos mokykla bibliotekoje, 2015 & Kauno m. SVB & SV \\
\hline 14 & $\begin{array}{l}\text { Žaliakalniečiai - aktyvi, kūrybinga, brandi } \\
\text { bendruomené }\end{array}$ & $\begin{array}{l}\text { Kauno m. SVB Aušros“ f.; } \\
\text { partneriai: labdaros fondas } \\
\text { „Aušta“, silpnaregių bendrija } \\
\text { „Akių šviesa“, Žaliakalnio seniū- } \\
\text { nija ir kt. }\end{array}$ & [nenurodyta] \\
\hline 15 & Švęskime Europos dieną kartu! & Kauno r. SVB & EKAL \\
\hline 16 & Kultūros laukas Kauno rajone & Kauno r. SVB & LKT \\
\hline 17 & $\begin{array}{l}\text { Lietuviu kino vakarai netradicinëje erdvejje } \\
(2014-2015 \mathrm{m.})\end{array}$ & Kauno r. SVB & LKT \\
\hline 18 & $\begin{array}{l}\text { Biblioterapija: atrask save [tęstinis; skirtas } \\
\text { vaikams] }\end{array}$ & Kauno r. SVB & $\begin{array}{l}\text { LKT, KM, SV, pri- } \\
\text { vatūs asmenys** }\end{array}$ \\
\hline 19 & $\begin{array}{l}\text { Moksleiviu bendrujų kompetenciju ugdymas } \\
\text { Kauno rajono bibliotekose ir mokyklose } \\
\text { panaudojant informacines technologijas } \\
(2015-2016 \mathrm{~m} .)\end{array}$ & $\begin{array}{l}\text { Kauno r. SVB; } \\
\text { partneriai: Kauno r. Garliavos } \\
\text { Jonučiu gimnazija, Kauno r. } \\
\text { Garliavos Jonučių progimnazija, } \\
\text { Kauno r. švietimo centras, aso- } \\
\text { ciacija „Inovatyvus moksleivių } \\
\text { papildomo ugdymo tinklas“ }\end{array}$ & BMGF, KM [BP 2] \\
\hline 20 & Ateitis paveldint praeiti [dvarų kultūra] & Kauno r. SVB & $\begin{array}{l}\text { Kultūros paveldo } \\
\text { departamentas prie } \\
\text { KM }\end{array}$ \\
\hline 21 & Etnografiniai regionai - kuo jie ypatingi ir saviti & Kauno r. SVB & LKT \\
\hline 22 & $\begin{array}{l}\text { Vaikų švietimo programa „Taikomosios informa- } \\
\text { cijos kultūra“ }\end{array}$ & Kèdainių r. SVB & [nenurodyta] \\
\hline 23 & Senieji kaimai pasakoja [skirtas etnokultūrai] & Kèdainių r. SVB Pajieslio f. & SV \\
\hline 24 & $\begin{array}{l}\text { Ateiti kuriame kartu! Prisidèk ir tu! [skirtas } \\
\text { Europos dienai] }\end{array}$ & Prienų SVB & EKAL \\
\hline 25 & $\begin{array}{l}\text { Inovatyvi komunikacija - naujos galimybès } \\
\text { vartotojams (2015-2016 m.) }\end{array}$ & Prienų SVB & BMGF, KM [BP 2] \\
\hline 26 & $\begin{array}{l}\text { Justino Marcinkevičiaus jubiliejinių metų rengi- } \\
\text { niai jo vardo bibliotekoje }\end{array}$ & Prienų SVB & LKT \\
\hline 27 & $\begin{array}{l}\text { Inovatyvi elektroniniu paslaugu sklaida Prienų } \\
\text { rajone }\end{array}$ & Prienų SVB & LKT \\
\hline 28 & $\begin{array}{l}\text { Draugų ratas kitoks: pažink-priimk-dalinkis } \\
\text { [tęstinis] }\end{array}$ & Prienų SVB & KM \\
\hline 29 & $\begin{array}{l}\text { Pažangëjanti biblioteka kiekvienam (2015-2016 m.) } \\
\text { [skirtas skaitmeninėms kompetencijoms ugdyti] }\end{array}$ & Raseinių SVB & BMGF, KM [BP 2] \\
\hline
\end{tabular}




\begin{tabular}{|c|c|c|c|}
\hline Eil.nr. & Pavadinimas & Biblioteka, partneriai & Rèmèjai \\
\hline 30 & $\begin{array}{l}\text { Marcelijus Martinaitis: pilietis ir kūrèjas epochü } \\
\text { sankirtoje (2015-2016 m.) }\end{array}$ & $\begin{array}{l}\text { Raseinių SVB; } \\
\text { partneriai: Lietuvos literatūros } \\
\text { ir tautosakos institutas, Lietuvos } \\
\text { dailès muziejus, Raseinių rajono } \\
\text { švietimo įstaigos, Raseinių kraš- } \\
\text { to istorijos muziejus, Raseinių r. } \\
\text { kultūros centras }\end{array}$ & $\begin{array}{l}\text { LKT, UAB „Rasei- } \\
\text { nių žuvininkyste“, } \\
\text { UAB „Danspin“, } \\
\text { UAB „Agra Cor- } \\
\text { poration“, Raseinių } \\
\text { bibliotekininkų } \\
\text { draugija }\end{array}$ \\
\hline 31 & Dailininkas ir vaikiška knyga - 2015 [tęstinis] & Raseinių SVB & $\begin{array}{l}\text { LKT, privatūs } \\
\text { asmenys }\end{array}$ \\
\hline 32 & $\begin{array}{l}\text { Raseinių žemès vardynas. Betygalos ir Girkalnio } \\
\text { valsčiai [tęstinis] }\end{array}$ & Raseinių SVB & SV \\
\hline 33 & Renginiais populiariname knyga [tęstinis] & Raseinių SVB & SV \\
\hline 34 & Sveikas vaikas - laiminga šeima & Raseinių SVB Vosiliškio f. & SV \\
\hline \multicolumn{4}{|c|}{2016 metai } \\
\hline 1 & Mūsu Europa - spalvos, muzika, skoniai... & Birštono SVB & EKAL \\
\hline 2 & $\begin{array}{l}\text { Interaktyvi erdvé - erdvé kūrybai ir atradimams! } \\
(2015-2016 \mathrm{~m} .)\end{array}$ & Birštono SVB & $\begin{array}{l}\text { BMGF, KM [BP 2], } \\
\text { SV (finansavimas } \\
\text { skirtas } 2015 \mathrm{~m} . \text { ) }\end{array}$ \\
\hline 3 & $\begin{array}{l}\text { Po žvaigždètu vasaros dangum. Literatūriniai } \\
\text { vakarai Birštone } 2016 \mathrm{~m} \text {. [tęstinis] }\end{array}$ & Birštono SVB & LKT, KM, SV \\
\hline 4 & Tavo ir mano EUROPA & Jonavos r. SVB & EKAL \\
\hline 5 & Mokomès įdomiau (2015-2016 m.) & Jonavos r. SVB & $\begin{array}{l}\text { BMGF, KM [BP 2] } \\
\text { (finansavimas skir- } \\
\text { tas } 2015 \mathrm{~m} \text {.) }\end{array}$ \\
\hline 6 & $\begin{array}{l}\text { Robotikos mokykla bibliotekoje } \\
(2015-2016 \mathrm{~m} .)\end{array}$ & Kaišiadorių r. SVB & $\begin{array}{l}\text { BMGF, KM [BP 2] } \\
\text { (finansavimas skir- } \\
\text { tas } 2015 \mathrm{~m} . \text { ) }\end{array}$ \\
\hline 7 & $\begin{array}{l}\text { Renginiu ciklas „Europos Sajunga: iššūkiai ir } \\
\text { galimybès“ }\end{array}$ & Kauno m. SVB & EKAL \\
\hline 8 & Atrask save 3D mieste (2015-2016 m.) & $\begin{array}{l}\text { Kauno m. SVB; } \\
\text { partnerė - VšI Robotikos mo- } \\
\text { kykla }\end{array}$ & $\begin{array}{l}\text { BMGF, KM [BP 2] } \\
\text { (finansavimas skir- } \\
\text { tas } 2015 \mathrm{~m} \text {.) }\end{array}$ \\
\hline 9 & Mano gatves istorija 360 laipsniu kampu & $\begin{array}{l}\text { Kauno m. SVB; } \\
\text { partneriai: KTU Vaižganto } \\
\text { progimnazija, Kauno jaunųjų } \\
\text { turistų centras, Kauno neigalaus } \\
\text { jaunimo užimtumo centras, } \\
\text { Kauno r. SVB }\end{array}$ & KM, SV \\
\hline 10 & Greimo žurnalistikos akademija & Kauno m. SVB & LKT \\
\hline 11 & Vienybëje stiprūs [skirtas Europos dienai] & $\begin{array}{l}\text { Kauno r. SVB; } \\
\text { partneriai: Garliavos sporto } \\
\text { ir kultūros centras, Garliavos } \\
\text { mokyklos }\end{array}$ & EKAL \\
\hline 12 & $\begin{array}{l}\text { Moksleiviu bendruju kompetenciju ugdymas } \\
\text { Kauno rajono bibliotekose ir mokyklose } \\
\text { panaudojant informacines technologijas } \\
(2015-2016 \mathrm{~m} .)\end{array}$ & $\begin{array}{l}\text { Kauno r. SVB; } \\
\text { partneriai: Kauno r. Garliavos } \\
\text { Jonučių gimnazija, Kauno r. } \\
\text { Garliavos Jonučių progimnazija, } \\
\text { Kauno r. švietimo centras, aso- } \\
\text { ciacija „Inovatyvus moksleivių } \\
\text { papildomo ugdymo tinklas“ }\end{array}$ & $\begin{array}{l}\text { BMGF, KM [BP 2] } \\
\text { (finansavimas skir- } \\
\text { tas } 2015 \mathrm{~m} . \text { ) }\end{array}$ \\
\hline
\end{tabular}




\begin{tabular}{|c|c|c|c|}
\hline Eil.nr. & Pavadinimas & Biblioteka, partneriai & Rèmèjai \\
\hline 13 & $\begin{array}{l}\text { Biblioterapija: atrask save } 2 \text { [tęstinis; skirtas } \\
\text { vaikams] }\end{array}$ & Kauno r. SVB & LKT \\
\hline 14 & Vasara su knyga & Kauno r. SVB & [nenurodyta] \\
\hline 15 & Knygos kelias j vaiko širdị & Kèdainių r. SVB & SV \\
\hline 16 & Mažais žingsneliais ị knygu pasauli & $\begin{array}{l}\text { Kèdainių r. SVB } \\
\text { Pajieslio f. }\end{array}$ & SV \\
\hline 17 & Europos savaitè „ESu ir aš! ESu - dèl ateities!“ & $\begin{array}{l}\text { Prienų SVB; } \\
\text { partneriai: Prienų r. savivaldy- } \\
\text { bės administracijos Kultūros, } \\
\text { jaunimo ir sporto skyrius, Švieti- } \\
\text { mo skyrius, Prienų kultūros ir } \\
\text { laisvalaikio centras ir kt. }\end{array}$ & EKAL \\
\hline 18 & $\begin{array}{l}\text { Inovatyvi komunikacija - naujos galimybès } \\
\text { vartotojams (2015-2016 m.) }\end{array}$ & Prienų SVB & $\begin{array}{l}\text { BMGF, KM [BP 2] } \\
\text { (finansavimas skir- } \\
\text { tas } 2015 \mathrm{~m} . \text { ) }\end{array}$ \\
\hline 19 & $\begin{array}{l}\text { Nuotolinių inovatyviu elektroniniu paslaugų } \\
\text { kūrimas, sklaida ir viešinimas Prienų rajone }\end{array}$ & Prienų SVB & LKT, KM, SV \\
\hline 20 & $\begin{array}{l}\text { Draugų ratas kitoks: pažink-priimk-dalinkis } \\
\text { [tęstinis] }\end{array}$ & Prienų SVB & KM \\
\hline 21 & $\begin{array}{l}\text { Pažangèjanti biblioteka kiekvienam } \\
(2015-2016 \mathrm{~m} \text {.) [skirtas skaitmeninėms kom- } \\
\text { petencijoms ugdyti] }\end{array}$ & Raseinių SVB & $\begin{array}{l}\text { BMGF, KM [BP 2] } \\
\text { (finansavimas skir- } \\
\text { tas } 2015 \mathrm{~m} \text {.) }\end{array}$ \\
\hline 22 & Europos ateitis - tvari aplinka & Raseinių SVB & EKAL \\
\hline 23 & Renginiais populiariname knyga [tęstinis] & Raseinių SVB & SV \\
\hline 24 & $\begin{array}{l}\text { Marcelijus Martinaitis: pilietis ir kūrëjas epochu } \\
\text { sankirtoje (2015-2016 m.) }\end{array}$ & $\begin{array}{l}\text { Raseinių SVB; } \\
\text { partneriai: Lietuvos literatūros } \\
\text { ir tautosakos institutas, Lietuvos } \\
\text { dailès muziejus, Raseinių rajono } \\
\text { švietimo įstaigos, Raseinių kraš- } \\
\text { to istorijos muziejus, Raseinių r. } \\
\text { kultūros centras }\end{array}$ & $\begin{array}{l}\text { LKT, UAB „Rasei- } \\
\text { nių žuvininkyste““, } \\
\text { UAB „Danspin“, } \\
\text { UAB „Agra Cor- } \\
\text { poration“, Raseinių } \\
\text { viešosios bibliote- } \\
\text { kos bibliotekininku } \\
\text { draugija (finan- } \\
\text { savimas skirtas } \\
2015 \text { m.) }\end{array}$ \\
\hline \multicolumn{4}{|c|}{2017 metai } \\
\hline 1 & $\begin{array}{l}\text { Po žvaigždètu vasaros dangum. Literatūriniai } \\
\text { vakarai Birštone } 2017 \mathrm{~m} \text {. [tęstinis] }\end{array}$ & Birštono SVB & LKT, KM, SV \\
\hline 2 & Universali biblioterapijos kalba & Birštono SVB & LKT, KM, SV \\
\hline 3 & $\begin{array}{l}\text { Biblioteka - kūrybiniu atradimų namai [skirtas } \\
\text { vaikams] }\end{array}$ & Birštono SVB & LKT, KM, SV \\
\hline 4 & $\begin{array}{l}\text { Sniego ilgesys [skirtas avangardinio kino kūrèjo } \\
\text { Jono Meko atminimui] }\end{array}$ & Birštono SVB & LKT \\
\hline 5 & $\begin{array}{l}\text { Informacinio-edukacinio terminalo ịrengimas } \\
\text { bibliotekoje }\end{array}$ & $\begin{array}{l}\text { Birštono SVB; } \\
\text { partneriai: VšI „3D“, Biržų } \\
\text { turizmo informacijos centras, } \\
\text { televizija „Balticum TV“ }\end{array}$ & LKT \\
\hline 6 & Sekmadienio kinas bibliotekoje & Birštono SVB & [nenurodyta] \\
\hline
\end{tabular}




\begin{tabular}{|c|c|c|c|}
\hline Eil.nr. & Pavadinimas & Biblioteka, partneriai & Rèmėjai \\
\hline 7 & Žingsnis po žingsnio - $i$ švaresnę Europa & Jonavos r. SVB & EKAL \\
\hline 8 & $\begin{array}{l}\text { „Skype“ seminarų ciklas „Išeivijos literatūra - } \\
\text { mūsų bibliotekoje“ }\end{array}$ & Jonavos r. SVB & LKT \\
\hline 9 & $\begin{array}{l}\text { Inovatyvios technologijos - lietuviško žodžio } \\
\text { puoselètojų žinomumui ir skaidai }\end{array}$ & Kaišiadorių r. SVB & $\begin{array}{l}\text { LKT [finansuo- } \\
\text { tas } 2017 \text { m. pab.; } \\
\text { veiklos vykdytos } \\
2018 \text { m.] }\end{array}$ \\
\hline 10 & Atsakingas skaitytojas & Kaišiadorių r. SVB & $\begin{array}{l}\text { Elektronikos platin- } \\
\text { tojų asociacija }\end{array}$ \\
\hline 11 & Viešoji biblioteka ir filialai & Kaišiadorių r. SVB & SV \\
\hline 12 & Europa kuriame mes! & Kauno m. SVB & EKAL \\
\hline 13 & $\begin{array}{l}\text { Feel better with a book: reading for well-being at } \\
\text { an older age / Jauskis geriau su knyga: skaitymas } \\
\text { geresnei savijautai vyresniame amžiuje }\end{array}$ & $\begin{array}{l}\text { Kauno m. SVB; } \\
\text { partneriai: Vilniaus m. SCB, } \\
\text { Utenos SVB, Lidšiopingo miesto } \\
\text { biblioteka (Švedija), Ventspilio } \\
\text { miesto biblioteka (Latvija), Per- } \\
\text { nu miesto biblioteka (Estija) }\end{array}$ & $\begin{array}{l}\text { Programa } \\
\text { „Nordplus Adult“ }\end{array}$ \\
\hline 14 & Medijų ir informacinio raštingumo akademija & Kauno m. SVB & LKT, KM, SV \\
\hline 15 & Jaunimo teatro akademija & $\begin{array}{l}\text { Kauno m. SVB; } \\
\text { partneriai: Kauno miesto kame- } \\
\text { rinis teatras, Senamiesčio vaikų } \\
\text { dienos centras, vaikų gerovès } \\
\text { centras „Pastoge““, VšI „Actio } \\
\text { Catholica Patria“, VšI Kauno } \\
\text { medijų centras }\end{array}$ & LKT, KM \\
\hline 16 & Piliakalniu takais [skirtas vaikams ir jaunimui] & $\begin{array}{l}\text { Kauno m. SVB; } \\
\text { partneriai: Lietuvos archeologi- } \\
\text { jos draugija, Vytauto Didžiojo } \\
\text { karo muziejus, Kauno miesto } \\
\text { muziejus }\end{array}$ & $\begin{array}{l}\text { LKT, KM, SV, VšI } \\
\text { „Turizmo akade- } \\
\text { mija“ }\end{array}$ \\
\hline 17 & Kauno miesto XXI vaikų knygos švente & Kauno m. SVB & SV \\
\hline 18 & Knygos pasaulis mano piešiniuose & Kauno m. SVB & SV \\
\hline 19 & IRT technologijos ir kūrybiškumas & Kauno m. SVB & SV \\
\hline 20 & Knygos improvizacijos teatras [skirtas vaikams] & Kauno m. SVB & SV \\
\hline 21 & Bendraukime anglų kalba: drąsiai ir atvirai & Kauno m. SVB & SV \\
\hline 22 & Tavo galimybès Europos Sajungoje & Kauno r. SVB & EKAL \\
\hline 23 & $\begin{array}{l}\text { Kürybiniai dialogai Kauno rajone [skirtas vai- } \\
\text { kams ir jaunimui] }\end{array}$ & Kauno r. SVB & LKT \\
\hline 24 & Pasitikrink kultūros istorijos žinias & Kauno r. SVB & LKT \\
\hline 25 & $\begin{array}{l}\text { Kauno rajono kraštovaizdžio populiarinimo } \\
\text { iniciatyvos ir sklaida }\end{array}$ & Kauno r. SVB & $\begin{array}{l}\text { Lietuvos kultūros } \\
\text { paveldo departa- } \\
\text { mentas prie KM }\end{array}$ \\
\hline 26 & $\begin{array}{l}\text { Inovaciju keliu: atrask, išbandyk ir tobulek [skir- } \\
\text { tas vaikams ir jaunimui] }\end{array}$ & Kauno r. SVB & LKT \\
\hline 27 & $\begin{array}{l}\text { Knygos menas bibliotekoje [skirtas vaikams ir } \\
\text { jaunimui] }\end{array}$ & Kauno r. SVB & LKT \\
\hline 28 & Išmanusis kultūros kelias Kauno rajone & Kauno r. SVB & LKT \\
\hline
\end{tabular}




\begin{tabular}{|c|c|c|c|}
\hline Eil.nr. & Pavadinimas & Biblioteka, partneriai & Rèmèjai \\
\hline 29 & $\begin{array}{l}\text { Respublikinis dainuojamosios poezijos festivalis } \\
\text { „Ant Nevezžio kranto“" }\end{array}$ & Kèdainių r. SVB & SV \\
\hline 30 & Europos ateitis - mano ateitis! & Prienų SVB & EKAL \\
\hline 31 & $\begin{array}{l}\text { Draugu ratas kiTOKS: pažink-priimk-dalinkis! } \\
\text { Didžiuokis tuo, kas esi! [tęstinis] }\end{array}$ & Prienų SVB & LKT, SV \\
\hline 32 & „Erasmus +“ pasidalink perpus & Raseinių SVB & EKAL \\
\hline 33 & Dailininkas ir vaikiška knyga [tęstinis] & Raseinių SVB & LKT, KM, SV \\
\hline 34 & $\begin{array}{l}\text { J. Brigio knygos „Pasistačius bendrą darbo tikslą. } \\
\text { 1918-1940 m. Raseinių krašte veikusiu draugijų, } \\
\text { politinių, visuomeninių, ekonominių organizaci- } \\
\text { jų sąvadas“ leidyba }\end{array}$ & Raseinių SVB & SV \\
\hline 35 & Būk fiziškai aktyvus - būk sveikas & Raseinių SVB Berteškių f. & SV \\
\hline
\end{tabular}

* Apskričių lentelès išdėstomos abėcèline tvarka pagal penkis bibliotekų veiklos regionus.

** Privatūs asmenys priskiriami vietos rèméjams.

2 priedas. Marijampolès apskr. savivaldybių viešųjų bibliotekų 2007, 2013, 2015-2017 metų projektai

\begin{tabular}{|c|c|c|c|}
\hline Eil. nr. & Pavadinimas & Biblioteka, partneriai & Rèmèjai \\
\hline 1 & $\begin{array}{l}\text { Švietėjiškos veiklos galimybès bibliotekoje [skir- } \\
\text { tas bibliotekininkų kvalifikacijai kelti] }\end{array}$ & Kalvarijos SVB & KM \\
\hline 2 & $\begin{array}{l}\text { Kalvarijos krašto šviesuoliai (II dalis) [leidybos, } \\
\text { tęstinis] }\end{array}$ & $\begin{array}{l}\text { Kalvarijos SVB; } \\
\text { partneris - Kalvarijos literatų } \\
\text { klubas „Rasa“ }\end{array}$ & SV \\
\hline 3 & $\begin{array}{l}\text { MULTICENTRŲ įkūrimas Olštyne ir Marijam- } \\
\text { polejje }\end{array}$ & $\begin{array}{l}\text { Marijampolès SVB; } \\
\text { partnerè - Olštyno viešoji } \\
\text { biblioteka }\end{array}$ & $\begin{array}{l}\text { Europos regioni- } \\
\text { nès plètros fondas } \\
\text { (INTERREG IIIA: } \\
\text { Lietuvos, Lenkijos } \\
\text { ir Rusijos Federa- } \\
\text { cijos Kaliningrado } \\
\text { srities Kaimynystės } \\
\text { programa) }\end{array}$ \\
\hline 4 & $\begin{array}{l}\text { Marijampoles ir Vroclavo viešujų bibliotekų } \\
\text { bendradarbiavimas diegiant naujas technologi- } \\
\text { jas bibliotekose }\end{array}$ & Marijampolès SVB & $\mathrm{KM}$ \\
\hline 5 & Muzika reikia atrasti (2006-2007 m.) & Marijampolès SVB & KM \\
\hline 6 & Neigaliujų socialinés integracijos programa & $\begin{array}{l}\text { Marijampolès SVB; } \\
\text { partneris - Lietuvos invalidų } \\
\text { draugijos Marijampolès skyrius }\end{array}$ & SV \\
\hline 7 & Spalvos metu rate [etnokultūra; skirtas vaikams] & $\begin{array}{l}\text { Marijampolès SVB Sasnavos f.; } \\
\text { partnerè - Sasnavos vidurinè } \\
\text { mokykla }\end{array}$ & [nenurodyta] \\
\hline 8 & Skaitau - augu, tobuleju & Šakių r. SVB & $\mathrm{KM}$ \\
\hline 9 & $\begin{array}{l}\text { Pradžia amžino... [skirtas Šakių viešosios } \\
\text { bibliotekos } 70 \text {-mečiui ir pirmosios lietuviškos } \\
\text { knygos } 460 \text { metų sukakčiai] }\end{array}$ & Šakių r. SVB & SV \\
\hline 10 & Vaiku skaitymo kultūros ugdymas & Šakių r. SVB & SV \\
\hline
\end{tabular}




\begin{tabular}{|c|c|c|c|}
\hline Eil. nr. & Pavadinimas & Biblioteka, partneriai & Rèmèjai \\
\hline 11 & $\begin{array}{l}\text { Kompleksinis renginys „Poezijos pavasaris - } \\
2007^{“}\end{array}$ & Vilkaviškio r. SVB & SV \\
\hline 12 & $\begin{array}{l}\text { Projektas, skirtas kraštiečio poeto } \\
\text { K. Bradūno 90-mečio jubiliejui paminèti }\end{array}$ & Vilkaviškio r. SVB & SV \\
\hline 13 & $\begin{array}{l}\text { Projektas, skirtas J. Zabielavičiaus knygos „Vir- } \\
\text { balis mano atsiminimuose“ leidybai }\end{array}$ & $\begin{array}{l}\text { Vilkaviškio r. SVB; } \\
\text { partnerè - bendruomenė „Vir- } \\
\text { balio vartai“ }\end{array}$ & [nenurodyta] \\
\hline \multicolumn{4}{|c|}{2013 metai } \\
\hline 1 & $\begin{array}{l}\text { Tavo teisés. Būk informuotas [skirtas Europos } \\
\text { dienai] }\end{array}$ & Kalvarijos SVB & EKAL \\
\hline 2 & Mano kaimas - tapybos kūrinys & Kalvarijos SVB & $\begin{array}{l}\text { Europos žemès } \\
\text { ūkio fondas kaimo } \\
\text { plètrai (LEADER } \\
\text { programa), valsty- } \\
\text { bės biudžetas }\end{array}$ \\
\hline 3 & $\begin{array}{l}\text { Kalvarijos savivaldybès viešosios bibliotekos } \\
\text { Akmenynų, Brukų, Liubavo, Jungènų, Sangrūdos } \\
\text { filialu patalpu pritaikymas visuomenès porei- } \\
\text { kiams (2012-2014 m.) }\end{array}$ & Kalvarijos SVB & $\begin{array}{l}\text { Europos žemès } \\
\text { ūkio fondas kaimo } \\
\text { plètrai (LEADER } \\
\text { programa), valsty- } \\
\text { bės biudžetas }\end{array}$ \\
\hline 4 & $\begin{array}{l}\text { Tarmés - brangūs akmenèliai lietuviu kalbos } \\
\text { lobyne }\end{array}$ & $\begin{array}{l}\text { Kazlų Rūdos SVB; } \\
\text { partneris - Lietuvių kalbos } \\
\text { draugijos Kazlų Rūdos skyrius }\end{array}$ & $\mathrm{KRF}$ \\
\hline 5 & $\begin{array}{l}\text { Bendradarbiavimas kuriant biblioteką šeimai } \\
(2013-2014 \mathrm{~m} .)\end{array}$ & $\begin{array}{l}\text { Marijampolės SVB; } \\
\text { partnerè - Černiachovsko } \\
\text { biudžetinė municipalinè ịstaiga } \\
\text { "Centralizuota bibliotekų siste- } \\
\text { ma“ (Rusijos Federacija) }\end{array}$ & $\begin{array}{l}\text { Europos struktūri- } \\
\text { niai fondai, SV }\end{array}$ \\
\hline 6 & Sveikatos informacija - kiekvienam žmogui & Marijampolės SVB & SV \\
\hline 7 & Reikia išmokti sveikam išlikti & Marijampolès SVB & SV \\
\hline 8 & $\begin{array}{l}\text { Skulptūrų parkas - vaikų literatūros klasiko } \\
\text { Vytauto Tamulaičio - 100-mečiui }\end{array}$ & Šakių r. SVB & $\begin{array}{l}\text { KM, SV, Kriūkų } \\
\text { seniūnija, Miškų } \\
\text { savininkų koope- } \\
\text { ratyvas „Zanavykų } \\
\text { šilas“ }\end{array}$ \\
\hline 9 & Poezijos pavasaris - 2013 & Vilkaviškio r. SVB & SV \\
\hline 10 & $\begin{array}{l}\text { Knygos „Virbalis mano atsiminimuose“ } 2 \text { dalies } \\
\text { leidyba }\end{array}$ & $\begin{array}{l}\text { Vilkaviškio r. SVB Virbalio f.; } \\
\text { partnere - miesto bendruomenè }\end{array}$ & VVG \\
\hline 11 & $\begin{array}{l}\text { Projektas, skirtas Virbalio miesto Magdeburgo } \\
\text { teisès } 420 \text { metų sukakčiai }\end{array}$ & $\begin{array}{l}\text { Vilkaviškio r. SVB Virbalio f.; } \\
\text { partnerè - miesto bendruomenė }\end{array}$ & [nenurodyta] \\
\hline 12 & Projektas, skirtas Gižu 400 metu jubiliejui & $\begin{array}{l}\text { Vilkaviškio r. SVB Gižų f;; } \\
\text { partnerè - kaimo bendruomenè }\end{array}$ & [nenurodyta] \\
\hline \multicolumn{4}{|c|}{2015 metai } \\
\hline 1 & $\begin{array}{l}\text { Kad galètum padèti - reikia pažinti [skirtas } \\
\text { Europos dienai] }\end{array}$ & Kalvarijos SVB & EKAL \\
\hline 2 & Europietiška Kazlų Rūda 2015 & Kazlų Rūdos SVB & EKAL \\
\hline 3 & Skaitome ir vaidiname [tęstinis] & Kazlų Rūdos SVB & LKT \\
\hline
\end{tabular}




\begin{tabular}{|c|c|c|c|}
\hline Eil. nr. & Pavadinimas & Biblioteka, partneriai & Rèmèjai \\
\hline 4 & $\begin{array}{l}\text { IT kartos iniciatyvos bibliotekoje } \\
(2015-2016 \mathrm{~m} .)\end{array}$ & $\begin{array}{l}\text { Marijampolès SVB; partne- } \\
\text { riai: VšI „Marijampolès teleki- } \\
\text { nas“ ir kūrybos namai „Exter“ }\end{array}$ & BMGF, KM [BP 2] \\
\hline 5 & $\begin{array}{l}\text { Marijampolès miesto gatvių kaita: iliustruotas } \\
\text { interaktyvus žinynas [tęstinis] }\end{array}$ & $\begin{array}{l}\text { Marijampolės SVB; } \\
\text { partneriai: } \\
\text { „Suvalkietis“ (Marijampolès } \\
\text { apskrities laikraštis), UAB } \\
\text { „Quadra reklama“, valstybės } \\
\text { ịmonės Registrų centro Mari- } \\
\text { jampolès filialas, UAB „Scenos } \\
\text { servisas“, Marijampolès apskri- } \\
\text { ties archyvas, Kultūros paveldo } \\
\text { departamento prie Kultūros mi- } \\
\text { nisterijos Marijampolės skyrius, } \\
\text { Marijampolės kolegija, Mari- } \\
\text { jampolès kraštotyros muziejus, } \\
\text { Lietuvos prezidento K. Griniaus } \\
\text { memorialinis muziejus ir kt. }\end{array}$ & SV \\
\hline 6 & Sveikai gyventi lengva & Marijampolès SVB & SV \\
\hline 7 & $\begin{array}{l}\text { Sveikatos informacija - kiekvienam žmogui } \\
\text { [tęstinis] }\end{array}$ & $\begin{array}{l}\text { Marijampolės SVB } \\
\text { Igliaukos ir Daukšių filialai }\end{array}$ & SV \\
\hline 8 & Europa su mumis & Šakių r. SVB & EKAL \\
\hline 9 & $\begin{array}{l}\text { Šiuolaikines technologijos - bendruomenes } \\
\text { sveikatai (2015-2016 m.) }\end{array}$ & $\begin{array}{l}\text { Šakių r. SVB; } \\
\text { partnere - Šakių pedagoginė } \\
\text { psichologinè tarnyba }\end{array}$ & BMGF, KM [BP 2] \\
\hline 10 & Laisvès kovu atmintis & Šakių r. SVB & LKT \\
\hline 11 & $\begin{array}{l}\text { Vilkaviškio krašto e-etnografijos akademija } \\
(2015-2016 \mathrm{~m} .)\end{array}$ & $\begin{array}{l}\text { Vilkaviškio r. SVB; } \\
\text { partneriai: Vilkaviškio turizmo } \\
\text { ir verslo informacijos centras, } \\
\text { Vilkaviškio rajono švietimo } \\
\text { pagalbos tarnyba }\end{array}$ & BMGF, KM [BP 2] \\
\hline 12 & Poezijos pavasaris - 2015 & Vilkaviškio r. SVB & SV \\
\hline 13 & $\begin{array}{l}\text { Virbalio vartai [tęstinis; } 2015 \text { m. bibliotekoje } \\
\text { veikè dailès studija] }\end{array}$ & $\begin{array}{l}\text { Vilkaviškio r. SVB Virbalio f.; } \\
\text { partnerè - miesto bendruomenè }\end{array}$ & [nenurodyta] \\
\hline \multicolumn{4}{|c|}{2016 metai } \\
\hline 1 & $\begin{array}{l}\text { Etniné kultūra - tiltas tarp bendruomenès nariu } \\
\text { ir bibliotekos }\end{array}$ & Kalvarijos SVB & SV \\
\hline 2 & $\begin{array}{l}\text { Europietiška Kazlų Rūda } 2016 \text { [skirtas Europos } \\
\text { dienai] }\end{array}$ & Kazlų Rūdos SVB & EKAL \\
\hline 3 & $\begin{array}{l}\text { Jaunimui aktualios informacijos sklaidos prie- } \\
\text { moniu plètra Kazlu Rūdos savivaldybèje }\end{array}$ & Kazlų Rūdos SVB & SV \\
\hline 4 & $\begin{array}{l}\text { IT kartos iniciatyvos bibliotekoje (2015- } \\
2016 \mathrm{m.} \text { ) }\end{array}$ & $\begin{array}{l}\text { Marijampolès SVB; } \\
\text { partneriai: Všt „Marijampolès } \\
\text { telekinas“ ir kūrybos namai } \\
\text { „Exter“ }\end{array}$ & $\begin{array}{l}\text { BMGF, KM [BP 2] } \\
\text { (finansavimas skir- } \\
\text { tas } 2015 \mathrm{~m} . \text { ) }\end{array}$ \\
\hline
\end{tabular}




\begin{tabular}{|c|c|c|c|}
\hline Eil. nr. & Pavadinimas & Biblioteka, partneriai & Rèmèjai \\
\hline 5 & $\begin{array}{l}\text { Marijampoles miesto gatvių kaita: iliustruotas } \\
\text { interaktyvus žinynas [tęstinis] }\end{array}$ & $\begin{array}{l}\text { Marijampolės SVB; } \\
\text { partneriai: Marijampolès apskri- } \\
\text { ties laikraštis „Suvalkietis“, UAB } \\
\text { „Quadra reklama“, valstybės } \\
\text { ịmonės Registrų centro Mari- } \\
\text { jampolès filialas, UAB „Scenos } \\
\text { servisas“, Marijampolès apskri- } \\
\text { ties archyvas, Kultūros paveldo } \\
\text { departamento prie Kultūros mi- } \\
\text { nisterijos Marijampolès skyrius, } \\
\text { Marijampolės kolegija, Mari- } \\
\text { jampolès kraštotyros muziejus, } \\
\text { Lietuvos prezidento K. Griniaus } \\
\text { memorialinis muziejus ir kt. }\end{array}$ & LKT \\
\hline 6 & Skaitymo virusas Marijampolèje [tęstinis] & $\begin{array}{l}\text { Marijampolės SVB; } \\
\text { partneriai: Lietuvos krikščioniš- } \\
\text { kojo jaunimo blaivybės sajun- } \\
\text { gos „Žingsnis“ Marijampolès } \\
\text { skyrius, } \\
\text { Marijampolės dramos teatro } \\
\text { jaunimo studija „Nauja karta“, } \\
\text { Marijampolès kolegija }\end{array}$ & LKT \\
\hline 7 & $\begin{array}{l}\text { Neformaliojo suaugusiujų švietimo ir tęstinio } \\
\text { mokymosi programa „IT akademija“ }\end{array}$ & $\begin{array}{l}\text { Marijampolès SVB; } \\
\text { partnerè - Marijampolès terito- } \\
\text { rinè darbo birža }\end{array}$ & ŠMM \\
\hline 8 & Menas gyventi - menas būti sveikam & Marijampolès SVB & SV \\
\hline 9 & Sveikatos informacija - kiekvienam žmogui & $\begin{array}{l}\text { Marijampolès SVB Sasnavos, } \\
\text { Gavaltuvos, Smilgių, Puskelnių, } \\
\text { Tautkaičių filialai }\end{array}$ & SV \\
\hline 10 & Sielos terapija & Marijampolès SVB & SV \\
\hline 11 & Programa „Knygos draugai“ & Marijampolès SVB & SV \\
\hline 12 & Drauge mes tvirtesni [skirtas Europos dienai] & Šakių r. SVB & EKAL \\
\hline 13 & $\begin{array}{l}\text { Šiuolaikinès technologijos - bendruomenès } \\
\text { sveikatai }\end{array}$ & Šakių r. SVB & $\begin{array}{l}\text { BMGF, KM [BP 2] } \\
\text { (finansavimas skir- } \\
\text { tas } 2015 \mathrm{~m} \text {.) }\end{array}$ \\
\hline 14 & Kelionè po Lietuvos rašytojų kūryba & Šakių r. SVB & LKT \\
\hline 15 & $\begin{array}{l}\text { Vilkaviškio krašto e-etnografijos akademija } \\
(2015-2016 \mathrm{~m} .)\end{array}$ & $\begin{array}{l}\text { Vilkaviškio r. SVB; } \\
\text { partneriai: Vilkaviškio turizmo } \\
\text { ir verslo informacijos centras, } \\
\text { Vilkaviškio r. švietimo pagalbos } \\
\text { tarnyba }\end{array}$ & $\begin{array}{l}\text { BMGF, KM [BP 2] } \\
\text { (finansavimas skir- } \\
\text { tas } 2015 \mathrm{~m} \text {.) }\end{array}$ \\
\hline 16 & Poezijos pavasaris - 2016 & Vilkaviškio r. SVB & SV \\
\hline 17 & $\begin{array}{l}\text { Virbalio vartai [tęstinis; } 2016 \text { m. bibliotekoje } \\
\text { veikè dailès studija] }\end{array}$ & $\begin{array}{l}\text { Vilkaviškio r. SVB Virbalio f.; } \\
\text { partnerè - miesto bendruomenè }\end{array}$ & [nenurodyta] \\
\hline \multicolumn{4}{|c|}{2017 metai } \\
\hline 1 & $\begin{array}{l}\text { Gimtiné: žmonés ir vietovès [kraštiečio tautosa- } \\
\text { kininko Jurgio Dovydaičio 110-osios metinès; } \\
\text { skirtas jaunimui] }\end{array}$ & Kazlų Rūdos SVB & [nenurodyta] \\
\hline
\end{tabular}




\begin{tabular}{|c|c|c|c|}
\hline Eil. nr. & Pavadinimas & Biblioteka, partneriai & Rèmèjai \\
\hline 2 & Skaitome ir vaidiname [tęstinis] & Kazlų Rūdos SVB & [nenurodyta] \\
\hline 3 & Suvalkijos elektroniné biblioteka & $\begin{array}{l}\text { Marijampolès SVB; } \\
\text { partneriai: Marijampolès apskri- } \\
\text { ties archyvas, } \\
\text { Lietuvos prezidento K. Griniaus } \\
\text { memorialinis muziejus, Mari- } \\
\text { jampolès Rimanto Stankevičiaus } \\
\text { pagrindinė mokykla, } \\
\text { Marijampolès „Šaltinio“ pagrin- } \\
\text { dinė mokykla, } \\
\text { AB „Lietuvos draudimas“, Mari- } \\
\text { jampolès filialas ir kt. }\end{array}$ & LKT \\
\hline \multirow[t]{2}{*}{4} & $\begin{array}{l}\text { Marijampolès miesto gatvių kaita: iliustruotas } \\
\text { interaktyvus žinynas [tęstinis] }\end{array}$ & $\begin{array}{l}\text { Marijampolės SVB; } \\
\text { partneriai: Marijampolès apskri- } \\
\text { ties laikraštis „Suvalkietis“, UAB } \\
\text { „Quadra reklama“, valstybės } \\
\text { ịmonės Registrų centro Mari- } \\
\text { jampolės filialas, UAB „Scenos } \\
\text { servisas“, Marijampolès apskri- } \\
\text { ties archyvas, Kultūros paveldo } \\
\text { departamento prie Kultūros mi- } \\
\text { nisterijos Marijampolės skyrius, }\end{array}$ & $\begin{array}{l}\text { LKT (finansavimas } \\
\text { skirtas } 2016 \mathrm{~m} . \text { ) }\end{array}$ \\
\hline & & $\begin{array}{l}\text { Marijampolès kolegija, Mari- } \\
\text { jampolès kraštotyros muziejus, } \\
\text { Lietuvos prezidento K. Griniaus } \\
\text { memorialinis muziejus ir kt. }\end{array}$ & \\
\hline 5 & Skaitymo virusas Marijampolëje [tęstinis] & $\begin{array}{l}\text { Marijampolės SVB; } \\
\text { partneriai: } \\
\text { Lietuvos krikščioniškojo jauni- } \\
\text { mo blaivybės sąjungos „Žings- } \\
\text { nis“ Marijampolès skyrius, } \\
\text { Marijampolès dramos teatro } \\
\text { jaunimo studija „Nauja karta“, } \\
\text { Marijampolės kolegija }\end{array}$ & $\begin{array}{l}\text { SV [pastaba: } \\
2016 \text { m. finansavi- } \\
\text { mą skyrè LKT] }\end{array}$ \\
\hline 6 & Laimè būti sveikam & $\begin{array}{l}\text { Marijampolès SVB; } \\
\text { partneris - Marijampolès savival- } \\
\text { dybės visuomenès sveikatos biuras }\end{array}$ & SV \\
\hline 7 & $\begin{array}{l}\text { Sveikatos informacija - kiekvienam žmogui } \\
\text { [tęstinis] }\end{array}$ & $\begin{array}{l}\text { Marijampolès SVB, Patašinės, } \\
\text { Meškučių, Igliškèlių, Valavičių, } \\
\text { Baraginės, Balsupių filialai; } \\
\text { partnerè - Marijampolès seniūnija }\end{array}$ & SV \\
\hline 8 & Knyga gali prakalbinti ir gydyti & $\begin{array}{l}\text { Marijampolės SVB } \\
\text { partneriai: } \\
\text { Marijampolės savivaldybės } \\
\text { visuomenės sveikatos biuras, } \\
\text { Marijampolės savivaldybės ne- } \\
\text { igaliųjų draugija, Marijampolès } \\
\text { „Sniego gniūžtės“ skyrius }\end{array}$ & SV \\
\hline
\end{tabular}




\begin{tabular}{|c|c|c|c|}
\hline Eil. nr. & Pavadinimas & Biblioteka, partneriai & Rèmèjai \\
\hline 9 & $\begin{array}{l}\text { Drauge mES tvirtesni [projekto pavadinimas } \\
\text { sutampa su } 2016 \mathrm{~m} \text {. projekto pavadinimu, tik } \\
\text { ES rašoma didžiosiomis raidemis] }\end{array}$ & Šakių r. SVB & EKAL \\
\hline 10 & Kultūriniai valstybingumo maršrutai Suvalkijoje & Šakių r. SVB & LKT \\
\hline 11 & Europa - Man, Aš - Europai & $\begin{array}{l}\text { Vilkaviškio r. SVB; } \\
\text { partneriai: Marijampolès } \\
\text { Europos informacijos centras } \\
\text { „Europe Direct“, Vilkaviškio } \\
\text { kultūros centras, Vilkaviškio r. } \\
\text { savivaldybė, Vilkaviškio „Jau- } \\
\text { nimo Europos“ komanda, TAU } \\
\text { Vilkaviškio poskyris, laikraščio } \\
\text { „Santaka“ atstovai }\end{array}$ & EKAL \\
\hline 12 & Poezijos pavasaris - 2017 & Vilkaviškio r. SVB & SV \\
\hline 13 & $\begin{array}{l}\text { Vaikų vasaros užimtumo stovykla „Pažintis su } \\
\text { literatūriniu Vilkaviškiu“" }\end{array}$ & Vilkaviškio r. SVB & SV \\
\hline 14 & $\begin{array}{l}\text { Virbalio vartai [tęstinis; } 2017 \text { m. bibliotekoje } \\
\text { veikè dailès studija] }\end{array}$ & $\begin{array}{l}\text { Vilkaviškio r. SVB Virbalio f.; } \\
\text { partnerè - miesto bendruomenè }\end{array}$ & [nenurodyta] \\
\hline
\end{tabular}

3 priedas. Klaipėdos apskr. savivaldybių viešųjų bibliotekų 2007, 2013, 2015-2017 metų projektai

\begin{tabular}{|c|c|c|c|}
\hline Eil. nr. & Projekto pavadinimas & Biblioteka, partneriai & Rèmèjai \\
\hline 1 & Skaitykime drauge & Klaipėdos m. SVB & $\mathrm{KM}$ \\
\hline 2 & Klaipèdos krašto tautodaile ir dailieji amatai & Klaipèdos m. SVB & KSRF \\
\hline 3 & Išsišluokime kalbos „šiukšles“ & Klaipėdos m. SVB & SV \\
\hline 4 & Vaiku vasaros skaitymo stovykla & Klaipèdos m. SVB & SV \\
\hline 5 & $\begin{array}{l}\text { Klaipèdos rajono seniūnijų dirbančiuju gyventoju } \\
\text { kompiuterinio raštingumo skatinimas } \\
(2006-2007 \text { m.) }\end{array}$ & Klaipèdos r. SVB & $\begin{array}{l}\text { Europos socialinis } \\
\text { fondas }\end{array}$ \\
\hline 6 & Klaipėdos regiono bibliotekų etnokultūros lobiai & $\begin{array}{l}\text { Klaipèdos r. SVB; } \\
\text { partneris - KlAVB }\end{array}$ & KM \\
\hline 7 & Žodi, nekrisk ant akmens [leidybos] & Klaipèdos r. SVB & $\begin{array}{l}\text { Klaipèdos apskrities } \\
\text { viršininko admini- } \\
\text { stracija }\end{array}$ \\
\hline 8 & $\begin{array}{l}\text { Aš patikèjau popieriui kaip draugui [numatyti } \\
\text { susitikimai su literatais] }\end{array}$ & Klaipèdos r. SVB & SV \\
\hline 9 & Biblioteka šių dienų visuomenèje & Klaipèdos r. SVB & SV \\
\hline 10 & Netradicinès knygos leidyba bibliotekoje & Klaipèdos r. SVB & SV \\
\hline 11 & $\begin{array}{l}\text { Rajono literatų tradicijos - impulsas jaunuju } \\
\text { kūrybos skatinimui [leidybos] }\end{array}$ & Klaipèdos r. SVB & SV \\
\hline 12 & Vakaras su knyga rankoje [skirtas vaikams] & Klaipèdos r. SVB & SV \\
\hline 13 & Astridos Lindgren „džiūgenos“ bibliotekoje & Klaipèdos r. SVB Dauparų f. & SV \\
\hline 14 & Iš senolių indaujos & Klaipėdos r. SVB Dovilų f. & SV \\
\hline 15 & Meno mylètoju kūrybos pleneras & Klaipėdos r. SVB Judrènų f. & SV \\
\hline 16 & Ateik ir pasikviesk draugus & $\begin{array}{l}\text { Klaipėdos r. SVB Kalotès, Slen- } \\
\text { gių filialai }\end{array}$ & SV \\
\hline
\end{tabular}




\begin{tabular}{|c|c|c|c|}
\hline Eil. nr. & Projekto pavadinimas & Biblioteka, partneriai & Rèmèjai \\
\hline 17 & Su knyga į magijos pasauli & Klaipèdos r. SVB & SV \\
\hline 18 & Senolių buitis & Klaipèdos r. SVB Slengų f. & SV \\
\hline 19 & Duona ne per veja ateina & $\begin{array}{l}\text { Klaipèdos r. SVB Tilvikų f.; } \\
\text { partneris - Tilvikų kultūros } \\
\text { namai }\end{array}$ & SV \\
\hline 20 & Kaimo šviesuoliai & Klaipėdos r. SVB Venckų f. & SV \\
\hline 21 & Ne vien tik sau [leidybos] & Klaipèdos r. SVB Endriejavo f. & SV \\
\hline 22 & Istorijos vingiais po Veiviržėnų seniūnijg & $\begin{array}{l}\text { Klaipėdos r. SVB Veiviržènų, } \\
\text { Daukšaičių, Pèžaičių, Šalpènų } \\
\text { filialai }\end{array}$ & SV \\
\hline 23 & Per knyga - i pasauli & Kretingos r. SVB & KM \\
\hline 24 & Klaipedos regiono etnokultūros lobiai & $\begin{array}{l}\text { Kretingos r. SVB; } \\
\text { partneris - KlAVB }\end{array}$ & KM \\
\hline 25 & $\begin{array}{l}\text { Elektroninio leidinio „Kretingos krašto enciklope- } \\
\text { dija kūrimas“ [tęstinis] }\end{array}$ & Kretingos r. SVB & SV \\
\hline 26 & Liob žaisti, liob dainiuoté & Kretingos r. SVB & $\begin{array}{l}\text { Klaipedos apskrities } \\
\text { viršininko adminis- } \\
\text { tracija, SV }\end{array}$ \\
\hline 27 & Per žodžio gyvastị ir dvasią [tęstinis] & Kretingos r. SVB & SV \\
\hline 28 & $\begin{array}{l}\text { Juozo Lukausko lobiai [leidybos; skirtas tauto- } \\
\text { dailininkui] }\end{array}$ & Kretingos r. SVB & SV \\
\hline 29 & Renginių ciklas „Senolių kraitele““ & Kretingos r. SVB & SV \\
\hline 30 & $\begin{array}{l}\text { Darbais iprasminti baubliškiu gyvenimai: senieji } \\
\text { amatai, kasdiene buitis ir darbymečio talkos }\end{array}$ & Kretingos r. SVB Baublių f. & SV \\
\hline 31 & $\begin{array}{l}\text { Rimantas Daugintis - tragiško likimo meninin- } \\
\text { kas iš Baubliu }\end{array}$ & $\begin{array}{l}\text { Kretingos r. SVB } \\
\text { Baublių f. }\end{array}$ & SV \\
\hline 32 & Knyga mūsu gyvenime & $\begin{array}{l}\text { Kretingos r. SVB } \\
\text { Budrių f. }\end{array}$ & SV \\
\hline 33 & $\begin{array}{l}\text { Kraštotyros darbas „Darbènų apylinkès architek- } \\
\text { tūriniai, archeologiniai ir gamtos paminklai“ }\end{array}$ & $\begin{array}{l}\text { Kretingos r. SVB } \\
\text { Darbėnų f. }\end{array}$ & SV \\
\hline 34 & $\begin{array}{l}\text { Kraštotyros darbas „Erlènų ir aplinkinių kaimų } \\
\text { etnokultūros lobynas“ }\end{array}$ & $\begin{array}{l}\text { Kretingos r. SVB } \\
\text { Erlènų f. }\end{array}$ & SV \\
\hline 35 & Etnokultūriné popietè „Duona, kvepianti ajerais“ & $\begin{array}{l}\text { Kretingos r. SVB } \\
\text { Erlènų f. }\end{array}$ & SV \\
\hline 36 & Grūšlaukès krašto drožybos tradicijos ir paveldas & Kretingos r. SVB Grūšlaukès f. & SV \\
\hline 37 & Skambèk, poezijos žodi & $\begin{array}{l}\text { Kretingos r. SVB } \\
\text { Juodupènų } f \text {. }\end{array}$ & SV \\
\hline 38 & Mažoji kaimo architektūra & Kretingos r. SVB Juodupènų f. & SV \\
\hline 39 & Knyga atskleidžia gamtos groži & Kretingos r. SVB Jokūbavo f. & SV \\
\hline 40 & $\begin{array}{l}\text { Kraštotyros darbas „Kurmaičiu istorija } \\
\text { dabarčiai“ }\end{array}$ & Kretingos r. SVB Kurmaičių f. & SV \\
\hline 41 & Edukacinè programa „Pasakos atgyja lèlèse“ & Kretingos r. SVB Raguviškių f. & SV \\
\hline 42 & $\begin{array}{l}\text { Renginys „Žemaičių poezijos ruduo“ ir kraštoty- } \\
\text { ros darbas „Taip kalbèjo mūsu senoliai“ }\end{array}$ & Kretingos r. SVB Rūdaičių f. & SV \\
\hline 43 & $\begin{array}{l}\text { Romansu ir dainuojamosios poezijos renginys } \\
\text { „Nuskaidrinantys būti palaiminga šviesa“" }\end{array}$ & Kretingos r. SVB Salantų f. & SV \\
\hline
\end{tabular}




\begin{tabular}{|c|l|}
\hline Eil. nr. & Projekto pavadinimas \\
\hline 44 & Kraštotyros darbas „Salantų tautodailininkai“ \\
\hline 45 & Vaikystè Astridos Lindgren šalyje \\
\hline 46 & Palangos vardai [tęstinis] \\
\hline 47 & Pasaka apie angelus \\
\hline 48 & Poezijos ruduo - 2007 \\
\hline
\end{tabular}

49 Lietuviškas žodis ir raštas Karaliaučiaus krašte

50 Vaikų ir jaunimo kultūrinès edukacijos programa „Kürybos ir saviraiškos takas - kelionè ị pažinimo šalį“

51 Knygos ir rašto paveldo aktualizavimas ir sklaida

52 Pamario krašto kultūros paveldo aktualizavimas ir sklaida socialineje aplinkoje

53 Knygų skaitymo pasaulis ir pažinimo galaktika

54 Kraštiečiu sueiga „Pirmąkart susitikę šviesos parnešti, gera padaryti... "[tęstinis]

55 Knygos slepiniai

56 Hermannas Sudermannas savo knygose ir biblioteka

57 Knygos pasaulis atviras visiems

58 Knyga - raktas i suvokimo pasauli

59 Literatūrinis ruduo „Prisijaukinkim žodi, paukštị, debesį... “[tęstinis]

60 Renginiu ciklas „Skaitau, ịsivaizduoju, piešiu...“

61 Poezija - sielos atgaiva

62 Knygos šventè „Žinau, širdis tava, visam pasauliui išdalyta“

63 Biblioteka - bendruomenei

64 Inkakliu krašto istorija - ateinančioms kartoms

65 Renginiu ciklas „Menas ir mes“

66 Biblioteka - knygos buveine

67 Vertinkime tai, ka turime [skirtas gyvenvietès ir Klaipèdos krašto istorijai]

68 Biblioteka - tai nuolatinis demesys skaitytojams...

\begin{tabular}{l|l}
\hline Biblioteka, partneriai & Rèmėjai \\
\hline Kretingos r. SVB Salantų f. & SV \\
\hline Kretingos r. SVB Vydmantų f. & SV \\
\hline Palangos SVB & [nenurodyta] \\
\hline Palangos SVB & [nenurodyta] \\
\hline Skuodo r. SVB; & [nenurodyta]
\end{tabular}

partneris - Skuodo literatų

klubas „Nojus“

Šilutès r. SVB;

KM

partnerè - asociacija Šilutès

raštijos ir knygių draugija

Šilutès r. SVB

KM

Šilutès r. SVB

KM

Šilutès r. SVB

KM

Šilutès r. SVB

KM

Šilutès r. SVB

KM, SV

Šilutès r. SVB

KM, SV

Šilutès r. SVB

KSRF

Šilutès r. SVB

Klaipedos apskrities viršininko administracija

Šilutès r. SVB $\quad$ SV

Šilutès r. SVB; $\quad$ SV

partnerè - asociacija Šilutès raštijos ir knygių draugija

Šilutès r. SVB SV

Šilutès r. SVB Bikavènų f. $\quad$ SV

Šilutès r. SVB Degučių f. $\quad$ SV

Šilutès r. SVB $\quad$ SV

Gardamo f.

Šilutès r. SVB

SV

Inkaklių f.

Šilutès r. SVB Juknaičių ir Pašy- SV šių filialai

Šilutès r. SVB $\quad$ SV

Katyčių f.

Šilutès r. SVB

SV

Kintų f.

Šilutès r. SVB Naumiesčio f. $\quad$ SV 


\begin{tabular}{|c|c|c|c|}
\hline Eil. nr. & Projekto pavadinimas & Biblioteka, partneriai & Rèmèjai \\
\hline 69 & $\begin{array}{l}\text { Renginių ciklas „Idomių žmonių galerija“ [skir- } \\
\text { tas kraštiečiams] }\end{array}$ & Šilutės r. SVB Rusnės f. & SV \\
\hline 70 & $\begin{array}{l}\text { Renginių ciklas „Nebūkim užmiršti“ [skirtas } \\
\text { gyvenvietės istorijai] }\end{array}$ & Šilutès r. SVB Usėnų f. & SV \\
\hline 71 & Vainuto biblioteka: savastis ir pokyčiai & Šilutès r. SVB Vainuto f. & SV \\
\hline 72 & Biblioteka: istorija ir žmonès & Šilutès r. SVB Vilkyčių f. & SV \\
\hline \multicolumn{4}{|c|}{2013 metai } \\
\hline 1 & Kai „Google“ nepadeda, pades Biblioteka! & $\begin{array}{l}\text { Klaipedos m. SVB; } \\
\text { partneriai: Klaipėdos pedagogų } \\
\text { švietimo ir kultūros centras, } \\
\text { Kretingos r. pedagogų švietimo } \\
\text { centras }\end{array}$ & $\mathrm{KM}$ \\
\hline 2 & $\begin{array}{l}\text { Nacionalinès kultūros ir meno premijos laurea- } \\
\text { tai-skaitome, matome, girdime }\end{array}$ & $\begin{array}{l}\text { Klaipedos m. SVB; } \\
\text { partneriai: Klaipėdos m. savival- } \\
\text { dybės administracijos švietimo } \\
\text { skyrius, Klaipèdos r. SVB }\end{array}$ & $\mathrm{KRF}$ \\
\hline 3 & $\begin{array}{l}\text { Minime Lietuvos Respublikos ir Klaipédos krašto } \\
\text { susijungimo 90-meti }\end{array}$ & Klaipėdos m. SVB & KM \\
\hline 4 & Esame piliečiai! Vakar, šiandien ir rytoj & Klaipėdos r. SVB & EKAL \\
\hline 5 & Per kūrybą - ị šiuolaikinę literatūrą & $\begin{array}{l}\text { Klaipèdos r. SVB; } \\
\text { partneré - Všt „Meno menë“ }\end{array}$ & $\mathrm{KM}$ \\
\hline 6 & $\begin{array}{l}\text { Rajoninè tarmiškų skaitymų šventè-konkursas } \\
\text { Tarmé - spalvinga versmé }\end{array}$ & Klaipèdos r. SVB & SV \\
\hline 7 & Tarmės šioj ir anoj gadynej [seminaras] & Klaipèdos r. SVB & SV \\
\hline 8 & Mano tarmé pati gražiausia & Klaipèdos r. SVB & SV \\
\hline 9 & $\begin{array}{l}\text { Edukaciniu užsiemimu programa „Kalendorinès } \\
\text { šventès - gyvosios kultūros dalis“ }\end{array}$ & Klaipėdos r. SVB Endriejavo f. & SV \\
\hline 10 & $\begin{array}{l}\text { Ei, pilieti, nežiopsok, savo teises sužinok! [skirtas } \\
\text { Europos dienai] }\end{array}$ & Kretingos r. SVB & EKAL \\
\hline 11 & Kretingos apylinkių šnektos & Kretingos r. SVB & $\mathrm{KRF}$ \\
\hline 12 & Atvira jaunimo erdve bibliotekoje [tęstinis] & Kretingos r. SVB & SV \\
\hline 13 & $\begin{array}{l}\text { Gimtoji kalba kaip duona kasdieninè [skirtas } \\
\text { kraštiečio, kalbininko, filologijos mokslo dakta- } \\
\text { ro Prano Kniūkštos } 80 \text { metų jubiliejui] }\end{array}$ & Kretingos r. SVB & SV \\
\hline 14 & Kretingos poezijos ir dainu pavasaris & Kretingos r. SVB & SV \\
\hline 15 & Ir išplauks žodžių upeliai [skirtas Tarmių metams] & Kretingos r. SVB & SV \\
\hline 16 & $\begin{array}{l}\text { Elektroninio leidinio „Kretingos krašto enciklope- } \\
\text { dija“ tekstu redagavimas ir priežiūra }\end{array}$ & Kretingos r. SVB & SV \\
\hline 17 & Niekas neužmiršta, niekas nepamirštas & Kretingos r. SVB Darbėnų f. & SV \\
\hline 18 & Erlènų filialui - 65 & Kretingos r. SVB Erlènų f. & SV \\
\hline 19 & Darbščiu rankų ir žodžio meistrai [tęstinis] & Kretingos r. SVB Grūšlaukès f. & SV \\
\hline 20 & Juodupènu ir aplinkiniu kaimų amatai ir menas & Kretingos r. SVB Juodupėnų $f$. & SV \\
\hline 21 & $\begin{array}{l}\text { Kraštotyros darbas „Kuriantys Kartenos krašto } \\
\text { žmonès“ }\end{array}$ & Kretingos r. SVB Kartenos f. & SV \\
\hline 22 & Külupènu filialui - 60 & Kretingos r. SVB Kūlupėnų f. & SV \\
\hline
\end{tabular}




\section{Eil. nr. Projekto pavadinimas}

23 Erdvé jaunoms šeimoms

24 Darbščiu rankų meistrai [tęstinis]

25 Literatūrinè popieté-susitikimas su žemaitiškai rašančiais literatais „Žodis žemaitiškas eilèm suskambo“

26 Bernardo Aleknavičiaus knygos apie neringiškị dailininka Eduarda Jonuša „Gyvenimas pasakoje leidyba"

27 Žemaičiu būdo ir išminties skleidejui Simonui Daukantui - 220

28 Renginiu ciklas „Laikas eina, todel, kad nekaltas" [skirtas poeto Stasio Jonausko 65-ajam jubiliejui]

29 Net ir būdamas namuose jauskis tikru europiečiu

30 Kristijonas Donelaitis: knygos metu laikai

31 Trys keliaujančios knygu mugès: lietuviško žodžio atodangos

32 Tarptautinè vaiku knygos muge „Kviečia baltos knygu burès"

33 Mokykla + Biblioteka $=$ Žinios XXL'2013

34 Tarptautine keliaujanti Klaipédos krašto istorijos žiniu lyga-turnyras „Kol esam lietuviai, to krašto nenustosim..."

35 Iš miesto ị kaima: keliaujantys sociokultūriniai turai

36 Elektroniniu paslaugu vadybininkai - kompetentingi bibliotekininkai

37 Biblioteka - kultūros paveldo buveine

38 Žodžio klèties duris atverus... [tikslas - pristatyti ir populiarinti naujausią originaliąją Lietuvos ir jos Vakarų krašto autorių kūrybą]

39 Andriaus Šikšniaus knygos „Paklausk žalčio“ leidyba

\section{Biblioteka, partneriai}

Kretingos r. SVB Kūlupènų f. SV

Kretingos r. SVB Laukžemès f. SV

Kretingos r. SVB Vydmantu f. SV

Neringos SVB

Skuodo r. SVB

KRF

Skuodo r. SVB

KRF

Šilutès r. SVB

EKAL

Šilutès r. SVB

KRF, SV

Šilutès r. SVB;

$\mathrm{KM}$

partneriai: Kaliningrado $\mathrm{m}$. municipaliteto centralizuota bibliotekų sistema, L. Rèzos lietuvių kultūros draugija (Kaliningradas), Salos etnokultūros ir informacijos centro Rusnès moterų vokalinis ansamblis „Luotužë“

Šilutès r. SVB

KRF

Šilutès r. SVB

KM, SV

Šilutès r. SVB

$\mathrm{KM}$

Šilutès r. SVB

KM

Šilutès r. SVB

KM

Šilutès r. SVB

SV

Šilutès r. SVB

SV

Šilutès r. SVB

SV

2015 metai

Klaipèdos m. SVB

LKT, KM

Klaipèdos $\mathrm{m}$. SVB

LKT, KM

Klaipèdos m. SVB

LKT, KM

Pempininku $\mathrm{f}$. 


\begin{tabular}{|c|c|c|c|}
\hline Eil. nr. & Projekto pavadinimas & Biblioteka, partneriai & Rèmëjai \\
\hline 4 & $\begin{array}{l}\text { Šeimos istorija - išsaugok atminti } \\
(2015-2016 \mathrm{~m} \text {.) }\end{array}$ & $\begin{array}{l}\text { Klaipèdos m. SVB; } \\
\text { partneriai: Klaipedos apskrities } \\
\text { archyvas, Klaipėdos m. pedago- } \\
\text { gu švietimo ir kultūros centras, } \\
\text { Lietuvos genealogijos ir heraldi- } \\
\text { kos draugija }\end{array}$ & $\begin{array}{l}\text { BMGF, KM [BP 2], } \\
\text { SV }\end{array}$ \\
\hline 5 & Biblioteka, burianti šeima & $\begin{array}{l}\text { Klaipedos m. SVB } \\
\text { Girulių ir Pempininkų filialai }\end{array}$ & LKT \\
\hline 6 & Klaipédos knyga - 2014 & Klaipèdos m. SVB & UAB „Mūsų laikas“ \\
\hline 7 & Biblioteka be sienu (2015-2016 m.) & Klaipèdos r. SVB & BMGF, KM [BP 2] \\
\hline 8 & $\begin{array}{l}\text { Bendruomenès „HUB’as“ bibliotekoje „Atrask } \\
\text { savo saviraiškos kodq“" } \\
(2015-2016 \text { m.) }\end{array}$ & $\begin{array}{l}\text { Klaipėdos r. SVB; } \\
\text { partneriai: Šilutès r. SVB, Pagè- } \\
\text { gių SVB }\end{array}$ & $\begin{array}{l}\text { [BMGF, KM [BP 2] } \\
\text { finansavimą skyrè } \\
\text { Šilutės r. SVB] }\end{array}$ \\
\hline 9 & Biblioteka - partnerystè, draugystè, žinios & Klaipèdos r. SVB & SV \\
\hline 10 & Nuo tradicijos iki meno & Klaipèdos r. SVB & SV \\
\hline 11 & $\begin{array}{l}\text { Šiuolaikinis požiūris j̣ tradicinị knygrišybos } \\
\text { amatą }\end{array}$ & Klaipèdos r. SVB & SV \\
\hline 12 & Vasaros skaitymai [tęstinis] & Klaipèdos r. SVB & SV \\
\hline 13 & Proza skaitoma rudeni & Klaipèdos r. SVB & SV \\
\hline 14 & Biblioteka - informacija ir žinios - kiekvienam & Klaipedos r. SVB & SV \\
\hline 15 & $\begin{array}{l}\text { Ir žmogus turi savo medị [skirtas Albino Klizo } \\
\text { knygos „Ir žmogus turi savo medį“ leidybai] }\end{array}$ & Klaipèdos r. SVB & SV \\
\hline 16 & Bibliotekos kasdienybe ir šventès & Klaipèdos r. SVB & SV \\
\hline 17 & Kürybos mozaika [skirtas vaikams ir jaunimui] & Klaipèdos r. SVB & SV \\
\hline 18 & Europos diena Kretingoje & Kretingos r. SVB & EKAL \\
\hline 19 & $\begin{array}{l}\text { Edukacinis kūrybiniu mediju centras bibliotekoje } \\
(2015-2016 \mathrm{~m} .)\end{array}$ & Kretingos r. SVB & BMGF, KM [BP 2] \\
\hline 20 & Skaityk, rašyk, kurk - moderniai! & Kretingos r. SVB & LKT, SV \\
\hline 21 & Istoriné-kultūrinè studija „Jotvingiai Žemaitijoje“ & Kretingos r. SVB Darbėnų f. & LKT, SV \\
\hline 22 & $\begin{array}{l}\text { Mobilios galimybès atnaujinant Kretingos krašto } \\
\text { enciklopedijg }\end{array}$ & Kretingos r. SVB & SV \\
\hline 23 & $\begin{array}{l}\text { Edukaciniu renginiu ciklas „Su knyga- } \\
\text { ¡kūryba ir pažinimo pasaulic [skirtas } \\
\text { vaikams ir jaunimui] }\end{array}$ & Kretingos r. SVB & SV \\
\hline 24 & $\begin{array}{l}\text { Biblioteka - informacijai, savišvietai ir savireali- } \\
\text { zacijai [skirtas viešosios bibliotekos } 80 \text {-mečiui] }\end{array}$ & Kretingos r. SVB & SV \\
\hline 25 & $\begin{array}{l}\text { Atvira jaunimo erdve „Savas kampas biblioteko- } \\
\text { je“ [tęstinis] }\end{array}$ & Kretingos r. SVB & SV \\
\hline 26 & $\begin{array}{l}\text { Renginiu ciklas „Žemaičiu maistas: šventei, kas- } \\
\text { dienai ir sveikatai“" }\end{array}$ & Kretingos r. SVB & SV \\
\hline 27 & $\begin{array}{l}\text { Edukacinès pamokèlès „Drabužèliu istorijos: } \\
\text { žemaičiu aprangos tradicijos, istorija“ }\end{array}$ & Kretingos r. SVB & SV \\
\hline 28 & $\begin{array}{l}\text { Jolantos Klietkutès monografija „Pirmieji pajūrio } \\
\text { fotografai: Paulina Mongirdaitè, Ignas Stropus“ }\end{array}$ & Kretingos r. SVB & SV \\
\hline 29 & Grūšlaukès filialui - 65 & Kretingos r. SVB Grūšlaukès f. & SV \\
\hline 30 & Renginys „Laukžemès filialui - 70“ & Kretingos r. SVB Laukžemès $\mathrm{f}$. & SV \\
\hline
\end{tabular}




\begin{tabular}{|c|c|c|c|}
\hline Eil. nr. & Projekto pavadinimas & Biblioteka, partneriai & Rèmëjai \\
\hline 31 & Kraštotyros darbas „Kürybiški kaimo žmonès" & Kretingos r. SVB Šukės $\mathrm{f}$. & SV \\
\hline 32 & $\begin{array}{l}\text { Šventinis vakaras „Vydmantų bibliotekai 65-eri } \\
\text { metai“ }\end{array}$ & Kretingos r. SVB Vydmantų $f$. & SV \\
\hline 33 & $\begin{array}{l}\text { Palangos istorija jungia kartas } \\
(2015-2016 \mathrm{~m} .)\end{array}$ & $\begin{array}{l}\text { Palangos SVB; } \\
\text { partneris - Palangos kurorto } \\
\text { muziejus }\end{array}$ & BMGF, KM [BP 2] \\
\hline 34 & Mes $+E S=$ Bendri siekiai & Skuodo r. SVB & EKAL \\
\hline 35 & $\begin{array}{l}\text { Žemaičiu kalba - 24/7 } \\
(2015-2016 \text { m.) }\end{array}$ & $\begin{array}{l}\text { Skuodo r. SVB; } \\
\text { partneriai: Žemaitijos viešosios } \\
\text { bibliotekos, kultūros ir švieti- } \\
\text { mo isstaigos, nevyriausybinès } \\
\text { organizacijos }\end{array}$ & BMGF, KM [BP 2] \\
\hline 36 & $\begin{array}{l}\text { Projektas-renginiu ciklas „Kultūru spiečius“ } \\
\text { [skirtas Etnografinių regionų metams] }\end{array}$ & Skuodo r. SVB & LKT \\
\hline 37 & Ta tèvu kalba taip širdžiai miela & Skuodo r. SVB & LKT \\
\hline 38 & $\begin{array}{l}\text { Tradiciškiausio lietuvių kaimiškosios prozos kū- } \\
\text { réjo Romualdo Granausko pèdsaku įamžinimas } \\
\text { Skuodo žemëje }\end{array}$ & Skuodo r. SVB & KM \\
\hline 39 & $\begin{array}{l}\text { Simono Daukanto „Būdas senoves lietuviü, } \\
\text { kalnènu ir žemaičiu“" - pirmoji lietuvių kultū- } \\
\text { ros istorija: aktualizavimas ir populiarinimas } \\
(2015-2016 \text { m.) }\end{array}$ & Skuodo r. SVB & LKT \\
\hline 40 & $\begin{array}{l}\text { Renginių ciklas „Kas nušviečia mūsu sielas, tuo } \\
\text { privalome dalintis su visais“ [skirtas poetès } \\
\text { D. Paulauskaitès ir literatūros kritiko R. Pakal- } \\
\text { niškio kūrybai ir gyvenimui] }\end{array}$ & Skuodo r. SVB & LKT \\
\hline 41 & Cirulielis [skirtas vaikų skaitymui skatinti] & $\begin{array}{l}\text { Skuodo r. SVB; } \\
\text { partnerè - leidykla „Druka“ }\end{array}$ & LKT \\
\hline 42 & Menas žmogaus gerovei & Skuodo r. SVB & SV \\
\hline 43 & $\begin{array}{l}\text { Padeddami kitiems padesime ir sau [skirtas Euro- } \\
\text { pos dienai] }\end{array}$ & Šilutės r. SVB & EKAL \\
\hline 44 & $\begin{array}{l}\text { Bendruomenès „HUB’as“ bibliotekoje „Atrask } \\
\text { savo saviraiškos kodq“"(2015-2016 m.) }\end{array}$ & $\begin{array}{l}\text { Šilutès r. SVB; } \\
\text { partnerès: Pagègių SVB, Klaipè- } \\
\text { dos r. SVB }\end{array}$ & $\begin{array}{l}\text { BMGF, KM [BP 2], } \\
\text { SV }\end{array}$ \\
\hline 45 & $\begin{array}{l}\text { Kūryba, diskursas ir pažinimas kultūros paslau- } \\
\text { gų inovacijoms }\end{array}$ & Šilutès r. SVB & LKT \\
\hline 46 & $\begin{array}{l}\text { Literatūrinis ruduo „Prisijaukinkim žodį, paukš- } \\
\text { tį, debesį..." }\end{array}$ & Šilutès r. SVB & LKT \\
\hline 47 & $\begin{array}{l}\text { Stovykla „Jaunieji genijai - menininkai“ } \\
\text { [tęstinis] }\end{array}$ & Šilutės r. SVB & LKT \\
\hline 48 & Kūrybiniai blyksniai iš arti & Šilutès r. SVB & SV \\
\hline 49 & $\begin{array}{l}\text { Lietuvos etnografiniu regionu subègtuves-varžy- } \\
\text { tuves „Prieteliau, atverk skarbinyčią savą" }\end{array}$ & $\begin{array}{l}\text { Šilutės r. SVB; } \\
\text { partneriai: Šilutės raštijos ir } \\
\text { knygių draugija, LBD Šilutès } \\
\text { skyrius, Gargždu kultūros cen- } \\
\text { tras, Šilutės turizmo ir paslaugų } \\
\text { verslo mokykla }\end{array}$ & SV \\
\hline
\end{tabular}




\section{Eil. nr. Projekto pavadinimas}

50 Maža kelione - dideli pasiekimai [tikslas - skatinti jaunimo tarpkultūrinị dialogą, plètoti Mažosios Lietuvos etnografinio regiono ir Palenkès vaivadijos jaunimo bendradarbiavimą, skatinti jaunų žmonių domèjimąsi bendra istorija, etnokultūra, tradicijomis ir kt.]

51 Auginkime Mažosios Lietuvos pažinimo medį... [Mažosios Lietuvos istorija leidiniuose]

52 Pripildè mus Lietuvos

\section{Biblioteka, partneriai}

Šilutès r. SVB;

partnerè - Bialystoko biblioteka

(Lenkija)

ilutès r. SVB

Šilutès r. SVB

\section{6 metai}

1 Kalbantys pastatai [skirtas nekilnojamajam kultūros paveldui]

2 STOP - knyga! [tęstinis]

3 Gyvoji kraštotyra

4 Šeimos istorija - išsaugok atminti (2015-2016 m.)

$5 \quad$ Kitokia realybe bibliotekoje

$9 \quad$ Perduok žinutę apie knyga

10 Klaipédos knyga-2015

11 Pagauk banga: ịvaldyk naujas medijas

12 Interaktyvi bibliotekos palapine [tętinis]

Klaipèdos m. SVB

Klaipedos m. SVB; partneris -Všt „Klaipedos keleivinis transportas“

Klaipèdos m. SVB

Klaipèdos m. SVB;

partneriai: Klaipedos apskrities archyvas, Klaipėdos m. pedagogų švietimo ir kultūros centras, Lietuvos genealogijos ir heraldikos draugija

Klaipèdos m. SVB; partneriai: Neringos SVB,

Kretingos r. SVB, Palangos SVB, Klaipèdos r. SVB

6 Kultūros edukacija pajūryje vaikams ir suaugusiems Klaipėdos m. SVB

7 Giruliu bendruomenes atminties stiprinimas

8 Mano šeima skaité, skaito ir skaitys

Klaipèdos m. SVB; partnerè bendruomenè

Klaipèdos m. SVB; partneris Klaipèdos m. pedagogų švietimo ir kultūros centras Klaipèdos m. SVB

Klaipèdos m. SVB

Klaipėdos m. SVB

Klaipedos m. SVB; partneriai: Klaipėdos laikrodžių muziejus, KlAVB, Všs Klaipèdos jaunimo teatras, Vš I Robotikos mokykla, Klaipėdos valstybinis muzikinis teatras, Klaipedos karalienès Luizès jaunimo centro Atviros jaunimo erdvès, Lietuvos aklųjų biblioteka, NVO „Art Figura“, įmoné Vakarų žaidimų klubas

Klaipėdos m. SVB

\section{Rèmèjai}

SV

SV

[nenurodyta]

\section{LKT, KM}

LKT, KM

\section{LKT, KM}

BMGF, KM [BP 2]

SV [finansavimas

skirtas $2015 \mathrm{~m}$.]

KM

\section{LKT, KM, SV}

Socialinès apsaugos ir darbo ministerija

LKT, KM

[nenurodyta]

UAB „Mūsų laikas“

LKT, KM

SV 


\section{Eil. nr. Projekto pavadinimas}

14 Biblioteka be sienu (2015-2016 m.)

15 Bendruomenès „HUB’as“ bibliotekoje „Atrask savo saviraiškos koda" (2015-2016 m.)

16 Vasaros skaitymai [tęstinis]

17 Aš patikèjau popieriui kaip draugui [tęstinis; numatè susitikimų su teatro ir kino aktoriais organizavimą]

18 Knygos tarnyste

19 Petras Dirgèla mūsu atmintyje: asmenybè, kūréjas, pilietis

20 Bibliotekų metus užbaigiant

21 Svečiuose pas pasakg

22 Vienybeje ateitis [skirtas Europos dienai]

23 Edukacinis kūrybiniu mediju centras bibliotekoje (2015-2016 m.)

24 Meno terapija ir edukacija moterims

25 Atvira biblioteka bendruomenei

26 Biblioteka - informacinés visuomenès dalis

27 Atvira jaunimo erdve „Savas kampas“ bibliotekoje [tęstinis]

28 Skaitome kitaip

29 Edukaciniu renginiu ciklas „Augalais kvepiantis pasaulis vaikiškose knygose“

30 Pažinimo kelias [tęstinis]

31 Edukacinè vaiku vasaros skaitymu programa „Medaus pieva“

32 Edukaciniu užsièmimu ciklas „Grūšlaukès kaimo tradicijos ir paveldas: nūdiena ir praeitis"

33 Senosios Ipilties filialui - 60 metu

34 Metų takais [skirtas Juodupènų filialo 65-erių metų sukakčiai]

\section{Biblioteka, partneriai}

Klaipėdos r. SVB

Klaipèdos r. SVB;

partnerès: Šilutès r. SVB, Pagègių SVB

Klaipèdos r. SVB

Klaipèdos r. SVB

Klaipèdos r. SVB

Klaipedos r. SVB

Klaipedos r. SVB

Klaipèdos r. SVB Veiviržènų f.

Kretingos r. SVB

Kretingos r. SVB

Kretingos r. SVB; partneriai: Kretingos moterų informacijos ir mokymų centras, Kretingos r. pedagogų švietimo centras, Kretingos meno klubas PINX

Kretingos r. SVB; partneriai: Kretingos m. seniūnija, Kretingos miesto ir rajono bendruomenès

Kretingos r. SVB; partnerè -

Kretingos r. nevyriausybinių organizacijų asociacija „Apskritasis stalas"

Kretingos r. SVB

Kretingos r. SVB

Kretingos r. SVB

Kretingos r. SVB

Kretingos r. SVB Baublių f.

Kretingos r. SVB Grūšlaukès f. SV

Kretingos r. SVB S. Ipilties f. SV

Kretingos r. SVB Juodupenų f. SV
SV

SV

SV

SV

SV

SV

Rèmèjai

BMGF, KM [BP 2]

(finansavimas skirtas $2015 \mathrm{~m}$.)

BMGF, KM [BP 2]

(finansavimas skirtas Šilutès r. SVB 2015 metais) [nenurodyta] SV

SV

SV

SV

EKAL

BMGF, KM [BP 2]

(finansavimas skirtas $2015 \mathrm{~m}$.)

LKT, SV

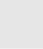

V

V
V

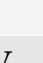

V

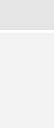




\begin{tabular}{|c|c|c|c|}
\hline Eil. nr. & Projekto pavadinimas & Biblioteka, partneriai & Rèmèjai \\
\hline 35 & $\begin{array}{l}\text { Renginiu ciklas vaikams „Knygose - mano } \\
\text { pasaulis“ }\end{array}$ & Kretingos r. SVB Kalniškių f. & SV \\
\hline 36 & Renginys „75-eri metai su skaitytojais“ & Kretingos r. SVB Kartenos f. & SV \\
\hline 37 & Kurmaičiu bibliotekai - 65 & Kretingos r. SVB Kurmaičių f. & SV \\
\hline 38 & Poezijos ir muzikos vakaras „Sielos žiedlapiai“ & Kretingos r. SVB Laukžemès f. & SV \\
\hline 39 & Raguviškiu filialui - 70 & Kretingos r. SVB Raguviškių f. & SV \\
\hline 40 & $\begin{array}{l}\text { Poezijos ir muzikos renginys „Deivès Mildos } \\
\text { meilès diena“ }\end{array}$ & Kretingos r. SVB Rūdaičių f. & SV \\
\hline 41 & Renginys „Poezijos ir muzikos pyne“ & Kretingos r. SVB Salantų f. & SV \\
\hline 42 & $\begin{array}{l}\text { Atvira jaunimo erdve Salantu miesto filiale } \\
\text { [tęstinis] }\end{array}$ & Kretingos r. SVB Salantų f. & SV \\
\hline 43 & Literatūros popietè „Žydintis poezijos pavasaris“ & Kretingos r. SVB Vydmantų f. & SV \\
\hline 44 & Sonetai Europai 2016 [skirtas Europos dienai] & $\begin{array}{l}\text { Palangos SVB, } \\
\text { Palangos kultūros ir jaunimo } \\
\text { centras, Palangos orkestras, } \\
\text { Palangos pakrančių apsaugos } \\
\text { rinktinė, Palangos Gintaro } \\
\text { muziejus, Antano Mončio } \\
\text { namai-muziejus, Dr. Jono } \\
\text { Šliūpo memorialinis muziejus, } \\
\text { Palangos Vl. Jurgučio pagrindi- } \\
\text { nė mokykla ir kt. }\end{array}$ & EKAL \\
\hline 45 & Palangos istorija jungia kartas (2015-2016 m.) & $\begin{array}{l}\text { Palangos SVB; } \\
\text { partneris - Palangos kurorto } \\
\text { muziejus }\end{array}$ & $\begin{array}{l}\text { BMGF, KM [BP 2] } \\
\text { (finansavimas skir- } \\
\text { tas } 2015 \text { metais) }\end{array}$ \\
\hline 46 & $\begin{array}{l}\text { Informacinis raštingumas - senjorų kelias } i \\
\text { pilnaverti rytoju }\end{array}$ & $\begin{array}{l}\text { Palangos SVB; } \\
\text { partnerè - Palangos švietimo } \\
\text { pagalbos tarnyba }\end{array}$ & LTK, SV \\
\hline 47 & EUropa - tai mES & Skuodo r. SVB & EKAL \\
\hline 48 & Žemaičių kalba - 24/7 (2015-2016 m.) & $\begin{array}{l}\text { Skuodo r. SVB; } \\
\text { partnerès: Žemaitijos etno- } \\
\text { grafinio regiono viešosios } \\
\text { bibliotekos, kultūros ir švieti- } \\
\text { mo ịstaigos, nevyriausybinès } \\
\text { organizacijos }\end{array}$ & $\begin{array}{l}\text { BMGF, KM [BP 2] } \\
\text { (finansavimas skir- } \\
\text { tas } 2015 \text { metais) }\end{array}$ \\
\hline 49 & Dvylika mènesiu su knyggraužiais & $\begin{array}{l}\text { Skuodo r. SVB; } \\
\text { partneriai: Skuodo meno } \\
\text { mokykla, Skuodo Bartuvos } \\
\text { progimnazija, Skuodo rajono } \\
\text { pagrindinès mokyklos ir gimna- } \\
\text { zijos bei jų bibliotekos, Skuodo } \\
\text { socialinių paslaugų šeimai } \\
\text { centras, KlAVB, Barstyčių vaikų } \\
\text { globos namai, Skuodo socialinių } \\
\text { paslaugų šeimai centras, Skuo- } \\
\text { do r. SVB Mosedžio, Ylakių, } \\
\text { Šačių, Barstyčių. Aleksandrijos, } \\
\text { Šauklių, Lenkimų filialai }\end{array}$ & LKT, KM \\
\hline
\end{tabular}




\begin{tabular}{|c|c|c|c|}
\hline Eil. nr. & Projekto pavadinimas & Biblioteka, partneriai & Rèmèjai \\
\hline 50 & $\begin{array}{l}\text { Simono Daukanto „Būdas senovès lietuvių, } \\
\text { kalnėnų ir žemaičių“- pirmoji lietuvių kultū- } \\
\text { ros istorija: aktualizavimas ir populiarinimas } \\
(2015-2016 \text { m.) }\end{array}$ & Skuodo r. SVB & $\begin{array}{l}\text { LKT (finansavimas } \\
\text { skirtas } 2015 \mathrm{~m} . \text { ) }\end{array}$ \\
\hline 51 & $\begin{array}{l}\text { Išgirskime istorija, kuri byloja mums [skirtas } \\
\text { etnologo Vacio Miliaus } 90 \text {-osioms gimimo } \\
\text { metinėms] }\end{array}$ & Skuodo r. SVB & LKT \\
\hline 52 & Tieskime kultūrinius draugystès tiltus & Skuodo r. SVB & SV \\
\hline 53 & Menas žmogaus gerovei - 2 [tęstinis] & Skuodo r. SVB & SV \\
\hline 54 & Sveika bendruomene - stipri bendruomene & Skuodo r. SVB & SV \\
\hline 55 & Tapk Europos Sajungos pažinimo triumfatoriumi & Šilutès r. SVB & EKAL \\
\hline 56 & $\begin{array}{l}\text { Bendruomenés „HUB’as“ bibliotekoje „Atrask } \\
\text { savo saviraiškos koda“"(2015-2016 m.) }\end{array}$ & $\begin{array}{l}\text { Šilutès r. SVB; } \\
\text { partnerès: Pagègių SVB, Klaipè- } \\
\text { dos r. SVB }\end{array}$ & $\begin{array}{l}\text { BMGF, KM [BP 2], } \\
\text { SV (finansavimas } \\
\text { skirtas } 2015 \text { m.) }\end{array}$ \\
\hline 57 & Knygnešių kelias interaktyvioje erdvëje & Šilutès r. SVB & LKT \\
\hline 58 & Inovatyvūs pramogadieniai kartu su biblioteka & $\begin{array}{l}\text { Šilutės r. SVB; } \\
\text { partneriai: Lietuvos pensinin- } \\
\text { kų sąungos „Bočiai“ Šilutès } \\
\text { rajono skyrius, klubas „Moterų } \\
\text { seklyčia“, Macikų socialinės } \\
\text { globos namai, Šilutès socialinių } \\
\text { paslaugų centras, Šilutės žmonių } \\
\text { su sielos negalia klubas „Sielos } \\
\text { paguoda“ }\end{array}$ & LKT \\
\hline 59 & Prabylančios mūzos \& inovatyvūs žiniadieniai & Šilutès r. SVB & LKT \\
\hline 60 & Prie knygos versmès... & Šilutės r. SVB & LKT \\
\hline 61 & Jaunimo divizionas - ateik, mąstyk, šturmuok & Šilutès r. SVB & SV \\
\hline 62 & $\begin{array}{l}\text { Šilutiškių sueiga „Šviesos parnešti, gera padary- } \\
\text { ti..." [tęstinis] }\end{array}$ & Šilutès r. SVB & $\begin{array}{l}\text { LKT, SV, UAB } \\
\text { „Šilutès vandenys“, } \\
\text { privatūs asmenys }\end{array}$ \\
\hline \multicolumn{4}{|c|}{2017 metai } \\
\hline 1 & Nugalèk elektroniniu paslaugu baimę & $\begin{array}{l}\text { Klaipėdos m. SVB; } \\
\text { partneriai: Všt „Trečiasis am- } \\
\text { žius“, Klaipèdos pagyvenusių } \\
\text { žmonių asociacija, VšI „, Ke- } \\
\text { leivinis transportas“, „Sodra“, } \\
\text { Lietuvos dailės muziejus, Lietu- } \\
\text { vos aklujų biblioteka, Lietuvos } \\
\text { pensininkų susivienijimas }\end{array}$ & $\begin{array}{l}\text { LKT, KM, UAB } \\
\text { „Mūsų laikas“ (Klai- } \\
\text { pèda) }\end{array}$ \\
\hline 2 & Medijos - kas, kodèl ir kaip? & $\begin{array}{l}\text { Klaipėdos m. SVB; } \\
\text { partneris - Klaipèdos miesto } \\
\text { pedagogų švietimo ir kultūros } \\
\text { centras }\end{array}$ & $\begin{array}{l}\text { LKT, KM, UAB } \\
\text { „Mūsų laikas“ (Klai- } \\
\text { pèda) }\end{array}$ \\
\hline 3 & $\begin{array}{l}\text { Teatralizuoti Ievos Simonaitytès kūrybos vakarai } \\
\text { „O buvo taip..." }\end{array}$ & $\begin{array}{l}\text { Klaipėdos m. SVB; } \\
\text { partneriai: Klaipėdos pedagogų } \\
\text { švietimo ir kultūros centras, } \\
\text { Klaipedos m. savivaldybės } \\
\text { etnokultūros centras }\end{array}$ & $\mathrm{KM}$ \\
\hline
\end{tabular}




\begin{tabular}{|c|c|c|c|}
\hline Eil. nr. & Projekto pavadinimas & Biblioteka, partneriai & Rèmèjai \\
\hline 4 & Sulèkime skaityti i gūžtas & $\begin{array}{l}\text { Klaipedos m. SVB; } \\
\text { partneriai: Klaipèdos Litorinos } \\
\text { mokykla, Klaipėdos pedagogų, } \\
\text { švietimo ir kultūros centras, } \\
\text { Klaipèdos apskrities gestų kal- } \\
\text { bos vertėjų centras }\end{array}$ & $\begin{array}{l}\text { LKT, KM, leidyklos: } \\
\text { UAB „Presa“, } \\
\text { UAB „Nieko rimto“, } \\
\text { UAB „Lutute““ }\end{array}$ \\
\hline 5 & Dingęs paveldas [skirtas jaunimui] & $\begin{array}{l}\text { Klaipèdos m. SVB; } \\
\text { partneriai: Všț Klaipedos tu- } \\
\text { rizmo ir kultūros informacijos } \\
\text { centras, Klaipèdos pedagogu } \\
\text { švietimo ir kultūros centras, } \\
\text { Klaipèdos m. savivaldybès } \\
\text { administracijos Urbanistinès } \\
\text { plètros departamento Paveldo- } \\
\text { saugos skyrius }\end{array}$ & $\begin{array}{l}\text { Kultūros paveldo } \\
\text { departamentas prie } \\
\text { KM }\end{array}$ \\
\hline 6 & Krašto ženklai [skirtas kultūros edukacijai] & Klaipèdos m. SVB & LKT, KM \\
\hline 7 & Stop - knyga! [tęstinis] & $\begin{array}{l}\text { Klaipèdos m. SVB; } \\
\text { partneris - Všt „Klaipedos } \\
\text { keleivinis transportas“ }\end{array}$ & SV \\
\hline 8 & Klaipédos knyga - 2016 & Klaipèdos m. SVB & $\begin{array}{l}\text { UAB „Mūsų laikas“ } \\
\text { (Klaipèda), SVB }\end{array}$ \\
\hline 9 & Interaktyvi bibliotekos palapine 2 [tęstinis] & $\begin{array}{l}\text { Klaipèdos m. SVB; } \\
\text { partneriai: Klaipèdos laikrodžių } \\
\text { muziejus, KlAVB, V̌̌t Klaipėdos } \\
\text { jaunimo teatras, Všt Robotikos } \\
\text { mokykla, Klaipeddos valstybinis } \\
\text { muzikinis teatras, Klaipèdos } \\
\text { karalienės Luizès jaunimo } \\
\text { centro Atviros jaunimo erdvès, } \\
\text { Lietuvos aklujjų biblioteka, NVO } \\
\text { "Art Figura“, i̇monė Vakarų } \\
\text { žaidimų klubas }\end{array}$ & $\begin{array}{l}\text { SV, SVB, UAB } \\
\text { „Baltic Pallets“ } \\
\text { (Klaipèda) }\end{array}$ \\
\hline 10 & $\begin{array}{l}\text { Vaikų vasaros užimtumo programa „Žalioji } \\
\text { biblioteka“ [tęstinis] }\end{array}$ & Klaipèdos m. SVB & SV \\
\hline 11 & mES ESame kartu & Klaipėdos r. SVB & EKAL \\
\hline 12 & Vasaros skaitymai [tęstinis] & Klaipèdos r. SVB & SV \\
\hline 13 & Etno book (Lietuva - Ukraina) & Klaipèdos r. SVB & $\begin{array}{l}\text { Klaipedos r. SV, } \\
\text { Skuodo r. SV }\end{array}$ \\
\hline 14 & $\begin{array}{l}\text { Klaipèdos rajono savivaldybès ir Agluonènu } \\
\text { seniūnijos rašytojos Ievos Simonaitytés vardo } \\
\text { premijos laureatai, 1997-2017 }\end{array}$ & Klaipèdos r. SVB & SV \\
\hline 15 & Babūnēles jopēlè & Klaipėdos r. SVB & SV \\
\hline 16 & Išsaugokime tautos savasti & Klaipèdos r. SVB Kretingalès f. & SV \\
\hline 17 & Tarmiu labirintai & Klaipėdos r. SVB Veiviržènų f. & SV \\
\hline 18 & Lyg vaikystès žaidimai & Klaipèdos r. SVB & SV \\
\hline 19 & Proza skaitoma rudeni [tęstinis] & Klaipėdos r. SVB & SV \\
\hline 20 & $\begin{array}{l}\text { E. Skaudvilaités poezijos knygos „Žodžiu dūzge- } \\
\text { sys leidyba“ }\end{array}$ & Klaipėdos r. SVB & SV \\
\hline
\end{tabular}




\section{Eil. nr. Projekto pavadinimas}

21 Aš patikèjau popieriui kaip draugui [tęstinis; numate susitikimus su rašytojais, visuomenès veikejais, dailininkais, rajono literatais]

22 Kuriame lèles, skaitome knygas. Aš aktorius, režisierius, scenografas

23 Savęs ir krašto pažinimas

$24 A \check{s}+k n y g a+\check{s y p s e n a}=\gtreqless$ Šypsenos dienai [skirtas vaikams ir jaunimui]

25 Jaunieji chemikai

26 Netradicinès knygos leidyba bibliotekoje

27 Rinkimés i kūrybinę kelione

28 Ji buvo Simonaitytè

29 Literatūriniai susitikimai. Pamilti literatūrą pamilti gyvenima

30 Metu veiklos rezultatu bei strategijų aptarimas. Išvyka i padalinius

31 Bibliotekos paslaugu ir ivaizdžio populiarinimas

32 Lietuvos kariuomenés diena bibliotekoje

33 A. Klizo knygos „Tik pušis ir ąžuolas dar saugo senojo kaimo atminti “leidyba

34 Kurkime Europos ateiti atsakingai

35 Keliaujantys pasakų lagaminai

36 Mobili biblioteka i jūsu sodybas

37 Branda, gyvenimas ir mintys poezijoje

38 Lietuvos valstybingumo gyneju - partizanu veiklos ženklai Kretingos rajone

39 Vaiku knygu klubas „Pelèdžiukai“

40 Pažinimo kelias [tęstinis]

41 Knygos invazija

42 Meno terapija ir edukacija moterims (2016- 2017 m.)

43 Piliakalniai Kretingos krašte

44 Atvira jaunimo erdve „Savas kampas bibliotekoje" [tęstinis]

45 Bibliotekos erdvé - šeimos ugdymuisi, kūrybai ir savišvietai

46 Konferencija „Lietuvių kalba - šalies dvasinès kultūros dalis"

47 Naujausios technologijos Z kartai

48 Mišučiu dvaro atmintis: Vladas Mongirdas

\section{Biblioteka, partneriai}

Klaipèdos r. SVB

Rèmèjai

SV

Klaipèdos r. SVB

SV

Klaipèdos r. SVB

SV

Klaipėdos r. SVB

SV

Klaipėdos r. SVB Lapių f.;

SV

partnerè - Lapių pagrindinè mokykla

Klaipèdos r. SVB

SV

Klaipèdos r. SVB

SV

Klaipèdos r. SVB

SV

Klaipèdos r. SVB

SV

Klaipèdos r. SVB

SV

Klaipèdos r. SVB

SV

Klaipèdos r. SVB

SV

Kretingos r. SVB

EKAL

Kretingos r. SVB

LKT, SV

Kretingos r. SVB

LKT, SV

Kretingos r. SVB

SV

Kretingos r. SVB

SV

Kretingos r. SVB

SV

Kretingos r. SVB

SV

Kretingos r. SVB

SV

Kretingos r. SVB;

SV [Pastaba: 2016

partneriai: Kretingos moterų in-

metų rèméjai - LKT formacijos ir mokymų centras,

ir SV]

Kretingos r. pedagogų švietimo centras, Kretingos meno klubas PINX

\begin{tabular}{|l|l|}
\hline $\begin{array}{l}\text { Kretingos r. SVB } \\
\text { Kretingos r. SVB }\end{array}$ & SV \\
\hline Kretingos r. SVB & SV \\
\hline Kretingos r. SVB & SV \\
\hline Kretingos r. SVB & SV \\
Kretingos r. SVB & SV \\
\hline
\end{tabular}




\begin{tabular}{|c|c|c|c|}
\hline Eil. nr. & Projekto pavadinimas & Biblioteka, partneriai & Rèmèjai \\
\hline 49 & $\begin{array}{l}\text { Edukacinè vasaros skaitymu programa „Siūlai, } \\
\text { siūlai, susivykit“ }\end{array}$ & $\begin{array}{l}\text { Kretingos r. SVB } \\
\text { Baublių f. }\end{array}$ & SV \\
\hline 50 & Su knyga - per gyvenimą & $\begin{array}{l}\text { Kretingos r. SVB } \\
\text { Budrių f. }\end{array}$ & SV \\
\hline 51 & Metu pynei ilgèjant & Kretingos r. SVB Darbėnų f. & SV \\
\hline 52 & $\begin{array}{l}\text { Kraštotyros darbas „Darbènų Šv. Apaštalų Petro } \\
\text { ir Pauliaus bažnyčios metraštis“ }\end{array}$ & Kretingos r. SVB Darbėnų f. & SV \\
\hline 53 & $\begin{array}{l}\text { Edukacinių užsièmimu ciklas „Žemaitišku tradicijų } \\
\text { atgarsis Grūšlaukès krašto kultūrinëje edukacijoje“ }\end{array}$ & Kretingos r. SVB Grūšlaukės f. & SV \\
\hline 54 & $\begin{array}{l}\text { Renginių ciklas jaunoms šeimoms ir vaikams } \\
\text { „Gyvenimui žmogu augina knyga“" }\end{array}$ & Kretingos r. SVB Kartenos f. & SV \\
\hline 55 & Renginys „Kumpikui bibliotekai - 65“ & Kretingos r. SVB Kumpikų f. & SV \\
\hline 56 & $\begin{array}{l}\text { Poezijos, muzikos ir dainos vakaras „Baltu vieš- } \\
\text { keliu einu..." }\end{array}$ & Kretingos r. SVB Laukžemės f. & SV \\
\hline 57 & $\begin{array}{l}\text { Skaitomosios ir dainuojamosios poezijos renginys } \\
\text { „Ir skambèkit, eilès, dainos mūs gražiausios“" }\end{array}$ & Kretingos r. SVB Salantų f. & SV \\
\hline 58 & $\begin{array}{l}\text { Atvira jaunimo erdve Salantų miesto filiale } \\
\text { [tęstinis] }\end{array}$ & Kretingos r. SVB Salantų f. & SV \\
\hline 59 & Paukščiais pakylantys žodžiai lietuviški & Kretingos r. SVB Vydmantų f. & SV \\
\hline 60 & Europos pédsakai Palangoje & $\begin{array}{l}\text { Palangos SVB; } \\
\text { partneriai: Palangos kultūros } \\
\text { ir jaunimo centras, Palangos } \\
\text { orkestras, Palangos pakrančių } \\
\text { apsaugos rinktinè, Palangos } \\
\text { Vl. Jurgučio pagrindinė mokyk- } \\
\text { la ir kt. }\end{array}$ & EKAL, SV \\
\hline 61 & Opa, Europa! & $\begin{array}{l}\text { Skuodo r. SVB; } \\
\text { partneriai: Skuodo meno mo- } \\
\text { kykla, Skuodo atviras jaunimo } \\
\text { centras, Skuodo kaimo verslų, } \\
\text { amatų ir paslaugų mokykla, } \\
\text { Skuodo Pranciškaus Žadeikio } \\
\text { gimnazija, Skuodo Bartuvos } \\
\text { progimnazija }\end{array}$ & EKAL \\
\hline 62 & $\begin{array}{l}\text { Tarptautinè kultūriniǔ mainu savaitė „Baltų } \\
\text { genčių - latgaliu, kuršių ir žemaičių kraštų pana- } \\
\text { šumai bei skirtumai“ }\end{array}$ & $\begin{array}{l}\text { Skuodo r. SVB; } \\
\text { partneriai: Latvijos Respublikos } \\
\text { Rėzeknės miesto biblioteka, } \\
\text { Latvijos Respublikos Priekulès } \\
\text { krašto savivaldybè, Skuodo } \\
\text { žemaičių draugija }\end{array}$ & LKT, KM \\
\hline 63 & Atrask neatrastus savo gebejjimus bibliotekoje & $\begin{array}{l}\text { Skuodo r. SVB; } \\
\text { partneriai: Skuodo r. Gėsa- } \\
\text { lų bendruomenè, Skuodo r. } \\
\text { Vižančių bendruomenè, Skuodo } \\
\text { kaimo verslų, amatų ir paslau- } \\
\text { gų mokykla, Skuodo dekanato } \\
\text { šeimos centras }\end{array}$ & LKT, KM \\
\hline
\end{tabular}




\begin{tabular}{|c|c|}
\hline Eil. nr. & Projekto pavadinimas \\
\hline 64 & Mūsu stiprybè kalboje ir kultūroje \\
\hline 65 & Kas sena, tas nauja šiandien \\
\hline 66 & Augu skaitydamas ir pažindamas kitas kultūras \\
\hline 67 & Iššūkis būti sveikam! - priimtas \\
\hline 68 & $\begin{array}{l}\text { Senujų tradicijų pedsakais [skirtas vaikams ir } \\
\text { jaunimui] }\end{array}$ \\
\hline
\end{tabular}

70 Tarptautinis ekslibrisu konkursas „Ex Libris. Vilhelmui Storostai Vydūnui - 150“

71 Stovykla „Jaunieji genijai - menininkai“ [tęstinis]

72 Trys žingsniai socializacijos link

73 Menu sampyna Lietuvos valstybès atkūrimo šimtmečiui

74 Keliaujanti dokumentikos paroda „IEVA SIMONAITYTÉ. Raskime akimirka stabteleti ties ja..."

75 Prie knygos versmès

76 Knygos istorija: nuo rašto ištaku iki ekslibriso [skirtas vaikams ir jaunimui]

77 Laike neišdylantys vardai - Hermanas Zudermanas

\begin{tabular}{l|l}
\hline Biblioteka, partneriai & R \\
\hline Skuodo r. SVB & SV \\
\hline Skuodo r. SVB & SV \\
\hline Skuodo r. SVB & SV \\
\hline Skuodo r. SVB & SV \\
Skuodo r. SVB & SV \\
Šliktinès f. &
\end{tabular}

Šilutès r. SVB;

partneriai: Šilutès Martyno

Jankaus pagrindinè mokykla,

Šilutės Žibų pradinè mokykla,

Šilutes vaikų lopšelis-darželis

„Gintarèlis“

Šilutès r. SVB

partneriai: Lietuvos dailininkų sąunga, Lietuvos ekslibrisininkų klubas, Vydūno draugija, Sovetsko (Rusija) miesto Isaako Jakovlevičiaus Rutmano centrinè biblioteka, Šilutès Vydūno gimnazija, Kintų Vydūno kultūros centras

Šilutès r. SVB

\section{Šilutès r. SVB}

Šilutes r. SVB;

partneriai: asociacija „Mažlie-

tuvių daga“, Lietuvos dailininkų sajunga, sutrikusio intelekto žmonių globos bendrija „Šilutès viltis“

\section{Šilutès r. SVB}

Šilutès r. SVB

Šilutès r. SVB;

partneriai: Šilutès Hugo Šojaus muziejus, Pagègių savivaldybès Martyno Jankaus muziejus, Šilutès raštijos ir knygių draugija

Šilutes r. SVB;

partneriai: Lietuvių literatūros ir tautosakos institutas, Goethe's institutas Lietuvoje, Hermanno Sudermanno fondas Berlyne (Vokietija), Šilutès Hermano Zudermano draugija, Šilutès Hugo Šojaus muziejus, Šilutes rajono vokiečių kilmės gyventojų bendrija „Heide“, asociacija Šilutès raštijos ir knygių draugija
EKAL

KM, SV

LKT

LKT

LKT, KM, SV

LKT

LKT

LKT, KM, SV

LKT, KM, SV

V

V

(n)

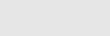

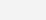

\section{ST}

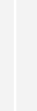




\section{Eil. nr. Projekto pavadinimas}

78 Išbandymų kambario šturmas

79 Bibliotekos iššūkis jaunimui - ateik, priimk, jueik

\section{Biblioteka, partneriai}

Šilutès r. SVB;

partneriai: Šilutès šaulių kuopa, asociacija Kintų jaunimo klubas, Jaunųjų konservatorių lygos Šilutès filialas, Šilutès meno mokyklos Dailès skyrius, Šilutès miesto mokyklos ir gimnazijos, Šilutès socialinių paslaugų centras

Šilutès r. SVB

\section{Rèmèjai}

LKT, KM, SV,

UAB „Šilutès

INFO-TEC“

SV

4 priedas. Tauragès apskr. savivaldybių viešųjų bibliotekų 2007, 2013, 2015-2017 metų projektai

\begin{tabular}{|c|c|c|c|}
\hline Eil. nr. & Pavadinimas & Biblioteka, partneriai & Rèmèjai \\
\hline 1 & „Sugrižtantis“Stasys Santvaras & Jurbarko r. SVB & KM, SV \\
\hline 2 & $\begin{array}{l}\text { Gerovè Skirsnemunès bendruomenei [už skirtas } \\
\text { lěšas pakeisti langai] }\end{array}$ & Jurbarko r. SVB Skirsnemunès f. & $\begin{array}{l}\text { Žemès ūkio minis- } \\
\text { terija }\end{array}$ \\
\hline 3 & Skaitymo skatinimo programa - 2007 & Jurbarko r. SVB & SV \\
\hline 4 & Bibliotekos likimas - 70 metu rašoma knyga & Jurbarko r. SVB & SV \\
\hline 5 & Vaikų knygos šventè „Atverkime knygai duris" & Jurbarko r. SVB & SV \\
\hline 6 & Knyga - paslaptis, paslaptis knygoje & Jurbarko r. SVB Skirsnemunès $\mathrm{f}$. & SV \\
\hline 7 & $\begin{array}{l}\text { Internetinis literatūros festivalis „Euroskaitymai } \\
2007^{(}(2007-2008 \mathrm{~m} .)\end{array}$ & $\begin{array}{l}\text { Pagègių SVB; } \\
\text { partneriai: Olštyno vaivadijos } \\
\text { viešoji biblioteka (Lenkija), } \\
\text { Tauragès r. viešoji biblioteka, } \\
\text { Kaliningrado srities universalioji } \\
\text { mokslinè regioninè biblioteka } \\
\text { (Rusija) }\end{array}$ & $\begin{array}{l}\text { Europos regioni- } \\
\text { nès plètros fondas } \\
\text { (Lietuvos, Lenkijos } \\
\text { ir Kaliningrado } \\
\text { srities (Rusija) Kai- } \\
\text { mynystes programa } \\
\text { INTERREG III) }\end{array}$ \\
\hline 8 & Klaipèdos regiono etnokultūros lobiai & $\begin{array}{l}\text { Pagègių SVB; } \\
\text { partneris - KlAVB }\end{array}$ & KM \\
\hline 9 & $\begin{array}{l}\text { Pagégiü krašto jaunimo kūrybos almanachas } \\
\text { „Mes nešam visa, kas gražu..." }\end{array}$ & Pagègių SVB & KM \\
\hline 10 & $\begin{array}{l}\text { Širdžiu šiluma daro stebuklus [skirtas vaikų ir } \\
\text { jaunimo kultūros edukacijai] }\end{array}$ & Pagègių SVB & KM \\
\hline 11 & $\begin{array}{l}\text { Europos kultūru dialogų metai [skirtas renginių } \\
\text { organizavimui vaikams] }\end{array}$ & $\begin{array}{l}\text { Pagègių SVB; } \\
\text { partneris - Tauragès apskr. } \\
\text { „Europe Direct“ informacinis } \\
\text { centras }\end{array}$ & EKAL \\
\hline 12 & Europos dienos renginio organizavimas Šilalèje & Šilalès r. SVB & EKAL \\
\hline 13 & Klaipèdos regiono biblioteku etnokultūros lobiai & $\begin{array}{l}\text { Šilalès r. SVB; } \\
\text { partneris - KlAVB }\end{array}$ & KM \\
\hline 14 & $\begin{array}{l}\text { Internetinis literatūros festivalis „Euroskaitymai } \\
2007^{(}(2007-2008 \mathrm{m.})\end{array}$ & $\begin{array}{l}\text { Tauragès r. SVB; } \\
\text { partneriai: Olštyno vaivadijos } \\
\text { viešoji biblioteka (Lenkija), Pa- } \\
\text { gėgių SVB, Kaliningrado srities } \\
\text { universalioji mokslinè regioninė } \\
\text { biblioteka (Rusija) }\end{array}$ & $\begin{array}{l}\text { Europos regioni- } \\
\text { nès plètros fondas } \\
\text { (Lietuvos, Lenkijos } \\
\text { ir Kaliningrado } \\
\text { srities (Rusija) Kai- } \\
\text { mynystes programa } \\
\text { INTERREG III) }\end{array}$ \\
\hline
\end{tabular}




\begin{tabular}{|c|c|c|c|}
\hline Eil. nr. & Pavadinimas & Biblioteka, partneriai & Rèmèjai \\
\hline 15 & Drauge [skirtas vaikų ekologiniam švietimui] & $\begin{array}{l}\text { Tauragès r. SVB; } \\
\text { partneris - Tauragès apskr. } \\
\text { „Europe Direct“ informacinis } \\
\text { centras }\end{array}$ & EKAL \\
\hline 16 & Klaipédos regiono bibliotekų etnokultūros lobiai & $\begin{array}{l}\text { Tauragès r. SVB; } \\
\text { partneris - KlAVB }\end{array}$ & KM \\
\hline 17 & Tauragé: 500 metų rašytiniuose šaltiniuose & Tauragès r. SVB & $\begin{array}{l}\text { Lietuvos tūkstan- } \\
\text { tmečio minejjimo } \\
\text { direkcija prie LR } \\
\text { Prezidento kance- } \\
\text { liarijos }\end{array}$ \\
\hline 18 & Skaitymo skatinimas šeimoje & Tauragès r. SVB „Aušros“ f. & $\mathrm{KM}$ \\
\hline 19 & $\begin{array}{l}\text { Kad kiekvienas priejęs diega pažintų [skirtas } \\
\text { vaikų skaitymo skatinimui] }\end{array}$ & Tauragès r. SVB Adakavo f. & $\mathrm{KM}$ \\
\hline 20 & Knygu pavasario gèlynas & Tauragès r. SVB Batakių f. & $\mathrm{KM}$ \\
\hline 21 & Skaitymas - tai kelias i pažinimą & Tauragès r. SVB Dacijonų f. & KM \\
\hline 22 & Poezijos pavasaris Taurageje & Tauragès r. SVB & $\begin{array}{l}\text { Tauragès apskrities } \\
\text { viršininko admini- } \\
\text { stracija, SV }\end{array}$ \\
\hline 23 & $\begin{array}{l}\text { Dainininko, operos solisto J. Mažeikos 100-metis } \\
\text { gimtinèje }\end{array}$ & $\begin{array}{l}\text { Tauragės r. SVB Pagramančio f.; } \\
\text { partnerè - kaimo bendruomenè }\end{array}$ & SV \\
\hline 24 & Taip uliojo mūs senoliai & $\begin{array}{l}\text { Tauragės r. SVB } \\
\text { Pagramančio f.; } \\
\text { partnerè - kaimo bendruomenè }\end{array}$ & SV \\
\hline \multicolumn{4}{|c|}{2013 metai } \\
\hline 1 & Europos dienos švente & Šilalès r. SVB & EKAL \\
\hline 2 & $\begin{array}{l}\text { Knygos „Šilalès krašto bažnyčios: istorija ir } \\
\text { architektūra“ leidyba }\end{array}$ & Šilalès r. SVB & KRF \\
\hline 3 & Skaityk, atmink, pasmuokavuok & Šilalès r. SVB & KRF, SV \\
\hline 4 & $\begin{array}{l}\text { Metų laikai [skirtas paskatinti Tauragès r. } \\
\text { moksleivius domėtis Mažąja Lietuva ir jos įtaka } \\
\text { lietuvių literatūrai spaudos draudimo metais] }\end{array}$ & Tauragès r. SVB & $\mathrm{KM}$ \\
\hline 5 & Poezijos pavasaris, 2013 & Tauragès r. SVB & $\mathrm{KRF}$ \\
\hline 6 & Parašyta moterų & Tauragès r. SVB & SV \\
\hline 7 & Knygos „Eilèraščiai su milinèmis“ leidyba & Tauragès r. SVB & SV \\
\hline 8 & Knygos „Poezija be sienu“ leidyba & Tauragès r. SVB & SV \\
\hline 9 & Kaip lèlès atgyja & Tauragès r. SVB & SV \\
\hline 10 & $\begin{array}{l}\text { Mažosios Lietuvos kultūros atspindžiai Tauragès } \\
\text { krašte }\end{array}$ & $\begin{array}{l}\text { Tauragès r. centrinè biblioteka, } \\
\text { Lauksargiu f.; } \\
\text { partneriai: Tauragès kultūros } \\
\text { centras, Lauksargių pagrindinè } \\
\text { mokykla }\end{array}$ & [nenurodyta] \\
\hline 11 & Donelaičio metus pasitinkant & $\begin{array}{l}\text { Tauragès r. SVB; } \\
\text { partneris - Tauragès kultūros } \\
\text { centras }\end{array}$ & SV \\
\hline 12 & $\begin{array}{l}\text { Lomių kaimo bendruomenès kultūros paveldo } \\
\text { tąsa ir sklaida }\end{array}$ & $\begin{array}{l}\text { Tauragės r. SVB; } \\
\text { partnerè - kaimo bendruomenè }\end{array}$ & VVG \\
\hline
\end{tabular}




\begin{tabular}{|c|c|c|c|}
\hline Eil. nr. & Pavadinimas & Biblioteka, partneriai & Rèmèjai \\
\hline 13 & Pasirokuokiam žemaitiškai & Tauragès r. SVB Pagramančio f. & SV \\
\hline 14 & Tarmiškasis žodžio rūbas & Tauragès r. SVB Žygaičių f. & SV \\
\hline 15 & Laiko delnuos prisiminimai & Tauragès r. SVB Žygaičių f. & SV \\
\hline \multicolumn{4}{|c|}{2015 metai } \\
\hline 1 & $\begin{array}{l}\text { Bendruomenès HUB’as bibliotekoje „Atrask savo } \\
\text { saviraiškos koda“"(2015-2016 m.) }\end{array}$ & $\begin{array}{l}\text { Pagėgių SVB; } \\
\text { partnerès: Šilutès r. SVB, Klaipè- } \\
\text { dos r. SVB }\end{array}$ & $\begin{array}{l}\text { [BMGF, KM [BP 2] } \\
\text { finansavimą skyrė } \\
\text { Šilutės r. SVB] }\end{array}$ \\
\hline 2 & $\begin{array}{l}\text { Interaktyvi edukacine - terapine erdvé jaunimui } \\
(2015-2016 \mathrm{~m} .)\end{array}$ & $\begin{array}{l}\text { Šilalès r. SVB; } \\
\text { partnerès: mokyklos, } \\
\text { AB „TEO LT“ }\end{array}$ & $\begin{array}{l}\text { BMGF, KM [BP 2], } \\
\text { SV }\end{array}$ \\
\hline 3 & $\begin{array}{l}\text { Jaunujų inžinierių laboratorija } \\
(2015-2016 \mathrm{m.})\end{array}$ & Tauragės r. SVB & BMGF, KM [BP 2] \\
\hline 4 & Vaikai-biblioteka-lèliu teatras & Tauragès r. SVB & $\begin{array}{l}\text { JAV lietuvių ben- } \\
\text { druomenès krašto } \\
\text { valdyba }\end{array}$ \\
\hline 5 & 3 dienu žygis-stovykla „Knygnešių keliais“ & $\begin{array}{l}\text { Tauragès r. SVB; } \\
\text { partnerè - Všt „Aktyvi Taurage““ }\end{array}$ & LKT, SV \\
\hline 6 & Poetu ir bardų vakaras „Prie garažų“ [tęstinis] & Tauragès r. SVB & SV \\
\hline 7 & $\begin{array}{l}\text { Literatūrinis-muzikinis vakaras „Rugpjūčcio } \\
\text { lyrika“ }\end{array}$ & Tauragès r. SVB & SV \\
\hline 8 & Mažosios Lietuvos lobiai // KP & Tauragės r. SVB Kęsčių f. & SV \\
\hline 9 & Skaitymo takas veda mus į knygǔ šalị [tęstinis] & Tauragės r. SVB A. Vymerio f. & SV \\
\hline 10 & $\begin{array}{l}\text { Knygos „Rūkainèlis ir miglų mergaité Jielimyte“ } \\
\text { leidyba }\end{array}$ & Tauragės r. SVB Žygaičių f. & SV \\
\hline 11 & $\begin{array}{l}\text { Knygos „Gyvasis žodis primena Žygaičių biblio- } \\
\text { tekos istorijq“leidyba }\end{array}$ & Tauragès r. SVB Žygaičių f. & SV \\
\hline \multicolumn{4}{|c|}{2016 metai } \\
\hline 1 & Pažink ir atrask & Jurbarko r. SVB & ŠMM \\
\hline 2 & $\begin{array}{l}\text { Bendruomenès HUB'as bibliotekoje „Atrask savo } \\
\text { saviraiškos koda“"(2015-2016 m.) }\end{array}$ & $\begin{array}{l}\text { Pagėgių SVB; } \\
\text { partnerès: Šilutės r. SVB, Klaipè- } \\
\text { dos r. SVB }\end{array}$ & $\begin{array}{l}\text { [2015 m. BMGF, } \\
\text { KM [BP 2] finansa- } \\
\text { vimą skyrė Šilutès r. } \\
\text { SVB] }\end{array}$ \\
\hline 3 & $\begin{array}{l}\text { Pažinsi bendruomenę - atrasi Europą [skirtas } \\
\text { Europos dienai] }\end{array}$ & Pagėgių SVB & EKAL \\
\hline 4 & Devintoji Europos diena & Šilalès r. SVB & EKAL \\
\hline 5 & $\begin{array}{l}\text { Interaktyvi edukaciné-terapiné erdvé jaunimui } \\
(2015-2016 \mathrm{m.})\end{array}$ & $\begin{array}{l}\text { Šilalès r. SVB; } \\
\text { partnerès: mokyklos, } \\
\text { AB „TEO LT“ }\end{array}$ & $\begin{array}{l}\text { BMGF, KM [BP 2], } \\
\text { SV (finansavimas } \\
\text { skirtas } 2015 \text { m.) }\end{array}$ \\
\hline 6 & $\begin{array}{l}\text { Jaunujų inžinierių laboratorija } \\
(2015-2016 \mathrm{m.})\end{array}$ & Tauragės r. SVB & $\begin{array}{l}\text { BMGF, KM [BP 2] } \\
\text { (finansavimas skir- } \\
\text { tas } 2015 \mathrm{~m} . \text { ) }\end{array}$ \\
\hline 7 & Poezijos pavasaris & Tauragės r. SVB & SV \\
\hline 8 & Dingęs Tauragès kraštas & Tauragès r. SVB & SV \\
\hline 9 & $\begin{array}{l}\text { Poros [numatytas susitikimas su rašytojais } \\
\text { Laura Sintija Černiauskaite ir Regimantu } \\
\text { Tamošaičiu] }\end{array}$ & Tauragès r. SVB & SV \\
\hline
\end{tabular}




\begin{tabular}{|c|c|c|c|}
\hline Eil. nr. & Pavadinimas & Biblioteka, partneriai & Rèmèjai \\
\hline 10 & Viešosios bibliotekos 85-metis & Tauragės r. SVB & SV \\
\hline 11 & Lèlių paradas & Tauragès r. SVB & SV \\
\hline 12 & Biblioteka be sienu [skirtas jaunimui] & Tauragès r. SVB & SV \\
\hline 13 & $\begin{array}{l}\text { Kurkime ir pažinkime kartu [skirtas } \\
\text { etnokultūrai] }\end{array}$ & $\begin{array}{l}\text { Tauragès r. SVB Dacijonų f.; } \\
\text { partneré - kaimo bendruomenè }\end{array}$ & $\begin{array}{l}\text { Socialinės apsaugos } \\
\text { ir darbo ministerija }\end{array}$ \\
\hline 14 & Rugpjūčio lyrika & $\begin{array}{l}\text { Tauragès r. SVB Baltrušaičių f.; } \\
\text { partneré - kaimo bendruomenė }\end{array}$ & SV \\
\hline 15 & Jubiliejinis sveikinimas & Tauragès r. SVB Batakių f. & SV \\
\hline 16 & Ka mena senų mokyklų slenksčiai & Tauragès r. SVB Kęsčių f. & SV \\
\hline 17 & $\begin{array}{l}\text { Šiam pasauly... [projekto pobūdis neiden- } \\
\text { tifikuotas; priskirtas bendriems edukacijos } \\
\text { projektams] }\end{array}$ & Tauragės r. SVB Lauksargių f. & SV \\
\hline 18 & Lai skamba žemaitiškas žodis & Tauragès r. SVB Mažonų $\mathrm{f}$. & SV \\
\hline 19 & $\begin{array}{l}\text { Spalvingos idèjos [projekto pobūdis neiden- } \\
\text { tifikuotas; priskirtas bendriems edukacijos } \\
\text { projektams] }\end{array}$ & Tauragès r. SVB Norkaičių f. & SV \\
\hline 20 & Nesekama pasaka & Tauragès r. SVB Skaudvilès f. & SV \\
\hline 21 & Skaitymo takas veda mus į knygų šali [tęstinis] & Tauragès r. SVB A. Vymerio f. & SV \\
\hline 22 & Bibliotekų kvarteto Žygaičių seniūnijoje sklaida & Tauragès r. SVB Žygaičių f. & SV \\
\hline \multicolumn{4}{|c|}{2017 metai } \\
\hline 1 & Susitikimo kodas \#BIBLIOTEKA & $\begin{array}{l}\text { Jurbarko r. SVB; } \\
\text { partneriai: Jurbarko r. kultū- } \\
\text { ros centrai, Vadžgirio muzikos } \\
\text { mylètojų klubas „Mūza“, rajono } \\
\text { bendruomenės }\end{array}$ & SV \\
\hline 2 & Veliuonos novelè, 2017 & $\begin{array}{l}\text { Jurbarko r. SVB; } \\
\text { partneriai: Jurbarko rajono } \\
\text { Eržvilko ir Veliuonos kultūros } \\
\text { centrai, Vadžgirio muzikos my- } \\
\text { lètojų klubas „Mūza“, Veliuonos } \\
\text { šeimų laisvalaikio klubas }\end{array}$ & SV \\
\hline 3 & $\begin{array}{l}\text { Pažink save ir kita [skirtas vaikų ir jaunimo } \\
\text { skaitymui skatinti] }\end{array}$ & $\begin{array}{l}\text { Jurbarko r. SVB Vadžgirio f.; } \\
\text { partneriai: Jurbarko rajono Erž- } \\
\text { vilko kultūros centro Vadžgirio } \\
\text { skyrius, Vadžgirio muzikos my- } \\
\text { lètojų klubas „Mūza“, Vadžgirio } \\
\text { pagrindinė mokykla, Vadžgirio } \\
\text { bendruomenės centras }\end{array}$ & SV \\
\hline 4 & Paveizèk kap graže, pasmuokavuok kap skane & $\begin{array}{l}\text { Šilalès r. SVB; } \\
\text { partneriai: Lenkijos Punsko ir } \\
\text { Latvijos Rygos lietuvių bendruo- } \\
\text { menès }\end{array}$ & SV \\
\hline 5 & $\begin{array}{l}\text { Vakaru ciklas „Pašnekesiai po toršeru. Susitiki- } \\
\text { mai su I. Simonaitytès premijos laureatais“ }\end{array}$ & Tauragès r. SVB & KM \\
\hline 6 & Poezijos pavasaris, 2017 & Tauragès r. SVB & SV \\
\hline
\end{tabular}




\begin{tabular}{|c|c|c|c|}
\hline Eil. nr. & Pavadinimas & Biblioteka, partneriai & Rèmèjai \\
\hline 7 & $\begin{array}{l}\text { Poros - II [numatė susitikimus su poetu, ra- } \\
\text { šytoju, režisieriumi Alvydu Šlepiku, poetu bei } \\
\text { fotografu Dainiumi Dirgèla, rašytoju Rimantu } \\
\text { Kmita, rašytoju Sauliumi Šalteniu] }\end{array}$ & Tauragės r. SVB & SV \\
\hline 8 & Padèkos vakaras „Dar vieni metai kartu“ & Tauragès r. SVB & SV \\
\hline 9 & Poetų ir bardų vakaras „Prie garažų“ [tęstinis] & Tauragès r. SVB & SV \\
\hline 10 & Skaitymo takas veda mus $i$ knygu šali [tęstinis] & $\begin{array}{l}\text { Tauragès r. SVB } \\
\text { A. Vymerio } \mathrm{f} \text {. }\end{array}$ & SV \\
\hline 11 & XVI Žemaitijos bibliotekininku sporto sąskrydis & Tauragès r. SVB & SV \\
\hline 12 & Romansu ir poezijos vakaras „Susitiksim dainoj“ & $\begin{array}{l}\text { Tauragès r. SVB } \\
\text { Baltrušaičių f. }\end{array}$ & SV \\
\hline 13 & $\begin{array}{l}\text { Baltrušaičiu kaimo senolių pagerbimo šventè } \\
\text { „Laikas skuba, neša metus“ }\end{array}$ & $\begin{array}{l}\text { Tauragès r. SVB } \\
\text { Baltrušaičių f. }\end{array}$ & SV \\
\hline 14 & I Lietuva einu istorijos keliu [skirtas jaunimui] & $\begin{array}{l}\text { Tauragès r. SVB } \\
\text { Dapkiškių f. }\end{array}$ & SV \\
\hline 15 & Vaikų svajonès & $\begin{array}{l}\text { Tauragès r. SVB } \\
\text { Lauksargių f. }\end{array}$ & SV \\
\hline 16 & $\begin{array}{l}\text { Kaimo vaiku ir jaunimo užimtumo programa } \\
\text { „Lai dūzgia vaiku aviliukas“" }\end{array}$ & $\begin{array}{l}\text { Tauragès r. SVB Lomių f.; } \\
\text { partneriai: Lomių kaimo } \\
\text { bendruomenė, Lomių pagrin- } \\
\text { dinè mokykla, Batakių vidurinė } \\
\text { mokykla }\end{array}$ & SV \\
\hline 17 & Apjuoskim juosta tautiškumo - piliakalnio žemę & $\begin{array}{l}\text { Tauragės r. SVB Pagramančio f.; } \\
\text { partneriai: Norkaičių biblioteka, } \\
\text { Mažonų biblioteka, Norkaičių } \\
\text { tradicinių amatų ir etnokultūros } \\
\text { centras, Pagramančio regioninio } \\
\text { parko direkcija, Pagramančio } \\
\text { pagrindinė mokykla, Mažonų } \\
\text { seniūnija, bendruomenè „Gra- } \\
\text { mančia“ }\end{array}$ & SV \\
\hline 18 & Auskim juostą tautiškumo - Lietuvos šimtmečiui & $\begin{array}{l}\text { Tauragès r. SVB Pagramančio f.; } \\
\text { partneriai: Norkaičių biblioteka, } \\
\text { Mažonų biblioteka, Norkaičių } \\
\text { tradicinių amatų ir etnokultūros } \\
\text { centras, Pagramančio regioninio } \\
\text { parko direkcija, Pagramančio } \\
\text { pagrindinè mokykla, Mažonų } \\
\text { seniūnija, bendruomenė „Gra- } \\
\text { mančia“ }\end{array}$ & SV \\
\hline 19 & Jubiliejinèje bibliotekos puokštèje - 80 žiedu & Tauragès r. SVB Skaudvilès f. & SV \\
\hline 20 & Lietuviški mezgimo raštai, spalvų deriniai & Tauragès r. SVB Žygaičių f. & SV \\
\hline 21 & $\begin{array}{l}\text { Albumo „Su vaivorykšte rankose“ leidyba [kraš- } \\
\text { totyrinio pobūdžio leidinys] }\end{array}$ & Tauragès r. SVB Žygaičių f. & SV \\
\hline
\end{tabular}


5 priedas. Panevėžio apskr. savivaldybių viešųjų bibliotekų 2007, 2013, 2015-2017 metų projektai

\begin{tabular}{|c|c|c|c|}
\hline Eil. nr. & Pavadinimas & Biblioteka, partneriai & Rèmèjai \\
\hline 1 & Tarptautinis Poezijos pavasaris 2007 Biržuose & Biržų r. SVB & KSRF \\
\hline 2 & Seku seku pasakų... & $\begin{array}{l}\text { Biržų r. centrinė biblioteka, } \\
\text { Kvetkų ir Pačeriaukštės filialai }\end{array}$ & ŠMM \\
\hline 3 & Skaitymo džiaugsmas & Kupiškio r. SVB & KM \\
\hline 4 & Sugrižimai i tèviškę & $\begin{array}{l}\text { Kupiškio r. SVB; } \\
\text { partnerės: Kupiškio r. savival- } \\
\text { dybė, Kupiškio L. Stuokos-Gu- } \\
\text { cevičiaus gimnazija }\end{array}$ & $\mathrm{KM}$ \\
\hline 5 & Atversk pasakos lapus ir raideles pabus & Kupiškio r. SVB & KM \\
\hline 6 & $\begin{array}{l}\text { Skaitymo skatinimas ir kultūros sklaida miesto } \\
\text { bibliotekose [tęstinis] }\end{array}$ & Panevėžio m. SVB & $\mathrm{KM}$ \\
\hline 7 & Vaiku knygos švente [tęstinis] & Panevėžio m. SVB & KM \\
\hline 8 & Sveikata - išmintingujų honoraras [tęstinis] & Panevėžio m. SVB & SV \\
\hline 9 & Vaiku vasaros stovykla & Panevėžio m. SVB (centrinè) & SV \\
\hline 10 & Vaiku vasaros stovykla & Panevėžio m. SVB Smèlynès f. & SV \\
\hline 11 & Vaiku vasaros stovykla & $\begin{array}{l}\text { Panevėžio m. SVB Vaikų bib- } \\
\text { lioteka „Žiburèlis“ }\end{array}$ & SV \\
\hline 12 & Vaiku vasaros stovykla & Panevėžio m. SVB „Židinio“ f. & SV \\
\hline 13 & $\begin{array}{l}\text { Palikime savo pédsakus (2007-2008 m.) } \\
\text { [pagal projekto programą Panevezžio r. biblio- } \\
\text { tekose metus dirbo trys savanoriai iš Turkijos, } \\
\text { Vokietijos ir Italijos] }\end{array}$ & $\begin{array}{l}\text { Panevėžio r. SVB; } \\
\text { partneriai: Jaunimo tarptauti- } \\
\text { nio bendradarbiavimo agentū- } \\
\text { ra, Panevěžio apskrities NVO } \\
\text { informacijos centras }\end{array}$ & $\begin{array}{l}\text { ES programa „Veiklus } \\
\text { jaunimas“ }\end{array}$ \\
\hline 14 & Arčiau knygos & Panevėžio r. SVB & KM \\
\hline 15 & $\begin{array}{l}\text { Edukaciniai knygu pristatymai „Mes pašèlę } \\
\text { pramuštgalviai“ }\end{array}$ & Panevėžio r. SVB & SV \\
\hline 16 & Jaunieji mokslininkai & Panevėžio r. SVB & SV \\
\hline 17 & Pažink pasauli per Astridą Lindgren & Panevėžio r. SVB Bernatonių f. & SV \\
\hline 18 & Menas būti savimi [skirtas jaunimui] & Panevėžio r. SVB Linkaučių f. & SV \\
\hline 19 & Per knyga ir skaitymą - i pažinimo šali & Panevėžio r. SVB Miežiškių f. & SV \\
\hline 20 & Kultūros užuovejja & Pasvalio SVB & $\mathrm{KM}$ \\
\hline 21 & $\begin{array}{l}\text { Renginiu ciklas „Knyga, biblioteka, žmogus } \\
\text { istorijoje ir šiandienoje“ }\end{array}$ & Pasvalio SVB & KSRF \\
\hline 22 & $\begin{array}{l}\text { Nekasdieniai pasimatymai [literatūrinių rengi- } \\
\text { nių ciklas jaunimui] }\end{array}$ & Pasvalio SVB & KM \\
\hline 23 & Šiaurès verdenès [leidybos; tęstinis] & $\begin{array}{l}\text { Pasvalio SVB; } \\
\text { partnerė - žurnalo visuomeni- } \\
\text { nė redakcija }\end{array}$ & $\begin{array}{l}\text { Spaudos, radijo ir } \\
\text { televizijos rèmimo } \\
\text { fondas, SV, Pasvalio } \\
\text { krašto muziejaus, } \\
\text { SVB }\end{array}$ \\
\hline 24 & $\begin{array}{l}\text { Seminaras „Archyvai, bibliotekos, muziejai: } \\
\text { bendradarbiavimo galimybès" }\end{array}$ & Pasvalio SVB & $\begin{array}{l}\text { Panevèžio apskrities } \\
\text { viršininko adminis- } \\
\text { tracija }\end{array}$ \\
\hline 25 & Knyga karpiniuose & Rokiškio r. SVB & KM \\
\hline
\end{tabular}




\begin{tabular}{|c|l|}
\hline Eil. nr. & \multicolumn{1}{|c|}{ Pavadinimas } \\
\hline 26 & $\begin{array}{l}\text { Keliuočiu patirtị - jauniems žurnalistams } \\
\text { [etnokultūrinè programa vaikams ir jaunimui] }\end{array}$ \\
\hline 27 & $\begin{array}{l}\text { Kai atgyja lèlès [tęstinis; etnokultūrinè progra- } \\
\text { ma vaikams ir jaunimui] }\end{array}$ \\
\hline 28 & Atrasti ir pažinti lietuvių literatūrą \\
\hline 29 & Metų ratą pasukus [skirtas etninei kultūrai] \\
\hline 30 & $\begin{array}{l}\text { Konferencija, skirta Juozo Keliuočio 105-osioms } \\
\text { gimimo metinèms }\end{array}$ \\
\hline
\end{tabular}

31 Literatūrinè Juozo Keliuočio premija [tęstinis]

32 Kelias i sveikos gyvensenos pažinima neturi amžiaus ribu

33 Renginiu ciklas, skirtas Spaudos atgavimo, kalbos ir knygos dienai

34 Poezijos pavasaris 2007 Rokiškyje

35 Rokiškio krašto žurnalas „Prie Nemunèlio“ [leidybos; tęstinis]

36 Mano knygele

37 Literatūros savaitè džiugenu šalyje

38 Turistiné-literatūriné-etnokultūrinè vaiku vasaros stovykla „Peledžiukas" [tęstinis]

39 Atverk duris pažinimui ir kūrybai

40 Tradicinè Europos kalbų savaitė Rokiškyje

41 Rankraštynas - vertingiausia kultūrinio paveldo dalis

42 Literatūrinis rudenèlis Konstantinavoje [skirtas vaikams]

43 Pandèlio krašto istorija [leidybos]

1 Tarpvalstybinio verslui palankiu biblioteku tinklo kürimas (2012-2014 m.)

2 Tarmèse - tikroji kalbos gyvastis

3 Moderni biblioteka - bendruomenes informacijos ir saviraiškos centras

4 Skaitymo akiratyje - nacionalinès premijos laureatai

\section{Biblioteka, partneriai}

Rokiškio r. SVB

Rèmèjai

$\mathrm{KM}$

Rokiškio r. SVB

KM

Rokiškio r. SVB

KM

Rokiškio r. SVB

KM

Rokiškio r. SVB;

KSRF

partneris - Juozo ir Alfonso

Keliuočių palikimo studijų

centras

Rokiškio r. SVB;

SV

partneris - Juozo ir Alfonso

Keliuočių palikimo studijų

centras

Rokiškio r. SVB

SV

Rokiškio r. SVB

SV

Rokiškio r. SVB

SV

Rokiškio r. SVB;

SV

partneris - Juozo ir Alfonso

Keliuočių palikimo studijų

centras

Rokiškio r. SVB

SV

Rokiškio r. SVB

SV

Rokiškio r. SVB

SV

Rokiškio r. SVB

SV

Rokiškio r. SVB

SV

Rokiškio r. SVB

[nenurodyta]

Rokiškio r. SVB Konstantina-

SV

vos $\mathrm{f}$.

Rokiškio r. SVB Pandèlio f. SV

\section{3 metai}

\section{Biržų r. SVB;}

partneriai: Pasvalio, Pakruojo, Bauskès ir Rundalès (Latvija) rajonų viešosios bibliotekos Biržų r. SVB

Kupiškio r. SVB

Kupiškio r. SVB
Europos žemès ūkio fondas kaimo plètrai (LEADER programa) [nenurodyta] Europos žemès ūkio fondas kaimo plètrai (LEADER programa)

KRF 


\begin{tabular}{|c|c|c|c|}
\hline Eil. nr. & Pavadinimas & Biblioteka, partneriai & Rèmèjai \\
\hline 5 & $\begin{array}{l}\text { Kupiškio krašto fotometraštininko Juozo Krau- } \\
\text { jūno fotografiju fondo formavimas ir sklaida }\end{array}$ & Kupiškio r. SVB & KRF \\
\hline 6 & $\begin{array}{l}\text { Kürybinès dirbtuvés - dar vienas žingsnis kny- } \\
\text { gos link }(2012-2013 \text { m.) }\end{array}$ & Kupiškio r. SVB & $\begin{array}{l}\text { KRF, SV, UAB „Pato- } \\
\text { gu pirkti“ }\end{array}$ \\
\hline 7 & Lèlių teatras - džiaugsmas ir erdve kūrybai & Kupiškio r. SVB & KRF \\
\hline 8 & Kupiškèniški vaizdèliai & Kupiškio r. SVB & $\mathrm{KM}$, privatūs rèmèjai \\
\hline 9 & Padekkime tèvams ir vaikams džiaugtis gyvenimu & Kupiškio r. SVB & KM \\
\hline 10 & Kupiškènu protų kovos „Minčių kosmosas“ & Kupiškio r. SVB & SV \\
\hline 11 & $\begin{array}{l}\text { Naktis bibliotekoje [skirtas jaunimo kūrybinei } \\
\text { meninei veiklai skatinti] }\end{array}$ & Kupiškio r. SVB Noriūnų f. & SV \\
\hline 12 & Kai mes kartu, net mūšis nebaisus & Kupiškio r. SVB Subačiaus $\mathrm{f}$. & SV \\
\hline 13 & E-žinios kiekvienam & Panevėžio m. SVB & KM \\
\hline 14 & $\begin{array}{l}\text { Kompleksine skaitymo skatinimo progra- } \\
\text { ma „Mažais žingsneliais i knygu pasauli““ }\end{array}$ & Panevėžio m. SVB & KRF \\
\hline 15 & Su „Šlepete“ per debesis & Panevėžio m. SVB & KRF \\
\hline 16 & Konkursas „Metai ir knygos“ [skirtas vaikams] & Panevėžio m. SVB Smèlynės f. & KRF \\
\hline 17 & $\begin{array}{l}\text { Skaitymo skatinimas ir kultūros sklaida miesto } \\
\text { bibliotekose [tęstinis] }\end{array}$ & Panevėžio m. SVB & SV \\
\hline 18 & Vasara su knyga miesto bibliotekose [tęstinis] & Panevėžio m. SVB & SV \\
\hline 19 & $\begin{array}{l}\text { Mokykimès ekologijos abècèlès } \\
\text { (2012-2013 m.) }\end{array}$ & Panevėžio m. SVB & SV \\
\hline 20 & $\begin{array}{l}3 \text { žingsniai sveikatos link } \\
(2012-2013 \mathrm{m.})\end{array}$ & Panevėžio m. SVB & SV \\
\hline 21 & Pakeliui $i$ vaistinę - užsuk j biblioteką & Panevėžio m. SVB & SV \\
\hline 22 & $\begin{array}{l}\text { Literatūrinès kelionès, menant } 1863 \text { metų suki- } \\
\text { lima Panevėžio krašte }\end{array}$ & Panevèžio r. SVB & $\mathrm{KM}$ \\
\hline 23 & Kino meno programa „Matyk kitaip“ & Panevėžio r. SVB Karsakiškio f. & $\mathrm{KM}$ \\
\hline 24 & Kuriu ir sveikai gyvenu [skirtas vaikams] & Panevėžio r. SVB & SV \\
\hline 25 & $\begin{array}{l}\text { Prikeltas antram gyvenimui [skirtas vaikams; } \\
\text { ekologija] }\end{array}$ & Panevėžio r. SVB & SV \\
\hline 26 & Sveikas maistas - sveika vaikyste & Panevėžio r. SVB Bernatonių f. & SV \\
\hline 27 & $\begin{array}{l}\text { Vaikų vasaros stovyklèle „Kodè į biblioteką, o } \\
\text { ne i gatvę?" }\end{array}$ & Panevėžio r. SVB Ėriškių f. & SV \\
\hline 28 & $\begin{array}{l}\text { Aš ir mane supantis pasaulis [skirtas sveikai } \\
\text { gyvensenai populiarinti] }\end{array}$ & Panevėžio r. SVB Paliūniškio f. & SV \\
\hline 29 & Užsiauginkime gerumo žiedą širdelèse & Panevėžio r. SVB Paliūniškio f. & SV \\
\hline 30 & $\begin{array}{l}\text { Vaiku sveikata - tai fizinè, dvasine, socialine } \\
\text { gerové }\end{array}$ & Panevėžio r. SVB Raguvos f. & SV \\
\hline 31 & Atsisakyti sunku, tačiau verta & Panevėžio r. SVB Velžio f. & SV \\
\hline 32 & $\begin{array}{l}\text { Vaikų kūrybiškumo skatinimas. Kūrybingas } \\
\text { laisvalaikis vasaros dienos stovyklos metu }\end{array}$ & Panevėžio r. SVB Velžio f. & SV \\
\hline 33 & $\begin{array}{l}\text { Tarpvalstybinio verslui palankiu biblioteku } \\
\text { tinklo kūrimas (2012-2014 m.) }\end{array}$ & $\begin{array}{l}\text { Pasvalio SVB; } \\
\text { partnerės: Biržų r. SVB, } \\
\text { Pakruojo r. SVB, Bauskès bei } \\
\text { Rundalès (Latvija) rajonų } \\
\text { viešosios bibliotekos }\end{array}$ & $\begin{array}{l}\text { Europos žemès ūkio } \\
\text { fondas kaimo plètrai } \\
\text { (LEADER programa) }\end{array}$ \\
\hline
\end{tabular}




\begin{tabular}{|c|c|c|c|}
\hline Eil. nr. & Pavadinimas & Biblioteka, partneriai & Rèmèjai \\
\hline 34 & $\begin{array}{l}\text { Libre-A: i pagalba Pasvalio ūkininkams } \\
(2011-2013 \mathrm{m.})\end{array}$ & $\begin{array}{l}\text { Pasvalio SVB; } \\
\text { partneriai: Pasvalio r. savival- } \\
\text { dybė, Lietuvos ūkininkų sąjun- } \\
\text { gos Pasvalio skyrius, Pasvalio } \\
\text { bitininkų draugija „Bičiulis“, } \\
\text { Lietuvos agrarinių mokslų ir } \\
\text { miškų mokslų centro Žem- } \\
\text { dirbystės instituto Joniškèlio } \\
\text { bandymų stotis }\end{array}$ & EIFL fondas \\
\hline 35 & E. bibliotekos „Pasvalia“ kūrimas [tęstinis] & Pasvalio SVB & KM \\
\hline 36 & $\begin{array}{l}\text { Pasvalio Mariaus Katiliškio viešoji biblioteka - } \\
\text { skaitmeninès kompetencijos ugdymo centras }\end{array}$ & Pasvalio SVB & KM \\
\hline 37 & $\begin{array}{l}\text { Literatūros dienos ir naktys - 2013: reveransas } \\
\text { poezijai }\end{array}$ & Pasvalio SVB & KRF \\
\hline 38 & $\begin{array}{l}\text { 1863-1864 metų sukilimas: už Jūsų ir mūsų } \\
\text { laisvę }\end{array}$ & Pasvalio SVB & KRF \\
\hline 39 & $\begin{array}{l}\text { „Europeana 1989“: Pasvalio Mariaus Katiliškio } \\
\text { viešosios bibliotekos patirtis }\end{array}$ & $\begin{array}{l}\text { Pasvalio SVB; } \\
\text { partnerės: KAVB, Utenos SVB }\end{array}$ & [nenurodyta] \\
\hline 40 & Kalbèkime ir rašykime sava tarme & Pasvalio SVB & KM \\
\hline 41 & Šiaurès verdenès [leidybos; tęstinis] & $\begin{array}{l}\text { Pasvalio SVB; } \\
\text { partnerè - žurnalo visuomeni- } \\
\text { nè redakcija }\end{array}$ & $\begin{array}{l}\text { Spaudos, radijo ir } \\
\text { televizijos remimo } \\
\text { fondas, SV, Pasvalio } \\
\text { krašto muziejaus, } \\
\text { SVB }\end{array}$ \\
\hline 42 & Pažink ir garsink savo kaima & $\begin{array}{l}\text { Pasvalio SVB Jurgėnų f.; part- } \\
\text { nerè - kaimo bendruomené }\end{array}$ & SV \\
\hline 43 & Mūsų Europa - mūsų teisès & Rokiškio r. SVB & EKAL \\
\hline 44 & Devyni bibliotekos dešimtmečiai & Rokiškio r. SVB & $\mathrm{KM}, \mathrm{SV}$ \\
\hline 45 & $\begin{array}{l}\text { Literatūrine-kūrybiné-edukacinè programa } \\
\text { „Sava tarmi rakuoju, dainuoju, kuriu“ }\end{array}$ & Rokiškio r. SVB & $\mathrm{KM}, \mathrm{SV}$ \\
\hline 46 & Literatūrinè piligrimyste & Rokiškio r. SVB & KM \\
\hline 47 & Romuvos keliais [leidybos; tęstinis] & $\begin{array}{l}\text { Rokiškio r. SVB; } \\
\text { partneris - Juozo ir Alfonso } \\
\text { Keliuočių palikimo studijų } \\
\text { centras }\end{array}$ & $\begin{array}{l}\text { Spaudos, radijo ir } \\
\text { televizijos rèmimo } \\
\text { fondas, SV }\end{array}$ \\
\hline 48 & Sèliu kultūra virtualioje erdvèje [tęstinis] & $\begin{array}{l}\text { Rokiškio r. SVB; } \\
\text { partneris - Juozo ir Alfonso } \\
\text { Keliuočių palikimo studijų } \\
\text { centras }\end{array}$ & $\begin{array}{l}\text { Spaudos, radijo ir } \\
\text { televizijos remimo } \\
\text { fondas, SV }\end{array}$ \\
\hline 49 & Biblioteka - bendruomenei & Rokiškio r. SVB & $\begin{array}{l}\text { Nacionalinè mokè- } \\
\text { jimo agentūra prie } \\
\text { Žemès ūkio minis- } \\
\text { terijos }\end{array}$ \\
\hline 50 & Poezijos pavasaris & Rokiškio r. SVB & SV \\
\hline 51 & Gyventi sveikai - gyventi laiminga & Rokiškio r. SVB & SV \\
\hline 52 & $\begin{array}{l}\text { Vaiku vasaros poilsio stovykla „Peledžiukas“ } \\
\text { [tęstinis] }\end{array}$ & Rokiškio r. SVB & SV \\
\hline
\end{tabular}




\begin{tabular}{|c|c|c|c|}
\hline Eil. nr. & Pavadinimas & Biblioteka, partneriai & Rèmèjai \\
\hline 53 & $\begin{array}{l}\text { Rédos ratas žmogaus gyvenime ir šventèse [skir- } \\
\text { tas vaikams ir jaunimui] }\end{array}$ & Rokiškio r. SVB & SV \\
\hline 54 & Keliuotiškos Juozinès & Rokiškio r. SVB & SV \\
\hline 55 & Biblioteka miesto dienai & Rokiškio r. SVB & SV \\
\hline 56 & Kai atgyja lèlès [tęstinis] & Rokiškio r. SVB & SV \\
\hline 57 & Aš beržas, lietuviškas beržas... & $\begin{array}{l}\text { Rokiškio r. SVB Aleksandra- } \\
\text { vèlès f. }\end{array}$ & SV \\
\hline \multicolumn{4}{|c|}{2015 metai } \\
\hline 1 & Europos diena Biržuose & Biržų r. SVB & EKAL \\
\hline 2 & $\begin{array}{l}\text { Gimtojoj mano Šiaurès Lietuvoj [skirtas litera- } \\
\text { tūrai] }\end{array}$ & $\begin{array}{l}\text { Biržų r. SVB; } \\
\text { partnerè - „Balticum TV“ } \\
\text { Biržų atstovybe் }\end{array}$ & LKT \\
\hline 3 & $\begin{array}{l}\text { Kaimas kine, kinas kaime } \\
(2015-2016 \text { m.) [skirtas jaunimui] }\end{array}$ & Biržų r. SVB & BMGF, KM [BP 2] \\
\hline 4 & Teatro karalystès išdaigos & Biržų r. SVB & LKT \\
\hline 5 & Augu su knyga [tęstinis] & $\begin{array}{l}\text { Biržų r. SVB Juostaviečių f.; } \\
\text { partneriai: Pačeriaukštės } \\
\text { ir Pasvaliečių filialai, Pače- } \\
\text { riaukštės ir Pasvaliečių kaimų } \\
\text { bendruomenės }\end{array}$ & LKT \\
\hline 6 & Berniukai ir mergaitès, būkit žmonès - skaitykit & Biržų r. SVB Vabalninko f. & LKT \\
\hline 7 & $\begin{array}{l}\text { Skulptoriaus Juozo Kèdainio kūryba šiandienos } \\
\check{z} \text { vilgsniu }\end{array}$ & Kupiškio r. SVB & LKT \\
\hline 8 & $\begin{array}{l}\text { Fotografijos mokymai-paroda „Neatrastas Ku- } \\
\text { piškis“(2015-2016 m.) }\end{array}$ & Kupiškio r. SVB & LKT \\
\hline 9 & $\begin{array}{l}\text { Prošvaitès [skirtas populiarinti kupiškènų } \\
\text { literatų kūrybai, išleisti Kupiškio r. literatų } \\
\text { klubo „Lèvens balsai“ narių kūrybos rinktinei } \\
\text { „Prošvaistès“] }\end{array}$ & Kupiškio r. SVB & $\begin{array}{l}\text { SV, literatų klubo } \\
\text { „Lèvens balsai“ narių } \\
\text { léšos }\end{array}$ \\
\hline 10 & $\begin{array}{l}\text { 3D: Domèkis. Dalyvauk. Dalinkis } \\
(2015-2016 \mathrm{~m} .)\end{array}$ & Panevėžio m. SVB & BMGF, KM [BP 2] \\
\hline 11 & Knygos (r)evoliucija & Panevėžio m. SVB & LKT \\
\hline 12 & Keliaujančio knygu portfelio paslaptys & Panevėžio m. SVB & LKT \\
\hline 13 & ETNO ir aš & Panevėžio m. SVB & LKT \\
\hline 14 & Aukštaitiška dèlionè & Panevėžio m. SVB & LKT \\
\hline 15 & $\begin{array}{l}\text { Skaitymo skatinimas ir kultūros sklaida miesto } \\
\text { bibliotekose [tęstinis] }\end{array}$ & Panevėžio m. SVB & SV \\
\hline 16 & Literatūros ir meno kaleidoskopas [tęstinis] & Panevėžio m. SVB & [nenurodyta] \\
\hline 17 & $\begin{array}{l}\text { Štai koks mano kaimas } \\
(2015-2016 \mathrm{~m} .)\end{array}$ & $\begin{array}{l}\text { Panevėžio r. SVB; } \\
\text { partneriai: Panevėžio r. švieti- } \\
\text { mo centras, Panevėžio rajono } \\
\text { bendruomenių sąjunga }\end{array}$ & BMGF, KM [BP 2] \\
\hline 18 & $\begin{array}{l}\text { Literatūrinès edukacinès kelionès su Šiaurès } \\
\text { Lietuvos kūrèjais }\end{array}$ & Panevėžio r. SVB & LKT \\
\hline 19 & Atvertos durys i kūrybines erdves & Panevėžio r. SVB & LKT \\
\hline 20 & Atmerk akis - generuok mintis & Panevėžio r. SVB & LKT \\
\hline
\end{tabular}




\begin{tabular}{|c|c|c|c|}
\hline Eil. nr. & Pavadinimas & Biblioteka, partneriai & Rèmèjai \\
\hline 21 & $\begin{array}{l}\text { Edukaciniai vasaros užsiemimai: saugus gatve- } \\
\text { je, namuose ir internete }\end{array}$ & Panevėžio r. SVB & SV \\
\hline 22 & $\begin{array}{l}\text { Vaikų vasaros stovykla „Menų miksas“ [skirtas } \\
\text { vaikams iš socialinès rizikos šeimų] }\end{array}$ & Panevėžio r. SVB & SV \\
\hline 23 & Augu sveikas, stiprus ir aktyvus & Panevèžio r. SVB & SV \\
\hline 24 & Europos dienos švente „Kartu mes jega“ & Pasvalio SVB & EKAL \\
\hline 25 & $\begin{array}{l}\text { Modernaus tarpvalstybinio vaiku ir jaunimo } \\
\text { verslumo kompetenciju ugdymo tinklo bibliote- } \\
\text { kose kūrimas (2015-2019 m.) }\end{array}$ & $\begin{array}{l}\text { Pasvalio SVB; } \\
\text { partnerès: Pasvalio r. savivaldy- } \\
\text { bės administracija, } \\
\text { Bauskès savivaldybès administ- } \\
\text { racija (Latvija) }\end{array}$ & $\begin{array}{l}\text { Europos regioni- } \\
\text { nès plètros fondas } \\
\text { (Latvijos ir Lietuvos } \\
\text { bendradarbiavimo } \\
\text { per sieną programa } \\
\text { INTERREG V-A) }\end{array}$ \\
\hline 26 & $\begin{array}{l}\text { Moderniu jaunimo erdviu } \\
\text { „Mono arba Stereo tinklo kūrimas“ } \\
(2015-2016 \mathrm{~m} .)\end{array}$ & $\begin{array}{l}\text { Pasvalio SVB; } \\
\text { partneriai: } \\
\text { Pasvalio r. savivaldybės švieti- } \\
\text { mo ir sporto skyrius, Panevėžio } \\
\text { teritorinės darbo biržos Pasvalio } \\
\text { skyrius, Pasvalio r. jaunimo } \\
\text { organizacijų sajunga „Apskritas } \\
\text { stalas“, Pasvalio verslininkų } \\
\text { asociacija „Verslo žiedas“, AB } \\
\text { „Swedbankas“ Pasvalio klientų } \\
\text { aptarnavimo padalinys ir kt. }\end{array}$ & BMGF, KM [BP 2] \\
\hline 27 & $\begin{array}{l}\text { Mariaus Katiliškio atminimo kambario } \\
\text { ekspozicijos Pasvalio viešojoje bibliotekoje } \\
\text { atnaujinimas }\end{array}$ & Pasvalio SVB & LKT, SV \\
\hline 28 & $\begin{array}{l}\text { Kino dienos Pasvalio krašte 2015: jaunieji } \\
\text { kūrèjai }\end{array}$ & Pasvalio SVB & LKT \\
\hline 29 & Šiaurès verdenès [leidybos, tęstinis] & $\begin{array}{l}\text { Pasvalio SVB; } \\
\text { partnerè - žurnalo visuomeni- } \\
\text { nè redakcija }\end{array}$ & $\begin{array}{l}\text { Spaudos, radijo ir } \\
\text { televizijos rėmimo } \\
\text { fondas, SV, Pasvalio } \\
\text { krašto muziejaus, } \\
\text { SVB }\end{array}$ \\
\hline 30 & $\begin{array}{l}\text { Literatūros dienos ir naktys 2015: ne tik rašy- } \\
\text { tojai... }\end{array}$ & Pasvalio SVB & LKT \\
\hline 31 & Pasvalios e. gidas & Pasvalio SVB & LKT, SV \\
\hline 32 & Kaimas gyvas, kol gyvos tradicijos & $\begin{array}{l}\text { Pasvalio SVB Jurgènų f.; par- } \\
\text { tnerè - kaimo bendruomenè }\end{array}$ & [nenurodyta] \\
\hline 33 & $\begin{array}{l}\text { Rokiškio krašto literatūriniai kelio pažinties } \\
\text { ženklai (I dalis) }\end{array}$ & Rokiškio r. SVB & LKT, SV \\
\hline 34 & A. Keliuočio kūrybos rinktiné & Rokiškio r. SVB & LKT, SV \\
\hline 35 & Romuvos keliais [tęstinis; leidybos] & $\begin{array}{l}\text { Rokiškio r. SVB; } \\
\text { partneris - Juozo ir Alfonso Ke- } \\
\text { liuočių palikimo studijų centras }\end{array}$ & $\begin{array}{l}\text { Spaudos, radijo ir } \\
\text { televizijos rèmimo } \\
\text { fondas, SV }\end{array}$ \\
\hline 36 & Sèlių kultūra virtualioje erdvèje [tęstinis] & $\begin{array}{l}\text { Rokiškio r. SVB; } \\
\text { partneris - Juozo ir Alfonso Ke- } \\
\text { liuočių palikimo studijų centras }\end{array}$ & $\begin{array}{l}\text { Spaudos, radijo ir } \mathrm{TV} \\
\text { rèmimo fondas, } \mathrm{SV}\end{array}$ \\
\hline
\end{tabular}




\begin{tabular}{|c|c|c|c|}
\hline Eil. nr. & Pavadinimas & Biblioteka, partneriai & Rèmèjai \\
\hline 37 & $\begin{array}{l}\text { Literatūriniai skaitymai „Mus jungia sèlių } \\
\text { žemé“ }^{\text {“ }}\end{array}$ & Rokiškio r. SVB & SV \\
\hline 38 & Gyvenk, man tavęs reikia & Rokiškio r. SVB & SV \\
\hline 39 & Išeivijos rašytoju kūrybos Aukštupiai & $\begin{array}{l}\text { Rokiškio r. SVB; } \\
\text { partneris - Juozo ir Alfonso } \\
\text { Keliuočių palikimo studijų } \\
\text { centras }\end{array}$ & SV \\
\hline 40 & $\begin{array}{l}\text { Rokiškio krašto literatu kūrybos almanacho } \\
\text { „Vaivorykšte“ “leidyba }\end{array}$ & Rokiškio r. SVB & SV \\
\hline 41 & $\begin{array}{l}\text { 19-oji Aukštaitijos regiono lèlių teatrų šventè } \\
\text { „Kai atgyja lèlès“ }\end{array}$ & Rokiškio r. SVB & SV \\
\hline 42 & $\begin{array}{l}\text { Grafų Komarovskiu gimtinès istorinè ir kultūri- } \\
n \dot{~ s k l a i d a ~(2015-2016 ~ m .) ~}\end{array}$ & $\begin{array}{l}\text { Rokiškio r. SVB; } \\
\text { partneris - Juozo ir Alfonso Ke- } \\
\text { liuočių palikimo studijų centras }\end{array}$ & SV \\
\hline 43 & Sveikatos vaivorykšte & Rokiškio r. SVB & SV \\
\hline \multicolumn{4}{|c|}{2016 metai } \\
\hline 1 & Europos diena Biržuose & Biržų r. SVB & EKAL \\
\hline 2 & $\begin{array}{l}\text { Kaimas kine, kinas kaime } \\
(2015-2016 \text { m.) [skirtas jaunimui] }\end{array}$ & Biržų r. SVB & $\begin{array}{l}\text { BMGF, KM [BP 2] } \\
\text { (finansavimas skirtas } \\
2015 \text { metais) }\end{array}$ \\
\hline 3 & $\begin{array}{l}\text { Teigiantis gyvenima [skirtas Balio Sruogos } \\
\text { 120-osioms gimimo metinèms] }\end{array}$ & Biržų r. SVB & LKT \\
\hline 4 & E. paslaugos arčiau namy & Biržų r. SVB & LKT \\
\hline 5 & $\begin{array}{l}\text { Virtuali ekskursija - Biržų pilis prieš šimtmečius } \\
\text { ir šiandien }\end{array}$ & $\begin{array}{l}\text { Biržų r. SVB; } \\
\text { partneriai: } \\
\text { Všt „3D Vilnius“, Biržų krašto } \\
\text { muziejus „Sèla“ }\end{array}$ & LKT \\
\hline 6 & Augu su knyga [tęstinis] & $\begin{array}{l}\text { Biržų r. SVB } \\
\text { Juostaviečių f.; } \\
\text { partneriai: Pačeriaukštės ir } \\
\text { Pasvaliečių filialai, Pačeriaukštès } \\
\text { ir Pasvaliečių kaimų bendruo- } \\
\text { menės }\end{array}$ & LKT \\
\hline 7 & $\begin{array}{l}\text { Bibliotekos - bendruomenems [skirtas krašto- } \\
\text { tyrai] }\end{array}$ & Kupiškio r. SVB & LKT \\
\hline 8 & $\begin{array}{l}\text { Fotografijos mokymai-paroda „Neatrastas Ku- } \\
\text { piškis (2015-2016 m.)“ }\end{array}$ & Kupiškio r. SVB & $\begin{array}{l}\text { LKT (finansavimas } \\
\text { skirtas } 2015 \text { metais) }\end{array}$ \\
\hline 9 & $\begin{array}{l}\text { Programa „Šeštadieninè mokyklèle 7-9 metu } \\
\text { amžiaus vaikams“ }\end{array}$ & Kupiškio r. SVB & $\begin{array}{l}\text { ES fondų investicijų } \\
\text { veiksmų programa } \\
\text { „Neformaliojo vaikų } \\
\text { švietimo paslaugų } \\
\text { plètra“ (administravo } \\
\text { Lietuvos mokinių } \\
\text { neformaliojo švietimo } \\
\text { centras) }\end{array}$ \\
\hline
\end{tabular}




\begin{tabular}{|c|c|c|c|}
\hline Eil. nr. & Pavadinimas & Biblioteka, partneriai & Rèmèjai \\
\hline 10 & Programa „Knygos bičiulių klubas“ & Kupiškio r. SVB & $\begin{array}{l}\text { ES fondų investicijų } \\
\text { veiksmų programa } \\
\text { „Neformaliojo vaikų } \\
\text { švietimo paslaugų } \\
\text { plėtra“ (administravo } \\
\text { Lietuvos mokinių ne- } \\
\text { formaliojo švietimo } \\
\text { centras) }\end{array}$ \\
\hline 11 & Programa „Eko dirbtuvèles“ & Kupiškio r. SVB & $\begin{array}{l}\text { ES fondų investicijų } \\
\text { veiksmų programa } \\
\text { „Neformaliojo vaikų } \\
\text { švietimo paslaugų } \\
\text { plètra“ (administravo } \\
\text { Lietuvos mokinių ne- } \\
\text { formaliojo švietimo } \\
\text { centras) }\end{array}$ \\
\hline 12 & $\begin{array}{l}\text { 3D: Domèkis. Dalyvauk. Dalinkis } \\
(2015-2016 \mathrm{~m} .)\end{array}$ & Panevėžio m. SVB & $\begin{array}{l}\text { BMGF, KM [BP 2] } \\
\text { (finansavimas skirtas } \\
2015 \text { metais) }\end{array}$ \\
\hline 13 & $\begin{array}{l}\text { Kompleksinè renginiu programa „Skaitantis } \\
\text { miestas“ }\end{array}$ & Panevėžio m. SVB & LKT \\
\hline 14 & Bibliotek@ - tavo šeimosnarys & $\begin{array}{l}\text { Panevėžio m. SVB } \\
\text { „Židinio“ f. }\end{array}$ & LKT \\
\hline 15 & Inovacija, kviečianti kurti & Panevėžio m. SVB & LKT \\
\hline 16 & $\begin{array}{l}\text { Skaitymo skatinimas ir kultūros sklaida miesto } \\
\text { bibliotekose [tęstinis] }\end{array}$ & Panevėžio m. SVB & SV \\
\hline 17 & Vasara su knyga miesto bibliotekose & Panevėžio $\mathrm{m}$. SVB & SV \\
\hline 18 & Literatūros ir meno kaleidoskopas [tęstinis] & Panevėžio $\mathrm{m}$. SVB & SV \\
\hline 19 & $\begin{array}{l}\text { Štai koks mano kaimas } \\
(2015-2016 \mathrm{~m} .)\end{array}$ & $\begin{array}{l}\text { Panevėžio r. SVB; } \\
\text { partneriai: Panevèžio r. } \\
\text { švietimo centras, Panevěžio r. } \\
\text { bendruomenių sąjunga }\end{array}$ & $\begin{array}{l}\text { BMGF, KM [BP 2] } \\
\text { (finansavimas skirtas } \\
2015 \text { metais) }\end{array}$ \\
\hline 20 & $\begin{array}{l}\text { Kultūriniai sambūriai menant Gabrielę Petke- } \\
\text { vičaitę-Bitę }\end{array}$ & Panevèžio r. SVB & LKT \\
\hline 21 & Programa „Modernus etnokultūrinis teatras“ & $\begin{array}{l}\text { Panevėžio r. SVB Naujaro- } \\
\text { džių f. }\end{array}$ & $\begin{array}{l}\text { ES finansinè parama } \\
\text { [nekonkretizuota], } \\
\text { SV }\end{array}$ \\
\hline 22 & Programa „Mes esam ETNO“ & Panevėžio r. SVB Raguvos f. & $\begin{array}{l}\text { ES finansinė parama } \\
\text { [nekonkretizuota], } \\
\text { SV }\end{array}$ \\
\hline 23 & $\begin{array}{l}\text { Pažinkime senoliu praeiti, pažinkime savo } \\
\text { kaima }\end{array}$ & Panevėžio $r$. SVB Raguvos f. & $\begin{array}{l}\text { ES finansinè parama } \\
\text { [nekonkretizuota], SV }\end{array}$ \\
\hline 24 & Programa „Etninès kultūros pažinimas“ & Panevėžio r. SVB Ramygalos f. & $\begin{array}{l}\text { ES finansinė parama } \\
\text { [nekonkretizuota], } \\
\text { SV }\end{array}$ \\
\hline 25 & $\begin{array}{l}\text { Edukaciniai vasaros užsièmimai „Žaislai atgyja } \\
\text { pasakose“ }\end{array}$ & Panevèžio r. SVB & SV \\
\hline
\end{tabular}




\begin{tabular}{|c|c|c|c|}
\hline Eil. nr. & Pavadinimas & Biblioteka, partneriai & Rèmèjai \\
\hline 26 & $\begin{array}{l}\text { Edukaciniai vasaros užsièmimai „Aktyvūs ir } \\
\text { kūrybingi“ }\end{array}$ & Panevėžio r. SVB Piniavos f. & SV \\
\hline 27 & Švęskime Europos dieną kartu & Pasvalio SVB & EKAL \\
\hline 28 & $\begin{array}{l}\text { Modernaus tarpvalstybinio vaiku ir jaunimo } \\
\text { verslumo kompetenciju ugdymo tinklo bibliote- } \\
\text { kose kūrimas (2015-2019 m.) }\end{array}$ & $\begin{array}{l}\text { Pasvalio SVB; } \\
\text { partneriai: Pasvalio r. savival- } \\
\text { dybès administracija } \\
\text { ir Bauskės savivaldybės admi- } \\
\text { nistracija (Latvija) }\end{array}$ & $\begin{array}{l}\text { Europos regioni- } \\
\text { nės plètros fondas } \\
\text { (Latvijos ir Lietuvos } \\
\text { bendradarbiavimo } \\
\text { per sieną programa } \\
\text { INTERREG V A) } \\
\text { (finansavimas skirtas } \\
2015 \text { metais) }\end{array}$ \\
\hline 29 & $\begin{array}{l}\text { Moderniu jaunimo erdviu „Mono arba Stereo“ } \\
\text { tinklo kūrimas (2015-2016 m.) }\end{array}$ & $\begin{array}{l}\text { Pasvalio SVB; } \\
\text { partneriai: Pasvalio r. savi- } \\
\text { valdybės švietimo ir sporto } \\
\text { skyrius, Panevežzio teritorinės } \\
\text { darbo biržos Pasvalio skyrius, } \\
\text { Pasvalio r. jaunimo organiza- } \\
\text { cijų sąunga „Apskritas stalas“, } \\
\text { Pasvalio verslininkų asociacija } \\
\text { „Verslo žiedas“, AB „Swedban- } \\
\text { kas“ Pasvalio klientų aptarna- } \\
\text { vimo padalinys ir kt. }\end{array}$ & $\begin{array}{l}\text { BMGF, KM (BP 2) } \\
\text { (finansavimas skirtas } \\
2015 \mathrm{~m} \text {.) }\end{array}$ \\
\hline 30 & Šiaurès verdenès [leidybos, tęstinis] & $\begin{array}{l}\text { Pasvalio SVB; } \\
\text { partnerè - žurnalo visuomeni- } \\
\text { nè redakcija }\end{array}$ & $\begin{array}{l}\text { Spaudos, radijo ir } \\
\text { televizijos rėmimo } \\
\text { fondas, SV, Pasvalio } \\
\text { krašto muziejaus, } \\
\text { SVB }\end{array}$ \\
\hline 31 & PASVALIOS modernizavimas ir plètra & Pasvalio SVB & LKT \\
\hline 32 & $\begin{array}{l}\text { Knyga+ [tikslas - sutelkti Pasvalio krašto bei } \\
\text { Panevež̌io regiono bendruomenès narius ben- } \\
\text { drai kultūrinei, meninei, pažintinei ir kūrybi- } \\
\text { nei veiklai] }\end{array}$ & Pasvalio SVB & LKT \\
\hline 33 & Europietiški susitikimai po lietuvišku ąžuolu & Rokiškio r. SVB & EKAL \\
\hline 34 & $\begin{array}{l}\text { Kultūrinè edukaciné programa „Lèlès atgyja } \\
\text { bibliotekoje“ }\end{array}$ & Rokiškio r. SVB & LKT, SV \\
\hline 35 & $\begin{array}{l}\text { Rokiškio krašto literatūriniai kelio pažinties } \\
\text { ženklai (II dalis) }\end{array}$ & Rokiškio r. SVB & LKT, SV \\
\hline 36 & Pasivaikščiojimai literatūros takais & Rokiškio r. SVB & LKT, SV \\
\hline 37 & Romuvos keliais [tęstinis] & $\begin{array}{l}\text { Rokiškio r. SVB; } \\
\text { partneris - Juozo ir Alfonso } \\
\text { Keliuočių palikimo studijų } \\
\text { centras }\end{array}$ & $\begin{array}{l}\text { Spaudos, radijo ir } \\
\text { televizijos remimo } \\
\text { fondas, SV }\end{array}$ \\
\hline 38 & Sèlių kultūra virtualioje erdvèje [tęstinis] & $\begin{array}{l}\text { Rokiškio r. SVB; } \\
\text { partneris - Juozo ir Alfonso } \\
\text { Keliuočių palikimo studijų } \\
\text { centras }\end{array}$ & $\begin{array}{l}\text { Spaudos, radijo ir TV } \\
\text { rèmimo fondas, } \mathrm{SV}\end{array}$ \\
\hline
\end{tabular}




\begin{tabular}{|c|c|c|c|}
\hline Eil. nr. & Pavadinimas & Biblioteka, partneriai & Rèmëjai \\
\hline 39 & $\begin{array}{l}\text { Grafu Komarovskiu gimtinès istorinè ir kultūri- } \\
\text { ne sklaida (2015-2016 m.) }\end{array}$ & $\begin{array}{l}\text { Rokiškio r. SVB; } \\
\text { partneris - Juozo ir Alfonso Ke- } \\
\text { liuočių palikimo studijų centras }\end{array}$ & $\begin{array}{l}\text { SV (finansavimas } \\
\text { skirtas } 2015 \mathrm{~m} \text {.) }\end{array}$ \\
\hline 40 & $\begin{array}{l}\text { Rokiškio krašto literatų kūrybos almanacho } \\
\text { „Vaivorykšté" leidyba }\end{array}$ & Rokiškio r. SVB & SV \\
\hline 41 & Poezijos pavasaris - 2016 & Rokiškio r. SVB & SV \\
\hline 42 & Padek sau - niekas kitas to nepadarys & Rokiškio r. SVB & SV \\
\hline 43 & $\begin{array}{l}\text { Sveika gyvensena - sveika bendruomené } \\
(2016-2017 \mathrm{~m} .)\end{array}$ & Rokiškio r. SVB Kavoliškio f. & SV \\
\hline 44 & Renginiu ciklas „Biblioteka - visu namai“ & Rokiškio r. SVB Obelių f. & SV \\
\hline \multicolumn{4}{|c|}{2017 metai } \\
\hline 1 & Europos diena Biržuose & Biržų r. SVB & EKAL \\
\hline 2 & $\begin{array}{l}\text { Sniego ilgesys [skirtas avangardo kino kūrèjo } \\
\text { Jono Meko 95-osioms metinėms] }\end{array}$ & Biržų r. SVB & LKT \\
\hline 3 & Sekmadienio kinas bibliotekoje & Biržų r. SVB & LKT \\
\hline 4 & $\begin{array}{l}\text { Informacinio-edukacinio terminalo ịrengimas } \\
\text { bibliotekoje }\end{array}$ & Biržų r. SVB & LKT \\
\hline 5 & Dirbantis europietis & Kupiškio r. SVB & EKAL \\
\hline 6 & Kupiškènai - Lietuvos istorijoje & Kupiškio r. SVB & $\begin{array}{l}\text { LKT, SV, SVB, UAB } \\
\text { „Kupiškènų mintys“, } \\
\text { Kupiškio kultūros } \\
\text { centras, Kupiškio } \\
\text { televizijos ir informa- } \\
\text { cijos centras, privatūs } \\
\text { rèmėjai }\end{array}$ \\
\hline 7 & $\begin{array}{l}\text { Prabylanti krašto istorija: interaktyvus žemé- } \\
\text { lapis }\end{array}$ & Kupiškio r. SVB & LKT \\
\hline 8 & $\begin{array}{l}\text { Vasaros ekspedicija [skirtas vaikų pažinčiai } \\
\text { su Kupiškio r. kultūros, istorijos ir gamtos } \\
\text { paminklais] }\end{array}$ & Kupiškio r. SVB & SV \\
\hline 9 & Metu knygos rinkimai & Kupiškio r. SVB & SV \\
\hline 10 & Programa „Knygu bičiuliu klubas 2“ & Kupiškio r. SVB & $\begin{array}{l}\text { ES fondų investicijų } \\
\text { veiksmų programa } \\
\text { „Neformaliojo vaikų } \\
\text { švietimo paslaugų } \\
\text { plètra“ (administravo } \\
\text { Lietuvos mokinių } \\
\text { neformaliojo švietimo } \\
\text { centras) }\end{array}$ \\
\hline 11 & Programa „Etno turistai“ & Kupiškio r. SVB & $\begin{array}{l}\text { ES fondų investicijų } \\
\text { veiksmų programa } \\
\text { „Neformaliojo vaikų } \\
\text { švietimo paslaugų } \\
\text { plètra“ (administravo } \\
\text { Lietuvos mokinių ne- } \\
\text { formaliojo švietimo } \\
\text { centras) }\end{array}$ \\
\hline
\end{tabular}




\begin{tabular}{|c|c|c|c|}
\hline Eil. nr. & Pavadinimas & Biblioteka, partneriai & Rèmèjai \\
\hline 12 & Programa „Eko dirbtuvèlès $2^{“}$ & Kupiškio r. SVB Skapiškio f. & $\begin{array}{l}\text { ES fondų investicijų } \\
\text { veiksmų programa } \\
\text { „Neformaliojo vaikų } \\
\text { švietimo paslaugų } \\
\text { plètra“ (administravo } \\
\text { Lietuvos mokinių ne- } \\
\text { formaliojo švietimo } \\
\text { centras) }\end{array}$ \\
\hline 13 & $\begin{array}{l}\text { E-žinios kiekvienam } 2 \text { [2013 m. vykdytas pro- } \\
\text { jektas E-žinios kiekvienam, kurị finansavo KM] }\end{array}$ & Panevėžio m. SVB & SV \\
\hline 14 & Prie vasaros varty & Panevėžio m. SVB & SV \\
\hline 15 & Vaikai ant vasaros ranku & Panevėžio m. SVB & SV \\
\hline 16 & Vasara su teta Bibliomile & Panevėžio m. SVB & SV \\
\hline 17 & Spalvota vasaros knyga & Panevėžio m. SVB & SV \\
\hline 18 & Mes norim, galim, padarysim & Panevėžio m. SVB & SV \\
\hline 19 & Literatūros ir meno kaleidoskopas [tęstinis] & Panevėžio m. SVB & SV \\
\hline 20 & $\begin{array}{l}\text { Skaitymo skatinimas ir kultūros sklaida miesto } \\
\text { bibliotekose [tęstinis] }\end{array}$ & Panevėžio m. SVB & SV \\
\hline 21 & $\begin{array}{l}\text { Savanoriai Panevéžio rajono savivaldybès viešo- } \\
\text { joje bibliotekoje }\end{array}$ & Panevėžio r. SVB & $\begin{array}{l}\text { ES „Aktyvaus jauni- } \\
\text { mo“ programa }\end{array}$ \\
\hline 22 & Kultūrinès interpretacijos: Puziniškio link & Panevėžio r. SVB & LKT, KM \\
\hline 23 & $\begin{array}{l}\text { Popietès Gustoniu bibliotekoje - UDC, vykdant } \\
\text { vaiku dienos centro veiklas (2017-2018 m.) }\end{array}$ & $\begin{array}{l}\text { Panevėžio r. SVB } \\
\text { Gustonių f. }\end{array}$ & $\begin{array}{l}\text { Socialinės apsaugos } \\
\text { ir darbo ministerija }\end{array}$ \\
\hline 24 & $\begin{array}{l}\text { Lietuviško kino seansai valstybès atkūrimo šimt- } \\
\text { mečio išvakarèse }\end{array}$ & Panevėžio r. SVB & LKT, SV \\
\hline 25 & $\begin{array}{l}\text { Biblioteka augina skaitytoją: „Maminukų aka- } \\
\text { demija“(2017-2018 m.) }\end{array}$ & Panevėžio r. SVB & LKT, KM \\
\hline 26 & Svaigintis - žalinga ir nemadinga & Panevėžio r. SVB & SV \\
\hline 27 & Grynas oras - švari gamta & Panevėžio r. SVB Berniūnų f. & SV \\
\hline 28 & Menas - sveikatai & Panevėžio r. SVB Miežiškių f. & SV \\
\hline 29 & Sveikata - tautos pamatas & $\begin{array}{l}\text { Panevėžio r. SVB Naujamies- } \\
\text { čio f. }\end{array}$ & SV \\
\hline 30 & Programa „Savišvietos akademija“ & $\begin{array}{l}\text { Panevėžio r. SVB centrinè } \\
\text { biblioteka, Paįstrio f. }\end{array}$ & SV \\
\hline 31 & Programa „Su pasaka i gyvenima“ & Panevėžio r. SVB Paliūniškio f. & SV \\
\hline 32 & Programa „Mes esam ETNO“ & Panevėžio r. SVB Raguvos f. & SV \\
\hline 33 & $\begin{array}{l}\text { Programa „Etninès kultūros pažinimas“ } \\
(2017-2018 \mathrm{~m} .)\end{array}$ & Panevėžio r. SVB Ramygalos f. & SV \\
\hline 34 & $\begin{array}{l}\text { Programa „Jaunieji krašto tyrinètojai } \\
(2017-2018 \mathrm{~m} .)\end{array}$ & Panevėžio r. SVB Velžio f. & SV \\
\hline 35 & $\begin{array}{l}\text { Vaikų vasaros poilsio projektas „Senovinių } \\
\text { lietuviškų žaidimų dirbtuves" }\end{array}$ & Panevėžio r. SVB Velžio f. & SV \\
\hline 36 & $\begin{array}{l}\text { Žinok, pažink ir dalinkis! [skirtas Europos } \\
\text { dienai] }\end{array}$ & Pasvalio SVB & EKAL \\
\hline
\end{tabular}




\begin{tabular}{|c|c|c|c|}
\hline Eil. nr. & Pavadinimas & Biblioteka, partneriai & Rèmèjai \\
\hline 37 & $\begin{array}{l}\text { Modernaus tarpvalstybinio vaiku ir jaunimo } \\
\text { verslumo kompetencijų ugdymo tinklo bibliote- } \\
\text { kose kūrimas (2015-2019 m.) }\end{array}$ & $\begin{array}{l}\text { Pasvalio SVB; } \\
\text { partnerės: Pasvalio r. savivaldy- } \\
\text { bės administracija, } \\
\text { Bauskės savivaldybės administ- } \\
\text { racija (Latvija) }\end{array}$ & $\begin{array}{l}\text { Europos regioni- } \\
\text { nės plètros fondas } \\
\text { (Latvijos ir Lietuvos } \\
\text { bendradarbiavimo } \\
\text { per sieną programa } \\
\text { INTERREG V-A) } \\
\text { (finansavimas skirtas } \\
2015 \text { metais) }\end{array}$ \\
\hline 38 & $\begin{array}{l}\text { Informacijos pasaulyje: suprask, vertink, nau- } \\
\text { dok (2017-2018 m.) }\end{array}$ & Pasvalio SVB & LKT, KM \\
\hline 39 & $\begin{array}{l}\text { Literatūros dienos ir naktys 2017: skaitymo } \\
\text { prieskoniai }\end{array}$ & Pasvalio SVB & LKT, KM \\
\hline 40 & $\begin{array}{l}\text { Rašytojo Mariaus Katiliškio kūrybinio palikimo } \\
\text { aktualizavimas ir populiarinimas, naudojant } \\
\text { inovatyvias ir interaktyvias technologijas }\end{array}$ & Pasvalio SVB & LKT, KM \\
\hline 41 & $\begin{array}{l}\text { Biblioteka ir bendruomenè: istoriju tiltai } \\
\text { [tikslas - telkti ir skatinti bendruomenès } \\
\text { narius bendrai kultūrinei, meninei, pažintinei, } \\
\text { edukacinei, kūrybinei veiklai; gilinti žinias apie } \\
\text { kultūros procesus, valstybės ir krašto istoriją] }\end{array}$ & Pasvalio SVB & LKT, KM \\
\hline 42 & Šiaurès verdenès [leidybos; tęstinis] & $\begin{array}{l}\text { Pasvalio SVB; } \\
\text { partnerè - žurnalo visuomeni- } \\
\text { nè redakcija }\end{array}$ & $\begin{array}{l}\text { Spaudos, radijo ir } \\
\text { televizijos rèmimo } \\
\text { fondas, SV, Pasvalio } \\
\text { krašto muziejaus, } \\
\text { SVB }\end{array}$ \\
\hline 43 & $\begin{array}{l}\text { Kino dienos Pasvalio krašte 2017: lietuviško } \\
\text { kino atradimai }\end{array}$ & Pasvalio SVB & $\mathrm{LKT}$ \\
\hline 44 & Renginių ciklas „Europos knyga - Rokiškyje“ & Rokiškio r. SVB & EKAL \\
\hline 45 & $\begin{array}{l}\text { Verslo paramos sistemos kūrimas ir prieinamu- } \\
\text { mas Žiemgaloje, Kuržemèje ir Šiaurés Lietuvoje } \\
(2017-2019 \text { m.) }\end{array}$ & $\begin{array}{l}\text { Rokiškio r. SVB; } \\
\text { partneriai: V̌̌t Žiemgalės pla- } \\
\text { navimo regionas, } \\
\text { Všt Kuržemės planavimo } \\
\text { regionas, Latvijos kaimo verslo } \\
\text { konsultavimo ir mokymų } \\
\text { centras, Aizkrauklės savival- } \\
\text { dybė (Latvija), Šiaulių verslo } \\
\text { inkubatorius, Panevěžio verslo } \\
\text { konsultacinis centras }\end{array}$ & $\begin{array}{l}\text { Europos regioni- } \\
\text { nės plètros fondas } \\
\text { (INTERREG V-A } \\
\text { Latvijos ir Lietuvos } \\
\text { bendradarbiavimo } \\
\text { per sieną programa) }\end{array}$ \\
\hline 46 & $\begin{array}{l}\text { Bibliotekos tradicijos ir inovacijos laiko sūpuo- } \\
\text { klèse [tikslas - sukurti krašto kūrèjus (lietuvių } \\
\text { literatūros klasikus) pristatančią, tradicijomis } \\
\text { ir šiuolaikinèmis technologijomis bei inovaci- } \\
\text { jomis pagrịstą bibliotekos paslaugų infrastruk- } \\
\text { tūrą] }\end{array}$ & Rokiškio r. SVB & LKT, SV \\
\hline 47 & $\begin{array}{l}\text { Lietuvos kodas - lietuviu kalba [skirtas } \\
\text { jaunimui] }\end{array}$ & Rokiškio r. SVB & LKT, SV \\
\hline 48 & Rokiškio krašto garbès piliečiai (CD leidyba) & Rokiškio r. SVB & LKT, SV \\
\hline
\end{tabular}




\begin{tabular}{|c|c|c|c|}
\hline Eil. nr. & Pavadinimas & Biblioteka, partneriai & Rèmèjai \\
\hline 49 & Romuvos keliais [tęstinis] & $\begin{array}{l}\text { Rokiškio r. SVB; } \\
\text { partneris - Juozo ir Alfonso } \\
\text { Keliuočių palikimo studijų } \\
\text { centras }\end{array}$ & $\begin{array}{l}\text { Spaudos, radijo ir } \\
\text { televizijos remimo } \\
\text { fondas, } \mathrm{SV}\end{array}$ \\
\hline 50 & Sèlių kultūra virtualioje erdvèje [tęstinis] & $\begin{array}{l}\text { Rokiškio r. SVB; } \\
\text { partneris - Juozo ir Alfonso } \\
\text { Keliuočių palikimo studijų } \\
\text { centras }\end{array}$ & $\begin{array}{l}\text { Spaudos, radijo ir } \\
\text { televizijos rèmimo } \\
\text { fondas, SV }\end{array}$ \\
\hline 51 & Neužsimerkime, kai skriaudžiami vaikai & Rokiškio r. SVB & SV \\
\hline 52 & Bibliotekos istorijos leidyba & Rokiškio r. SVB & SV \\
\hline 53 & $\begin{array}{l}\text { Sveika gyvensena - sveika bendruomene } \\
(2016-2017 \mathrm{~m} .)\end{array}$ & Rokiškio r. SVB Kavoliškio f. & $\begin{array}{l}\text { SV (finansavimas } \\
\text { skirtas } 2016 \text { metais) }\end{array}$ \\
\hline 54 & $\begin{array}{l}\text { Neformalus suaugusiujų švietimas [anglų kal- } \\
\text { bos kursai] }\end{array}$ & Rokiškio r. SVB & SV \\
\hline
\end{tabular}

6 priedas. Utenos apskr. savivaldybių viešųjų bibliotekų 2007, 2013, 2015-2017 metų projektai

\begin{tabular}{|c|c|c|c|}
\hline Eil. nr. & Pavadinimas & Biblioteka, partneriai & Rèmèjai \\
\hline 1 & Skirtingi, bet panašūs [skirtas literatūrai] & Anykščių r. SVB & KM \\
\hline 2 & 100 bibliotekos Anykščiuose gyvavimo metu & Anykščių r. SVB & KSRF \\
\hline 3 & Atmintis. Sinagogu aikštè & Anykščių r. SVB & SV \\
\hline 4 & Poezijos pavasaris - 2007 & Anykščių r. SVB & SV \\
\hline 5 & Atraskime laiko tobuleti jau šiandien & Anykščių r. SVB & SV \\
\hline 6 & Vaikų rašytojai Astridai Lindgren - 100 & Anykščių r. SVB & SV \\
\hline 7 & Pasaulis telpa delne & Anykščių r. SVB & SV \\
\hline 8 & Su knyga... & $\begin{array}{l}\text { Anykščių r. SVB } \\
\text { Andrioniškio f. }\end{array}$ & SV \\
\hline 9 & Skaityk, netingèk, o paskaitęs pakrutèk & $\begin{array}{l}\text { Anykščių r. SVB } \\
\text { Ažuožerių f. }\end{array}$ & SV \\
\hline 10 & Skaityk. Pažink. Mėgaukis & $\begin{array}{l}\text { Anykščių r. SVB } \\
\text { Debeikių f. }\end{array}$ & SV \\
\hline 11 & Kas namelyje gyvena & $\begin{array}{l}\text { Anykščių r. SVB } \\
\text { Elmininkų f. }\end{array}$ & SV \\
\hline 12 & Laiko vingiuose & $\begin{array}{l}\text { Anykščių r. SVB } \\
\text { Kavarsko f. }\end{array}$ & SV \\
\hline 13 & Už rankos vesim vasara ir knyga & Anykščių r. SVB Kurklių f. & SV \\
\hline 14 & $\begin{array}{l}\text { Išgirsk ir pamatyk, ką tau sako mūsų senolių } \\
\text { praeitis... }\end{array}$ & $\begin{array}{l}\text { Anykščių r. SVB } \\
\text { Rubikių f. }\end{array}$ & SV \\
\hline 15 & Biblioteka - viešo bendruomenès gyvenimo erdve & $\begin{array}{l}\text { Anykščių r. SVB } \\
\text { Svėdasų f. }\end{array}$ & SV \\
\hline 16 & Išširdies $i$ širdị [dailès edukacija vaikams] & Anykščių r. SVB Šerių f. & SV \\
\hline 17 & Tiltas tarp rašytojo ir skaitytojo & Anykščių r. SVB Troškūnų f. & SV \\
\hline 18 & $\begin{array}{l}\text { Kūrybinio jaunimo sambūris [literatūros; } \\
\text { tęstinis] }\end{array}$ & $\begin{array}{l}\text { Molètų r. SVB; } \\
\text { partnerè - Molètų rajono } \\
\text { literatų brolija }\end{array}$ & KM, SV \\
\hline
\end{tabular}




\begin{tabular}{|c|c|c|c|}
\hline Eil. nr. & Pavadinimas & Biblioteka, partneriai & Rèmèjai \\
\hline 19 & $\begin{array}{l}\text { Molètų rajono literatūrinio palikimo populiari- } \\
\text { nimas [tęstinis] }\end{array}$ & Molètų r. SVB & KM \\
\hline 20 & $\begin{array}{l}\text { Olandijos skaitymo patirtis Dapkūniškiu kaime } \\
\text { [skirtas vaikams ir jaunimui] }\end{array}$ & Molètų r. SVB Dapkūniškių f. & KM \\
\hline 21 & Vaikų klubo „Knyggraužiai“ ikūrimas & Molètų r. SVB Giedraičių f. & KM \\
\hline 22 & Lietuviu rašytojai - vaikams ir jaunimui & Molètų r. SVB Inturkès f. & KM \\
\hline 23 & Atverkim langa i knygu pasauli & Molètų r. SVB Mindūnų f. & KM \\
\hline 24 & Skaitau. Kuriu. Džiaugiuosi & Molètų r. SVB Suginčių f. & KM \\
\hline 25 & $\begin{array}{l}\text { Skaitymo skatinimo renginiai Utenos A. ir } \\
\text { M. Miškiniu viešosios bibliotekos kaimo filialuose }\end{array}$ & Utenos SVB & KM, SV \\
\hline 26 & $\begin{array}{l}\text { Portalo „Utenos kraštas“ atnaujinimas [techno- } \\
\text { loginis projektas] }\end{array}$ & Utenos SVB & [nenurodyta] \\
\hline 27 & $\begin{array}{l}\text { Nakties pasakų skaitymai „Žvaigždètoj pasakų } \\
\text { šaly“ }\end{array}$ & Utenos SVB & [nenurodyta] \\
\hline 28 & $\begin{array}{l}\text { Utenos rajono biblioteku darbuotoju dalyvavi- } \\
\text { mas seminare Torunès (Lenkija) universiteto } \\
\text { bibliotekoje }\end{array}$ & Utenos SVB & [nenurodyta] \\
\hline 29 & Dvieju seminary organizavimas & Utenos SVB & [nenurodyta] \\
\hline 30 & $\begin{array}{l}\text { Renginiai, skirti visuomenès skaitymo skatini- } \\
\text { mui, kultūros ir kraštotyros veiklos sklaidai }\end{array}$ & Utenos SVB & [nenurodyta] \\
\hline 31 & Skaitymas „veža!“ & Visagino SVB & KM \\
\hline 32 & $\begin{array}{l}\text { Lietuvos šiaurès rytu Aukštaitija - kur mūsu } \\
\text { proseneliai gyveno }\end{array}$ & Visagino SVB & [nenurodyta] \\
\hline 33 & $\begin{array}{l}\text { Lietuvos šiaurès rytu Aukštaitijos kultūros pavel- } \\
\text { do paminklai }\end{array}$ & Visagino SVB & [nenurodyta] \\
\hline 34 & $\begin{array}{l}\text { Vaiku socializacijos programa „Vasaros skaitykla } \\
\text { moksleiviams“ }\end{array}$ & Visagino SVB & [nenurodyta] \\
\hline 35 & Kürybiné stovykla „Vasara graži kaip Zarasai“ & $\begin{array}{l}\text { Zarasų r. SVB; } \\
\text { partneris - Zarasų krašto } \\
\text { muziejus }\end{array}$ & ŠMM \\
\hline 36 & Pažink kraštiečius virtualioje erdvejje & Zarasų r. SVB & KM \\
\hline 37 & Literatūrinè programa „Nešami mūzos sparnü“ & Zarasų r. SVB & KM \\
\hline 38 & $\begin{array}{l}\text { Edukacinès vasaros skaitymo skatinimo progra- } \\
\text { mos igyvendinimas Zarasų viešojoje bibliotekoje }\end{array}$ & Zarasų r. SVB & KSRF \\
\hline 39 & $\begin{array}{l}\text { Programa „Skaitymo ménuo „Pagauk mane“ } \\
\text { Zarasu viešojoje bibliotekoje“ }\end{array}$ & Zarasų r. SVB & KM \\
\hline \multicolumn{4}{|c|}{2013 metai } \\
\hline 1 & $\begin{array}{l}\text { Europos diena Anykščiuose „Pilieti, ar žinai savo } \\
\text { teises?" }\end{array}$ & Anykščių r. SVB & EKAL \\
\hline 2 & $\begin{array}{l}\text { Po meilès Anykščiams sparnu [skirtas Pasaulio } \\
\text { anykštėnų metams] }\end{array}$ & Anykščių r. SVB & [nenurodyta] \\
\hline 3 & Skaityti - save ir pasaulị pažinti & Anykščių r. SVB & [nenurodyta] \\
\hline 4 & Mèlynojo drugelio inscenizacija & Anykščių r. SVB Ažuožerių f. & [nenurodyta] \\
\hline 5 & Vaiku užimtumo vasaros stovykla & Anykščių r. SVB Ažuožerių f. & [nenurodyta] \\
\hline 6 & $\begin{array}{l}\text { Jauno žmogaus akimis [skirtas vaikų ir jaunimo } \\
\text { kūrybinei meninei veiklai skatinti] }\end{array}$ & Ignalinos r. SVB & KM \\
\hline
\end{tabular}




\begin{tabular}{|c|c|c|c|}
\hline Eil. nr. & Pavadinimas & Biblioteka, partneriai & Rèmèjai \\
\hline 7 & Literatūriniai etiudai Ignalinoje - 5 [tęstinis] & Ignalinos r. SVB & KRF \\
\hline 8 & $\begin{array}{l}\text { Tarme - gyvoji kalbos versmé } \\
(2012-2013 \mathrm{~m} .)\end{array}$ & Molètų r. SVB & KM, SV \\
\hline 9 & Kūrybinio jaunimo sambūris [tęstinis] & $\begin{array}{l}\text { Molètų r. SVB; } \\
\text { partnerè - Molètų r. literatų } \\
\text { brolija }\end{array}$ & KRF, SV \\
\hline 10 & Mokykimés gyventi sveikai [tęstinis] & Molètų r. SVB Inturkès f. & SV \\
\hline 11 & Europos informacijos centro įkūrimas & Utenos SVB & EKAL \\
\hline 12 & Žaisdami mokomès [tęstinis] & Utenos SVB & EIFL fondas \\
\hline \multirow[t]{2}{*}{13} & $\begin{array}{l}\text { Maistas kūnui, protui ir sielai - sutelkime Euro- } \\
\text { pa aplink stala (2013-2014 m.) }\end{array}$ & $\begin{array}{l}\text { Utenos SVB; } \\
\text { partnerės: Italijos, Jungti- } \\
\text { nės Karalystės, Portugalijos, } \\
\text { Lenkijos, Vokietijos ir Turkijos } \\
\text { institucijos (Miedzynarodowe }\end{array}$ & $\begin{array}{l}\text { Švietimo mainų para- } \\
\text { mos fondas („Grund- } \\
\text { tvig“" programa ) }\end{array}$ \\
\hline & & $\begin{array}{l}\text { Towarzystwo Swiadomosci } \\
\text { Kryszny, Piasečnas, Lenkija; } \\
\text { Akademie für Management, } \\
\text { Kaselis, Vokietija ir kt.) }\end{array}$ & \\
\hline 14 & Knygos paraiška gyventi kartu bendrystejje & Utenos SVB & KM \\
\hline 15 & $\begin{array}{l}\text { Efektyvus technologiju naudojimas: neatrastos } \\
\text { galimybės mokymuisi, laisvalaikiui ir kūrybai }\end{array}$ & $\begin{array}{l}\text { Utenos SVB; } \\
\text { partneriai: Anykščių r. SVB, } \\
\text { Ignalinos r. SVB, Molètų r. } \\
\text { SVB, Visagino SVB, Zarasų r. } \\
\text { SVB, VU Komunikacijos } \\
\text { fakultetu, VGTU leidyklos } \\
\text { „Technika“ elektroninès } \\
\text { leidybos skyrius, VšI „Skai- } \\
\text { tmeninių bendruomenių link“, } \\
\text { VšIt Informacijos technologijų } \\
\text { mokymo centras }\end{array}$ & KM \\
\hline 16 & $\begin{array}{l}\text { Gyvojo žodžio sukviesti [skirtas Tarmių } \\
\text { metams] }\end{array}$ & Utenos SVB & $\mathrm{KRF}$ \\
\hline 17 & $\begin{array}{l}\text { Skaitymo skatinimas panaudojant informa- } \\
\text { cines technologijas ir kūrybinę veiklą (Zara- } \\
\text { sai - Daugpilis) (2012-2013 m.) [sutrumpintas } \\
\text { pavadinimas „Skaitymas - IT - Kūryba“] }\end{array}$ & $\begin{array}{l}\text { Zarasų r. SVB; } \\
\text { partneré - Latgalès centrinè } \\
\text { biblioteka (Latvija) }\end{array}$ & $\begin{array}{l}\text { Europos regioni- } \\
\text { nės plètros fondas } \\
\text { (Latvijos ir Lietuvos } \\
\text { bendradarbiavimo } \\
\text { per sieną programa } \\
\text { „INTERREG V-A } \\
\text { Latvia Lithuania“) }\end{array}$ \\
\hline 18 & $\begin{array}{l}\text { Mobilus mokymo centras kaimo bendruomeniu } \\
\text { švietimui (2012-2014 m.) }\end{array}$ & Zarasų r. SVB & $\begin{array}{l}\text { Europos žemės ūkio } \\
\text { fondas kaimo plètrai } \\
\text { (LEADER programa) }\end{array}$ \\
\hline 19 & Knygos šventè Zarasuose [tęstinis] & Zarasų r. SVB & KRF \\
\hline 20 & Vasarą skaitome kitaip [tęstinis] & Zarasų r. SVB & $\mathrm{KRF}$ \\
\hline 21 & $\begin{array}{l}\text { Mokslinè konferencija „Tarmiu gyvastis ir ịtaka } \\
\text { šiaurrytinei aukštaičiu šnektai: tarmiu analizè, da- } \\
\text { bartine situacija - ịtaka ir šnektos metamorfozès“ }\end{array}$ & Zarasų r. SVB & KRF \\
\hline
\end{tabular}




\begin{tabular}{|c|c|c|c|}
\hline Eil. nr. & Pavadinimas & Biblioteka, partneriai & Rèmèjai \\
\hline \multicolumn{4}{|c|}{2015 metai } \\
\hline 1 & Europa vienu ritmu & Anykščių r. SVB & EKAL \\
\hline 2 & $\begin{array}{l}\text { Ideju laboratorija: saviraiškos ir realizacijos } \\
\text { erdve (2015-2016 m.) }\end{array}$ & Anykščių r. SVB & BMGF, KM [BP 2] \\
\hline 3 & $\begin{array}{l}\text { Literatūriniai maršrutai anykštènams ir sve- } \\
\text { čiams: gidai - rašytojai, išmanioji programa }\end{array}$ & Anykščių r. SVB & LKT \\
\hline 4 & Knyga gyva: šiuolaikinès formos ir tradicijos & Anykščių r. SVB & LKT, SV \\
\hline 5 & Poezija vaikams „Vaikiškas parkas“ & Anykščių r. SVB & SV \\
\hline 6 & $\begin{array}{l}\text { Biblioteka - didelis, šviečiantis ir skaitantis } \\
\text { jonvabalis }\end{array}$ & Anykščių r. SVB & SV \\
\hline 7 & Lèlių teatrą kuria vaikai & Anykščių r. SVB Ažuožerių f. & SV \\
\hline 8 & Knygu lobynas atviras visiems & Anykščių r. SVB Kavarsko f. & SV \\
\hline 9 & $\begin{array}{l}\text { Kokia graži aukštaičiu žemè, tik neužkalkime } \\
\text { joje langu }\end{array}$ & Anykščių r. SVB Kurklių f. & SV \\
\hline 10 & Tegul atgyja šiaudinukai & Anykščių r. SVB Svėdasų f. & SV \\
\hline 11 & Mes - europiečiai & Ignalinos r. SVB & EKAL \\
\hline 12 & $\begin{array}{l}\text { Kultūrinis bendradarbiavimas tarp Ignalinos } \\
\text { rajono savivaldybès viešosios bibliotekos (Lietu- } \\
\text { va) ir Estfoldo apskrities bibliotekos (Norvegija), } \\
\text { siekiant skaitmeninti kraštotyra } \\
(2015-2016 \text { m.) }\end{array}$ & Ignalinos r. SVB & $\begin{array}{l}\text { Europos ekonomi- } \\
\text { nės erdvès programa } \\
\text { „Europos kultūros pa- } \\
\text { veldo kultūros ir menų } \\
\text { įvairovès skatinimas“ }\end{array}$ \\
\hline 13 & $\begin{array}{l}\text { Vidutinio, vyresnio ir pagyvenusio amžiaus žmo- } \\
\text { nių informacinių, socialiniu ir sveikatingumo } \\
\text { igūdžių ugdymas naudojant naujausias kompiu- } \\
\text { terines technologijas Ignalinos rajono ir Visagino } \\
\text { miesto bibliotekose (2015-2016 m.) }\end{array}$ & $\begin{array}{l}\text { Ignalinos r. SVB; } \\
\text { partnere - Visagino SVB }\end{array}$ & BMGF, KM (BP 2) \\
\hline 14 & $\begin{array}{l}\text { Inovatyvių technologiju ir kūrybiškumo taikymas } \\
\text { populiarinant bibliotekos paslaugas jaunimui }\end{array}$ & Ignalinos r. SVB & LKT \\
\hline 15 & $\begin{array}{l}\text { Tolimi kraštai - artimi gyvenimai. prisidekime } \\
\text { ir mes! }\end{array}$ & $\begin{array}{l}\text { Molètų r. SVB; } \\
\text { partneriai: Molètų r. savival- } \\
\text { dybės administracija, Molètų } \\
\text { švietimo centras, Molètų tu- } \\
\text { rizmo ir informacijos centras, } \\
\text { Molètų menų mokykla ir kt. }\end{array}$ & EKAL \\
\hline 16 & $\begin{array}{l}\text { Sutrikusios raidos vaikų bendrujų gebejiimų ir } \\
\text { socialiniu igūdžių ugdymas bibliotekose panau- } \\
\text { dojant tikslinius žaidimus bei kompiuterines ir } \\
\text { aplinkos technologijas (2015-2016 m.) }\end{array}$ & $\begin{array}{l}\text { Utenos SVB; } \\
\text { partneriai: Vilniaus universi- } \\
\text { teto Matematikos ir informati- } \\
\text { kos institutas, Šiaulių universi- } \\
\text { tetas, VšI „Hiteco“, UAB „Gluk } \\
\text { Media“ }\end{array}$ & BMGF, KM [BP 2] \\
\hline 17 & Pažintis su lietuvišku kinu bibliotekoje & Utenos SVB & LKT \\
\hline 18 & $\begin{array}{l}\text { Atminties institucija - inovatyvi mokymo erdvé } \\
\text { jaunimui }(2015-2016 \mathrm{m.})\end{array}$ & $\begin{array}{l}\text { Utenos SVB; } \\
\text { partneriai: Lietuvos regionų } \\
\text { bibliotekų asociacija, Vilniaus } \\
\text { universiteto Komunikacijos } \\
\text { fakultetas, VšI „Creativitas“, } \\
\text { UAB „Ženkliukų amatas“ }\end{array}$ & LKT \\
\hline
\end{tabular}




\begin{tabular}{|c|c|c|c|}
\hline Eil. nr. & Pavadinimas & Biblioteka, partneriai & Rèmèjai \\
\hline 19 & $\begin{array}{l}\text { Antanas Miškinis - Utenai ir pasauliui [skirtas } \\
\text { jaunimui] }\end{array}$ & Utenos SVB & LKT \\
\hline 20 & Utenos krašto tarmé atgimsta animacijoje & Utenos SVB & LKT \\
\hline 21 & Skaito vaikai, kalba lèlès - 2 [tęstinis] & Visagino SVB & LKT \\
\hline 22 & $\begin{array}{l}\text { Imki su šypsena - duoki su mintimi [skirtas } \\
\text { Europos dienai] }\end{array}$ & Zarasų r. SVB & EKAL \\
\hline 23 & $\begin{array}{l}\text { Kürybiniu idejų igyvendinimas judriojoje medijų } \\
\text { studijoje (2015-2016 m.) }\end{array}$ & $\begin{array}{l}\text { Zarasų r. SVB, } \\
\text { VšI Zarasų jaunimo centras, } \\
\text { Zarasų meno mokykla }\end{array}$ & BMGF, KM [BP 2] \\
\hline 24 & Knygos šventè Zarasuose [tęstinis] & Zarasų r. SVB & LKT \\
\hline 25 & Vasarq skaitome kitaip 3 [tęstinis] & Zarasų r. SVB & LKT \\
\hline 26 & $\begin{array}{l}\text { Pasaulis pagal poetus romantikus (Antana } \\
\text { Vienažindį, Faustą Kiršą, Paulių Širvį ir Petrą } \\
\text { Gaulę) }\end{array}$ & Zarasų r. SVB & LKT \\
\hline \multicolumn{4}{|c|}{2016 metai } \\
\hline 1 & $\begin{array}{l}\text { Idejų laboratorija: saviraiškos ir realizacijos } \\
\text { erdvé (2015-2016 m.) }\end{array}$ & Anykščių r. SVB & $\begin{array}{l}\text { BMGF, KM [BP 2] } \\
\text { (finansavimas skirtas } \\
2015 \text { metais) }\end{array}$ \\
\hline 2 & Istorijos ir žmonès: pasakojimai bibliotekoje & Anykščių r. SVB & KM \\
\hline 3 & $\begin{array}{l}\text { Anykščiu kraštotyrininkų biobibliografinis žody- } \\
\text { nas [leidybos] }\end{array}$ & Anykščių r. SVB & SV \\
\hline 4 & Tautų ìvairovè [skirtas Europos dienai] & Ignalinos r. SVB & EKAL \\
\hline 5 & $\begin{array}{l}\text { Vidutinio, vyresnio ir pagyvenusio amžiaus žmo- } \\
\text { niu informacinių, socialiniu ir sveikatingumo } \\
\text { igūdžių ugdymas naudojant naujausias kompiu- } \\
\text { terines technologijas Ignalinos rajono ir Visagino } \\
\text { miesto bibliotekose }(2015-2016 \mathrm{~m} \text {.) }\end{array}$ & $\begin{array}{l}\text { Ignalinos r. SVB; } \\
\text { partnerè - Visagino SVB }\end{array}$ & $\begin{array}{l}\text { BMGF, KM [BP 2] } \\
\text { (finansavimas skirtas } \\
2015 \text { metais) }\end{array}$ \\
\hline 6 & $\begin{array}{l}\text { Kultūrinis bendradarbiavimas tarp Ignalinos } \\
\text { rajono savivaldybés viešosios bibliotekos (Lietu- } \\
\text { va) ir Estfoldo apskrities bibliotekos (Norvegija), } \\
\text { siekiant skaitmeninti kraštotyra } \\
(2015-2016 \text { m.) }\end{array}$ & Ignalinos r. SVB & $\begin{array}{l}\text { Europos ekonominès } \\
\text { erdvės programa } \\
\text { „Europos kultūros } \\
\text { paveldo kultūros ir } \\
\text { menu ivvairovės skati- } \\
\text { nimas“ (finansavimas } \\
\text { skirtas } 2015 \text { metais) }\end{array}$ \\
\hline 7 & Mano dienoraščio puslapiai [literatūros] & Ignalinos r. SVB & LKT \\
\hline 8 & Europos diena šveskime kartu! & Molètų r. SVB & EKAL \\
\hline 9 & $\begin{array}{l}\text { Literatūriniai susitikimai. Pamilti literatūrą - } \\
\text { pamilti gyvenima }\end{array}$ & Molètų r. SVB & LKT, SV \\
\hline 10 & $\begin{array}{l}\text { Sutrikusios raidos vaiku bendruju gebejimu ir } \\
\text { socialiniu igūdžiu ugdymas bibliotekose panau- } \\
\text { dojant tikslinius žaidimus bei kompiuterines ir } \\
\text { aplinkos technologijas (2015-2016 m.) }\end{array}$ & $\begin{array}{l}\text { Utenos SVB; } \\
\text { partneriai - Vilniaus universi- } \\
\text { teto Matematikos ir informati- } \\
\text { kos institutas, Šiaulių universi- } \\
\text { tetas, V̌̌I „Hiteco“, UAB „Gluk } \\
\text { Media“ }\end{array}$ & $\begin{array}{l}\text { BMGF, KM [BP 2] } \\
\text { (finansavimas skirtas } \\
2015 \text { metais) }\end{array}$ \\
\hline
\end{tabular}




\begin{tabular}{|c|c|c|c|}
\hline Eil. nr. & Pavadinimas & Biblioteka, partneriai & Rèmèjai \\
\hline 11 & $\begin{array}{l}\text { Atminties institucija - inovatyvi mokymo erdve } \\
\text { jaunimui (2015-2016 m.) }\end{array}$ & $\begin{array}{l}\text { Utenos SVB; } \\
\text { partneriai: Lietuvos regio- } \\
\text { nų bibliotekų asociacijos, } \\
\text { Vilniaus universiteto Ko- } \\
\text { munikacijos fakultetas, VšI } \\
\text { „Creativitas“, UAB „Ženkliukų } \\
\text { amatas“ }\end{array}$ & $\begin{array}{l}\text { LKT (finansavimas } \\
\text { skirtas } 2015 \text { metais) }\end{array}$ \\
\hline 12 & Skaitmeninés atminties pamokos senjorams & Utenos SVB & ŠMM \\
\hline 13 & $\begin{array}{l}\text { Kultūra kitaip: malonūs atradimai savame kraš- } \\
\text { te [numatè interaktyvaus maršruto sukūrimą } \\
\text { krašto etninei kultūrai pažinti] }\end{array}$ & Utenos SVB & LKT \\
\hline 14 & Biblioteka - kultūros vartai & Utenos SVB & LKT \\
\hline 15 & $\begin{array}{l}\text { Literatūrinè relaksacija bibliotekoje [skirtas } \\
\text { vaikams] }\end{array}$ & Utenos SVB & LKT \\
\hline 16 & $\begin{array}{l}\text { Tarptautinè poezijos šventè literatūrine Aukštai- } \\
\text { tijos vasara „...ir saulas diementas žéruos... } \\
\text { (A. Miškinis)“ }\end{array}$ & $\begin{array}{l}\text { Utenos SVB; } \\
\text { partneriai: Utenos kraštotyros } \\
\text { muziejus, Utenos r. Daugailių } \\
\text { seniūnija }\end{array}$ & [nenurodyta] \\
\hline 17 & Pažink Europa - 2016 & Zarasų r. SVB & EKAL \\
\hline 18 & $\begin{array}{l}\text { Kūrybiniu ideju igyvendinimas judriojoje mediju } \\
\text { studijoje (2015-2016 m.) }\end{array}$ & $\begin{array}{l}\text { Zarasų r. SVB, } \\
\text { Všt Zarasų jaunimo centras, } \\
\text { Zarasų meno mokykla }\end{array}$ & $\begin{array}{l}\text { BMGF, KM [BP 2] } \\
\text { (finansavimas skirtas } \\
2015 \text { metais) }\end{array}$ \\
\hline 19 & $\begin{array}{l}\text { Kuriame knygas Zarasų viešojoje bibliotekoje ir } \\
\text { padaliniuose }\end{array}$ & Zarasų r. SVB & LKT \\
\hline 20 & Knygos šventè Zarasuose [tęstinis] & Zarasų r. SVB & LKT \\
\hline 21 & Vasarą skaitome kitaip 4 [tęstinis] & Zarasų r. SVB & LKT \\
\hline 22 & $\begin{array}{l}\text { Pilietiškumo skatinimo programa „Partneryste - } \\
\text { jega“ }\end{array}$ & Zarasų r. SVB & LKT \\
\hline \multicolumn{4}{|c|}{2017 metai } \\
\hline 1 & Mes - Europa! & Anykščių r. SVB & EKAL \\
\hline 2 & Knygos anatomija: knygos vaikams & Anykščių r. SVB & $\mathrm{LKT}$ \\
\hline 3 & $\begin{array}{l}\text { Mokymasis, išmaniosios technologijos ir kūrybiš- } \\
\text { kumas (2017-2018 m.) }\end{array}$ & $\begin{array}{l}\text { Ignalinos r. SVB; } \\
\text { partneriai: Ignalinos TAU, } \\
\text { Prachaticės miesto biblioteka, } \\
\text { Senjorų pilietinė organizacija } \\
\text { (Čekija), Estfoldo apskrities } \\
\text { biblioteka, „Inspiria“ mokslo } \\
\text { centras (Norvegija) }\end{array}$ & $\begin{array}{l}\text { Švietimo mainų ir } \\
\text { paramos fondas (pro- } \\
\text { grama „Erasmus“) }\end{array}$ \\
\hline 4 & $\begin{array}{l}\text { Rytų Lietuvos X faktoriai (žmonés, renginiai, } \\
\text { objektai) - turiningai valstybès šimtmečio šventei }\end{array}$ & Ignalinos r. SVB & LKT \\
\hline 5 & Kürybos $A B C$ & $\begin{array}{l}\text { Ignalinos r. SVB; } \\
\text { partneriai: Ignalinos r. vi- } \\
\text { suomenès sveikatos biuras, } \\
\text { Ignalinos TAU, Ignalinos r. } \\
\text { neigaliųjų draugija }\end{array}$ & LKT \\
\hline
\end{tabular}




\begin{tabular}{|c|c|c|c|}
\hline Eil. nr. & Pavadinimas & Biblioteka, partneriai & Rèmèjai \\
\hline 6 & Knyga ieško draugo & Ignalinos r. SVB Didžiasalio f. & LKT \\
\hline \multirow[t]{2}{*}{7} & Piliakalniu istorija žadina vaizduotę & $\begin{array}{l}\text { Ignalinos r. SVB; } \\
\text { partneriai: Aukštaitijos naci- } \\
\text { onalinio parko ir Labanoro } \\
\text { regioninio parko direkcija, } \\
\text { VšI „Mūsų Ignalina“, }\end{array}$ & LKT \\
\hline & & $\begin{array}{l}\text { UAB „Nauja vaga“, Švenčio- } \\
\text { nių r. Kaltanėnų ugdymo ir } \\
\text { turizmo centras, Ignalinos } \\
\text { rajono bendruomenės cen- } \\
\text { tras „Bruknele“, Švenčionių r. } \\
\text { SVB, Ignalinos TAU }\end{array}$ & \\
\hline 8 & Europos dieną švęskime kartu! & Molètų r. SVB & EKAL \\
\hline 9 & Molinukès kelionè su knyga & Molètų r. SVB & LKT, KM \\
\hline 10 & $\begin{array}{l}\text { Interaktyvus žemèlapis Molètų rajono literatūri- } \\
\text { niai tiltai }\end{array}$ & Molètų r. SVB & LKT, SV \\
\hline 11 & $\begin{array}{l}\text { Švietimui ir gerovei skirtų šeimos skaitmeninių } \\
\text { veiklu centrų sukūrimas Rytų Aukštaitijoje ir } \\
\text { Pietų Latgaloje (2017-2019 m.) }\end{array}$ & $\begin{array}{l}\text { Utenos SVB; } \\
\text { partneriai: Zarasų r., Daugpi- } \\
\text { lio ir Preilių viešosios bibliote- } \\
\text { kose (Latvija) }\end{array}$ & $\begin{array}{l}\text { Europos regioni- } \\
\text { nès plètros fondas } \\
\text { [Latvijos ir Lietuvos } \\
\text { bendradarbiavimo } \\
\text { per sieną programa } \\
\text { INTERREG V-A] }\end{array}$ \\
\hline 12 & $\begin{array}{l}\text { Utenos A. ir M. Miškinių viešosios bibliotekos } \\
\text { modernizavimas }\end{array}$ & Utenos SVB & $\begin{array}{l}\text { Europos regioninès } \\
\text { plètros fondas, valsty- } \\
\text { bės biudžeto lěšos }\end{array}$ \\
\hline 13 & $\begin{array}{l}\text { Šiuolaikinių technologiju taikymas ir kūrybiška } \\
\text { partnerystè populiarinant kultūros paslaugas } \\
\text { jaunimui: interneto svetainès ir socialiniai } \\
\text { tinklai }\end{array}$ & $\begin{array}{l}\text { Utenos SVB; } \\
\text { partnere - UAB „IT akade- } \\
\text { mija“ }\end{array}$ & LKT, KM \\
\hline 14 & Išmanusis bibliotekų ir literatūros gidas & Utenos SVB & LKT, KM \\
\hline 15 & Skaito vaikai, kalba lèles - 3 [tęstinis] & Visagino SVB & LKT, KM \\
\hline 16 & Europos ateitis - mano ateitis & Zarasų r. SVB & EKAL \\
\hline 17 & $\begin{array}{l}\text { Švietimui ir gerovei skirtų šeimos skaitmeniniu } \\
\text { veiklų centrų sukūrimas Rytų Aukštaitijoje ir } \\
\text { Pietų Latgaloje (2017-2019 m.) }\end{array}$ & $\begin{array}{l}\text { Zarasų r. SVB; } \\
\text { partnerès: Utenos SVB, } \\
\text { Daugpilio ir Preilių viešosios } \\
\text { bibliotekos (Latvija) }\end{array}$ & $\begin{array}{l}\text { Europos regioninis } \\
\text { plètros fondas }\end{array}$ \\
\hline 18 & Knygos šventè Zarasuose [tęstinis] & Zarasų r. SVB & LKT \\
\hline 19 & $\begin{array}{l}\text { Kürybinių improvizaciju ciklas „Knygos kelias } \\
\text { Zarasų viešojoje bibliotekoje ir padaliniuose“ }\end{array}$ & Zarasų r. SVB & LKT \\
\hline 20 & $\begin{array}{l}\text { Istoriniai literatūriniai personažai Zarasu viešo- } \\
\text { sios bibliotekos languose (2017-2018 m.) }\end{array}$ & Zarasų r. SVB & LKT, KM \\
\hline
\end{tabular}


7 priedas. Šiaulių apskr. savivaldybių viešųjų bibliotekų 2007, 2013, 2015-2017 metų projektai

\begin{tabular}{|c|c|c|c|}
\hline Eil. nr. & Pavadinimas & Biblioteka, partneriai & Rèmèjai \\
\hline 1 & Etnokultūra ir jos sklaida & Akmenès r. SVB & SV \\
\hline 2 & $\begin{array}{l}\text { Tradicinè Poezijos rudens šventè viešojoje } \\
\text { bibliotekoje }\end{array}$ & Akmenès r. SVB & SV \\
\hline 3 & Sveikata - brangiausias turtas & Akmenès r. SVB & SV \\
\hline 4 & Bibliotekos - informacijos ir kultūros skleidejos & Akmenès r. SVB & SV \\
\hline 5 & Imkit mane ir skaitykit [skirtas vaikams] & $\begin{array}{l}\text { Akmenės r. SVB; } \\
\text { partneris - lopšelis-darželis } \\
\text { „Žvaigždute““ }\end{array}$ & [nenurodyta] \\
\hline 6 & $\begin{array}{l}\text { Rašytojo aura knygos ir žiniu šventovéje [skirtas } \\
\text { J. Avyžiaus } 85 \text {-osioms gimimo metinèms ir viešo- } \\
\text { sios bibliotekos } 70 \text {-mečiui] }\end{array}$ & Joniškio r. SVB & $\mathrm{KM}, \mathrm{SV}$ \\
\hline 7 & Jaunuju menininku galerija bibliotekos erdveje & Joniškio r. SVB & KM \\
\hline 8 & Sugrịzimai, susitikimai, pristatymai [kraštotyros] & Joniškio r. SVB & SV \\
\hline 9 & Žagarès žemèje įmintos pédos & $\begin{array}{l}\text { Joniškio r. SVB } \\
\text { Žagarès } \mathrm{f} \text {. }\end{array}$ & SV \\
\hline 10 & Antrieji Žemaités skaitymai & Kelmès r. SVB & KM \\
\hline 11 & Rajoninè skaitytojų konferencija & Kelmès r. SVB & SV \\
\hline 12 & Kražiu bibliotekos 70-metis & $\begin{array}{l}\text { Kelmès r. SVB } \\
\text { Kražių f. }\end{array}$ & SV \\
\hline 13 & Tradicinè poezijos šventè Pagryžuvyje & $\begin{array}{l}\text { Kelmès r. SVB } \\
\text { Pagryžuvio f. }\end{array}$ & SV \\
\hline 14 & $\begin{array}{l}\text { Tradicinè literatu šventè ir 55-asis Šedbarų bibliote- } \\
\text { kos jubiliejus }\end{array}$ & $\begin{array}{l}\text { Kelmès r. SVB } \\
\text { Šedbarų f. }\end{array}$ & SV \\
\hline 15 & Žemaitès viešosios bibliotekos 70-metis & Kelmès r. SVB & SV \\
\hline 16 & $\begin{array}{l}\text { Skaitymo skatinimo iniciatyvu populiarinimas } \\
\text { Pakruojo rajone }\end{array}$ & Pakruojo r. SVB & KM \\
\hline 17 & Nè dienelès be knygeless & Pakruojo r. SVB & ŠMM \\
\hline 18 & Žaidžiame teatrą & $\begin{array}{l}\text { Pakruojo r. SVB } \\
\text { Linkuvos f. }\end{array}$ & ŠMM \\
\hline 19 & Skaitytojui naujausios informacinès technologijos & Radviliškio r. SVB & KM, SV \\
\hline 20 & $\begin{array}{l}\text { Radviliškio krašto kultūros ir istorijos žurnalo „Ra- } \\
\text { dviliškio kraštas"leidyba [tęstinis] }\end{array}$ & Radviliškio r. SVB & KSRF \\
\hline 21 & Vaiku socializacijos programa & Radviliškio r. SVB & SV \\
\hline 22 & Vaiku socializacijos programa & $\begin{array}{l}\text { Radviliškio r. SVB } \\
\text { Šeduvos } \mathrm{f} \text {. }\end{array}$ & SV \\
\hline 23 & Su knyga į pasauli & Šiaulių m. SVB & KSRF \\
\hline 24 & Biblioteka ir vaiko ugdymas & Šiaulių m. SVB & KM \\
\hline 25 & Tarptautinis seminaras Latvijoje & Šiaulių m. SVB & KM \\
\hline 26 & $\begin{array}{l}\text { Šiauliu miesto savivaldybès viešosios bibliotekos } \\
\text { istorija gyva elektroninejje laikmenoje } \\
(2007-2008 \mathrm{~m} .)\end{array}$ & Šiaulių m. SVB & SV \\
\hline 27 & Šventu Kaledų belaukiant & Šiaulių m. SVB & SV \\
\hline 28 & Pasibelsk į knygos širdį & Šiaulių r. SVB & KM \\
\hline
\end{tabular}


Eil. nr. Pavadinimas

\section{3 metai}

1 Sveikata - brangiausias turtas [skirtas vaikams]

2 Sveikata-mūsu rankose

3 Nagrubi mūsa tarmie, tik rupi kap rugieni douna

4 Renginiu ciklas Europos dienai ir Europos piliečiu metams paminèti

5 Gyvasis žodis iš gimtosios tarmès versmiu

6 Moderniosios architektūros apraiškos Joniškyje 1918-1940 m

7 Lietuviu autoriai vaikams [tęstinis]

8 Vaiguvos šnektos žodynas

9 Tarpvalstybiniu verslui palankiu biblioteku tinklo kūrimas (2012-2014 m.)

10 Renginiu ciklas „Pasimatymai su vaikišku knygu kūrèjais"

11 Iš kartos $j$ kartą [skirtas kraštiečio poeto Kazio Binkio 120-osioms gimimo metinèms]

12 Tarmiu atstovai! Vienykimès Šeduvoj!

13 Vaiku vasaros stovykla „Būsim, dalyvausim, daug ka sužinosim“

14 Geros emocijos - stipri sveikata

15 Sveikatinimo festivalis "Jaunimo sveikatos atgaja“

16 Šiauliai - aktyviu piliečių Europos miestas

17 Kaip muziejai, galerijos, bibliotekos ir archyvai gali prisideti prie mokymosi visa gyvenima (2011-2013 m.)

18 Senjoru klubas bibliotekoje - mokymosi visa gyvenimą erdve

19 Kompiuterinis ir informacinis raštingumas: mokymosi visa gyvenima galimybès
Akmenès r. SVB SV

Akmenès r. SVB Jučių f.; $\quad$ SV partnerè - kaimo bendruomenè

Akmenès r. SVB [nenurodyta]

Papilès $\mathrm{f}$.

Joniškio r. SVB EKAL

Joniškio r. SVB KRF

Joniškio r. SVB; $\quad$ SV

partnerè - Joniškio A. Rau-

donikio meno mokykla

Kelmès r. SVB

KRF

Kelmès r. SVB

KM

Pakruojo r. SVB;

Europos žemès ūkio partnerès: Pasvalio, Biržų r., fondas kaimo plètrai Rundalès ir Bauskès (Latvija) bibliotekos

Pakruojo r. SVB

KRF

Pakruojo r. SVB

SV

Radviliškio r. SVB;

KRF partneriai: rajono švietimo, kultūros ir sporto skyrius, Šeduvos kultūros namai Radviliškio r. SVB

JAV lietuvių bendruomenès krašto valdyba (Niu Heivenas, Konektikuto valstija)

Radviliškio r. SVB SV

Radviliškio r. SVB SV

Šiaulių m. SVB

EKAL

Šiaulių m. SVB;

Švietimo mainų partneriai:

Lenkijos, Latvijos, Prancūparamos fondas zijos, Italijos, Turkijos muziejai, bibliotekos, archyvai Šiaulių m. SVB („Leonardo da Vinci“ programa)

KM

Šiaulių m. SVB

KM 


\begin{tabular}{|c|c|c|c|}
\hline Eil. nr. & Pavadinimas & Biblioteka, partneriai & Rèmèjai \\
\hline 20 & $\begin{array}{l}\text { Šiaulių krašto pažinimas: interaktyvi skaitmeninio } \\
\text { turinio sklaida jaunujų kraštotyrininkų interneti- } \\
\text { niame puslapyje }\end{array}$ & $\begin{array}{l}\text { Šiaulių m. SVB; } \\
\text { partneriai: UAB „Edukcinès } \\
\text { sistemos“, VšI „3D Vilnius“ }\end{array}$ & KM \\
\hline 21 & $\begin{array}{l}1863 \text { metų sukilimo istorinè ir kultūrinè reikšmé: } \\
\text { praeitis ir rytojus [skirtas vaikams] }\end{array}$ & Šiaulių m. SVB & KM \\
\hline 22 & $\begin{array}{l}\text { Septynios spindinčios Šiaulių dienos [skirtas miesto } \\
\text { 777-ajam gimtadieniui] }\end{array}$ & Šiaulių m. SVB & SV \\
\hline 23 & Esu pilietis - mano teisés ir galimybès & Šiaulių r. SVB Kuršėnų f. & EKAL \\
\hline 24 & Informacinès technologijos - tiltas tarp kartu & $\begin{array}{l}\text { Šiaulių r. centrinè bibliote- } \\
\text { ka, Gilaičių f. }\end{array}$ & KM \\
\hline \multicolumn{4}{|c|}{2015 metai } \\
\hline 1 & $\begin{array}{l}\text { Internetinès literatūrinès svetainès sukūrimas } \\
\text { viešojoje bibliotekoje (2015-2016 m.) }\end{array}$ & $\begin{array}{l}\text { Akmenès r. SVB; } \\
\text { partnerè - Lietuvos ne- } \\
\text { priklausomųjų rašytojų } \\
\text { sąjunga }\end{array}$ & BMGF, KM [BP 2] \\
\hline 2 & $\begin{array}{l}\text { Žalingu ipročių, smurto ir patyčiu prevencija, psi- } \\
\text { chikos sveikatos stiprinimas }\end{array}$ & $\begin{array}{l}\text { Akmenès r. SVB centrinè } \\
\text { biblioteka, Sablauskių f. }\end{array}$ & SV \\
\hline 3 & Iš Europos - i pasauli & Joniškio r. SVB & EKAL \\
\hline 4 & Intriguojame skaityti & Joniškio r. SVB & LKT, SV \\
\hline 5 & Pasisemkim savasties iš tautos lobyno & Joniškio r. SVB & LKT, SV \\
\hline 6 & Miesto istorijos ženklai & Joniškio r. SVB & SV \\
\hline 7 & Išvien su Europa & Kelmès r. SVB & EKAL \\
\hline 8 & $\begin{array}{l}\text { Inovatyvi bibliotekos erdve - jaunimo saviraiškai } \\
(2015-2016 \mathrm{~m} .)\end{array}$ & $\begin{array}{l}\text { Kelmès r. SVB; } \\
\text { partneriai: VšI Kelmès } \\
\text { profesinio rengimo centras, } \\
\text { visuomeninè organizacija } \\
\text { „Krašto informacija“ }\end{array}$ & $\begin{array}{l}\text { BMGF, KM [BP 2], } \\
\text { SV }\end{array}$ \\
\hline 9 & Lietuviu autoriai vaikams [tęstinis] & Kelmès r. SVB & LKT \\
\hline 10 & Šeštieji Žemaitès skaitymai & $\begin{array}{l}\text { Kelmės r. SVB; } \\
\text { partneriai: Vilniaus uni- } \\
\text { versiteto Kauno humani- } \\
\text { tarinis fakultetas, Lietuvių } \\
\text { literatūros ir tautosakos } \\
\text { institutas, Maironio lietuvių } \\
\text { literatūros muziejus }\end{array}$ & SV \\
\hline 11 & Su gimimo diena, Europa & Pakruojo r. SVB & EKAL \\
\hline 12 & $\begin{array}{l}\text { IRT kilnojamojo centro ịkūrimas Pakruojo Juozo } \\
\text { Paukštelio viešojoje bibliotekoje [skirtas sociali- } \\
\text { nėms vaikų ir jaunimo problemoms spręsti] }\end{array}$ & $\begin{array}{l}\text { Pakruojo r. SVB; } \\
\text { partneriai: Žeimelio gim- } \\
\text { nazija, Pakruojo r. savival- } \\
\text { dybės visuomenės sveikatos } \\
\text { biuras }\end{array}$ & $\mathrm{BMGF}, \mathrm{KM}[\mathrm{BP} 2]$ \\
\hline 13 & Veiklu fontanas & Pakruojo r. SVB & LKT \\
\hline 14 & Radviliškis - dalele Europos širdies & Radviliškio r. SVB & EKAL \\
\hline 15 & Sveikata - per pažinima & Radviliškio r. SVB & SV \\
\hline 16 & Radviliškis. Lankytinų vietų žemèlapis ir maršrutai & $\begin{array}{l}\text { Radviliškio r. SVB; } \\
\text { partneris - Radviliškio } \\
\text { turizmo centras }\end{array}$ & SV \\
\hline
\end{tabular}




\begin{tabular}{|c|c|c|c|}
\hline Eil. nr. & Pavadinimas & Biblioteka, partneriai & Rèmèjai \\
\hline 17 & $\begin{array}{l}\text { Kürybinés dirbtuvés-stovykla „Kurkime kartu - } \\
2015^{“} \text { [tęstinis] }\end{array}$ & Radviliškio r. SVB & SV \\
\hline 18 & Stovykla „Skaityk. Pažink. Tobulèk“ & Radviliškio r. SVB & SV \\
\hline 19 & Vabaliukai [tęstinis] & Radviliškio r. SVB & SV, privatūs asmenys \\
\hline 20 & Europoje mES: dalinamès, augam, stiprëjam & Šiaulių m. SVB & EKAL \\
\hline 21 & Komiksu erdvé bibliotekoje (2015-2016 m.) & Šiaulių m. SVB & BMGF, KM [BP 2] \\
\hline 22 & $\begin{array}{l}\text { Privatus ir viešas asmuo. Ju ribos ir galimybès } \\
\text { medijose }\end{array}$ & Šiaulių m. SVB & LKT \\
\hline 23 & Atradus bibliotekg - gyventi patogiau & Šiaulių m. SVB & LKT \\
\hline 24 & $\begin{array}{l}\text { Informacinių paslaugu plètra neigaliuju vaiku } \\
\text { tévams }\end{array}$ & $\begin{array}{l}\text { Šiaulių m. SVB (Lietuvos } \\
\text { bibliotekininkų draugijos } \\
\text { Šiaulių m. skyrius) }\end{array}$ & LKT \\
\hline 25 & Visuomenine mokykla bibliotekoje [tęstinis] & $\begin{array}{l}\text { Šiaulių m. SVB } \\
\text { Lieporių f. }\end{array}$ & LKT \\
\hline 26 & $\begin{array}{l}\text { Tradicijos ir modernumas: interaktyviai kuriame } \\
\text { istoriją Šiauliams } 2 \text { [ị ši projektą buvo taip pat } \\
\text { buvo integruotas savivaldybės paremtas projektas } \\
\text { „Tradicijos ir modernumas: interaktyviai kuriame } \\
\text { istoriją Šiauliams“; skirtas vaikams ir jaunimui] }\end{array}$ & $\begin{array}{l}\text { Šiaulių m. SVB } \\
\text { „Šaltinèlio“ f. }\end{array}$ & LKT, SV \\
\hline 27 & Žaliuok ir žydèk, mano mieste! & $\begin{array}{l}\text { Šiaulių m. SVB „Šaltinè- } \\
\text { lio“ f.; } \\
\text { partneriai: Šiaulių sutriku- } \\
\text { sios klausos ugdymo centras, } \\
\text { Šiaulių sanatorinė mokykla, } \\
\text { Juventos progimnazija, lop- } \\
\text { šelis-darželis „Žibute“ }\end{array}$ & [nenurodyta] \\
\hline 28 & Mūsu planeta - mūsu bendras rūpestis & Šiaulių r. SVB & EKAL \\
\hline 29 & Verslo ir amatu akademija (2015-2016 m.) & Šiaulių r. SVB & BMGF, KM [BP 2] \\
\hline 30 & $\begin{array}{l}\text { Kuršènu biblioteka - lituanistikos atminties ir } \\
\text { sklaidos vieta }\end{array}$ & Šiaulių r. SVB & LKT \\
\hline 31 & $\begin{array}{l}\text { Verbūnai. Čia mano šaknys, čia aš gyvenu [skirtas } \\
\text { jaunimui] }\end{array}$ & Šiaulių r. SVB & LKT \\
\hline 32 & $\begin{array}{l}\text { Aisiu ị kalną: Šiauliu krašto liaudies dainu pateiké- } \\
\text { jos Mortos Katkienés dainų rinkinys }\end{array}$ & Šiaulių r. SVB & SV \\
\hline 33 & Sveikatos gūsis & Šiaulių r. SVB & SV \\
\hline 34 & Tëvyste் „veža“ & Šiaulių r. SVB & SV \\
\hline \multicolumn{4}{|c|}{2016 metai } \\
\hline 1 & $\begin{array}{l}\text { Internetinès literatūrinès svetainès sukūrimas Vie- } \\
\text { šojoje bibliotekoje (2015-2016 m.) }\end{array}$ & $\begin{array}{l}\text { Akmenės r. SVB; } \\
\text { partnerè - Lietuvos ne- } \\
\text { priklausomųjų rašytojų } \\
\text { sąunga }\end{array}$ & $\begin{array}{l}\text { BMGF, KM [BP 2] } \\
\text { (finansavimas skirtas } \\
2015 \text { metais) }\end{array}$ \\
\hline 2 & Kai mes sveiki - pasaulis šypsosi [skirtas vaikams] & $\begin{array}{l}\text { Akmenès r. SVB centrinè } \\
\text { biblioteka, Sablauskių f. }\end{array}$ & SV \\
\hline 3 & $\begin{array}{l}\text { Joniškio piliečiai - geriausi europiečiai [skirtas } \\
\text { Europos dienai] }\end{array}$ & Joniškio r. SVB & EKAL \\
\hline 4 & Intriguojame skaityti & Joniškio r. SVB & LKT, SV \\
\hline 5 & Eko - karuselè [skirtas Europos dienai] & Kelmès r. SVB & EKAL \\
\hline
\end{tabular}




\begin{tabular}{|c|c|c|c|}
\hline Eil. nr. & Pavadinimas & Biblioteka, partneriai & Rèmèjai \\
\hline 6 & $\begin{array}{l}\text { Inovatyvi bibliotekos erdve - jaunimo saviraiškai } \\
(2015-2016 \mathrm{~m} .)\end{array}$ & $\begin{array}{l}\text { Kelmès r. SVB; } \\
\text { partneriai: Všt Kelmės } \\
\text { profesinio rengimo centras, } \\
\text { visuomeninė organizacija } \\
\text { „Krašto informacija“ }\end{array}$ & $\begin{array}{l}\text { BMGF, KM [BP 2], } \\
\text { SV (finansavimas } \\
\text { skirtas } 2015 \text { metais) }\end{array}$ \\
\hline 7 & Jaunimo inovatyvios erdvés paslaugu plètra & Kelmès r. SVB & LKT, SV \\
\hline 8 & $\begin{array}{l}\text { Sakmé apie knyga [skirtas vaikų kūrybinès meni- } \\
\text { nės veiklos skatinimui] }\end{array}$ & Kelmès r. SVB & LKT, SV \\
\hline 9 & Lietuviu autoriai vaikams [tęstinis] & Kelmės r. SVB & LKT, SV \\
\hline 10 & $\begin{array}{l}\text { Poezijos pavasarèis ir R. Biržinytès literatūrinès } \\
\text { premijos įteikimo šventé }\end{array}$ & Kelmès r. SVB & SV \\
\hline 11 & Žemaitès literatūrinès premijos įteikimo šventé & Kelmès r. SVB & SV \\
\hline 12 & Pasaulis, Europa ir mES & Pakruojo r. SVB & EKAL \\
\hline 13 & $\begin{array}{l}\text { IRT kilnojamojo centro ịkūrimas Pakruojo Juozo } \\
\text { Paukštelio viešojoje bibliotekoje (2015-2016 m.) }\end{array}$ & $\begin{array}{l}\text { Pakruojo r. SVB; } \\
\text { partneriai: Žeimelio gim- } \\
\text { nazija, Pakruojo rajono } \\
\text { savivaldybės visuomenès } \\
\text { sveikatos biuras }\end{array}$ & $\begin{array}{l}\text { BMGF, KM [BP2] } \\
\text { (finansavimas skirtas } \\
2015 \text { metais) }\end{array}$ \\
\hline 14 & Saules ratu su Knyga & Pakruojo r. SVB & LKT \\
\hline 15 & $\begin{array}{l}\text { Veiklu fontanas - } 2 \text { [skirtas vaikams ir jaunimui; } \\
\text { tęstinis] }\end{array}$ & Pakruojo r. SVB & LKT \\
\hline 16 & $\begin{array}{l}\text { Bibliotekininkų veikla ir gebèjimai - žingeidžiai } \\
\text { bendruomenei }\end{array}$ & $\begin{array}{l}\text { Pakruojo r. SVB (LBD } \\
\text { Pakruojo skyrius) }\end{array}$ & SV \\
\hline 17 & Pavasarinis knygų kermošius [tęstinis] & Radviliškio r. SVB & LKT \\
\hline 18 & $\begin{array}{l}\text { Knygos ir kompaktiné plokštelès „Šeduvos mestely } \\
\text { aušrela auša“ leidyba }\end{array}$ & Radviliškio r. SVB & LKT, SV \\
\hline 19 & $\begin{array}{l}\text { Kūrybinès dirbtuvès-stovykla „Kurkime kartu - } \\
2016^{\prime \prime} \text { [tęstinis] }\end{array}$ & $\begin{array}{l}\text { Radviliškio r. SVB; } \\
\text { partneris - rajono literatų } \\
\text { klubas „Jonvabalis“ }\end{array}$ & SV \\
\hline 20 & Vaiku vasaros stovykla „Knygu bičiuliu vasara“ & Radviliškio r. SVB & SV \\
\hline 21 & Laikas gyvena knygose & $\begin{array}{l}\text { Radviliškio r. SVB (LBD } \\
\text { Radviliškio skyrius) }\end{array}$ & SV \\
\hline 22 & $\begin{array}{l}\text { Vaikeliui iš mano širdelès [skirtas vaikų skaitymui } \\
\text { skatinti] }\end{array}$ & $\begin{array}{l}\text { Radviliškio r. SVB; } \\
\text { partneris - rajono literatų } \\
\text { klubas „Jonvabalis“ }\end{array}$ & SV \\
\hline 23 & Man šypsosi Europa & Šiaulių m. SVB & EKAL \\
\hline 24 & Komiksu erdve bibliotekoje (2015-2016 m.) & Šiaulių m. SVB & $\begin{array}{l}\text { BMGF, KM [BP 2] } \\
\text { (finansavimas skirtas } \\
2015 \text { metais) }\end{array}$ \\
\hline 25 & $\begin{array}{l}\text { Mediju ir informacinio raštingumo mokymai Šiau- } \\
\text { liu miesto bendruomenems }\end{array}$ & $\begin{array}{l}\text { Šiaulių m. SVB; } \\
\text { partneris - UAB „Media } \\
\text { Traffic“ }\end{array}$ & LKT \\
\hline 26 & Aktyvus ir kultūringas senjoras bibliotekoje & Šiaulių m. SVB & LKT \\
\hline 27 & $\begin{array}{l}\text { Didelis mažuju skaitytojų pasaulis [projekto } \\
\text { tikslas - atkurti klubo „Skaitanti mama“ veiklas ir } \\
\text { skatinti jaunas šeimas neatitrūkti nuo kultūrinès, } \\
\text { meninès ir visuomeninès veiklos] }\end{array}$ & Šiaulių m. SVB & LKT \\
\hline
\end{tabular}




\begin{tabular}{|c|c|c|c|}
\hline Eil. nr. & Pavadinimas & Biblioteka, partneriai & Rèmèjai \\
\hline 28 & $\begin{array}{l}\text { Interaktyvus Šiaulių žemèlapis: pažink Šiaulius per } \\
\text { virtualia viktorina - labirinta }\end{array}$ & $\begin{array}{l}\text { Šiaulių m. SVB; } \\
\text { partneris - V̌̌I } \\
\text { „3D Vilnius“ }\end{array}$ & LKT \\
\hline 29 & Visuomenine mokykla bibliotekoje 2 [tęstinis] & Šiaulių m. SVB & LKT \\
\hline 30 & $\begin{array}{l}\text { Tylos kalba: integruota kūrybiné edukacija klausos } \\
\text { negalia turintiems }\end{array}$ & Šiaulių m. SVB & KM \\
\hline 31 & Šiaulių krašto istorija atgimsta animacijoje & Šiaulių m. SVB & SV \\
\hline 32 & Europos diena Šiaulių rajone & Šiaulių r. SVB & EKAL \\
\hline 33 & Verslo ir amaty akademija (2015-2016 m.) & Šiaulių r. SVB & $\begin{array}{l}\text { BMGF, KM [BP 2] } \\
\text { (finansavimas skirtas } \\
2015 \text { metais) }\end{array}$ \\
\hline 34 & Susipažinkim su Šiauliu rajonu kitaip & Šiaulių r. SVB & KM \\
\hline 35 & $\begin{array}{l}\text { Verbūnai - čia mūsu etninè savastis, čia aš } \\
\text { gyvenu... [skirtas jaunimui; projektas kiek kitu } \\
\text { pavadinimu] }\end{array}$ & Šiaulių r. SVB & LKT, SV \\
\hline 36 & $\begin{array}{l}\text { Pamatykim kiekviena nepastebètą kaimo bibliote- } \\
\text { ka... [infrastruktūros] }\end{array}$ & Šiaulių r. SVB & LKT, SV \\
\hline 37 & Personažų šèlsmas bibliotekose & Šiaulių r. SVB & LKT, SV \\
\hline 38 & $\begin{array}{l}\text { Biblioteka - kūrybiškumui ir edukacijai [tikslas - } \\
\text { sudaryti sąlygas socialinę atskirtį patiriantiems } \\
\text { Šiaulių r. vaikams ir jaunimui integruotis ị visuo- } \\
\text { menę, ugdyti jų savivertę ir kūrybiškumą] }\end{array}$ & Šiaulių r. SVB & LKT, SV \\
\hline 39 & Žvilgsnis į senelių žaislų dėžę & Šiaulių r. SVB & SV \\
\hline 40 & Nežiopsok, kas dar liko, užfiksuok (1 etapas) & $\begin{array}{l}\text { Šiaulių r. SVB } \\
\text { Kuršènų f. }\end{array}$ & SV \\
\hline 41 & 122 žingsniai bendravimo ir tobulëjimo link & $\begin{array}{l}\text { Šiaulių r. SVB } \\
\text { Kuršènų f. }\end{array}$ & SV \\
\hline
\end{tabular}

\section{7 metai}

$1 \quad$ Piliakalnių kraštas - Papilè

2 Teisingo požiūrio ị sveiką gyvensena formavimas, žalingu ípročiu prevencija [skirtas vaikams ir jaunimui]

3 Europos sukaktys

4 Bibliotekos gidas visai šeimai

5 Gyvenimas - tai nesibaigiantis kūrybos procesas (Jonas Avyžius)

6 Joniškio kraštai dvarai. Didžioji ir Mažoji Daunoravos, Bertaučiai, Satkūnai

7 Knygos „Joniškio krašto dvarai. Didžioji ir Mažoji Daunorava, Bertaučiai, Satkūnai“ leidyba

8 Didžiuotis. Būti. Kurti: MES - šimtmečio istorijos dalis

9 Visi keliai veda iš Romos...

10 Inovatyvios bibliotekos paslaugos vaikams

11 Poezijos pavasarèlis ir R. Biržinytès literatūrinès premijos įteikimo švente
Akmenès r. SVB Papilès f. LKT

Akmenès r. SVB centrinè SV

biblioteka, Sablauskių f.

Joniškio r. SVB

EKAL

Joniškio r. SVB

LKT, KM, SV

Joniškio r. SVB

LKT, KM, SV

Joniškio r. SVB

LKT, KM

Joniškio r. SVB

SV

Joniškio r. SVB

[nenurodyta]

Kelmès r. SVB

EKAL

Kelmès r. SVB

LKT, SV

Kelmès r. SVB

SV 


\begin{tabular}{|c|c|c|c|}
\hline Eil. nr. & Pavadinimas & Biblioteka, partneriai & Rèmèjai \\
\hline 12 & Mes drauge su Europa & Pakruojo r. SVB & EKAL \\
\hline 13 & $\begin{array}{l}\text { Draugaukime [vaikų skaitymo skatinimo ir kūry- } \\
\text { biškumo ugdymo projektas] }\end{array}$ & Pakruojo r. SVB & $\begin{array}{l}\text { Pakruojo labdaros ir } \\
\text { paramos fondas }\end{array}$ \\
\hline 14 & Švęskime Europos dieną kartu & Radviliškio r. SVB & EKAL \\
\hline 15 & Pavasarinis knygų kermošius [tęstinis] & Radviliškio r. SVB & LKT \\
\hline 16 & Minaičiai - Lietuvos laisvés kovų istorinè sostinè & Radviliškio r. SVB & LKT, SV \\
\hline 17 & 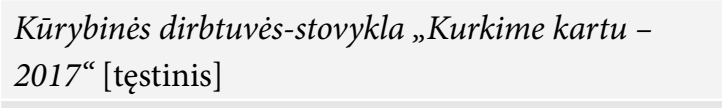 & Radviliškio r. SVB & SV \\
\hline 18 & $\begin{array}{l}\text { Nauja veikla bibliotekoje [skirtas vaikams ir } \\
\text { jaunimui] }\end{array}$ & Radviliškio r. SVB & SV \\
\hline 19 & Vabaliukai [tęstinis] & Radviliškio r. SVB & $\begin{array}{l}\text { Radviliškio m. Gar- } \\
\text { bės piliete prof. Elona } \\
\text { Vaišnienè (JAV) }\end{array}$ \\
\hline 20 & Švietimo programa „Viešieji ryšiai“ & Radviliškio r. SVB & SV, SVB \\
\hline 21 & Vaiku vasaros stovykla - 2017 & $\begin{array}{l}\text { Radviliškio r. SVB } \\
\text { Šeduvos } \mathrm{f} \text {. }\end{array}$ & SV \\
\hline 22 & Europa Šiauliuose - Šiauliai Europoje & Šiaulių m. SVB & EKAL \\
\hline 23 & $\begin{array}{l}\text { Inovatyviu bibliotekos sprendimu skirtingoms kar- } \\
\text { toms pletra pasienio regione } \\
(2017-2019 \mathrm{~m} .)\end{array}$ & $\begin{array}{l}\text { Šiaulių m. SVB; } \\
\text { partnerės: Jelgavos m. } \\
\text { biblioteka, Liepojos cen- } \\
\text { trinė mokslinė biblioteka } \\
\text { (Latvija) }\end{array}$ & $\begin{array}{l}\text { Europos regioninès } \\
\text { plètros fondas, SV }\end{array}$ \\
\hline 24 & $\begin{array}{l}\text { Biblioteka - erdve kūrybai ir draugystei [skirtas } \\
\text { skaitymo skatinimui šeimoje] }\end{array}$ & Šiaulių m. SVB & LKT, SV \\
\hline 25 & $\begin{array}{l}\text { 24/3: spalvotos laisvés dienos } \\
\text { [tikslai: skatinti Lietuvos piliečių dalyvavimą } \\
\text { kultūriniame gyvenime, ugdyti pilietiškas asme- } \\
\text { nybes, skatinti patriotiškumą, kūrybiškumą, kartų } \\
\text { bendradarbiavimą ir tarpusavio supratimą] }\end{array}$ & Šiaulių m. SVB & LKT, SV \\
\hline 26 & Rèkyvos lobiu paieška & Šiaulių m. SVB & LKT, SV \\
\hline 27 & $\begin{array}{l}\text { Inžinerinių kompetencijų ugdymas kuriant savo 3D } \\
\text { miestą [skirtas moksleiviams] }\end{array}$ & Šiaulių m. SVB & SV \\
\hline 28 & $\begin{array}{l}\text { Šimtmečio biblioteka - istorija ir kūryba [skirtas } \\
\text { valstybès atkūrimo šimtmečiui] }\end{array}$ & Šiaulių m. SVB & SV \\
\hline 29 & $\begin{array}{l}\text { Bendruomenių biblioteka: keturi dešimtmečiai } \\
\text { kaitos ir pastovumo }\end{array}$ & Šiaulių m. SVB & SV \\
\hline 30 & $\begin{array}{l}\text { Skaitymo džiaugsmas: knygų muge po atviru } \\
\text { dangumi }\end{array}$ & Šiaulių m. SVB & SV \\
\hline 31 & Keliaujantis lagaminas: $3 \times 5$ & Šiaulių m. SVB & SV \\
\hline 32 & Kas europietis? Mes! & $\begin{array}{l}\text { Šiaulių r. SVB; } \\
\text { partneriai: Šiaulių r. savi- } \\
\text { valdybės kultūros centras, } \\
\text { asociacija Atviras Šiaulių } \\
\text { rajono jaunimo centras, } \\
\text { Kuršènų politechnikos } \\
\text { mokykla ir kt. }\end{array}$ & EKAL \\
\hline
\end{tabular}




\begin{tabular}{|c|c|c|c|}
\hline Eil. nr. & Pavadinimas & Biblioteka, partneriai & Rèmèjai \\
\hline 33 & $\begin{array}{l}\text { Išdriskime pasitikti kintanti pasauli [medijų ir } \\
\text { informacinio raštingumo ugdymo projektas bibli- } \\
\text { otekininkams] }\end{array}$ & Šiaulių r. SVB & LKT, SV \\
\hline 34 & $\begin{array}{l}\text { Šiauliu rajono turistiniu maršrutu vizija jaunimo } \\
\text { akimis }\end{array}$ & Šiaulių r. SVB & LKT, SV \\
\hline 35 & Gilaičių knygos teatro įkūrimas & $\begin{array}{l}\text { Šiaulių r. SVB } \\
\text { Gilaičių f. }\end{array}$ & LKT \\
\hline 36 & $\begin{array}{l}\text { Ginkūnų žemès šviesuoliu Janulaičiu gyvenimo ir } \\
\text { darbų keliais }\end{array}$ & $\begin{array}{l}\text { Šiaulių r. SVB } \\
\text { Ginkūnų f. }\end{array}$ & LKT, SV \\
\hline 37 & Fotomeno erdvès Kuršènu bibliotekoje & $\begin{array}{l}\text { Šiaulių r. SVB } \\
\text { Kuršenų f. }\end{array}$ & LKT, SV \\
\hline 38 & Kairiai - sveikos gyvensenos centras & $\begin{array}{l}\text { Šiaulių r. SVB } \\
\text { Kairių f. }\end{array}$ & SV \\
\hline 39 & Petankè pasirinko Kuršènus & $\begin{array}{l}\text { Šiaulių r. SVB } \\
\text { Kuršenų f. }\end{array}$ & SV \\
\hline 40 & $\begin{array}{l}\text { Nežiopsok - kas dar liko, užfiksuok } \\
\text { (2 etapas) }\end{array}$ & $\begin{array}{l}\text { Šiaulių r. SVB } \\
\text { Kuršènų f. }\end{array}$ & SV \\
\hline
\end{tabular}

8 priedas. Telšių apskr. savivaldybių viešųjų bibliotekų 2007, 2013, 2015-2017 metų projektai

\begin{tabular}{|c|c|c|c|}
\hline Eil. nr. & Pavadinimas & Biblioteka, partneriai & Rèmèjai \\
\hline 1 & Su knyga ị Knygiu kluba & Mažeikių r. SVB & KM \\
\hline 2 & Žemaitija vaiku akimis & Mažeikių r. SVB & KM \\
\hline 3 & Dvasinè sveikata - fizinès sveikatos pagrindas & Mažeikių r. SVB Ventos $\mathrm{f}$. & KSRF, SV \\
\hline 4 & Biblioteka tradiciju ir modernumo kelyje & Mažeikių r. SVB & SV \\
\hline 5 & Kultūrinès kompetencijos ugdymas & Mažeikių r. SVB & SV \\
\hline 6 & Gyvenu tik karta & Mažeikių r. SVB & SV \\
\hline 7 & $\begin{array}{l}\text { Kaimynai Europoje - Latvijos ir Lietuvos biblioteku } \\
\text { kontaktai }\end{array}$ & $\begin{array}{l}\text { Plungès r. SVB; } \\
\text { partneré - Saldaus bibliote- } \\
\text { ka (Latvija) }\end{array}$ & $\begin{array}{l}\text { Europos regioninès } \\
\text { plètros fondas (Bal- } \\
\text { tijos jūros regiono } \\
\text { Kaimynystès pro- } \\
\text { grama INTERREG } \\
\text { III B) }\end{array}$ \\
\hline 8 & $\begin{array}{l}\text { Kino menas - naujas būdas atrasti ir pažinti rašyto- } \\
\text { jus bei jų kūryba }\end{array}$ & Plungès r. SVB & KM, SV \\
\hline 9 & $\begin{array}{l}\text { Nuo gelstančiu lapu iki sniego gniūžtès [skirtas } \\
\text { floristikai] }\end{array}$ & $\begin{array}{l}\text { Plungès r. SVB } \\
\text { Narvaišių f. }\end{array}$ & KM \\
\hline 10 & $\begin{array}{l}\text { Kultūros tekstai ir kontekstai: Skandinavijos } \\
\text { ieškojimai }\end{array}$ & Plungès r. SVB & KSRF \\
\hline 11 & Poezijos, muzikos ir kino vakarai Plungèje & Plungès r. SVB & SV \\
\hline 12 & Lietuviu literatūra - jaunimui vertybe & Telšių r. SVB & ŠMM \\
\hline 13 & Kraštiečiu šventè „Žemaičiu žemèj užaugę dideli“ & Telšių r. SVB & SV \\
\hline 14 & Poezija sodų žydejjime [tęstinis] & $\begin{array}{l}\text { Telšiu r. SVB } \\
\text { Kaunatavos f. }\end{array}$ & KSRF \\
\hline 15 & Boružé ant vaiko delno & $\begin{array}{l}\text { Telšiu r. SVB } \\
\text { Kaunatavos f. }\end{array}$ & ŠMM, SV \\
\hline
\end{tabular}




\begin{tabular}{|c|c|}
\hline Eil. nr. & Pavadinimas \\
\hline 16 & $\begin{array}{l}\text { Tavęs vèl pasigedo gimtinès vieškeliai ir mèlynas } \\
\text { dangus }\end{array}$ \\
\hline 17 & $\begin{array}{l}\text { Vieniši gimtinès medžiai [skirtas informacijos apie } \\
\text { nykstančius kaimus rinkimui] }\end{array}$ \\
\hline 18 & Varniu apylinkių etnosodybos \\
\hline \multirow[t]{2}{*}{19} & $\begin{array}{l}\text { Kunigo, knygnešio Mykolo Šaikūno atminimo įamži- } \\
\text { nimas mene }\end{array}$ \\
\hline & 2013 met \\
\hline 1 & Gyva tarme - gyva kalba \\
\hline 2 & Tarme - gyvo žodžio šaltinis \\
\hline 3 & $\begin{array}{l}\text { Didèjantys vartotoju poreikiai - nauji iššūkiai tobu- } \\
\text { lëjimui }\end{array}$ \\
\hline & gimèm, kur augom, mi \\
\hline
\end{tabular}

4 Kur gimèm, kur augom, mūs žemè šventa

5 Europos diena Plungès rajone

6 Biblioterapija - visiems ir kiekvienam, žmogaus vidinių jeggu ir sveikatos potencialo budinimas [tęstinis]

$7 \quad$ Paskutinis pasivaikščiojimas po žydiškają Plunge

Fotoalejja- 2013

9 Senosios kaimo tradicijos - šiuolaikiškai

2 Informacijos sklaidos inovacijos Mažeikių viešojoje bibliotekoje

3 Nauja erdve - jaunimo laisvalaikiui ir iniciatyvoms [tęstinis]

4 Aš noréčiau taip gyvent savoj šaly [skirtas Europos dienai]

5 Renginys Žolinès dienai paminèti „Žolele - ir maistas, ir vaistas"

2015 metai
1 Pažangiu technologiju ir laisvalaikio centras (2015 - 2016 m.)

\section{Biblioteka, partneriai}

Telšių r. SVB

Kegų f.

Telšių r. SVB

Luokès $\mathrm{f}$.

Telšių r. SVB

Pavandenès $\mathrm{f}$.

Telšių r. SVB

Viekšnalių f.

\begin{tabular}{l|l}
\hline Mažeikų r. SVB & KRF \\
\hline Mažeikų r. SVB & SV \\
\hline Mažeikų r. SVB, & SV \\
\hline
\end{tabular}

Mažeikių r. BD skyrius

Mažeikų r. SVB Žemalès f.; [nenurodyta] partnerè - kaimo bendruomenè

\begin{tabular}{|l|l|}
\hline Plungès r. SVB & EKAL \\
\hline Plungès r. SVB & SV \\
\hline
\end{tabular}

\begin{tabular}{l|l} 
Plungès r. SVB & $\begin{array}{l}\text { Kultūros paveldo } \\
\text { departamentas prie } \\
\text { KM }\end{array}$
\end{tabular}

Plungès r. SVB SV

Plungės r. SVB Europos žemės Aleksandravo f.; $\quad$ ùkio fondas kaimo partnerès: VVG, kultūros plètrai (LEADER centras, moterų klubas „At- programa) gaiva“, asociacija „Vizijos“

Pastaba: Telšių r. SVB 2013 metų ataskaitos LNB portale ir bibliotekos tinklalapyje nèra.

Mažeikių r. SVB;

BMGF, KM [BP 2]

partneriai: Mažeikių r. nevyriausybinių organizacijų asociacija, Mažeikių r. savivaldybès švietimo skyrius, Mažeikių moterų LIONS klubas, Mažeikių r. visuomenès sveikatos biuras

Mažeikių r. SVB

LKT

Mažeikių r. SVB (Mažeikių r. SV

bibliotekininkų draugija)

Mažeikių r. SVB Balènų f. EKAL

Mažeikių r. SVB Balènų f. SV 


\begin{tabular}{|c|c|c|c|}
\hline Eil. nr. & Pavadinimas & Biblioteka, partneriai & Rèmèjai \\
\hline 6 & $\begin{array}{l}\text { Edukacinių renginių ciklas „Patriotiškumas - } \\
\text { vertybe } \dot{e}^{\text {“ }}\end{array}$ & Mažeikių r. SVB Ukrinų f. & LKT \\
\hline 7 & Gimtine mana - Ukrinai. Pažink ir brangink & Mažeikių r. SVB Ukrinų f. & SV \\
\hline 8 & Europos diena Plungès rajone & Plungès r. SVB & EKAL \\
\hline 9 & Plungès išmanusis parkas (2015-2016 m.) & $\begin{array}{l}\text { Plungės r. SVB; } \\
\text { partneriai: Žemaičių dailès } \\
\text { muziejus, Žemaitijos naci- } \\
\text { onalinis parkas, Klaipėdos } \\
\text { universiteto Botanikos } \\
\text { sodas, Plungès ir Rietavo } \\
\text { krašto fotoklubas „Žybt“, } \\
\text { kultūros draugija „Saulute““, } \\
\text { klubas „Oginskių dvaro } \\
\text { bičiuliai“ }\end{array}$ & BMGF, KM [BP 2] \\
\hline 10 & Pasièlgau žemaitéška žuodè & Plungès r. SVB & LKT \\
\hline 11 & Kunigaikštis M. K. Oginskis ir jo epocha & $\begin{array}{l}\text { Plungès r. SVB; } \\
\text { partnerès: LNB, VU biblio- } \\
\text { teka }\end{array}$ & LKT \\
\hline 12 & $\begin{array}{l}\text { Leidinio „Plungès „Palazzo Vechio“: nuo grafu } \\
\text { Zubovu pilaitès iki bibliotekos (1846-2012)“antras } \\
\text { pataisytas leidimas }\end{array}$ & Plungès r. SVB & LKT \\
\hline 13 & Knygos teatras - žaidimas žodžiu ir forma [tęstinis] & Plungès r. SVB & LKT \\
\hline 14 & $\begin{array}{l}\text { Biblioterapija - visiems ir kiekvienam - žmogaus } \\
\text { vidinių jègu ir sveikatos potencialo budinimas [tęs- } \\
\text { tinis] }\end{array}$ & Plungès r. SVB & SV \\
\hline 15 & $\begin{array}{l}\text { Lauko fotografijos paroda „Fotoalèja - 2015“ } \\
\text { [tęstinis] }\end{array}$ & Plungès r. SVB & SV \\
\hline 16 & Kap liob rokouteis žemaitee & Plungès r. SVB & SV \\
\hline 17 & $\begin{array}{l}\text { Vizualios informacijos pateikimo galimybès Aleksan- } \\
\text { dravo bibliotekoje }\end{array}$ & $\begin{array}{l}\text { Plungès r. SVB Aleksandra- } \\
\text { vo f. }\end{array}$ & SV \\
\hline 18 & Savo krašto istorija arčiau širdies & $\begin{array}{l}\text { Plungès r. SVB } \\
\text { Norvaičių f. }\end{array}$ & SV \\
\hline 19 & Žvelgiu naujai & $\begin{array}{l}\text { Plungės r. SVB } \\
\text { Platelių f. }\end{array}$ & SV \\
\hline 20 & $\begin{array}{l}\text { Vaiku vasaros stovykla „Pažinsi pavelda - pažinsi } \\
\text { pats save“ }\end{array}$ & $\begin{array}{l}\text { Rietavo SVB; } \\
\text { partneriai: Lauryno Ivinskio } \\
\text { gimnazija, Rietavo kultūros } \\
\text { centras }\end{array}$ & SV \\
\hline 21 & $\begin{array}{l}\text { MOKI ŽODI - RANDI KELIĄ: mokymosi visa gy- } \\
\text { venima nauda praktiškai, užsienio kalbu mokymasis } \\
(2015-2016 \text { m.) }\end{array}$ & Telšių r. SVB & BMGF, KM [BP 2] \\
\hline 22 & $\begin{array}{l}\text { Septintoji kalva [tęstinis; skirtas jaunų žmonių } \\
\text { (14-29 metų) literatūrinių kūrinių konkursams } \\
\text { organizuoti] }\end{array}$ & Telšių r. SVB & SV \\
\hline 23 & Julija Žemaité - tautos atmintyje, neįveikta laiko & Telšių r. SVB & SV \\
\hline 24 & Biblioteka: informacija ir žinios - kiekvienam & Telšių r. SVB & SV \\
\hline
\end{tabular}




\begin{tabular}{|c|c|c|c|}
\hline Eil. nr. & Pavadinimas & Biblioteka, partneriai & Rèmèjai \\
\hline 25 & $\begin{array}{l}\text { Literatūriniai-muzikiniai renginiai „Keliaujanti } \\
\text { poezija“ }\end{array}$ & Telšių r. SVB & SV \\
\hline 26 & Inovacijos naujoje Tryškių bibliotekoje & Telšių r. SVB Tryškių f. & SV \\
\hline 27 & Kraštiečiu šventè „Sugrįžkime paukščiai ị namus..." & Telšių r. SVB Viekšnalių f. & SV \\
\hline \multicolumn{4}{|c|}{2016 metai } \\
\hline 1 & $\begin{array}{l}\text { Pažangių technologijų ir laisvalaikio centras } \\
(2015-2016 \mathrm{m.})\end{array}$ & $\begin{array}{l}\text { Mažeikių r. SVB; } \\
\text { partneriai: Mažeikių r. ne- } \\
\text { vyriausybinių organizacijų } \\
\text { asociacija, Mažeikių r. savi- } \\
\text { valdybės švietimo skyrius, } \\
\text { Mažeikių moterų LIONS } \\
\text { klubas, Mažeikių r. savival- } \\
\text { dybės visuomenės sveikatos } \\
\text { biuras }\end{array}$ & $\begin{array}{l}\text { BMGF, KM [BP 2] } \\
\text { (finansavimas skir- } \\
\text { tas } 2015 \text { metais) }\end{array}$ \\
\hline 2 & Pasaulio pažinimas knygose ir kelionèse & Mažeikių r. SVB & LKT \\
\hline 3 & $\begin{array}{l}\text { Kraštiečių kūrybiniai susitikimai su vietos bendruo- } \\
\text { mene Mažeikių viešojoje bibliotekoje }\end{array}$ & Mažeikių r. SVB & SV \\
\hline 4 & Jaunimo erdve - laisvalaikiui ir iniciatyvoms & $\begin{array}{l}\text { Mažeikių r. SVB (Mažeikių r. } \\
\text { bibliotekininkų draugija) }\end{array}$ & SV \\
\hline 5 & Atverkime adventinę kraičio skrynia & Mažeikių r. SVB Balėnų f. & SV \\
\hline 6 & Bibliotekoje skaitau, kuriu, su draugais susitinku & Mažeikių r. SVB Ukrinų f. & SV \\
\hline 7 & Plungès išmanusis parkas (2015-2016 m.) & $\begin{array}{l}\text { Plungès r. SVB; } \\
\text { partneriai: Žemaičių dailès } \\
\text { muziejus, Žemaitijos naci- } \\
\text { onalinis parkas, Klaipėdos } \\
\text { universiteto Botanikos } \\
\text { sodas, Plungès ir Rietavo } \\
\text { krašto fotoklubas „Žybt“, } \\
\text { kultūros draugija „Saulute“, } \\
\text { klubas „Oginskių dvaro } \\
\text { bičiuliai“ }\end{array}$ & $\begin{array}{l}\text { BMGF, KM [BP 2] } \\
\text { (finansavimas skir- } \\
\text { tas } 2015 \text { metais) }\end{array}$ \\
\hline 8 & Skaitīmā žemaitèškā & Plungès r. SVB & SV \\
\hline 9 & $\begin{array}{l}\text { Dingstančio ir atgimstančio kultūros paveldo vaizdai } \\
\text { Vlado Gaudiešiaus fotografijose }\end{array}$ & Plungès r. SVB & SV \\
\hline 10 & Praeinančio laiko fiksuotojai & Plungès r. SVB & SV \\
\hline 11 & $\begin{array}{l}\text { Lauko fotografijos paroda „Fotoaleja - 2016“ } \\
\text { [tęstinis] }\end{array}$ & Plungès r. SVB & SV \\
\hline 12 & Projektas, skirtas miesto šventei organizuoti & Plungès r. SVB & SV \\
\hline 13 & Knygos teatras - žaidimas žodžiu ir forma [tęstinis] & Plungès r. SVB & SV \\
\hline 14 & $\begin{array}{l}\text { Mūsų pasaulis, mūsų - Jūsų ateitis [skirtas Europos } \\
\text { dienai] }\end{array}$ & Rietavo SVB & EKAL \\
\hline 15 & $\begin{array}{l}\text { MOKI ŽODI - RANDI KELIĄ: mokymosi visa gy- } \\
\text { venima nauda praktiškai, užsienio kalbų mokymasis } \\
(2015-2016 \text { m.) }\end{array}$ & Telšių r. SVB & $\begin{array}{l}\text { BMGF, KM [BP 2] } \\
\text { (finansavimas skir- } \\
\text { tas } 2015 \text { metais) }\end{array}$ \\
\hline 16 & $\begin{array}{l}\text { Nuo rankraštinès knygos iki skaitmeninio pasakojimo } \\
\text { (+ Gidas kraštiečiu galerijai kurti) }\end{array}$ & Telšių r. SVB & SV \\
\hline 17 & Kartu susitikimas: skaitykime kartu su vaikais & Telšių r. SVB & SV \\
\hline
\end{tabular}




\begin{tabular}{|c|c|}
\hline Eil. nr. & Pavadinimas \\
\hline 18 & 7 meno kalbos \\
\hline 19 & Biblioteku erdvès tobulejimui ir grožiui \\
\hline 20 & $\begin{array}{l}\text { Lietuvos maironiečių sambūris ir kūrybinès dirbtuvès } \\
\text { „Ant septyniu Telšiu miesto kalvų“ }\end{array}$ \\
\hline 21 & $\begin{array}{l}\text { Septintoji kalva [tęstinis; skirtas jaunų žmonių } \\
\text { (14-29 metų) literatūrinių kūrinių konkursams } \\
\text { organizuoti] }\end{array}$ \\
\hline 22 & Biblioteka laiko vingiuose \\
\hline 23 & Tobulèjimas per kūryba \\
\hline
\end{tabular}

2017 metai

1 B. A. B. 2017 (Biblioteka arčiau bendruomenes bendruomenè arčiau bibliotekos)

2 Lietuvos įvaizdžio sąsaja Sofijos Šviesaitès poezijoje ir muzikoje

3 Poezijos pavasario renginiai Mažeikių rajone

4 Pažinti ir vaizda, ir minti [skirtas vaikams ir jaunimui]

5 Susitikimas su žymiais Mažeikiu krašto žmonèmis (ciklas Mūsų krašto šviesuoliai)

6 Jaunimo erdvé - vieta, kurioje gera būti

7 Pažink tautinio kostiumo groži [skirtas vaikams]

8 Lietuviu liaudies ornamentikos taikymas namy puošyboje

9 Ka byloja Daubariu piliakalnis

10 Vasara - skaitymų ir kūrybinių nuotykių metas

11 Piliakalniai - turtingas praeities pažinimo šaltinis

12 Gyvoliu piliakalnio atsiradimo istorija

13 Europos diena Plungèje

14 Kultūros paribiuose (Žemaičių saulutè)

$15 X X I$ a. tarptautinis neskubejimo festivalis upe

16 Plungès išmaniojo parko objektu sklaida

17 TA vieta - jaučiu, liečiu, girdžiu esu - „žalieji pasimatymai“ [skirtas neigaliesiems]

18 Fotoalèja - 2017 [tęstinis]

19 Mes - žemaičiu žemès

20 Meno pleneras Babrungo kraštovaizdžio draustinyje

21 Fotopleneras „Saulutés 100-mečio keliais“

22 Judek kartu - 2017

\begin{tabular}{|l|l|}
\hline Biblioteka, partneriai & Rèmèjai \\
\hline Telšių r. SVB & SV \\
\hline Telšių r. SVB & SV \\
\hline Telšių r. SVB & SV \\
\hline
\end{tabular}

Telšių r. SVB SV

Telšių r. SVB Varnių f. SV

Telšių r. SVB Varnių f.; $\quad$ SV

partnerè - Varnių senolių

bendruomenè

Mažeikių r. SVB

LKT

Mažeikių r. SVB

SV

Mažeikių r. SVB SV

Mažeikių r. SVB

SV

Mažeikių r. SVB

SV

Mažeikių r. SVB (Mažeikių r. SV bibliotekininkų draugija)

Mažeikių r. SVB Auksodès ir SV

Laižuvos filialai

Mažeikių r. SVB Buknaičių f. SV

Mažeikių r. SVB Tirkšlių ir SV

Šerkšnènų filialai

Mažeikių r. SVB Ukrinų f. SV

Mažeikių r. SVB Ukrinų, $\quad$ SV

Pikelių, Židikų filialai

Mažeikių r. SVB Viekšnių f. SV

Plungès r. SVB

EKAL

Plungès r. SVB

Spaudos, radijo ir televizijos rèmimo fondas

\begin{tabular}{l|l}
\hline Plungès r. SVB & LKT, SV \\
\hline Plungès r. SVB & LKT, KM, SV \\
\hline Plungès r. SVB & LKT
\end{tabular}

Plungès r. SVB SV

Plungès r. SVB SV

Plungès r. SVB SV

Plungès r. SVB SV

Plungès r. SVB SV 


\begin{tabular}{|c|c|c|c|}
\hline Eil. nr. & Pavadinimas & Biblioteka, partneriai & Rèmèjai \\
\hline 23 & Kultūros paveldo aktualizacija & Plungès r. SVB & SV \\
\hline 24 & $\begin{array}{l}\text { Biblioterapija - visiems ir kiekvienam - žmogaus } \\
\text { vidinių jeggų ir sveikatos potencialo budinimas [tęs- } \\
\text { tinis] }\end{array}$ & Plungès r. SVB & SV \\
\hline 25 & Jaunimo kūrybos laboratorija & Telšių r. SVB & SV \\
\hline 26 & Keliaujanti poezija & Telšių r. SVB & SV \\
\hline 27 & $\begin{array}{l}\text { Septintoji kalva [tęstinis; skirtas jaunų žmonių } \\
(14-29 \text { m.) literatūrinių kūrinių konkursams orga- } \\
\text { nizuoti] }\end{array}$ & Telšių r. SVB & SV \\
\hline 28 & Per Europos istorija $i$ valstybès šimtmeti & $\begin{array}{l}\text { Telšių r. SVB; } \\
\text { partneris - Telšių „Europe } \\
\text { Direct“ informacijos centras }\end{array}$ & SV \\
\hline 29 & Šiuolaikiniai rašytojai vaikams & Telšių r. SVB & SV \\
\hline 30 & Tegul joukas dūšè & Telšių r. SVB Degaičių f. & SV \\
\hline 31 & Poezija sodu žydejime [tęstinis] & $\begin{array}{l}\text { Telšių r. SVB Kaunatavos f.; } \\
\text { partnerè - kaimo bendruo- } \\
\text { mené }\end{array}$ & SV \\
\hline 32 & $\begin{array}{l}\text { Mūsu dienos kaip šventė... [numatė mokymus apie } \\
\text { žemaitiškų valgių gaminimą] }\end{array}$ & Telšių r. SVB Varnių f. & SV \\
\hline 33 & $\begin{array}{l}\text { Padedi žmogui - padedi sau [skirtas sveikatingumo } \\
\text { problemoms] }\end{array}$ & $\begin{array}{l}\text { Telšių r. SVB } \\
\text { Varnių f.; } \\
\text { partneris - Senjorų klubas }\end{array}$ & SV \\
\hline 34 & Nuo rašytojo link skaitytojo & $\begin{array}{l}\text { Telšių r. SVB } \\
\text { Viešvènų f. }\end{array}$ & SV \\
\hline
\end{tabular}

9 priedas. Vilniaus apskr. savivaldybių viešųjų bibliotekų 2007, 2013, 2015-2017 metų projektai

\begin{tabular}{|c|c|c|c|}
\hline Eil. nr. & Pavadinimas & Biblioteka, partneriai & Rèmèjai \\
\hline 1 & $\begin{array}{l}\text { Knygu pasaulis - nuostabus. Vaikai kuria savo knygu } \\
\text { namus }\end{array}$ & Elektrėnų SVB & KM \\
\hline 2 & Elektrènų krašto kultūros paveldo istorija ir dabartis & Elektrėnų SVB & $\begin{array}{l}\text { Lietuvos tūkstant- } \\
\text { mečio minèjimo } \\
\text { direkcija prie LR } \\
\text { Prezidento kance- } \\
\text { liarijos }\end{array}$ \\
\hline 3 & Aktyvios jungtys [skirtas skaitymui skatinti] & Širvintų r. SVB & [nenurodyta] \\
\hline 4 & Gyvenimas skaitymo šalyje & Širvintų r. SVB & [nenurodyta] \\
\hline 5 & $\begin{array}{l}\text { Maži atradimai sau [skirtas vaikų skaitymui } \\
\text { skatinti] }\end{array}$ & Širvintų r. SVB & [nenurodyta] \\
\hline 6 & Mano vaikystès knyga & Švenčionių r. SVB & [nenurodyta] \\
\hline 7 & Knyga vaiko vertybiu kontekste & $\begin{array}{l}\text { Švenčionių r. SVB Švenčio- } \\
\text { nèlių f. }\end{array}$ & [nenurodyta] \\
\hline 8 & Vakaro skaitymai Adutiškio kaimo bibliotekoje & $\begin{array}{l}\text { Švenčionių r. SVB Adutiš- } \\
\text { kio f. }\end{array}$ & [nenurodyta] \\
\hline 9 & Senujų amatų mokyklèlè Strūnaityje & $\begin{array}{l}\text { Švenčionių r. SVB Strūnai- } \\
\text { čio f. }\end{array}$ & [nenurodyta] \\
\hline
\end{tabular}




\begin{tabular}{|c|c|}
\hline Eil. nr. & Pavadinimas \\
\hline 10 & Atostogos be knygos - ne atostogos \\
\hline 11 & Astrida Lindgren ir jos herojai \\
\hline 12 & Mes piešiame Trakus \\
\hline 13 & $\begin{array}{l}\text { Džiūgenu beieškant, arba Tegyvuoja knyga! [skirtas } \\
\text { A. Lindgren kūrybai] }\end{array}$ \\
\hline 14 & $\begin{array}{l}\text { Bibliografijos rodyklè „Kraštotyrininkè Albina Kati- } \\
\text { naitè-Navickiené“ }\end{array}$ \\
\hline 15 & Vaiko draugystè su knyga \\
\hline 16 & Aš skaitau, skaityk ir tu \\
\hline 17 & Skatinam skaityma - per garsą ir vaizdą prie žodžio \\
\hline 18 & Kiekviena knyga reikia mokèti skaityti \\
\hline 19 & $\begin{array}{l}\text { Pažinimo medis [edukacinè programa vaikams ir } \\
\text { jaunimui] }\end{array}$ \\
\hline 20 & Biblioterapija \\
\hline
\end{tabular}

21 Knygos tiesia tiltus (Книги строят мосты)

$22 B \bar{k}$ savas matomas pilietis [skirtas tautinių mažumų pilietiškumui ugdyti]

23 Vaiku vasaros dienos stovykla „Robinzonu Sala“

24 Vaiku vasaros poilsio programa "Fantazija“

\section{Biblioteka, partneriai}

Trakų r. SVB

Traku r. SVB

Traku r. SVB

Ukmergès r. SVB;

partnerės; Ukmergès Dukstynos pagrindiné mokykla, Ukmergès dailès mokykla

Ukmergès r. SVB Lyduokių f. [nenurodyta]

Vilniaus m. SCB

KM

Tomo Zano f.

Vilniaus m. SCB „Saulutes“ $f$. KM

Vilniaus m. SCB Kalvarijų f. KM

Vilniaus m. SCB Antakalnio f. KM

Vilniaus m. SCB Naujosios

$\mathrm{KM}$

Vilnios $\mathrm{f}$.

Vilniaus m. SCB Naujosios

KM

Vilnios $\mathrm{f}$.

Vilniaus m. SCB;
partnerè - Sankt Peterburgo

tarprajoninè centralizuota

Michailo Lermontovo viešų-

jų bibliotekų sistema (Rusija)

Vilniaus m. SCB Naujosios

Vilnios $\mathrm{f}$.

Vilniaus m. SCB Naujosios

Vilnios $\mathrm{f}$.

Vilniaus m. SCB

Tomo Zano f.

ŠMM

KM

KM

KM

Rèmèjai

[nenurodyta]

SV

SV

SV
EKAL

KM

Elektrènų SVB,

Šalčininkų r. SVB,

Širvintų r. SVB,

Švenčionių r. SVB,

Trakų r. SVB,

Ukmergès r. SVB,

Vilniaus m. SCB,

Vilniaus r. SCB,

partnerè - VAVB

Elektrẻnų SVB

KRF

Elektrènų SVB

Gilučių f.

Europos žemès ūkio fondas kaimo plètrai (LEADER programa)

KM

Širvintu r. SVB

12 Skaitome kitaip 


\begin{tabular}{|c|c|c|c|}
\hline Eil. nr. & Pavadinimas & Biblioteka, partneriai & Rèmèjai \\
\hline 13 & $\begin{array}{l}\text { Apie žodị-išlekiantị ir sugrịžtantị } \\
(2012-2013 \mathrm{m.})\end{array}$ & Širvintų r. SVB & $\begin{array}{l}\text { Europos žemès } \\
\text { ūkio fondas kaimo } \\
\text { plètrai (LEADER } \\
\text { programa) }\end{array}$ \\
\hline 14 & E. paslaugos - saugu, patogu, patikima & Švenčionių r. SVB & $\mathrm{KRF}$ \\
\hline 15 & $\begin{array}{l}\check{Z} u v e ̨ \text {, bet nepralaimèję [S. Dariaus ir S. Girèno skry- } \\
\text { džio per Atlantą } 80 \text {-mečiui; skirtas moksleiviams] }\end{array}$ & Švenčionių r. SVB & $\mathrm{KRF}$ \\
\hline 16 & Mano Europa - mano teisès & Trakų r. SVB & EKAL \\
\hline 17 & Pažink pasaku (knygu) pasauli su Lèle & Trakų r. SVB & KM \\
\hline 18 & $\begin{array}{l}\text { Donelaitis praeityje ir dabartyje [skirtas mokslei- } \\
\text { viams] }\end{array}$ & $\begin{array}{l}\text { Trakų r. SVB; } \\
\text { partneris - rajono švietimo } \\
\text { skyrius }\end{array}$ & KRF, SV \\
\hline 19 & $\begin{array}{l}\text { Kelione i aviacijos pasauli [skirtas S. Dariaus ir } \\
\text { S. Girèno skrydžio per Atlantą 80-mečiui ] }\end{array}$ & Trakų r. SVB & KM \\
\hline 20 & $\begin{array}{l}\text { Esu jaunas, energingas, naujoviu ieškantis žmo- } \\
\text { gus [skirtas jaunimo skaitmeniniam raštingumui } \\
\text { ugdyti] }\end{array}$ & Trakų r. SVB & KM, SV \\
\hline 21 & Nuo knygos iki meno [skirtas vaikams] & $\begin{array}{l}\text { Trakų r. SVB } \\
\text { Lentvario f. }\end{array}$ & $\mathrm{KRF}$ \\
\hline 22 & $A \check{s}, t u, m E S$ - piliečiai & Ukmergès r. SVB & EKAL \\
\hline 23 & $\begin{array}{l}\text { @š mokausi su draugais [skirtas kompiuteriniam } \\
\text { raštingumui ugdyti specialiosios mokyklos vai- } \\
\text { kams] }\end{array}$ & $\begin{array}{l}\text { Ukmergès r. SVB; } \\
\text { partnerè - „Ryto“ specialioji } \\
\text { mokykla }\end{array}$ & KM \\
\hline 24 & $\begin{array}{l}\text { Interaktyviu elektroniniu paslaugu, skirtų leidiniams } \\
\text { ir publikacijoms užsakyti bei gauti viešosiose biblio- } \\
\text { tekose, plètra }\end{array}$ & Vilniaus m. SCB & $\begin{array}{l}\text { ES struktūriniai } \\
\text { fondai }\end{array}$ \\
\hline 25 & $\begin{array}{l}\text { Po Vilnių su knyga [tęstinis, skirtas miesto kultūros } \\
\text { paveldui] }\end{array}$ & $\begin{array}{l}\text { Vilniaus m. SCB; } \\
\text { partneriai: V̌̌I Tautinių } \\
\text { bendrijų namai, Senamiesčio } \\
\text { jaunimo klubas „Kregždute“ }\end{array}$ & [nenurodyta] \\
\hline 26 & $\begin{array}{l}\text { Klausome ir piešiame pasakas LRT mobiliosioms } \\
\text { programèlems kurti }\end{array}$ & $\begin{array}{l}\text { Vilniaus m. SCB; } \\
\text { partneriai: LRT, V̌̌t „Links- } \\
\text { mos spalvos“ }\end{array}$ & [nenurodyta] \\
\hline \multicolumn{4}{|c|}{2015 metai } \\
\hline 1 & $\begin{array}{l}\text { Lietuva Europos Sajungoje: pasiekimai ir ateities } \\
\text { perspektyvos }\end{array}$ & Elektrènų SVB & EKAL \\
\hline 2 & $\begin{array}{l}\text { Saviraiškos erdvès paaugliams ir jaunimui įkūrimas } \\
(2015-2016 \mathrm{~m} .)\end{array}$ & Elektrènų SVB & BMGF, KM [BP 2] \\
\hline 3 & Jaunimo užimtumo skatinimas [tęstinis] & Elektrènų SVB & SV \\
\hline 4 & Menas - sielos gydytojas & Elektrènų SVB & SV \\
\hline 5 & Liaudies amatu kūrybinès dirbtuvès & Elektrėnų SVB Gilučių f. & SV \\
\hline 6 & Europa - mūsų dabartis ir ateitis & $\begin{array}{l}\text { Širvintų r. SVB; } \\
\text { partneriai: Širvintų pradinė } \\
\text { mokykla, Širvintų r. kultūros } \\
\text { centras, Širvintų r. Musnin- } \\
\text { kų kaimo bendruomenè, } \\
\text { Širvintų r. Švietimo centras } \\
\text { ir kt. }\end{array}$ & EKAL \\
\hline
\end{tabular}




\begin{tabular}{|c|c|c|c|}
\hline Eil. nr. & Pavadinimas & Biblioteka, partneriai & Rèmèjai \\
\hline 7 & $\begin{array}{l}\text { Nuo nemokèjimo skaityti iki negalëjimo neskaityti } \\
\text { [tęstinis] }\end{array}$ & $\begin{array}{l}\text { Širvintų r. SVB; } \\
\text { partneriai: asociacija Tẻvų ir } \\
\text { vaikų klubas, UAB „Danie- } \\
\text { lita“, asociacija „Intelektinio } \\
\text { kapitalo ugdymas“ }\end{array}$ & LKT \\
\hline 8 & $\begin{array}{l}\text { Informaciniu technologiju centro „Failiukas“ } i k u ̄ r i- \\
\text { mas ir veikla bibliotekose } \\
(2015-2016 \mathrm{~m} .)\end{array}$ & Švenčionių r. SVB & BMGF, KM [BP 2] \\
\hline 9 & Mes su Vilnija suaugę [literatūros] & $\begin{array}{l}\text { Švenčionių r. SVB Švenčio- } \\
\text { nèlių, Milkuškų, Pašaminès } \\
\text { filialai }\end{array}$ & [nenurodyta] \\
\hline 10 & Kompiuterio labirintai [skirtas vaikams] & $\begin{array}{l}\text { Švenčionių r. SVB Švenčio- } \\
\text { nèlių f. }\end{array}$ & SV \\
\hline 11 & Vaikai-mūsų ES ateitis & Trakų r. SVB & EKAL \\
\hline 12 & Migruojantis kinas (2015-2016 m.) & $\begin{array}{l}\text { Trakų r. SVB; } \\
\text { partneriai: Trakų kultū- } \\
\text { ros rūmai, Trakų istorijos } \\
\text { muziejus, Trakų r. kūno } \\
\text { kultūros ir sporto centras, } \\
\text { bendruomenè „Santalk“a }\end{array}$ & $\begin{array}{l}\text { BMGF, KM [BP 2], } \\
\text { SV }\end{array}$ \\
\hline 13 & $\begin{array}{l}\text { Istoriné-muzikiné dekada „Sugrižimas i Tëvynę } \\
\text { [skirta Mykolo Kleopo Oginskio 250-osioms gimi- } \\
\text { mo metinèms] }\end{array}$ & $\begin{array}{l}\text { Trakų r. SVB; } \\
\text { partneriai: Trakų meno mo- } \\
\text { kykla, Trakų kultūros rūmai }\end{array}$ & LKT, SV \\
\hline 14 & Tiltu krašto kaimai šimtmečių kaitoje & Trakų r. SVB & LKT, SV \\
\hline 15 & $\begin{array}{l}\text { E. paslaugu fakultetas „Žinios naudingos tada, kai } \\
\text { jos gali palengvinti gyvenima“"(2015-2016 m.) }\end{array}$ & Ukmergės r. SVB & $\begin{array}{l}\text { BMGF, KM [BP 2], } \\
\text { SV }\end{array}$ \\
\hline 16 & Geraknyga+@@+šauni kompanija=biblioteka & Ukmergès r. SVB & LKT \\
\hline 17 & Edukacijų, dailès ir lazdynų mozaika & Ukmergès SVB Lèno $\mathrm{f}$. & LKT \\
\hline 18 & $\begin{array}{l}\text { Po senojo dvaro skliautais - Šventupé senose fotogra- } \\
\text { fijose }\end{array}$ & $\begin{array}{l}\text { Ukmergės SVB Šventupės f.; } \\
\text { partnerė - kaimo bendruo- } \\
\text { mene் }\end{array}$ & SV \\
\hline 19 & $\begin{array}{l}\text { Mes Knygus s@loje“(2015-2016 m.) [skirtas } \\
\text { vaikams] }\end{array}$ & $\begin{array}{l}\text { Vilniaus m. SCB; } \\
\text { partneriai: Mykolo Romerio } \\
\text { universitetas, VAVB, Radvi- } \\
\text { liškio r. SVB, Utenos SVB, } \\
\text { Zarasų r. SVB, Vilniaus m. } \\
\text { Antakalnio vaikų socialinės } \\
\text { globos namai, Vaikų ir jau- } \\
\text { nimo dienos centras „Mūsų } \\
\text { nameliai“ }\end{array}$ & BMGF, KM [BP 2] \\
\hline 20 & Raktas $i$ Čiurlioni & $\begin{array}{l}\text { Vilniaus m. SCB } \\
\text { Tomo Zano f. }\end{array}$ & [nenurodyta] \\
\hline 21 & Pažistamas ir nepažịstamas Vilnius [tęstinis] & Vilniaus m. SCB „Saulutės“ f. & LKT \\
\hline 22 & $\begin{array}{l}\text { Ar skaitei Vilniu 2? [tęstinis; skirtas vaikų skaitymui } \\
\text { skatinti] }\end{array}$ & $\begin{array}{l}\text { Vilniaus m. centrinè biblio- } \\
\text { teka, Antakalnio ir Pilaitès } \\
\text { filialai }\end{array}$ & LKT \\
\hline 23 & $\begin{array}{l}\text { Skaitymo skatinimo teatralizuotos biblioterapijos } \\
\text { programa romu vaikams ir jaunimui }\end{array}$ & $\begin{array}{l}\text { Vilniaus m. SCB } \\
\text { Naujosios Vilnios f. }\end{array}$ & LKT \\
\hline
\end{tabular}




\begin{tabular}{|c|c|c|c|}
\hline Eil. nr. & Pavadinimas & Biblioteka, partneriai & Rèmèjai \\
\hline \multicolumn{4}{|c|}{2016 metai } \\
\hline 1 & Mes Europoje vakar, šiandien ir rytoj & Elektrènų SVB & EKAL \\
\hline 2 & $\begin{array}{l}\text { Saviraiškos erdvè paaugliams ir jaunimui ịkūrimas } \\
(2015-2016 \text { m.) }\end{array}$ & Elektrènų SVB & $\begin{array}{l}\text { BMGF, KM [BP 2] } \\
\text { (finansavimas skir- } \\
\text { tas } 2015 \text { metais) }\end{array}$ \\
\hline 3 & Knyga - sielos namų vaistine & Elektrènų SVB & LKT \\
\hline 4 & Sveiki vaikai - sveika ateitis [skirtas vaikams] & Elektrènų SVB & SV \\
\hline 5 & Jaunimo užimtumo skatinimas [tęstinis] & Elektrènų SVB & SV \\
\hline 6 & Tëvynès meilès ir grožio keliu [skirtas vaikams] & Elektrènų SVB & SV \\
\hline 7 & Europos Sajunga: suvienijusi įvairovę & Širvintų r. SVB & EKAL \\
\hline 8 & Medijos keičia mūsu pasauli & Širvintų r. SVB & LKT \\
\hline 9 & $\begin{array}{l}\text { Nuo nemokèjimo skaityti iki negalejimo neskaityti } \\
\text { [bibliotekos tinklalapyje tai antras projektas tuo } \\
\text { pačiu pavadinimu kaip ir } 2015 \text { m., skiriasi igyven- } \\
\text { dinimo terminai] }\end{array}$ & $\begin{array}{l}\text { Širvintų r. SVB; } \\
\text { partneriai: asociacija Tẻvų ir } \\
\text { vaikų klubas, UAB „Danie- } \\
\text { lita“, asociacija „Intelektinio } \\
\text { kapitalo ugdymas“ }\end{array}$ & LKT \\
\hline 10 & $\begin{array}{l}\text { Informaciniu technologiju centro „Failiukas“ i ikūri- } \\
\text { mas ir veikla bibliotekose“ } \\
(2015-2016 \text { m.) }\end{array}$ & Švenčionių r. SVB & $\begin{array}{l}\text { BMGF, KM [BP 2] } \\
\text { (finansavimas skir- } \\
\text { tas } 2015 \text { metais) }\end{array}$ \\
\hline 11 & ES(u) čia! [skirtas Europos dienai] & Trakų r. SVB & EKAL \\
\hline 12 & Migruojantis kinas (2015-2016 m.) & $\begin{array}{l}\text { Trakų r. SVB; } \\
\text { partneriai: Trakų kultū- } \\
\text { ros rūmai, Trakų istorijos } \\
\text { muziejus, Trakų r. kūno } \\
\text { kultūros ir sporto centras, } \\
\text { bendruomenè „Santalka“ }\end{array}$ & $\begin{array}{l}\text { BMGF, KM [BP 2] } \\
\text { (finansavimas skir- } \\
\text { tas } 2015 \text { metais) }\end{array}$ \\
\hline 13 & BKB: biblioteka-knyga-bendruomené & Trakų r. SVB & LKT \\
\hline 14 & 3D aš: dizainas-darbas-dialogas & Trakų r. SVB & LKT, SV \\
\hline 15 & Europa - Ukmergèje, Ukmergé - Europoje & Ukmergès r. SVB & EKAL \\
\hline 16 & $\begin{array}{l}\text { E. paslaugu fakultetas „Žinios naudingos tada, kai } \\
\text { jos gali palengvinti gyvenima“ (2015-2016 m.) }\end{array}$ & Ukmergès r. SVB & $\begin{array}{l}\text { BMGF, KM [BP 2] } \\
\text { (finansavimas skir- } \\
\text { tas } 2015 \text { metais) }\end{array}$ \\
\hline 17 & $\begin{array}{l}\text { Balsa žemès gimtos išnešiojęs giliausiai širdy... („Ir } \\
\text { groja Šlaitas vargonais“) }\end{array}$ & Ukmergès r. SVB & LKT \\
\hline 18 & $\begin{array}{l}\text { Mes Knygus s@loje (2015-2016 m.) [e. biblioterapinis } \\
\text { žaidimas, skirtas vaikams] }\end{array}$ & $\begin{array}{l}\text { Vilniaus m. SCB; } \\
\text { partneriai: Mykolo Romerio } \\
\text { universitetas, VAVB, Radvi- } \\
\text { liškio r. SVB, Utenos SVB, } \\
\text { Zarasų r. SVB, Vilniaus m. } \\
\text { Antakalnio vaikų socialinės } \\
\text { globos namai, Vaikų ir jau- } \\
\text { nimo dienos centras „Mūsų } \\
\text { nameliai“ }\end{array}$ & $\begin{array}{l}\text { BMGF, KM [BP 2] } \\
\text { (finansavimas skir- } \\
\text { tas } 2015 \text { metais) }\end{array}$ \\
\hline 19 & $\begin{array}{l}\text { Atvirumo s@la bibliotekoje [e. biblioterapinis žaidi- } \\
\text { mas; skirtas socialinę riziką patiriantiems vaikams } \\
\text { ir suaugusiems jų šeimų nariams] }\end{array}$ & $\begin{array}{l}\text { Vilniaus m. SCB Naujosios } \\
\text { Vilnios, Antakalnio ir Karo- } \\
\text { liniškių filialai }\end{array}$ & KM \\
\hline
\end{tabular}




\begin{tabular}{|c|c|c|c|}
\hline Eil. nr. & Pavadinimas & Biblioteka, partneriai & Rèmèjai \\
\hline 20 & $\begin{array}{l}360^{\circ} \text { [virtualiosios realybės pagal lietuvių autorių } \\
\text { kūrinius akinių instaliacija bibliotekoje] }\end{array}$ & Vilniaus m. SCB & LKT \\
\hline 21 & $\begin{array}{l}\text { Pažistamas ir nepažistamas Vilnius } 2 \text { [tęstinis; skir- } \\
\text { tas vaikų skaitymui skatinti] }\end{array}$ & $\begin{array}{l}\text { Vilniaus m. SCB } \\
\text { „Saulutès“ f. }\end{array}$ & LKT \\
\hline 22 & $\begin{array}{l}\text { Vilnius GO (2016-2018 m.) [mobilioji aplikacija; } \\
\text { tikslas - supažindinti su Vilniaus miesto istoriniu, } \\
\text { gamtiniu ir kultūriniu palikimu, I etapas - } 2016 \mathrm{~m} \text {.] }\end{array}$ & $\begin{array}{l}\text { Vilniaus m. SCB } \\
\text { UAB „Gluk media“, Lietuvos } \\
\text { edukologijos universitetas, } \\
\text { Kultūros paveldo centras }\end{array}$ & LKT \\
\hline 23 & Mokèti kalbq - pažinti Lietuva & $\begin{array}{l}\text { Vilniaus m. SCB Naujosios } \\
\text { Vilnios } \mathrm{f} .\end{array}$ & LKT \\
\hline 24 & $\begin{array}{l}\text { Mano kambarèly keturios kèdutès [skirtas vaikams ir } \\
\text { paaugliams bibliotekoje savo personalinei „erdvę“ } \\
\text { susikurti] }\end{array}$ & Vilniaus m. SCB & LKT \\
\hline 25 & $\begin{array}{l}\text { Priimti Negalima Grįžti [skirtas pabègèlių socialinei } \\
\text { integracijai] }\end{array}$ & $\begin{array}{l}\text { Vilniaus m. CB, Antakalnio, } \\
\text { Karoliniškių, Pilaitès filialai }\end{array}$ & LKT \\
\hline 26 & Kuriantys lazdyniečiai & Vilniaus m. SCB Lazdynų f. & LKT \\
\hline 27 & $\begin{array}{l}\text { Kultūrų dialogas vienija: programa romu vaikams ir } \\
\text { jaunimui }\end{array}$ & $\begin{array}{l}\text { Vilniaus m. SCB Naujosios } \\
\text { Vilnios } \mathrm{f} .\end{array}$ & LKT \\
\hline 28 & $\begin{array}{l}\text { Psichosocialinés paslaugos vaiku ir jaunimo dienos } \\
\text { centro „Mūsų nameliai“ lankytojams ir jų šeimoms } \\
\text { (2016-2017 m.) }\end{array}$ & $\begin{array}{l}\text { Vilniaus m. SCB Naujosios } \\
\text { Vilnios f.; } \\
\text { partneris - vaikų ir jauni- } \\
\text { mo dienos centras „Mūsų } \\
\text { nameliai“ }\end{array}$ & $\begin{array}{l}\text { Socialinès apsaugos } \\
\text { ir darbo ministerija }\end{array}$ \\
\hline 29 & $\begin{array}{l}\text { Karoliniškių biblioteka - bendruomenès traukos ir } \\
\text { meninès saviraiškos centras }\end{array}$ & $\begin{array}{l}\text { Vilniaus m. SCB Karoliniš- } \\
\text { kių f. }\end{array}$ & SV \\
\hline 30 & Pasauliu netikiu, o pasaka - tikiu & Vilniaus $\mathrm{m}$. SCB Pilaitès $\mathrm{f}$. & SV \\
\hline 31 & $\begin{array}{l}\text { Drauge i vasara [vasaros stovykla vaikams; anglų } \\
\text { kalbos igūdžių stiprinimas] }\end{array}$ & $\begin{array}{l}\text { Vilniaus m. SCB Naujosios } \\
\text { Vilnios } \mathrm{f} .\end{array}$ & SV \\
\hline \multicolumn{4}{|c|}{2017 metai } \\
\hline 1 & Europa: nuo Romos sutarties iki šiandien & Elektrènų SVB & EKAL \\
\hline 2 & $\begin{array}{l}\text { Kultūros paveldo išsaugojimas, mokymai ir sklaida } \\
\text { pasitelkiant inovatyvias technologijas }\end{array}$ & Elektrènų SVB & LKT \\
\hline 3 & $\begin{array}{l}\text { Lietuviškas kinas regionuose: nuo pristatymo iki } \\
\text { peržiūros }\end{array}$ & Elektrènų SVB & SV \\
\hline 4 & Fraktalu terapija - netradiciné sielu gydykla & Elektrènų SVB & SV \\
\hline 5 & $\begin{array}{l}\text { Žvilgsnis i Lietuvos praeitị [skirtas vaikams; pagrin- } \\
\text { dinès veiklos susijusios su etnokultūros pažinimu] }\end{array}$ & Elektrènų SVB & SV \\
\hline 6 & Tobulèk 3D erdvèje & Elektrènų SVB & SV \\
\hline 7 & Skaitymas su šunimi & Elektrènų SVB & SV \\
\hline 8 & Vasara smagiai ir kūrybingai & Elektrènų SVB & SV \\
\hline 9 & Sveika gyvensena pilnaverčiam rytojui & Elektrènų SVB & SV \\
\hline 10 & Vaikų sveikatinimo įpročių ugdymas & Elektrènų SVB & SV \\
\hline 11 & Amatų kalvé & $\begin{array}{l}\text { Elektrènų SVB } \\
\text { Gilučių f. }\end{array}$ & [nenurodyta] \\
\hline
\end{tabular}




\begin{tabular}{|c|c|c|c|}
\hline Eil. nr. & Pavadinimas & Biblioteka, partneriai & Rèmèjai \\
\hline 12 & Europos Sajunga: suvienijusi įvairovę & $\begin{array}{l}\text { Širvintų r. SVB; } \\
\text { partneriai: Širvintų r. savival- } \\
\text { dybės kultūros centras, Širvin- } \\
\text { tų r. švietimo centras, Širvintų } \\
\text { Lauryno Stuokos-Gucevičiaus } \\
\text { gimnazija ir kt. }\end{array}$ & EKAL \\
\hline 13 & Gydanti knygos galia & Širvintų r. SVB & [nenurodyta] \\
\hline 14 & Medijos keičia mūsu pasauli - suprask jas & Širvintų r. SVB & LKT \\
\hline 15 & Europos karuselè - ateiti kurk ir tu! & Švenčionių r. SVB & EKAL \\
\hline 16 & $\begin{array}{l}\text { Tarpkultūrinis migrantu švietimas } \\
(2017-2018 \mathrm{m.})\end{array}$ & $\begin{array}{l}\text { Švenčionių r. SVB, } \\
\text { partnerè - VAVB }\end{array}$ & $\begin{array}{l}\text { „Erasmus +“(„Mo- } \\
\text { bility“ programa) }\end{array}$ \\
\hline 17 & Kūrybiniu ideju sklaida „Pelèdos dvaro“ erdvèse & Švenčionių r. SVB & LKT \\
\hline 18 & $\begin{array}{l}\text { Maironis - lietuviu tautinio atgimimo dainius } \\
\text { [pastaba: ataskaitoje projektai ir renginiai neatskirti; } \\
\text { pateiktas atvejis, panašus į projektą] }\end{array}$ & Trakų r. SVB & SV \\
\hline 19 & Pažinkime Europos miestą, kuriame gyvename & Ukmergès r. SVB & EKAL \\
\hline 20 & Menas tarp knygu & Ukmergès r. SVB & LKT \\
\hline 21 & Šalin akinius & $\begin{array}{l}\text { Ukmergès r. SVB } \\
\text { Liaušių f. }\end{array}$ & SV \\
\hline 22 & 100 nuotrauku prie Gedimino pilaitès Lyduokiuose & $\begin{array}{l}\text { Ukmergès r. SVB Lyduo- } \\
\text { kių f.; } \\
\text { partneris - Lyduokių moterų } \\
\text { informacijos ir užimtumo } \\
\text { klubas }\end{array}$ & SV \\
\hline 23 & $\begin{array}{l}\text { Senojo karpymo tradiciju populiarinimas Dainavos } \\
\text { kaime }\end{array}$ & $\begin{array}{l}\text { Ukmergès r. SVB Daina- } \\
\text { vos f.; } \\
\text { partneris - Ukmergès kultū- } \\
\text { ros centro Dainavos skyrius }\end{array}$ & SV \\
\hline 24 & $\begin{array}{l}\text { Vilnius GO [mobilioji aplikacija; programos } \\
\text { tikslas - supažindinti su Vilniaus miesto istoriniu, } \\
\text { gamtiniu ir kultūriniu palikimu, tęstinis, } 2017 \mathrm{~m} . \text { - } \\
\text { II etapas] }\end{array}$ & $\begin{array}{l}\text { Vilniaus m. SCB } \\
\text { UAB „Gluk media“, Lietuvos } \\
\text { edukologijos universitetas, } \\
\text { Kultūros paveldo centras }\end{array}$ & LKT \\
\hline 25 & Nerk i knyga - išlaisvink vaizduotę! & Vilniaus m. SCB & LKT \\
\hline 26 & Nestovék vietoje - menas padès & $\begin{array}{l}\text { Vilniaus m. SVB } \\
\text { Naujosios Vilnios } \mathrm{f} .\end{array}$ & LKT \\
\hline 27 & $\begin{array}{l}\text { Supermodelis [praktinès kūrybinès 3D modeliavimo } \\
\text { ir virtualiosios realybės projektavimo dirbtuvės; 3D } \\
\text { modeliavimo ir virtualiosios realybės projektavimo } \\
\text { mokymai] }\end{array}$ & Vilniaus m. SVB & LKT \\
\hline 28 & Literatūroslobiųs@loje & Vilniaus m. SCB & SV \\
\hline 29 & $\begin{array}{l}\text { Tiltas tarp Vilniaus ir Rygos [skirtas Lietuvos ir } \\
\text { Latvijos šiuolaikinei literatūrai populiarinti] }\end{array}$ & Vilniaus $\mathrm{m} . \mathrm{SCB}$ & SV \\
\hline 30 & $\begin{array}{l}\text { Pažinimo legenda: programa romų vaikams ir jau- } \\
\text { nimui }\end{array}$ & $\begin{array}{l}\text { Vilniaus m. SCB Naujosios } \\
\text { Vilnios } \mathrm{f} .\end{array}$ & SV \\
\hline 31 & Kürybinis anglu kalbos mokymasis & $\begin{array}{l}\text { Vilniaus m. SCB Naujosios } \\
\text { Vilnios } \mathrm{f} .\end{array}$ & SV \\
\hline
\end{tabular}




\begin{tabular}{|c|c|c|c|}
\hline Eil. nr. & Pavadinimas & Biblioteka, partneriai & Rèmèjai \\
\hline 32 & $\begin{array}{l}\text { Atvirumo s@la vaikui ir šeimai [interneto erdveje } \\
\text { sukurta pokalbių svetainè su žaidimo elementais, } \\
\text { taikant biblioterapijos metodą igalina spręsti socia- } \\
\text { liai pažeidžiamų vaikų ir paauglių, vaikų ir jaunimo } \\
\text { dienos centro „Mūsų nameliai“ lankytojų bei kitų } \\
\text { Naujosios Vilnios švietimo ir ugdymo institucijų } \\
\text { auklètinių ir jų tėvų ar globėjų psichosocialines } \\
\text { problemas] }\end{array}$ & $\begin{array}{l}\text { Vilniaus m. SCB Naujosios } \\
\text { Vilnios } \mathrm{f} .\end{array}$ & SV \\
\hline 33 & $\begin{array}{l}\text { Psichosocialinès paslaugos vaikų ir jaunimo dienos } \\
\text { centro „Mūsų nameliai“ lankytojams ir jų šeimoms } \\
\text { (2016-2017 m.) }\end{array}$ & Vilniaus $\mathrm{m}$. SCB & $\begin{array}{l}\text { Socialinès apsaugos } \\
\text { ir darbo ministerija } \\
\text { (finansavimas skir- } \\
\text { tas } 2016 \text { metais) }\end{array}$ \\
\hline 34 & $\begin{array}{l}\text { Vasaros stovykla „Būk sveikas ir laimingas“ [skirta } \\
\text { vaikams ir paaugliams iš socialinès rizikos šeimų] }\end{array}$ & $\begin{array}{l}\text { Vilniaus m. SCB Naujosios } \\
\text { Vilnios } \mathrm{f} .\end{array}$ & SV \\
\hline 35 & Vasaros stovykla „Mano atrastas Vilnius“ & $\begin{array}{l}\text { Vilniaus m. SCB Naujosios } \\
\text { Vilnios } \mathrm{f} \text {. }\end{array}$ & SV \\
\hline
\end{tabular}

10 priedas. Alytaus apskr. savivaldybių viešųjų bibliotekų 2007, 2013, 2015-2017 metų projektai

\begin{tabular}{|c|c|c|c|}
\hline Eil. nr. & Pavadinimas & Biblioteka, partneriai & Rèmèjai \\
\hline 1 & Baltoji idile [literatūrinis edukacijos projektas] & $\begin{array}{l}\text { Alytaus SVB; } \\
\text { partnerè - asociacija „Salo- } \\
\text { nas Balta varna“ }\end{array}$ & KSRF, SV \\
\hline 2 & Knygele, vesk mane $i$ savo šali & Alytaus SVB & $\mathrm{KM}$ \\
\hline 3 & Literatūriniai metai po Jurgio Kunčino ženklu & $\begin{array}{l}\text { Alytaus SVB; } \\
\text { partnerè - asociacija „Salo- } \\
\text { nas Balta varna“ }\end{array}$ & $\begin{array}{l}\text { KM, Alytaus aps- } \\
\text { krities viršininko } \\
\text { administracija, SV }\end{array}$ \\
\hline 4 & $\begin{array}{l}\text { Alytaus rajono savivaldybès viešosios bibliotekos } \\
\text { kraštotyros duomenu bazès „Alytaus krašto etnokul- } \\
\text { tūra“ sukūrimas elektronineje laikmenoje }\end{array}$ & Alytaus r. SVB & KM \\
\hline 5 & $\begin{array}{l}\text { Su knyga draugaut smagiau, su knyga gyvent } \\
\text { linksmiau }\end{array}$ & Alytaus r. SVB & KM \\
\hline 6 & Etninès kultūros pédomis & Alytaus r. SVB & $\begin{array}{l}\text { Alytaus apskrities } \\
\text { viršininko admini- } \\
\text { stracija }\end{array}$ \\
\hline 7 & Skaitau - kuriu - mąstau & Alytaus r. SVB & SV \\
\hline 8 & Biblioteka - informacijos ir saviraiškos centras & Alytaus r. SVB Makniūnų f. & SV \\
\hline 9 & $\begin{array}{l}\text { Gyvas darbuose ir prisiminimuose } \\
\text { [skirtas kraštiečio, teatrologo V. Maknio 100-ajam } \\
\text { jubiliejui] }\end{array}$ & Alytaus r. SVB Vankiškių f. & SV \\
\hline 10 & $\begin{array}{l}\text { Menas - tai veržimasis ì gèrį [skirtas vaikams ir } \\
\text { jaunimui] }\end{array}$ & Alytaus r. SVB Vankiškių f. & SV \\
\hline 11 & Monografijos „Meteliai“ leidyba & Lazdijų r. SVB & $\mathrm{KM}, \mathrm{SV}$ \\
\hline 12 & $\begin{array}{l}\text { Lazdijų krašto etninès kultūros paveldo fiksavimas ir } \\
\text { perteikimas visuomenei [tęstinis] }\end{array}$ & Lazdijų r. SVB & SV \\
\hline 13 & Skaitymo skatinimas šeimoje ir bibliotekoje & Varėnos r. SVB & $\mathrm{KM}$ \\
\hline 14 & Knygos „Burokaraistis“ II dalies leidyba & Varénos r. SVB & $\mathrm{KM}$ \\
\hline
\end{tabular}




\begin{tabular}{|c|c|c|c|}
\hline Eil. nr. & Pavadinimas & Biblioteka, partneriai & Rèmèjai \\
\hline \multicolumn{4}{|c|}{2013 metai } \\
\hline 1 & $\begin{array}{l}\text { Kas pasakè, kad skaityti nuobodu ir nemadin- } \\
\text { ga?! - II [tęstinis] }\end{array}$ & Alytaus SVB & KRF, SV \\
\hline 2 & 20 metų drauge: susipažinkime iš naujo & Alytaus SVB & KRF \\
\hline 3 & Cieskim kelali, dzūkų žodeliu & Alytaus r. SVB & $\mathrm{KRF}$ \\
\hline 4 & Tikro garso valanda [skirtas lietuvių rašytojams] & Alytaus r. SVB & KRF \\
\hline 5 & Susitikime bibliotekoje & $\begin{array}{l}\text { Druskininkų SVB } \\
\text { Viečiūnų ir Leipalingio } \\
\text { filialai }\end{array}$ & VVG \\
\hline 6 & $\begin{array}{l}\text { Prie atsiminimų medžio su poetu } \\
\text { Just. Marcinkevičiumi }\end{array}$ & $\begin{array}{l}\text { Druskininkų SVB; } \\
\text { partnerė - poezijos ir kitų } \\
\text { menų mėgèjų asociacija } \\
\text { „Branduma“ }\end{array}$ & [nenurodyta] \\
\hline 7 & $\begin{array}{l}\text { Mums rūpi! [informacinio raštingumo projektas } \\
\text { vaikams ir jaunimui] }\end{array}$ & Lazdijų r. SVB & KM \\
\hline 8 & Veik prasmingai & Lazdijų r. SVB & $\begin{array}{l}\text { Jaunimo reikalų } \\
\text { departamentas prie } \\
\text { Socialinès ap- } \\
\text { saugos ir darbo } \\
\text { ministerijos }\end{array}$ \\
\hline 9 & Audžia jaunos rankos & Lazdijų r. SVB & SV \\
\hline 10 & $\begin{array}{l}\text { Renginių ciklas „Dzūkiškai šneku - apsisomyc } \\
\text { negaliu“ }\end{array}$ & Lazdijų r. SVB & KRF \\
\hline 11 & $\begin{array}{l}\text { Senuju amatu puoselejimas Veisieju ir Seiriju biblio- } \\
\text { tekü kiemeliuose bei amatu demonstravimas Lazdiju } \\
\text { rajono bendruomenese }\end{array}$ & $\begin{array}{l}\text { Lazdijų r. SVB Veisiejų ir } \\
\text { Seirijų filialai; } \\
\text { partnerè - Barčių kaimo } \\
\text { bendruomenė }\end{array}$ & $\begin{array}{l}\text { Europos žemès } \\
\text { ūkio fondas kaimo } \\
\text { plètrai (LEADER } \\
\text { programa) }\end{array}$ \\
\hline 12 & Anzelmo Matučio Dreves atnaujinimas & Varėnos r. SVB & $\begin{array}{l}\text { ES struktūriniai } \\
\text { fondai }\end{array}$ \\
\hline 13 & Anzelmo Matučio Drevès aplinkos sutvarkymas & Varènos r. SVB & $\begin{array}{l}\text { ES struktūriniai } \\
\text { fondai }\end{array}$ \\
\hline 14 & $\begin{array}{l}\text { Varènos krašto jaunimo iniciatyvų skatinimas } \\
(2013-2014 \mathrm{~m} .)\end{array}$ & $\begin{array}{l}\text { Varènos r. SVB; } \\
\text { partnerè - VVG }\end{array}$ & $\begin{array}{l}\text { Europos žemès } \\
\text { ūkio fondas kaimo } \\
\text { plètrai (LEADER } \\
\text { programa) }\end{array}$ \\
\hline 15 & Poezijos pavasarèlis - 2013 & Varènos r. SVB & $\mathrm{KRF}$ \\
\hline 16 & $\begin{array}{l}\text { Mums patinka Dzūkijos miškai ir mes norime čia } \\
\text { būti [skirtas vaikams] }\end{array}$ & Varènos r. SVB & SV \\
\hline \multicolumn{4}{|c|}{2015 metai } \\
\hline 1 & $\begin{array}{l}\text { Išmanioji biblioteka jaunimui } \\
(2015-2016 \mathrm{~m} .)\end{array}$ & Alytaus SVB & $\begin{array}{l}\text { BMGF, KM [BP 2], } \\
\text { SV }\end{array}$ \\
\hline 2 & $\begin{array}{l}\text { Dèmesio! Dvi kartos traukinyje [tęstinis; skirtas } \\
\text { literatūrai] }\end{array}$ & Alytaus SVB & LKT, SV \\
\hline 3 & $\begin{array}{l}\text { Alytietiškos istorijos. (Ne)šventujų gyvenimai - II } \\
\text { [tęstinis; skirtas literatūrai] }\end{array}$ & Alytaus SVB & SV \\
\hline 4 & $\begin{array}{l}\text { Kas pasaké, kad skaityti nuobodu ir nemadin- } \\
\text { ga?! - III [tęstinis] }\end{array}$ & Alytaus SVB & LKT, SV \\
\hline
\end{tabular}




\begin{tabular}{|c|c|c|c|}
\hline Eil. nr. & Pavadinimas & Biblioteka, partneriai & Rèmèjai \\
\hline 5 & $\begin{array}{l}\text { \#MŪSŲKRAŠTAS: Alytaus ir Vilniaus bendruome- } \\
\text { nių tapatumo ugdymas bibliotekose (2015-2016 m.) }\end{array}$ & $\begin{array}{l}\text { Alytaus r. SVB; } \\
\text { partnerè - VAVB }\end{array}$ & BMGF, KM [BP 2] \\
\hline 6 & $\begin{array}{l}90 \text { metú po knygos ženklu [skirtas bibliotekos jubi- } \\
\text { liejui] }\end{array}$ & Alytaus r. SVB & SV \\
\hline 7 & $\begin{array}{l}\text { Intelektinè ir pramogine biblioteka } \\
(2015-2016 \mathrm{~m} .)\end{array}$ & $\begin{array}{l}\text { Lazdijų r. SVB; } \\
\text { partneris - Kauno technolo- } \\
\text { gijos universitetas }\end{array}$ & $\begin{array}{l}\text { BMGF, KM [BP 2], } \\
\text { SV }\end{array}$ \\
\hline 8 & $\begin{array}{l}\text { Europietiškai lietuviškos - mobilios kūrybinès dirbtu- } \\
\text { vés [skirtas Europos dienai] }\end{array}$ & Lazdijų r. SVB & EKAL \\
\hline 9 & Prozos ruduo - 2015 & Lazdijų r. SVB & LKT, SV \\
\hline 10 & $\begin{array}{l}\text { Istorijos menas [skirtas jaunimo kūrybinei meninei } \\
\text { veiklai skatinti] }\end{array}$ & Lazdijų r. SVB & $\begin{array}{l}\text { Lietuvos ir Lenki- } \\
\text { jos jaunimo mainų } \\
\text { fondas, Socialinès } \\
\text { apsaugos ir darbo } \\
\text { ministerija }\end{array}$ \\
\hline 11 & Knygrišystès amatas Veisieju bibliotekoje & Lazdijų r. SVB Veisiejų f. & SV \\
\hline 12 & Skaitymo skatinimas ir kūrybinès dirbtuvès & Varènos r. SVB & [nenurodyta] \\
\hline 13 & Atviro jaunimo centro steigimas & Varènos r. SVB & [nenurodyta] \\
\hline \multicolumn{4}{|c|}{2016 metai } \\
\hline 1 & $\begin{array}{l}\text { Išmanioji biblioteka jaunimui } \\
(2015-2016 \mathrm{~m} .)\end{array}$ & Alytaus SVB & $\begin{array}{l}\text { BMGF, KM [BP 2] } \\
\text { SV (finansavi- } \\
\text { mas skirtas } 2015 \\
\text { metais) }\end{array}$ \\
\hline 2 & $\begin{array}{l}\text { Tarptautiniai trumposios prozos skaitymai „Imbiero } \\
\text { vakarai-2016“ }\end{array}$ & Alytaus SVB & LKT, SV \\
\hline 3 & $\begin{array}{l}\text { Kas pasake, kad skaityti nuobodu ir nemadinga?! - } \\
\text { IV [tęstinis] }\end{array}$ & Alytaus SVB & LKT, SV \\
\hline 4 & $\begin{array}{l}\text { \#MŪSŲKRAŠTAS: Alytaus ir Vilniaus bendruome- } \\
\text { niu tapatumo ugdymas bibliotekose (2015-2016 m.) }\end{array}$ & $\begin{array}{l}\text { Alytaus r. SVB; } \\
\text { partneris - VAVB }\end{array}$ & $\begin{array}{l}\text { BMGF, KM [BP 2] } \\
\text { (finansavimas skir- } \\
\text { tas } 2015 \text { metais) }\end{array}$ \\
\hline 5 & $\begin{array}{l}\text { Alytaus rajono kultūros darbuotoju diena Alytaus } \\
\text { rajono savivaldybès viešojoje bibliotekoje }\end{array}$ & Alytaus r. SVB & SV \\
\hline 6 & $\begin{array}{l}\text { Aš toks pat kaip tu [skirtas vaikams iš socialinès } \\
\text { rizikos šeimų] }\end{array}$ & Alytaus r. SVB & SV \\
\hline 7 & Atrask erdves saviraiškai ir kūrybai & Alytaus r. SVB Ūdrijos f. & SV \\
\hline 8 & Daug žinosi, daug matysi, jeigu knygeles skaitysi & Druskininkų SVB & KM, LKT, SV \\
\hline 9 & Europietiška biblioteka [skirtas Europos dienai] & Lazdijų r. SVB & EKAL \\
\hline 10 & $\begin{array}{l}\text { Intelektine ir pramogine biblioteka } \\
(2015-2016 \mathrm{~m} .)\end{array}$ & $\begin{array}{l}\text { Lazdijų r. SVB; } \\
\text { partneris - Kauno technolo- } \\
\text { gijos universitetas }\end{array}$ & $\begin{array}{l}\text { BMGF, KM [BP 2] } \\
\text { (finansavimas skir- } \\
\text { tas } 2015 \text { metais) }\end{array}$ \\
\hline 11 & $\begin{array}{l}\text { 52-asis tarptautinis poezijos festivalis „Poezijos } \\
\text { pavasaris“ }\end{array}$ & Varènos r. SVB & SV \\
\hline 12 & Stipri biblioteka - stipri visuomene & Varènos r. SVB & SV \\
\hline 13 & $\begin{array}{l}\text { 5-asis respublikinis vaikų meninès kūrybos festivalis } \\
\text { „Susitikimas ežio dvare“ [tęstinis] }\end{array}$ & Varènos r. SVB & SV \\
\hline 14 & $\begin{array}{l}\text { Vaikų literatūros kūrëjai ir atlikèjai vyksta ị kaimus } \\
\text { [tęstinis] }\end{array}$ & Varènos r. SVB & SV \\
\hline
\end{tabular}




\begin{tabular}{|c|c|c|c|}
\hline Eil. nr. & Pavadinimas & Biblioteka, partneriai & Rèmèjai \\
\hline 15 & Skaitau kūrybiškai & Varènos r. SVB & SV \\
\hline \multicolumn{4}{|c|}{2017 metai } \\
\hline 1 & $\begin{array}{l}\text { Dèmesio! Dvi kartos traukinyje [tęstinis; skirtas } \\
\text { literatūrai] }\end{array}$ & Alytaus SVB & LKT, SV \\
\hline 2 & Jurgio Kunčino gimimo 70-mečio jubiliejus & Alytaus SVB & SV \\
\hline 3 & $\begin{array}{l}\text { Ekslibrisu konkursas, skirtas Jurgio Kunčino gimimo } \\
\text { 70-mečiui }\end{array}$ & Alytaus SVB & SV \\
\hline 4 & Poezijos festivalis „Laukinès vaivorykštès - 2017“ & Alytaus r. SVB & LKT, SV \\
\hline 5 & Aš Europoje, mes Europoje & Lazdijų r. SVB & EKAL \\
\hline 6 & Kürybinès verslo industrijos jauniems & Lazdijų r. SVB & $\begin{array}{l}\text { Lietuvos ir Lenki- } \\
\text { jos jaunimo mainų } \\
\text { fondas }\end{array}$ \\
\hline 7 & $\begin{array}{l}\text { Medijų ir informacinis raštingumas: galimybès ir } \\
\text { iššūkiai }\end{array}$ & $\begin{array}{l}\text { Lazdijų r. SVB; } \\
\text { partneriai: Lazdijų švieti- } \\
\text { mo centras, Lazdijų rajono } \\
\text { neigaliųjų draugija, Alytaus } \\
\text { TAU Seirijų filialas }\end{array}$ & LKT, SV \\
\hline 8 & Prozos ruduo'2017 Lazdijuose & Lazdijų r. SVB & KM \\
\hline 9 & Knygos atgimsta vaiku rankose & Lazdijų r. SVB & SV \\
\hline 10 & $\begin{array}{l}\text { 6-asis respublikinis vaikų meninès kūrybos festivalis } \\
\text { „Susitikimas ežio dvare“ [tęstinis] }\end{array}$ & Varènos r. SVB & LKT \\
\hline 11 & 19-asis poezijos pavasarelis & Varènos r. SVB & SV \\
\hline 12 & Skaitau. Kuriu. Tobulèju & Varènos r. SVB & SV \\
\hline 13 & Leidinio „Varènos krašto dienoraščiai“ leidyba & Varėnos r. SVB & SV \\
\hline 14 & Vaikų knygų kūrejjai vyksta ị kaimus [tęstinis] & Varènos r. SVB & SV \\
\hline 15 & $\begin{array}{l}\text { Gimtasis kraštas Lietuvos valstybès atkūrimo } \\
\text { 100-mečio šviesoje ir skaitymo malonumas }\end{array}$ & Varènos r. SVB & SV \\
\hline 16 & Bibliotekos pokyčiai modernioje visuomeneje & Varènos r. SVB & SV \\
\hline 17 & $\begin{array}{l}\text { 53-iasis tarptautinis poezijos festivalis „Poezijos } \\
\text { pavasaris“ }\end{array}$ & Varènos r. SVB & SV \\
\hline
\end{tabular}

